\title{
Bestuurlijk gedonder - onderzoek naar bestuurlijke probleemgemeenten in Nederland (1998-2010)
}

Citation for published version (APA):

Schoenmaker, M. (2011). Bestuurlijk gedonder - onderzoek naar bestuurlijke probleemgemeenten in Nederland (1998-2010). [Doctoral Thesis, Maastricht University]. Wolf Legal Publishers. https://doi.org/10.26481/dis.20110922ms

Document status and date:

Published: 01/01/2011

DOI:

10.26481/dis.20110922ms

Document Version:

Publisher's PDF, also known as Version of record

\section{Please check the document version of this publication:}

- A submitted manuscript is the version of the article upon submission and before peer-review. There can be important differences between the submitted version and the official published version of record.

People interested in the research are advised to contact the author for the final version of the publication, or visit the DOI to the publisher's website.

- The final author version and the galley proof are versions of the publication after peer review.

- The final published version features the final layout of the paper including the volume, issue and page numbers.

Link to publication

\footnotetext{
General rights rights.

- You may freely distribute the URL identifying the publication in the public portal. please follow below link for the End User Agreement:

www.umlib.nl/taverne-license

Take down policy

If you believe that this document breaches copyright please contact us at:

repository@maastrichtuniversity.nl

providing details and we will investigate your claim.
}

Copyright and moral rights for the publications made accessible in the public portal are retained by the authors and/or other copyright owners and it is a condition of accessing publications that users recognise and abide by the legal requirements associated with these

- Users may download and print one copy of any publication from the public portal for the purpose of private study or research.

- You may not further distribute the material or use it for any profit-making activity or commercial gain

If the publication is distributed under the terms of Article $25 \mathrm{fa}$ of the Dutch Copyright Act, indicated by the "Taverne" license above, 


\title{
Bestuurlijk gedonder
}

\author{
Onderzoek naar \\ bestuurlijke probleemgemeenten \\ in Nederland \\ (1998-2010)
}

Milo Schoenmaker 


\section{Bestuurlijk gedonder}

Onderzoek naar bestuurlijke probleemgemeenten in Nederland (1998-2010)

Milo Schoenmaker

ISBN: 978-90-5850-685-6

Wolf Legal Publishers

Postbus 31051

6503 CB Nijmegen

\section{Herinnering}

Bij het ter perse gaan van dit boek werd bekend dat één van de gesprekspartners voor het onderzoek, mr. C.J.D. Waal, op 11 juli 2011 is overleden. Cees Waal blijft in mijn herinnering als een plezierig en ervaren bestuurder, die een grote bijdrage leverde aan het in rustiger bestuurlijk vaarwater brengen van één van de in dit boek beschreven gemeenten, Delfzijl.

\section{Foto voorpagina:}

Donder en bliksem bij de oversteekplaats van de veerpont HekelingenNieuw-Beijerland, met zicht op Nieuw-Beijerland, 28 juni 2011.

Foto: Patrick Koster/www. pakosphotography.com

(C) 2011

M. Schoenmaker 


\section{Bestuurlijk gedonder}

\section{PROEFSCHRIFT}

ter verkrijging van

de graad van doctor aan de Universiteit Maastricht op gezag van de Rector Magnificus, prof.mr. G.P.M.F. Mols, volgens besluit van het College van Decanen in het openbaar te verdedigen op donderdag 22 september 2011 om 16.00 uur

door

Milo Schoenmaker geboren op 17 november 1967 te Alkmaar 


\section{Promotor:}

Prof. dr. A.F.A. Korsten

(Universiteit Maastricht / Open Universiteit Nederland)

\section{Leden van de beoordelingscommissie:}

Prof. dr. L. Verheij (voorzitter)

Prof. dr. J.Th.J. van den Berg

Prof. dr. Th. W.A. Camps (Universiteit van Tilburg)

Prof. dr. J.W. Foppen

Prof. dr. J.L.A. Geurts (Universiteit van Tilburg) 


\section{Inhoudsopgave}

\section{Voorwoord}

\section{Hoofdstuk 1: Probleemstelling en werkwijze}

1.1: Inleiding

1.2: Bestuurlijke probleemgemeenten als studieobject

1.3: Relevantie van het onderzoek

1.4: Begrippen

1.5: Centrale vraagstelling en onderzoeksperiode

1.6: Onderzoekstrategie

Hoofdstuk 2: Lokaal bestuur en gedwongen vertrek anno 2010

2.1: Inleiding

2.2: Gemeenten en lokale politiek

2.3: Nieuwe ontwikkelingen

2.4: Gedwongen tussentijds vertrek van gemeentebestuurders

2.5: Conclusies

Hoofdstuk 3: Onderzoek naar bestuurlijke probleemgemeenten

3.1: Inleiding

3.2: De bestuurskrachtbenadering

3.3: Good governance: de normatieve benadering

34

3.4: De benadering via factoren en schaalniveaus

3.5: Sterke colleges

3.6: Samenvatting van mogelijke benaderingen

3.7: Negen factoren

3.8: Verwachtingen

Hoofdstuk 4: Bestuurlijke probleemgemeenten in Nederland 1998-2010 4.1: Inleiding

4.2: Uitgangspunten bij inventarisatie en registratie

4.3: De algemene resultaten

4.3.1: Gemeenten met de meeste bestuurlijke conflicten en bestuurscrises

4.3.2: De val van colleges van $B \& W$

4.3.3: Conflict met raad of fractie

4.3.4: Verschillen tussen grote en kleine gemeenten

4.5: De situatie per provincie 
Hoofdstuk 5: Bestuurlijke problematiek in Den Helder 1998-2010

5.1 : Inleiding

85

5.2: Introductie van de gemeente Den Helder 86

5.3: 12 jaar Helderse politiek 86

5.4: De problemen op een rij 88

5.4.1: Periode 1998-2002 88

5.4.2: Periode 2002-2006 92

5.4.3: Periode 2006-2010 100

5.5: De analyse op microniveau 105

5.6: De analyse op mesoniveau 107

5.7: De analyse op macroniveau 111

5.8: De dynamiek 114

5.9: Conclusie $\quad 115$

Hoofdstuk 6: Bestuurlijke problematiek in Leiden 1998-2010

$\begin{array}{ll}6.1 \text { : Inleiding } & 119\end{array}$

6.2: Introductie van de gemeente Leiden 119

6.3: 12 jaar Leidse politiek $\quad 120$

6.4: De problemen op een rij 122

6.4.1: Periode 1998-2002 122

6.4.2: Periode 2002-2006 124

$\begin{array}{ll}\text { 6.4.3: Periode 2006-2010 } & 127\end{array}$

6.5: De analyse op microniveau 131

6.6: De analyse op mesoniveau 134

6.7: De analyse op macroniveau 137

6.8: De dynamiek 139

6.9: Conclusie $\quad 140$

Hoofdstuk 7: Bestuurlijke problematiek in Delfzijl 1998-2010

7.1: Inleiding

143

7.2: Introductie van de gemeente Delfzijl 144

7.3: 12 jaar Delfzijlster politiek $\quad 145$

7.4: De problemen op een rij 147

$\begin{array}{ll}\text { 7.4.1: Periode 1998-2002 } & 147\end{array}$

$\begin{array}{ll}\text { 7.4.2: Periode 2002-2006 } & 148\end{array}$

$\begin{array}{ll}\text { 7.4.3: Periode 2006-2010 } & 154\end{array}$

7.5: De analyse op microniveau 157

7.6: De analyse op mesoniveau 160

$\begin{array}{ll}\text { 7.7: De analyse op macroniveau } & 162\end{array}$

$\begin{array}{ll}\text { 7.8: De dynamiek } & 166\end{array}$

$\begin{array}{lr}\text { 7.9: Conclusie } & 167\end{array}$ 
Hoofdstuk 8: Bestuurlijke problematiek in Zundert 1998-2010

8.1: Inleiding

8.2: Introductie van de gemeente Zundert

8.3: 12 jaar Zundertse politiek

170

8.4: De problemen op een rij

8.4.1: Periode 1997-2002

172

8.4.2: Periode 2002-2006

174

8.4.3: Periode 2006-2010

181

8.5: De analyse op microniveau

184

8.6: De analyse op mesoniveau

187

8.7: De analyse op macroniveau 190

8.8: De dynamiek 193

8.9: Conclusie 194

\section{Hoofdstuk 9: Conclusies}

9.1: Inleiding

9.2: Verwachte verklaringen 197

9.3: Beantwoording van de centrale onderzoeksvraag 213

Hoofdstuk 10: Reflectie op bevindingen

10.1: Inleiding

10.2: Het autonomieperspectief

10.2.1: Wat is er gedaan in bestuurlijke probleemgemeenten?

10.2.2: Suggesties en aanbevelingen op basis van het patroon van factoren

10.2.3: Doen alle factoren ertoe?

10.3: Het perspectief van de systeemverantwoordelijke overheid

10.4: Het ecologisch perspectief

Bijlage 1: De gegevens van alle gemeenten 



\section{Voorwoord}

Met het verschijnen van dit boek gaat een lang gekoesterde wens in vervulling: het doen van onderzoek en het schrijven van een proefschrift. De gedachte hier daadwerkelijk mee aan de slag te gaan ontstond eind 2005, het eerste gesprek met beoogd promotor prof.dr. Arno Korsten was in het voorjaar van 2006. Het onderwerp was door de promotor snel aangereikt: conflicten en crises in gemeenten, in het bijzonder in gemeenten waar dit veel voorkomt. De promotor sprak hierbij over 'moeilijke gemeenten', waarop hij bij het doen van onderzoek naar de val van burgemeesters gestoten was.

Een onderwerp dat ook mij na aan het hart ligt, niet in de laatste plaats vanwege mijn werkzaamheden als burgemeester. Niet omdat de gemeente Bussum, waar ik sinds 2003 met veel genoegen burgemeester ben, een gemeente is met veel 'gedoe'. Verre van dat: Bussum is een bestuurlijk stabiele gemeente, met wethouders en raadsleden die hun best doen dat zo te houden. Het gedwongen vertrek van gemeentebestuurders is echter een actueel onderwerp in de Nederlandse lokale politiek, dat velen zorgen baart. Pure nieuwsgierigheid naar de bestuurlijke praktijk in gemeenten waar dit veel voor komt zette mij vervolgens aan tot het doen van onderzoek.

Vaak wordt in dit soort voorwoorden gezegd dat er een last van de auteur af is gevallen, dat het een martelgang was, waarin lange uren achter de pc werden doorgebracht, terwijl de rest van de wereld vrolijk lachend aan het werk was of aan de borrel zat. Mijn voorwoord is anders. Ik heb genoten van het onderzoek en het schrijven aan het stuk en ben echt vergroeid geraakt met mijn onderwerp. Natuurlijk is het plezierig dat er nu een afronding plaats heeft gevonden, want ook andere zaken in het leven verdienen aandacht.

Ik dank veel mensen voor de hulp die ik mocht krijgen. Op de eerste plaats natuurlijk promotor Arno Korsten, die niet ophield mij handreikingen te bieden, kritisch te volgen, te inspireren en van nieuwe inzichten te voorzien. Wij gingen gezamenlijk voor niets minder dan succes. Zonder hem was het absoluut niet gelukt. Verder dank ik ook een aantal andere (voormalig) hoogleraren, met wie ik gedurende het traject tussenproducten mocht bespreken en zodoende kon profiteren van hun, vaak zeer verhelderende, inzichten. Het gaat dan met name om prof. dr. Bas Denters (UT), prof. dr. Jacques Geurts (UvT), prof. dr. Wim Derksen (EUR) en dr. Michiel Herweijer (RUG). Mijn dank gaat ook vit naar de groep meelezers, te weten dr. Marcel Boogers, dr. Klaartje Peters, dr. Marcel van Dam, leden van het Bussums college van B\&W (wethouder drs. Gerard Boekhoff, wethouder drs. Arie Gouka en gemeentesecretaris mr. Marjolein Plantinga), de Bussumse griffier mr. Lars Wieringa, oud-gemeentesecretaris van Bussum Jan Buijs, alsmede dr. Hans Gilissen (burgemeester van Venray), dr. Joost Cox (gemeentesecretaris van Alkmaar) en de dames (vooral Diana en Nicolette) van het bestuurssecretariaat.

Ik dank ook de lezers uit de promovendikring van de promotor. De kritische en opbouwende kritiek op eerdere versies van (onderdelen van) dit boek hielden of brachten mij op het rechte pad en hebben bijgedragen aan verbetering van onderzoek en rapportage. Mijn 
dank geldt uiteraard ook de personen die mij informeerden vanuit de probleemgemeenten en die de casusbeschrijving hebben beoordeeld op herkenning ('dit waren wij') en erkenning ('zo was het'). Tevens dank ik alle respondenten (waaronder veel collega-burgemeesters) uit de aangeschreven Nederlandse gemeenten voor de informatie die zij mij hebben gestuurd.

Het laatste woord is voor het thuisfront. Mijn echtgenote en kinderen hebben mij alle steun en ruimte geboden aan dit project te beginnen en mij waar mogelijk gesteund. Dat dit boek er ligt, is dan ook vooral aan mijn gezin te danken.

Milo Schoenmaker

Bussum, juni 2011 


\section{Probleemstelling en werkwijze}

\section{$1.1 \quad$ Inleiding}

In het lokaal bestuur in Nederland vertrekken regelmatig burgemeesters en wethouders voordat de periode waarvoor zij benoemd of gekozen zijn, is verstreken. Zij vertrekken zogezegd 'tussentijds'. Soms is dat een eigen keuze. De gezondheid laat verder werken niet meer toe, of er is een verandering van werkkring. Soms is dat echter bepaald geen eigen keuze. Door een bestuurlijk conflict of bestuurscrisis (of de dreiging daarvan) in de gemeente, wordt (of voelt) de betrokken bestuurder (zich) gedwongen zijn of haar positie op te geven en te vertrekken. In sommige gemeenten gebeurt dat zelden, in andere gemeenten vaak. Zelfs zo vaak dat deze gemeenten enige bekendheid ontlenen aan de bestuurlijke problemen, die zich er voordoen of hebben voorgedaan. Dit onderzoek richt zich op deze categorie gemeenten: bestuurlijke probleemgemeenten.

Gedwongen vertrek van gemeentelijke bestuurders is geen onbekend thema in de bestuurskunde. Al ruim 20 jaar geleden ging de aandacht uit naar bestuurscrises in gemeenten. Over de vraag hoe deze kunnen worden verklaard is sindsdien een aantal artikelen, boeken of studies verschenen (zie 0.a. Derksen, 1990; Korsten en Tops, 1998; Carabain, 2009). Van redelijk recente datum zijn ook de studies naar vallende burgemeesters (Korsten en Aardema, 2006) en teruggetreden wethouders (Castenmiller, Meesters en Pluut, 2006; Castenmiller, Van Dam, Namen en Emans, 2010). Het Ministerie van Binnenlandse Zaken en Koninkrijksrelaties liet in 2007 onderzoeken welke mogelijkheden er zijn om in te grijpen in gemeenten waar het bestuurlijk stelselmatig mis gaat (Fleurke, 200 ).

Dit onderzoek is op te vatten als een vervolgstap op deze onderzoeken. Er zijn nog vele vragen onbeantwoord. Niet duidelijk is hoeveel en welke gemeenten daadwerkelijk opvallen als het gaat om het aantal gedwongen vertrokken gemeentebestuurders, en welke problematiek er in deze gemeenten speelt of speelde. Er zijn schattingen, er circuleren aantallen en er worden namen van gemeenten genoemd, maar een totaaloverzicht ontbreekt. De eerdere analyses vragen om een vervolg, waarin de conflicten en crises in deze gemeenten dieper worden onderzocht. Er is tot op dit moment geen onderzoek beschikbaar waarin systematisch is gekeken naar gemeenten met (chronische) bestuurlijke problematiek (zie Korsten en Schoenmaker: 2008: 229). Doel van dit onderzoek is om daarin te voorzien, de bestaande kennis en inzichten met betrekking tot conflicten en crises in bestuurlijke probleemgemeenten uit te bouwen en daaruit enige lessen te kunnen trekken.

Het gaat dus om twee zaken. Op de eerste plaats draagt dit onderzoek bij aan datgene wat menig bestuurskundig onderzoek beoogt: het beter begrijpen van de werking van het openbaar bestuur. Onderzoek naar bestuurlijke conflicten en bestuurscrises in bestuurlijke probleemgemeenten biedt de mogelijkheid te bezien wat daar aan de hand 
is of was. Op de tweede plaats is het de bedoeling van de uitkomsten te leren. De bestuurskunde is een sterk op de praktijk gerichte wetenschap, die probeert probleemoplossend te opereren (zie: Nelissen, De Goede en Van Twist, 2004: 307). Vooral de laatste twee decennia is er veel belangstelling voor het feitelijk functioneren van het openbaar bestuur en de problemen daarbij. Hier is inmiddels veel onderzoek naar gedaan. Doel van het onderzoek is dus ook om te reflecteren op de uitkomsten en zo mogelijk aanbevelingen te doen.

\subsection{Bestuurlijke probleemgemeenten als studieobject}

Om te beginnen enkele relativerende woorden. Hoe bijzonder is het dat er gemeenten zijn waar kennelijk meer bestuurlijke problemen aan de orde zijn of zijn geweest dan in andere gemeenten? Is dat nader onderzoek waard? In de hele wereld vertrekken mensen wel eens vanwege een conflict in hun werk, waarom zou dat in de gemeentelijke politiek anders zijn? Op zich is het inderdaad niet bijzonder dat, in een politiekbestuurlijke omgeving als het gemeentebestuur, meningen botsen. Daarbij kan het gebeuren dat een wethouder, of soms een burgemeester, het vertrouwen van de gemeenteraad verliest en niet verder kan functioneren. Ook binnen een college of tussen de wethouder en de eigen fractie kunnen problemen ontstaan. Politiek is mensenwerk en soms zit de juiste man of vrouw domweg niet op de juiste plaats. Voormalig burgemeester Opstelten van Rotterdam is er bijvoorbeeld realistisch over: "Als blijkt dat mensen niet met elkaar kunnen samenwerken, moet er verandering in het team komen. Daar moet je dan niet droevig om zijn, het is de realiteit" (Van Lonkhuyzen, 2007). Eén van de respondenten voor dit onderzoek meldde dat het ook interessant zou zijn om te onderzoeken wat er in sommige gemeenten gebeurd zou zijn als het niét tot het vertrek van een bepaalde wethouder zou zijn gekomen. Daar was, zo vermoedde hij, de kwaliteit van het bestuur ook niet mee gediend geweest. Het vertrek van individuele bestuurders is, blijkt uit deze reactie, niet altijd te beschouwen als een probleem.

De situatie verandert echter als het hele college van burgemeester en wethouders de steun van de gemeenteraad verliest en moet aftreden. Dan is er geen sprake meer van een relatief overzichtelijk probleem met één bestuurder, maar wordt gesproken van een 'crisis': een bestuurscrisis, waarbij er onoverkomelijk grote problemen zijn ontstaan in de vertrouwensrelatie tussen het college van B\&W en (een deel van) de gemeenteraad. In het algemeen worden dergelijke crisissituaties in gemeenten als een probleem ervaren. Het schaadt het aanzien van de (lokale) politiek als de leden van het gemeentebestuur ruziënd door het leven gaan en de lokale, regionale en soms landelijke media daar vitgebreid verslag van doen. Bovendien komt het in de regel de besluitvaardigheid van dergelijke gemeenten niet ten goede als de bestuurders meer met elkaar dan met de buitenwereld bezig zijn. Toch komen ook deze situaties vrij frequent voor in de Nederlandse lokale politiek, al is het aantal vertrokken colleges viteraard veel lager dan het aantal 'solitair' vertrokken gemeentebestuurders.

Er zijn in Nederland echter ook gemeenten die opvallen door het grote aantal bestuurlijke conflicten en bestuurscrises, dat plaatsvindt. Gemeenten waar regelmatig wethouders de biezen moeten pakken, na druk of een motie van wantrouwen van de raad 
of na problemen in de coalitie. Gemeenten waar de burgemeester ineens onder vuur kan komen te liggen. Gemeenten waar colleges er in de regel eerder niet dan wel in slagen de termijn van vier jaar volledig uit te dienen en grote kans lopen tussentijds te 'struikelen'. In dit opzicht wijken deze gemeenten negatief af ten opzichte van andere gemeenten in Nederland. Ze vallen op, er wordt over ze geschreven. Ze staan bekend om de bestuurlijke problemen die zich er voordoen.

\subsection{Relevantie van het onderzoek}

De problemen die uit deze situaties voortvloeien geven aan dat nader onderzoek relevant is. Op de eerste plaats blijkt dat gemeenten met veel bestuurlijke problemen moeite hebben het vertrouwen van de inwoners te behouden. Uit vergelijkend onderzoek van 'De Staat van de Gemeente' blijkt dat gemeenten met veel bestuurlijke problemen als Den Helder en Zundert laag scoren op het punt van 'goed bestuur in de ogen van de burgers', met respectievelijk een cijfer van 3,9 en 4,5 (Korsten, 2010c: 49). In gemeenten met bestuurlijke problemen staan de rubrieken met ingezonden brieven in dag- en weekbladen vaak vol met producties van mensen die iets vinden van de crisis in hun gemeente. Zeker als het niet de eerste keer is dat er iets gebeurt. De mening van deze briefschrijvers is veelal niet positief. Velen menen te weten hoe het komt dat er altijd problemen zijn of worden gemaakt en wat er aan gedaan zou moeten worden. De schrijver van een ingezonden brief naar aanleiding van de problemen in Delfzijl: "Wat moet er gebeuren? Na de burgemeester moeten ook de drie wethouders hun verantwoordelijkheid nemen en ontslag indienen. De gemeenteraadsverkiezingen dienen te worden uitgesteld. Oudgedienden moeten van het politieke toneel verdwijnen. Als dit op orde is, dan kunnen er nieuwe gemeenteraadsverkiezingen worden gehouden. Eerst moet er schoon schip gemaakt worden" (Dagblad van het Noorden, 23/02/06). Frequente problemen kunnen dus negatieve invloed hebben op de manier waarop mensen naar hun gemeente kijken. Bij de gemeenteraadsverkiezingen van maart 2006 stond in Delfzijl zelfs een groep mensen op, die de inwoners opriep een blanco stem uit te brengen tijdens de verkiezing, uit protest tegen de problemen. Een oproep waar uiteindelijk $25 \%$ van de kiezers gehoor aan gaf.

Gemeenten waar gedurende meerdere jaren achter elkaar bestuurlijke problemen optreden, komen hier op enig moment om bekend te staan. De naam Delfzijl wordt, hoe jammer dat voor de betrokken gemeente ook is, vaker geassocieerd met al het negatieve 'gedoe' van de afgelopen 10 jaar dan met bijvoorbeeld de op zich positieve ontwikkelingen in de nabijgelegen Eemshaven, waar de stad ook bij betrokken is.

Buiten het feit dat de eigen inwoners zich eraan storen, geeft het constante geruzie in sommige gemeenten ook voeding aan een negatief oordeel van anderen over 'de' politiek. Velen worden volgens hun reacties in de media bevestigd in hun beeld dat de overheid en/of de politiek, het bestuur of de ambtenaren 'niet deugen'. Maatschappelijk gezien gaat het dus om een relevant onderwerp. Oud-burgemeester M.J. Cohen van Amsterdam verwoordde het in het interview met hem in het kader van deze studie als volgt: "Het feit dat mensen aan hun stutten trekken en weggaan, kan soms heel goed zijn. Maar als het er veel zijn, om redenen in de persoon gelegen, zou dat wel eens niet 
kunnen bijdragen aan vertrouwen in het bestuur. Dan kan je je ook afvragen: vinden we de goede mensen nog? Dat leidt weer tot wantrouwen in het bestuur en de democratie. En met vertrouwen staat of valt de hele democratie."

Op de derde plaats is relevant dat lokale bestuurders zelf het feit dat zich bestuurlijke problemen voordoen in een gemeente als hun belangrijkste probleem gaan beschouwen. Minderhedenproblematiek, openbare orde en veiligheid zijn voor slechts een kleine minderheid van de lokale bestuurders een ernstig probleem. Conflicten binnen het gemeentehuis en de gemeentelijke financiën worden veel vaker als belangrijk, zelfs als belangrijkste probleem ervaren. Dat blijkt uit onderzoek van de afdeling bestuurskunde van de Radboud Universiteit Nijmegen. Dit onderzoek (2006) is gebaseerd op een enquête onder lokale bestuurders en leidinggevende ambtenaren in middelgrote gemeenten (25.000-250.000 inwoners) die sinds 1989 om de vijf jaar is gehouden. Over de jaren zijn in totaal 1358 lokale bestuurders en ambtenaren ondervraagd, waarvan in de laatste ronde 338. Gevraagd naar de twee belangrijkste problemen in de eigen gemeente noemt $45,5 \%$ van hen problemen binnen het lokale bestuur zelf en $27,7 \%$ de gemeentelijke financiën. Gevraagd naar de belangrijkste conflicten noemen opnieuw vier op de tien ondervraagden conflicten binnen het gemeentehuis als de meest belangrijke. De ernst van die problemen en conflicten wordt op flinke afstand gevolgd door maatschappelijke problemen en conflicten (zie Smit, Dijk en De Vries, 2006).

Steeds terugkerende bestuurlijke problemen hebben een vierde negatief effect: als gemeentebestuurders vooral met elkaar bezig zijn, komt er van daadkrachtig bestuur in de regel minder terecht. Vaak speelt het proces van ruzie maken al geruime tijd en hebben raad en college al veel langer moeite tot kloeke besluitvorming te komen. Men houdt elkaar als het ware in een wurggreep, waarbij de bom op enig moment barst en er een niet te beheersen conflict of crisis ontstaat.

Op de vijfde plaats ondervinden de betrokken personen bijna altijd negatieve gevolgen van een crisis. Gedwongen vertrek gaat gepaard met veel spanning en emoties. Een insider gaf aan dat er karrenvrachten 'negatieve energie' rondgaan in het gemeentehuis tijdens dagen van crisis. Er zijn vele overleggen, emoties lopen hoog op. Als dan uiteindelijk de climax daar is en de raad een motie van wantrouwen aanneemt tegen een wethouder, burgemeester of college, heeft dat het effect van een bom die barst (vgl. Van Hulst, 2008: 143). Vaak gaat het om emotionele confrontaties tussen mensen, die nog jarenlang, soms zelfs een leven lang niet vergeten of vergeven worden (vgl. Boverhof en Krijnsen, 2010). De betrokken gemeentebestuurders verliezen door de ontstane situatie van de ene op de andere dag hun baan. Echt makkelijk om een nieuwe betrekking te vinden is het niet. Slechts $31 \%$ van de afgetreden wethouders heeft binnen twee jaar weer een betaalde baan. De 25 grootste gemeenten hadden samen in 2008 een wachtgeldverplichting aan oud-wethouders van omstreeks 6,4 miljoen euro (IVA, 2008: 4).

Op de laatste plaats stuitte de auteur van dit boek tijdens het onderzoek op veel mensen met interesse voor de uitkomsten. Op lokaal, provinciaal en landelijk niveau is er veel belangstelling voor het onderzoek en de vraag of er lessen te trekken zijn uit de conclusies. 
Kortom: onderzoek naar de oorzaken van bestuurlijke conflicten en bestuurscrises in Nederlandse bestuurlijke probleemgemeenten en de wellicht hieruit te trekken lessen lijkt zeer welkom en relevant te zijn voor de Nederlandse politiek-bestuurlijke praktijk op lokaal niveau.

\subsection{Begrippen}

Aan het begin van een onderzoek is het nuttig een aantal begrippen te definiëren, zodat duidelijk wordt wat er wel en niet onder wordt verstaan. Op de eerste plaats is er in dit onderzoek regelmatig sprake van gemeentebestuurders (ook wel simpelweg bestuurders genoemd). In de Gemeentewet staat omschreven dat onder het gemeentebestuur ieder bevoegd orgaan wordt verstaan (artikel 5), waarbij de wet in artikel 6 de raad, het college van B\&W en de burgemeester onderscheidt. Dit onderzoek richt zich op het gedwongen vertrek van het 'dagelijks bestuur' van de gemeente, dat wordt gevormd door het college van B\&W en bestaat uit de burgemeester en de wethouders. Daar waar in dit onderzoek wordt gesproken over gemeentebestuurders, wordt op deze groep bestuurders gedoeld en derhalve niet op raadsleden, die buiten de scope van onderzoek vallen.

Als er in dit onderzoek gerapporteerd wordt over de val van een college, wordt in principe gedoeld op het vertrek van de wethouders uit dat college, waarbij de burgemeester in functie kan blijven. Strikt genomen zou in deze gevallen gesproken moeten worden over de val van het 'wethouderscollectief', aangezien de burgemeester deel uit maakt van het college en het college met zijn of haar aanblijven dus niet geheel 'gevallen' is. Het woord wethouderscollectief is echter niet ingeburgerd onder gemeentebestuurders en ook in de praktijk wordt onder de val van een college eerder gedacht aan de wethouders dan aan de burgemeester. Als de burgemeester ook is vertrokken, wordt dat in voorkomende gevallen apart in dit onderzoek vermeld.

Vervolgens wordt in dit onderzoek gesproken over bestuurlijke problemen. Hierbij wordt gedoeld op het in een gemeente voorkomen van bestuurlijke conflicten en/of bestuurscrises. Het verschil zit in de hoeveelheid betrokken personen en de impact op de gemeente. Definities zijn op verschillende plaatsen te vinden (Korsten en Aardema, 2006; Zannoni, 2009). Onder een bestuurlijk conflict wordt in deze studie verstaan: een zodanig groot meningsverschil tussen een gemeentebestuurder en de eigen fractie, het college of de gemeenteraad, dat de betreffende bestuurder zich gedwongen voelt of gedwongen wordt zijn functie neer te leggen. Het gaat daarbij om één persoon, waarbij de rest van het college in functie blijft. Anders is dit bij een bestuurscrisis ofwel collegecrisis of val van het college, waarbij het hele college valt. Een bestuurscrisis heeft in de regel grotere impact op de dagelijkse gang van zaken in het gemeentebestuur. Als het college valt breekt er vaak een onzekere tijd aan, met veel formeel en informeel overleg, spanning en weinig aandacht voor andere zaken dan de bestuurlijke problematiek. Soms komt een deel van de wethouders in een nieuw college overigens weer terug. Gemeenten waar zowel bestuurlijke conflicten als bestuurscrises veelvuldig voor komen of zijn voor gekomen, worden in dit onderzoek bestuurlijke probleemgemeenten genoemd. Om dit begrip te operationaliseren is als uitgangspunt genomen dat (1) bij 
bestuurlijke probleemgemeenten in ieder geval in twee aaneengesloten raadsperioden bestuurlijke conflicten zijn opgetreden, waarbij er (2) minimaal één keer een bestuurscrisis aan de orde was, waarbij (3) alle wethouders definitief dienden te vertrekken (zie verder hoofdstuk 4). Om hoeveel gemeenten in Nederland het gaat en wat er in deze gemeenten aan de hand is of is geweest en waarom, vormt de kern van dit onderzoek.

Tenslotte is het nuttig te verklaren wat in deze studie onder gedwongen vertrek wordt verstaan. Hiertoe wordt een onderscheid gemaakt tussen direct en indirect gedwongen vertrek.

\section{Direct gedwongen vertrek}

Onder direct gedwongen vertrek van gemeentebestuurders worden in deze studie alle situaties verstaan waarin de gemeenteraad middels een motie het vertrouwen in de samenwerking met een wethouder, met meerdere of alle wethouders of het hele college, inclusief de burgemeester, heeft opgezegd, dan wel een aanbeveling tot ontslag van de burgemeester heeft gedaan. Juridisch gesproken is er overigens wel verschil tussen de wethouders en de burgemeester. Hierover meer in paragraaf 2.2, die ingaat op alle relevante aspecten met betrekking tot gedwongen vertrek van gemeentebestuurders.

\section{Indirect gedwongen vertrek}

Naast de directe aanleiding van een motie van wantrouwen, gaat het in deze studie ook om indirect gedwongen vertrek. Hiervan is sprake in een tweetal gevallen. Op de eerste plaats kan het zijn dat een gemeentebestuurder besluit om een daadwerkelijke motie van wantrouwen niet af te wachten en vooruitlopend hierop ontslag in te dienen. Dit vertrek is dus niet direct afgedwongen, maar wel indirect. Zeker als er door fracties in de gemeenteraad al verklaringen over mogelijk stemgedrag zijn afgelegd. Ook situaties waarin er nog geen motie is aangekondigd, maar een bestuurder vertrekt op basis van signalen, waaruit kan worden afgeleid dat het politieke draagvlak is weggevallen, worden gerekend tot indirect vertrek.

Op de tweede plaats kunnen er in de praktijk rond wethouders situaties optreden, waarin zij het vertrouwen van de gemeenteraad nog hebben, maar toch gedwongen worden hun ambt op te geven. Dit kan het geval zijn als de eigen fractie geen steun meer wil geven aan de coalitie naar aanleiding van een bepaalde gebeurtenis of besluitvorming in de raad, dan wel de wethouder niet meer het vertrouwen van de eigen fractie geniet. Ook dit wordt in deze studie gerekend tot een indirect gedwongen vertrek.

\subsection{Centrale vraagstelling en onderzoeksperiode}

De vraag die centraal staat in dit onderzoek naar bestuurlijke probleemgemeenten in Nederland is in de kern terug te brengen tot zes woorden: wat is daar aan de hand? In onderzoekstermen luidt de centrale vraagstelling van het onderzoek:

Wat is de verklaring voor de aanhoudende crisissituaties en daarmee het gedwongen vertrek van burgemeesters, wethouders en/of hele colleges in bestuurlijke probleemgemeenten in Nederland in de periode maart 1998-maart 2010? 
In de onderzochte tijdsperiode, maart 1998 tot en met maart 2010, vallen drie collegeperioden: 1998-2002, 2002-2006 en 2006-2010. Er zijn drie redenen om voor deze tijdsperiode te kiezen. Op de eerste plaats is dat de komst van het dualisme, in maart 2002. Volgens veel bestuurders uit de praktijk de oorzaak van het voortijdig vertrek van veel gemeentebestuurders. Door de periode voor en na het dualisme te nemen, kunnen goede vergelijkingen worden gemaakt. Op de tweede plaats was op veel plaatsen in 2002 sprake van de opkomst of opleving van lokale partijen. Het zou kunnen dat ook deze ontwikkeling (zie hoofdstuk 3) effect heeft gehad op het gedwongen vertrek van gemeentebestuurders. De laatste reden is praktisch van aard: van de periode vóór 1998 is het beduidend lastiger (zo niet vrijwel onmogelijk) alle gedwongen vertrokken gemeentebestuurders in kaart te brengen, waardoor de kans op onvolledigheid te groot wordt.

\subsection{Onderzoekstrategie}

De centrale vraagstelling is opgedeeld in drie deelvragen. Deze deelvragen geven richting aan het onderzoek en gaan in op de gebruikte woorden 'verklaring' en de veronderstelde aanwezigheid van 'bestuurlijke probleemgemeenten' in Nederland.

De deelvragen luiden:

1. Wat zegt de bestaande literatuur over mogelijke verklaringen voor de aanhoudende bestuurlijke problematiek in bestuurlijke probleemgemeenten?

2. Welke gemeenten in Nederland zijn aan te duiden als bestuurlijke probleemgemeente in de periode maart 1998- maart 2010?

3. Welke verklaringen komen naar voren na analyse van de praktijk in bestuurlijke probleemgemeenten?

Voor de beantwoording van deelvraag 1 is bureauonderzoek gedaan naar de al beschikbare kennis over bestuurlijke probleemgemeenten en de mogelijkheden om dergelijke gemeenten te onderzoeken. Gekozen is om te werken met de analyse van Korsten en Aardema (2006), waarmee in gemeenten factoren worden onderscheiden, die de kans op het gedwongen tussentijds vertrek van wethouders, burgemeesters of hele colleges vergroten. De resultaten zijn samengevat in hoofdstuk 3, waar ook op drie andere mogelijke benaderingen van bestuurlijke probleemgemeenten wordt ingegaan. Op grond van dit materiaal is een aantal verwachtingen opgesteld, die in het empirisch deel van de studie zijn gebruikt in de analyse.

Om deelvraag 2 te kunnen beantwoorden is kwantitatief onderzoek naar bestuurlijke probleemgemeenten gedaan in Nederland en vitgezocht om hoeveel en welke gemeenten en om welke aantallen bestuurders het gaat. Hoofdstuk 4 geeft de resultaten weer van dit kwantitatief onderzoek, waarbij is geinventariseerd hoeveel burgemeesters, wethouders en hele colleges in alle Nederlandse gemeenten in de genoemde periode 1998-2010 gedwongen zijn vertrokken. Hiervoor werden diverse bronnen geraadpleegd, waarbij (naast materiaal uit ander onderzoek en vit de media) de rechtstreekse informatie van gemeenten zelf de belangrijkste bron is. Door deze informatie 
systematisch op te slaan is een totaaloverzicht van bestuurlijke conflicten en bestuurscrises in de Nederlandse lokale politiek in de periode 1998-2010 ontstaan. Uit dit overzicht blijkt welke gemeenten relatief (afgezet tegen de andere gemeenten) vaak te maken hebben (gehad) met conflicten of crises van bestuurlijke aard.

Het derde element van de onderzoekstrategie (deelvraag 3) betreft het praktijkonderzoek in enkele gemeenten. Hiervoor zijn casestudies gemaakt van vier bestuurlijke probleemgemeenten (hoofdstuk $5 \mathrm{t} / \mathrm{m} \mathrm{8}$ ), die op basis van het breedteonderzoek zijn geselecteerd (zie paragraaf 4.8).

De keuze voor het doen van casestudies is ingegeven door de volgende overwegingen. Een casestudy is volgens één van de definities een 'empirisch onderzoek, dat een hedendaags fenomeen onderzoekt in zijn alledaagse context, wanneer de grenzen tussen het fenomeen en de context niet zo duidelijk zijn en waarin verschillende waarnemingsmethoden worden gebruikt' (Yin, 1984). Voor het onderzoek naar bestuurlijke probleemgemeenten is de casestudy een bruikbare aanpak. Yin stelt dat onderzoek in de vorm van casestudy de voorkeur heeft, wanneer aan de volgende vier voorwaarden is voldaan (Yin, 1984: 16/20, geciteerd in Boskma en Herweijer, 1988: 59).

1. De probleemstelling heeft betrekking op een verklaring (waarom-vraag) of op een beschrijving van een longitudinaal proces (hoe-vraag).

2. Het waar te nemen verschijnsel kan niet worden gemanipuleerd, waardoor een experiment wordt vitgesloten.

3. Het te onderzoeken verschijnsel speelt zich af in het recente verleden, zodat men niet uitsluitend is aangewezen op secundaire (historische) bronnen en dus nog in de gelegenheid is direct betrokkenen te interviewen.

4. Het te onderzoeken verschijnsel kan niet worden waargenomen onafhankelijk van de context waarin het zich afspeelt, waardoor meer gestandaardiseerde vormen van gegevensverzameling minder goed toepasbaar zijn.

Onderscheidend is, aldus Boskma en Herweijer (1988: 59) dat bij een casestudy een verschijnsel in zijn 'real-life'context wordt bestudeerd. Daarbij zal het onderzoek vaak het proces betreffen en zich niet beperken tot een 'snap-shot' op een bepaald tijdstip.

In dit onderzoek, naar gemeenten waar veel bestuurscrises en bestuurlijke conflicten voorkomen, kan gesteld worden dat aan bovenstaande criteria en omschrijving wordt voldaan. De probleemstelling zoekt naar een verklaring en het waar te nemen verschijnsel kan niet worden gemanipuleerd. Bovendien spelen de situaties zich af in het heden of recente verleden, waardoor het houden van interviews met betrokkenen mogelijk is. Het te onderzoeken verschijnsel (het gedwongen vertrek van burgemeesters, wethouders of colleges) kan niet waargenomen worden zonder acht te slaan op de context waarin het zich afspeelt.

Wellicht zijn in een later stadium meer gestandaardiseerde vormen van gegevensverzameling toepasbaar. Dit onderzoek heeft echter een explorerend karakter: er zijn nog te weinig gegevens beschikbaar van bestuurlijke probleemgemeenten om tot een gestandaardiseerde meting te komen. 
De nadelen van casestudies zijn eveneens bekend en beschreven (vgl. o.a. Yin, 1984; Hertogh en Westerveld, 2009). Het gaat dan met name om het feit dat het proces van gegevensverzameling- en verwerking weinig gestandaardiseerd is en case-beschrijvingen vaak anekdotisch zijn, waardoor de grote lijn minder makkelijk herkenbaar wordt. Ook generalisatie naar grote populaties is een probleem met casestudies. In de wetenschap dat het doel van deze studie is om een eerste inzicht te krijgen in wat er aan de hand is of was in enkele concrete bestuurlijke probleemgemeenten, is de meervoudige casestudy echter een geschikte onderzoeksmethode, omdat er op een goede manier vergelijkingen kunnen worden gemaakt. En het maken van vergelijkingen zit in het hart van het empirisch wetenschappelijk onderzoek. We weten dat appels geen peren zijn, omdat we ze met elkaar hebben vergeleken. 'Comparison is a key operation in any empirical scientific effort' (Rihoux en Ragin, 2009: xvii).

Om de vergelijkbaarheid van de onderzochte situaties zo groot mogelijk te laten zijn en daardoor de betrouwbaarheid van de conclusies te vergroten, is bij de bestudering van elke gemeente op vaste wijze gewerkt. Als start van elke casestudy is relevante informatie verzameld, waaronder zowel gemeentelijke informatie, verslagen van raads- en commissievergaderingen als artikelen in lokale, regionale en landelijke media. Hierna zijn interviews afgenomen met betrokken gemeentebestuurders en ambtenaren. Hiervoor is een selectie gemaakt van hoofdrolspelers uit de gemeenteraad, het college en de ambtelijke organisatie, gespreid naar periode, waarbij in sommige gevallen de betrokkenen zicht hadden op het politieke spel in meerdere perioden. Voor elke casestudy is ook de Commissaris van de Koningin in de betreffende provincie geïnterviewd.

De interviews verliepen steeds volgens dezelfde structuur. Eerst werd de geïnterviewden gevraagd hun eigen visie op de gebeurtenissen te geven en daarbij ook hun eigen rol te belichten. Vervolgens kwamen in de vragen steeds alle relevante factoren aan de orde, met de vraag aan de hoofdrolspelers in te gaan op het belang en de relevantie van deze factoren. De informatie is gebruikt in de beschrijving van de cases. Triangulatie is toegepast door bij de vaststelling van gebeurtenissen en de verbanden daartussen gebruik te maken van meerdere bronnen en de gegevens over en weer te checken.

De geïnterviewden hebben inzage gekregen in het viteindelijke verhaal en ingestemd met eventuele citaten, al komen de conclusies geheel voor rekening van de onderzoeker. Sommigen gaven echter wel spontaan aan ook de hoofdlijn van de conclusies voor hun gemeente te delen, dus het met de conclusies eens te zijn. In sommige gevallen waren gesprekspartners het niet eens met hoe er door anderen over hun rol of inbreng gesproken werd. Dit is in de betreffende casestudy aan gegeven, waarbij tevens nader is gekeken naar de gang van zaken. Daarnaast verschilde soms per gesprekspartner de weging van sommige zaken, bijvoorbeeld met betrekking tot de vraag of een bepaald college in een bepaalde periode nu wel of niet als team functioneerde. De geïnterviewde wethouder(s) en de burgemeester hadden de neiging het college wel degelijk een team te vinden, terwijl anderen het college als 'los zand' neerzetten. Er is dus geen overeenstemming over de hele linie verkregen, maar dat was ook niet te verwachten. Als een groep van 10 à 15 personen terugkijkt op een gebeurtenis vanuit verschillende invalshoeken en verantwoordelijkheden, komen er niet als vanzelf gelijke inzichten. 


\section{Patroonvoorspelling}

Bij de vergelijking tussen de data uit de verschillende gemeenten is gekozen voor de methode van de 'patroonvoorspelling'. Boskma en Herweijer (1988) geven aan dat het er bij deze methode in de kern om gaat dat de onderzoeker voorafgaand aan bestudering van het betreffende proces een bepaald 'patroon' van verwachte uitkomsten formuleert. In dit onderzoek kan dit worden vertaald in een risicopatroon van relevante factoren. De vraag die na de casestudies moet worden beantwoord is: is er een bepaald terugkerend patroon vast te stellen?

$\mathrm{Na}$ het breedteonderzoek en het diepteonderzoek is antwoord te geven op de centrale vraagstelling. In hoofdstuk $g$ is de analyse van de resultaten beschreven. Een reflectie op de uitkomsten, waarin stof tot nadenken wordt gegeven, vindt plaats in hoofdstuk 10.

In het volgende hoofdstuk, hoofdstuk 2, volgt eerst een blik op de brede context waarin dit onderzoek plaatsvindt. 


\section{Lokaal bestuur en gedwongen vertrek anno 2010}

\section{$2.1 \quad$ Inleiding}

Dit onderzoek richt zich op bestuurlijke probleemgemeenten, waar in de periode maart 1998 - maart 2010 relatief veel gemeentebestuurders gedwongen tussentijds dienden te vertrekken. In dit hoofdstuk is aandacht voor de brede context waarin de problematiek in dergelijke gemeenten zich afspeelt. In paragraaf 2.2 wordt ingegegaan op de positie die gemeenten innemen in het bestuurlijk bestel in Nederland, de bestuurlijke structuur en verantwoordelijkheidsverdeling en de bijzondere kenmerken van lokale politiek. Hier kan worden aangesloten bij Boogers: "Om de lokale politiek beter te kunnen begrijpen en beoordelen, is het van belang om na te gaan wat de eigenstandige rol en positie is van de lokale politiek" (Boogers, 2007: 15). In paragraaf 2.3 is vervolgens aandacht voor een aantal ontwikkelingen op lokaal bestuurlijk niveau, zoals dat zich de afgelopen vijftien à twintig jaar heeft voorgedaan. Duidelijk zal worden dat er weinig structurele, maar wel culturele veranderingen zijn opgetreden. Geconstateerd kan worden dat het besturen van gemeenten door een aantal van deze ontwikkelingen beduidend ingewikkelder is geworden. Dit heeft onmiskenbaar een rol gespeeld in de toename van het aantal tussentijds vertrekkende gemeentebestuurders. In paragraaf 2.4 worden de meest recente cijfers hierover op een rij gezet. Aangetoond zal worden dat er sprake is van een geleidelijke stijging van het aantal gemeentebestuurders, in het bijzonder wethouders, dat tussentijds gedwongen moest vertrekken. Deze stijging zette al in de jaren negentig in en is nog niet tot stilstand gekomen. Ingegaan wordt op de begrippen vertrouwen en verantwoording, die hier een rol spelen. Tevens wordt een korte vergelijking gemaakt met vertrek van bestuurders op andere bestuursniveaus en in andere landen. Het hoofdstuk eindigt met een conclusie in paragraaf 2.5.

\subsection{Gemeenten en lokale politiek}

Het staatsrechtelijk begrip 'gemeente' werd voor het eerst gebruikt in de Staatsregeling van 1798 van de Bataafse Republiek (Ministerie van BZK, 1998: 3). Een halve eeuw later, in 1848, kregen de gemeenten in Nederland in de nieuwe Grondwet autonomie en verwierven zij definitief hun plaats in het constitutionele bestel. In de Gemeentewet van 1851 werd daarnaast de mogelijkheid van het opdragen van medebewind opgenomen. Om elke twijfel aan de grondwettigheid daarvan weg te nemen, werd bij de grondwetswijziging van 1887 ook in de Grondwet van de mogelijkheid van medebewind voor het lokaal bestuur melding gemaakt. De lokale besturen werden onder het regime van dezelfde wet- en regelgeving gebracht. In een voor elk dorp en elke stad gelijkgeldend wettelijk kader kregen gemeenten, naast medebewindstaken, het recht van initiatief (de mogelijkheid om al hetgeen te doen wat hen goed leek) en de instrumenten om integrale besluitvorming te plegen (Willemse, 2001: 1; ook Veldheer, 1994). Aan het gemeentebestuur is in Nederland een zestal kenmerken te onderscheiden (Derksen en Korsten, 1985, 1989; Korsten en Tops, 1998: 15). Het gemeentebestuur heeft de jurisdictie over een specifiek grondgebied (1), is onderdeel van een bestuurlijk 
stelsel (2), het hoogste lokaal bestuur, de gemeenteraad, wordt democratisch verkozen (3), het gemeentebestuur heeft eigen inkomsten en het recht om belasting te heffen (4), het gemeentebestuur is algemeen en integraal bestuur (5) en het takenpakket is in principe onbeperkt (open huishouding), waarbij er wel beleidsmatige begrenzingen door regelgeving van een hogere overheid mogelijk zijn (6).

Het maken van de nodige lokale politieke keuzen gebeurt in gemeenten door de burgemeester, het college van B\&W en de gemeenteraad, ieder voor de eigen bevoegdheden. De gemeenteraad staat formeel aan het hoofd van de gemeente, de vergadering van de raad is de arena voor het bedrijven van lokale politiek. In de kern gaat het daarbij, net als op andere overheidsniveaus, om het 'verwerken' van vraagstukken tot gedragen oplossingen. Hieruit vloeit gedrag voort dat in de praktijk politiek is gaan heten, waarbij het gaat om het behartigen van (algemene) belangen, sluiten van compromissen, profileren, etcetera. De verschillende opvattingen worden gerepresenteerd door politieke partijen, die van elkaar kunnen afwijken doordat zij (gedeeltelijk) andere oplossingen voor de vraagstukken voor ogen hebben.

In die zin is meningsverschil in elk politiek systeem, dus ook op lokaal niveau, ingebouwd. "Welke definitie je ook hanteert (en er zijn er vele), politiek gaat in de kern over het oplossen of hanteerbaar maken van verschillen van mening" (Van Stipdonk en Leeuwenburg, 2007: 28). Meningsverschillen horen dus bij politiek, ook op lokaal niveau, en dat is van alle tijden (zie kader).

\section{Spanning in de gemeente}

Spanningen zijn er al vanaf het ontstaan van de Nederlandse gemeenten in de huidige vorm, in 1848. Raden wilden 100 jaar geleden al niet altijd wat het college voorstelde, concludeerde Van Poelje in 1914:"In de meeste gemeenten is de Raad behoedzaam, niet tot het nieuwe geneigd, en vóór alles bevreesd voor belastingverhooging. Zoolang het geen geld kost, mag 'men' doen wat men wil, zoodra er extra uitgaven noodig zijn, klinkt het veto. En zoo is dit het moeilijkste deel van de taak des burgemeesters èn van den secretaris, èn dikwijls van het 'stadhuis', van de 'secretarie' als geheel (wat de groote gemeenten aangaat, behooren hierbij ook nog de wethouders genoemd te worden; dáár behoorden ook dezen tot het ambtelijke deel van het bestuur; in de kleine gemeenten is de rechtstreeksche invloed der wethouders dikwijls zeer gering), om, wanneer men ten volle er van overtuigd is, dat een bepaalde maatregel door het belang der gemeente onafwijsbaar wordt vereischt, langzamerhand, langs zeer geleidelijk stijgende paden, den Raad tot de erkenning van die noodzakelijkheid te brengen. Zeldzaam moeilijk is dit vaak, en wie wel eens het oor te luisteren heeft gelegd, hoorde eindelooze klachten van burgemeesters van allerlei richting en gezindte over de moeite, die het vaak kost den Raad mee te krijgen, dikwijls waar het groote belangen van de gemeente geldt. Moeten we nu daarom al deze menschen schavotteeren als warhoofden, die van de beginselen van ons gemeenterecht geen benul hebben, en niet beseffen, dat daarvan het eerste en grootste is de erkenning van de souvereniteit van den gemeenteraad in zijnen kring?.... Neen, eerlijk en moeizaam hebben zij getracht, en trachten zij nog steeds, hun raden te overtuigen dat er wat gedaan moet en kan worden en dat de eerste en eenige taak van het gemeentebestuur niet is de belastingen laag te houden"

(Van Poelje, 1914: 27). 


\section{Drie verschillen}

Het maken van keuzen in de lokale politiek onderscheidt zich op drie fronten van provincie en Rijk. Het meest duidelijke verschil is dat het lokale politieke systeem zich op korte afstand van de inwoners voltrekt. De lokale politiek is nabij, lokale politiek gaat over de directe leefomgeving van de inwoners van een gemeente, over openbare orde, huisvesting en cultuur. "De nabijheid kenmerkt zich ook door een grotere toegankelijkheid van de bestuurders: in de lokale politiek kunnen burgers gemakkelijker hun wensen en opvattingen kenbaar maken en kunnen volksvertegenwoordigers zich gemakkelijker hierover laten informeren" (Boogers, 2007: 16). Hier staat tegenover dat belangentegenstellingen en inhoudelijke meningsverschillen door die nabijheid minder makkelijk kunnen worden verhuld in compromissen of andere algemene uitspraken. Het verschil tussen beleid en uitvoering is in de praktijk soms niet zo groot, waardoor de politieke besluitvorming vrij rechtstreeks doorwerkt bij de inwoners. Een partij is voor of tegen de herinrichting van een bepaalde straat, de invoering van betaald parkeren, de bouw van een nieuw zwembad. Hierdoor liggen conflicten op praktisch niveau op de loer: "Omdat raadsleden door burgers worden aangesproken op de spreekwoordelijke scheve stoeptegels en andere uitvoeringskwesties, zullen ze die in de gemeenteraad als een politiek probleem presenteren. In zekere zin is dat eigen aan het karakter van de lokale politiek. Wat elders een bestuurlijk onderwerp is, wordt in de gemeente opgevat als politiek, en andersom. In tegenstelling tot de uitvoering van het rijksbeleid, kunnen lokale uitvoeringspraktijken vaak de inzet zijn van grote politieke conflicten" (Boogers, 2007: 127).

Buiten de korte afstand zijn ander kenmerken van lokale politiek dat bij de gemiddelde gemeente de beleidsruimte beperkter is en de vraagstukken minder ideologisch van aard zijn, of minder makkelijk in een ideologisch perspectief te plaatsen zijn (vgl. Tops en Zouridis, 2002). Natuurlijk is de ene gemeente de andere niet en zijn er gemeenten met grote en brede vraagstukken op het bord. Toch verzuchten lokale bestuurders in de praktijk wel eens dat de verschillen tussen de opvattingen van de lokale partijen op de keper beschouwd niet zo groot zijn. En als er al initiële kleurverschillen zijn tussen partijen in hun kijk op beleid, dan ontstaat toch geleidelijk een proces van 'van kleur verschieten', soms zo dat bijvoorbeeld een links verkeersveiligheidsbeleid nauwelijks van een ander veiligheidsbeleid te onderscheiden is (Tops, Korsten en Schalken, 1994). Het is voor veel deelnemers aan de lokale politiek iedere vier jaar weer een hele toer om een onderscheidend verkiezingsprogramma te maken. Kun je liberaal vuilnis laten ophalen of op sociaal-democratische wijze paspoorten verstrekken? Toegegeven, het is wat gechargeerd, maar in de kern is de beleidsruimte over veel thema's op lokaal niveau niet groot en is de inzet meer praktisch en minder ideologisch van karakter. Er heerst in Nederland in gemeenten een relatief apolitieke cultuur, concluderen Tops en Zouridis (Tops en Zouridis, 2002: 18).

In de praktijk blijkt tevens dat partijen die met elkaar een compromis hebben bereikt over een bepaalde ontwikkeling in een gemeente, in een verkiezingsprogramma niet zo snel terugvallen op hun eerste uitgangspunten, maar dat compromis overnemen of in ieder geval aanvaardbaar noemen. Hierdoor kan op beleidsniveau op veel punten een vervlakking van de verschillen optreden, terwijl tegelijkertijd het aantal nieuwe vraag- 
stukken in aard en omvang in de meeste gevallen beperkt en overzichtelijk is. Een gevaar schuilt hier ook in: door de relatief kleine hoeveelheid discussiepunten kan het zijn dat de strijd over punten, waar partijen zich wel op profileren, harder wordt.

Kortom: politiek op gemeentelijk niveau gaat in principe om het maken van keuzen. De afstand tot de inwoners is echter korter, terwijl de beleidsruimte kleiner is en de onderwerpen die zich aandienen ook minder ideologisch van aard zijn. Dat maakt lokale politiek bijzonder. Boogers concludeert tevens dat lokale politiek een eigen plaatselijke logica en dynamiek heeft, die zich onderscheidt van politieke processen op andere bestuursniveaus en die verschilt van de lokale politiek in andere gemeenten. "Wie zich in de lokale politiek verdiept, komt erachter dat het een heel eigen soort politiek is. Het is politiek, maar niet zoals we politiek doorgaans aanschouwen" (Boogers, 2007: 128).

\subsection{Nieuwe ontwikkelingen}

De afgelopen decennia hebben zich grote veranderingen voorgedaan in de politiekbestuurlijke verhoudingen in de Nederlandse gemeenten. Boogers, Denters en Reusing (2010) vergeleken de situatie in het lokaal bestuur in 1995 met de situatie anno 2010 op het gebied van intergouvernementele verhoudingen, politiek-electorale verhoudingen en de verhoudingen binnen het gemeentebestuur en onderscheiden de volgende ontwikkelingen: schaalvergroting en decentralisatie, vermaatschappelijking, politieke versplintering, problemen rond partijpolitiek, verzakelijking en dualisering. Ook de verdergaande 'politisering' (zie Korsten en Tops, 1998) kan hierbij nog genoemd worden. Deze veranderingen komen hieronder kort aan bod. Aan het einde van de paragraaf volgt een korte samenvatting, waarin wordt aangegeven welke invloed deze ontwikkelingen hebben (gehad) op het functioneren van gemeentebestuurders.

\section{Schaalvergroting en decentralisatie}

Als er één zaak onmiddellijk opvalt in het lokaal bestuur in Nederland, is het de voortgaande schaalvergroting, waarbij kleinere gemeenten zijn samengevoegd of opgegaan in grotere gemeenten. Als gevolg hiervan is het aantal gemeenten de laatste eeuw geleidelijk gedaald. In tabel 1 is een vergelijking opgenomen tussen het aantal gemeenten in 1900 en het aantal gemeenten in 2010, met een verdeling over inwonertal.

Tabel 1: Inwoneraantal gemeenten in 1900 resp. 2010

\begin{tabular}{|l|c|c|}
\hline Inwoneraantal & Aantal gemeenten in 1900 & Aantal gemeenten in 2010 \\
\hline Minder dan 10.000 & $918(=82 \%)$ & $45(=10,4 \%)$ \\
\hline $10.000-20.000$ & $179(=16 \%)$ & $179(=41,5 \%)$ \\
\hline $20.000-50.000$ & $16(=1,4 \%)$ & $138(=32,1 \%)$ \\
\hline $50.000-100.000$ & $4(=0,3 \%)$ & $43(=10,0 \%)$ \\
\hline 100.000 en groter & $4(=0,3 \%)$ & $26(=6,0 \%)$ \\
\hline Totaal & $1.121(=100 \%)$ & $431(=100 \%)$ \\
\hline Bron: CBS, opgave maart 2010 & \\
\hline
\end{tabular}

Duidelijk is te zien dat het aantal gemeenten met een inwoneraantal van minder dan 10.000 inwoners enorm is gedaald. De daling is vooral de laatste 50 jaar opmerkelijk snel gegaan. Tussen 1960 en 2010 is het aantal gemeenten ruim gehalveerd, van 994 in 
1960 tot 431 in 2010. In relatie met deze daling nam het aantal inwoners per gemeente toe. Op 1 januari 2010 woonden er gemiddeld 38.485 mensen in een gemeente.

De schaalvergroting ging gepaard met een tweede trend: decentralisatie, vooral op het gebied van zorg, welzijn, onderwijs en arbeidsvoorziening. Gemeenten kiezen hierbij soms voor intergemeentelijke samenwerkingsverbanden.

\section{Vermaatschappelijking}

Een derde trend vanaf 1995 is de vermaatschappelijking van het lokaal bestuur. "Het besturen van de gemeente is niet meer een zaak van het gemeentebestuur alleen, maar is een samenspel tussen de verschillende onderdelen van het gemeentebestuur, instellingen, bedrijven, organisaties en individuele inwoner"(Boogers, Denters en Reussing, 2010: 11). Een ontwikkeling die voort kwam uit de wens voor een kleinere overheid, meer democratisering (onder druk van dalende opkomstcijfers bij gemeenteraadsverkiezingen) en effectiviteitsoverwegingen: door de kennis van lokale spelers te benutten zou de effectiviteit van het beleid vergroot kunnen worden. Deze vermaatschappelijking van het bestuur leidde onder meer tot meer publiek-private arrangementen, maar ook tot een opleving van het wijk- en gebiedsgericht werken, ieder ook weer met eigen problemen op het gebied van democratische controle en sturing.

\section{Politieke versplintering}

De afgelopen decennia is er tevens sprake geweest van een grote mate van politieke versplintering. De aanhang van de grotere partijen kalfde af, ten gunste van lokale spelers (Korsten en Kuiper, 1991; Janssen en Korsten, 1995; Boogers en Keizers, 1991; Ohlenforst, 1992; Van Tilburg, 1993; Euser, 2009). In dit verband kunnen ook de zogeheten one-issue-partijen worden genoemd, partijen die een plek in de gemeenteraad proberen te veroveren op basis van één in het oog springend punt. Geen Windmolens Rijnwoude, een partij uit de Zuid-Hollandse gemeente Rijnwoude, is zo'n voorbeeld. Overigens zonder ook maar te suggereren dat in deze partijen alleen maar conflictzoekers zouden zitten, wordt in de wetenschap wel gesignaleerd dat de raadsleden voor deze partijen vaak minder ervaren zijn dan hun collega's van de ook in Den Haag vertegenwoordigde bestuurderspartijen: "De 'afbrokkeling' van lokale macht bij de klassieke bestuurspartijen CDA (in het zuiden vanaf 1980 voortdurend een stabiele factor) en PvdA (in de steden) en de introductie van nieuwe (onervaren) spelers in de lokale politieke arena (met name ook in het college van B\&W), kan eveneens bijdragen aan een toename van conflicten en crises. Zo is een aantal 'affaires' sinds 1994 veroorzaakt door of heeft te maken met de 'nieuwe spelers' " (Tops en Zouridis, 1998: 421).

In het begin van de jaren zeventig werd het succes van de lokale lijsten vooral behaald in Noord-Brabant en Limburg. Zo werd in 1974 in Noord-Brabant niet minder dan 72\% van de stemmen uitgebracht op lokale lijsten, gevolgd door Limburg met 51\%. In andere delen van Nederland was er ook aanhang voor lokale lijsten, maar dan vooral in kleinere gemeenten. In gemeenten met meer dan 100.000 inwoners is er nauwelijks aanhang voor lokale lijsten, minder dan twee procent. De belangstelling voor de lokale lijsten is behoorlijk toegenomen na het succes bij de gemeenteraadsverkiezingen in 1994. De positie van lokale lijsten was tot die tijd namelijk verslechterd (Van Tilburg, 1993: 31-66 en 195-6). De verkiezingen in 2002 waren een absoluut hoogtepunt voor de 
lokale lijsten, met een percentage van 26,3\%. Bij de verkiezingen in 2006 daalde dit aantal weer licht.

\section{Problemen voor partijen}

Een volgende trend is het feit dat het functioneren van politieke partijen problematischer is geworden. Door de individualisering en ontzuiling is de binding tussen partijen en kiezers grotendeels verdwenen (vgl. Janssen en Korsten, 1995). Steeds minder burgers voelen duurzame verbondenheid met een partij, steeds meer mensen beslissen op het moment zelf op welke partij zij hun stem zullen uitbrengen, aan de hand van actuele thema's en stellingnames. Lokale partijen hebben ook steeds meer moeite leden te werven of vast te houden.

Partijen en de voor deze partijen optredende personen proberen zich hierdoor scherper te profileren. Dit leidt soms tot een zekere verruwing in het politieke taalgebruik. Bekend is het voorbeeld van een minister uit het kabinet Balkenende IV, die door een parlementariër voor 'knettergek' werd verklaard. Maar ook op lokaal niveau loopt het soms uit de hand. "In de gemeenteraad van Rotterdam wordt publiekelijk gediscussieerd over de vraag waarom je iemand niet 'eikel' mag noemen, maar wel 'flapdrol'. Als je in de politiek zo grensverleggend bezig bent, hoef je viteindelijk niet op veel respect van de bevolking te rekenen", aldus CDA-senator Jos Werner (geciteerd in NRC Handelsblad, 141009).

\section{Van personen naar partijen}

Inwoners stemmen, ook op lokaal niveau, op één van de kandidaten van de aan de verkiezingen deelnemende politieke partijen. Dat is niet altijd zo geweest. Het huidige Nederlands stelsel van politieke partijen ontstond pas aan het einde van de negentiende eeuw. Daarvoor werden de volksvertegenwoordigers op basis van het in 1848 ingevoerde censuskiesrecht als persoon gekozen en dienden zij te handelen naar eigen inzicht en, in de woorden van Thorbecke, 'zonder eenigen band met de kiezers'. Die ongebondenheid staat overigens nog steeds in de Gemeentewet, waar in artikel 27 is bepaald dat de 'leden van de raad stemmen zonder last.' Aan het einde van de 19e eeuw kwam een ontwikkeling op gang naar meer partijgebondenheid. Van Poelje beschrijft in zijn bijdrage 'Met ledige handen' in het Gedenkboek Gemeentewet 1851-1951 dat "vóór de invoering van de evenredige vertegenwoordiging van bijna alle gemeenten gemeld werd, dat de raad niet meer te zien was als een verzameling van individuen, die ieder naar beste weten het openbaar belang dienden, maar als een vereniging van politieke groepen. Het houden van afzonderlijke fractievergaderingen voor de vergaderingen van de raad was ook toen reeds normaal" (Van Poelje, 1951: 90). Borrie vermeldt in zijn Wibaut-biografie: "Dat er verandering in de lucht zat, bleek echter al in de jaren 1890 in Amsterdam: voor het eerst zou de gemeenteraad de kenmerken van een politiek lichaam gaan vertonen" en "de gemeenteraden (gaan) omstreeks 1900 steeds meer het karakter (...) krijgen van een platform voor het verkondigen van politieke meningen" (Borrie, 1968: 80). De Raad voor het openbaar bestuur (Rob) gaat in haar advies over politieke partijen in op deze ontwikkeling. "In het parlement kristalliseerden de politieke stromingen zich langzamerhand tot 'Kamerclubs', het prototype van de fractie. In het land vormden zich lokale kiesverenigingen, die kandidaten selecteerden en deze bij het beperkte 
kiezerscorps aanbevolen. Gaandeweg bundelden zij zich en zochten samenwerking met geestverwante parlementaire fracties. Hiermee kwam aan het einde van de negentiende eeuw de moderne, hechte partijorganisatie te voorschijn" (Rob, 2009: $11)$.

De invoering van het stelsel van evenredige vertegenwoordiging en het algemeen kiesrecht in 1917 (voor mannen) en in 1919 (voor vrouwen) stimuleerden de ontwikkeling en centralisering van het partijstelsel. Het kiesrecht was niet langer meer aan sexe en inkomen gebonden en het werd mogelijk als politieke partij of groepering een kandidatenlijst in te dienen. Dit betekende een hele omslag voor de zittende bestuurders. Het bekleden van politieke functies, omschrijven Boogers en Keizers (1991: 31), was nu ineens afhankelijk geworden van een brede steun onder de bevolking. Uiteindelijk zou zo het partijstelsel geboren worden en was er voor eenlingen geen plek meer. De politieke partijen vormden zich op deze manier en organiseerden zich op landelijk, provinciaal en lokaal niveau. Met de komst van de lijsten is de huidige manier van het opstellen van lijsten ontstaan en de verkiezing van personen via partijen.

\section{Verzakelijking}

De schaalvergroting betekende ook iets voor de manier waarop gemeenten dienen te worden 'gemanaged'. Steeds meer aandacht ging uit naar de wens om bedrijfsmatig en op resultaat gericht te werken, zeker onder invloed van het New Public Management (Osborne en Gaebler, 1992). Van dagelijks bestuurders wordt in het algemeen steeds meer gevraagd, concluderen Castenmiller c.s.. "Ze moeten in staat zijn over complexere en abstractere vraagstukken te oordelen en een standpunt in te nemen. Temeer daar door decentralisatie het gemeentelijk takenpakket de afgelopen decennia is vergroot. Ook al gebeurt het vaak in medebewind, gemeenten zullen het rijksbeleid een plaats moeten geven en de lokale politieke keuzen moeten maken. Zo bezien worden ook aan een wethouder nu hele andere eisen gesteld dan 25 jaar geleden" (Castenmiller c.s., 2010: 5).

\section{Politisering}

$\mathrm{Er}$ is in het algemeen sprake geweest van een zekere mate van politisering van het bestuur (zie Korsten en Tops, 1998: 24, Castenmiller c.s. 2010: 6). Deze politisering vormt de weerslag van maatschappelijke veranderingen als ontzuiling, individualisering en in het algemeen een kritischer houding ten opzichte van gezagsdragers. Door de ontzuiling (vgl. Lijphart, 1984: 35) laten mensen zich minder dan voorheen leiden door richtinggevende kaders vanuit de zuilen of maatschappelijke organisaties waarbij ze zich betrokken voelen; in toenemende mate wordt door burgers voor een eigen leefwijze gekozen. Mensen zijn anno 2010 bovendien hoger opgeleid, geïndividualiseerd en daarmee kritischer geworden. Als je zelf over zaken na gaat denken, kom je tot andere inzichten en opvattingen dan in een tijd waarin anderen voor je dachten. "Depillarization radically changed the relations between local politicians and their electorates, gradually broke up previously close relations between pillar parties and 'their' organizational networks", concluderen Denters en Klok (in: Denters en Rose, 2005: 71).

De individualisering en het versterken van het zelf nadenken zijn alleen maar groter geworden. Mensen hebben een scherper beeld gekregen van hun eigen belangen en 
weten daar ook beter voor op te komen. Regelmatig blijken die belangen te botsen en daarmee is de samenleving politieker geworden (politiek in de zin van het beslechten van belangentegenstellingen). Dat stelt meer eisen aan een politiek-bestuurlijk systeem dan in een tijd waarin dat systeem de mogelijke belangentegenstellingen signaleerde en afhandelde. Dit heeft het effect dat lokaal bestuur niet meer vanzelfsprekend als legitiem wordt ervaren; een beroep op het 'algemeen belang' is doorgaans ontoereikend om beslissingen gezaghebbend te doen zijn. Er is sprake van een meer kritische houding ten opzichte van gezagsdragers.

\section{Dualisering}

Tot slot is een belangrijke verandering de wijziging van de Gemeentewet in het begin van deze eeuw, waarbij de dualisering op lokaal niveau haar intrede deed. Met de invoering werd bewerkstelligd dat, anders dan voor 2002, de gemeenteraad als volksvertegenwoordigend orgaan een eigen en zelfstandige positie in ging nemen ten opzichte van het 'dagelijks bestuur', het college van burgemeester en wethouders. Daar waar wethouders tot 2002 lid waren van de gemeenteraad, waren zij dat na maart 2002 niet meer. Wethouders konden ook geen voorzitter van bijvoorbeeld een raadscommissie meer zijn. Gemeenteraad en college kregen enkele andere bevoegdheden en verantwoordelijkheden. De raadsleden zouden zich meer op kaderstelling, controle en vertegenwoordiging moeten gaan richten en de leden van het college meer op het (dagelijks) bestuur. De doelstelling van de invoering van het dualisme was om de afstand tussen burger en bestuur te verkleinen en de lokale democratie te vernieuwen. Het debat moest weer terugkomen in de gemeenteraad. Inwoners moesten meer betrokken worden bij beleidsvoorbereiding en besluitvorming. Raadsleden zouden meer tijd moeten krijgen voor contact met hun achterban. De Stuurgroep Evaluatie Dualisering Gemeentebestuur omschrijft in haar eindrapport van 15 december 2004 de memorie van toelichting bij de wet dualisering gemeentebestuur: "De dualisering impliceert volgens de memorie van toelichting voor een deel een aanpassing van de situatie aan de gegroeide bestuurspraktijk en draagt verder bij aan een verduidelijking van de rollenscheiding tussen het bestuur en de controle op het bestuur, aan een versterking van de eenheid van het beleid van B\&W en aan een versterking van de positie van de politieke partijen in de lokale democratie"(Stuurgroep Evaluatie Dualisering Gemeentebestuur, 2004: 10).

In het duaal functionerende lokale bestuur zou de gemeenteraad zich dienen te concentreren op contacten met de achterban en op het opstellen van algemene kaders van beleid (kaderstelling). Het college van B\&W zou binnen deze kaders (die van financiële aard zouden kunnen zijn, maar ook op andere terreinen richting zouden kunnen geven), de gemeente vervolgens kunnen besturen. Als de burgemeester of de wethouders tijdens hun bestuurlijk werk op nieuwe of andere informatie stuiten, die voor de raad van belang is, dienen zij de raad daar terstond over te informeren, op grond van de in de wet geformuleerde actieve informatieplicht. De gemeenteraad heeft de taak te controleren of het college binnen de kaders is gebleven en beschikt hiervoor onder meer over de jaarrekening en begroting (budgettaire bevoegdheid).

Overigens is het dualisme met betrekking tot de controlefunctie van de raad niet nieuw. De Gemeentewet kende vanaf het begin een vorm van verantwoordingsplicht van het 
college jegens de raad. Bestuurskundige G.A. van Poelje schreef er al over in Hedendaagsch Gemeenterecht uit 1914. In dit werk gaat hij in op de spanning die er kan bestaan tussen het college van B\&W en de gemeenteraad, die hij overigens al eens, met alle eerbied, een 'instituut voor restverwerking' noemde (Tops en Zouridis, 2002: 25). De taak van deze gemeenteraad is, zo beschrijft Van Poelje, in de loop der tijd omgeslagen van besturen naar controleren. Precies de bedoeling, aldus de auteur, die ook verwijst naar J. Stuart Mill: "Instead of the function of governing, for which it is radically unfit, the proper office of a representative assembly is to watch and control the government... The only task to which a representative assembly can possibly be competent, is not that of doing the work, but of causing it to be done; of determining to whom or to what sort of people it shall be confided, and giving or withholding the national sanction to it, when performed... A representative assembly which attempts to decide on special acts of administration... At its best, it is inexperience sitting in judgment on experience, ignorance on knowledge" (Van Poelje, 1914: 49).

Gelijktijdig met de invoering van de dualisering werd het niet meer noodzakelijk dat wethouders uit de gemeenteraad voort komen. Zij kunnen ook 'van buiten' worden aangetrokken en, na te zijn benoemd door de gemeenteraad, aan de slag gaan als wethouder in de betreffende gemeente. Hiervoor dienen zij overigens wel ieder jaar te worden ontheven van de verhuisplicht, wat in sommige gemeenten tot politieke problemen op zich leidt. Uit onderzoek blijkt dat inmiddels bijna $25 \%$ van de wethouders van buiten de raad komt (zie tabel 2). Kennelijk is deze mogelijkheid in veel gemeenten aangegrepen om het wethouderspotentieel vit te breiden.

Tabel 2: Percentage wethouders van buiten de raad, gespecificeerd naar gemeentegrootte

\begin{tabular}{|l|c|c|c|}
\hline $\begin{array}{l}\text { Gemeentegrootte } \\
\text { In aantal inwoners }\end{array}$ & $\begin{array}{c}\text { Wethouders } \\
\text { van buiten de } \\
\text { raad }\end{array}$ & $\begin{array}{c}\text { Wethouders van } \\
\text { buiten de raad en van } \\
\text { binnen de gemeente }\end{array}$ & $\begin{array}{c}\text { Wethouders van } \\
\text { buiten de raad en van } \\
\text { buiten de gemeente }\end{array}$ \\
\hline$<10.000$ & 24,4 & 16,8 & 7,6 \\
\hline $10.000-20.000$ & 19,2 & 13,4 & 5,9 \\
\hline $20.000-50.000$ & 22,9 & 18,2 & 4,7 \\
\hline $50.000-100.000$ & 26,1 & 18,7 & 7,4 \\
\hline$>100.000$ & 28,6 & 23,6 & 5,0 \\
\hline Totaal & 23,0 & 17,4 & 5,6 \\
\hline Bron: Min. BZK, Staat van het bestuur 2008
\end{tabular}

Bovenstaande ontwikkelingen hebben de aard van het werk van gemeentebestuurders veranderd. Door de schaalvergroting en decentralisatie werd hun werkveld groter, terwijl door de vermaatschappelijking en verzakelijking andere eisen aan hun capaciteiten werden en worden gesteld. Bovendien is het politieke klimaat door de verdergaande politisering verhard, aangewakkerd door het feit dat partijen zich sterker moeten profileren, in een poging de steeds grotere groep zwevende kiezers voor zich te winnen.

Tenslotte heeft ook de dualisering haar intrede gedaan, waardoor veel gemeentebestuurders een in toenemende mate kritische raad tegenover zich kregen. Al deze ontwikkelingen hebben in meer of mindere mate invloed gehad op de laatste onmiskenbare trend: het aantal tussentijds vertrokken gemeentebestuurders is de afgelopen jaren sterk gestegen. 


\subsection{Gedwongen tussentijds vertrek van gemeentebestuurders}

De laatste opvallende ontwikkeling is ongetwijfeld het de afgelopen decennia toegenomen tussentijds vertrek van gemeentebestuurders. Hierbij kan een onderscheid worden gemaakt tussen het vertrek van burgemeesters en dat van wethouders.

\section{Burgemeesters}

Ten aanzien van het vertrek van burgemeesters dient op de eerste plaats gesteld te worden dat het op zich niet verwonderlijk is dat zij tussentijds vertrekken. Anders dan wethouders, die in principe na de gemeenteraadsverkiezingen door de raad worden benoemd voor vier jaar, hebben burgemeesters een benoeming voor zes jaar, die los staat van de verkiezingen. Bovendien is in de loop der jaren gebleken dat het burgemeesterschap allang geen baan meer voor het leven is. Steeds vaker vragen gemeenteraden in hun profielschets naar een burgemeester, die de betreffende gemeente 'niet als eindstation ziet', zo blijkt uit de door de gemeenteraad vastgestelde profielschetsen van nieuwe burgemeesters voor onder meer de gemeenten Coevorden (2004), Lochem (2005), Ommen (2006) en Menterwolde (2006). Dat betekent dus dat de betreffende sollicitanten de bedoeling moeten hebben op enig moment op te stappen en een nieuwe vitdaging elders aan te gaan.

Op zich is het dus te billijken dat burgemeesters tussentijds opstappen. Hier kunnen, zo blijkt uit informatie van het Ministerie van Binnenlandse Zaken, meerdere redenen voor zijn. De voornaamste redenen voor burgemeesters om hun functie neer te leggen zijn het aanvaarden van een nieuwe functie in het ambt en vervroegd pensioen (Staat van het bestuur, 2006: 125). Toch lijkt er een stijging te zitten in het aantal gedwongen vertrokken burgemeesters. Korsten, Aardema en Resoort komen tot een totaal van 49 gedwongen vertrokken burgemeesters in de periode januari 2000 - juli 2008 (Korsten, Aardema en Resoort, 2008: 12). Het ministerie van BZK telt in de periode 2000 - april 2010 het aantal van 60 gedwongen vertrokken burgemeesters (Ministerie BZK, 2010: 112). Meer nog dan bij wethouders is er veel publiciteit rond burgemeesters, die het vertrouwen van de raad verliezen of dreigen te verliezen. Dit geldt in ieder geval voor de lokale en regionale pers, maar de laatste jaren is er ook steeds massaler aandacht van de landelijk opererende media.

\section{Wethouders}

Ook het gedwongen vertrek van wethouders staat de laatste jaren behoorlijk in de schijnwerpers. Uit diverse bronnen (Bouwmans, v.a. 2004; Castenmiller C.S., 2006; Carabain, 2009) komt een wisselend beeld over de omvang naar voren. De tellingen beginnen vrijwel allemaal begin jaren negentig. Eerder materiaal is er in meer globale vorm (Tops, 1990). Castenmiller c.s. publiceerden in 2010 een totaaloverzicht, opgesteld in opdracht van het Ministerie van BZK. Zij legden de verschillende cijfers over vertrokken wethouders naast elkaar en kwamen tot een aantal constateringen. De conclusie is dat het aantal vertrokken wethouders al 25 jaar aan het stijgen is, in tegenstelling tot de opvatting dat deze stijging vooral na de eeuwwisseling is ingezet. 
Het totaaloverzicht ziet er als volgt uit:

Tabel 3: Afgetreden wethouders per bestuursperiode

\begin{tabular}{|l|c|c|c|c|}
\hline $\begin{array}{l}\text { Bestuurs- } \\
\text { periode }\end{array}$ & $\begin{array}{c}\text { Aantal gemeen- } \\
\text { ten bij aanvang } \\
\text { periode }\end{array}$ & $\begin{array}{c}\text { Aantal } \\
\text { afgetreden } \\
\text { wethouders }\end{array}$ & $\begin{array}{c}\text { Totaal aantal } \\
\text { wethouders bij } \\
\text { aanvang periode }\end{array}$ & $\begin{array}{c}\text { Afgetreden } \\
\text { wethouders over } \\
\text { bestuursperiode }\end{array}$ \\
\hline $1986-1990$ & 714 & 374 & 1854 & $20 \%$ \\
\hline $1990-1994$ & 672 & 359 & 1799 & $20 \%$ \\
\hline $1994-1998$ & 636 & 456 & 1726 & $26 \%$ \\
\hline $1998-2002$ & 548 & 444 & 1677 & $26 \%$ \\
\hline $2002-2006$ & 496 & 464 & 1648 & $28 \%$ \\
\hline $2006-2010$ & 458 & 449 & 1513 & $30 \%$ \\
\hline Bron: Castenmiller c.s., 2010 & \multicolumn{5}{l}{} \\
\hline
\end{tabular}

Uit de tabel blijkt dat het percentage afgetreden wethouders is gestegen van $20 \%$ in de periode 1986-1990 tot 30\% in de periode 2006-2010. De sterkste stijging vond plaats in de jaren negentig. Hierbij dient wel opgemerkt te worden dat het daarbij gaat om het totale aftreden, dat wil zeggen om alle mogelijke oorzaken, vitgezonderd herindeling. Een uitsplitsing naar gedwongen vertrek om politieke redenen is niet gemaakt voor de hele periode. Uit de cijfers die hierover wel beschikbaar zijn blijkt dat dit percentage is gestegen, van $25 \%$ in de periode $1986-1990$ naar $57 \%$ in de periode 1994 -1998. Onderzoek van Binnenlands Bestuur (Bouwmans, v.a. 2004) laat zien dat dit aandeel verder is gestegen. Er traden dus niet extreem veel meer wethouders af, maar er werd vaker aangegeven dat het vanwege een politiek conflict was. Omdat het niet aannemelijk is dat het aantal andere vertrekredenen (gezondheid, pensioen, andere baan) dramatisch zou zijn gedaald, kan het niet anders dan dat er meer openheid is over politieke conflicten als reden van vertrek (zie: Castenmiller c.s., 2010).

\section{Niet nieuw}

Het aantal tussentijds opstappende gemeentebestuurders is dus vooral de laatste twintig jaar gestegen, waarbij ook de publiciteit hierover is toegenomen. Daarmee is echter niet gezegd dat het hier om een nieuw verschijnsel gaat. Een korte blik in de geschiedenis maakt dat duidelijk. Van Poelje verhaalt al in 1914 over burgemeester Sj. Vening Meinesz, die van 1881 tot 1891 burgemeester was van Rotterdam en daarna van 1891 tot 1901 burgemeester van Amsterdam. In Amsterdam was hij in 1869 al wethouder geweest, maar daar moest hij aftreden vanwege het feit dat hij in het huwelijk trad met de dochter van burgemeester Jhr. Mr. C.J.A. den Tex. In 1891 keerde Vening Meinesz dus terug als burgemeester, maar hij werd tot aftreden gedwongen in 1901 vanwege de kwestie van de discipline over de gemeentepolitie (Van Poelje, 1914: 130). Het ging over de kwestie wie er bevoegd is tot het opleggen van straffen aan politieambtenaren. "Naar mijn oordeel ligt de kern der kwestie in het herhaaldelijk in den raad gebleken wantrouwen in het stelsel, onder verantwoordelijkheid van den burgemeester toegepast bij het opleggen van straffen aan politiebeambten", reflecteerde de toenmalige burgemeester van Ouderkerk aan den IJssel op de kwestie.

De $20 e$ eeuw kent vele verhalen over bestuurders die voortijdig hun ambt dienden te verlaten als gevolg van gerezen problemen. Aansprekende voorbeelden zijn er genoeg. Zo was daar het gedwongen vertrek van de Amsterdamse wethouder De Miranda in 
1939, na een groot aantal publicaties in De Telegraaf over vermeende malversaties bij bouwprojecten; het ongevraagde ontslag aan de eveneens Amsterdamse burgemeester Van Hall in 1967, ten gevolge van diens als niet adequaat beschouwde optreden bij de rellen in 1966 in Amsterdam (ook Wolthekker, 2006). Te memoreren zijn ook de gevolgen van een avondje stappen van de burgemeesters Smallenbroek van Smallingerland (Drachten) en Faber van Hoogeveen (1989), vitmondend in een vechtpartij met enkele jongeren, waarna Smallenbroek gedwongen werd af te treden en Faber mocht blijven zitten. En zo zullen vele gemeenten hun kleinere en grotere verhalen hebben. $\mathrm{Er}$ was ook wel aandacht voor, maar tegelijkertijd bleven het incidenten. Pas eind jaren tachtig, begin jaren negentig van de vorige eeuw verschenen er studies en kwam er wetenschappelijke aandacht voor het tussentijds opstappen van gemeentebestuurders, naar aanleiding van de steeds hoger wordende aantallen 'vertrekkers'. Vaak ging de aandacht daarbij uit naar individuele gemeenten met problemen, waarbij soms werd gekozen voor een (persoonlijke) beschrijving van de gebeurtenissen (o.a. Boogers en Keizers, 1991; Ohlenforst, 2002; Brouwer, 2002; Van Maaren-Van Balen, 2003; Westerink, 2006; Warbroek, 2007) en er soms meer analytisch werd gekeken (Tops en Zouridis, 2002; Korsten en Aardema, 2006; Korsten en Van de Laar, 2007; Korsten en Schoenmaker, 2008).

\section{De juridische kant van vertrek}

In de Gemeentewet is voor zowel burgemeesters als wethouders aangegeven hoe de zaken met betrekking tot benoeming en ontslag van gemeentebestuurders dienen te verlopen. Voor burgemeesters geldt dat zij formeel worden benoemd bij Koninklijk besluit, op voordracht van de Minister (artikel 61, 1e lid, Gemeentewet). Wel is het zo dat de gemeenteraad de te benoemen kandidaat heeft aanbevolen, na een uitgebreid selectieproces. Als er sprake is van een 'verstoorde verhouding' tussen de burgemeester en de gemeenteraad, kan de raad, door tussenkomst van de Commissaris van de Koningin (CdK), een aanbeveling tot ontslag zenden aan de minister (artikel $61 b, 2 e$ lid). Dit dient wel volgens een vast protocol te verlopen. Voordat de raad verklaart dat er van een verstoorde verhouding tussen de burgemeester en de raad sprake is, overlegt hij met de CdK over de aanleiding tot die verklaring (artikel 61b, зe lid). Een aanbeveling kan vervolgens alleen worden besproken en vastgesteld als de raad minstens twee weken en ten hoogste drie maanden tevoren heeft verklaard dat er sprake is van een verstoorde verhouding (artikel 61b, 4 e lid). Als de aanbeveling tot ontslag is vastgesteld brengt de $\mathrm{CdK}$ advies uit aan de minister, die alleen op grond van dit advies of op andere 'zwaarwegende gronden' kan afwijken van de aanbeveling (artikel 61b, lid 6 en 7 ).

Voor wethouders is de situatie anders, omdat zij rechtstreeks door de raad worden benoemd (artikel 35, 1e lid, Gemeentewet). De gemeenteraad kan dan ook zelf tot ontslag van een wethouder overgaan. Hij dient hiervoor een uitspraak te doen, waarin het vertrouwen in de betreffende wethouder wordt opgezegd. Indien deze vitspraak er niet toe leidt dat de betrokken wethouder onmiddellijk ontslag neemt, kan de raad besluiten tot ontslag. Op dit ontslagbesluit is artikel 4:8 van de Algemene wet bestuursrecht (houdende de mogelijkheid tot het indienen van zienswijzen) niet van toepassing (artikel 49 Gemeentewet). De rechter kan vervolgens niet treden in beoordeling van de gronden waarop de raad tot ontslag heeft besloten (artikel 50 Gemeentewet). Voor colleges geldt overigens hetzelfde, waarbij is geregeld dat 
'indien zoveel wethouders hun ontslag indienen of worden ontslagen dat niet ten minste de helft van het met inachtneming van artikel 36 bepaalde aantal wethouders in functie is, de burgemeester in de plaats van het college treedt totdat dit wel het geval is' (artikel 42, 2e lid, Gemeentewet). Overigens kreeg de gemeenteraad pas in 1948 de formele mogelijkheid een wethouder in geval van verlies van vertrouwen te ontslaan. Dit gebeurde door het opnemen van het toenmalige artikel 87a in de Gemeentewet, naar aanleiding van een zeer concrete gebeurtenis in Amsterdam. In de hoofdstad wilden twee CPN-wethouders niet opstappen, nadat de gemeenteraad in verband met de communistische omwenteling in het toenmalige Tsjecho-Slowakije een motie van wantrouwen tegen hen had aangenomen. Gelegenheidswetgeving dus, maar wel vanaf die tijd verankerd in de Gemeentewet.

\section{Vertrouwen}

Een belangrijk woord bij het gedwongen vertrek van gemeentebestuurders is het woord 'vertrouwen'. Als er geen vertrouwen meer is tussen de gemeenteraad en een gemeentebestuurder, kan dat leiden tot ontslag, dan wel een aanbeveling tot ontslag, blijkt uit de Gemeentewet. In de praktijk is er een sterk verband gegroeid tussen de 'verantwoording' die gemeentebestuurders over hun handelen moeten afleggen aan de gemeenteraad en het 'vertrouwen' dat zij vervolgens wel of niet hebben. Als er niet goed is gehandeld en het vertrouwen weg is, dient de bestuurder te vertrekken. Het opzeggen van vertrouwen is daarmee een sanctie op onjuist handelen van de politieke bestuurders. Vaak is de vraag in verantwoordingsdebatten of de bestuurders iets valt te verwijten en of dat zo ernstig is dat het vertrouwen dient te worden opgezegd. De behoefte is zelfs ontstaan om hier enige regels voor af te spreken (Van Thijn e.a. 1998). Van den Berg stipt de gebeurtenissen rond de RSV-enquête uit de jaren tachtig aan als het begin van de verwevenheid tussen verantwoording en vertrouwen. In het rapport over deze kwestie werd vastgesteld dat minister Van Aardenne doelbewust, maar verklaarbaar, de Tweede Kamer onjuist had geïnformeerd over één van zijn beleidsdaden. De commissie noemde dat 'onaanvaardbaar'. Volgens Van den Berg wekte zij echter ten onrechte de indruk dat in zulke gevallen de volksvertegenwoordiging staatsrechtelijk gehouden is het vertrouwen in de bestuurder op te zeggen. "Sindsdien wordt er een ware sport van gemaakt om in de controle vooral na te gaan of er 'onjuist, onvolledig of ontijdig' informatie is geleverd. Zo ja, dan ligt de conclusie al snel voor de hand dat de bestuurder moet aftreden of daartoe is gedwongen. Van zulk een morele, laat staan juridische, norm is echter geen sprake. Waar veel mensen bij besluiten zijn betrokken, kan het haast niet anders of er zijn (totaal) verschillende versies van de waarheid. Dat kan heel gemakkelijk leiden tot onjuiste, onvolledige of ontijdige informatie door bestuurders aan de volksvertegenwoordiging. In plaats van die bestuurders aan de schandpaal te nagelen, zijn bestuurders en volksvertegenwoordigers er meer bij gebaat na te gaan waar de toevoer van relevante informatie kan en moet worden verbeterd" (Van den Berg, 1999: 31).Toch kan het zijn dat de vertrouwensvraag op tafel komt. "Bij de vertrouwensvraag gaat het maar om één ding: beschikt de bestuurder (in ons geval: het college of de wethouder) nog over het gezag om doeltreffend leiding te geven aan de hem toevertrouwde taken? Heeft hij dus voldoende erkenning bij 'zijn' ambtenaren of bij de maatschappelijke organisaties waarmee hij verkeert, om met vrucht zijn politieke opdracht vit te oefenen? Is er reden om erop te vertrouwen dat hij van eigen 
fouten in staat is te leren en anderen, ambtenaren in het bijzonder, te laten leren? Zo ja, dan verdient hij het vertrouwen te houden, zelfs als hij de raad niet steeds naar waarheid heeft ingelicht. Als de raad oordeelt dat de wethouder of zelfs het college geen gezag meer heeft en niet echt meer in staat is tot doeltreffend bestuur, dan is dat een goede reden om het vertrouwen op te zeggen" (Van den Berg, 1999: 31-32).

Waar het vooral op neerkomt is dat het bij het vertrouwen uiteindelijk gaat om een politieke vraag, niet om een juridische. Een vraag die door de gemeenteraad moet worden beantwoord en kan leiden tot gedwongen vertrek van gemeentebestuurders.

\section{Nationaal perspectief}

Gedwongen vertrek van bestuurders komt ook bij een andere decentrale bestuurslaag voor, de provincie. Anders dan bij het (toenemend) vertrek van gemeentelijke bestuurders is er echter geen grote zorg om het bestuurlijk functioneren van de provincies. Een relativerende opmerking hierbij is uiteraard dat de provincie normaal gesproken minder in de publieke schijnwerpers staat. Wel blijft een bestuurlijk probleem bij deze bestuurslaag vaak lang in het collectieve geheugen hangen. Voorbeelden zijn de Ceteco-affaire in Zuid-Holland in 1999 en de Landsbanki-affaire en de nasleep daarvan in Noord-Holland in 2009. Soms komt er ook wel een gedeputeerde in de problemen (bijv. Gelderland 2000, Limburg 2008) of valt een heel college (Utrecht en Noord-Holland, 2009).

Ook bij waterschappen, die al helemaal op forse afstand van de gemiddelde burger staan, is het rustig qua bestuurlijke problematiek. Zelfs zozeer dat er over bestuurlijke 'oasen' van rust wordt gesproken (Bekkers en Warbroek, 2008: 28).

Op Rijksniveau komt het vertrek van bestuurders eveneens voor. Dit kan het individuele vertrek van een minister zijn, of de val van een kabinet. Voorbeelden zijn er te over (zie Bovens e.a., 2010). In de voor dit onderzoek gekozen onderzoeksperiode vielen, naast enkele ministers, op landelijk niveau de kabinetten Paars II (2002, Srebrenica), Balkenende I (2002, ruzies rond LPF), Balkenende II (2006, conflict rond paspoort Hirsi Ali), Balkenende IV (2010, Uruzgan). Van Thijn wijt de problemen aan het politieke systeem: "De voortijdige val van een kabinet is een typisch uitvloeisel van ons kwetsbare politieke systeem, waarin meerderheidscoalities met moeite tot stand komen en het onderlinge wantrouwen tussen regeringspartijen slechts moeizaam is uit te bannen. Als er nieuwe verkiezingen in zicht zijn, steekt dat telkens weer de kop op" (Van Thijn, 2010: 46).

Groot verschil met het vertrek van bestuurders of colleges van bestuurders op decentraal niveau is, dat bij de val van een kabinet in de regel nieuwe verkiezingen worden uitgeschreven; deze mogelijkheid is bij provincies, gemeenten en waterschappen niet aanwezig.

\section{Internationaal perspectief}

Het valt buiten het oogmerk van deze studie een sluitende internationale vergelijking tussen het fenomeen van de vallende bestuurder(s) in Nederland en het buitenland te maken. En als dat al de bedoeling zou zijn geweest, zou het nog niet meevallen. Opvallend is dat er over bestuurlijke crisissituaties op lokaal niveau weinig internationale literatuur beschikbaar is.

Er is wel enig materiaal over crises op nationaal niveau. Garrard en Newell beschrijven in hun boek over schandalen in vroegere en hedendaagse politiek een groot aantal 
politieke kwesties (Garrard en Newell, 2006). Het gaat hier om kwesties die op nationaal niveau speelden in landen als Australië, lerland, Griekenland en de Verenigde Staten, vaak corruptiezaken. Uit de omschrijving van de verschillende zaken komt een analyse met betrekking tot de normatieve kant van het geheel naar voren: "Scandals mostly, and almost necessarily, involve public people: politicians, public officials, and/or people in positions of public trust - positions that involve them being trusted bij substantial numbers of others and being assumed to deploy high standards of personal conduct. (....).. what matters is not the conduct itself, but its relation to a public role, and the attendant expectations of that role" (Garrard/Newell, 2006: 17).

Op zich is het overigens logisch te veronderstellen dat zich in andere landen ook bestuurlijke problemen in gemeenten voordoen. De omringende landen kennen ook burgemeesters, colleges en gemeenteraden, waar besluiten worden genomen en dus spanningen zijn te verwachten. Aangetekend dient hierbij wel te worden dat de Nederlandse constellatie (met de gekozen raad en de benoemde burgemeester) vrij uniek is in Europa (zie John, 2001). Vrijwel alle andere landen kennen een rechtstreeks gekozen burgemeester, die over een eigen mandaat beschikt van de kiezer en vaak ook zijn of haar eigen wethouders aanstelt. Deze bestuurders nemen derhalve een andere positie in tegenover de gemeenteraad en zullen vermoedelijk (het is een aanname) minder snel worden weggestuurd. Dit geldt zeker voor Frankrijk, waar de positie van de gekozen burgemeester traditioneel vrij sterk is (Boraz en Le Galès, 2005: 28). In België komt de burgemeester voort uit de gemeenteraad, waarbij in veel gemeenten degene met de meeste voorkeurstemmen verkozen wordt (Plees, 2005: 52). Ook hier is op zich iets minder bestuurlijke problematiek te verwachten. Van een studie naar bestuurlijke probleemgemeenten is in België geen sprake (mondelinge informatie van Herwig Reynaert; ook Reynaert en Steyvers, 2010).

Toch zijn er wel aanwijzingen voor bestuurlijke problemen in andere landen op lokaal niveau. Enige voorbeelden zijn te vinden in de vergelijkende studie van Denters en Rose naar lokaal bestuur in een twaalftal landen. Door verschillende respondenten wordt melding gemaakt van moties van wantrouwen (votes of non-confidence), waarbij gemeentelijke bestuurders de politieke arena dienen te verlaten. Gabriel en Eisenmann wijzen op de situatie in het Duitse Frankfurt, die ontstond na de verkiezing van een nieuwe burgemeester in 2000: "After her electoral victory in autumn 2000, Lord Mayor Petra Roth (CDU) experienced substantial problems in building a party coalition in the city council, and decisions on important issues proved difficult" (Gabriel en Eisenmann, 2005: 128). Ook in Italië kan de direct gekozen burgemeester tegen een motie van wantrouwen van de lokale gemeenteraad aanlopen, maar als deze wordt aangenomen komen er nieuwe verkiezingen, voor zowel de burgemeester als de gemeenteraad. Volgens Bobbio heeft dat voor meer rust gezorgd in Italiaanse gemeenten, waar eerder veel sprake was van vallende colleges (Bobbio, 2005: 41).

\subsection{Conclusies}

Het politieke landschap op lokaal niveau is de afgelopen decennia gekenmerkt door een groot aantal veranderingen. Niet voor wat betreft de formele positie van gemeen- 
ten: die is sinds het formele ontstaan van de gemeenten in 1848 niet wezenlijk veranderd. Wel als het gaat om het aantal gemeenten, dat tussen 1960 en 2010 bijna is gehalveerd. Tevens is een aantal andere ontwikkelingen te onderscheiden: schaalvergroting en decentralisatie, vermaatschappelijking, politieke versplintering, problemen rond partijpolitiek, verzakelijking, dualisering en verdergaande 'politisering'. Op grond hiervan kan worden geconcludeerd dat het werk van gemeentebestuurders ingewikkelder is geworden: de 'scope' van wat zij moeten overzien is vergroot, het aantal 'spelers' waar ze rekening mee moeten houden is vergroot, het politieke klimaat waarin zij hun werk moeten doen is verhard, hun prestaties worden in vergelijking tot het verleden kritischer beoordeeld. Al deze omstandigheden werken in op de laatste beschreven ontwikkeling: het aantal tussentijds vertrokken gemeentebestuurders is de afgelopen twintig jaar gestegen, naar viteindelijk 30\% in de periode 2006-2010.

Bovenstaande ontwikkelingen gelden voor alle gemeenten, dus ook voor de bestuurlijke probleemgemeenten die in dit onderzoek centraal staan. De ontwikkelingen zullen derhalve een plaats moeten krijgen in de onderzoeksaanpak. Dit geldt niet voor schaalvergroting en decentralisatie, wat meer algemene ontwikkelingen zijn. Maar de overige ontwikkelingen dienen in de onderzoeksaanpak terug te komen, waarbij deze aanpak tegelijkertijd een mogelijkheid dient te bieden 'dieper' te kijken.

In het volgende hoofdstuk wordt een keuze voor een specifieke onderzoeksaanpak gemaakt, waarin de in dit hoofdstuk beschreven ontwikkelingen terug te vinden zijn. 


\section{Onderzoek naar bestuurlijke probleemgemeenten}

\subsection{Inleiding}

Het bestuderen van bestuurlijke probleemgemeenten kan niet zonder goed onderzoekskader. Om dit kader op te bouwen is bureauonderzoek gedaan, waarbij gezocht is naar het antwoord op deelvraag 1 :

Wat zegt de bestaande literatuur over mogelijke verklaringen voor de aanhoudende bestuurlijke problematiek in bestuurlijke probleemgemeenten?

Uit het bureauonderzoek blijkt dat het onderzoeken van bestuurlijke probleemgemeenten op verschillende manieren uitgevoerd kan worden. Richtinggevend is waar naar gezocht wordt: naar een antwoord op de vraag wat kenmerken van bestuurlijke probleemgemeenten zijn, of naar een antwoord op de vraag hoe de problemen ontstaan. Vanuit de bestuurskundige literatuur dienen zich voor beide onderzoeksrichtingen in grote lijnen twee mogelijkheden aan.

Ten aanzien van de vraag wat kenmerken van bestuurlijke probleemgemeenten zijn, is het op de eerste plaats mogelijk een gemeentebestuur te beoordelen op basis van bestuurskracht. In dit perspectief gaat een onderzoeker na of een gemeentebestuur in staat is de eigen ambities en wettelijke opgaven op een voldoende niveau te realiseren. Voor de beoordeling daarvan is een beoordelingskader nodig. Hierbij kan onderscheid worden gemaakt tussen de kwaliteit van het strategisch, tactisch en operationeel beleid, of criteria die te relateren zijn aan (categorieën van) gemeentelijke taken. De veronderstelling met betrekking tot dit perspectief luidt dat de bestuurskracht van bestuurlijke probleemgemeenten in een aantal opzichten op dit beoordelingskader lager scoort dan de bestuurskracht van gemeenten die niet als bestuurlijk problematisch zijn te beschouwen. Een studie naar de ontwikkeling van bestuurskracht in de tijd in een probleemgemeente zou duidelijk kunnen maken wat kenmerkend is voor probleemgemeenten. Probleemgemeenten zouden dan 'normaler' worden, naarmate ze beter gaan scoren op bestuurskracht. Zijn probleemgemeenten, om een voorbeeld te noemen, gemeenten waarvan het bestuur in strategisch opzicht dolend is of zit de zwakte van de bestuurskracht ergens anders?

Een tweede entree tot het verschijnsel probleemgemeente ligt in de buurt van de eerste benadering. Recent zijn voor overheidsorganisaties principes van 'good governance' (goed bestuur) geformuleerd door het Ministerie van BZK (Min. BZK, 2009). Vanuit een 'good governance'- perspectief zouden gemeentebesturen op deze criteria zijn te beoordelen. De veronderstelling luidt ook hier dat gemeentebesturen van bestuurlijke probleemgemeenten absoluut en/of relatief zwakker scoren op alle of bepaalde criteria van good governance dan andere gemeenten. Deze analyse zou nuttig kunnen zijn, omdat die direct aanwijzingen oplevert voor het zoeken naar verbetering van het bestuur. 
Ten aanzien van de vraag hoe een gemeente een bestuurlijke probleemgemeente wordt, is al enig onderzoeksmateriaal voor handen. Korsten en Aardema (Korsten en Aardema, 2006) onderzochten de hoe-vraag door het gedwongen vertrek van burgemeesters op verschillende niveaus te analyseren. Zij onderscheiden een drietal niveaus, te weten het microniveau, het mesoniveau en het macroniveau. Lag het vertrek aan individuele factoren (micro-niveau), dat wil zeggen aan de (gebrekkige) kwaliteiten van één of meer wethouders of een burgemeester? Of moeten de beïnvloedende factoren, wellicht zelfs oorzaken, gezocht worden op mesoniveau, in de sfeer van de verhoudingen binnen een college of een raad of de betrekkingen binnen een college en raad of tussen college en gemeenteraad? Misschien waren het de macrofactoren, waaronder de bestuursstructuur en -cultuur en de rol van de media worden gerekend? Korsten en Aardema kwamen tot het besef dat het gedwongen vertrek van burgemeesters in bestuurlijke probleemgemeenten niet aan één factor ligt, maar dat er meerdere factoren tegelijkertijd invloedrijk zijn. Hoe zou dat zijn als ook de val van wethouders en hele colleges bij de analyse wordt betrokken?

Er is nog een vierde entree tot probleemgemeenten mogelijk: aansluiting zoeken bij de studie van sterke en zwakke bestuurscolleges. In het lokaal bestuur geldt over het algemeen de norm dat een college van B\&W sterk moet zijn. Maar wat is een sterk college en wanneer is een college zwak? Korsten en Schoenmaker hebben op grond van zeer vitgebreide literatuurstudie en onderzoek een checklist vastgesteld (Korsten/ Schoenmaker, 2008: 298-301). Een voorbeeld hieruit is illustratief. Als een bestuurlijk college groot is en uit veel coalitiepartijen bestaat, is de kans groter dat een college na enige tijd uit elkaar valt. Grote colleges blijken in de praktijk vaak de rit (tussen verkiezingen) niet uit te zitten. Een groot college is moeilijk bij elkaar te houden, omdat alle partijen wensen hebben, kunnen verschillen in de belangen die ze van betekenis vinden in een belangenafweging of een uiteenlopend bestuurlijk perspectief hanteren. Als er heel sterke temperende krachten aanwezig zijn, zoals een sterk bindende burgemeester en partijen die nadrukkelijk eenheid en conflictvermijding nastreven, kan zo'n groot college toch voortbestaan. De aanname om vanuit het perspectief van sterke colleges te kijken naar probleemgemeenten, is dat probleemgemeenten slecht scoren op alle of veel factoren die maken dat het bestuur niet sterk is. De vraag is: op welke factoren precies? Het onderzoek van Korsten en Schoenmaker kan opgevat worden als een rapportage met verwachte uitkomsten van een onderzoek naar probleemgemeenten. Een beperking van dit vierde perspectief is dat de oorzaken voor het ontstaan van een probleemgemeente herleid worden tot de (probleem)accelererende en temperende krachten in en rond een dagelijks bestuur van een gemeente en niet breder kijken naar bijvoorbeeld het algemeen bestuur.

In dit onderzoek zal een keuze gemaakt moeten worden. Om duidelijk te maken hoe deze keuze tot stand is gekomen, komt in paragraaf 3.2 de invalshoek van de bestuurskracht aan de orde, in paragraaf 3.3 gevolgd door de invalshoek van good governance. In paragraaf 3.4 wordt ingegaan op de micro-, meso- en macroanalyse van probleemgemeenten, terwijl in paragraaf 3.5 de 'sterke colleges' aan bod komen. Het uiteindelijk onderzoekskader, de manier waarop in dit onderzoek het probleem wordt onderzocht, 
wordt uitgewerkt in paragraaf 3.6. Op basis van in paragraaf 3.7 uitgewerkte factoren worden verwachtingen geformuleerd in paragraaf 3.8 .

\subsection{De bestuurskrachtbenadering}

De eerste benadering die nader vitgewerkt wordt is het beoordelen van gemeenten op basis van bestuurskracht. Een bekende invalshoek: "Wie de laatste halve eeuw van het gemeentebestuur in Nederland overziet, kan niet om 'bestuurskracht' heen", concluderen Korsten, Abma en Schutgens in een overzichtswerk over bestuurskracht en de metingen van bestuurskracht (Korsten, Abma en Schutgens, 2007: 24; ook Korsten, Abma, Schoenmaker en Schutgens, 2007). Bestuurskracht wordt in vele beschouwingen over met name het presteren van gemeenten genoemd. In de loop der tijd zijn hierbij vele definities van bestuurskracht gehanteerd. Definities die elkaar in beginsel niet veel ontlopen, aangezien ze alle spreken over taken, ambities en opgaven, al dan niet opgelegd door anderen, en de mate waarin gemeenten in staat zijn die te realiseren. Zo spreekt een omschrijving van de bestuurskracht van gemeenten in Limburg over 'het formuleren van gemeentelijke opgaven en bezien wat daarvan in de uitvoering terecht komt' (Korsten, Abma en Schutgens, 2007: 58). In 't Gooi in de provincie Noord-Holland hanteerde het onderzoeksbureau een op kleine onderdelen andere definitie: "Een bestuurskrachtige gemeente is voldoende in staat om de door haar zelf en door anderen (Rijk, provincie) opgelegde taken en ambities alleen of in samenwerking met anderen op te pakken c.q. te realiseren" (Capgemini Nederland, 2005: 4).

\section{Meting}

Bestuurskracht kan worden gemeten. Korsten c.s. omschrijven een bestuurskrachtmeting als een algemene, basale meting van de kracht van een gemeente en vergelijken deze met een keuring door huisarts of schoolarts. "Deze meting heeft veel weg van hoe een huisarts of schoolarts een algemeen beeld van een burger kan krijgen door middel van een test van tien standaardmetingen (de test van de knie, de kniebuiging, enz.). De huisarts is geen specialist die een nadere analyse maakt, zoals een internist, neuroloog of bijvoorbeeld chirurg kan doen. Een huisarts kan op basis van zijn analyse wel doorverwijzen naar de specialist. Zo moet ook een bestuurskrachtmeting gezien worden. Een bestuurskrachtmeting van een gemeente geeft dus een algemeen omvattend beeld van de kwaliteit van het betreffende lokaal bestuur in termen van bestuurlijk vermogen. Het is geen precies dieptebeeld of specialistisch beeld van bijvoorbeeld handhaving en toezicht of de financiële situatie, de organisatiecultuur of van de bestuurlijk-ambtelijke betrekkingen" (Korsten c.S., 2007: 23). De auteurs benadrukken dat het niet om keihard feitenmateriaal gaat: "Omdat we spreken van bestuurskrachtmetingen kan de suggestie worden gewekt dat het om keiharde, feitelijke en cijfermatige analyses gaat. Dat is echter niet het geval. Er is sprake van een zekere weging. Dat is wellicht een beter woord dan 'meting'. Desondanks blijven we hier het woord 'meting' gebruiken. Het is immers een ingeburgerde term"' (Korsten C.S., 2007: 24).

De beoordeling geschiedt altijd op basis van een kwaliteitskader, waarbij hier en daar met een kwaliteitsmatrix wordt gewerkt (zie tabel 4). Met name Toonen c.s. (1998) legden hier de basis voor. Hierbij worden aan het gemeentebestuur vier rollen toe- 
bedeeld: de gemeente als bestuur van de gemeenschap, als verlener van diensten, als medeoverheid en als werkgever van een organisatie. De vier rollen worden vervolgens op drie niveaus bezien: het strategisch niveau (ontwikkelen van een visie), tactisch niveau (organiserende en structurerende taken) en operationeel niveau (beleid op korte termijn).

Tabel 4: De kwaliteitsmatrix voor beoordeling van de gemeentelijke bestuurskracht

\begin{tabular}{|c|c|c|c|c|c|}
\hline & \multicolumn{4}{|c|}{ Rollen gemeentelijke overheid } \\
\hline & & Bestuur & Dienstverlener & Deelnemer & $\begin{array}{c}\text { Organisatie/ } \\
\text { Bedrijfsvoering }\end{array}$ \\
\hline \multirow{3}{*}{$\begin{array}{l}\text { Kwaliteits- } \\
\text { niveau }\end{array}$} & Strategisch & $\begin{array}{l}1.1: \\
\text { Strategisch } \\
\text { bestuur }\end{array}$ & $\begin{array}{l}1.2: \\
\text { Strategische } \\
\text { dienstverlener }\end{array}$ & $\begin{array}{l}1.3: \\
\text { Strategische } \\
\text { participant }\end{array}$ & n.v.t. \\
\hline & Tactisch & $\begin{array}{l}2.1 \text { : } \\
\text { Tactisch } \\
\text { bestuur }\end{array}$ & $\begin{array}{l}\text { 2.2: } \\
\text { Tactische } \\
\text { dienstverlener }\end{array}$ & \begin{tabular}{|l} 
2.3: \\
Tactische \\
participant \\
\end{tabular} & $\begin{array}{l}2.4: \\
\text { Tactische } \\
\text { organisatie }\end{array}$ \\
\hline & Operationeel & n.v.t. & $\begin{array}{l}\text { 3.2: } \\
\text { Operationele } \\
\text { dienstverlener }\end{array}$ & $\begin{array}{l}\text { 3.3: } \\
\text { Operationele } \\
\text { participant }\end{array}$ & $\begin{array}{l}3.4: \\
\text { Operationele } \\
\text { organisatie }\end{array}$ \\
\hline
\end{tabular}

\section{Aanpak verschilt}

Bij het meten van de bestuurskracht zijn veel verschillende aanpakken gekozen, concluderen Eenhoorn en Rozenberg in een onderzoek naar bestuurskrachtmetingen in de Randstad, in opdracht van het Ministerie van BZK. "Er zijn zeer verschillende aanpakken gekozen, variërend van zelfreflectie, van intervisie tot zeer kwantitatief gericht (op resultaat gemeten) onderzoek. Dat de waarde van de onderzoeken zeer verschillend kan uitpakken is evident" (Eenhoorn/Rozenberg, 2006: 1). Overigens kan hier bij worden gezegd dat de aanpakken weliswaar verschillen, maar dat er regionaal weer wel homogeen gewerkt wordt. In grote lijnen zijn de volgende typen bestuurskrachtmetingen te onderscheiden: visitaties (waarbij een onafhankelijke commissie de bestuurskracht van een gemeente beoordeelt), een meting door een adviesbureau, zelfevaluatie en een kwaliteitsmeting door een projectgroep van ambtenaren.

\section{Ontwikkeling}

Bij het in beschouwing nemen van bestuurskracht als mogelijke invalshoek vallen twee zaken op. De eerste is dat bestuurskracht vaak in verband is en wordt gebracht met de schaal, de omvang in inwonertal van een gemeente. Een op enig moment geconstateerd gebrek in de bestuurskracht van een gemeente zou hierbij te verhelpen zijn door het inwonertal van een gemeente te vergroten, dus de gemeente op te nemen in een herindeling (fusie) met andere gemeenten. Dit schaaldenken is altijd prominent aanwezig geweest in discussies over bestuurskracht. De Vereniging van GemeenteSecretarissen (VGS) spreekt in een essay uit 2007 (opgesteld samen met de Vereniging voor Bestuurskunde) in dit verband over een mantra: "Voor bestuurlijk Nederland is de term bestuurskracht inmiddels een mantra, terwijl het begrip tegelijkertijd niet onomstreden is. Dat houdt in belangrijke mate verband met de impliciete relatie die 
onderzoeken naar bestuurskracht hebben met herindelingsoperaties. Een vermeend gebrek aan bestuurskracht is veelal de opmaat naar een min of meer gedwongen fusie tussen twee of meer gemeenten" (VGS/VB, 2007: 4).

De tweede opvallende constatering is dat het denken over bestuurskracht zich gaandeweg ontwikkelt van het puur beschouwen van het kunnen van een gemeente op zich, naar een beschouwing van de kracht van een hele samenleving. Hierbij gaat het om een smalle en een brede opvatting van bestuurskracht. Tot de bredere opvattingen worden onder meer gerekend de ideeën van Van Hijum en Hiemstra. Zij vinden dat bestuurskwaliteit en het presteren van gemeenten nauw verbonden zijn. In een artikel uit 2002 omschrijven zij bestuurskwaliteit als 'de mate waarin een gemeente bestuurlijk en organisatorisch in staat is haar opgaven en rollen waar te maken en de gewenste prestaties te leveren' (Van Hijum/Hiemstra, 2002: 11). Deze auteurs proberen de gehele organisatie, de interne samenwerking en verkokering, het ondersteunend management en het verband tussen bestuur en organisatie in brede zin in beeld te krijgen. Ook anderen ( $\mathrm{vgl}$. Wesseling, 2004c) kiezen voor een breed normatief perspectief op bestuurskracht, maar argumenteren anders. Zij hameren niet op een brede organisatieanalyse, maar op de relatie bestuur-samenleving. Zij erkennen dat een gemeente vaak niet alleen iets voor elkaar kan krijgen, maar opereert in netwerken en in ketens. En dat moet bij bestuurskrachtmeting in beeld komen. Bestuurskracht is voor hen in normatief opzicht de mate waarin een bestuur mét de samenleving er in slaagt gezamenlijk gerichte krachten te organiseren om bepaalde effecten te realiseren, en niet dat het politiek bestuur dit alleen tracht te doen. Bestuurskrachtmeting is voor deze auteurs dus niet alleen bestaand gemeentelijk beleid bekijken (dat is mogelijk een te bestuurs-centrische blik) maar ook bezien of gemeenten en actoren daarbuiten gericht zijn op gezamenlijk te bereiken bestuurlijk en maatschappelijk gewenste effecten (niet-bestuurscentrisch). Een gemeentebestuur kan het zelden of nooit alleen af, volgens dit bredere perspectief.

\section{Relatie met probleemgemeente}

De vraag is op welke wijze de uitgevoerde bestuurskrachtmetingen van nut zijn bij het onderwerp van dit onderzoek, de bestuurlijke probleemgemeenten. Geconstateerd kan worden dat vrijwel alle metingen vanuit het 'smalle' perspectief van de gemeente zelf zijn uitgevoerd. (Korsten c.S., 2007: 39). Tegelijkertijd kan worden geconstateerd dat in het bredere perspectief juist de relatie met de actoren in de samenleving van belang is. Het is aannemelijk dat ook de oorzaken van bestuurlijke problemen in datzelfde bredere perspectief moeten worden bezien. De bestuurskrachtmetingen die tot op heden zijn uitgevoerd, brengen relaties echter niet in beeld. Ook de bestuurlijke relaties komen niet in beeld bij de uitgevoerde onderzoeken (zie ook Korsten, 2010c: 29).

Conclusie: de aanpak via de weg van kwaliteit en bestuurskrachtmetingen is op zich wel kansrijk. De uitwerking die er in de praktijk aan is gegeven, geeft echter (nog) niet de brede benadering weer, die voor het doen van onderzoek naar de oorzaken van crises in bestuurlijke probleemgemeenten nodig is. Met name het ontbreken van 'mensen' in de metingen is voor het doen van onderzoek in bestuurlijke probleemgemeenten een beperking. 


\subsection{Good governance: de normatieve benadering}

De tweede mogelijke benadering voor het onderzoeken van bestuurlijke probleemgemeenten, ligt in het denken in termen van 'good governance', dus 'goed bestuur'. De gedachte is dat op basis van de in deze benadering omschreven principes van goed bestuur onderzocht kan worden op welke terreinen bestuurlijke probleemgemeenten van deze principes afwijken (Bovaird \& Löffler, 2002).

Alvorens kan worden ingegaan op de vraag wat 'good governance' en 'good local governance' is, eerst iets over het begrip 'governance' in het algemeen. Het denken over 'governance' in het perspectief van ontwikkelingslanden of de Europese Unie blijft hier buiten beschouwing (Rokx, 2006; Smith, 2007; Dijkstra en Van de Walle, 2011).

\section{Van government naar governance}

'Governance' is in het wetenschappelijk denken op het gebied van de bestuurskunde aanvullend geworden op de term 'government' vanuit de gedachte dat een overheid, in dit geval het gemeentebestuur, niet altijd het bestuurscentrisch middelpunt van alle taakontwikkeling en uitvoering is. Een gemeentebestuur is voor veel taken afhankelijk van andere actoren, die er eigen preferenties op nahouden. Zij beschikken soms ook over taken en middelen ('resources'), die bij voorkeur verbonden moeten worden met die van het gemeentebestuur. Het is immers doeltreffend en doelmatig als actoren samen de neus in dezelfde richting hebben staan en elkaar in (collectieve) wilsuitingen en handelen versterken, in plaats van tegenwerken of laten aanmodderen.

Een gemeentebestuur kan daarbij niet alleen samenwerken met andere overheden, maar uiteraard ook met semi-overheidsorganisaties of private organisaties. Te denken valt bijvoorbeeld aan het realiseren van woningbouw, waar gemeentelijke organisaties weliswaar (bestemmings)plannen voor maken, maar ook te maken krijgen met grondeigenaren, corporaties en ontwikkelaars die (kunnen) bouwen. Een stedelijke corporatie kan niet zonder een gemeentebestuur en omgekeerd meestal ook niet. In situaties van sterke afhankelijkheid heeft een gemeentebestuur niet zonder meer doorzettingsmacht. Vandaar dat tussen deze organisaties veelvuldig overleg plaatsvindt.

Een gemeentebestuur kan op zich bij tal van andere taken dan woningbouw ook weinig alleen. Daarom is het in geval van afhankelijkheden van belang dat regelmatige netwerkconstitutie plaatsvindt (de goede partijen op het goede moment rond de tafel) en netwerkproductiviteit optreedt. Een netwerk van van elkaar afhankelijke actoren kan productief worden als vervolgens doelcongruentie plaatsvindt en op basis van een gedeeld verhaal of perspectief, ook wel een gezamenlijk gedragen 'discours' genoemd, ook financiële en andere middelen gebundeld kunnen worden. Het pogen de eigen wil aan andere organisaties op te leggen heeft doorgaans niet het beoogde effect. In situaties dat netwerken productief moeten worden, is derhalve regie aan de orde (regie door een gemeentebestuur?) en soms het doorbreken van fixaties, zodat geen 'dialoog van doven' plaatsvindt (Rhodes, 1997; Klijn, 2005). Het denken in termen van 'governance' is - zo gezien - heel nuttig.

Maar de vraag is vervolgens wat 'good governance' nog meer is. 'Good governance' is historisch gezien niet opgevat als goed bestuur in netwerken, maar meer als goed 
bestuur van bestuurders, van vorsten, of van goede politiek. Eeuwen terug was het denken in termen van netwerken nog niet zo aan de orde.

\section{Denken over good governance al eeuwen oud}

De vraag wat goed bestuur is houdt wetenschappers al bezig sinds de tijd dat bestuur en politieke macht nog geconcentreerd waren bij de vorst, koning of keizer. Er zijn vele beschouwingen over de vraag hoe dergelijke heersers het best, het eerlijkst, het meest deugdelijk konden of zouden moeten opereren. Hoogerwerf (2004) wijst er in een overzicht op dat er in de loop der eeuwen vele handleidingen zijn geschreven, bedoeld als wegwijzers naar een 'goede politiek' en een 'goede samenleving'; wegwijzers die concrete gedragsregels omvatten en ook meer uitvoerende beschouwingen. Zij houden zich bezig met de kunst van het regeren, de wetenschap van het regeren en de filosofie van het regeren. Er zijn ook beschouwingen over het te voeren beleid, de maatschappelijke omstandigheden en de levensbeschouwelijke fundamenten van het politieke handelen. Tot de auteurs van de wegwijzers voor politici behoren een aantal van de grootste denkers uit de Europese en andere beschavingen. "Voorlopers zijn de Babylonische koning Hammoerabi, de Egyptische farao Echnaton, de Chinese denkers Confucius, Mencius en Lao-tzu, de Indische geleerde Kautilya en de joodse en christelijke schrijvers van de bijbelboeken. In de Griekse oudheid formuleren Plato en Aristoteles hun visie op de staatsman. Later publiceren Arabische moslimgeleerden, Thomas van Aquino, Jacob van Maerlant, Erasmus en anderen hun vorstenspiegels. Daarin komen naast politieke deugden ook het te voeren beleid en andere praktische onderwerpen aan de orde" (Hoogerwerf, 2004: 11). Deze beschouwingen hebben nog steeds een zekere indirecte actualiteitswaarde, omdat ze in meer actuele beschouwingen vitlopen op transformaties naar maatstaven ter beoordeling van overheidshandelen. Zo komt Korsten (2010c), vertrekkend vanuit de in het Italiaanse Siena te bezichtigen fresco's van Lorenzetti over goed en slecht bestuur en de gevolgen daarvan, uit bij de historisch gegroeide aanwas van moderne criteria ter beoordeling van overheidsbestuur. Persoonsgebonden maatstaven zijn teruggedrongen, terwijl algemene beginselen en maatstaven opmarcheerden. Te denken valt bijvoorbeeld aan de 'beginselen van behoorlijk bestuur' (Pennarts, 2008; Addink, 2010).

\section{Corporate governance}

Het denken in termen van 'good governance' is niet beperkt tot het genoemde denken in termen van beleidsnetwerken ('van government naar governance') of in termen van oudere, normatieve wegwijzers voor bestuurders en politici en modernere criteria ter beoordeling van overheidshandelen. De discussie over 'good governance' is, zo blijkt uit de literatuur, óók verbonden met denken over 'corporate governance' en 'governance' in organisaties vit het bedrijfsleven, de gezondheidszorg en het onderwijs. In 2003 verscheen de Code-Tabaksblat, die onder meer handelde over normering van bestuurlijke verhoudingen in beursgenoteerde bedrijven. Deze commissie bouwde voort op werk van de commissie-Peters uit 1997. Hoe belangrijk bleek die normering? Hoogleraar Corporate Finance Kees Cools richt(te) zich in zijn onderzoek op de corporate strategie, corporate finance, corporate governance en leiderschap, ondernemerschap en performance management, met een bijzondere belangstelling voor de energiesector. Cools is actief betrokken bij (corporate) governance-activiteiten, met name als lid 
van de Nederlandse Corporate Governance Monitoring Commissie, onder voorzitterschap van J. Frijns. Die commissie houdt toezicht op de Nederlandse Corporate Governance Code (de 'Code Tabaksblat') van december 2003 en adviseert de regering over corporate governance, zoals aandeelhoudersactivisme, diversiteit in raden van bestuur en de bezoldiging van bestuurders. Cools publiceerde een - bekroonde - studie over 'governance' en leiderschap getiteld 'Controle is goed, vertrouwen nog beter', waarin hij de 25 grootste bedrijfsschandalen die zich rond het begin van het millennium voordeden (bijvoorbeeld Enron, Shell, Ahold) analyseert. Zijn analyses tonen aan dat niet zozeer een gebrekkige 'corporate governance' de oorzaak was van de schandalen, maar zonnekoningengedrag (ook wel narcistisch gedrag genoemd) van de CEO's, hebzucht en geloof in luchtkastelen. Geloof in luchtkastelen heet in een theorie van 'groupthink' (Janis): overoptimisme. Personen doen er dus toe, als het gaat om goed bestuur van bedrijven. Het boek werd bekroond met de prijs voor het beste managementboek uit 2005. Overigens waren er ook met de VOC rond 1600 al corporate-problemen. Ze zijn van alle tijden, maar wetten en codes zijn daar de oplossing niet voor. Het gaat om de wenselijkheid van gedragscorrectie, zo laat de studie van Cools zien.

Morris Tablaksblat en zijn commissie waren in Nederland niet de eersten die zich bezighielden met 'governance'- codes. Eerder had de Rotterdamse hoogleraar Pauline Meurs zich al ingelaten met governance in instellingen voor gezondheidszorg, zoals bleek uit de al uit 1999 daterende code, kortheidshalve aangeduid als de Code-Meurs. Codes werden in die jaren een hausse. In 2000 verscheen een pleidooi voor 'cultural governance' in de cultuursector. Het ging in een rapport van de commissie onder leiding van Melle Daamen om kwaliteit van bestuur en toezicht. En in 2000 verscheen ook een rapport van de commissie-Glasz 'Naar professioneel toezicht'. Dat rapport had betrekking op woningcorporaties. Eind 2005 verscheen een branchecode governance voor het hoger beroepsonderwijs (HBO). De Algemene Vergadering van de HBO-raad heeft destijds ingestemd met een branchecode voor hogescholen. De branchecode is bindend voor alle leden. Hiermee hebben de hogescholen in eigen kring de regels bepaald voor goed intern bestuur en toezicht. En op welke wijze zij in een open dialoog met 'stakeholders' inhoud geven aan onderwijs en onderzoek. In de sector van het middelbaar beroepsonderwijs en de volwasseneneducatie - ook wel de BVE-sector genoemd - verscheen rond 2005 ook een advies voor een sectoraal geïnspireerde 'governance' - code. Opsteller: de commissie- Meijerink. Die code is nader bediscussieerd in de mbo-sector en door de grote meerderheid van instellingsbesturen en toezichthouders voor middelbaar beroepsonderwijs vrij snel overgenomen. Deze code wordt hier kort als voorbeeld behandeld, om te bezien of dit 'governance' - perspectief bruikbaar is voor het doel van dit onderzoek.

De MBO-code impliceert vooral dat duidelijk wordt wie per instelling voor welke bestuurlijke vraagstukken verantwoordelijk is en wie waarover aan wie rapporteert. Deze code ging en gaat dus over markering van interne bestuurlijke verantwoordelijkheden, verantwoording en transparantie in de betrekkingen tussen een raad van toezicht van een mbo-instelling en een college van bestuur, en over de verhouding met de leerlingen, leerkrachten, afnemende bedrijven en andere 'stakeholders'. De komst van 
een dergelijke op modernisering van bestuur en toezicht gerichte code is begrijpelijk, vanuit het omvangrijke overheidsbudget dat in de sector omgaat, de zekere mate van autonomie die instellingen bezitten, de toegenomen resultaatgerichtheid en de aandacht voor de al of niet verzwakte kwaliteit van primaire processen en de rol van inspecties daarbij.

Aan het ontstaan van deze code en andere codes droegen niet slechts normatieve opvattingen over goed bestuur bij (zoals over cumulatie van commissariaten) maar zeker ook incidenten en affaires in diverse sectoren. Die incidenten hadden bijvoorbeeld betrekking op de onzichtbaarheid van beloningen voor bestuurders, de hoogte van beloningen, mistigheid over wie voor wat verantwoordelijk was en aan wie verantwoording schuldig was, en twijfel over de bestendige kwaliteit van primaire processen. Het toezicht kwam daardoor meer in zicht en werd meer van belang. Raden van toezicht hebben dan ook werk gemaakt van discussie over de 'governance'- codes.

Het denken over 'corporate governance' heeft inmiddels geleid tot tal van studies. Een studie van Cools werd al genoemd. Hij houdt een pleidooi voor het belang van controle en vooral voor vertrouwen in organisaties. Enkele oraties worden er hier vitgelicht. Bossert (2003) onderscheidt in zijn oratie vier kernthema's en een aantal dimensies van 'corporate governance'. Tot de kernthema's rekent hij sturing, toezicht, verantwoording en beheersing (planning \& control). Dat zijn grofweg de onderwerpen die al zijn aangestipt. Onder dimensies van 'governance' schaart hij onder meer de stabiliteit van een 'governance'-systeem, de kosten, de risico's, het risicomanagement en de 'governance' in beleidsketens. Van Montfort (2008) gaat in zijn oratie in op het bestuur van publiek-private samenwerking. Hij is niet voor of tegen PPS, maar verkent het terrein en formuleert een programma voor onderzoek. In zijn oratie vraagt hij onder meer aandacht voor de balans van krachten en tegenkrachten in de publiek-private arrangementen. Raden van toezicht zijn als tegenkracht belangrijk. Wie van daaruit verder analyseert heeft kunnen constateren dat raden van toezicht hier en daar toch teveel tegen besturen hebben aangeleund en te weinig afstand hebben bewaard, waardoor affaires als bij de hogeschool Inholland (onder andere een soepele route naar een einddiploma in bepaalde studies; zie het rapport van de commissie-Leers en inspectierapporten) niet verhinderd zijn. Noordegraaf (2008) heeft voor gedrag van bestuurders en professionals ook aandacht in zijn oratie 'Professioneel bestuur'. Hij meent dat in diverse organisaties, die voorheen strak gereguleerd werden door de overheid, professionals (een verzamelcategorie voor 'werkers' ) aan het kortste eind hebben getrokken ten faveure van bestuurders en managers. Terwijl van besturen vroeger niet veel merkbaar was, voelen werkers van allerlei soort sinds het begin van de jaren negentig van de vorige eeuw wel de hete adem van op 'sturen' gerichte besturen, niet zelden in de vorm van verandermanagement. Binnen veranderende kaders wordt van professionals medeverantwoordelijkheid en meer verantwoording gevraagd. Dat geeft aanleiding tot ongemak, ficties, fricties en zelfs afkeer aan de kant van die werkers. Ongenoegen krijgt een stem. De 'bestuurlijk manager' wordt voor de werkvloer zelfs een zwart schaap: teveel bezig met zichzelf en met ornamenten, te weinig aandacht voor primaire processen. 'Governance'- codes hebben dit proces van op de tocht staande interne 
verhoudingen bij instellingen en een poging tot dialoog met externe partners blijkbaar niet kunnen keren. Cools waarschuwde al.

\section{'Goed bestuur' van gemeenten}

Het denken over normen voor openbaar bestuur nam de laatste jaren ook een grotere vlucht, waarbij ook toezicht in ogenschouw werd genomen. Het toezicht op gemeenten is vanuit interbestuurlijk perspectief zeker financieel gericht (denk aan provinciaal toezicht, art. 12-status van gemeenten) maar niet uitsluitend. Er bestaan ook tal van beleids(gebied)gebonden toezichtarrangementen. Denk maar aan de monumentenzorg. De commissie-Oosting hield in 2007 een pleidooi voor meer generiek toezicht. Maar van een commissie die een code voorstelde, zoals die van de commissieTabaksblat, -Meurs en -Meijerink, is in de gemeentelijke sfeer geen sprake geweest. Desalniettemin kregen gemeenten ook te maken met prikkeling om te komen tot meer verantwoording en transparantie door middel van bestuurskrachtmetingen en specifieke monitoring (Abma en Korsten, 2009).

Hoe staat het verder met goed gemeentebestuur? Gewezen kan worden op meerdere publicaties (Hiemstra, 2003; Kaiser, 2004; Korsten, 2010c). Kaiser onderscheidt in de publicatie 'De deugdelijke gemeente' een tiental basisregels voor deugdelijk besturen, waartoe onder meer behoren het hebben van visie, goed luisteren en responsiviteit. Kaiser ziet deze deugden als de uitgangspunten die een moderne gemeente zich stelt, of die aan een lokaal bestuur worden gesteld. De deugden moeten in ieder geval toe te leiden zijn naar herkenbare dienstverlening, gedrag of communicatiekenmerken. Pas dan zal de burger de gemeente erkennen als deugdelijk bestuurd (Kaiser, 2004: 9). Ook de Commissie Vernieuwingsimpuls Dualisme en lokale democratie analyseert een aantal aspecten van goed bestuur. Ook hier gaat het om zaken als consensus, transparantie, participatie, het goede voorbeeld geven, responsiviteit, billijkheid en inclusiviteit, efficiency en effectiviteit en het afleggen van verantwoording (Verbeek, 2006). Brandsen c.s. kwamen in 2006, geïnspireerd door werk van de commissie-Meurs in de gezondheidszorg, tot de volgende werkdefinitie met betrekking tot 'good governance': "Good governance in de publieke sector duidt op een stelsel van effectieve omgangsvormen en spelregels voor goed bestuur van en goed toezicht op organisaties in de publieke sector, en een systematiek van deugdelijke verantwoording aan en evenwichtige beïnvloeding door belanghebbenden van de wijze waarop organisaties in de publieke sector te werk gaan en publieke waarden, goederen en diensten voortbrengen" (Brandsen c.s., 2006).

Omdat de maatstaven voor goed overheidsbestuur in de loop van de afgelopen decennia sterk zijn toegenomen, zoals Korsten (2010c) laat zien, ontstaat er als vanzelfsprekend een behoefte om te komen tot een korter overzicht van kerncriteria. In 2009 is door het Ministerie van BZK de Nederlandse Code voor goed openbaar bestuur vastgesteld, die in die behoefte voorziet. In deze code zijn slechts zeven beginselen opgenomen: openheid en integriteit, participatie, behoorlijke contacten met burgers, doelgerichtheid en doelmatigheid, legitimiteit, lerend en zelfreinigend vermogen en het afleggen van verantwoording (Ministerie van BZK, 2009: 9). Elk van die beginselen kent overigens een onderverdeling, waardoor het in de praktijk toch om meer criteria gaat. 
Het ministerie sluit daarbij aan bij de Verenigde Naties, die met acht maatstaven kwamen waaraan de kwaliteit van besturen is af te meten: rechtszekerheid, onpartijdigheid, openheid en transparantie, afleggen van publieke verantwoording, effectiviteit en efficiency, vraaggerichtheid, participatief vermogen en gerichtheid op consensus (Huberts, 2009: 102).

Tot zover een beknopt overzicht op hoofdlijnen van de discussie over 'corporate governance' en 'public governance'. Wat leert deze beschouwing voor het onderwerp van deze studie?

\section{Good governance en bestuurlijke probleemgemeenten}

Hier wordt ervoor gekozen om niet naar probleemgemeenten te kijken vanuit het perspectief van 'corporate governance' en ook niet specifiek vanuit uitsluitend het netwerkdenken. De overheid verschilt van een private organisatie en daarom is een perspectief als dat van de code van de commissie-Tabaksblat, uitsluitend gericht op de private sector, hier onvruchtbaar. De verhoudingen in instellingen voor zorg en onderwijs verschillen ook zeer van het gemeentebestuur, waardoor een analyse vanuit bijvoorbeeld de code van de commissie-Meurs (gezondheidszorg) en - Meijerink (onderwijs) hier niet bruikbaar is.

Bij het analyseren van bestuurlijke probleemgemeenten zouden daarentegen wél de normen uit de Code voor goed bestuur gebruikt kunnen worden. Deze code verdisconteert immers dat een gemeentebestuur op tal van gebieden niet meer bestuurscentrisch opereert en juist in netwerken met van elkaar afhankelijke actoren actief is. Vanuit de Code voor goed openbaar bestuur zou de vraag kunnen zijn: werden sommige normen overtreden, waardoor er bestuurlijke problemen ontstonden? Huberts (2009: 103) werkte deze invalshoek enigszins uit. Hij vraagt zich af: werden bijvoorbeeld wetten en regels overtreden (rechtmatigheid), werden geen resultaten geboekt (doelmatigheid), werd niet integer gehandeld (integriteit) of was er een democratisch probleem (legitimiteit)? Het zijn vragen die zonder meer nader onderzoek rechtvaardigen en een mooie invalshoek kunnen bieden bij het analyseren van bestuurlijke probleemgemeenten. Deze effectanalyses zijn volgens Huberts echter lastig te maken zonder eerst zicht te hebben op de 'basis' van de problematiek: wat speelt er nu allemaal in dergelijke gemeenten? "Bijna per definitie gaat het dan om een complex van achtergronden en factoren, maar wat meer zicht moet haalbaar zijn. Gaat het om factoren die te maken hebben met het individu en de baan (bijvoorbeeld individuele hebzucht, respectievelijk de mate van beleidsvrijheid), om organisatiekenmerken (leiderschap, organisatiestructuur, organisatiecultuur) of was het falen te wijten aan externe factoren (economie, misdaad, etcetera). Al deze factoren zijn van invloed op de kans dat zich in een organisatie integriteitschendingen voordoen en een soortgelijk verklaringsmodel lijkt bruikbaar voor 'bestuurlijk falen'." (Huberts, 2009: 105)

Het is dus zaak eerst meer zicht te krijgen op de relevante factoren, alvorens dieper kan worden ingegaan op de effecten van bestuurlijke problemen op verschillende terreinen.

Bovendien speelt bij de benadering via 'good governance' nog een ander probleem: het is een wat statisch geheel van benaderingen, dat weinig recht doet aan het feit dat gemeenten en gemeentebesturen ook op dit terrein een ontwikkeling in de tijd kunnen 
doormaken. Als een gemeentebestuur op enig moment geen resultaten boekt en dus slecht scoort op bijvoorbeeld effectiviteit, kan dat in een later stadium beter zijn. De conclusie is dat ook de 'good governance'- benadering (nog) niet het eerste handvat biedt dat nodig is voor onze analyse. Huberts en Van Hout (2011: 61) voegen in een recente beschouwing toe dat uit de literatuur 'verschillende en tegenstrijdige concepten, theoretische aanzetten en mogelijke aanbevelingen oprijzen'.

Wat overigens wel goed in het oog gehouden moet worden, is het inzicht van Cools dat 'bijzonder' gedrag van individuele bestuurders zeer van belang kan zijn voor het uit de bocht vliegen van besturen en organisaties (Cools, 2005). Dat kan in bestuurlijke probleemgemeenten aan de orde zijn.

\subsection{De benadering via factoren en schaalniveaus}

Daar waar de eerste twee benaderingen uit gingen van het vinden van een antwoord op de vraag wat kenmerken zijn van bestuurlijke probleemgemeenten, is het ook mogelijk te kijken naar de vraag hoe de problematiek ontstaat. Deze derde benadering, de benadering via factoren en schaalniveaus, is afkomstig uit onderzoek naar het gedwongen vertrek van burgemeesters (Korsten en Aardema, 2006). Zij onderscheiden een aantal oorzaken voor het gedwongen of 'vrijwillig' gedwongen vertrek van een burgemeester, die zij vervolgens indelen op een drietal schaalniveaus: micro-, meso- en macroniveau. De indeling werd ingegeven door literatuurstudie (o.a. Derksen, 1980; 1990; Louter, 1988; Van Maaren-Van Balen, 2003; Tops \& van Spijker, 2004; Steur, 2005) en is in een expertmeeting met onder meer burgemeesters, provinciale kabinetchefs en begeleiders van vertrouwenscommissies herbevestigd als ordeningskader (Korsten c.s. 2008). Het gaat hierbij om de volgende factoren op de onderscheiden niveaus (Korsten en Aardema, 2006: 25).

\section{Microniveau}

Onder factoren op microniveau (microfactoren) wordt verstaan: het geheel aan oorzaken en omstandigheden die te maken hebben met de persoon van de bestuurders zelf en inwerk(t)en op de val. Het gaat om persoonsgebonden eigenschappen, de rolopvatting van de burgemeester en de wethouders, de stijl van optreden en kwaliteit op psychologisch vlak, de kwaliteiten in rolonderdelen, zoals het vervullen van voorzitterschappen, de kracht en zwakte op het vlak van integriteit, etc. Sporen de wijze van functioneren van de burgemeester en/of de wethouders en hun rolopvatting met de verwachting van anderen? Doen zij wat zij moeten doen?

\section{Mesoniveau}

Tot de factoren op mesoniveau (mesofactoren) behoren alle invloedsfactoren die inwerken op de val van de burgemeester en/of de wethouders en te maken hebben met collectiviteiten (arena's) en interacties. Het gaat er zowel om hoe de raad en/of het college zich opstelt en hoe de verbindingen zich voltrekken, als om hoe de burgemeester en wethouders daarin opereren: zij staan er immers niet buiten. Te denken valt aan de positie van de burgemeester en/of de wethouders in het college, in de raad, in raadscommissies, in het presidium en in de samenleving. 


\section{Macroniveau}

Tot de factoren op macroniveau (macrofactoren) zijn factoren te rekenen die betrekking hebben op de politieke structuur en cultuur in een gemeente en de achterliggende sociale, fysieke, economische en demografische structuur en de cultuur van de samenleving. Voor wat betreft de politieke structuur valt te denken aan het aantal fracties in de raad en de gemiddelde grootte, waarbij een gefragmenteerde raad veel kleine fracties kent. Een politiek-bestuurlijke cultuur verwijst naar de mentale programmering van politieke fracties en partijen. Korsten en Aardema onderscheiden als macrofactor ook de samenlevingscultuur, die verwijst naar de opvattingen en houdingen van burgers, zoals morele verontwaardiging in delen van de samenleving over een handelwijze van een bestuurder. Ook de rol van de media wordt gerekend tot de macrofactoren.

De benadering via factoren op enkele niveaus lijkt een mooie entree te geven voor het onderzoeken van bestuurlijke probleemgemeenten. Hiermee is namelijk op alle niveaus inzichtelijk te maken welke rol de factor speelde in de bestuurlijke problematiek. Lag het aan de burgemeester of de wethouder individueel? Ging het eerder om slechte verbindingen tussen het college en de raad? Of was vooral de raad continu op 'oorlogspad', waardoor er zoveel gemeentebestuurders vielen in de gemeenten?

Alvorens tot nadere uitwerking over te gaan, wordt nog een vierde entree belicht: die via al verricht onderzoek naar de sterkte van bestuurscolleges.

\subsection{Sterke colleges}

Onderzoek naar bestuurlijke probleemgemeenten en de problemen die daar spelen zou ook ingestoken kunnen worden via de vraag of de colleges en de individuele bestuurders daarin wel sterk genoeg waren. Ontbrak er iets aan de kracht van een college, waardoor er viteindelijk geen steun meer voor was? Naar deze invalshoek, die van de kracht van colleges, is eerder onderzoek gedaan (Korsten en Schoenmaker, 2008). In dit onderzoek wordt vastgesteld dat bestuur in Nederland geen individuele taak is, maar een kwestie van collegiaal bestuur. Het is niet de wethouder die bestuurt, maar het college als geheel. Bestuur vindt bovendien plaats in een omgeving: gemeenten in Nederland worden bestuurd door colleges van burgemeester en wethouders, binnen de door de gemeenteraad gestelde kaders en worden door diezelfde raad gecontroleerd. Dit allemaal binnen het kader van de Gemeentewet en daarin recent verwerkte dualismeregels. De vraag is: bestaan er sterke colleges van burgemeester en wethouders? En dus ook minder sterke? Om een antwoord op die vraag te geven vroegen beide auteurs aan meer dan zestig personen uit het lokale bestuur wat zij onder een sterk college van burgemeester en wethouders verstaan, met het verzoek dat zoveel mogelijk te illustreren. De antwoorden van de groep van (ex-) burgemeesters, (ex-) wethouders, (ex-) gemeentesecretarissen en andere ambtenaren, (ex-) raadsleden en enkele externe adviseurs, tesamen met de andere bronnen, leverden een aantal uitgangspunten op met betrekking tot de vraag of sterke colleges bestaan en zo ja, hoe die kracht is te stimuleren.

Uit de antwoorden bleek onder meer dat de kwaliteit van een college afhangt van de criteria die gesteld worden en het perspectief waarmee naar colleges gekeken wordt. 
Een gemeentesecretaris: "Of een college een sterk college is, is naar mijn ervaring afhankelijk van de wijze waarop de collegeleden invulling geven aan de diverse relaties: de relaties binnen het college; de relaties buiten het college: met de raad, met de ambtelijke organisatie, met de inwoners, bedrijven en instellingen en met andere overheden" (Korsten en Schoenmaker, 2008: 20). Bij de zoektocht naar een sterk college speelt dus een brede waaier aan perspectieven een rol. Korsten en Schoenmaker analyseren 13 verschillende perspectieven:

1. De coalitievorming: een sterk college smeden

2. De wethouder: sterk college, professionele wethouders

3. Het college: sterk college als sterk team

4. De burgemeester: een sterk college heeft een goede burgemeester nodig

5. De ambtenaren en de bestuurlijk - ambtelijke betrekkingen

6. De beoordelaar van bestuurskracht: een sterk college is een bestuurskrachtig college?

7. Het raadslid: het samenspel van college en raad

8. Het debatperspectief: discussie over inhoud en de rol van macht

9. De dualisering: een sterk college werkt binnen dualistisch kader

10. De burgers: een sterk college volgens de inwoners van een gemeente

11. De electorale cyclus: wanneer een college sterk kan zijn

12. De 'moeilijke' gemeente: waar colleges grotere risico's lopen

13. De mobiliserende kracht: bestuur met andere partijen of alleen?

De door de auteurs geraadpleegde wethouders, burgemeesters, gemeentesecretarissen, andere ambtenaren en adviseurs beschouwen solisme van wethouders, gebrekkige collegialiteit en elkaar niets gunnen, wispelturigheid en gebrek aan koers doorgaans als een indicatie dat een college als geheel niet sterk is. Ze hechten bij hun beeld van een sterk college vooral aan 'teamwork' en gedeelde ambitie. Meer precies geformuleerd, een sterk college van B\&W moet minimaal een hecht team van leden zijn, die ambitie hebben, met elkaar overweg kunnen, geïnspireerd en bevlogen aan de gang gaan, overtuigingskracht leggen in wat ze doen, visie tonen en elkaar als collegeleden succes gunnen. Uiteindelijk kwamen Korsten en Schoenmaker tot 37 adviesregels, die de kracht van colleges kunnen vergroten.

De invalshoek van Korsten en Schoenmaker levert waardevolle aanknopingspunten op voor het analyseren van bestuurlijke probleemgemeenten. Tegelijkertijd is het een studie van colleges, dus dagelijkse besturen. Er is minder aandacht voor de raad, het algemeen bestuur. Een combinatie met de iets breder kijkende analyse lijkt voor de hand te liggen.

\subsection{Samenvatting van mogelijke benaderingen}

Samengevat zijn de mogelijke onderzoeksbenaderingen weergegeven in tabel 5, waarbij is aangegeven wat de sterke kanten en beperkingen van de geschetste theoretische perspectieven zijn. 
Tabel 5: Perspectieven op onderzoek van bestuurlijke probleemgemeenten

\begin{tabular}{|l|l|l|l|}
\hline $\begin{array}{l}\text { Theoretisch } \\
\text { perspectief }\end{array}$ & \multicolumn{1}{|c|}{ Focus } & \multicolumn{1}{c|}{ Sterke kant } & \multicolumn{1}{c|}{ Beperking } \\
\hline $\begin{array}{l}\text { Studie van } \\
\text { bestuurskracht }\end{array}$ & $\begin{array}{l}\text { Een probleem- } \\
\text { gemeente kent } \\
\text { een zwakke } \\
\text { algemene } \\
\text { bestuurskracht }\end{array}$ & $\begin{array}{l}\text { Aandacht voor be- } \\
\text { stuurskracht-criteria }\end{array}$ & $\begin{array}{l}\text { Tot nu toe vooral smal } \\
\text { vitgevoerd. Een bredere } \\
\text { beschouwing zou meer } \\
\text { inzicht moeten kunnen } \\
\text { opleveren. } \\
\text { Geen aandacht voor } \\
\text { mensen en voor ontwikke- } \\
\text { ling in de tijd }\end{array}$ \\
\hline $\begin{array}{l}\text { Good } \\
\text { governance }\end{array}$ & $\begin{array}{l}\text { In probleem- } \\
\text { gemeenten zijn } \\
\text { principes van } \\
\text { 'good governance' } \\
\text { zwak }\end{array}$ & $\begin{array}{l}\text { Beoordeling van } \\
\text { probleemgemeente } \\
\text { op basis van criteria } \\
\text { van good governance }\end{array}$ & $\begin{array}{l}\text { Statisch: geen aandacht } \\
\text { voor ontwikkeling in de } \\
\text { tijd }\end{array}$ \\
\hline $\begin{array}{l}\text { Micro-, meso- } \\
\text { en macro- } \\
\text { analyse: } \\
\text { genese }\end{array}$ & $\begin{array}{l}\text { Focus op } \\
\text { processen in } \\
\text { ontwikkeling naar } \\
\text { probleem- } \\
\text { gemeente }\end{array}$ & $\begin{array}{l}\text { Genese: aansluiting } \\
\text { op onderzoek naar } \\
\text { val (omstandigheden) } \\
\text { van burgemeesters }\end{array}$ & $\begin{array}{l}\text { Letten op dynamiek en } \\
\text { verstrengeling in de tijd } \\
\text { van beïnvloedende facto- } \\
\text { ren. }\end{array}$ \\
\hline $\begin{array}{l}\text { Sterke en } \\
\text { zwakke colleges } \\
\text { van B\&W }\end{array}$ & $\begin{array}{l}\text { is niet 'sterk' } \\
\text { and }\end{array}$ & $\begin{array}{l}\text { Stellingen van } \\
\text { Korsten en } \\
\text { Schoenmaker }\end{array}$ & $\begin{array}{l}\text { Minder aandacht voor } \\
\text { algemeen bestuur }\end{array}$ \\
\hline
\end{tabular}

In deze studie is gekozen voor een combinatie van de factorenbenadering op micro-, meso- en macroniveau, aangevuld met de al verworven inzichten uit het onderzoek naar sterke en zwakke colleges. De niveaus worden nu niet alleen beschouwd voor burgemeesters, maar ook voor wethouders of complete colleges. De analyse over sterke colleges van Korsten en Schoenmaker is herkenbaar in de hierna volgende beschrijving van de factoren en de onderscheiden indicaties voor deze factoren.

\subsection{Negen factoren}

In de voor dit onderzoek uit te voeren casestudies in bestuurlijke probleemgemeenten zullen in totaal negen factoren worden geanalyseerd. Zij zijn ontleend aan de analyse van Korsten en Aardema, met een tweetal uitzonderingen. Korsten en Aardema onderscheiden de variabele 'maatschappij', waarbij het vooral gaat om morele verontwaardiging van (een deel van) de inwoners over bepaalde gebeurtenissen. Deze factor kan op macroniveau ook worden belicht in de rol van de (pers)media, die immers berichten over dergelijke verontwaardiging. Tevens is een factor toegevoegd: bij de verbindingen is specifiek gekeken naar de relatie tussen de coalitiepartijen. Het lijkt immers aannemelijk dat, als er continu bestuurlijke problemen zijn in een gemeente waarbij wethouders vallen en dus coalities uit elkaar spatten, er iets schort aan de verbinding tussen de coalitiepartijen. 
De volgende factoren worden onderzocht:

Op microniveau:

1. De burgemeester

2. De wethouder

Op mesoniveau:

3. De verbinding binnen het college

4. De verbinding tussen het college en de ambtelijke organisatie

5. De verbinding tussen college en raad

6. De verbinding tussen coalitiepartijen

Op macroniveau:

7. De bestuurstructuur

8. De bestuurscultuur

9. De rol van de (pers)media

De verschillende factoren worden hieronder kort beschreven en voorzien van indicatoren, waarmee ze in de praktijk van de bestuurlijke probleemgemeenten kunnen worden bezien. In de factoren kunnen ook de nieuwe ontwikkelingen worden opgenomen, zoals die in hoofdstuk 2 zijn beschreven. Verzakelijking en vermaatschappelijking zijn ontwikkelingen die inwerken op de toenemende eisen, die aan gemeentebestuurders worden gesteld en in de microfactoren naar voren komen. Dualisering is opgenomen in de verhouding tussen college en raad, politieke versplintering is onder de noemer 'bestuursstructuur' een aparte factor. De politisering (en de scherpere profilering als gevolg van de afnemende betekenis van partijen) is terug te vinden in de aparte factor 'bestuurscultuur'.

\section{Microfactor: de burgemeester}

De eerste invloedsfactor op microniveau bij het ontstaan en voortduren van bestuurlijke conflicten en bestuurscrises is de persoon van de burgemeester. Zij bekleden een bij vitstek openbaar ambt. Het oog van de publiciteit is nooit geloken, een negatief oordeel over handelen of niet handelen snel geschreven. Een voorbeeld is de aandacht in de media, begin 2010, voor al of niet juiste declaraties van gemeentebestuurders. Oudvoorzitter van het Nederlands Genootschap van Burgemeesters (NGB) en oud-burgemeester van Dordrecht, R.J.G. Bandell, werd er wel eens moe van: "Dan denk ik: mijn verantwoordingskader is de gemeenteraad en de gemeente heeft ook een accountant. Het lijkt wel of sommigen alleen maar op zoek zijn naar schandaaltjes" (Crul, 2010: 22).

Buiten deze 'dreigingen van buiten' zijn er ook in het werk zelf de nodige hindernissen te overwinnen en problemen te ondervangen. Daarbij is gebrekkige signaalgevoeligheid van de burgemeester een belangrijke oorzaak van problemen. Uit de literatuur wordt duidelijk dat burgemeesters die problemen niet zien aankomen en signalen niet oppikken, problemen kunnen krijgen. Signalen uit een college over bepaalde aspecten van het functioneren, signalen van de fractievoorzitters of uit de gemeenteraad. Een tweede oorzaak betreft het feit dat de burgemeester vasthoudt aan een bepaalde bestuursstijl, ook als deze niet of niet meer past bij de gegroeide verwachtingen van anderen, zoals raadsleden. Een door anderen ervaren gebrek aan flexibiliteit van de burge- 
meester zou hier een belangrijke indicatie voor kunnen zijn. Uiteraard kunnen ook meer persoonlijke zaken (een integriteitsprobleem of een probleem met huisvesting bijvoorbeeld) de oorzaak van mogelijke problemen zijn.

Kortom: bij de microfactor 'burgemeester' gaat het er om dat burgemeesters signalen kunnen oppikken en hierna ook flexibiliteit vertonen. Burgemeesters moeten zichzelf kunnen corrigeren als ze 'zwakten' vertonen en niet (meer) beantwoorden aan verwachtingen over hun persoon. Ook het bindend vermogen dat burgemeesters aan de dag leggen, bijvoorbeeld blijkend uit hun capaciteiten tot compromisvorming en relativering, speelt een belangrijke rol op microniveau.

\section{Microfactor: de wethouder}

De tweede microfactor is/zijn de wethouder(s). Deze zijn er in vele soorten en maten. Fulltimers, parttimers, ervaren en net begonnen, jong en oud. Over het geheim van het vak zijn al boeken vol geschreven en hebben vele wethouders zich uitgelaten (zie bijvoorbeeld Werkgroep2duizend, 2002). Duidelijk is dat het zijn van wethouder op lokaal niveau een vak apart is. Niet iedereen is er geschikt voor. Vaak hebben mensen dat zelf al wel in de gaten en zullen zij zich niet kandideren voor een wethoudersfunctie. 'Politiek is niets voor mij', hoor je dan. Soms echter denken personen dat zij het vak wel onder de knie hebben of zullen krijgen en worden zij wel wethouder. Succes kan hierna op allerlei manieren ontstaan, maar dat geldt ook voor problemen. Als het gaat om de persoon van de wethouder zelf geldt een soortgelijke redenering als voor de burgemeester. Wethouders die politiek gevoelig zijn en een antenne hebben voor mogelijke problemen, houden het in de regel lang vol. Zij weten wat zij wel en niet moeten doen, zij vangen op hoe sommige zaken in de gemeenteraad of de samenleving liggen en doen daar hun voordeel mee. Signaalgevoeligheid is dus belangrijk. Andere wethouders zijn niet of in veel mindere mate uitgerust met een 'politieke' antenne. Zij profileren zich bijvoorbeeld erg voor één partij, stellen zich niet collegiaal op, beheersen hun stukken onvoldoende en merken niet dat op deze zaken steeds negatiever wordt gereageerd. Indicaties zijn herhaalde discussies over het veronderstelde zwakke optreden van een wethouder, bijvoorbeeld in politiek gevoelige dossiers. Ook persoonlijke factoren kunnen een conflict of crisis erg in de hand werken, vergelijkbaar met de factor burgemeester.

Ook wethouders moeten zichzelf dus kunnen corrigeren als ze in de gaten krijgen dat hun gedrag niet beantwoord aan verwachtingen van 'relevante anderen.'

\section{Mesofactor: het college}

De vraag hoe sterk of hoe zwak een college is, blijkt in de praktijk moeilijk te beantwoorden. Veel literatuur over het presteren van colleges en de factoren die van invloed zijn op de kracht van colleges is niet voor handen. In hun boek over sterke colleges komen Korsten en Schoenmaker (2008) wel tot een opsomming van krachten die inwerken op een college.

Er zijn verschillende mogelijkheden een college samen te stellen. In de regel wordt gewerkt met meerderheidscolleges, die zich gesteund weten door een meerderheid van de gemeenteraad. In enkele gevallen komt ook wel een minderheidscollege voor, vaak omdat het niet mogelijk blijkt een meerderheid van de raad te vinden om het 
college te steunen. Zo'n college werkt dan met gedoogsteun van één of meerdere partijen. Colleges kunnen wethouders hebben die allen afkomstig zijn uit de gemeenteraad, maar sinds een aantal jaren is het ook mogelijk te werken met wethouders van buiten de raad. In enkele gevallen (Goirle, Zundert, Bergen) kwamen, vaak na een crisis, alle wethouders van buiten. Dan wordt gesproken over een 'zakencollege'. Ook de manier van samenwerken in een college kan verschil maken. Daar waar het er elke week verbaal hard aan toe gaat in een college, de wethouders elkaar weinig gunnen en collegiaal bestuur ver te zoeken is, wordt wel gesproken over een vechtcollege.

Colleges krijgen het moeilijk, zo blijkt uit de literatuur (zie o.a. Korsten en Schoenmaker, 2008), door in ieder geval twee zaken. Ten eerste een gebrek aan teamgeest, waarbij indicaties zijn dat er teveel wethouders zijn, wethouders elkaar niet aanvullen, de chemie ontbreekt of de verbindend leider ontbreekt. Een tweede oorzaak is een gebrek aan visie, dat blijkt uit het totaal ontbreken van een visiedocument, maar ook uit door raadsleden of de samenleving ervaren gebrekkige bestuurskracht. Dit college is niet krachtig, heet het dan, het weet niet waar het heen wil. Sterke colleges zijn in dit onderzoek dan ook colleges met een goede teamgeest, die op basis van een gedeelde visie en een goede relatie met de gemeenteraad aan de slag gaan en er door hun optreden in slagen opdoemende problemen te dempen.

\section{Mesofactor: de verbinding tussen college en ambtelijke organisatie}

Een volgende mesofactor is de verbinding tussen het college van B\&W en de ambtelijke organisatie. Korsten en Aardema gaan in hun onderzoek naar vallende burgemeesters specifiek in op de relatie tussen de burgemeester en de secretaris. Zij concluderen dat beide functionarissen een belangrijke spil in de organisatie vormen en dus functioneel goed met elkaar moeten omgaan. Uit media-uitingen blijkt dat eventuele problemen van een burgemeester vaak samenhangen met zijn of haar relatie met de secretaris (Van Maaren-van Balen, 2003; Westerink, 2006). In dit onderzoek wordt die relatie beschouwd, maar dan in breder verband. Niet alleen burgemeesters hebben immers een relatie met de ambtelijke organisatie, dat geldt tevens voor wethouders en het hele college. Bij bestuurlijke problematiek wordt snel verwezen naar de niet optimale organisatie- en managementcondities waaronder het college moest functioneren. Indicaties voor mogelijke problemen op dit front zijn dat er weinig patroonmatigheid in de relaties zit, of dat er veel klachten over de ambtelijke ondersteuning worden gevit.

\section{Mesofactor: de verbinding tussen college en raad}

Een veel gehoorde verklaring voor de bestuurlijke problematiek in sommige gemeenten is de komst van het dualisme op lokaal niveau, ingevoerd na de raadsverkiezingen van maart 2002. In sommige gemeenten is dit gepaard gegaan met behoorlijke problemen, waarbij vooral opvalt dat er zwakke verbindingen ontstonden tussen college en gemeenteraad. Zo namen sommige gemeenteraden hun eigen verantwoordelijkheid wel erg letterlijk. Colleges moesten soms gissen of en wanneer hun voorstellen besproken zouden worden, laat staan hoe de besluitvorming zou uitpakken. Fracties voelden zich, onder het mom van duale verhoudingen, op geen enkele manier meer verbonden met of verantwoordelijk voor de coalitie en dus voor het college. Niet voor niets kwam in 2002 en 2003 de term 'duellisme' in zwang, om aan te geven hoe de verhoudingen tussen gemeenteraad en college hier en daar waren komen te liggen. Uit de literatuur en uit 
vele media-uitingen is af te leiden dat, naar de mening van velen, deze post-duale verhoudingen de sfeer in menig gemeenteraad hebben veranderd en garant hebben gestaan voor menig politiek-bestuurlijk probleem. Indicaties zijn onder meer dat het debat niet goed van de grond komt, er noodgedwongen veel van tevoren wordt 'dichtgetimmerd' en er in het algemeen geen herkenbaar patroon (onder meer door middel van kaderstelling) is in de verhouding tussen college en gemeenteraad.

\section{Mesofactor: de coalitie}

Nederland is een coalitieland, ook op lokaal niveau. Slechts zelden behaalt een partij de absolute meerderheid in een vertegenwoordigend orgaan. Dat komt op landelijk en provinciaal niveau in het geheel niet voor en maar hoogst zelden op gemeentelijk niveau. Partijen zijn dus na de verkiezingen genoodzaakt te gaan onderhandelen, om te bezien welke partijen een coalitie zullen vormen en het college van B\&W gaan samenstellen. De vraag is vervolgens welke invloed zo'n coalitie heeft op het ontstaan van bestuurlijke conflicten en bestuurscrises. Uit de literatuur (o.a. Korsten en Aardema, 2006; Korsten en Schoenmaker, 2008) blijkt dat er twee zaken van groot belang zijn bij het ontstaan van problemen: de gebrekkige samenhang tussen de coalitiepartijen en de onderlinge chemie tussen fracties en fractievoorzitters. Een indicatie voor een gebrekkige samenhang is, dat er heel veel coalitiepartijen kunnen zijn met een ruime raadsmeerderheid, waardoor partijen elkaar niet echt meer nodig hebben om een meerderheid te behalen bij stemmingen in de gemeenteraad. Ook een weinig ambitieus collegeprogramma is een indicatie voor een gebrekkige samenhang. Een indicatie voor het ontbreken van chemie is als gerapporteerd wordt dat er niet alleen nauwelijks formeel overlegd wordt, maar er ook geen informele contacten zijn. Dit geldt uiteraard voor de fractievoorzitters, die een belangrijke rol spelen in het 'afstemmen van opvattingen' van de fracties, zowel richting de coalitiepartijen zelf als in de richting van het college. Als het niet lekker loopt tussen de fractievoorzitters, neemt de kans op bestuurlijke problematiek toe. Maar ook de communicatie in algemene zin tussen collegeleden en coalitiefracties of tussen de fracties onderling moet op niveau zijn en blijven. Als individuele fractieleden hun eigen gang gaan en op geen enkele wijze afstemming zoeken, dus communiceren over hun opvattingen en bedoelingen, werkt dit problemen in de hand.

\section{Macrofactor: de bestuursstructuur}

Onder de bestuursstructuur wordt de mate van fragmentatie in de lokale democratie verstaan, dan wel de dominantie van één partij, zoals die zich uit in de gemeenteraad. Een onevenwichtig samengestelde, gefragmenteerde raad is een raad met veel (kleine) fracties, waaronder fracties van zuiver lokale lijsten. Dit kan het gevolg zijn van de verkiezingsuitslag, maar ook van tussentijdse afsplitsingen. Uit onderzoek voor het Centrum voor Lokaal Bestuur (Fransman, 2005) blijkt dat sinds 1986 in $80 \%$ van de gemeenten het aantal politieke partijen in de gemeenteraad is toegenomen. Niet alleen zijn er na raadsverkiezingen meer partijen in de gemeenteraad gekozen, maar er is ook sprake geweest van een toename van het aantal tussentijdse afsplitsingen (Fransman, 2005: 12). Vooral in dit laatste geval sluipt er vaak enig venijn in de gemeenteraad.

Vrijwel altijd is de afsplitsing het gevolg van een meningsverschil of ruzie binnen de fractie, waarna de kans groot is dat deze strijd zich in de raad voortzet. Soms gebeurt 
het dat door een afsplitsing een college de meerderheid in de gemeenteraad verliest. Sterke fragmentatie kan ertoe leiden dat raadsfracties makkelijk tot wisselende meerderheden in de raad komen, waardoor een patroon, een consistente lijn, in het bestuurlijk handelen gaat ontbreken. Bovendien kan er, als de inhoudelijke koersdiscussie niet steeds de boventoon voert, een neiging tot persoonlijke profilering ontstaan, in de vorm van 'bijterig gedrag', bits taalgebruik en op de man spelen (Korsten/Aardema, 2006: 61). In dit onderzoek wordt de berekende fractiequote gebruikt: het aantal raadsleden gedeeld door het aantal fracties. Als deze quote onder de drie zakt, is er reden met meer dan gemiddelde aandacht naar de structuur van de raad als factor te kijken. Dit kan ook in een ander geval: in sommige gemeenten is al jaren sprake van dominantie van één politieke partij (Van Maaren-van Balen, 2003). Het probleem is soms (niet altijd) dat deze dominante partij de dienst uit wil maken en de burgemeester en het college als een soort zetbaas wil gebruiken om uit te voeren wat de partij buiten de raad al besloten heeft. Ook dit is een factor die mee kan spelen in bestuurlijke probleemgemeenten.

\section{Macrofactor: de bestuurscultuur}

Onder bestuurscultuur, ofwel politiek-bestuurlijke cultuur, wordt de 'mentale programmering' van raadsleden, wethouders, burgemeesters en (top)ambtenaren verstaan. Zo'n cultuur kan een cultuur van regels zijn, maar ook destructieve trekken hebben, extreem kritisch zijn, ruw, cliëntelistisch. In deze cultuur schuilt vaak een grote bron van leed, ergernis en conflict. Interessant is hier de vergelijking met de oratie van Derksen uit 1990, die ook inging op de geldende normen en waarden in een gemeente in relatie tot crises (vgl. ook Hiemstra, 2003). Derksen (1990) spreekt over institutionele normen, die per gemeente kunnen verschillen. Hij onderscheidt daarbij selectienormen, interne omgangsnormen en bestuursnormen. Selectienormen hebben betrekking op de input, onder andere op het selecteren van politieke ambtsdragers. Interne omgangsnormen gaan over de conversie, over de wijze waarop de verschillende actoren binnen de gemeente met elkaar omgaan. Bestuursnormen tenslotte hebben betrekking op de output, op de wijze waarop de lokale gemeenschap wordt bestuurd. "Het aardige van die institutionele normen is nu dat ze niet voor alle gemeenten gelijk zijn. Voor alle gemeenten geldt hetzelfde wettelijke kader, maar de overige institutionele normen kunnen van gemeente tot gemeente en van regio tot regio verschillen. Het is dan ook goed om een duidelijk onderscheid te maken tussen de formele regels en al die andere normen, rolopvattingen, percepties, ideeën en dergelijke, die richting geven aan de wijze van besturen en politiek bedrijven" (Derksen, 1990: 8). Het feit echter dat er in de ene gemeente een crisis ontstaat en in de andere gemeente niet, is volgens Derksen niet te wijten aan het feit dat er in beide gemeenten andere institutionele normen bestaan. "Nadere analyse geeft steun aan de veronderstelling dat bovenal het ontbreken van consensus over institutionele normen (dus over de vraag: hoe bestuur ik een gemeente?) de diepere oorzaak is geweest van alle vruchteloze conflicten" (Derksen, 1990: 10).

De vraag op welke manier de bestuurscultuur te maken heeft met de problematiek in een gemeente is ook beantwoord door Korsten en Aardema (2006). Zij analyseerden een aantal onderzoeken, ingesteld door Commissarissen van de Koningin of door 
andere organen, naar de cultuur van bestuurlijk risicovolle gemeenten en stuitten op de termen 'destructieve cultuur' en 'cliëntelistische cultuur': "Een destructieve politieke cultuur uit zich doorgaans in één of meer van de volgende verschijnselen: veel discussie over korte termijn aspecten van beleid, veel schermutselingen in de raad in termen van gekissebis, onheuse uitingen en weinig elegante conversatie, op de man spelen en discussie over geruchten, polemiek in plaats van debat, toedekken van bepaalde kwesties die juist onderzoek vragen. Een cliëntelistische bestuurscultuur verwijst naar het opkomen voor bepaalde belangen, discussie over individuele belangen en niet steeds over algemene belangen, verrassende vitkomsten en wispelturigheid in de besluitvorming, vaak en op onduidelijke gronden terugkomen op eenmaal genomen besluiten. In de praktijk kan een bestuurscultuur een mix zijn van de genoemde elementen en nog andere dan die hier genoemd zijn" (Korsten en Aardema, 2006: 59).

\section{Macrofactor: de (pers)media}

De laatste macrofactor is de rol van de (pers)media. Hoogerwerf signaleert dat deze rol groter is geworden en dat bestuurders erdoor beïnvloed worden: "Daarnaast hebben de democratisering, de secularisatie, de economisering van het wereldbeeld en de opkomst van de massamedia ertoe bijgedragen dat de politicus meer dan voorheen aan kritiek wordt blootgesteld" (Hoogerwerf, 2004: 9). Kennelijk worden bestuurders, ongetwijfeld ook op lokaal niveau, meer dan voorheen aan kritiek blootgesteld via de (lokale) media. Ook in andere publicaties wordt de rol van de media als belangrijk beoordeeld. "De professionalisering van regionale en lokale zenders, waarvan het Amsterdamse AT5 misschien het beste voorbeeld is, wekt een grote belangstelling voor de lokale politiek. Maar dit leidt ook tot een grotere profileringdrang bij lokale bestuurders. De televisie geeft hen een gezicht. Met zijn positieve en negatieve kanten. Want deze media zorgen ervoor dat conflicten, spanningen en affaires worden uitvergroot" (Depla, 2010). "Als colleges vallen, fracties scheuren, wethouders of burgemeesters aftreden, kun je er vergif op innemen dat de publiciteit een grote rol heeft gespeeld", aldus J. Wallage, in 2010 voorzitter van de Raad voor het Openbaar Bestuur (Wallage, 2008: 11). Een rol speelt hierbij ongetwijfeld ook de onderzoeksjournalistiek, waarbij middels een beroep op de Wet Openbaarheid Bestuur (WOB) kwesties actueel worden. Uit onderzoek blijkt dat de media een grote rol kunnen spelen in de manier waarop kerngebeurtenissen in een gemeente worden beschreven en het verloop van de discussies wordt gevolgd. "De media zijn zelden beslissend over wel of niet gedwongen vertrek, maar werken wel drukverhogend, doordat ze de kans op bepaalde alternatieve beslisroutes voor een gemeenteraad soms beperken. Wijdt de pers eenmaal artikelen aan een bepaalde kwestie, dan is het zoeken naar een compromis heel moeilijk" (Korsten en Aardema, 2006: 65).

Het is zinvol de rol van de media in bestuurlijk moeilijke gemeenten nader te analyseren. In de casestudies wordt tevens aandacht besteed aan een relatief nieuw fenomeen: het gebruik van digitale media als weblog en twitter, waarbij raadsleden soms (onbedoeld of niet) een probleem in de hand werken. Ook de rol van actiegroepen, waar media-aandacht voor is, kan via deze factor worden behandeld. Hier zijn volop voorbeelden van. Zo ontstond in Dinkelland een actiegroep ten tijde van de crisis rond het gedwongen vertrek van burgemeester Willeme. In Den Helder had een actiegroep opvattingen over de problematiek rond burgemeester Hulman. De berichtgeving hierĞ

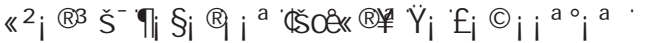


De hierboven beschreven factoren, oorzaken en indicaties worden in onderstaand schema samengebracht:

Tabel 6: Overzicht van aspecten en indicaties per analyseniveau

\begin{tabular}{|c|c|c|}
\hline Factor & Aspect & Indicator \\
\hline \multicolumn{3}{|l|}{ Microniveau } \\
\hline \multirow{4}{*}{$\begin{array}{l}\text { Kwaliteiten van } \\
\text { burgemeester }\end{array}$} & $\begin{array}{l}\text { Signalerend, reflec- } \\
\text { tief en adaptief } \\
\text { vermogen van } \\
\text { burgemeester }\end{array}$ & $\begin{array}{l}\text { - Continuïteit in gekritiseerd persoonlijk } \\
\text { optreden } \\
\text { - Mate van signalerend vermogen enz. } \\
\text { volgens henzelf } \\
\text { - Mate van signalerend vermogen enz. vlg. } \\
\text { informanten en/of rapporten }\end{array}$ \\
\hline & $\begin{array}{l}\text { Bestuursstijl van } \\
\text { burgemeester }\end{array}$ & $\begin{array}{l}\text { - Kenmerken van en oordeel over bestuurs- } \\
\text { stijl } \\
\text { - Mate van flexibiliteit in gedrag }\end{array}$ \\
\hline & $\begin{array}{l}\text { Professionaliteit } \\
\text { van burgemeester } \\
\text { in algemene zin }\end{array}$ & $\begin{array}{l}\text { - Spectrum van professionele rolcompeten- } \\
\text { ties (voorzitter etc.) } \\
\text { - Kwaliteit van competentievervulling, zoals } \\
\text { aanvoelen van verhoudingen, etc. }\end{array}$ \\
\hline & $\begin{array}{l}\text { Bindend vermogen } \\
\text { van burgemeester }\end{array}$ & $\begin{array}{l}\text { - Capaciteit om in debat alternatieven te } \\
\text { bedenken } \\
\text { - Capaciteit tot compromisvorming } \\
\text { - Capaciteit tot stressreductie (relativering, } \\
\text { etc.) }\end{array}$ \\
\hline \multirow{4}{*}{$\begin{array}{l}\text { Kwaliteiten van } \\
\text { wethouder }\end{array}$} & $\begin{array}{l}\text { Signalerend, reflec- } \\
\text { tief en adaptief } \\
\text { vermogen van } \\
\text { wethouder }\end{array}$ & $\begin{array}{l}\text { - Continuïteit in gekritiseerd persoonlijk } \\
\text { optreden } \\
\text { - Mate van signalerend en reflectief vermo- } \\
\text { gen enz. : aard zelfbeeld } \\
\text { - Mate van signalerend en reflectief vermo- } \\
\text { gen enz. vlg. informanten en/of rapporten }\end{array}$ \\
\hline & $\begin{array}{l}\text { Bestuursstijl van } \\
\text { wethouder }\end{array}$ & $\begin{array}{l}\text { - Kenmerken van en oordeel over bestuurs- } \\
\text { stijl } \\
\text { - Mate van flexibiliteit in gedrag }\end{array}$ \\
\hline & $\begin{array}{l}\text { Professionaliliteit in } \\
\text { algemene zin van } \\
\text { wethouder }\end{array}$ & $\begin{array}{l}\text { - Spectrum van professionele rolcompeten- } \\
\text { ties } \\
\text { - Kwaliteit van professionele competenties, } \\
\text { zoals aanvoelen van verhoudingen, etc. }\end{array}$ \\
\hline & $\begin{array}{l}\text { Bindend vermogen } \\
\text { van wethouder }\end{array}$ & $\begin{array}{l}\text { - Capaciteit om in debat alternatieven te } \\
\text { bedenken } \\
\text { - Capaciteit om compromis te bereiken } \\
\text { - Capaciteit tot stressreductie (relativering, } \\
\text { etc.) }\end{array}$ \\
\hline \multicolumn{3}{|l|}{ Mesoniveau } \\
\hline $\begin{array}{l}\text { Verbindingen } \\
\text { binnen college }\end{array}$ & Homogeniteit & $\begin{array}{l}\text { - Aantal wethouders } \\
\text { - Invulling verbindende rol door voorzitter } \\
\text { - Mate van complementariteit van wethou- } \\
\text { - Mers } \\
\text { - Mate van chemie tussen collegeleden }\end{array}$ \\
\hline
\end{tabular}




\begin{tabular}{|c|c|c|}
\hline & Verhoudingen & $\begin{array}{l}\text { - Mate van eensgezindheid van college } \\
\text { - Mate van daadkracht en durf van college } \\
\text { - Aanwezigheid van strategische visie en } \\
\text { mate van steun als bindmiddel }\end{array}$ \\
\hline $\begin{array}{l}\text { Verbindingen tus- } \\
\text { sen college en } \\
\text { ambtelijk apparaat }\end{array}$ & $\begin{array}{l}\text { Relatie met ambte- } \\
\text { lijke organisatie }\end{array}$ & $\begin{array}{l}\text { - Mate van ondersteuning bestuurlijk- } \\
\text { ambtelijke relatie } \\
\text { - Patroonmatigheid in betrekkingen } \\
\text { - Klachten over ambtelijke ondersteuning }\end{array}$ \\
\hline $\begin{array}{l}\text { Verbindingen tus- } \\
\text { sen college(leden) } \\
\text { en (delen van) de } \\
\text { gemeenteraad }\end{array}$ & $\begin{array}{l}\text { Formele en infor- } \\
\text { mele verbindingen }\end{array}$ & $\begin{array}{l}\text { - Patroonmatigheid in relatie tussen college } \\
\text { en raad resp. leden en fracties } \\
\text { - Oriëntatie van college op debat en kwali- } \\
\text { teit: wel of niet positief } \\
\text { - Oriëntatie van raad op debat en kwaliteit: } \\
\text { - wel of niet positief } \\
\text { - Wij-zij verhoudingen }\end{array}$ \\
\hline \multirow[b]{2}{*}{$\begin{array}{l}\text { Verbindingen tus- } \\
\text { sen fracties in de } \\
\text { gemeenteraad }\end{array}$} & Verhoudingen & $\begin{array}{l}\text { - Aantal coalitiepartijen } \\
\text { - Mate van aanwezigheid van ambitie in een } \\
\text { akkoord }\end{array}$ \\
\hline & Betrekkingen & $\begin{array}{l}\text { - Kwaliteit van formele betrekkingen } \\
\text { - Kwaliteit van informele betrekkingen } \\
\text { - Aanwezigheid van centrifugale krachten } \\
\text { - Hechtheid coalitie: grote mate van dichtge- } \\
\text { timmerde relatie }\end{array}$ \\
\hline \multicolumn{3}{|l|}{ Macroniveau } \\
\hline Bestuursstructuur & $\begin{array}{l}\text { Samenstelling van } \\
\text { gemeenteraad }\end{array}$ & $\begin{array}{l}\text { - Aantal fracties in de raad (versnippering in } \\
\text { raad resp. dominante partij) } \\
\text { - Fractiesterkte: dominantie één partij (qua } \\
\text { grootte) } \\
\text { - Gevolgen van raadsfragmentatie voor } \\
\text { raadsdiscussies }\end{array}$ \\
\hline Bestuurscultuur & $\begin{array}{l}\text { Werkwijzen bij } \\
\text { besturen en ge- } \\
\text { woonten }\end{array}$ & $\begin{array}{l}\text { - Manier van discussiëren en perceptie daar- } \\
\text { van } \\
\text { - Toon en woordgebruik in debatten en per- } \\
\text { ceptie daarvan } \\
\text { - Cliëntelistisch gedrag (aard en omvang) en } \\
\text { perceptie daarvan }\end{array}$ \\
\hline (Pers)media & $\begin{array}{l}\text { Invloed van pers- } \\
\text { media }\end{array}$ & $\begin{array}{l}\text { - Mate van berichtgeving over bestuur } \\
\text { - Tijdstip van berichtgeving } \\
\text { - Waarheidsgehalte van berichtgeving } \\
\text { - Toon van berichtgeving }\end{array}$ \\
\hline
\end{tabular}

Door met bovenstaande risicofactoren te werken, ontstaat naar verwachting een goed beeld van het ontstaan en aanhouden van bestuurlijke conflicten of bestuurscrises in een gemeente. Onderkend moet daarbij onmiddellijk worden dat één aspect niet automatisch in beeld komt: de inhoud van de bestuurlijke problematiek. De vraag waar het conflict over gaat wordt middels bovenstaande variabelen niet beantwoord, beleidsinhoud is geen verklarende variabele. In dit onderzoek is er bewust voor gekozen deze variabele niet toe te voegen. Weliswaar zijn er aanwijzingen dat sommige dossiers 
zich vaker dan andere lenen voor bestuurlijke discussie, bijvoorbeeld problemen rondom financiële zaken (Bouwmans, 2010), maar aan de andere kant mag worden aangenomen dat het in veel gemeenten gebeurt dat zaken niet lopen zoals bedoeld was. Het gaat er vervolgens om hoe daarmee wordt omgegaan in de bestuurlijke praktijk. Voor een analyse hiervan lenen de risicofactoren zich weer vitstekend. In een gemeente met bijvoorbeeld een sterk gefragmenteerde raad (bestuursstructuur) zullen de katterigheid en het gesteggel sneller toeslaan, waardoor bestuurlijke problemen vlot op de loer liggen. Ook de manier waarop bij optredende problematiek de verbinding tussen raad en college is georganiseerd komt in de omschreven factoren goed naar voren.

$\mathrm{Er}$ is bovendien nog een algemene reden om de beleidsinhoud niet specifiek te benoemen als te analyseren punt. Vaak blijkt een bepaalde kerngebeurtenis niet op zich te staan, maar de spreekwoordelijke druppel in de overlopende emmer te zijn. Ook hier voegt een analyse van de precieze beleidsinhoudelijke toedracht van dat ene dossier niet veel toe: het gaat immers om een grote hoeveelheid omstandigheden, die met de factorenanalyse naar voren worden gehaald. Bovendien is het in lang niet alle gevallen duidelijk waar een bestuurlijk conflict of crisis om ging en of de kerngebeurtenis slechts het resultaat en/of het begin van een heel scala aan gebeurtenissen was. Reden om de factoren uit tabel 6 te handhaven en te gebruiken in de analyse van de geselecteerde gemeenten.

\section{Aanjagen en dempen door dezelfde factoren}

In bestuurlijke probleemgemeenten kunnen de hierboven beschreven factoren geanalyseerd worden, om te bezien of ze een rol hebben gespeeld in de bestuurlijke conflicten en bestuurscrises die daar aan de orde zijn geweest. Het antwoord op die vraag is echter niet zo spannend: alle factoren zullen een rol hebben gespeeld in bestuurlijke probleemgemeenten. Kan de analyse nog een stap verder gaan? Dat kan. Uit de literatuur blijkt namelijk ook dat er nooit sprake is van één verklarende factor, ze treden meestal in samenhang op. Bovendien dragen niet alle verklarende variabelen in dezelfde mate bij aan de optredende bestuurlijke problematiek. Korsten en Aardema (2006) kwamen in hun onderzoek naar vallende burgemeesters niet in alle gemeenten dezelfde factoren tegen. Sommige factoren speelden heel vaak een rol, zoals de microfactor 'burgemeester' ( 26 van de 28 keer). Andere factoren werden ook aangetroffen, maar in mindere mate (Korsten en Aardema, 2006: 42).

Verder lijkt het redelijk om aan te nemen dat er een wisselwerking tussen factoren kan optreden, waarbij factoren soms de problematiek als het ware 'aanjagen', maar soms ook nadrukkelijk een dempende werking op het ontstaan of voortbestaan van bestuurlijke problemen hebben. Tops en Zouridis benoemen een aantal factoren waar een dempende werking van kan uitgaan (Tops en Zouridis, 1998: 418). Het gaat dan vooral om de burgemeester als gedepolitiseerde 'arbiter', die partijen bij elkaar zou kunnen brengen, tenzij deze burgemeester zelf het middelpunt van het conflict gaat vormen. Verder wijzen zij op de onmogelijkheid verkiezingen uit te schrijven op lokaal niveau, waardoor partijen als het ware tot elkaar veroordeeld zijn. Conflicten zullen daardoor niet snel escaleren. Ook de traditioneel sterke traditie van collegiaal bestuur in 
gemeenten en het monistisch karakter van de gemeenten zouden dempend werken, evenals het gebruik van coalitieprogramma's.

Sommige argumenten zijn anno 2010 achterhaald met de wijziging van de gemeentewet in 2002. Dit geldt specifiek voor het monistisch karakter van de gemeente, maar ook het tot elkaar veroordeeld zijn is, met de mogelijkheid wethouders van buiten aan te trekken, minder relevant geworden.

Waar het hier om gaat is dat uit de literatuur dus blijkt dat sommige variabelen zowel een aanjagende als een dempende werking op bestuurlijke problemen kunnen hebben. Op grond van het bureauonderzoek is te beredeneren dat deze factoren in samenhang optreden, maar de vraag is op welke manier. Bovendien is interessant te onderzoeken of de factoren in een bepaalde gemeenten in de te onderzoeken periode altijd dezelfde werking hebben gehad. Het zou immers kunnen zijn dat factoren die in een gemeente op enig moment een aanjagende werking hebben gehad op bestuurlijke conflicten en zelfs bestuurscrises, in dezelfde gemeente zes jaar later juist dempend van aard zijn geweest. Zo kan het zijn dat op microniveau op enig moment de burgemeester juist goed in staat was de 'boel bij elkaar te houden' en veel bindend vermogen aan de dag kon leggen, terwijl zijn of haar opvolger hier geen mogelijkheden toe zag en dus als bindende factor wegviel, met bestuurlijke problematiek als gevolg.

Op mesoniveau zou de verbinding tussen de fracties in een bepaalde periode zodanig goed kunnen zijn (bijvoorbeeld door een collegeprogramma), dat eventuele problemen met bijvoorbeeld een niet functionerende wethouder rustig worden opgelost en er geen sprake is van conflicten of crises. Een periode later zou dit weer anders kunnen liggen. Ook kan het zijn dat de cultuur in de gemeenteraad (macroniveau) juist gericht is op het pacificeren van problemen, in plaats van het oprakelen ervan.

Juist het samenkomen van verschillende factoren en het aanwezig of afwezig zijn van voldoende dempende factoren op een bepaald moment in de tijd, lijkt te bepalen of er bestuurlijke problemen ontstaan of niet. De vraag in de casestudies is: is er in de vier bestuurlijke probleemgemeenten een gemeenschappelijk patroon van aanjagers en dempers te herkennen?

\subsection{Verwachtingen}

Ten aanzien van bestuurlijke probleemgemeenten is op basis van het bovenstaande een aantal verwachtingen geformuleerd. Hiervoor is gekozen in plaats van het werken met hypothesen. Dit heeft te maken met het karakter van de studie. Hypothesen zoeken vaak naar een causaal verband, waarbij aannemelijk wordt gemaakt dat de ene factor (onafhankelijke variabele) de andere factor heeft veroorzaakt (afhankelijke variabele). In dit geval zou het gaan om negen onafhankelijke variabelen, die in causaal verband staan met de bestuurlijke probleemgemeenten. Oorzaak en gevolg moeten met elkaar correleren. De vraag is of deze positivistische benadering hier past. Uit het bovenstaande is namelijk duidelijk geworden dat de werkelijkheid in bestuurlijke probleemgemeenten niet zo makkelijk te duiden is. Veel zaken hangen met elkaar samen. De kennis over wat er gebeurt of is gebeurd in bestuurlijke probleemgemeen- 
ten kan alleen worden opgedaan in interactie met de actoren in zo'n gemeente. Het gaat hier meer om contextuele betekenisvorming (zie Haverland en Yanow, 2010: 91). Bij deze meer interpretatieve benadering passen hypothesen minder, maar past wel het werken met verwachtingen (hunches), die wel of niet uitkomen.

Voor deze studie is voor elke factor een verwachting opgesteld, waarvan in de praktijk bezien zal worden of deze factor vit komt of niet (zie tabel 7).

Tabel 7: Verwachte uitkomsten per factor

\begin{tabular}{|c|c|}
\hline Verwachting 1 & $\begin{array}{l}\text { In bestuurlijke probleemgemeenten legt de burgemeester weinig bindend } \\
\text { vermogen aan de dag, waardoor de potentiële dempende werking van de } \\
\text { burgemeester afwezig is. }\end{array}$ \\
\hline Verwachting 2 & $\begin{array}{l}\text { In bestuurlijke probleemgemeenten hebben de persoonlijke risicofactoren } \\
\text { van één of meer wethouder(s) een aanjagende werking op bestuurlijke } \\
\text { problemen. }\end{array}$ \\
\hline Verwachting 3 & $\begin{array}{l}\text { In bestuurlijke probleemgemeenten kunnen colleges niet sterk worden, } \\
\text { waardoor de potentiële dempende werking van een sterk college afwezig } \\
\text { is. }\end{array}$ \\
\hline Verwachting 4 & $\begin{array}{l}\text { In bestuurlijke probleemgemeenten zit weinig patroon in de relatie van het } \\
\text { college van } B \& W \text { met het ambtelijk apparaat, wat een aanjagende wer- } \\
\text { king heeft op bestuurlijke problemen. }\end{array}$ \\
\hline Verwachting 5 & $\begin{array}{l}\text { In bestuurlijke probleemgemeenten zit geen of weinig patroon in de relatie } \\
\text { tussen het college van B\&W en de gemeenteraad, wat een aanjagende } \\
\text { werking heeft op bestuurlijke problemen. }\end{array}$ \\
\hline Verwachting 6 & $\begin{array}{l}\text { In bestuurlijke probleemgemeenten bestaat weinig binding tussen coali- } \\
\text { tiefracties, wat een aanjagende werking heeft op bestuurlijke problemen. }\end{array}$ \\
\hline Verwachting 7 & $\begin{array}{l}\text { In bestuurlijke probleemgemeenten is sprake van versplintering van het } \\
\text { politieke landschap, wat een aanjagende werking heeft op bestuurlijke } \\
\text { problemen. }\end{array}$ \\
\hline Verwachting 8 & $\begin{array}{l}\text { In bestuurlijke probleemgemeenten is de bestuurscultuur negatief tot zeer } \\
\text { negatief, wat een aanjagende werking heeft op bestuurlijke problemen. }\end{array}$ \\
\hline Verwachting 9 & $\begin{array}{l}\text { In bestuurlijke probleemgemeenten hebben de (pers)media een grote } \\
\text { invloed op het debat, wat een aanjagende werking heeft op bestuurlijke } \\
\text { problemen. }\end{array}$ \\
\hline
\end{tabular}

In het algemeen is de verwachting dat vrijwel alle factoren ofwel niet dempend werkten, dan wel een aanjagende werking hadden. Zo is de verwachting dat in bestuurlijke probleemgemeenten de burgemeester niet in staat is een bindende rol te spelen tussen partijen en zo, door zijn of haar positie, vanuit het neutrale midden partijen aan elkaar te verbinden. Van de wethouders zijn er altijd wel enkele met een 'persoonlijke risicofactor', die problemen in de hand werkt. Colleges groeien in bestuurlijke probleemgemeenten niet uit tot sterke eenheden, waardoor er geen dempende werking van uit gaat. Door het ontbreken van een patroon in de verbindingen tussen het college en de gemeenteraad komen zaken snel onder druk te staan, gevoed door de eveneens weinig patroonmatige relatie tussen college en ambtelijke organisatie. Coalitiepartijen overleggen weinig, wat bestuurlijke problemen sterk in de hand werkt. Bovendien hebben bestuurlijke probleemgemeenten naar verwachting een moeilijke bestuursstructuur. Dit zorgt voor moeizame coalitievorming en (als er een coalitie is gevormd) voor moei- 
zame besluitvorming, doordat meerderheden nooit vanzelfsprekend zijn. De negatieve bestuurscultuur en kritische media maken het bestuurlijk problematische beeld compleet.

Per casestudy wordt bezien of de verwachting per factor: (1) is uitgekomen, (2) niet is uitgekomen of (3) geen eenduidig beeld geeft. De analyse wordt in drie bestuursperioden gemaakt, zodat ook het verloop in de tijd in beeld kan worden gebracht.

\subsection{Conclusies}

In dit hoofdstuk is een antwoord op deelvraag 1 geformuleerd. Deelvraag 1 luidde:

Wat zegt de bestaande literatuur over mogelijke verklaringen voor de aanhoudende bestuurlijke problematiek in bestuurlijke probleemgemeenten?

In dit hoofdstuk is nader gekeken naar vier mogelijkheden om bestuurlijke probleemgemeenten te onderzoeken. Op grond van deze orientatie is gekozen voor de 'factorenanalyse', zoals die door Korsten en Aardema is ontwikkeld. Zij onderscheiden drie analyseniveaus in elke gemeente: het microniveau (het niveau van de individuele bestuurders), het mesoniveau (het niveau van de verbindingen tussen de verschillende spelers op gemeentelijk niveau, zoals het ambtelijk apparaat, het college, de gemeenteraad en de coalitiepartijen) en het macroniveau (het niveau dat individuele spelers overstijgt, zoals de bestuursstructuur, de bestuurscultuur en de invloed van de (pers)media).

Op grond van deze indeling zijn negen relevante factoren onderscheiden, die invloed hebben op het ontstaan of voortduren van bestuurlijke problematiek in bestuurlijke probleemgemeenten.

Het antwoord op deelvraag 1 luidt:

De bestaande literatuur geeft aan dat er negen factoren (variabelen) een rol kunnen spelen in de aanhoudende bestuurlijke problematiek in bestuurlijke probleemgemeenten.

Op basis hiervan is een aantal verwachtingen opgesteld, waarvan in de praktijk moet blijken of deze uitkomen of niet. Het volgende hoofdstuk doet eerst verslag van het kwantitatief onderzoek, dat in het kader van deze studie is verricht. 


\section{Bestuurlijke probleemgemeenten in Nederland 1998-2010}

\subsection{Inleiding}

Om te kunnen bepalen welke Nederlandse gemeenten aangeduid kunnen worden als bestuurlijke probleemgemeente, is kwantitatief onderzoek gedaan in heel Nederland. In dit hoofdstuk wordt verslag gedaan van dit onderzoek en van de resultaten. Uit de aangetroffen bestuurlijke probleemgemeenten is vervolgens een selectie gemaakt voor het doen van casestudies.

Centraal staat de beantwoording van deelvraag 2:

Welke gemeenten in Nederland zijn aan te duiden als bestuurlijke probleemgemeente in de onderzochte periode?

Om de vraag te kunnen beantwoorden is gekozen voor een benadering in twee stappen. Op de eerste plaats is onderzocht hoeveel wethouders, burgemeesters of colleges er gedwongen zijn vertrokken in alle Nederlandse gemeenten, in de periode maart 1998maart 2010. Dit is gebeurd door aan alle burgemeesters te vragen naar het eventuele tussentijds vertrek van alle bestuurders in hun gemeente. Na een aantal herinneringen en telefonische verzoeken is het uiteindelijk gelukt om van of via alle aangeschreven burgemeesters in Nederland respons te krijgen. Ter controle zijn de aangeleverde gegevens vergeleken met materiaal uit andere bronnen, waaronder gesprekken met een aantal kabinetchefs van provincies. Ook zij kwamen met suggesties, nuanceringen en aanvullingen. De analyses in het magazine Binnenlands Bestuur, dat vanaf 2004 jaarlijks een uitgebreid overzicht presenteert van de vertrokken burgemeesters, wethouders, en colleges zijn eveneens als check gebruikt (Bouwmans, in: Binnenlands Bestuur, de januarinummers van de jaren $2005 \mathrm{t} / \mathrm{m}$ 2011).

Op de tweede plaats kon, op basis van de resultaten uit de eerste stap, worden opgemaakt welke gemeenten het hoogste aantal vertrokken gemeentebestuurders telden in de onderzoeksperiode. Op basis van een aantal criteria is viteindelijk een negental bestuurlijke probleemgemeenten uit de analyses naar voren gekomen.

\subsection{Uitgangspunten bij de inventarisatie en registratie}

Bij het opstellen van de lijst en het registreren van de aantallen vertrokken burgemeesters, wethouders en hele colleges in de betreffende periode in Nederland, is een aantal uitgangspunten gekozen. Duidelijk moet immers zijn in welke gevallen het vertrek van één (of meerdere) bestuurder(s) of een heel college wèl en in welke gevallen het vertrek niet wordt meegerekend. Deze uitgangspunten luiden als volgt:

\section{Peildatum}

Op de eerste plaats is de peildatum van belang. Hoeveel gemeenten zijn opgenomen in het onderzoek? Die vraag dient beantwoord te worden, omdat de al eerder (zie hoofd- 
stuk 2) aangehaalde daling van het aantal gemeenten ook in de voor dit onderzoek onderzochte periode aan de orde is geweest. Daar waar in 1998 in 548 gemeenten een nieuw college en een nieuwe raad aan de start verschenen, waren er op 1 januari 2010 nog 431 over, een daling van ruim $21 \%$. In deze studie is ervoor gekozen bij de rapportage van de aantallen vertrokken bestuurders en colleges vit te gaan van het jaar 2010 en het aantal van 431 gemeenten. Een andere peildatum, bijvoorbeeld 1 januari 2008, zou een gemankeerd beeld opleveren. Dat zou namelijk betekenen dat er resultaten zijn verwerkt van gemeenten, die aan het einde van de meetperiode (maart 2010) niet meer bestaan. In 2008 en 2009 zijn er bijvoorbeeld nog 12 gemeenten opgeheven. Op zich is dat geen probleem, maar dan zou dat voor de hele periode moeten opgaan en moeten gelden voor alle gemeenten die na maart 1998, maar voor maart 2010 zijn opgeheven. Dat levert in de praktijk een probleem op, omdat het zeker van de fusies van voor de eeuwwisseling vrijwel ondoenlijk is nauwkeurig te achterhalen of er gedwongen vertrokken bestuurders zijn geweest, laat staan hoeveel. Betrokkenen zijn verspreid over het land, archieven geven niet altijd uitsluitsel. Van fusies van meer recente datum is wel aan te geven wat er vóór de fusie in de betreffende gemeente is gebeurd op het in deze studie onderzochte terrein. Het is dus zeker niet in alle gevallen onduidelijk, maar omwille van de zorgvuldigheid is ervoor gekozen uit te gaan van de groep van 431 Nederlandse gemeenten, waarvan alle gegevens konden worden geverifieerd.

\section{Verkiezingen}

Op de tweede plaats vertrekken wethouders ook wel eens tegen hun zin na gemeenteraadsverkiezingen, doordat een hernieuwd wethouderschap er niet in blijkt te zitten. In sommige gevallen kwamen deze raadsverkiezingen overigens ook als een oplossing voor een gespannen tot zeer gespannen situatie in de gemeenteraad of in de eigen partij, waar anders absoluut bestuurlijke ellende van was gekomen. In dit onderzoek zijn deze vertrekken niet meegeteld. De verklaring is eenvoudig: in een democratie vinden verkiezingen plaats en kunnen mensen die graag door hadden willen gaan met hun werk, afhankelijk van de uitslag, hun baan verliezen. Dat is inherent aan een politieke functie. Het niet terugkeren na verkiezingen is dus in feite wel gedwongen, maar tegelijkertijd 'part of the deal' en dus niet meegenomen in de totaaluitslagen.

\section{Geen herbenoeming}

Burgemeesters die niet worden herbenoemd na het verstrijken van hun periode van zes jaar zijn in principe niet opgenomen in het totaal, behalve als openbaar duidelijk is gemaakt dat er aan de niet-herbenoeming een conflict ten grondslag lag. Hier zijn twee redenen voor. Herbenoemingsprocedures spelen zich af in vertrouwelijkheid. Vaak wordt het feit dat de gemeenteraad geen aanbeveling tot herbenoeming wil doen, al vroeg aan de betrokken burgemeester aangegeven. Dit geeft betrokkenen de tijd om een andere betrekking te zoeken, of voorbereidingen voor bijvoorbeeld vervroegde vittreding via FPU te regelen, dan wel een andere mooie reden te bedenken. Het is hierdoor lastig te achterhalen of het vertrek van een burgemeester nu indirect gedwongen was of niet. Aanwijzingen zijn er soms wel (Blaricum, Andijk, Bergen), maar de openbare informatie is anders en op die openbare informatie is dit onderzoek gebaseerd. Bovendien is er nog een andere reden om burgemeesters die niet worden herbe- 
noemd niet mee te tellen in het totaal. Dit onderzoek gaat over het tussentijds vertrek van gemeentebestuurders. Burgemeesters die niet worden herbenoemd hebben hun termijn wel volgemaakt en vertrekken dus per definitie niet tussentijds.

\section{Vertrek op eigen initiatief... of toch niet?}

Op de vierde plaats is in een groot aantal gevallen door de respondenten vanuit de gemeenten gemeld dat een wethouder of burgemeester op eigen initiatief is vertrokken. Meestal is dat om een direct aanwijsbare reden: er bleek een andere baan in het spel, waarbij het enkele malen is voorgekomen dat een wethouder of burgemeester kon toetreden tot de Tweede Kamer der Staten-Generaal of een andere functie ging bekleden. In een aantal gevallen van vertrokken bestuurders ligt het iets genuanceerder. Weliswaar was er sprake van een eigen besluit, maar dan wel gevoed door onvrede met een bepaalde situatie. Zo zijn er wethouders die besloten hun ontslag in te dienen vit onvrede met het dualisme. Zij zijn in principe niet in de lijst opgenomen. Deze wethouders kunnen worden gezien als personen die het in hun baan niet naar de zin hebben en iets anders zoeken, zonder daartoe gedwongen te zijn.

Lastiger worden echter de situaties waarbij er weliswaar sprake is van vertrek op eigen verzoek, maar waarbij er ook problemen aan de orde waren. Een wethouder of burgemeester kan per slot van rekening besluiten de 'eer aan zichzelf' te houden en te vertrekken, voordat er bijvoorbeeld een motie van wantrouwen wordt ingediend. In dit onderzoek zijn in dit verband de volgende methodologische keuzes gemaakt:

\section{Openbare informatie}

Dit onderzoek is gebaseerd op openbare, verifieerbare informatie. Als er door de correspondenten duidelijk is aangegeven dat een wethouder is vertrokken vooruitlopend op een motie van wantrouwen, dan is dit vertrek opgenomen in de lijst. Als er slechts sprake is van niet verifieerbare geruchten, is het vertrek niet als gedwongen aangemerkt.

\section{Zelfstandig vertrek in relatie met een politieke kwestie}

Gemeentebestuurders die zelfstandig verantwoordelijkheid wensen te nemen voor een bepaalde ontwikkeling in de gemeente, zonder dat er openbaar aanwijsbare politieke druk is uitgeoefend, zijn niet opgenomen op de lijst. Het vertrek van de Amsterdamse wethouder Tj. Herrema in 2009 met betrekking tot de Noord-Zuidlijn is zo'n voorbeeld. Herrema vond dat hij zou moeten vertrekken, omdat hij politiek gezien verantwoordelijkheid droeg voor de enorme kostenoverschrijdingen en problemen rond de aanleg van deze metrolijn. Politiek gezien was hier geen noodzaak toe, al is natuurlijk niet uitgesloten dat deze noodzaak op enig moment wel was ontstaan. Een ander voorbeeld: het vertrek van wethouder P. van Woensel uit Den Haag in 2007. Ook voor dit vertrek was politiek gezien geen aanwijsbare reden, in de vorm van een motie van wantrouwen of iets dergelijks. Van Woensel vond echter dat hij de kosten- en tijdsoverschrijding van Randstadrail niet meer kon vitleggen en trad daarom af. Het gaat in dit soort gevallen dus om het politiek verantwoordelijkheid nemen voor een bepaalde kwestie, zonder dwang. 


\section{Vertrek om 'gezondheidsredenen'}

Als er door de correspondenten is aangegeven dat de gezondheid of de leeftijd de belangrijkste reden was om tussentijds te vertrekken, is het vertrek niet opgenomen in de totaaltelling. Hier ontstaat ontegenzeggelijk een grijs gebied. Sommige vertrekken zijn immers onder de noemer 'gezondheid' in de openbaarheid gebracht, terwijl er tegelijkertijd geruchten gingen dat het vertrek ook niet veel langer had moeten duren, omdat anders de raad wel eens.... etcetera. Toch is besloten deze categorie niet in de lijst op te nemen. Wat dat betreft blijft dit onderzoek gebaseerd op informatie vit de officiële kanalen en niet op de officieuze achtergronden.

\section{Wethouders die weer terugkeerden of ... zich bedachten}

Wethouders die bij een collegecrisis hun zetel moesten inleveren, maar in een nieuwe coalitie weer terug mochten keren, zijn niet opgenomen in de totaallijst. Dit is in een aantal gemeenten aan de orde geweest. Het draait in dit onderzoek dus echt om wethouders die definitief weg zijn gegaan. Wethouders die besloten hun ontslag in te dienen, maar zich enkele dagen later bedachten dan wel door de raad werden verzocht hun ontslag te heroverwegen, zijn eveneens niet in de lijst opgenomen.

\section{De val van een college}

Van de val van een college is in dit onderzoek sprake als na een bestuurlijk conflict of bestuurscrisis de coalitie gaat bestaan uit minder of (één of meer) andere partijen en dus de politieke samenstelling van het college verandert. Een college komt immers tot stand na lang en vaak zorgvuldig overleg tussen collegepartijen. Als er dan een einde komt aan de op die manier gevormde samenstelling, telt dat in dit onderzoek mee als de val van een college. Soms kan een dergelijk situatie redelijk beperkt blijven. Er zijn situaties voorgekomen waarin een partij besloot 'vit' het college te stappen en de wethouder terug te trekken, waarna de andere collegepartijen samen verder gingen. Een nieuwe coalitie werd niet gevormd, de basis van de zittende coalitie werd echter smaller. Ook dit soort situaties rekenen wij als de val van een zittend college, hoewel ze niet zo heel vaak zijn voorgekomen. Vaker is gebeurd dat de ene coalitiepartij stopt en een andere partij in het college komt. Ook deze situatie wordt in dit onderzoek geteld als de val van een college. Overigens: zoals in hoofdstuk 1 aangestipt wordt in dit onderzoek, ook als de burgemeester aan blijft, gesproken over de val van een college.

\subsection{De algemene resultaten}

Het algemene beeld van bestuurlijke conflicten en bestuurscrises in lokaal bestuurlijk Nederland in de periode 1998-2010 is weergegeven in tabel 8. Op de eerste plaats blijkt dat 278 van de 431 gemeenten in Nederland $(64,5 \%)$ te maken hebben gehad met het gedwongen vertrek van burgemeesters, wethouders en/of hele colleges in de periode maart 1998- maart 2010. In 153 van de 431 gemeenten was geen sprake van gedwongen vertrek van gemeentebestuurders. In deze gemeenten $(35,5 \%)$ was de afgelopen twaalf jaar alleen sprake van wisselingen in de (politieke) samenstelling van het college na verkiezingen, of na echt eigen keuzes van de betrokken bestuurders. Van de 278 gemeenten waar wel problemen waren, meldden 134 gemeenten één of twee vertrokken gemeentebestuurders of colleges, wat neerkomt op 31,1\%. Het aantal gemeenten 
met drie tot vijf vertrokken bestuurders of colleges komt op $94(21,8 \%)$, terwijl nog eens 38 gemeenten met zes, zeven of acht conflicten of crises te maken hadden $(8,8 \%)$. In twaalf gemeenten $(2,8 \%)$ werden negen of meer gedwongen vertrekken gemeld. Meer over deze gemeenten in paragraaf 4.3.1. Het totaaloverzicht met de vermelding van alle Nederlandse gemeenten is opgenomen in de bijlagen.

Tabel 8: Totaalbeeld aantal conflicten en crises in Nederland, periode maart 1998 - maart 2010

\begin{tabular}{|l|c|c|}
\hline $\begin{array}{l}\text { Aantal gedwongen } \\
\text { vertrokken burgemeesters, } \\
\text { wethouders of colleges }\end{array}$ & Aantal gemeenten & In procenten \\
\hline o & 153 & $35,5 \%$ \\
\hline 1 of 2 & 134 & $31,1 \%$ \\
\hline $3 \mathrm{t} / \mathrm{m} 5$ & 94 & $21,8 \%$ \\
\hline $6 \mathrm{t} / \mathrm{m} 8$ & 38 & $8,8 \%$ \\
\hline$>9$ & 12 & $2,8 \%$ \\
\hline Totaal & 431 & $100 \%$ \\
\hline
\end{tabular}

De cijfers liggen over het algemeen overigens wat lager dan de cijfers die in hoofdstuk 2 zijn gerapporteerd. Dit heeft een aantal oorzaken. Op de eerste plaats gaat het hier puur om bestuurders die na een politiek conflict of crisis zijn vertrokken. In andere onderzoeken, bijvoorbeeld de Staat van het bestuur (Min. van BZK, 2010) worden meerdere oorzaken voor vertrek in de cijfers meegenomen. Op de tweede plaats speelt mee, dat wethouders die moesten aftreden, maar later weer terugkeerden in het college, niet zijn meegenomen. Dit in tegenstelling tot de rapportages van bijvoorbeeld het magazine Binnenlands Bestuur, waar deze bestuurders wel zijn meegeteld. Op de derde plaats spelen herindelingen een rol. Gemeentebestuurders die vielen in gemeenten die per peildatum 1 januari 2010 niet meer bestonden, zijn niet meegeteld.

Wat is nu het gemiddeld aantal om politieke redenen vertrokken bestuurders? In de onderzoeksperiode zijn in totaal 657 wethouders en 42 burgemeesters gedwongen vertrokken in de betrokken gemeenten, wat het totaal op 699 gemeentebestuurders brengt. Dit komt in de gemeten tijdsperiode van 12 jaar neer op 58 gemeentebestuurders gemiddeld per jaar. Als het aantal van 699 verdeeld wordt over alle 431 gemeenten die er per 1 januari 2010 in Nederland waren, betekent dit grofweg dat er in een gemiddelde Nederlandse gemeente 1,6 wethouder of burgemeester gedwongen moest vertrekken in de periode 1998-2010.

Voor wat betreft de verdeling over de jaren is een duidelijk onderscheid aan te brengen in de periode voor en de periode na 2002. Vanaf 2003 lopen de totalen op, met als absolute uitschieter het 'bestuurlijke rampjaar' 2004, met 129 vertrokken gemeentebestuurders (zie figuur 1). 
Figuur 1: Aantal gedwongen vertrokken gemeentebestuurders in Nederland, maart 1998- maart 2010

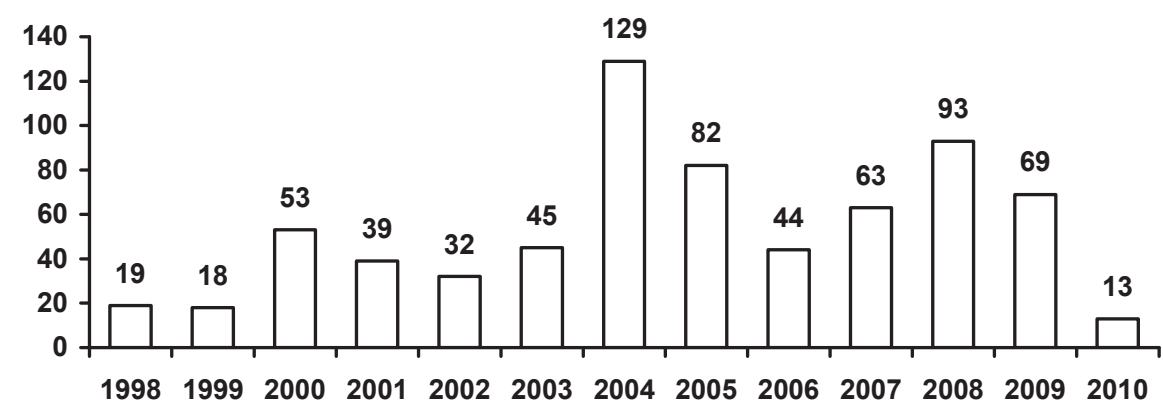

Uit bovenstaande cijfers blijkt dat steeds halverwege een bestuursperiode, dus in 2000, 2004 en 2008 een piek waarneembaar is in het vertrek, al is het in 2000 geen grote afwijking. De vraag hoe dat komt is er één voor nader onderzoek. Wellicht speelt een rol dat halverwege een periode de raad en wethouders precies weten wat ze aan elkaar hebben, of... niet hebben. Als er frictie is over onderwerpen of over personen komt die halverwege de periode kennelijk sneller tot een uitbarsting. Bovendien is het vaak lastig om voor een relatief korte tijd vervanging te vinden. Het wordt vaak niet aantrekkelijk gevonden om als wethouder een jaar of korter voor de verkiezingen te moeten invallen. Dat is bij politieke fracties doorgaans bekend vóór de vertrouwensvraag in de raad op tafel komt.

\subsubsection{Gemeenten met de meeste bestuurlijke conflicten en bestuurscrises}

De gemeenten met het hoogste aantal gedwongen vertrokken gemeentebestuurders en colleges tussen maart 1998 en maart 2010 zijn opgenomen in tabel 9.

Tabel 9: Gemeenten met het hoogste aantal gedwongen vertrokken bestuurders, 1998-2010

\begin{tabular}{|c|l|c|c|c|c|c|}
\hline Nr & Naam gemeente & Inwoners & $\begin{array}{l}\text { Vertrokken } \\
\text { burgemeesters }\end{array}$ & $\begin{array}{l}\text { Vertrokken } \\
\text { wethouders }\end{array}$ & $\begin{array}{l}\text { Afgetreden } \\
\text { colleges }\end{array}$ & Totaal \\
\hline 1. & Delfzijl (Gron.) & 27.314 & 2 & 10 & 4 & 16 \\
\hline 2. & Leiden (ZH) & 116.878 & 1 & 9 & 3 & 13 \\
\hline 3. & Losser (Ov.) & 22.492 & 1 & 8 & 2 & 11 \\
\hline 4. & Nijmegen (Gld.) & 161.251 & 0 & 9 & 2 & 11 \\
\hline 5. & Sittard-Geleen (Lim.) & 95.691 & 1 & 8 & 2 & 11 \\
\hline 6. & Beverwijk(NH) & 37.347 & 0 & 8 & 2 & 10 \\
\hline 7 & Den Helder (NH) & 57.795 & 2 & 6 & 2 & 10 \\
\hline 8. & Hilversum (NH) & 83.815 & 0 & 8 & 2 & 10 \\
\hline 9. & Valkensward (NB) & 30.867 & 0 & 8 & 2 & 10 \\
\hline 10. & Leerdam (ZH) & 20.624 & 0 & 6 & 3 & 9 \\
\hline 11. & Veghel (NB) & 36.913 & 1 & 6 & 2 & 9 \\
\hline 12. & Zundert (NB) & 20.947 & 1 & 5 & 3 & 9 \\
\hline
\end{tabular}


De in de tabel opgenomen gemeenten bevinden zich het meest in Noord-Holland (3x) en Noord-Brabant (ook 3x). Er zijn drie gemeenten met minder dan 25.000 inwoners, vier zitten er in de categorie 25.000-50.000, weer drie tussen de 50.000 en 100.000 inwoners en er zijn twee gemeenten bij met meer dan 100.000 inwoners.

Het staat overigens nog te bezien of dit allemaal bestuurlijke probleemgemeenten zijn. Het aantal conflicten kan niet het enige criterium zijn, want dan zouden grote gemeenten (waar het vertrek van een college van vijf of zes personen gelijk grote invloed heeft op de cijfers) in het 'nadeel' zijn. De vraag welke gemeenten in Nederland bestuurlijke probleemgemeenten zijn, wordt beantwoord in paragraaf 4.7.

\subsubsection{De val van colleges van $B \& W$}

In de onderzoeksperiode is in totaal 227 keer een college gevallen, waaronder in dit onderzoek zoals aangegeven een verandering van politieke samenstelling wordt verstaan. Dit vond plaats in 174 gemeenten, aangezien er in sommige gemeenten meer dan eens een college viel. In 38 gemeenten was sprake van twee colleges met verandering van samenstelling, in zes gemeenten gebeurde dat drie keer, in Delfzijl vier keer. Het aantal van 174 gemeenten betekent dat 257 gemeenten geen colleges tussentijds zagen veranderen, een verhouding van ongeveer twee op drie. In een tabel ziet dit er als volgt uit.

Tabel 10: Aantal collegecrises in Nederland 1998-2010

\begin{tabular}{|c|c|c|c|}
\hline Aantal gemeenten & $\begin{array}{c}\text { Aantal } \\
\text { collegecrises }\end{array}$ & $\begin{array}{c}\text { Totaal aantal } \\
\text { collegecrises }\end{array}$ & $\begin{array}{c}\text { \% van 431 } \\
\text { gemeenten }\end{array}$ \\
\hline 257 & 0 & 0 & $59,6 \%$ \\
\hline 129 & 1 & 129 & $29,9 \%$ \\
\hline 38 & 2 & 76 & $8,8 \%$ \\
\hline 6 & 3 & 18 & $1,1 \%$ \\
\hline 1 & 4 & 4 & $0,5 \%$ \\
\hline Totaal 431 & & 227 & $100 \%$ \\
\hline
\end{tabular}

\subsubsection{Conflict met raad of fractie}

Uit de ingeleverde gegevens is ook af te leiden met wie de vertrokken bestuurder in conflict kwam. Was dat met de gemeenteraad, binnen het college of wellicht met de eigen fractie of achterban? Uit de resultaten blijkt dat in verreweg de meeste gevallen een conflict met de gemeenteraad tot het vertrek van de bestuurder leidde, namelijk in $56 \%$ van de gevallen. In nog eens $15 \%$ van de gevallen wachtten de bestuurders een motie van de gemeenteraad niet af, maar vertrokken zij zelf onder de dreiging van politiek-bestuurlijke problemen met (een meerderheid van) de gemeenteraad.

Gemeentebestuurders stuitten echter ook op problemen in het college, maar dan gaat het om een klein percentage van 4,4\%. Groter was het aantal bestuurders (in dit geval wethouders), dat onder druk van de eigen fractie of achterban gedwongen was het ambt te verlaten: bijna 10,5\%. De laatste categorie vertrekkende wethouders betreft wethouders die vertrokken na een breuk in de coalitie, bijvoorbeeld doordat een coalitiepartij besloot uit de coalitie te stappen en de wethouder terug te trekken. Op die manier kwam het soms niet eens tot een debat in de gemeenteraad. Zo'n situatie kan 
zich voordoen als het college een besluit neemt waar de betreffende partij zich niet in kan vinden en om die reden uit de coalitie stapt. Uit de bestudeerde gegevens in de onderzoeksperiode blijkt dat dit in 13,9\% van de gevallen aan de orde was.

Tabel 11: Reden voor vertrek van gemeentebestuurder(s)

\begin{tabular}{|l|c|}
\hline Reden & Percentage \\
\hline Direct conflict met gemeenteraad & $56,7 \%$ \\
\hline Opgestapt wegens dreigend conflict met gemeenteraad & $14,6 \%$ \\
\hline Breuk in coalitie & $13,9 \%$ \\
\hline Conflict met eigen fractie & $10,4 \%$ \\
\hline Conflict in college & $4,4 \%$ \\
\hline
\end{tabular}

\subsubsection{Verschillen tussen grote en kleine gemeenten}

Zijn bestuurlijke problemen voorbehouden aan relatief grote of juist relatief kleine gemeenten? Komen bestuurders in gemeenten met minder dan 10.000 inwoners meer in de problemen dan bestuurders in de 26 Nederlandse gemeenten die meer dan 100.000 inwoners tellen? In tabel 12 zijn alle gemeenten met zes of meer bestuurlijke conflicten of crises opgenomen, in totaal 51 . Het gaat hier dus om de 51 gemeenten in Nederland met de meeste gedwongen vertrokken bestuurders, gemeten in de periode 1998-2010. Als deze 51 gemeenten worden gerubriceerd op inwoneraantal, ziet het beeld er als volgt uit.

Tabel 12: Gemeenten met de meeste bestuurlijke problemen, ingedeeld naar inwoneraantal

\begin{tabular}{|l|c|c|c|}
\hline Inwoneraantal & $\begin{array}{c}\text { Totaal in } \\
\text { Nederland }\end{array}$ & $\begin{array}{c}\text { Aantal gemeenten met zes of meer ver- } \\
\text { trokken colleges of besturders }\end{array}$ & Percentage \\
\hline$<10.000$ & 45 & 2 & $4,4 \%$ \\
\hline $10.000-25.000$ & 179 & 17 & $9,5 \%$ \\
\hline $25.000-50.000$ & 138 & 14 & $10,1 \%$ \\
\hline $50.000-100.000$ & 43 & 8 & $18,6 \%$ \\
\hline$>100.000$ & 26 & 10 & $38,5 \%$ \\
\hline Totaal & 431 & 51 & $11,6 \%$ \\
\hline
\end{tabular}

Deze tabel is als volgt te lezen, met als voorbeeld de categorie gemeenten met een inwonertal van minder dan 10.000 inwoners. Nederland kende op 1 januari 2010 in totaal 45 gemeenten met een dergelijk inwonertal. Van deze 45 gemeenten waren er twee gemeenten met zes of meer gedwongen vertrokken gemeentebestuurders en/of colleges in de periode 1998-2010, wat neerkomt op een percentage van 4,4\%. De scores van zes of meer gedwongen vertrokken bestuurders en/of colleges gedurende de onderzochte periode werd gemeld in Muiden en Abcoude. Abcoude viel op, doordat er bij elk vertrek van een wethouder ook een collegewisseling plaatsvond. Daarmee kwam er in Abcoude tussentijds dus drie keer een ander college, wat in de onderzoeksperiode verder alleen voorkwam in de Zuid-Hollandse gemeenten Hardinxveld-Giessendam en Leerdam.

In gemeenten met tussen de 10.000 en 25.000 inwoners kende 9,5\% zes of meer bestuurlijke conflicten of bestuurscrises. De grootste gemeenten komen op hogere percentages uit. Zeker de gemeenten met meer dan 100.000 inwoners kampen relatief 
vaak met een bestuurlijk conflict of bestuurscrisis. In totaal ging het in de aangegeven periode om tien gemeenten (Leiden, Nijmegen, Tilburg, Zoetermeer, Amsterdam, Haarlemmermeer, 's-Hertogenbosch, Rotterdam, Almere en Utrecht). Het totaaloverzicht van de grootste gemeenten is samengevoegd in tabel 13.

Tabel 13:

Vertrokken bestuurders en colleges in de 26 grootste Nederlandse gemeenten, 1998-2010

\begin{tabular}{|c|c|c|c|c|c|c|c|c|}
\hline $\mathrm{Nr}$ & Naam gemeente & Provincie & Inw. & \begin{tabular}{|l|}
1 jaar \\
bepal.
\end{tabular} & $\begin{array}{l}\text { Aantal } \\
\text { Weth. }\end{array}$ & $\begin{array}{l}\text { Aantal } \\
\text { Burg. }\end{array}$ & \begin{tabular}{|l|} 
Aantal \\
Colleges
\end{tabular} & \begin{tabular}{|l|} 
Totaal \\
Vertrek
\end{tabular} \\
\hline 1. & Leiden & Z-H & 117.342 & 0 & 9 & 1 & 3 & 13 \\
\hline 2. & Nijmegen & Gld & 162.932 & 2009 & 9 & 0 & 2 & 11 \\
\hline 3. & Tilburg & $\mathrm{N}-\mathrm{B}$ & 204.924 & 2008 & 5 & 1 & 2 & 8 \\
\hline 4. & Zoetermeer & Z-H & 121.580 & 2010 & 7 & 0 & 1 & 8 \\
\hline 5. & Amsterdam & $\mathrm{N}-\mathrm{H}$ & 767.849 & 0 & 6 & 0 & 1 & 7 \\
\hline 6. & Haarlemmermeer & $\mathrm{N}-\mathrm{H}$ & 142.882 & 0 & 5 & 1 & 1 & 7 \\
\hline 7. & 's-Hertogenbosch & $N-B$ & 139.754 & 1998 & 5 & 0 & 2 & 7 \\
\hline 8. & Almere & $\mathrm{FI}$ & 188.209 & 0 & 4 & 0 & 2 & 6 \\
\hline 9. & Rotterdam & Z-H & 590.131 & 0 & 5 & 0 & 1 & 6 \\
\hline 10. & Utrecht & Ut & 306.731 & 2009 & 5 & 0 & 1 & 6 \\
\hline 11. & Apeldoorn & Gld & 155.775 & 2006 & 4 & 0 & 1 & 5 \\
\hline 12. & Eindhoven & $\mathrm{N}-\mathrm{B}$ & 214.036 & 2005 & 4 & 0 & 1 & 5 \\
\hline 13. & Zaanstad & $\mathrm{N}-\mathrm{H}$ & 145.282 & 2002 & 3 & 1 & 1 & 5 \\
\hline 14. & Amersfoort & Ut & 144.879 & 0 & 2 & 0 & 1 & 3 \\
\hline 15. & Maastricht & Lb & 118.597 & 0 & 2 & 1 & 0 & 3 \\
\hline 16. & Arnhem & Gld & 147.244 & 0 & 2 & 0 & 0 & 2 \\
\hline 17. & Breda & $\mathrm{N}-\mathrm{B}$ & 173.445 & 0 & 2 & 0 & 0 & 2 \\
\hline 18. & Emmen & $\mathrm{Dr}$ & $109 \cdot 510$ & 0 & 2 & 0 & 0 & 2 \\
\hline 19. & Enschede & Ov & 157.321 & 2000 & 2 & 0 & 0 & 2 \\
\hline 20. & Haarlem & $\mathrm{N}-\mathrm{H}$ & $149 \cdot 516$ & 0 & 2 & 0 & 0 & 2 \\
\hline 21. & Zwolle & Ov & 118.943 & 0 & 2 & 0 & 0 & 2 \\
\hline 22. & Den Haag & Z-H & 489.375 & 0 & 1 & 0 & 0 & 1 \\
\hline 23. & Dordrecht & Z-H & 118.607 & 0 & 1 & 0 & 0 & 1 \\
\hline 24. & Groningen & $\mathrm{Gr}$ & 187.622 & 0 & 1 & 0 & 0 & 1 \\
\hline 25. & Ede & Gld & 107.832 & 0 & 0 & 0 & 0 & 0 \\
\hline \multirow[t]{3}{*}{26.} & Venlo & Lb & 100.328 & 0 & 0 & 0 & 0 & 0 \\
\hline & & & & & & & & \\
\hline & Totaal & & 5.380 .646 & & 90 & 5 & 20 & 115 \\
\hline
\end{tabular}

In tabel 13 is ook aangegeven of een bepaald jaar bepalend was. Dit is relevant, omdat grotere gemeenten in de regel ook grotere colleges hebben. Als zo'n college geheel of gedeeltelijk valt in een bepaald jaar, telt het aantal vertrokken bestuurders gelijk fors op. Dit was voor de gemeenten met zes of meer gedwongen vertrokken bestuurders en/of colleges het geval in 's- Hertogenbosch (waar de grote collegewisseling in 1998 een rol speelde), Tilburg (de crisis rond het theater van acteur Adje in 2008), Nijmegen (de val van het college in 2009) en Utrecht (val van een deel van het college in 2009). In andere jaren werden in deze gemeenten geen of veel minder problemen gemeld.

Een andere conclusie is dat de $\mathbf{2 6}$ grote gemeenten in twaalf jaar tijd maar vijf keer een burgemeester gedwongen of vrijwillig gedwongen ('onder druk') zagen vertrekken, te 
weten in Leiden (2003), Zaanstad (2005), Haarlemmermeer (2006), Tilburg (2009) en Maastricht (2010).

\subsection{Bijzondere zaken}

Uiteraard zijn er ook veel 'bijzondere' zaken te melden, die afwijken van het gebruikelijke patroon. Zo zijn er gemeenten waar niet één keer, maar zelfs twee keer een burgemeester het veld moest ruimen. In bijvoorbeeld de gemeente Menterwolde werd burgemeester mw. Lantinga niet herbenoemd in 2003, een op zich niet al te gebruikelijke zaak in bestuurlijk Nederland. Burgemeester F. Liemburg vertrok uit dezelfde gemeente in 2005. In Delfzijl vertrokken de burgemeesters Haaksman en Appel-de Waart (zie casestudy Delfzijl), in Den Helder de burgemeesters Staatsen en Hulman (zie casestudy Den Helder). Ook in de gemeente Middelburg vertrokken twee burgemeesters, waarvan er één als waarnemer was aangesteld.

Wethouders blijven zitten, ondanks probleem met fractie

Wethouders hebben in de regel het vertrouwen van hun partij. Als dat niet meer het geval is, stappen ze normaal gesproken op. Maar niet altijd. In Buren verloor een wethouder het vertrouwen van haar VVD-fractie. Zij bleef echter wethouder, terwijl de VVD de coalitie verliet. Eind 2005 speelde een soortgelijk conflict in de gemeente Cuijk, waar ook een wethouder problemen kreeg met de eigen VVD-fractie. Een motie van wantrouwen werd echter niet ingediend, het college liet de wethouder ook niet vallen, waardoor de betreffende persoon de periode tot maart 2006 af kon maken.

\section{Opmerkelijk eigen gedrag}

In Bergen op Zoom viel een wethouder van zijn kruk in een café na een kennelijk heel gezellige avond, maar mocht wel aanblijven. Het betrapt worden op rijden onder invloed was echter vaak wèl een reden om te moeten vertrekken als wethouder, onder meer in de gemeenten Borsele en Drimmelen. Ook in Uden hield een wethouder de eer aan zichzelf na aanhoudende geruchten in de plaatselijke media dat de betreffende bestuurder zich nogal misdragen zou hebben na afloop van de gemeentelijke Kerstborrel. Opmerkelijk is ook de zogeheten 'pizza-affaire' in Delft. Een wethouder werd heimelijk gefilmd in een pizzeria, waar het ging over de manier om subsidies aan te vragen en wat dies meer zij. De manier waarop het gesprek verliep was aanleiding tot een heuse affaire en het vertrek van de wethouder. In Delfzijl (zie de casestudy in hoofdstuk 7) vertrokken veel wethouders, sommigen eveneens om opmerkelijke zaken. De ene wethouder reed rond met een vals kenteken en kon vertrekken (hij werd overigens later weer wethouder), de andere vertrok na beschuldigd te zijn van het betalen van steekpenningen aan een raadslid. Ook de computer kan een rol spelen. In Schiedam vertrok een wethouder in 2005 na beschuldigd te zijn van het bezoeken van pornosites via de gemeentecomputer. De wethouder ontkende overigens in alle toonaarden.

\section{Terugkeer na vertrek}

Terugkeer als wethouder na eerder gedwongen vertrek kwam ook voor. Een voorbeeld speelde in de gemeente Heerde. De wethouder van Financiën diende hier in november 
2005 zijn ontslag in, nadat er veel onenigheid was ontstaan over de begroting. De begroting werd niet vastgesteld, waarna Heerde onder financieel toezicht van de provincie kwam te staan. Enkele weken later werd dezelfde wethouder echter door de raad verzocht om toch weer aan te treden en volgde zijn herbenoeming op 8 december 2005 .

Een SP-wethouder in Schijndel vertrok in 1999 na een motie van wantrouwen, omdat de raad vond dat hij zich tegen de afspraken in toch had vitgelaten over bouwlocaties voor een woningbouwproject voor gehandicapten. In 2002 keerde dezelfde persoon terug als wethouder, totdat de SP in 2006 niet meer in het college kwam.

\section{Verschillende moties}

Als een wethouder of burgemeester moet vertrekken door het ontbreken van het vertrouwen van de gemeenteraad, komt dat meestal doordat een 'motie van wantrouwen' wordt ingediend. In sommige gemeenten ging men echter op zoek naar eigen varianten. Zo kwam in de gemeenteraad van Laarbeek in 2007 een 'motie van deernis' in stemming tegen één van de wethouders. De motie haalde geen meerderheid. In september 2008 werd in dezelfde gemeente een 'motie van afkeuring' ingediend, die tijdens de raadsvergadering nog werd geamendeerd tot een 'motie van ernstige bezorgdheid' en vervolgens met nipte meerderheid werd aangenomen. Overigens zonder personele gevolgen. Ook in Sint-Michielsgestel diende in 2005 een bijzondere motie, namelijk een motie van 'ongenoegen.'

\section{Twee keer dezelfde steen}

In de gemeente Arcen en Velden vertrok twee keer een wethouder in de periode 19982010. Opvallend: het ging twee keer om dezelfde persoon. De betreffende wethouder, lid van de plaatselijke politieke partij PvdA/PK, kwam volgens de beschikbare informatie twee keer in conflict met coalitiepartij CDA om dezelfde reden: onoverbrugbare verschillen in bestuursstijl. Een vergelijkbare zaak kwam voor in de gemeente Barneveld, voor die gemeente een bijzonderheid. Zowel in 2004 als in 2005 diende daar een wethouder te vertrekken over hetzelfde dossier: de perikelen rondom de realisatie van nieuwbouwwijk Veller in Barneveld.

\subsection{De situatie per provincie}

Uit de per gemeente ingeleverde resultaten is de situatie per provincie goed te achterhalen. Voor de volledigheid wordt dat beeld hier geschetst.

\section{Provincie Groningen}

De provincie Groningen telde per 1 januari 201023 gemeenten, na de samenvoeging van Reiderland, Scheemda en Winschoten tot de gemeente Oldambt. Het ging hier niet om samenvoeging van gemeenten met grote bestuurlijke problemen. Veel ophef gaf wel het vertrek van de Reiderlandse wethouder Hietbrink in 2008, na de ophef over de voorgenomen sloop van het dorpje Ganzedijk. De meest opvallende gemeente in de provincie Groningen voor wat betreft het aantal vertrokken bestuurders is Delfzijl, de gemeente waar het hoogste aantal vertrokken wethouders, burgemeesters en colleges in heel Nederland kan worden gemeld. Meer over Delfzijl in de casestudy, die gemaakt 
is over deze gemeente in hoofdstuk 7. Andere gemeenten met een iets meer dan gemiddeld vertrek zijn Menterwolde, Appingedam en Winsum. In Menterwolde vertrok de pas een jaar eerder aangetreden burgemeester in 2005. De reden is in een persverklaring aangegeven (zie kader).

Verklaring n.a.v. het aftreden van burgemeester F. Liemburg, Menterwolde, 2005 "Menterwolde wilde een burgemeester die initiatief toont, prioriteiten stelt en knopen weet door te hakken. Ook een burgemeester die een bruggenbouwer is, mensen in de besluitvorming betrekt en naar gemeenschappelijke doelstellingen zoekt, kortom een verbinder en een koersbepaler. Helaas heb ik de afgelopen maanden moeten constateren dat mij, door zowel de meerderheid van de raad als het college, onvoldoende gelegenheid is geboden om op een dergelijke wijze invulling te geven aan het ambt."

Naast Liemburg vertrok ook een wethouder in Menterwolde in 2006, nadat de eigen SP-fractie het vertrouwen opzegde. Appingedam kreeg te maken met het vertrek van wethouders in 2004 en 2005, waarbij in het laatste geval ook de coalitie een andere samenstelling kreeg. Winsum tenslotte kende één onrustig bestuurlijk jaar, 2008. Het jaar waarin het college met drie wethouders viel en een minderheidscoalitie terugkeerde, dat gedoogsteun kreeg.

\section{Provincie Friesland}

In Friesland zijn bijzonder weinig bestuurlijke problemen gemeld. Slechts in negen van de 31 gemeenten is in de periode 1998-2010 een wethouder of burgemeester vertrokken, in de andere 22 gemeenten (71\%) niet. Bestuurscrises, waarbij het hele college moest verdwijnen, deden zich volgens de opgave van de gemeenten maar één keer voor, in de gemeente Boarnsterhim in 2009. Friesland is daarmee (samen met de qua aantal gemeenten kleinere provincie Drenthe) de provincie met het laagste aantal vallende colleges. Met Boarnsterhim is tegelijkertijd de gemeente genoemd waar door de val van het college in 2009 de grootste problemen te melden waren. Voor Friese insiders is dat niet verwonderlijk: de gemeente staat al langer bekend om de soms oprispende bestuurlijke problematiek. Ook in 2001 en 2005 was er een bestuurscrisis, waarbij uiteindelijk maar één keer een wethouder moest vertrekken.

Voor de andere acht gemeenten met een melding geldt dat het vaak om een eenmalig vertrek van een wethouder ging. Enkele jaren geleden ging wel veel aandacht uit naar de gemeente Leeuwarden, waar na veel turbulentie burgemeester L. van Maarenvan Balen ( $\mathrm{PvdA}$ ) in 2001 vertrok. Zij ging weg na wat formeel werd genoemd een 'onoverbrugbaar verschil van inzicht met de wethouders betreffende het dagelijks bestuur van de gemeente Leeuwarden'. Hierover is veel gezegd en geschreven, niet in de laatste plaats door betrokkene zelf (Van Maaren-van Balen, 2003). De scheidende burgemeester werd begin 2002 gevolgd door de wethouder Financiën, die zwaar onder vuur kwam te liggen van de gemeenteraad na gemaakte fouten met de Onroerende Zaak Belasting (OZB). Zij besloot de eer aan zichzelf te houden en te vertrekken. Hierna zijn er geen bestuurlijke vertrekken meer geweest. Wel bleef opvolgend burgemeester G. Dales (VVD) relatief kort; hij werd na drie jaar al opgevolgd door F. Crone (PvdA). Een opvallende andere gemeente is nog Gaasterlận-Sleat, waar in 2001 een wethouder vertrok en in 2007 burgemeester Th. de Roos na conflicten het veld moest ruimen. 
Bijzonder was de situatie overigens ook in Littenseradiel. Hier zegde de meerderheid van de raad het vertrouwen op in burgemeester J. Liemburg, maar na enkele lange vergaderingen kon de zaak weer worden gelijmd. Wel viel na deze crisis de coalitiefractie van de PvdA in twee delen uiteen.

\section{Provincie Drenthe}

De provincie Drenthe bestaat na de grootschalige herindeling van 1998 uit twaalf gemeenten. Voor wat betreft eventuele bestuurlijke problemen is in het verleden vooral de gemeente Emmen in het oog springend geweest. Hier speelde in de jaren negentig een omvangrijke crisis, waarbij op één wethouder na het hele college werd vervangen. Dit vond echter vóór 1998 plaats, derhalve voor de tijdsperiode in dit onderzoek. Inmiddels is het al een groot aantal jaren rustiger in het Emmens gemeentebestuur, al vertrokken er nog wethouders in 1999 en 2003. Bij de andere Drentse gemeenten zijn in de onderzochte periode geen grote bestuurlijke problemen te melden, op één na: de gemeente Westerveld, waar bij de crisis rondom een schoolbestuur in 2007 het hele college (inclusief de burgemeester) vertrok. Dat was tegelijk de enige keer dat een compleet college diende op te stappen in de onderzoeksperiode in de provincie Drenthe. De overige gemeenten meldden geen, één of twee vertrokken bestuurders.

In twee gemeenten speelde wel een kwestie rondom de herbenoeming van de burgemeester. In 2001 was er een probleem rondom de vertrouwelijkheid van de herbenoeming van de toenmalige burgemeester in Assen, omdat er een aantekening was uitgelekt. Het had verder geen gevolgen. Ook in Tynaarlo speelde een dergelijke kwestie, maar dan in 2004. Een raadslid van Leefbaar Tynaarlo werd door de politierechter in Assen uiteindelijk veroordeeld tot vier weken voorwaardelijke gevangenisstraf en een geldboete van vijfhonderd euro, wegens het lekken van informatie over de herbenoeming van de toenmalige burgemeester. Het raadslid maakte deel uit van de vertrouwenscommissie, die de herbenoeming van de burgemeester behandelde en achtte het zijn plicht bepaalde vertrouwelijke informatie toch naar buiten te brengen.

\section{Provincie Overijssel}

De provincie Overijssel telde officieel 25 gemeenten per 1 januari 2010. Als het gaat om de bestuurlijke problematiek in Overijssel, valt op dat er in veel gemeenten weinig tot geen meldingen zijn te noteren over vertrokken wethouders of burgemeesters. In twaalf van de 25 gemeenten vertrok niemand gedwongen (48\%), waar nog eens acht gemeenten bij komen met een gemiddeld vertrek van één of twee bestuurders. Opvallend was natuurlijk de grote crisis in de gemeente Dinkelland, waar burgemeester F. Willeme na veel commotie diende te vertrekken in 2007 (zie Boverhof en Krijnsen, 2010).

Hoger vallen de aantallen uit voor Raalte, Hardenberg en Deventer. In Raalte speelde de crisis rond burgemeester A. Bolhuis in 2007 (zie Warbroek, 2007). Hardenberg telde in 2002 en 2004 een vertrekkend wethouder, wat in één geval leidde tot een collegecrisis. Deventer kende het bestuurlijk 'rampjaar' 2009, waarin de stad twee keer geconfronteerd werd met een collegecrisis, waarna twee wethouders niet meer terugkeerden. De gemeenten met de hoogste aantallen vertrokken bestuurders in Overijssel zijn Kampen, waar in totaal vier wethouders en twee colleges vertrokken en de gemeente Losser. Deze laatste gemeente verkeerde in 2004 in een crisis, toen na een conflict over de Landesgartenschau het complete college, inclusief burgemeester, opstapte. Een 
nieuwe grote crisis volgde in 2009, waarna viteindelijk een zakencollege de rit tot de verkiezingen in maart 2010 afmaakte.

\begin{abstract}
Begin van de verklaring van de aftredende wethouder F. van Dam-Scholten, Epe, 2008

"Ik dank de raad voor de tijd die mij is gegund om een afgewogen besluit te nemen en om hierover een verklaring af te leggen. Gaat u gerust achterover zitten, want het gaat even duren. En nu kan niemand mij interrumperen, dus neem ik het er ook maar even van. Een aantal van u kan ik overigens gelijk gerust stellen, want ik zal niet op de persoon spelen of, zoals mij gevraagd is, niet natrappen. Zo'n vraag kan alleen maar komen van iemand die niet goed snapt hoe ik in elkaar steek of waar ik voor sta. Staat u mij toe u rond te leiden in mijn werkelijkheid en hoe ik deze werkelijkheid beleef. Een kijkje in mijn keuken, zoals u wilt.

Laat ik beginnen met de boodschap. Sommigen nemen daar een lange aanloop in, maar ik houd van duidelijkheid. Alsof eerst omstandig vitleggen een vervelende boodschap verzacht. Ik verzoek $u$ mijn ontslag te aanvaarden. I $k$ weet eigenlijk niet eens of je het zo zegt, maar u begrijpt me wel. Ik kan niet anders dan tot dit besluit komen, na het besluit van de VVD-fractie om niet langer deel vit te willen maken van de coalitie. Voor de goede orde, ik ben hier mede verantwoordelijk voor. Als het dan toch moet gebeuren, laat het dan nu maar gebeuren, heb ik de fractie verzocht. Er wordt blijkbaar toch ook nog wel eens naar mij geluisterd..."
\end{abstract}

\title{
Provincie Gelderland
}

De bestuurlijke situatie in Gelderland wordt gekenmerkt door een grote hoeveelheid gemeenten met één moeilijk bestuurlijk jaar. In zo'n jaar sneuvelt dan een heel college, waardoor het aantal gedwongen vertrokken bestuurders snel stijgt. Zo'n situatie deed zich voor in Culemborg (2004), Renkum (2004), Groesbeek (2004), Aalten (2006), Voorst (2006), Lochem (2006), Apeldoorn (2006) en Nijmegen (2009). Meer gespreide bestuurlijke problematiek was te zien in Millingen aan de Rijn, Heumen, Rheden en Doetinchem. De aantallen vertrokken bestuurders komen alleen in Nijmegen boven de acht, maar daar was de grote crisis in 2009 debet aan, toen een groot college in het geheel demissionair werd.

Deel van de verklaring van aftredend wethouder S. van Bodegraven, Arnhem, 2008 "Vandaag, 25 augustus 2008, heb ik mijn functie van wethouder van de gemeente Arnhem neergelegd. Dit besluit heb ik genomen naar aanleiding van het onderzoek naar de toedracht van de forse overschrijding van de verbouwing van het Museum Moderne Kunst Arnhem (MMKA). De rapportage van dit onderzoek brengt feiten aan het licht, waarvoor ik als portefeuillehouder verantwoordelijk ben. Mijn persoonlijke conclusie is: ik ben niet in staat gesteld om in dit proces op het juiste moment de regie te voeren en sturing te geven. Maar zoals dat gaat in een politieke en ambtelijke organisatie: de bestuurder is verantwoordelijk voor al het handelen. Dat is de politieke consequentie en ik heb daarin mijn afweging gemaakt. Dat leidt onvermijdelijk tot mijn besluit van heden: mijn functie neerleggen. Het rapport dat door PWC geschreven is, geeft wat mij betreft een verbijsterend beeld van de gang van zaken rond de verbouwing van het museum. Er is fout op fout gestapeld. Niet alleen zijn er, in een vroeg stadium al, forse over- 
schrijdingen geweest, ook is het projectmanagement in gebreke gebleven bij het informeren van het hogere management, de portefeuillehouder en het college. Zo beschouwd is mij dit overkomen. Terugkijkend daarop, met de wetenschap van nu in de hand, zijn er wel momenten geweest waarop ik als verantwoordelijk bestuurder had moeten en kunnen inspringen. Als ik in februari 2008 een eerste signaal krijg van de problemen, is dat voor mij geen reden om aan de bel te trekken; ik was mij toen niet bewust van de omvang. Bovendien moest er op dat moment nog van alles worden vitgezocht en werd er gezocht naar oplossingen. Overigens waren de werkzaamheden toen al lang achter de rug; het project was in oktober 2007 afgerond en het budget was ruim overschreden. Sturing was dus op dat moment niet meer mogelijk geweest. Vervolgens werd ik pas in mei 2008 op de hoogte gebracht van de volle omvang van de problemen. Ook toen werd echter nog gezocht naar oplossingen door het ambtelijk apparaat. Dat was het tweede moment waarop ik aan de alarmbel had moeten trekken. De signalen, hoe vaag misschien ook, hadden aanleiding moeten zijn om door te vragen, om de volledige informatie die in feite al vorig jaar beschikbaar was, op tafel te krijgen. Dan was sturing weliswaar niet meer mogelijk geweest, maar had ik wel mijn verantwoordelijkheid kunnen nemen en de regie in handen kunnen nemen, voor welk proces dan ook, met welke uitkomst dan ook. Ik voel mij in ieder geval medeverantwoordelijk voor deze gang van zaken en aanvaard de viterste politieke consequentie, namelijk mijn functie neerleggen. Bij mijn aantreden als wethouder heb ik verschillende malen geroepen: dit is een fantastische baan. Ik heb de afgelopen jaren aan geweldige projecten mogen werken en samengewerkt met heel veel geweldige mensen, binnen het college, de raad, het ambtelijk apparaat, maar ook daarbuiten in de stad. Een fantastische baan, die ik nu met pijn in het hart ga opgeven. Ik weet dat dit soort momenten inherent zijn aan het wethouderschap; evengoed zal ik met heel veel plezier terugkijken op de afgelopen ruim vijf jaar."

\section{Provincie Noord-Holland}

De provincie Noord-Holland (6o gemeenten per 1 januari 2010) telt relatief veel gemeenten met een groot aantal gedwongen vertrokken bestuurders. In slechts vijftien gemeenten wordt geen gedwongen vertrek gemeld, wat neerkomt op 25\%. Drie gemeenten (Den Helder, Beverwijk en Hilversum) staan op een totaal van tien vertrokken burgemeesters, wethouders of colleges

\section{Verklaring van wethouder Y. Tan, Amstelveen, 2008}

"De afgelopen maanden waren voor mij niet gemakkelijk, vanwege de discussie over mijn functioneren als wethouder. Mijn persoonlijke beleving is dat het daarbij vaak meer ging om de vorm en stijl dan om de inhoud van de voorstellen, die ik namens het college inbracht. Die discussie duurt voort en maakt het voor mij onmogelijk om naar behoren mijn taken succesvol vit te oefenen. Na rijp beraad en na het publieke belang, het belang van mijn partij, de Partij van de Arbeid, en mijn persoonlijke belang afgewogen te hebben, heb ik besloten mijn ontslag als wethouder in te dienen."

Het gaat hier steeds om door de jaren heen gespreide bestuurlijke problematiek. Dit beeld geldt ook voor veel andere gemeenten in Noord-Holland: af en toe een conflict, soms een crisis. In weinig gemeenten concentreert de problematiek zich in één jaar. 
Noord-Holland noteerde in de onderzoeksperiode negen vertrokken burgemeesters, waarbij er twee zijn weggegaan in de gemeente Den Helder (zie hoofdstuk 5).

Brief d.d. 24 augustus 2004 van wethouder C.W. Zwakman aan de gemeenteraad van Bergen, waarin hij zijn aftreden aankondigt. Drie andere wethouders werden een week later op grond van artikel 49 van de Gemeentewet ontslagen.

"Geachte voorzitter,

Op 24 juni jl. heeft uw raad een motie aangenomen, waarin het vertrouwen in het collectief van het college van $B \& W$ is opgezegd. Op verzoek van uw raad ben ik, evenals de andere wethouders, in het belang van de continuiteit van het dagelijks bestuur aangebleven om de lopende zaken te behartigen. Nu mij is gebleken dat uw raad het voornemen heeft tijdens de raadsvergadering van 31 augustus a.s. een nieuw college te benoemen, bied ik bij deze conform artikel 43 lid 1 van de Gemeentewet per 31 augustus a.s. mijn ontslag aan. Op grond van artikel 43 lid 2 zal ik, overeenkomstig uw verzoek, tot de benoeming van de wethouders de lopende zaken blijven behartigen.

Hoewel de motie zich nadrukkelijk richt op het collectief van het college van B\&W en met een motivatie waarin ik mij in mijn persoonlijk functioneren niet herken, ben ik van mening dat met het aannemen van de motie de vertrouwensbasis waarop mijn wethouderschap is gebaseerd, is komen te vervallen. Daarmee voel ik mij genoodzaakt mijn functie ter beschikking te stellen. Uiteraard ben ik bereid verantwoording af te leggen voor hetgeen onder mijn primaire verantwoordelijkheid als portefeuillehouder heeft plaatsgehad. Het spijt mij zeer dat met deze stap een einde komt aan een periode, waarin ik met veel inzet en plezier een bijdrage heb mogen leveren aan het dagelijks bestuur van onze gemeente. De belangrijkste voorwaarde voor het mogen leveren van deze inzet is een vertrouwensbasis met uw raad. Ik ben graag bereid een vervolg te geven aan deze functie, indien blijkt dat de vertrouwensbasis kan worden hersteld."

\section{Provincie Zuid-Holland}

De provincie Zuid-Holland is met bijna 3,5 miljoen inwoners de meest bevolkingsrijke provincie van Nederland.

Deel van de verklaring van wethouder F. Speel (Zoetermeer), waarin hij zijn ontslag aanbiedt en excuses maakt vanwege gemaakte fouten met betrekking tot de handhaving bij het bedrijf Stegenerics (Zoetermeer, 26 januari 2010).

"Het waren vier waanzinnig mooie en boeiende jaren. Tegen de inwoners van Zoetermeer zeg ik: ik bied nogmaals mijn oprechte excuses aan... Ik zeg dus tegen de inwoners van Zoetermeer: ik bied mijn oprechte excuses aan voor de fouten die zijn gemaakt met de gemeentelijke handhaving. En tot slot zeg ik tegen mijn vrouw en mijn zoons, die mij geweldig hebben gesteund: sorry dat ik de afgelopen maanden zo vaak extra afwezig was. Het ga u allen goed."

Het bestuurlijk beeld van de 74 Zuid-Hollandse gemeenten is als volgt. 51 gemeenten meldden geen, één of twee gedwongen vertrekken, wat neerkomt op bijna $69 \%$. Hierna volgt een groep met gedurende de periode een enkele keer een vertrekkende wethouder, meestal gevolgd door een collegewisseling. In de meeste gevallen is er sprake van een zekere spreiding door de periode heen. Ook in Zuid-Holland zijn er gemeenten 
met een bestuurlijk rampjaar, zoals Gorinchem (2004) en Albrandswaard (2008). De stad Leiden telt het grootste aantal vertrekkende bestuurders of colleges in ZuidHolland. Ook over Leiden is een casestudy gemaakt (zie hiervoor hoofdstuk 6).

\begin{abstract}
CDA-fractievoorzitter B. van der Deijl (Pijnacker-Nootdorp) na de breuk in de coalitie met de VVD (op website CDA Pijnacker-Nootdorp, januari 2010).

"Heel vaak wordt beweerd dat de politiek een spelletje is. Wat mij betreft is het dat zeker niet, maar er zijn wel spelregels. En de VVD hield zich niet aan de spelregels, door niet op één lijn te zitten met de coalitiepartners en daar niet van tevoren overleg over te plegen. Als je samenwerkt in een coalitie moet je van elkaar op aan kunnen en dat vertrouwen was weg."
\end{abstract}

\title{
Provincie Utrecht
}

De provincie Utrecht telde per 1 januari 201029 gemeenten. Abcoude valt hier op door het hoogste aantal vertrokken colleges in de provincie: drie keer in de afgelopen twaalf jaar. Elke keer als een wethouder vertrok (2000, 2001 en 2008) veranderde ook het college van samenstelling. De gemeente Utrecht zelf kampte vooral in de laatste raadsperiode met bestuurlijke problemen, waardoor viteindelijk drie wethouders vertrokken en het college van samenstelling veranderde.

\section{Deel van de verklaring van wethouder Wisse (uit: raadsnotulen Breukelen, 9 november 2009):}

"Als een donderslag bij heldere hemel voor mij en aanwezigen met mij, liet u weten bij monde van de heer Van den Bosch tijdens de raadsvergadering van 27 oktober jl., problemen te hebben met mijn functioneren. Wat daar de diepere achtergrond van was bleef op dat moment onduidelijk en is tot op de dag van vandaag nog steeds onduidelijk. In het coalitieoverleg van vrijdag 30 oktober heeft $u$ daarop het niet goed functioneren genoemd: de wethouder heeft "te vaak, niet, half of omslachtig voorgelicht". Op de vraag naar concrete voorbeelden kwam u niet verder dan het steeds maar weer herhalen van een paar voorvallen, die u "druppels" noemde die de emmer hadden doen overlopen. Nooit is er melding gemaakt van een emmer die halfvol is, laat staan van een emmer die bijna overloopt. Voor ik inga op die "druppels" wil ik viting geven aan mijn teleurstelling over de handelswijze van enige fracties. Bij een geschil met een wethouder van de coalitie wordt dat uitgepraat en verbeterpunten afgesproken, dat is de gebruikelijke gang van zaken. Vaak is het zo dat na twee waarschuwingen bij het derde incident de wethouder vrijwillig opstapt. Echter in deze situatie is er niet tijdig gepraat, zijn geen waarschuwingen vitgedeeld en bleek bovendien tijdens genoemd coalitie overleg geen enkele bereidheid te zijn bij de helft van de fracties om zaken uit te praten en op te lossen. Ik vraag me nu ook af wat het nut was van deze bijeenkomst, immers het vooringenomen oordeel lag al vast. Ik ben daar verontwaardigd over en vind het ongeloofwaardig en voor mij zeer beschadigend. Te meer daar ik gevraagd was bij die vergadering aanwezig te zijn.

Ik vraag me ook af wat de inwoners zo vlak voor de herindeling voor voordeel hebben om zonder deze wethouder de rit vit te zitten, immers een coalitie doet doorgaans zijn viterste best om ten gunste van die inwoners de hele zittingsperiode bij elkaar te blijven en eventuele geschillen op te lossen. Die wil is er blijkbaar bij de helft van het aantal fracties van de coalitie in mijn situatie niet. Ik vind dat ronduit verbijsterend en ben zeer benieuwd hoe $u$ de inwoners van de gemeente Breukelen gaat overtuigen dat mijn vertrek 
veel beter is voor hen. Een wethouder onverwacht dwingen tot opstappen, een wethouder die het collegeprogramma naar tevredenheid van de raad vitvoert en als het even kan meer dan dat, is niet uit te leggen. (....)

Voorzitter en leden van de Raad, ik ben een mens en maak dus fouten, maar deze fouten hebben nooit ernstige consequenties gehad, niet voor de raad, niet voor het college en ook niet voor de burgers, voor wie we dit allemaal doen. Toch zegt u zonder waarschuwing vooraf - dus ook niet in het kort voor de raad gehouden coalitieoverleg- het vertrouwen in mij als wethouder, op. Dat raakt mij diep. Ik begrijp niet, en vele anderen met mij, waarom de helft van de fracties van de coalitie zo handelt en voel me vernederd en ervaar het als een dolksteek in mijn rug."

\section{Provincie Flevoland}

De provincie Flevoland is de twaalfde en jongste provincie van Nederland. Alle zes gemeenten kenden grote of kleinere bestuurlijke problemen. De gemeente Dronten werd in 2004 geconfronteerd met een bestuurlijke crisis, die leidde tot het vertrek van twee wethouders. In 2007 vertrok wethouder De Graaf na kritiek (Bouwmans, 2008) en onvoldoende vertrouwen van de raad. In de gemeente Noordoostpolder ontstond een crisis in 2007, met als gevolg dat een VVD-wethouder opstapte en werd opgevolgd door een wethouder van SGP-huize. In Urk vertrok de enige burgemeester in de onderzoeksperiode in Flevoland, als gevolg van wat de vis-affaire is gaan heten. Lelystad verloor in 2009 een wethouder, wat tot het vertrek van de VVD uit de coalitie leidde. Zeewolde en Almere (zie kader) kenden, beiden met vier wethouders en twee colleges, het grootste aantal vertrokken bestuurders.

\section{Almere}

Dé groeikern van Nederland, Almere, met in 2010 een inwoneraantal van ruim 180.000 inwoners, heeft inmiddels ook haar bestuurlijke perikelen gehad. In de onderzoeksperiode laat de collegeperiode 1998-2002 zich kenmerken door het vertrek van enkele wethouders, respectievelijk in 1999 en 2001 . In het laatste geval leidde het vertrek van een VVD-wethouder (na een breuk in het college) tot een ware crisis (Hazelnootreeks, deel 1). Na wekenlange gesprekken werd de coalitie uiteindelijk uitgebreid met een wethouder van het CDA, waarbij de VVD van drie naar twee wethouders ging. Het jaar 2002 was het jaar waarin Leefbaar Almere een grote sprong maakte, vanuit het niets op negen zetels kwam en daarmee de grootste partij in de gemeenteraad werd. Leefbaar Almere kwam ook in het college, waar de VVD in eerste instantie niet in werd opgenomen. Later wel, want na het indienen van het ontslag door de CDA-wethouder trad de VVD toe tot het college met twee wethouders (Bouwmans, 2005). In 2004 vertrok een (Leefbaar) Almeerse wethouder, omdat hij in Amsterdam een huis kocht en de raad van mening was dat hij in Almere zou moeten blijven wonen. In 2005 tenslotte keerde Leefbaar-wethouder Huis terug naar de raad, om te voorkomen dat een vrijvallende zetel zou toevallen aan een afgesplitst deel van zijn partij. Na de verkiezingen van 2006 zit Leefbaar Almere, dat terugzakte naar vier zetels, niet meer in het college. Dat bestaat vanaf die datum tot maart 2010 uit wethouders van CDA (ook namens ChristenUnie), PvdA en VVD. 


\section{Provincie Zeeland}

Het bestuurlijk beeld van de provincie Zeeland (13 gemeenten) is redelijk rustig, waarbij vier gemeenten eruit springen: Middelburg, Schouwen-Duiveland, Sluis en Vlissingen. Gemeenten die werden gekenmerkt door het vertrek van hele colleges, waarbij vooral de crisis in Vlissingen in 2007 opvalt (Schipper, 2010). Middelburg kende een meer gespreid beeld van vertrokken bestuurders, waaronder twee keer een burgemeester. Acht van de dertien gemeenten meldden geen of één vertrek, de inwoners van de gemeente Kapelle zagen twee wethouders en een college vertrekken.

\section{Verklaring wethouder M. Walraven-van der Sloot, Vlissingen, 30 januari 2007}

"Vannacht heb ik besloten om mijn functie als wethouder van de gemeente Vlissingen neer te leggen. Deze morgen heb ik mijn besluit kenbaar gemaakt aan het college van burgemeester en wethouders. Ik zal vandaag schriftelijk mijn ontslag aan de gemeenteraad aanbieden.

De herinrichting van de begraafplaats in Oost-Souburg heeft veel commotie en emotionele reacties opgeroepen. Gisteren heb ik mijn spijt betuigd over het feit dat wij niet iedereen hebben kunnen bereiken met onze informatie. Gisteravond heb ik met mijn fractie van de Partij Souburg Ritthem uitvoerig gesproken over wat er de afgelopen weken is gebeurd rondom de begraafplaats en mijn rol daarin als wethouder. Als bestuurder van de gemeente Vlissingen ben ik verantwoordelijk voor de uitvoering van het beleid op begraven en begraafplaatsen. Tijdens het gesprek met de PSR is gebleken dat mijn fractie geen vertrouwen meer heeft in mij als wethouder. Zonder steun en vertrouwen van mijn eigen fractie, mis ik het noodzakelijke draagvlak om mijn functie uit te kunnen oefenen. Daarom heb ik zelf besloten mijn functie als wethouder neer te leggen."

\section{Provincie Noord-Brabant}

De provincie Noord-Brabant kende in totaal 68 gemeenten op peildatum 1 januari 2010. In Noord-Brabant meldde ruim $61 \%$ van de gemeenten geen, één of twee gedwongen vertrokken bestuurders of colleges. In Noord-Brabant is er een vrij grote groep gemeenten met een relatief hoog aantal 'losse' vertrekken door de jaren heen. Voorbeelden zijn Nuenen, Drimmelen, Cranendonck.

De inwoners van Steenbergen zagen in de onderzoeksperiode drie keer een nieuw college aantreden, samen met Zundert het hoogste aantal in Noord-Brabant. HeezeLeende en Veghel kregen te maken met een bestuurlijk rampjaar, in respectievelijk 2004 en 2008. Valkenswaard zag zowel in 2002 als in 2008 een college met drie wethouders vertrekken. Van de gemeente Zundert is in het kader van dit onderzoek een casestudy gemaakt (zie hoofdstuk 8).

\section{Provincie Limburg}

De provincie Limburg telde op de peildatum van 1 januari 201034 gemeenten. Het bestuurlijk beeld van Limburg voor wat betreft vertrekkende bestuurders is wisselend. Bijna de helft van de gemeenten heeft helemaal geen bestuurders zien vertrekken na een conflict. Er zijn echter ook gemeenten die meer problemen hebben gehad. Het meest in het oog springend is de gemeente Sittard-Geleen, ontstaan per 1 januari 2003 als gevolg van een fusie tussen de gemeenten Born, Geleen en Sittard. Hier vertrokken 
op verschillende momenten negen wethouders, een burgemeester en een college, wat het totaal op elf brengt. Debet hieraan is vooral de grote crisis in 2003, waarbij zes wethouders betrokken waren en het college viel. In 2005 was er opnieuw gedwongen vertrek (twee wethouders en de burgemeester), daarna werd het op het oog rustiger. Andere gemeenten in Limburg met een hoog aantal gedwongen vertrokken bestuurders zijn Heerlen en Stein, met een gespreid beeld door de jaren heen.

\subsection{Typen gemeenten}

Bestuurlijke conflicten en crises kunnen in verschillende vormen voorkomen. In de inleiding is al een onderscheid gemaakt tussen een bestuurlijk conflict en een bestuurscrisis. In het eerste geval gaat het om het gedwongen vertrek van een wethouder, in het tweede geval moet een heel college het veld ruimen en is er in de regel veel onrust in een gemeente.

Uit het onderzoek onder de Nederlandse gemeenten van 1998 t/m 2010 blijkt dat er verschillende typologieën te onderscheiden zijn. Het gaat in totaal om vijf verschillende soorten gemeenten.

\section{Gemeenten zonder gedwongen vertrek}

In $35 \%$ van de Nederlandse gemeenten kwam gedwongen vertrek van bestuurders of hele colleges niet voor in de onderzoeksperiode. "Sinds mensenheugenis is het niet voorgekomen dat een burgemeester of een wethouder van onze gemeente 'gedwongen' moest vertrekken", meldt een burgemeester in reactie op de oproep met betrekking tot dit onderzoek. Een collega uit het noorden van het land schrijft: "Het is hier zo stabiel... Sinds de oorlog al hetzelfde college (haast) en nog nooit iemand weggestuurd. Ze zijn hier heeeel aardig voor elkaar." Een medewerker communicatie is ook tevreden over de eigen gemeente: "Moge onze gemeente als voorbeeld dienen als het gaat om bestuurlijke stabiliteit." Uit het zuiden van het land kwam de volgende reactie: "Er zijn de laatste tien jaar geen wethouders/burgemeesters vertrokken wegens een conflict. Het betreft slechts de normale dingen: pensioen, andere baan en 'geen zin meer'."

Het feit dat er geen gedwongen vertrek werd gemeld, wil echter niet zeggen dat er geen spanningen zijn gerapporteerd. Spanningen die zich in het college konden manifesteren, maar ook in de coalitie of in de hele raad. Een voorbeeld is de gemeente Breda, waar in maart 2008 een crisissfeer in de raad ontstond toen de vier oppositiepartijen (D66, VVD, SP en Leefbaar Breda) de gemeenteraadsvergadering demonstratief verlieten. Zij protesteerden daarmee tegen de manier waarop de coalitiepartijen CDA, PvdA, GroenLinks en Breda '97 in de ogen van de oppositie al besloten hadden welke politieke prioriteiten er het komende jaar gesteld zouden moeten worden. "Worden wij geacht voor de Bühne mee te doen? Wij dachten het niet. Wij laten ons niet voor het karretje van de coalitie spannen. Wij lezen wel in de krant wat er besloten wordt", zei D66-fractievoorzitter Boelema namens de vier partijen (BN/De Stem, 14 maart 2008).

De gemeenteraad in Duiven besloot op initiatief van burgemeester Zomerdijk op informele excursie te gaan, om de slechte verhoudingen wat te verbeteren (Binnenlands Bestuur, 160508). Terwijl Duiven geen vertrokken wethouders of burgemeesters te melden had. In Littenseradiel beleefde burgemeester Liemburg een spannende zomer 
in 2007. In juni wilde een meerderheid van de gemeenteraad haar ontslag, maar enkele maanden later waren de problemen toch opgelost. Een opvallende actie was er ook van burgemeester R. van Loo van de gemeente Vaals. Hoewel deze gemeente geen gedwongen vertrokken bestuurders kon melden, was er wel reden tot zorg. Burgemeester Van Loo stuurde in het voorjaar van 2008 een brief aan de gemeenteraad, waarin hij een dringend beroep deed op de raadsleden om respectvoller met elkaar om te gaan. Tijdens een vergadering liep de oppositie zelfs weg. Van Loo: "Het is niet zozeer de sfeer bij de raadsvergaderingen, maar vooral de discussie die raadsleden ook via de regionale media voeren. Nadat de oppositie vorige week de raadsvergadering had verlaten, heb ik de gemeenteraad een brief geschreven. Het lijkt erop dat we in een vicieuze cirkel van respectloosheid terecht zijn gekomen, die we nog koesteren ook. Het kon zo echt niet langer" (Binnenlands Bestuur, 300508).

Kortom: in de 153 gemeenten zonder bestuurlijke incidenten waren er soms (grote) spanningen, maar die leidden niet tot gedwongen vertrek. In het beste geval werden de problemen overwonnen, in het slechtste geval 'hobbelde' men in een raadsperiode van incident naar incident. In deze categorie gemeenten vallen overigens ook de gemeenten waar bestuurders op een elegante manier het veld konden ruimen. Burgemeesters gingen soms met vervroegd pensioen, wethouders vertrokken geheel uit zichzelf, zonder aanwijsbare druk uit de raad. In de verantwoording van het onderzoek is al uiteengezet waarom deze categorie bestuurders niet tot de categorie 'gedwongen vertrek' gerekend wordt. Deze gemeenten komen verspreid over het hele land voor.

\section{Gemeenten met een gemiddeld vertrek}

Tot de tweede categorie behoren gemeenten die het gedwongen vertrek van één of twee gemeentebestuurders konden melden in de onderzoeksperiode, wat dus gemiddeld te noemen is. Het gaat hier om 139 gemeenten, ruim 30\% van het totaal. Het betreft hier losse, eenmalige incidenten, waarbij ook een duidelijk aanwijsbare reden is aan te geven. Het door bestuurders onjuist informeren van de raad, rijden onder invloed van alcohol, etcetera. In deze gemeenten bleef het vervolgens bij het vertrek van deze ene bestuurder. Hooguit kwam er een beperkte collegewisseling, waarbij de ene partij de andere verving. Soms werd de wethouder niet vervangen.

Overigens wil dit niet zeggen dat dit vertrek niet omgeven kan zijn met veel publiciteit. Een voorbeeld is het gedwongen vertrek van burgemeester Willeme van de gemeente Dinkelland, die na problemen in het college van de raad moest vertrekken. Het bijzondere was hier dat een deel van de bevolking een actie op touw zette om te proberen Willeme te behouden voor de gemeente. De emoties in woord en beeld liepen hoog op. Tevergeefs overigens, want toenmalig minister Ter Horst van Binnenlandse Zaken zag geen concrete reden het oordeel van de gemeenteraad niet te volgen. Willeme vertrok, later gevolgd door nog een wethouder. Kortom: een zeer turbulent vertrek, met veel publiciteit, maar in een gemeente waar de teller van het gedwongen vertrek op 'gemiddeld' vit komt.

Een ander voorbeeld van een landelijk gevolgd ontslag is het vertrek van wethouder Rietbrink uit de (per 1 januari 2010 gefuseerde) gemeente Reiderland. Niet ogenblikkelijk een gemeente waar het zoeklicht van het lokaal bestuur langer op blijft stil staan, 
maar ook in dit geval was er iets aan de hand. Het ging om het dorpje Ganzedijk, waarvan werd gezegd dat het college, in het bijzonder wethouder Rietbrink, dat zonder meer zou willen opheffen. En hoewel de feiten volgens Hietbrink iets anders lagen (Mudde, 2008: 18) kreeg de wethouder ook hier te horen dat hij kon vertrekken, in dit geval eerst van de eigen fractie.

\section{Gemeenten met een 'onrustig jaar'}

Een derde categorie is de groep gemeenten waar één onrustige periode te melden viel, waardoor er meerdere wethouders, soms ook de burgemeester, moesten vertrekken en een heel college van samenstelling veranderde. In deze gemeenten is het jaren bestuurlijk rustig en ontstaat plotseling een heftige crisis. Voorbeelden zijn er te over. In Veghel vertrok in 2008 het hele college, inclusief de burgemeester. Zonder dit incident was Veghel absoluut niet als opvallende gemeente naar voren gekomen in de totaallijst qua cijfers. Wel is bekend dat er destijds een analyse is gemaakt van de situatie in het gemeentehuis van Veghel, waar een verontrustend beeld uit kwam.

Een ander voorbeeld is de gemeente Apeldoorn, waar het voltallige college in februari 2006 opstapte vanwege het jarenlange conflict tussen de gemeente Apeldoorn en het bedrijf Reesink. Burgemeester De Graaf bleef als enige zitten.

In de gemeente Bergen (NH) moest het hele college in augustus 2004 opstappen vanwege een motie van wantrouwen, die gesteund werd met veertien stemmen voor en drie stemmen tegen. De raad had er geen vertrouwen in dat het zittende college de financiële positie van de gemeente Bergen en de aansturing van de ambtelijke organisatie onder de knie zou krijgen. Veel beschreven en besproken was ook de grote crisis in de raad van Culemborg in 2004. Drie wethouders sneuvelden, waarna ook de burgemeester en in de nasleep de secretaris en griffier een andere functie moesten zoeken. In de gemeente Goirle viel in 2004 het hele college na affaires rondom bouwvergunningen. Uiteindelijk kwam er via een externe bemiddelaar een zakencollege, met twee bestuurders uit buurgemeente Tilburg. Dit college nam met burgemeester De Vrey tot de verkiezingen in 2006 het lopende werk voor zijn rekening. In Groesbeek viel in 2004 het hele college, na kritiek van het CDA op coalitiepartner VOLG. Uiteindelijk kwam er een nieuwe coalitie, met de partij VOLG, en moesten de drie andere wethouders het veld ruimen.

In Vlissingen ging het om de zogeheten Scheldekwartieraffaire, een groot plan op het terrein van de voormalige scheepswerf De Schelde. In juli 2007 ontstond hierover een vertrouwensbreuk tussen het college en de ambtenaren. B\&W en de gemeentesecretaris grepen hard in en stuurden de twaalf belangrijkste ambtenaren die hieraan werkten, met inschakeling van een forensisch accountantsbureau, naar huis. In de coulissen stonden al interim-managers klaar. De grote rel die hieruit volgde leidde tot het vertrek van de gemeentesecretaris en het hele college. De ambtenaren gingen overigens na korte tijd weer aan het werk. Ook in Lochem, Albrandswaard, Losser, Westerveld en vele andere gemeenten speelde vooral een eenmalig incident in een bestuurlijk 'onrustig' jaar de gemeente parten.

\section{Gemeenten met zo nu en dan een incident}

Er zijn ook gemeenten waar door de jaren heen zo nu en dan een incident voorkomt. Meestal gaat het dan om een individuele wethouder, soms verandert daardoor het 
college van samenstelling. Een echte crisis wordt het zelden. De wethouders komen vaak door persoonlijk gedrag in de problemen. Er zitten behoorlijke periodes tussen de verschillende conflicten of crises, waardoor ze op zich als incident zijn te beschouwen. Het zijn er echter meer dan één of twee, zonder dat er een bestuurlijk rampjaar tussen zit. De term 'structureel incidentalisme' lijkt hier van toepassing. Voorbeelden van deze gemeenten zijn Middelburg, Rheden, Abcoude en Nuenen.

\section{De bestuurlijke probleemgemeenten}

Bestuurlijke probleemgemeenten zijn gemeenten die bij voortduring worden geconfronteerd met bestuurlijke conflicten en bestuurscrises: individuele wethouders vertrekken, partijen stappen uit de coalitie, hele colleges moeten vertrekken, burgemeesters liggen onder vuur. De conflicten en crises zijn niet in een bepaald jaar te plaatsen, maar komen gedurende de hele looptijd voor, al kan het zijn dat een bepaald jaar er met een complete collegecrisis uitspringt. Van deze gemeenten is er in Nederland een aantal te noemen. Ze halen de landelijke media, omdat ze zo veelvuldig negatief in het nieuws zijn. De vraag welke gemeenten op basis van alle gegevens onderscheiden kunnen worden, wordt beantwoord in paragraaf 4.7 .

\subsection{Bestuurlijke probleemgemeenten}

Om vast te kunnen stellen welke gemeenten nu echt zijn te kwalificeren als bestuurlijke probleemgemeente, is gekeken naar vier aspecten.

Het lijkt logisch op de eerste plaats te kijken naar de top van de 'ranglijst' van gemeenten met bestuurlijke problemen. Er is voor gekozen de grens hierbij te leggen op minimaal zes vertrokken gemeentebestuurders of colleges in de onderzochte periode. Als het er minder zijn, gaat het vaak om gemeenten met zo nu en dan een incident of een onrustig jaar. De grens kan ook niet te hoog liggen, want dan bestaat de kans dat relatief kleine gemeenten, met kleine colleges, op grond daarvan niet in de hoogste categorie te vinden zijn, terwijl ze wel bestuurlijk problematisch zouden kunnen zijn. Als de grens wordt gelegd op minimaal zes vertrokken burgemeesters, wethouders of colleges gaat het in Nederland in de onderzochte periode om 51 gemeenten (zie tabel 12).

Dit is echter een puur cijfermatige berekening, er is meer nodig om echt tot bestuurlijke probleemgemeente te kunnen worden benoemd. Een tweede zoekcriterium is daarom het aantal collegecrises. Uit tabel 10 blijkt dat er 44 gemeenten zijn met twee, drie of zelfs vier crises. Ook dit is een indicator voor een bestuurlijke probleemgemeente. In de overzichten tot nu toe is echter elke verandering van politieke samenstelling van het college als 'collegecrisis' geteld. Het lijkt nuttig bij de zoektocht naar echte bestuurlijke probleemgemeenten dit criterium te verscherpen en te specificeren op situaties waarin daadwerkelijk een grote crisis aan de orde was, waarbij het hele college (soms inclusief de burgemeester) het veld diende te ruimen. Ernstige crises dus.

Het derde criterium is dat er in bestuurlijke probleemgemeenten structurele bestuurlijke problemen moeten zijn of moeten zijn geweest. In dit onderzoek gaat het er dan om dat er minimaal twee perioden achter elkaar een bestuurlijk conflict of een bestuurscrisis 
moet zijn geweest. Als er in een gemeente een bestuurlijk probleem is ontstaan in een raadsperiode, en tijdens een nieuwe raadsperiode ontstaat opnieuw een bestuurlijk conflict of bestuurscrisis, dan is dat eveneens een indicator voor een bestuurlijke probleemgemeente (zie Fleurke, 2008).

Op de vierde plaats is gelet op de vraag of er sprake is geweest van een bepalend bestuurlijk rampjaar, waarin een grote bestuurscrisis plaatsvond. Als dat in een grote gemeente gebeurt, waar colleges van zes of zelfs zeven wethouders kunnen voorkomen, levert dat gelijk een hoge score op in het totaalbeeld. Terwijl deze ene crisis niet hoeft te betekenen dat de gemeente een bestuurlijke probleemgemeente is gedurende een langere periode. De crisis kan een bijzondere aanleiding hebben en een uitzondering zijn in een over het algemeen bestuurlijk rustige gemeente. Het is dus relevant om te bekijken of deze crisis op zichzelf staat of niet. Het belang van dit criterium is aan te geven aan de hand van een voorbeeld. In de gemeente Nijmegen speelde in 2009 een grote crisis, waardoor het hele college demissionair werd. Dit vertekent het beeld voor Nijmegen behoorlijk. Hetzelfde geldt bijvoorbeeld voor Veghel (waar met name de crisis in 2008 een grote rol speelde), Doetinchem (bestuurscrisis in 2006), HeezeLeende (bestuurscrisis in 2004) en Muiden (bestuurscrisis in 2004).

Op grond van bovenstaande analyse en criteria kunnen negen gemeenten in Nederland tot de categorie bestuurlijke probleemgemeenten worden gerekend (zie tabel 14). Deze gemeenten hebben het hoogste aantal bestuurlijke problemen gekend in heel Nederland, met minimaal twee gevallen colleges, waarvan zeker één keer een ernstige crisis en problemen in twee opeenvolgende perioden.

Tabel 14: Bestuurlijke probleemgemeenten in Nederland 1998-2010

\begin{tabular}{|c|l|c|c|c|c|}
\hline Nr & Naam & $\begin{array}{c}\text { Aantal } \\
\text { conflicten }\end{array}$ & $\begin{array}{c}\text { Waarvan } \\
\text { gevallen } \\
\text { colleges }\end{array}$ & $\begin{array}{c}\text { Ernstige } \\
\text { crisis }\end{array}$ & $\begin{array}{c}\text { Problemen in twee } \\
\text { aaneengesloten } \\
\text { perioden }\end{array}$ \\
\hline 1 & Delfzijl & 16 & 4 & $\mathrm{Ja}$ & $\mathrm{Ja}$ \\
\hline 2 & Leiden & 13 & 3 & $\mathrm{Ja}$ & $\mathrm{Ja}$ \\
\hline 3 & Losser & 11 & 2 & $\mathrm{Ja}$ & $\mathrm{Ja}$ \\
\hline 4 & Beverwijk & 10 & 2 & $\mathrm{Ja}$ & $\mathrm{Ja}$ \\
\hline 5 & Den Helder & 10 & 2 & $\mathrm{Ja}$ & $\mathrm{Ja}$ \\
\hline 6 & Hilversum & 10 & 2 & $\mathrm{Ja}$ & $\mathrm{Ja}$ \\
\hline 7 & Valkenswaard & 10 & 2 & $\mathrm{Ja}$ & $\mathrm{Ja}$ \\
\hline 8 & Leerdam & 9 & 3 & $\mathrm{Ja}$ & $\mathrm{Ja}$ \\
\hline 9 & Zundert & 9 & 3 & $\mathrm{Ja}$ & \\
\hline
\end{tabular}

Op de kaart van Nederland levert dit het volgende beeld op: 


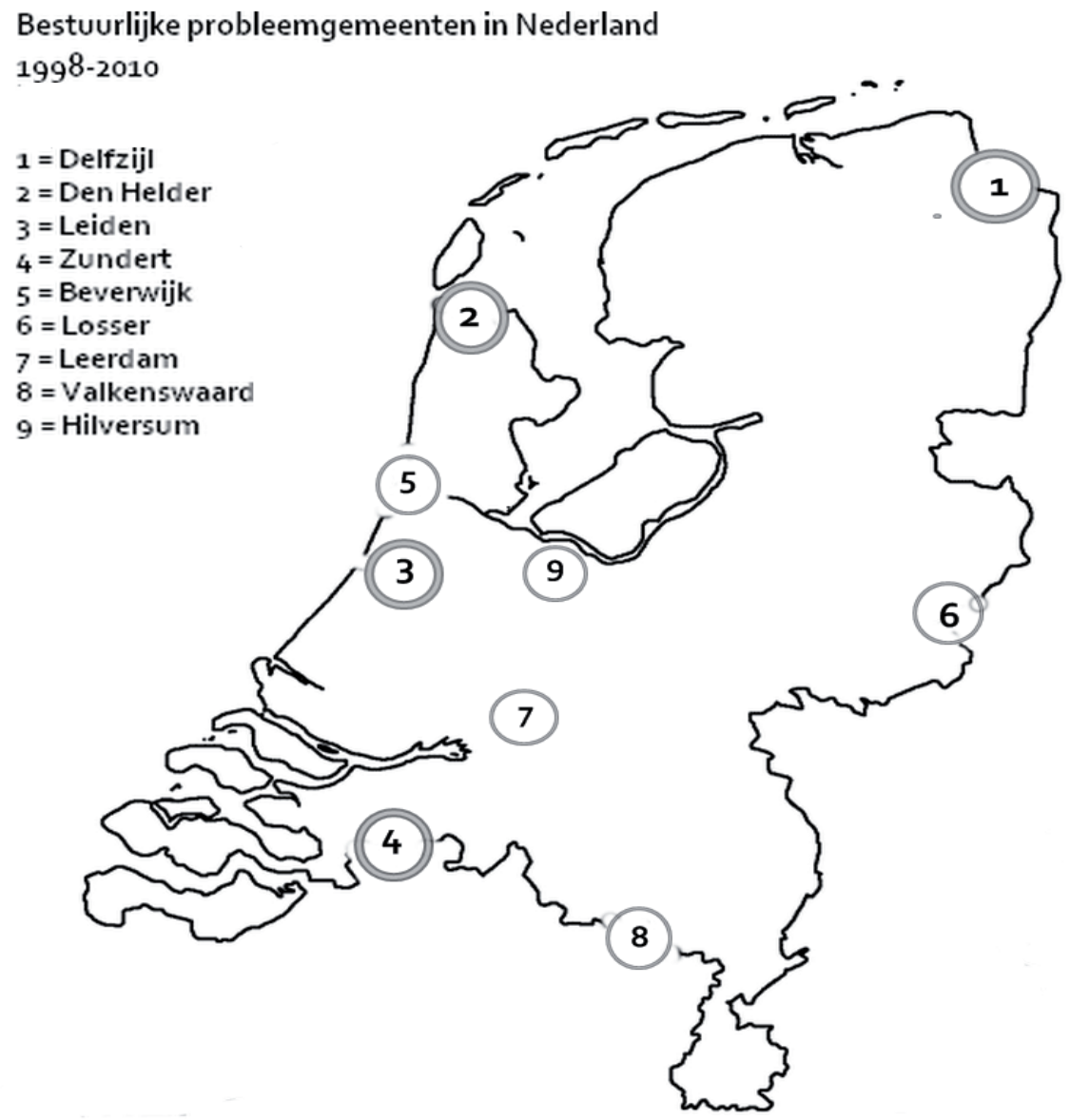

\subsection{De selectie voor de casestudies}

Om te bepalen welke gemeenten geselecteerd moeten worden voor het doen van nader diepteonderzoek in de casestudies, is een drietal criteria ontwikkeld.

Het eerste criterium komt voort uit het feit dat dit onderzoek zich richt op gemeenten waar veel bestuurscrises en bestuurlijke conflicten zijn voorgekomen in de afgelopen drie raadsperioden (1998-2010). Om daar een goed beeld van te krijgen in de cases, lijkt het raadzaam gemeenten te selecteren waar ook inderdaad in drie perioden sprake is geweest van vertrekkende bestuurders of colleges. Gemeenten met twee aaneengesloten perioden met problemen zijn ook bestuurlijke probleemgemeenten, maar voor de casestudies is het zinvol de onderzoeksperiode zo ruim mogelijk te maken. Voor de selectie is daarom als criterium gesteld dat er in elke raadsperiode sprake moet zijn geweest van minimaal één gedwongen vertrokken burgemeester, wethouder of college. Een kleine nuancering is nog wel op zijn plaats. In een enkel geval vond er een crisis 
plaats aan het uiterste einde van een bestuursperiode, zodanig dat er grote invloed van vitging op de nieuwe periode. De crisis werkt als het ware nog door in de nieuwe periode. Als dat het geval is, voldoet de gemeente aan dit criterium. Dit geldt specifiek voor de gemeente Delfzijl, die de vertrekkersranglijst aanvoert.

Criterium twee heeft te maken met landelijke spreiding. Dit onderzoek richt zich immers op alle Nederlandse gemeenten. Het verdient aanbeveling dat de te onderzoeken gemeenten gespreid liggen in Nederland, om te voorkomen dat specifieke regionale of provinciale invloeden te zeer doorwerken.

Het laatste criterium heeft te maken met het aantal inwoners van de gemeente. Om een breed inzicht te krijgen verdient het aanbeveling, als dat mogelijk is, het onderzoek te richten op gemeenten van verschillende grootte.

Te bestuderen gemeenten dienen dus aan de volgende criteria te voldoen.

A. In elke raadsperiode moet minimaal er minimaal één bestuurder gedwongen zijn vertrokken.

B. De te selecteren gemeenten bevinden zich bij voorkeur in verschillende provincies.

C. De te selecteren gemeenten zijn bij voorkeur verschillend van grootte.

Bewust wordt dus gezocht naar gemeenten met chronische bestuurlijke problematiek. Uiteraard had de keuze ook anders gemaakt kunnen worden, door ook gemeenten te selecteren waar géén bestuurlijke problemen hebben gespeeld. Op die manier zou een vergelijking gemaakt kunnen worden. Toch is er in dit exploratieve onderzoek voor gekozen om in te zoomen op de feitelijke bestuurlijke probleemgemeenten en te proberen de daar optredende problematiek beter te begrijpen. Het is eerst nodig, is de opvatting die onder deze selectie ligt besloten, om zicht te krijgen op de werkelijk dominante factoren in deze gemeenten, voordat verder gekeken kan worden.

\section{Selectie}

Uit de vorige paragraaf blijkt dat er een keuze gemaakt moet worden uit negen gemeenten (zie tabel 14). Het is ondoenlijk om alle negen gemeenten uitgebreid te bestuderen, maar het kunnen er ook niet te weinig zijn, zeker als op veel verschillende aspecten gelet wordt (zie hoofdstuk 3). Bij te weinig cases schuilt hier een risico in, volgens de analyse van Rihoux en Ragin: "A large number of conditions tends to 'individualize' each case, making it difficult to find any regularity or any synthetic explanation of the outcome across the cases. Altogether, a good balance must be reached between the number of cases and the number of conditions" (Rihoux/Ragin, 2009: 28).

Criterium A (in elke periode minimaal één bestuurder weg) maakt duidelijk dat Losser afvalt, omdat hier in de eerste raadsperiode van dit onderzoek geen bestuurlijke problemen gemeld werden. Dit geldt ook voor de gemeente Hilversum, waar in de laatste periode (2006-2010) wel wethouders voortijdig vertrokken, maar formeel op vrijwillige basis. 
De gemeenten die overblijven zijn:

Noord-Holland: Beverwijk en Den Helder

Zuid-Holland: Leerdam en Leiden

Groningen: Delfzijl

Noord-Brabant: Valkenswaard en Zundert

Op basis van criterium B (verschillende provincies) dient Delfzijl zich als eerste te onderzoeken gemeente aan. In de andere gevallen dient een keuze gemaakt te worden.

Uiteindelijk is op basis van criterium C de keuze gevallen (naast Delfzijl) op de gemeenten Leiden, Den Helder en Zundert. Zundert is afkomstig uit de categorie gemeenten met minder dan 25.000 inwoners, Delfzijl uit de groep met 25.000 - 50.000 inwoners, Den Helder vit de groep van 50.000 - 100.000 inwoners en Leiden voor de $100.000+$ gemeenten. Over Zundert dient opgemerkt te worden dat de eerste onderzoeksperiode (1998-2002) een gemankeerd beeld geeft, omdat Zundert in 1999 tussentijdse gemeenteraadsverkiezingen kende. Het college veranderde hierbij na twee jaar wel van politieke samenstelling. Interessant is tevens dat Zundert lange tijd met een compleet college met wethouders van buiten de gemeente werkte.

\section{Twaalf eenheden}

De selectie is dus bepaald op vier te bestuderen gemeenten, te bezien over drie raadsperioden van vier jaar. Daarmee is het aantal selectie-eenheden bepaald op twaalf. In de vier onderzochte gemeenten is in elke periode een bestuurlijk conflict of bestuurscrisis geweest. Tegelijkertijd blijkt uit de breedtestudie dat in twee gemeenten de bestuurlijke rust de laatste vier jaar redelijk lijkt te zijn weergekeerd, terwijl in andere gemeenten nog bestuurlijke problemen aan de orde waren. In Leiden viel in 2007 het college en veranderde het in 2010 opnieuw van samenstelling door het vertrek van de wethouder van GroenLinks, terwijl in Den Helder nog in 2009 een grote crisis rond de burgemeester aan de orde was. Delfzijl en Zundert daarentegen laten een rustiger beeld zien. In Delfzijl lijkt na de crisis in 2006 de rust enigszins te zijn weergekeerd en hetzelfde beeld geeft Zundert, althans voor de buitenstaander. Hoewel... een week voor de gemeenteraadsverkiezingen in maart 2010 stelde in Zundert een wethouder zijn portefeuille ter beschikking. Of de schijn inderdaad heeft bedrogen moet de casestudy uitwijzen.

\section{Pattern-matching}

In hoofdstuk 3 is aangegeven dat in de vier gemeenten naar een patroon wordt gezocht, op basis van een aantal geformuleerde verwachtingen. Naar dit patroon wordt in de opeenvolgende casestudies als volgt onderzoek gedaan. In de eerste casestudy worden alle negen factoren onderzocht door te bezien of de verwachtingen wel of niet kloppen. Hiervoor is onderzoek gedaan (hoofdstuk 5) in één van de twee gemeenten met ook in de laatste raadsperiode (2006-2010) aanhoudende bestuurlijke problematiek:

Den Helder.

In de tweede casestudy (hoofdstuk 6) wordt het in Den Helder gevonden patroon van factoren onderzocht in de praktijk van een andere gemeente. Ook hier zal dan blijken in hoeverre de verwachtingen uit komen. Hiervoor is onderzoek gedaan in de gemeente, 
die ook nog tot zeer recent te maken had met bestuurlijke problemen en bovendien tweede staat op de lijst van het aantal per gemeente gedwongen vertrokken bestuurders en colleges, te weten Leiden. Op grond van de praktijk in de eerste twee gemeenten ontstaat een eerste beeld van een relevant patroon.

In de derde casestudy (hoofdstuk 7) wordt het patroon van factoren, dat in Den Helder en Leiden is gevonden, getoetst en waar nodig aangescherpt. Hiervoor is onderzoek gedaan in een gemeente waar de rust de afgelopen periode terug lijkt te zijn gekeerd. Interessant is of er inderdaad een verandering is opgetreden in het patroon van relevante factoren. Is er op één van de factoren uit het relevante patroon gestuurd? De derde casestudy is uitgevoerd in Delfzijl.

In de vierde casestudy (hoofdstuk 8) worden de eerder gevonden criteria finaal getoetst, om de bevestiging van de theorie overeind te houden. Hiervoor is onderzoek gedaan in de gemeente Zundert.

Op deze manier ontstaat een patroon van factoren, dat in de praktijk van bestuurlijke probleemgemeenten is waargenomen. Tevens geeft het patroon wellicht aan op welke factoren gestuurd kan worden om verbetering in de situatie aan te brengen. De analyse van de resultaten vindt plaats in hoofdstuk 9 van deze studie, waarin conclusies worden getrokken. In hoofdstuk 10 vindt een reflectie op de uitkomst plaats. 


\section{Hoofdstuk 5}

\section{Bestuurlijke problematiek in Den Helder 1998-2010}

\subsection{Inleiding}

"Helemaal in de Kop van Noord-Holland, daar waar Nederland bijna overgaat in de zee, ligt Den Helder. Het einde van de wereld? Welnee, het begin van iets moois! Den Helder heeft nu al eindeloos veel te bieden. Acht kilometer zee, strand en duinen bijvoorbeeld. Schone lucht. Het grootste bloembollengebied ter wereld. En de meeste zonne-uren van Nederland."

Mooie teksten, te lezen op de website van de gemeente Den Helder, een gemeente waar het goed toeven lijkt. En dat zal voor de inwoners in de meeste gevallen ook best

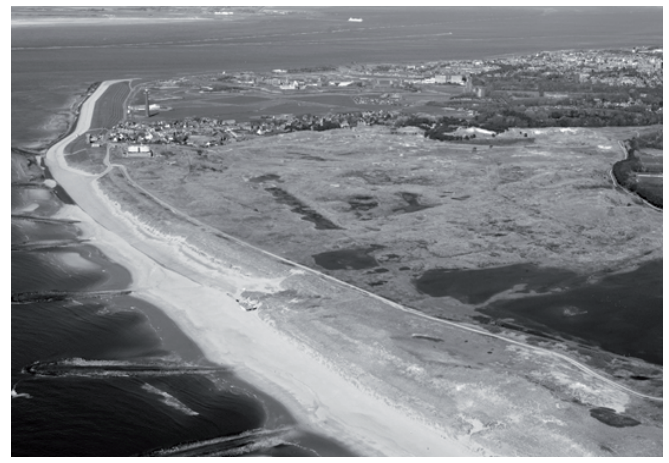

De Grafelijkheidduinen bij Den Helder Foto: Gemeente Den Helder zo zijn. Bij gemeentebestuurders gaat er echter al snel een belletje rinkelen bij het horen van de naam Den Helder: daar is bestuurlijk vaak een probleem. De gemeente kende verschillende bestuurlijke crises, waarbij diverse bestuurders aftraden. Den Helder staat bij kenners van het lokaal bestuur dan ook bekend om het woelige bestuurlijke klimaat dat er heerst. In deze analyse wordt een poging gedaan te ontrafelen welke factoren van invloed zijn, of zijn geweest, op de problematiek. Hierbij is het schema van factoren uit hoofdstuk 3 leidend. De belangrijkste vraag in deze casestudy is in hoofdlijn dezelfde als de algemene vraagstelling van dit onderzoek, maar dan gericht op Den Helder:

Wat is de verklaring voor het gedwongen vertrek van burgemeesters, wethouders en/of hele colleges in Den Helder in de periode maart 1998 - maart 2010?

Om deze vraag te beantwoorden worden in dit hoofdstuk de verschillende bestuurlijke probleemsituaties in Den Helder onderzocht, waarna alle onderscheiden verwachtingen (zie hoofdstuk 3) worden geanalyseerd. De indeling in paragrafen zal ook in de nog komende casestudies worden gehanteerd. Dit maakt onderlinge vergelijking mogelijk en vergemakkelijkt de latere analyse. In de laatste paragraaf zullen steeds conclusies worden getrokken. Bezien wordt of het mogelijk is factoren te onderscheiden die bepalend waren bij het ontstaan van bestuurlijke conflicten en bestuurscrises. Als dit lukt, ontstaat er een bepaalde rangorde in factoren, althans een rangorde die in Den Helder aan de orde was. Dit 'patroon' van factoren zal vervolgens in de volgende casestudies getoetst worden op houdbaarheid. 


\subsection{Introductie van de gemeente Den Helder}

De gemeente Den Helder ligt in de kop van Noord-Holland, ten noorden van de gemeenten Zijpe en Anna Paulowna. De gemeente telde per 1 januari 201057.454 inwoners, op een oppervlakte van $178,83 \mathrm{~km}^{2}$, waarvan $133,42 \mathrm{~km}^{2}$ water.

Den Helder is aan drie kanten omringd door water en daardoor is de ligging uniek. De gemeente beschikt over zeven kilometer zandstrand en duinen en een aantal bekende natuurgebieden, zoals de Grafelijkheidduinen. In de stad Den Helder zelf wonen ongeveer 44.000 mensen. De andere inwoners van de gemeente wonen in de kernen Julianadorp en in Huisduinen (ongeveer 1.00o). De stad kenmerkt zich door een bijzondere open structuur, die te danken is aan de Napoleontische Stelling van Den Helder, met zijn forten, de linie en de schootsvelden (Strategische Visie 2020: 1).

Den Helder is bekend als de thuisbasis van de Koninklijke Marine, die een belangrijke werkgever voor de stad en de omgeving is. De aanwezigheid van de marine stamt uit de Franse tijd, toen werd begonnen met de aanleg van een marinehaven. Ook na het vertrek van de Fransen in 1813 bleef de marine in Den Helder, die het uitbouwde tot haar belangrijkste steunpunt. De meeste marineactiviteiten zijn dan ook in of nabij de stad geconcentreerd: de meeste schepen hebben er hun thuishaven, daarnaast is er een (onderhouds-)werf, zijn er diverse werkplaatsen en opleidingen (o.a. het Koninklijk Instituut voor de Marine, K.I.M.) en zijn nabij de stad nog een marine-vliegveld (De Kooy) en een marinierskazerne (de Joost Dourleinkazerne op Texel) gevestigd. De marine heeft op vele terreinen invloed gehad op de ontwikkeling van de stad. Soms in letterlijke zin. De aanwezigheid van de marine was voor de Duitsers in de Tweede Wereldoorlog aanleiding het centrum van de stad plat te bombarderen. Tot vandaag de dag zijn hier de littekens van te zien in het patroon van de stad. Ook de vele huizen uit de wederopbouw van de jaren ' 50 , vaak niet al te best gebouwd, wijzen op dit verleden.

Sinds een aantal jaar is de gemeente bezig met het maken van plannen om de binnenstad van Den Helder te vernieuwen. Enkele musea en andere bezienswaardigheden in Den Helder zijn onder meer Fort Kijkduin (in 1811 in opdracht van Keizer Napoleon gebouwd), het Marinemuseum, het Nationaal Reddingmuseum Dorus Rijkers, de Marinedagen van de Koninklijke Marine en de gerenoveerde Oude Rijkswerf Willemsoord.

\subsection{2 jaar Helderse politiek}

De gemeente Den Helder telde in de onderzochte periode (1998-2010) eerst 33 en later 31 raadsleden, na de daling van het aantal inwoners onder de 60.000. De samenstelling van de raad vanaf 1998 is weergegeven in tabel 15.

Aan de samenstelling van de raad valt een aantal zaken op. Op de eerste plaats is duidelijk dat de dominerende partijen in de Helderse raad door de jaren heen altijd PvdA, CDA en VVD zijn geweest. Van een overheersende dominantie van één partij gedurende alle drie raadsperioden is geen sprake. Gezamenlijk konden de drie genoemde partijen bogen op een redelijk ruime meerderheid in de raad van gemiddeld achttien zetels. D66 en GroenLinks zagen hun aanhang wat afkalven, ten gunste van stadspartijen als Leefbaar Den Helder (in 2002), Progressief Den Helder en de Stadspartij Den Helder. 
Tabel 15: Samenstelling gemeenteraad Den Helder 1998-2010

\begin{tabular}{|c|c|c|c|c|c|}
\hline Naam partij & 1998 & 2002 & $\begin{array}{c}\mathrm{Na} \\
\text { afsplitsing }\end{array}$ & 2006 & $\begin{array}{c}\mathrm{Na} \\
\text { afsplitsing }\end{array}$ \\
\hline VVD & 9 & 6 & & 6 & \\
\hline PvdA & 7 & 5 & 4 & 8 & \\
\hline CDA & 5 & 6 & & 4 & \\
\hline D66 & 4 & 3 & & 2 & \\
\hline GroenLinks & 3 & 2 & & 1 & \\
\hline Leefbaar Den Helder & - & 5 & 4 & - & \\
\hline SP & - & - & - & 4 & 2 \\
\hline AOV/Unie $55^{+}$ & 3 & 1 & & - & \\
\hline GPV/RPF & 2 & - & & - & \\
\hline ChristenUnie & - & 2 & & 2 & \\
\hline Progressief Den Helder & - & - & & - & 2 \\
\hline Stadspartij Den Helder & - & 3 & & 2 & 1 \\
\hline Prins voor behoorlijk best. & - & - & 1 & 1 & \\
\hline KiesKees & - & - & & 1 & \\
\hline Fractie Abbenes & - & - & 1 & - & \\
\hline v. Dongen en v. Dongen & - & - & & - & 1 \\
\hline Totaal & 33 & 33 & 33 & 31 & 31 \\
\hline Aantal fracties & 7 & 9 & 11 & 10 & 12 \\
\hline Fractiequote & 4,7 & 3,7 & 3 & 3,1 & 2,6 \\
\hline
\end{tabular}

Verder kan worden geconstateerd dat het aantal fracties in de loop der jaren steeds groter is geworden, tot twaalf fracties in 2006. De fractiequote (het aantal raadsleden gedeeld door het aantal fracties) is gedurende de onderzoeksperiode dan ook fors gedaald. De gemiddelde fractiegrootte was in de periode 2006-2010 in Den Helder viteindelijk 2,6, wat klein is. Dit is vooral te verklaren door een aantal afsplitsingen. In totaal waren er in Den Helder in genoemde periode niet minder dan vijf eenmansfracties actief.

Tabel 16: Samenstelling Colleges van B\&W gemeente Den Helder 1998-2010

\begin{tabular}{|l|c|l|c|c|c|c|c|c|c|}
\hline 1998 & Weth. & 1999 & Weth. & 2002 & Weth. & 2005 & Weth. & 2006 & Weth. \\
\hline PvdA & 1 & PvdA & 1 & VVD & 1 & PvdA & 1 & PvdA & 2 \\
VVD & 1 & VVD & 1 & CDA & 1 & CDA & 1 & CDA & 1 \\
CDA & 1 & CDA & 1 & LDH & 1 & VVD & 1 & VVD & 2 \\
& & D66 & 1 & D66 & 1 & Stadspt. & 1 & & (part- \\
& & & & & & $\begin{array}{l}\text { (Zaken- } \\
\text { college) }\end{array}$ & & & time) \\
\hline
\end{tabular}

De colleges van B\&W kenden vrijwel altijd een vertegenwoordiging van PvdA, CDA en VVD. Uitzondering hierop was de samenstelling van het college in 2002, toen de PvdA niet tot het college toetrad. De vierde plek in het college (voor zover daarvoor werd gekozen) werd wisselend ingenomen door D66, Leefbaar Den Helder of de Stadspartij Den Helder. Na de verkiezingen van 2006 ontstond een college met alleen PvdA, CDA en VVD. De PvdA was hierin vertegenwoordigd met twee fulltime wethouders, de VVD leverde een tweetal parttime wethouders. Het CDA had één wethouder, die tot september 2009 tevens de positie van loco-burgemeester vervulde. Hierna trad deze 
wethouder terug en werd de fractievoorzitter van het CDA wethouder. Het locoburgemeesterschap kwam in handen van één van de twee PvdA-wethouders. In de onderzoeksperiode is deze coalitie de enige die qua partijen in ongewijzigde samenstelling de hele raadsperiode in stand bleef.

Tabel 17: Burgemeesters van Den Helder vanaf 1985

\begin{tabular}{|l|l|}
\hline Dhr. J. Gmelich Meijling (VVD) & $1985-1994$ \\
\hline Dhr. W. Hoekzema (VVD) & $1994-2001$ \\
\hline Dhr. J. Staatsen (VVD) & $2001-2005$ \\
\hline Mw. G. Faber (waarnemend, PvdA) & Okt. 2005-mei 2007 \\
\hline Dhr. S. Hulman (VVD) & Juni 2007-mei 2009 \\
\hline Dhr. K. Vriesman (waarnemend, PvdA) & Mei 2009-December 2009 \\
\hline Dhr. K. Schuiling (VVD) & Januari 2010- heden \\
\hline
\end{tabular}

Den Helder heeft al tientallen jaren een burgemeester van VVD-huize. De enige uitzonderingen op deze regel van de laatste decennia betreffen waarnemend burgemeesters. Op de eerste plaats was dat mw. G. Faber, die van PvdA-huize is. Zij trad aan na het vertrek van VVD-er J. Staatsen. In juni 2007 werd VVD-er S. Hulman burgemeester van Den Helder, tot hij op 1 mei 2009 na een vertrouwensbreuk met raad en college over de berekeningen omtrent de voorgenomen vergoeding voor zijn dubbele woonlasten (zie later in deze analyse) vertrok. Hij werd opgevolgd door waarnemend burgemeester K. Vriesman (PvdA). Als burgemeester droeg de raad in oktober $2009 \mathrm{~K}$. Schuiling (VVD), oud-wethouder van Groningen, voor. Hij begon op 1 januari 2010.

\subsection{De problemen op een rij}

Den Helder heeft in de afgelopen twaalf jaar te maken gehad met vier grote crisissituaties, in 1999, 2003, 2005 en 2009. In totaal vertrokken hierbij twee colleges, twee burgemeesters en zes wethouders voortijdig. In deze paragraaf wordt op chronologische wijze op een rij gezet wat er in de onderzoeksperiode precies is gebeurd. De beschrijving is gebaseerd op informatie die is verkregen uit gesprekken met betrokkenen en gedrukte informatie uit diverse bronnen. Alle geïnterviewden hebben kennis genomen van de strekking van de hieronder beschreven informatie, waarbij vaak instemming werd betuigd. Afwijkende meningen zijn terug te vinden in de casestudy. Als er letterlijk geciteerd wordt in de beschrijving hebben de betreffende personen met het citaat ingestemd. De getrokken conclusies komen uiteraard geheel voor rekening van de onderzoeker.

\subsubsection{Periode 1998-2002}

In 1998 treedt na de verkiezingen in Den Helder een college aan dat gevormd wordt door CDA, PvdA en VVD. Het beschikt over een ruime meerderheid van 21 van de 33 zetels. Wethouders worden J.J.M. Manderfeld (PvdA), G.J.A.M. Nijpels (VVD) en M. Stegers (CDA). D66, tot 1998 nog wel vertegenwoordigd in het college via wethouder E.E. Kip, treedt niet toe tot het nieuwe stadsbestuur. Buiten het feit dat Kip zelf aangeeft niet meer beschikbaar te zijn als wethouder, liggen hier strategische redenen aan ten grondslag. Al voor de verkiezingen speelde er namelijk een probleem rond nietinteger gedrag van enkele ambtenaren, een probleem waar het nieuwe college het 
behoorlijk lastig mee zou kunnen krijgen. D66 heeft geen behoefte onder zo'n gesternte tot het college toe te treden: men wil niet geconfronteerd worden met zaken die men niet aan zou kunnen. De sociaal-liberalen blijken een vooruitziende blik te hebben, want al snel moet het nieuwe college behoorlijk aan de slag met de kwestie. Wat is er aan de hand?

Al voor de verkiezingen kwamen er bij het toen nog zittende college anonieme signalen binnen dat er fraude zou zijn gepleegd bij de dienst Stadsontwikkeling en Beheer. Binnen het op dat moment vigerende concern-dienstenmodel in Den Helder had deze dienst, gehuisvest in een ander gebouw op ongeveer vijf kilometer van het gemeentehuis, een eigen administratie en een eigen archief, waar zaken niet zouden deugen. Een jaar eerder was over deze kwestie aan Deloitte \& Touche opdracht verstrekt om de boeken te controleren en na te gaan of er op één of andere manier fraude was gepleegd. Eind 1997 meldde Deloitte \& Touche dat er geen frauduleuze handelingen vielen te constateren. Begin 1998 komen er echter opnieuw meldingen binnen dat er toch zaken niet in orde zijn. Er moet echt iets aan de hand zijn, het gedane onderzoek zou niet diepgaand genoeg zijn geweest.

Het college heeft het er moeilijk mee en spreekt lang over de zaak. Het besluit valt, in overleg met de ook bij de zaak gevraagde commissaris van politie, de zaak in handen te geven van KPMG Forensic Accountants. De onderzoekers van dit bedrijf komen na enige tijd wèl tot de conclusie dat er sprake is van fraude. Het gaat daarbij om 'gefingeerde' rekeningen: rekeningen van leveranciers en bouwbedrijven, die in de administratie worden aangetroffen, maar voor werk dat niet is uitgevoerd. Het geld dat werd betaald bleek voor andere producten en diensten te zijn, die niet in de gemeentebegroting werden gedekt. Dit varieerde van de dakbedekking van een voetbalkleedkamer tot een dienstreis met overnachting, de bedragen varieerden van enkele duizenden guldens tot 120.000 gulden. Deloitte \& Touche had dit niet gevonden, omdat er pogingen waren gedaan om achteraf alsnog enkele zaken administratief juist te regelen. Ook zou er sprake zijn van 'samenspanning' tussen betrokkenen. De conclusie is dat er weliswaar geen sprake is van zelfverrijking, maar dat er wel degelijk sprake is van fraude. Gemeentesecretaris De Bruin zit vervolgens twee dagen op het politiebureau om aangifte te doen, waarna tegen enkele betrokkenen een strafrechtelijk proces wordt ingesteld.

De zaak heeft voor het college nog een ander effect. De gemeenteraad begint zich ermee te bemoeien en vraagt zich hardop af hoe het eigenlijk is gesteld met de administratieve organisatie en interne controle in het gemeentehuis. Had niet iemand dit door moeten hebben? Weliswaar was de zaak aan het licht gekomen, maar had dat niet veel eerder gemoeten? Heeft het college haar rol wel goed gespeeld? Het zijn vragen die op het nieuwe college afschieten en steeds kritischer van aard worden. De raad wil een onderzoek, niet alleen naar de organisatie, maar ook naar de cultuur bij de betreffende dienst. KPMG gaat er opnieuw mee aan de slag. De raad voert ook nog een ander punt op: weet het college eigenlijk wel zeker dat er niet nog meer dingen fout zitten? Er dient, zo besluit de gemeenteraad, een mogelijkheid te komen om eventuele misstanden anoniem aan te geven: de 'kliklijn' wordt in het leven geroepen. Het college en KPMG willen liever een algemene discussie over integriteit voeren, maar dat vindt de raad niet ver genoeg gaan. De kliklijn wordt ingesteld en leidt tot zestien geruchten over mogelijke misstanden. Een commissie vit de gemeenteraad buigt zich over de vraag welke geruchten wel en welke niet onderzocht zouden moeten worden door 
KPMG. De zaak krijgt al snel een politieke lading, als blijkt dat het ook gaat om zaken waar wethouders bij betrokken zijn. Bij zowel een manege als een school zouden asfalteringswerkzaamheden zijn uitgevoerd op kosten van de gemeente, zonder toestemming van de gemeenteraad. KPMG gaat er mee aan de slag.

\section{Declaraties}

Intussen speelt er nog een andere kwestie: de declaraties van het college worden onderwerp van gesprek. Aanleiding hiervoor is een onderzoek van journalist Dick Berts, die in Den Helder op zoek is naar declaraties van de inmiddels tot staatssecretaris van Defensie benoemde oud-burgemeester Gmelich Meijling. Het onderzoek breidt zich al snel uit naar de declaraties van het zittende college. Met een beroep op de Wet Openbaarheid Bestuur (WOB) komen alle bonnetjes in de openbaarheid. Met de bonnetjes komen de verhalen en de kritische vragen. Zijn de gedeclareerde taxiritten van burgemeester Hoekzema wel allemaal voor Den Helder, of gaat het ook wel eens om ritten voor de VVD, waar hij in die jaren landelijk voorzitter van is? Van andere collegeleden blijken van sommige declaraties geen bonnetjes aanwezig te zijn, waar dat wel had gemoeten. Het gebruik van de gemeentelijke creditcard kan ook niet altijd met bonnetjes worden belegd. Ook hier wordt besloten tot een onderzoek, waar VB Deloitte \& Touche voor wordt ingehuurd.

In dit klimaat van negativiteit rondom het college komt KPMG in 1999 met haar twee rapporten, over de verantwoordelijkheid voor de administratieve organisatie en het waarheidsgehalte van een aantal van de zestien geruchten. Politiek gevoelig in het laatste rapport ligt onmiddellijk de conclusie dat twee wethouders ieder een bedrijf op kosten van de gemeente zouden hebben bevoordeeld. Ze lieten privé-terreinen gratis of voor minder dan de kostprijs asfalteren. Er was volgens de accountants geen sprake van algemeen belang.

In het onderzoeksrapport over de administratieve organisatie en interne controle is het oordeel dat het college hier strakker op had moeten zitten. Het leidt tot de eerste crisis in de onderzoeksperiode van dit onderzoek, want als eerste besluit verantwoordelijk wethouder Manderfeld de pijp aan Maarten te geven. Onder druk van het afdelingsbestuur van de PvdA, dat meent dat het vertrouwen in het huidige gemeentebestuur is verdwenen, neemt hij ontslag. De fractie van de PvdA maakt hierop duidelijk een motie van wantrouwen tegen de rest van het college te zullen steunen. In een verklaring zegt de wethouder ontslag te hebben genomen, omdat het aanzien van het openbaar bestuur en de politiek is geschaad. "Daardoor is de geloofwaardigheid van het openbaar bestuur en de politiek in het geding" (De Volkskrant, 100399).

In het college wordt vervolgens gesproken over de vraag wat dit voor de andere wethouders en de burgemeester zou moeten betekenen. Wethouder Stegers vindt dat ook hij en zijn collega-wethouder moeten opstappen, uiteindelijk in deze conclusie gevolgd door wethouder Nijpels. Van besturen komt niets meer terecht, het college is lamgelegd door de discussies over declaraties en de problemen bij de dienst S\&B. Beide wethouders treden op 10 maart 1999 ten overstaan van de complete gemeenteraad af. "Er is sprake van een ernstige bestuurscrisis. Er moet duidelijk een daad worden gesteld. Den Helder heeft een positieve impuls nodig om verdere beschadiging te voorkomen", verklaart wethouder Stegers (Trouw, 110399). De raad is buitengewoon kritisch in de richting van het college, maar ook naar de ambtelijke organisatie. De VVD dient zelfs 
een motie in, waarin de liberalen voorstellen de volledige gemeentelijke organisatie op te doeken. Alle gemeente-ambtenaren zouden opnieuw kunnen solliciteren naar de nieuwe gemeentelijke diensten, waarvoor ze alleen in aanmerking komen als ze 'bevoegd, bereid en bekwaam' zijn (Trouw, 110399). De nieuwe gemeentelijke organisatie zou op 1 januari 2000 moeten begin-

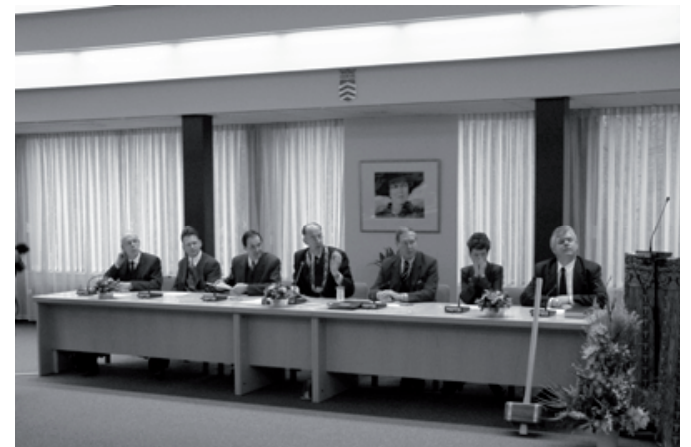

Het college van B\&W van Den Helder in functie in 2001.

Foto: gemeente Den Helder. nen. "Alleen zo kan de heersende cultuur doorbroken worden", zegt VVD-fractievoorzitter R. Waltmann. "Maar de raad heeft de crisis ook aan zichzelf te wijten. We hebben jarenlang verzaakt."

Burgemeester Hoekzema, die zelf ook niet geheel wordt gevrijwaard van kritiek, constateert met vreugde dat een groot deel van de raad nog voldoende vertrouwen in hem heeft. "Ik zal proberen dat niet te beschamen."

Kortom: het college valt in 1999 en er komen nieuwe onderhandelingen. Wethouders Stegers keert als enige wethouder terug in het college, waarna hij in 2001 vertrekt om burgemeester van Tubbergen te worden. Wethouder Nijpels keert niet terug en wordt uiteindelijk burgemeester van Opmeer. Eerder is hij waarnemend (en beoogd) burgemeester van Uitgeest, maar dat loopt als gevolg van de vele publiciteit rondom de Helderse kwestie fout. Er zit zelfs een delegatie raadsleden uit Uitgeest op de tribune in Den Helder om te beluisteren hoe de Helderse raad over de crisis en de rol van Nijpels spreekt. Uiteindelijk wordt hij gerehabiliteerd en benoemd in Opmeer. De VVD levert in 1999 als opvolger van Nijpels de jonge liberaal en fractievoorzitter R.Waltmann als wethouder. D. Scholte wordt wethouder voor de PvdA. Nieuw is dat D66 terugkeert in het college: mevrouw E.J. Vos-Brandjes wordt wethouder. N. Bais is in 2001 voor het CDA de opvolger van Stegers.

In 2001 is er overigens nog een wisseling in het college. Burgemeester Hoekzema gaat met pensioen en wordt opgevolgd door partijgenoot J. Staatsen, die in Den Helder zijn eerste burgemeestersambt mag bekleden. Hij is afkomstig van de provincie Overijssel, waar hij griffier van Provinciale Staten was. Eerder was hij eerste loco-griffier van de provincie Gelderland en gemeentesecretaris in Rheden. Staatsen kenschetst zichzelf vooral als een burgemeester die gefocust is op de inhoud: "Ik ben geen sherry- en receptieburgemeester, om het maar zo te zeggen. Ik ben sterk gefocust op de inhoud, op het bereiken van resultaten. Voor rituele dansen en wat ik maar noem folkloristisch gedoe moet je mij niet hebben. Dat heb ik ook aangegeven aan de vertrouwenscommissie, men moest weten wie men met mij binnen zou halen. Ik heb ook nadrukkelijk verzocht om na een jaar te evalueren om te zien hoe het gaat."

Na het verstrijken van het jaar is de raad positief over de nieuwe burgemeester. 


\subsubsection{Periode 2002-2006}

De verkiezingen in 2002 leveren in veel gemeenteraden een grote verschuiving op, ook in Den Helder. VVD en PvdA verliezen respectievelijk drie en twee zetels en Leefbaar Den Helder komt op. De partij wint vanuit het niets vijf van de 33 raadszetels. Tijdens de formatie stapt een fractielid, uit teleurstelling geen wethouder te zullen worden, op om als eenmansfractie verder te gaan (Prins voor Behoorlijk bestuur), waardoor het aantal zetels van Leefbaar Den Helder vitkomt op vier. Er wordt een college gevormd van vier partijen, die elk een wethouder leveren: CDA, VVD, Leefbaar Den Helder en D66. De PvdA is hier niet in vertegenwoordigd en krijgt een rol in de oppositie krijgt. Het college weet zich gesteund door negentien van de 33 raadsleden. Van de vier wethouders is nieuwkomer J. de Groot van Leefbaar Den Helder de minst ervaren kracht, de andere wethouders waren ook voor de verkiezingen al lid van het college: Bais, Waltmann en Vos-Brandjes. Rondom het wethouderschap van De Groot ligt wel enige gevoeligheid in de raad. Hij was eerder voorzitter van de PvdA-fractie, stapte als gevolg van een conflict op, keerde via Leefbaar Den Helder terug in de raad en wordt nu wethouder. Terwijl de PvdA in de oppositie zit. Enige spanning tussen deze wethouder en de oppositionele PvdA-fractie is dus al 'ingebakken'.

De verhouding tussen de CDA-wethouder (dezelfde als in de vorige periode) en de eigen fractie blijkt ook niet verbeterd. Sommige betrokkenen hebben het gevoel dat de wethouder zo ongeveer 'een permanente motie van wantrouwen van de eigen fractie aan de broek heeft.'

Desalniettemin gaat het nieuwe college enthousiast aan het werk. Betrokkenen geven aan dat de start van de nieuwe ploeg goed is en er de eerste maanden goed wordt gewerkt. Toch zullen zich al snel problemen voordoen, rondom een lastig dossier: de nieuwe functie van de Oude Rijkswerf Willemsoord.

\section{Probleemdossier: Oude Rijkswerf Willemsoord}

De Oude Rijkswerf Willemsoord is een belangrijk dossier voor het nieuwe college. Welke nieuwe bestemming zou er moeten worden gegeven aan dit belangrijke deel van de stad, met tal van monumentale gebouwen? Er liggen vele kansen en uitdagingen, maar ook bedreigingen. Het college werkt voor de invulling samen met het bedrijf Libema, dat gespecialiseerd is in themaparken en mogelijkheden ziet in de Oude Rijkswerf. Om zich te laten inspireren wordt een werkbezoek gebracht aan Engeland, waar wethouder Waltmann verslag van doet: "Tenslotte hebben we de historische dockyards van Chatham bezocht. Dat deed het sterkst aan onze eigen oude rijkswerf denken. De walkthrough was daar heel goed. Als je ze hout zag zagen, rook je ook zaagsel. Maar dat was meteen ook het enige entertainment. Voor de rest was het wel heel erg veel geschiedenis. Dat moeten we beter kunnen" (Van Heijningen, 2002). De bedoeling is dat het gebied in Den Helder een metamorfose ondergaat en er tal van nieuwe functies komen, waaronder een megabioscoop en... een bedrijf met kansspelautomaten. Over deze optie waren al voor de verkiezingen politieke meningsverschillen ontstaan, maar een meerderheid van de raad steunde toen de komst van deze automaten. Na de verkiezingen is het anders: een meerderheid van de gemeenteraad wil niet meer dat er kansspelautomaten komen in het gebied en weigert in de vergadering van de avond en nacht van 10 september 2003 de Algemene Plaatselijke Verordening (APV) aan te passen. Een meerderheid in de raad blijkt ook niet bereid extra geld bij te dragen. Wel 
zal men eventuele schadeclaims voor lief nemen, vanuit de opvatting dat principes nu eenmaal geld kosten. Een enorm probleem doemt op. Gemeenteraad en college staan lijnrecht tegenover elkaar. Het college ziet geen alternatieven voor de speelautomaten en vindt dat het plan voor de Oude Rijkswerf in zijn geheel uitgevoerd moet worden. Een dag later, op 11 september, zet burgemeester Staatsen de positie van het college uiteen: "Als voorzitter van het college moet ik ook concluderen dat het raadsbesluit

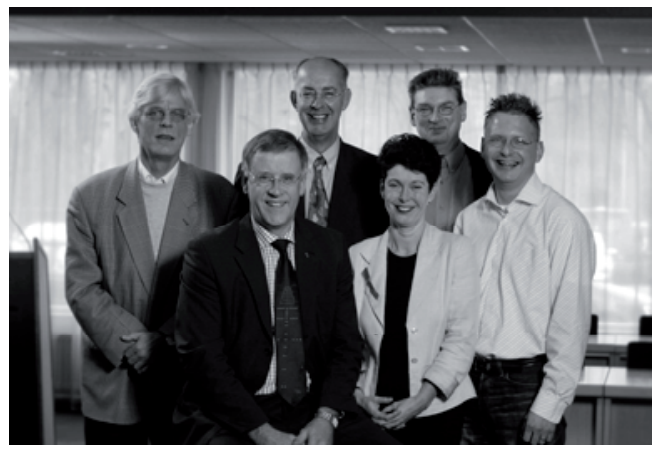

Het college van $B \& W$ van Den Helder van eind 2003, met staand v.l.n.r. wethouder De Groot, burgemeester Staatsen, wethouder Vos-Brandjes, gemeentesecretaris Van der Mark en wethouder Waltmann. Zittend: wethouder Bais. Foto: gemeente Den Helder. schadelijk is voor de geloofwaardigheid en de betrouwbaarheid van het stadsbestuur. Daar gaat het om; het is niet zo maar een discussie over 53 speelautomaten. Het gaat fundamenteel om het succes van de Oude Rijkswerf, om het succes van Cape Holland en om de interne en externe geloofwaardigheid van dit stadsbestuur. Als het college het door de raad genomen besluit correct heeft geïnterpreteerd, dan is het onvermijdelijk dat het college tot de volgende conclusie komt. En het is de conclusie van een unaniem college. Het is met spijt dat ik dit namens het college moet zeggen, want wij zouden graag met hart en ziel voor deze stad hebben willen blijven werken, maar het college kan tot geen andere conclusie komen dan dat het geen verantwoordelijkheid meer kan dragen voor het bestuur van deze stad. Dit betekent dat het college unaniem zijn positie ter beschikking stelt" (Raadsnotulen 110903).

Een crisis is geboren. Vier dagen later komt de raad opnieuw bijeen, waarbij Staatsen ook over zijn eigen positie geen onduidelijkheid laat bestaan. Als het college wordt weggestuurd, zal hij ook vertrekken: "Het is mijn verantwoordelijkheid om als voorzitter van het college ervoor te zorgen dat het raadsprogramma en het collegeprogramma worden uitgevoerd. Daar zet ik mij helemaal voor in en juist in het duale stelsel is de rol van voorzitter van het college belangrijker dan de rol van voorzitter van de gemeenteraad. Ik kan het ook niet helpen dat de Gemeentewet nu verouderd is."

De positiebepaling van de burgemeester roept bij staatsrechtgeleerden vragen op. Bestaat er wel zoiets als een demissionaire burgemeester? Volgens de kenners niet. Staatsen is het daar op zich mee eens, maar geeft aan dat er meer is dan alleen een juridische invalshoek: "Formeel-juridisch klopt dat, maar feitelijk en politiek ben ik wel demissionair." De opstelling van Staatsen valt niet goed bij de raad. Raadslid Prins geeft in het raadsdebat aan het gevoel te hebben 'het concept burgemeester kwijt te zijn' (Raadsnotulen 150903).

De situatie beperkt zich overigens niet meer tot de politieke arena van Den Helder. Ook vanuit de plaatselijke ondernemers komt actie: deze laten weten het college te 
steunen, vanwege de grote werkgelegenheidsperspectieven van de nieuwe ontwikkeling. De Rijkswerf moet immers een magneet worden voor Den Helder en de stad opstuwen in de vaart der volkeren. Er gaan zelfs reclamevliegtuigjes over de stad, waarop is aangegeven dat het college wordt gesteund. Volgens enkele geïnterviewden kunnen sommige raadsleden deze maatschappelijke steun voor het college moeilijk verkroppen.

Tijdens de raadsvergadering van 15 september wordt besloten te bezien of er een nieuwe coalitie samengesteld zou kunnen worden. De fractievoorzitters van VVD en CDA, respectievelijk de heren Bellinga en Mulder, worden aangesteld als informateur. De opdracht luidt een nieuw college te vormen. In hun analyse, die begin oktober 2003 verschijnt, gaan zij echter ook in op de huidige situatie. Op de eerste plaats luidt de conclusie dat het conflict rondom de speelautomatenhallen op de ORW slechts de druppel was die de emmer deed overlopen. "De crisis zou vroeg of laat toch zijn ontstaan. Alle partijen wijzen de cultuur/sfeer binnen de raad en tussen de raad en het college als belangrijkste voedingsbodem daarvoor aan; zij vinden dan ook dat die cultuur/sfeer een drastische verbetering behoeft" (Bellinga en Mulder, 2003: 2). Daarnaast noemen de rapporteurs nog negen andere oorzaken, maar die zijn alle min of meer van het vorenstaande afgeleid, zo schrijven zij. Deze oorzaken zijn:

1 De worsteling met het dualisme.

2. De slechte informatievoorziening en onderlinge communicatie.

3. Onvoldoende inzicht in de financiële situatie.

4. Onvoldoende coaching van de burgemeester en individuele wethouders.

5. De aanwezigheid van tien fracties en veel nieuwe raadsleden (met informatieachterstand).

6. De aanwezigheid bij sommige raadsleden van een constant negativisme c.q. het ontbreken van een constructieve bijdrage aan de discussie, het zoeken naar oplossingen.

7. Stekeligheden tussen partijen of personen die niet (gelijk) met elkaar worden uitgesproken.

8. Coalitie die niet echt een coalitie blijkt te zijn.

9. Te weinig bereidheid zich als college/wethouder kwetsbaar op te stellen, kritiek te accepteren, naar de oppositie te luisteren en met hun inbreng iets te doen (met andere woorden, een verandering van houding en bestuursstijl).

Waar het gaat om de samenstelling van de coalitie en het mogelijk aftreden van het hele college adviseren beide raadsleden het zittende college te laten zitten. In diverse media geven zij hierover vitleg: "Het ziet er wellicht wat raar uit voor buitenstaanders", erkent de heer Mulder, "maar er is wel degelijk wat veranderd. Het coalitieprogramma is bijvoorbeeld aangepast en deelname aan de coalitie is ook minder vrijblijvend dan voorheen" (Binnenlands Bestuur, 141103).

Wethouders en fractievoorzitters van de deelnemende partijen ondertekenen een nieuw programma (met daarin ook ruimte voor de speelautomaten) en verklaren zich bereid om samen te werken. Beide formateurs hadden ook graag de PvdA als ondertekenaar gezien, maar die wil alleen meedoen als D66 en Leefbaar Den Helder níet mee 
doen. Daarmee zou een coalitie van drie partijen overblijven en dat vinden Bellinga en Mulder te mager. En dus valt de keuze op de oude coalitie. "Ik kan geen garantie geven, maar ik heb er wel vertrouwen in. We beseffen allemaal dat we een ander pad op moeten" (Binnenlands Bestuur, 141103).

Het college kan in ongewijzigde samenstelling verder, maar echt lekker loopt het niet meer. Er ontstaat ruzie als er opnieuw geruchten verschijnen over fraude bij het project, waardoor de geplande opening van het project Oude Rijkswerf door ZKH Prins WillemAlexander in het water valt. Gefluisterd wordt dat wethouder De Groot de aanstichter van het gerucht is. De gemeenteraad duikt opnieuw bovenop de zaak, die verder escaleert als zowel de huisaccountant als de rijksrecherche aanleiding zien nader onderzoek te doen naar mogelijke malversaties. Uiteindelijk besluit de raad ook zelf een onderzoekscommissie in te stellen (zie verderop), met als taak onderzoek te doen naar het college en de afzonderlijke leden met betrekking tot hun rol in het dossier Willemsoord.

Ook op andere dossiers ontstaan er spanningen, al is het niet alleen maar kommer en kwel. Zo wordt er flink doorgewerkt aan verbetering van de organisatie. De afdeling Publiekszaken wordt vernieuwd en burgemeester Staatsen spreekt persoonlijk de welkomstboodschap in die mensen te horen krijgen als ze de gemeente Den Helder opbellen. "Het leek ons best grappig, zo'n persoonlijk welkom", licht Staatsen het bandje toe. "We willen dat mensen zich thuis voelen bij de gemeente, ook als ze opbellen" (Binnenlands Bestuur, 090404).

Commissaris van de Koningin $\mathrm{H}$. Borghouts ziet intussen met lede ogen aan wat er gebeurt in Den Helder. Hij realiseert zich dat hem formeel geen bestuurlijke middelen ter beschikking staan, anders dan praten en overtuigen dat het anders moet. Als eerste stap om de Helderse bestuurders te overreden de situatie te veranderen, stelt het college van Gedeputeerde Staten voor op kosten van de provincie een externe deskundige in te huren, om de situatie te analyseren. De Helderse bestuurders zijn akkoord en kiezen voor de Tilburgse hoogleraar P. Tops, die hiervoor samen gaat werken met onderzoeker W. van Spijker. Hun opdracht is een onafhankelijk advies op te stellen over de bestuurscultuur en de bestuurskracht van de gemeente Den Helder. De nadruk zou daarbij moeten liggen op het opstellen van een verbeterprogramma. Afgesproken wordt tussen de provincie en de gemeente Den Helder dat de burgemeester, de raad en het college het verbeterprogramma zullen beschouwen als een basis voor de verbetering van de bestuurscultuur en dat zij zich gaan inspannen om dat verbeterprogramma uit te voeren. In totaal spreken de onderzoekers met zo'n 60 personen, bestuderen zij vele documenten en houden zij een burgerenquête. Het resultaat wordt uiteindelijk ten overstaan van bijna heel politiek Den Helder gepresenteerd in een bomvolle schouwburg. De resultaten liegen er niet om.

\section{Den Helder: Doe normaal}

In het rapport, getiteld: 'Den Helder, doe normaal', constateren de onderzoekers dat er in Den Helder sprake lijkt van een verzuringsvirus, dat persoonlijke verhoudingen lijkt te verzieken: "Structureel verstoord en zodanig verbreid en ingebakken dat het als een virus alles en iedereen lijkt te besmetten. Het hele systeem (raad, college, griffie, 
ambtelijke organisatie en de ijzeren ring van direct betrokkenen) is ermee besmet. Nieuwe mensen en nieuwe initiatieven worden ook snel aangestoken. Alles op de persoon, geen vergeving, niets aan elkaar gunnen. Vergeten is dat de kern van de politiek weliswaar conflict is, maar dat tegelijkertijd de kunst van politiek is om (tijdelijk) tot verzoening te komen" (Tops en Van Spijker, 2004: 3).

Andere typische punten voor Den Helder zijn volgens de onderzoekers de onderontwikkelde uitvoerende macht, de beperkte slagkracht van het college en het sterk achterblijvend ambtelijk apparaat, met groot achterstallig onderhoud en erg weinig geloof in zichzelf. Daarnaast worden nog genoemd de viterst moeizame en soms afwezige relatie met maatschappelijke partners en het onderliggend transformatieproces van Den Helder. Hiermee wordt bedoeld dat de stad moet leren op eigen benen te staan en verantwoordelijkheid te nemen, in plaats van te leunen op de marine en anderen.

Bovenstaande punten zorgen er volgens de onderzoekers uit 2004 voor dat de rek er zo goed als uit is. Zelfreinigende en zelfcorrigerende mechanismen, countervailing powers en ruimte voor nieuwe impulsen zijn te weinig aanwezig. Dat heeft tot gevolg dat veel zaken tot crisis of incidenten leiden, dat eenmaal ingeslagen foute wegen niet of nauwelijks meer terug te gaan zijn en dat bijna niets tot goed resultaat leidt of tot trots en tevredenheid, ook al zou daar op zichzelf wel reden toe zijn. De vertrouwenscrisis uit 2003 is nooit echt hersteld, zo concluderen Tops en Van Spijker, er is noodgedwongen mee geleefd. De Helderse situatie geeft al met al een zeer zorgelijk beeld, dat overigens door iedereen wordt gedeeld, aldus de onderzoekers in hun rapport: "Ons is bij bestudering van deze documenten en in de gesprekken opgevallen dat er in de inhoud van de analyse een betrekkelijk grote overeenstemming is over wat er in Den Helder aan de hand is; slechts de toon en de taxatie van de ernst van de situatie lopen wat viteen" (Tops en Van Spijker, 2004: 4).

De onderzoekers benoemen specifiek drie personen die een belangrijk stempel op de bestuurscultuur in Den Helder drukken: burgemeester Staatsen, wethouder De Groot en griffier Van der Paard (tevens lid van Provinciale Staten in Noord-Holland namens de PvdA). Volgens Tops en Van Spijker is Staatsen niet de oorzaak van de situatie in Den Helder, maar wordt hij wel gezien als een exponent van een cultuur die veranderd moet worden. Zij beschrijven het huidige functioneren van de burgemeester als 'bijzonder risicovol'. Wethouder De Groot zou vooral 'verwarrend en ontregelend' bezig zijn en over de griffier (wiens dochter overigens gemeenteraadslid is namens de PvdA) wordt in Den Helder zowel positief als negatief gesproken. De onderzoekers: "Sommigen zijn heel tevreden en anderen zijn dat juist niet en zien met name in de persoon van de huidige griffier een bevestiging van de bestaande ongewenste Helderse cultuur van vermenging van rollen en functies en van persoonlijke en functionele relaties" (Tops en Van Spijker, 2004: 7).

\section{Aanbevelingen}

$\mathrm{Na}$ de inhoudelijke analyse komen de onderzoekers met een groot aantal aanbevelingen, op alle niveaus. Er zijn aanbevelingen op het persoonlijke vlak, waarbij de spelers op het politieke toneel in Den Helder opgeroepen worden te stoppen met onfatsoenlijk gedrag, roddel en achterklap en het spelen op de persoon in plaats van op de inhoud: "Haal de 
kramp eruit en geef wat ruimte, voor relativering en zelfreflectie. Gun elkaar successen, en vergeef gemaakte fouten; dat is volwassen politiek" (Tops en Van Spijker, 2004: 4).

De aanbeveling is verder om wat de onderzoekers noemen de 'vicieuze cirkel van ontwrichtende afhankelijkheden tussen de geledingen/actoren/personen' te doorbreken. Hiervoor moet er op alle fronten tegelijk tot verbetering en ander gedrag gekomen worden, zowel in de inhoudelijke opgaven als in personen en werkwijzen. "Het is dringend nodig dat de raad van Den Helder dezelfde 'normale' wijze van werken gaat hanteren als andere raden in andere gemeenten. Daar horen bij: jaaragenda, agendasetting, reguliere informatie- en stukkenstromen, spelregels voor het overleg in commissies en raad (spreektijd etc.), helderheid in de besluitvormingsgang, gedragsregels (bijv. geen namen noemen van ambtenaren), omgang met burgers. Hiertoe dient een protocol te worden opgesteld. Het presidium is daartoe het aangewezen orgaan. De voltallige raad dient vooraf haar vertrouwen uit te spreken dat dit presidium een goed protocol zal opstellen en zich te verplichten zich aan het protocol te houden. Het is verstandig om hierbij enige vorm van toezicht van buiten te maken, die periodiek toetst of de afspraken worden nageleefd. Ook moet getraind worden in het hanteren van dit nieuwe protocol; in scholing en vorming van raadsleden dient stevig geïnvesteerd te worden" (Tops en Van Spijker, 2004: 6).

Verder dienen personele verbindingen en rolverwarringen ontbonden te worden en is het tijd om zaken concreet te doen, in plaats van visies te maken en veel te praten. Samen met partners in de stad zullen de majeure opgaven aangepakt moeten worden. Tops en Van Spijker zijn overigens niet al te optimistisch over het vermogen van de Helderse bestuurders iets met hun aanbevelingen te doen. Letterlijk schrijven zij: "Als de geledingen in Den Helder op hun nu normale wijze reageren op onze adviezen, dan valt te verwachten dat de raad heel verdeeld zal reageren, slakken zout legt op details en niet tot een gezamenlijk beraad komt (inclusief reflectie op het eigen functioneren van de raad) over hoe tot een effectieve aanpak te komen. Het college wordt ter verantwoording geroepen hoe zo'n rapport heeft kunnen vitkomen. Het college, inclusief burgemeester, zoekt elkaar op, stelt zich op als blok, zegt dat het college er al hard aan werkt in goede collegialiteit, dat de situatie in Den Helder ook zeker niet gemakkelijk is vanwege de terugloop van de marine en onvoldoende steun van hogere overheden en dat de aanbevelingen over raad en ambtelijke organisatie ter harte genomen zullen worden. De ambtelijke organisatie houdt zich wat stil, wacht eerst het politieke gekrakeel af en hoopt daarbij dat nu de politiek er eens voor gaat staan. Met de aanbevelingen zijn ze het eens, maar ze betwijfelen of dat in Den Helder wel kan lukken. Maatschappelijke partners zullen zeggen, zie je wel, hebben we altijd al gezegd. Eens kijken wat de politiek er mee doet, zal wel weer niet veel wezen. Partners blijven zo toeschouwers aan de kant. Provincie en Rijk onderschrijven conclusies en aanbevelingen, roepen stevig dat dit niet zonder gevolgen kan blijven, maar pakken waarschijnlijk niet door als men in Den Helder niet echt wil verbeteren. Una, ISV, Kop en Munt worden niet teruggetrokken. Het zou mooi zijn als deze karikatuur geen werkelijkheidsgrond meer zou hebben" (Tops en Van Spijker, 2004: 13).

De onderzoekers krijgen niet op alle punten gelijk. Wel reageert burgemeester Staatsen verontwaardigd en geeft aan zich 'ongelofelijk afgebrand' te voelen door het rapport. Hij verwijt de Commissaris van de Koningin onzorgvuldig met het rapport om te zijn 
gesprongen door het gelijk in het openbaar te presenteren (Brouwer, 2004). In de raadsvergadering over het rapport blijkt echter al snel dat het college en de burgemeester hun werk kunnen blijven doen. Enkele ingediende moties van wantrouwen worden verworpen. Staatsen spreekt uit van plan te zijn zijn positie bij de raad te verstevigen, onder meer door enkele functies die hij als burgemeester in de regio vitoefende (voorzitter van de veiligheidsregio en de ambulancedienst) af te stoten. De gemeenteraad is hiermee akkoord en besluit een stuurgroep in te stellen, bestaande uit de burgemeester, een wethouder, de vice-voorzitter van de raad, de gemeentesecretaris en de griffier, met als specifieke opdracht om voor 15 september 2004 aan de hand van een verbeterprogramma te komen met een plan van aanpak, dat zowel een prioriteitsstelling als een concreet tijdpad bevat. Daarnaast dient de stuurgroep de uitvoering van het plan van aanpak te begeleiden en te bewaken en dienaangaande regelmatig overleg te voeren met de raad, alsmede met de provincie Noord-Holland c.q. de Commissaris van de Koningin.

Het plan verschijnt voor de afgesproken datum en draagt de titel: Tops uit, spot aan. Ook de relatie met de provincie Noord-Holland krijgt een nieuwe impuls. De gemeente richt samen met de provincie Noord-Holland, het Ministerie van VROM, de marine en de woningstichting de projectorganisatie Zeestad op.

\section{Einde oefening}

Ondanks deze voortgang blijft de spanning zich in het college opbouwen, vooral rond wethouder De Groot. In september 2005 barst de bom en besluit het college de vertrouwensband met De Groot te verbreken. Directe aanleiding is dat hij wordt beschuldigd van verduistering van een gouden ketting. Bovendien gaat er een verhaal over aanranding, dat De Groot zelf als smaad afdoet. Voor het college is de maat echter vol. In een persverklaring geven de andere wethouders en burgemeester Staatsen aan dat De Groot niet meer als 'geloofwaardig, onbesproken en effectief lid van het college kan functioneren'.

Vrijwel direct wordt duidelijk dat nu ook de VVD er genoeg van heeft en haar wethouder terugtrekt, waarmee het college definitief valt. Fractievoorzitter Bellinga is het, om het ronduit te zeggen, helemaal zat: "Het ging maar door, we werden geconfronteerd met de gekste dingen. Die diefstal, maar er gingen de meest wilde verhalen over sommige leden van het stadsbestuur rond. Na de verklaring van het college hebben wij gedacht: nu houdt het op, dit kan zo niet meer. Ook onze wethouder liep het risico meegesleurd te worden en die was nog jong, met een mooie carrière in het verschiet."

$\mathrm{Na}$ het vertrek van de VVD ontvalt de basis voor het college helemaal en laten ook CDA en D66 weten met het huidige college niet verder te willen. De druk ligt vervolgens bij burgemeester Staatsen, waar ook veel kritiek op is. De kranten berichten dat zijn positie 'onhoudbaar' zou zijn. En inderdaad valt in de raadsvergadering van 5 oktober 2005 het doek voor de burgemeester. Zelf verklaart hij (zie kader) zich te willen beraden op zijn positie en in die zin te 'defungeren' als burgemeester. De raad neemt hierop, op initiatief van het CDA, een motie aan, waarin duidelijk wordt gemaakt dat men niet verder wil met Staatsen als burgemeester. 


\section{Verklaring van burgemeester drs. J.M. Staatsen van Den Helder, afgelegd in de gemeenteraad op 5 oktober 2005.}

\section{Integriteit en geloofwaardigheid}

Sinds vorige week donderdag maken wij een - zelfs voor Helderse begrippen - buitengemeen hevige politiek-bestuurlijke storm mee. Waarom nu ineens zo'n heftige turbulentie? De oorzaken liggen in het nu en in het verleden. En stemmen niet tot grote vrolijkheid!

Tijdens mijn installatie als burgemeester op 10 janvari 2001 zei ik onder meer:

"Uw verwachtingspatroon t.a.v. mij is niet gering; dat streelt, maar geeft tegelijkertijd aan, dat ook veel moet worden waar gemaakt! Dat kan ik niet alleen. Dat zal ook u mogelijk moeten maken en daar zult ook $v$ in moeten investeren."

Mijn inzet voor deze gemeente in de voorbije vijf jaren was gebaseerd op principiële noties inzake integriteit, kwaliteit en geloofwaardigheid. Mijn inzet: er zijn voor de mensen in de stad, inzet bij inhoudelijke dossiers als werkgelegenheid, het Marinevliegkamp De Kooy en de veiligheid in Den Helder, inzet om aan bestuur en ambtelijk apparaat een kwaliteitsslag te geven. Deze inzet en die van het college en het ambtelijk apparaat hebben geleid tot een vruchtbare en resultaatrijke periode.

Van inhoud naar proces. Het politiek-bestuurlijke proces en de politieke cultuur leveren al lang een zekere vermaardheid op: Den Helder als lastige gemeente, die het zichzelf onnodig moeilijk maakt! Tops analyseerde en fileerde onder andere proces en cultuur. Er is een verbeteringsproces in gang gezet, zeker. Maar desondanks ontkomen we niet aan de slotsom dat politiek en bestuur op essentiële punten nog een te hoog "Tops-gehalte" hebben. De analyse van toen is nog steeds pijnlijk correct voor nu.

Enkele citaten: "...de verziekte verhoudingen, structureel verstoord en zodanig verbreid dat het als een virus alles en iedereen lijkt te besmetten." "Alles op de persoon, geen vergeving, niets aan elkaar gunnen. Vergeten is dat de kern van de politiek weliswaar conflict is, maar dat tegelijkertijd de kunst van politiek is om (tijdelijk) tot verzoening te komen." "Zelfreinigende en zelfcorrigerende mechanismen ..... zijn te weinig aanwezig." Integriteit en geloofwaardigheid van een bestuurder: dat was de principiële inzet vorige week donderdag. Het onderbouwde oordeel van het college, dat wethouder De Groot niet meer voldeed aan die waarden, leidde tot het opzeggen van de werkrelatie. Daarbij ging het om een personele crisis, niet om een inhoudelijk-politieke! Maar deze personele vonk kwam wel terecht in het Topsiaanse politiek-bestuurlijke kruidvat. Met de bekende effecten vandien!

Het is spijtig te moeten constateren, dat vitale aanbevelingen van Tops niet hebben geleid tot een wezenlijk andere cultuur en tot ander gedrag. Ook de casus De Groot maakt dat duidelijk. Er is - de goeden overigens niet te na gesproken - nog te veel sprake van agressiviteit, op de man spelen, wantrouwen, gebrek aan elementair respect, negativisme, onvoldoende zelfreflectie. Ik bespeur al bijna bij mijzelf, dat ik dingen gewoon dreig te gaan vinden die elders onacceptabel zijn.lk zei het al: de analyse van toen is nog steeds pijnlijk correct voor nu. En heeft geleid tot de huidige crisis en kan leiden tot de volgende.

Mijn conclusie kan geen andere zijn dan dat de bestuurlijke verhoudingen zijn verstoord. Als gevolg daarvan zal ik mij de komende tijd beraden op mijn positie. Vanaf heden zal ik in feitelijke zin defungeren als burgemeester.

Ik heb dit vandaag mede gedeeld aan de Minister van Binnenlandse Zaken en aan de Commissaris van de Koningin.

I $k$ verlaat nu deze vergadering. 
$\mathrm{Na}$ dit moment is de situatie in Den Helder dramatisch. Er is geen burgemeester meer, wethouders zijn er evenmin, het stadsbestuur ligt, figuurlijk gesproken, geheel in puin. Commissaris van de Koningin Borghouts benoemt mw. drs. G. Faber als waarnemend burgemeester. Zij was burgemeester van Zeewolde, staatssecretaris op het Ministerie van LNV en waarnemend burgemeester in Wageningen. Faber treedt twee weken na de crisis aan en treft in figuurlijke zin rokende puinhopen aan: "ledereen zat nog te stuiteren van wat er gebeurd was. Wat ik aantrof was opperste verwarring. Er was sprake van een enorm wantrouwen tussen raad en college. Echt gigantisch."

Als college treedt een gezelschap waarnemers op, bestaande vit de wethouders F. Verveld (VVD), E. Vermeer (PvdA), M. Don (Stadspartij) en C. Hienkens (CDA). Dit

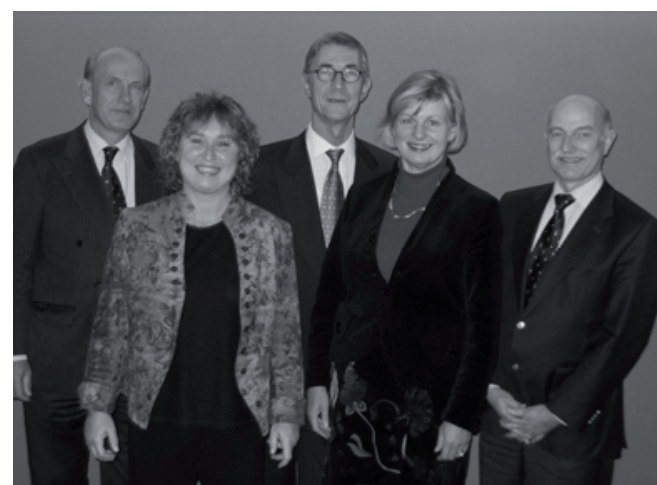

Het interim-college dat in 2005 aantrad, met v.l.n.r. wethouder Verveld, wethouder Don, wethouder Vermeer, waarnemend

burgemeester Faber en wethouder Hienkens. Foto: gemeente Den Helder. college dient tot de verkiezingen in 2006 de boel draaiende te houden.

Tegelijkertijd beseffen alle spelers dat het zo echt niet door kan gaan: "Het besef was breed aanwezig dat er nu echt een nieuwe start gemaakt zou moeten worden. Een miskleun kon Den Helder zich niet meer veroorloven", aldus de nieuwe griffier, M. Huisman. Breed wordt de wens geuit de negatieve spiraal te doorbreken en met de misère uit het verleden te breken.

Al snel blijkt overigens dat dit niet zomaar lukt. In november verschijnt een rapport van een uit raadsleden bestaande onderzoekscommissie, die de gang van zaken rondom de Oude Rijkswerf in beeld heeft gebracht. Het is een kritisch rapport, waarin vooral oudburgemeester Staatsen het moet ontgelden. Over hem schrijft de commissie onder meer dat zijn 'solitair optreden' volstrekt onacceptabel zou zijn, waarbij hem de kwalificaties 'niet betrouwbaar' en 'niet integer' worden toegevoegd. De oud-burgemeester voelt zich beschadigd en eist rectificatie. Uiteindelijk (na twee jaar) dient de zaak bij de rechtbank Alkmaar, die het met Staatsen eens is: de kwalificaties worden niet gedragen door de inhoud van het rapport. Onrechtmatig is de zaak echter ook weer niet, omdat ook raadsleden vrijheid van meningsuiting hebben.

\subsubsection{Periode 2006-2010}

In 2006 treedt na de raadsverkiezingen weer een nieuwe coalitie aan, met drie partijen: PvdA, CDA, VVD, samen goed voor achttien van de 31 raadszetels. De machtsbalans is wel veranderd. De VVD is gelijk gebleven met zes zetels, maar de PvdA wint drie zetels en komt op een totaal van acht, het CDA verliest er twee en komt op vier. Er komt uiteindelijk een college met vijf wethouders, waarvan beide VVD-ers parttime werken. Wethouder worden B. Fritzsche (VVD, parttime) en L. Smit (VVD, parttime), H. Boskeljon (PvdA), P. Kragt (PvdA) en C. Hienkens (CDA). Vanaf het begin nemen de fractievoorzitters zich voor nu strakke afspraken te maken: men houdt elkaar vast, deze 
periode gaat er niets meer gebeuren. Deze toenadering ontstond al voor de verkiezingen, toen de lijsttrekkers elkaar regelmatig in de verkiezingsstrijd tegen kwamen. Men spreekt het voornemen uit om, als het even kan, samen een college te vormen en te laten zien dat Den Helder ook een periode zonder problemen door kan komen. "Er was behoefte aan rust en stabiliteit", zegt Th. Rijnten, lijsttrekker en PvdAfractievoorzitter in 2006. Na de verkiezingen komt dit college er dan ook. Er wordt veel gedaan aan informele contacten, coalitieoverleg wordt ingevoerd. Ingezien wordt dat het noodzaak is om eenheid uit te stralen. Rijnten: "Er werd wel gezegd dat er voor het eerst echt een coalitie aan het werk was."

Het geheel staat onder leiding van waarnemend burgemeester Faber, die er veel aan doet om de teamspirit en collegialiteit in het college te bevorderen. "Ik heb er bijna als een mantra ingebracht dat collegiaal bestuur van het grootste belang is. Het kan niet zo zijn dat iedereen maar zijn eigen gang gaat. Wethouders moeten doordrongen zijn van het feit dat je het gezamenlijk moet doen. Ik gebruik wel eens het voorbeeld van de tennisvereniging. Accepteer je dat de voorzitter en secretaris van jouw tennisclub iedere keer iets anders zeggen? Dat soort voorbeelden helpt." Ook aan de individuele inbreng van collegeleden wordt gewerkt door middel van coaching.

Voor nieuw elan zorgt ook de vernieuwing van de strategische visie. Onder het motto: 'Doen, doen, doen' wordt een toekomstvisie voor de stad gemaakt, die moet zorgen voor oplossing van één van de grotere problemen: mensen moeten niet meer vertrekken uit Den Helder. Het betekent wel het maken van keuzes, die ook gemaakt worden. Er zijn drie projecten (Willemsoord, het stadshart en de Haven), die concreet prioriteit krijgen en waar de schouders unaniem onder worden gezet. Het project wordt begeleid door het bureau van stedenbouwkundige Riek Bakker, die nog met een andere suggestie komt: de Club van Kritische Vrienden. Een adviescollege met ter zake kundige mensen uit Den Helder en omgeving, die advies geven en raad en college af en toe een spiegel voor houden. Voorzitter wordt oud-VROM-man en directeur van Staatsbosbeheer, K. Vriesman. Ook oud-burgemeester W. Hoekzema is lid van de Kritische Vrienden.

Intussen loopt de sollicitatieprocedure voor de nieuwe burgemeester. De raad selecteert de Rotterdamse wethouder S. Hulman, die in juni 2007 aantreedt. De kranten berichten wel dat de raad verdeeld stemt en dat de PvdA tegen is. Fractievoorzitter Rijnten zou ontevreden zijn over de manier waarop er gesprekken zijn gevoerd met kandidaten, die hij als te weinig inhoudelijk beoordeelt. Hulman wordt echter gekozen, verhuist redelijk vlot vanuit Rotterdam naar Den Helder en gaat wonen in Julianadorp.

De nieuwe burgemeester staat te boek als een doener en een aanpakker, ambitieus en gedreven. Hij is overal, probeert de banden met het bedrijfsleven aan te trekken, zet de schouders onder veel zaken. Het horecabeleid wordt aangescherpt, waarbij hij er niet voor terugschrikt sancties op te leggen aan cafés die zich niet aan de regels houden. De stijl van Hulman levert ook wel irritaties op. Sommigen missen empathie in zijn manier van doen, anderen spreken over het ontbreken van voldoende verbindende kwaliteiten. In het college wil Hulman een discussie over een door hem ingediend voorstel volgens een gesprekspartner nog wel eens afdoen met de zin: "En toch gaan we het zo doen." 
Zelf ontkent hij ooit zoiets gezegd te hebben en zou juist afgesproken zijn met de coalitiepartijen om 'stevig' voor te zitten. Hoe het ook zij: er sluipt enige ergernis in het college, dat desalniettemin probeert de eenheid te bewaren.

De raad probeert intussen werk te maken van zijn intenties deze termijn niets fout te laten gaan. Functie-onderhoud voor de burgemeester maakt hier onderdeel van uit. De aanbevelingen van de Commissaris van de Koningin aan alle gemeenten om periodiek (respectievelijk na één, drie en vijf jaar) met de burgemeester de gang van zaken te evalueren, wordt overgenomen. Hiervoor wordt een verordening aangenomen en in april 2008 wordt een evaluatiecommissie ingesteld, die een gesprek met de burgemeester voert. De commissie voert voorafgaand hieraan individuele gesprekken met raadsleden, collegeleden en de secretaris, waarvan de inhoud als input voor het gesprek met Hulman dient. Dit is overigens een 'wederkerig' gesprek; ook Hulman kan inbrengen hoe hij tegen het functioneren van bestuurlijk Den Helder aankijkt. De aandachtspunten worden onder de aandacht van de Commissaris van de Koningin gebracht.

Ook op een ander terrein, dat van de dualisering, zet de gemeenteraad stappen vooruit. Er wordt veel aandacht besteed aan raadscommunicatie en interactie met de inwoners. Projecten als 'Over de kook' (koken met de raad) en 'Klas in de raad' respectievelijk 'Raadslid in de klas' worden heel goed ontvangen en zelfs landelijk als voorbeeld van mogelijke invulling van de raadscommunicatie aangehaald.

Al met al lijkt het de goede kant op te gaan met de bestuurlijke verhoudingen in Den Helder. Betrokkenen geven aan dat het gevoel leeft dat het 'nog nooit zo goed is gegaan.'

\section{Woonlasten}

De broze vooruitgang wordt echter danig op de proef gesteld vanaf 11 november 2008, als de veelbesproken en beschreven woonlastenaffaire begint. Burgemeester Hulman stelt op die dag in de rondvraag van het college zijn persoonlijke financiële situatie aan de orde. Hij heeft problemen. Het blijkt niet te lukken zijn appartement in Rotterdam te verkopen, waardoor de hypothecaire lasten op dit huis blijven doorlopen. De boodschap aan het college is simpel: er dient op korte termijn financieel bijgesprongen te worden door het gemeentebestuur, anders dreigt een persoonlijk faillissement. Het college is van mening dat de zaak serieus opgepakt moet worden, met de bedoeling een oplossing te zoeken: de burgemeester dient geholpen te worden. Ondanks de wetenschap dat het qua regels ongetwijfeld lastig ligt, wordt aan de gemeentesecretaris (bijgestaan door een in rechtspositionele zaken gespecialiseerde ambtenaar), alsmede aan de griffier (die in zijn rol overigens op afstand van de besluitvorming wil blijven) het verzoek gedaan op ad-hoc basis de zaak te analyseren en mogelijkheden te verkennen. De gedachte bij het college was dat er ook in andere gemeenten met betrekking tot de huisvesting van de burgemeester creatieve constructies waren uitgewerkt en dit ook in Den Helder zou moeten kunnen. Op 15 december ligt er een voorstel op tafel en besluit het college op grond hiervan Hulman tegemoet te komen in zijn woonlasten en elke maand een bedrag van 3200 euro bruto extra uit te keren. De leidende gedachte is: we laten de burgemeester niet zakken en failliet gaan, we proberen 
te helpen. De fractievoorzitters worden ingelicht en die hebben in eerste instantie hetzelfde gevoel: dit zou moeten kunnen, er is een noodgeval.

Het verhaal neemt echter een dramatische wending, als de eerste berichten in de kranten verschijnen over de zaak. Berichten met een kritische tot zeer kritische ondertoon. Berichten over een wellicht veel te hoge vraagprijs voor het huis in Rotterdam, over de aanwezigheid van nog een derde huis in Spanje. Het college besluit op basis hiervan nadere voorwaarden te verbinden aan de toezegging en deze in een brief vast te leggen. Op 23 december staat de brief op de agenda van het college en geeft Hulman nadere vitleg over zijn financiële situatie. Op een flip-over legt hij uit hoe e.e.a. in elkaar zit. Het college besluit na zijn vertrek uit de vergadering dat het geheel niet goed meer is te overzien. Besloten wordt een feitenonderzoek te laten uitvoeren naar de draagkracht en de inkomenspositie van de burgemeester, die hier mee in stemt. De eerste week van januari komen er meer gegevens boven tafel met betrekking tot het inkomen van Hulman, waarbij partijen het er achteraf in het kader van dit onderzoek niet over eens zijn of het hier nu om nieuwe of reeds bekende informatie gaat. De wethouders houden er in ieder geval een onbehagelijk gevoel aan over. Inmiddels gaat de berichtgeving in de media over de kwestie verder. Er ontstaan actiecomités van inwoners, die de voorgenomen extra steun niet begrijpen. De situatie krijgt nog meer aspecten als één raadsfractie vraagt alle declaraties van Hulman openbaar te maken. Het college gaat hier relatief snel toe over, volgens sommigen wel heel erg snel. In de haast transparant te zijn worden zelfs sommige creditcard-nummers meegeleverd. "Er zaten ook facturen bij die ik zelf had betaald of nooit heb gezien", geeft Hulman in het kader van dit onderzoek aan. Het geeft voeding aan een nieuwe serie negatieve verhalen in de media over de burgemeester.

Het feitenonderzoek verschijnt op 15 januari 2009. De wethouders trekken er de conclusie uit dat de feiten toch anders liggen dan men op 15 december 2008 dacht en rekenen dit de burgemeester aan: "Hierbij willen wij benadrukken dat wij niet uitgaan van opzet danwel bewuste misleiding. Wel zijn wij van mening dat de burgemeester ervoor had dienen zorg te dragen dat er geen misverstand kon ontstaan over de gegevens die de basis vormden voor dit besluit. Dit is temeer het geval daar te voorzien was dat een besluit als dit, onderwerp zou worden van politieke en maatschappelijke discussie" (Raadsinformatiebrief 16 januari 2009). Hulman zelf geeft aan absoluut niet te hebben willen misleiden, maar slechts te weinig aandacht te hebben gegeven aan de gegevens waarmee gewerkt is. Zowel bij de wethouders als bij de raad valt de nieuwe rapportage heel slecht: "Ik heb toen gezegd: nu ben ik er klaar mee. De geloofwaardigheid was totaal weg", zegt PvdA-voorman Rijnten.

De wethouders laten aan Hulman en de gemeenteraad weten van mening te zijn dat er een onwerkbare situatie is ontstaan en samenwerking met betrekking tot toekomstig functioneren niet meer mogelijk is. Hulman informeert de raad hierover middels een brief, waarin hij zijn gevoelens van verdriet beschrijft, zijn kant van de zaak belicht en aangeeft dat er in het college geen vertrouwen meer is: "Ik heb daar kennis van genomen en moet vervolgens als eerste denken aan het belang van de stad en mijn eigen belang proberen daarin te passen. De continuïteit van het stadsbestuur is van groot belang. Om deze reden heb ik besloten mij te beraden op mijn positie. Ik zal daartoe 
onder andere in overleg gaan met de Commissaris van de Koningin. Tot het moment van een definitief besluit zal ik me beperken tot mijn kerntaken en bijvoorbeeld het voorzitterschap van het college en de raad aan mijn respectievelijke plaatsvervangers overlaten" (Brief burgemeester Den Helder aan gemeenteraad, 160109).

Commissaris der Koning Borghouts stelt voor een lijmpoging te doen en benadert een mediator. Er volgt een periode van enkele weken windstilte. Na zeven gesprekken komen de partijen tot de conclusie dat een werkbare relatie niet meer mogelijk is. "Wij zijn in de mediation gezamenlijk op basis van het voorgaande tot de slotsom gekomen dat verdere bestuurlijke samenwerking niet langer mogelijk is op een wijze die politiek houdbaar en slagvaardig bestuurlijk optreden mogelijk maken en dus ook niet wenselijk meer is. De wethouders zien dan ook geen reden om tot herziening te komen van het collegebesluit van 16 januari jl. Dit bestuurlijke conflict moet worden opgelost, rekening houdend met continuïteit van bestuur. Het is aan de gemeenteraad om in de situatie die wij met deze verklaring aangeven nader te besluiten. In dit verband zijn de wethouders van oordeel dat de procedure als bedoeld in artikel 61b Gemeentewet moet worden ingezet" (Gezamenlijke slotverklaring van het mediationtraject, 190209).

Het doek valt dus definitief. Hulman keert in mei 2009 terug naar Rotterdam, nadat de gemeente bereid blijkt zijn Helderse woning aan te kopen. Dit laatste gebeurt op voorspraak van de Commissaris van de Koningin, die hiertoe afzonderlijke gesprekken met veel fractievoorzitters voert. Ook oppositiepartijen stemmen met de regeling in, zoals D66: "Onze afweging was: als wij hier niet mee instemmen, gaan we een periode in van ellendige rechtszaken, die veel schade zouden doen aan het imago van Den Helder. We wilden er gewoon vanaf en dit was daarvoor een goede mogelijkheid", zegt raadslid F. Klut. Om dezelfde reden wordt een verzoek van Hulman om een raadsonderzoek of enquete te houden naar de feiten en omstandigheden van de crisis (wat volgens hem echt een ander beeld zou opleveren) niet ingewilligd: een meerderheid van de gemeenteraad wil de zaak definitief afsluiten.

Een nieuwe crisis is afgesloten. Een crisis die in dit geval vooral persoonlijke wonden slaat. Velen begrijpen achteraf niet hoe het zo uit de hand heeft kunnen lopen. Ook de enorme opwinding en grote media-aandacht hebben verbazing gewekt: "40 journalisten in de gang, zes televisiecamera's, de oppositie die de meest wilde dingen gaat roepen. Ik heb er met afgrijzen naar gekeken", zegt oud-fractievoorzitter en VVD-raadslid Bellinga.

$\mathrm{Na}$ het vertrek van Hulman wordt K. Vriesman (PvdA), eerder lid van de Kritische Vrienden van Den Helder, waarnemend burgemeester in Den Helder. Hij kent het klappen van de zweep in de stad en weet de gemoederen langzaam weer tot bedaren te brengen. De raad begint opnieuw aan de zoektocht naar een nieuwe burgemeester, die in oktober 2009 leidt tot de aanbeveling om K. Schuiling (VVD) te benoemen tot burgemeester. Hij begint op 1 januari 2010. 


\subsection{De analyse op microniveau}

Na de beschrijving van de gebeurtenissen, noodzakelijkerwijs een beschrijving op hoofdlijnen, is het mogelijk de verschillende aspecten te analyseren op micro-, mesoen macroniveau. Hierbij wordt gebruik gemaakt van verschillende indicatoren, zoals viteengezet in hoofdstuk 3 .

Op microniveau zijn twee factoren onderscheiden: de burgemeester en de wethouder(s). Indicatoren voor problemen rond deze factoren zijn het ontbreken van signalerend vermogen, het ontstaan van discussies over de bestuursstijl of het optreden in het openbaar debat. Bij de burgemeester is vooral het niet hebben of kunnen tonen van bindend vermogen een indicator.

Microfactor: de burgemeester(s)

De burgemeesters van Den Helder hadden allen te maken met verschillende krachten, die op hen inwerkten. Op de eerste plaats de gemeenteraad zelf, waar zowel de cultuur als de structuur (vanaf 2002) aanleiding gaf tot zorg (zie onder macrofactoren). Daarnaast werd van de burgemeester en van het college vaak een, moeilijk te vervullen, dubbele houding verwacht. Aan de ene kant werd stevigheid verwacht van burgemeesters. Den Helder stond en staat voor grote opgaven en daar past bestuurlijke daadkracht van burgemeester en college bij. Aan de andere kant diende dat wel vriendelijke daadkracht te zijn: al te solitair en eigenzinnig optreden van burgemeesters werd al snel niet zo gewaardeerd. Onder dit gesternte hebben de verschillende burgemeesters invulling gegeven aan het ambt. Hierbij kan geconcludeerd worden dat de stijlen van de burgemeesters verschilden. Grote discussies over signaalgevoeligheid of flexibiliteit deden zich echter niet of nauwelijks voor, al was met name rond burgemeester Hulman niet iedereen gecharmeerd van zijn aanpak. Belangrijker is echter dat beide gedwongen vertrokken burgemeesters hun gedrag en opvattingen niet wilden of konden aanpassen, dus een gebrekkig adaptief vermogen leken te hebben. In de situatie van Staatsen ging het vooral om zijn principiële keuze zich solidair te verklaren met het college. Desgevraagd geeft hij aan dat hier meerdere redenen voor waren. Zo beschouwt Staatsen het als een weeffout in de wet met betrekking tot de dualisering, dat de burgemeester zowel voorzitter van de raad als voorzitter van het college is. "Wat mij betreft is die dubbele rol niet passend", aldus Staatsen. Tegelijkertijd speelde deze specifieke kwestie in 2003, de tijd dat ook de gekozen burgemeester eraan leek te komen. Ook deze gekozen burgemeester zou op enige afstand van de gemeenteraad gaan opereren. Daarnaast hoorde Staatsen dat sommigen in Den Helder vonden dat zijn voorganger enkele jaren eerder ook had moeten aftreden, om daarmee zijn mede-verantwoordelijkheid te nemen voor de gang van zaken. "Ik wilde door mijn standpunt laten zien dat ik inderdaad bereid was die verantwoordelijkheid te nemen." Het gevolg was dat Staatsen zijn lot vrijwillig aan dat van het college verbond en zijn onafhankelijke positie als boven het college en raad staande burgemeester welbewust op gaf. Een keuze die de raad niet begreep en niet waardeerde; een keuze die leidde tot zijn voortijdig vertrek.

In de situatie van het voortijdig vertrek van burgemeester Hulman speelde het feit dat hij zelf onderdeel van de discussie was geworden, de belangrijkste rol. Ook nu kon de verbindende rol van de burgemeester niet gespeeld worden. Hij opereerde in die periode naar mening van sommige gesprekspartners vrij eigenzinnig en was te star in 
zijn opstelling in de crisis. Als hij serieus ingegaan was op de suggesties die waren gedaan over zijn financiële problematiek, was het anders gelopen, wordt gezegd. Hulman zelf ontkent dat overigens: "Mijn conclusie is dat uiteindelijk de enige reden dat het fout is gegaan ligt in de onverwacht grote en hevige media aandacht. Het gaat dus om angst voor beeldvorming."

Verwachting 1 lvidt: In bestuurlijke probleemgemeenten legt de burgemeester weinig bindend vermogen aan de dag, waardoor de potentiële dempende werking van de burgemeester afwezig is. De conclusie is dat in Den Helder deze verwachting voor wat betreft de regulier benoemde burgemeesters in de laatste twee perioden is uitgekomen. De eerste periode is niet goed te duiden. In de beschreven gevallen konden de burgemeesters, om wisselende redenen, niet meer boven de partijen staan en viel hun vermogen om te binden weg. Signalen met betrekking tot gewenste verandering werden niet of onvoldoende opgepikt. Door het wegvallen van het bindende vermogen van de burgemeester ging er van deze microfactor geen remmende of dempende werking meer vit in deze perioden.

Microfactor: de wethouders

In elke raadsperiode is bedekte en openlijke kritiek geuit op het functioneren van sommige wethouders. Nu is dat in meer gemeenten het geval, maar in Den Helder leidde het tot terugkerende ophef. Oud-gemeentesecretaris en raadslid De Bruin verklaart het uit het armoedebewustzijn; de meeste mensen in Den Helder hadden en hebben het niet al te breed. Hier komt de opvatting uit voort dat dit ook zo hoort en dat het niet de bedoeling is dat sommigen hier boven uit stijgen: "Liever allemaal arm dan de één ietsje meer." Het gevolg is dat ook wethouders van nature met een behoorlijke dosis scepsis worden bekeken. Wie is hij of zij eigenlijk om die positie te gaan bekleden? Tegelijkertijd wordt er veel van wethouders verwacht. Aan de ene kant moet een wethouder dus krachtdadig zijn, aan de andere kant niet teveel boven het maaiveld uitsteken. Dat blijkt in de praktijk een wankele basis om op te werken.

Toch vielen niet alle wethouders in Den Helder voortijdig. Persoonlijk functioneren speelt hierbij wel degelijk een rol. Bij de crisis in 1999 was het functioneren van het college als geheel niet meer mogelijk, door het feit dat enkele wethouders continu bezig waren zich te verdedigen tegen aanvallen op hun beleid of zelfs hun integriteit. De crisis in 2005 werd ingeleid door tal van vragen rondom het optreden van de wethouder van Leefbaar Den Helder. Het college zegde uiteindelijk het vertrouwen in deze wethouder op, wat het vertrek van alle wethouders en de burgemeester inluidde.

De wethouders die in 2006 aan de slag gingen stonden volgens betrokkenen ook niet allemaal te boek als heel sterk. De persoonlijke optredens hebben echter niet bijgedragen aan het ontstaan van bestuurlijke conflicten of bestuurscrises.

Verwachting 2 luidt: In bestuurlijke probleemgemeenten hebben de persoonlijke risicofactoren van één of meer wethouder(s) een aanjagende werking op de bestuurlijke problemen De conclusie luidt dat in Den Helder in de eerste twee perioden is uitgekomen. Zowel in de periode 1998-2002 als in de periode 2002-2006 waren er voorbeelden van persoonlijke risicofactoren van wethouders, die een crisis inlvidden. In de laatste periode zijn daar minder verhalen over op te tekenen, al betekent dit niet dat de wethouders zonder kritiek zijn gebleven. 


\subsection{De analyse op mesoniveau}

Op mesoniveau gaat het zoals omschreven om de betrekkingen tussen de verschillende spelers. Betrekkingen in het college, tussen college en raad, college en ambtelijke organisatie en tussen de coalitiefracties. Indicatoren zijn opgenomen in tabel 6 in paragraaf 3.7 .

\section{Mesofactor: het college}

De opeenvolgende colleges in Den Helder hadden ieder in de eigen periode te maken met wat sommigen omschrijven als 'het probleem' van Den Helder: de allergie voor alles wat boven het maaiveld uitsteekt en de hieruit voortvloeiende neiging hier zeer kritisch tegenover te gaan staan. De colleges kregen bovendien te maken met een gemeenteraad, die zich in de praktijk vooral beperkte tot controleren en het leveren van kritiek achteraf. Van besturen of meebesturen kwam niet veel: het was controleren, proberen zaken die niet goed zitten te ontdekken en die vervolgens breed uit te meten. In zo'n situatie komt er van een gezond samenspel tussen raad en college niet al te veel terecht. De verschillende colleges wilden zaken tot stand brengen, maar troffen in de raad geen partner die in zaken meegenomen wilde worden. Dat deed het college dan ook niet, waardoor er van goede samenwerking nauwelijks sprake was. Soms opereerden de colleges ook wel erg 'stoer' in de richting van de raad, wat weer tot een tegenreactie leidde. Insiders menen dat het bij de verschillende crises wel beter had gekund.

Van een teveel aan partijen in het college is geen sprake geweest. Wel ontbrak het in de colleges van de eerste perioden aan chemie, aan samenwerking en ook aan doorzettingskracht. Enkele colleges waren bovendien geboren onder een slecht gesternte. Dat gold zeker voor het college dat in 1998 aantrad en in 1999 viel. De voorbodes van de naderende fraudezaak waren er al. Tijdens de rit kwam er verschil van mening in het college over de manier waarop gehandeld moest worden, bijvoorbeeld met betrekking tot de manier van declareren. Feitelijk heeft het college maar één jaar gefunctioneerd, waarna eerst de PvdA-wethouder en later ook beide andere wethouders hun ontslag aanboden.

Het hierop volgende college (1999-2002) kwam voortvarend uit de startblokken, maar had ook al snel een probleem: het boterde niet tussen enkele wethouders en hun respectievelijke fracties. Dat leverde spanningen op, die hun weerslag kregen in het college. Naar analyse van oud-burgemeester Staatsen stonden enkele wethouders met enige regelmaat onder druk van de fractie. "De ene wethouder had al heel snel een slechte relatie met de eigen fractie, omdat men vond dat hij te overheersend was. De andere wethouder communiceerde naar mening van de eigen fractie onvoldoende, dus dat leverde ook spanningen op."

Het college dat in 2002 aantrad ging ook vol elan van start. Problemen doemden echter al snel op, zeker in de relatie met de gemeenteraad, rondom het dossier Oude Rijkswerf Willemsoord. Het probleem dat ontstond met de gemeenteraad zette de relaties zwaar onder druk. De slagkracht van het college was door deze moeilijke situatie niet groot. Het ontbrak aan uitvoeringskracht. "Er wordt weinig doorgepakt en de verbindingen 
met de raad, met maatschappelijke partners en met de ambtelijke organisatie zijn overwegend slecht. Vanuit het college wordt vaak krampachtig op de raad gereageerd. De schakelfunctie tussen raad en ambtelijke organisatie wordt onvoldoende vervuld. $\mathrm{Er}$ bestaat een cultuur van conflictmijding, waardoor dingen vooruitgeschoven worden en dan soms alleen door stevig 'powerplay' kunnen worden opgelost, wat de verhoudingen weer onder druk zet. Van een ruimhartige en actieve informatievoorziening richting gemeenteraad is tot nu toe onvoldoende sprake. Dit voedt de argwaan in de gemeenteraad. Tegelijkertijd wordt vanuit de gemeenteraad ook wel erg weinig ruimte voor creatief besturen gegeven, wordt soms wel erg formalistisch en gedetailleerd gereageerd en lijkt dualisme vooral te worden aangegrepen om collegeleden in het ongewisse te laten over de steun voor hun voorstellen. Zo houden raad en college elkaar in een ijzeren houdgreep", concluderen Tops en Van Spijker in hun rapport (2004: 7). Zij gaan ook in op de neiging van sommige collegeleden om de rol van 'superdirecteur/ superambtenaar' aan te nemen, door directe interventies in het ambtelijk apparaat. Collegeleden regelden in de door Tops en Van Spijker bestudeerde periode ook veel zelf; het collectief 'college' had, bij gebrek aan onderling vertrouwen, weinig betekenis.

Het college dat in 2006 startte ging beduidend beter vit de startblokken. Coalitieoverleg werd ingevoerd en de afspraak was om de coalitie, en dus het college, in stand te laten. Bij het bestuurlijk conflict rondom burgemeester Hulman betekende dit uiteindelijk dat de wethouders verder konden functioneren. Dit had echter meer te maken met een andere (meso-)factor dan met het dempende vermogen van het college.

Verwachting 3 lvidt: In bestuurlijke probleemgemeenten kunnen colleges niet sterk worden, waardoor de potentiële dempende werking van een sterk college afwezig is. Zwakke colleges worden in dit onderzoek opgevat als colleges met een niet zo goede teamgeest, zonder gedeelde visie en met een slechte relatie met de gemeenteraad. De conclusie met betrekking tot deze verwachting is dat deze in de eerste twee perioden is uitgekomen en in de laatste periode het beeld wat genuanceerder is.

Mesofactor: de verbinding van het college met de ambtelijke organisatie

Het ambtelijk apparaat verkeerde tijdens de crisisjaren in Den Helder in een reorganisatie. Er werd gewerkt aan invoering van het directiemodel, waar veel energie in ging zitten. Gesprekspartners geven aan dat het daardoor een nogal naar binnen gerichte organisatie was, die ook nog eens te maken had met de politieke problemen op het gemeentehuis. Het gevolg was dat de ambtelijke organisatie 'zekerheden ging inbouwen', om niet afgerekend te hoeven worden op fouten. Gemeentesecretaris H. Raasing constateert nóg een negatief effect: "Een belangrijk effect van de politiek-bestuurlijke problemen is het feit dat de negatieve gevoelens hierover worden geprojecteerd op het ambtelijk apparaat. Als het bestuur niet deugt, kunnen de ambtenaren onmogelijk wel deugen, is de redenering. Dit betekent dat er in het algemeen een negatief sentiment heerst rondom de verrichtingen van ambtelijk Den Helder, ondanks het feit dat de gemeente goed scoort als het gaat om metingen van dienstverlening en klanttevredenheid." Raasing probeert vanaf haar aantreden die feiten dan ook te laten spreken. 
Wat volgens diverse gesprekspartners meespeelde met de ambtelijke onzekerheid, is het feit dat er door het bestuur geen heldere keuzes werden gemaakt over de te volgen richting. Er was niet alleen geen of heel weinig beleid, maar er waren ook geen beleidsprioriteiten. Als er prioriteiten worden gesteld moeten er immers ook dingen achterwege blijven. Elke partij had echter zijn eigen voorkeur. De VVD was erg gericht op cultuur, met een projectie op school, kunstprojecten en dergelijke. De PvdA had een voorkeur voor een zeer uitgebreid beleid op het gebied van welzijn en sociale zaken, met veel bijzondere bijstandsmogelijkheden en individuele regelingen. Het CDA ging daar in mee. D66, lang groot geweest in Den Helder, had natuur- en milieueducatie. "En vervolgens ziet de stad eruit zoals die eruit ziet", aldus oud-waarnemend burgemeester Faber. "Het beschikbare geld is jarenlang enorm versnipperd uitgegeven. Ook stedelijke vernieuwing bleef achter: er is ongelooflijk veel gesloopt, maar weinig bijgebouwd." Inmiddels is het tij gekeerd. Er is een strategische visie aangenomen en de prioriteiten zijn gesteld.

Verwachting 4 luidt: In bestuurlijke probleemgemeenten zit weinig patroon in de relatie van het college met het ambtelijk apparaat, wat een aanjagende werking heeft op bestuurlijke problemen. De conclusie luidt dat deze verwachting de eerste periode is uitgekomen, daarna werd de relatie geleidelijk patroonmatiger.

\section{Mesofactor: de verbinding tussen raad en college}

In zowel de periode 1998-2002 als de periode 2002-2006 stonden de verbindingen tussen de gemeenteraad en het college onder zware druk. In eerstgenoemde periode kwam dat door de vele kwesties (geruchten over fraude, declaratieproblematiek) die de gemoederen bezig hielden. In de tweede periode was dit niet anders. Hier kwam het dualisme als probleempunt bij. Op de eerste plaats is er relatief laat, pas in januari 2003, een start gemaakt met de aanpak van het dualisme, terwijl de wet in maart 2002 van kracht werd. Een griffier werd benoemd, maar wel één die afkomstig was uit de ambtelijke organisatie, al 20 jaar aan Den Helder verbonden was en bovendien politieke binding had met de lokale PvdA-afdeling. Stelselmatige pogingen het dualisme goed te implementeren kwamen in die periode niet van de grond. Het resultaat was dat de raad, kritisch van nature, zijn eigen invulling ging geven aan het dualisme en het ging gebruiken als vrijbrief voor vrijblijvende relaties tussen college en verwante fracties. Het 'wij-zij'-denken, toch al niet vreemd aan de Helderse politiek, kreeg een nieuwe impuls. Het dualisme bood overigens ook voordelen: na het aftreden van het college in 2005 konden enkele wethouders van buiten worden aangetrokken, die de raadsperiode konden afmaken. In het monistische stelsel was deze opzet niet mogelijk geweest.

Vanaf 2006 is het met het dualisme de goede kant op gegaan. Zowel in de structuur (andere opzet van commissievergaderingen) als in de cultuur (pogingen tot grotere openheid door middel van actieve raadscommunicatie) zijn veranderingen ingezet. In de raadsperiode 2006-2010 zijn wat betreft de verbinding tussen gemeenteraad en college verbeteringen te constateren. Een bestuurlijk conflict is in deze periode wel ontstaan, maar het groeide niet uit tot een bestuurscrisis. Dit kwam echter vooral door de verbeterde verbinding tussen coalitiepartijen, die dominanter was dan de verbinding tussen raad en college. 
Verwachting 5 luidt: In bestuurlijke probleemgemeenten zit geen of weinig patroon in de relatie tussen het college van $B \& W$ en de gemeenteraad, wat een aanjagende werking heeft op bestuurlijke problemen. De conclusie is dat deze verwachting de eerste twee perioden is vitgekomen, de laatste periode niet.

\section{Mesofactor: de verbinding tussen de coalitiepartijen}

De coalities die vanaf 1998 zijn ontstaan hadden stuk voor stuk een meerderheid van gemiddeld achttien van de 31 of 33 zetels. Op zich dus ruim, terwijl men wel op elkaar was aangewezen: meerderheden in de raad konden alleen worden behaald als alle partijen voor een voorstel zouden stemmen.

Toch bleken in de praktijk de gemaakte afspraken al snel door de actualiteit te worden ingehaald. De colleges kregen na het verlaten van de startblokken te maken met vrij forse problemen, op het gebied van fraude en declaraties (1999), dan wel in de relatie met de gemeenteraad (2003) of rondom een wethouder (2005). De coalities bleken niet bestand tegen de krachten die hierbij los kwamen. Bovendien speelde er nog iets anders mee: van coalitieoverleg was eigenlijk nauwelijks sprake. D66 gaf in 2002 aan niet te houden van 'achterkamertjes' en wilde niet of nauwelijks overleg voeren met de andere coalitiepartijen. Het gevolg was dat de andere fracties voorafgaand aan een raadsvergadering niet of nauwelijks wisten welke standpunten de coalitiepartijen zouden gaan innemen. Van enige hechtheid in de coalitie kon op die manier geen sprake zijn, het geheel hing als los zand aan elkaar.

Pas vanaf 2006 is de coalitie hechter in elkaar gezet, waardoor de burgemeesterscrisis rond het vertrek van burgemeester Hulman (2009) niet leidde tot het vertrek van het hele college. Dat wil niet zeggen dat er geen kritiek was. Door de stevige omarming van de drie coalitiepartijen leek er soms een tegenstelling coalitie-oppositie te ontstaan. Volgens sommige oppositiepartijen liet de coalitie ook goede ideeën uit de oppositie gewoon links liggen. Daar staat tegenover, vindt oud-wethouder Fritzsche, dat in de laatste periode wel vooruitgang is geboekt voor wat betreft de besluitvorming over enkele belangrijke dossiers: "Als wij de laatste periode niet een sterke coalitie hadden gehad, hadden wij nog steeds in de plannenmakerij en het gekissebis gezeten. Dus je moet op een gegeven moment ook over je eigen schaduw heen willen springen."

Verwachting 6 luidt: In bestuurlijke probleemgemeenten bestaat weinig binding tussen coalitiefracties, wat een aanjagende werking heeft op bestuurlijke problemen. De conclusie is dat deze verwachting in de eerste twee perioden is vitgekomen. De kans op een conflict of crisis nam in de eerste raadsperiode door het ontbreken van goede (communicatieve) verbindingen toe en leidde zelfs tot vertrek van colleges. Op het moment dat er betere afspraken gemaakt werden (vanaf 2006) en er een betere persoonlijke verstandhouding tussen fractievoorzitters leek te zijn, namen de spanningen in de coalitie af. 


\subsection{De analyse op macroniveau}

Op macroniveau worden drie factoren onderzocht: de bestuursstructuur, de bestuurscultuur en de rol van de media (inclusief berichtgeving over opvattingen van actiegroepen).

\section{Macrofactor: de bestuursstructuur}

Geconcludeerd kan worden dat de gemeenteraad van Den Helder door de jaren heen steeds meer versplinterd is geraakt. In de raadsperiode 2006-2010 was er viteindelijk sprake van 12 fracties. Vaak slaagden relatieve nieuwkomers in de Helderse politieke arena erin één of twee raadszetels te bemachtigen. Het ging om mensen met weinig ervaring in de gemeentepolitiek. Nieuwkomers die zich van de gangbare spelregels niet veel aantrokken, het niet volgen daarvan eerder als een pluspunt ervaren (zie: Tops en Van Spijker, 2004: 3).

Bovendien heeft de Helderse raad te maken gehad met afscheidingen binnen raadsfracties. Zo is de fractie van de PvdA in het verleden enkele malen gesplitst. Leefbaar Den Helder werd vertegenwoordigd door oud-PvdA-ers, maar ook raadsleden van de Stadspartij Den Helder hadden een PvdA-achtergrond. Redelijk snel na de raadsverkiezingen in 2006 splitste ook de vierkoppige fractie van de SP zich alweer. Enkele leden gingen een eigen weg onder de naam Progressief Den Helder. Deze splitsingen hadden drie effecten. Op de eerste plaats zorgde het voor een gefragmenteerde raad, met 31 raadszetels verdeeld over twaalf partijen in 2006. Op de tweede plaats werd de vorming van stabiele coalities er ernstig door bemoeilijkt. Maar ook belangrijk: op de derde plaats hadden de afsplitsingen grote invloed op de sfeer in de raad. Tops en Van Spijker concludeerden dat ook in 2004: "Er wordt niet vergeven en vergeten. Er wordt niet veel gegund. De conflicten in de PvdA hebben een reservoir aan spanningen gecreëerd" (Tops en Van Spijker, 2004: 5). In de praktijk is gebleken dat er een forse concurrentiestrijd ontstond tussen de PvdA en de bovengenoemde fracties. Beide onderzoekers wijzen erop dat er ook weinig herstelmechanismen en verbindende mensen zijn en het aan 'natuurlijk(e) politieke leider(s)' ontbreekt. Oud-burgemeester Hulman keek toen hij aantrad ook op van het grote aantal partijen. "Er was sprake van negen oppositiefracties, die allemaal vonden dat ze oppositieleider waren."

Overigens is gebleken dat in de periode dat het aantal fracties het grootst was, dus het aantal raadsleden per fractie (fractiequote) het kleinst, het bestuurlijk conflict rondom de burgemeester niet leidde tot een bestuurscrisis. Waren er andere factoren actief die dempend werkten?

Verwachting 7 lvidt: In bestuurlijke probleemgemeenten is sprake van versplintering van het politieke landschap, wat een aanjagende werking heeft op bestuurlijke problemen. De conclusie is dat de bestuursstructuur een factor van betekenis was in alle perioden en de verwachting dus is uitgekomen.

\section{Macrofactor: bestuurscultuur}

De gemeenteraden in Den Helder werden in de onderzoeksperiode gekenmerkt door een nogal strikte scheiding tussen besturen en controleren. Met name de controlefunctie werd intensief beoefend, van gezamenlijk met het college besturen van de stad leek minder te komen. Partijen verklaren deze houding uit het dualisme, waarin het college 
formeel bestuurt en de raad controleert en kaders stelt. Toch zou dat genuanceerder moeten liggen, vindt raadslid Klut (D66): "We staan er toch gezamenlijk voor om deze stad te besturen."

Een opvallend kenmerk van de verschillende gemeenteraden was in ieder geval de enorm bijterige cultuur. De omgangsvormen in de raad waren bij tijd en wijle zeer ruw: "Ik was wel wat gewend, maar wat je hier in Den Helder kon horen was echt bikkelhard", zegt oud-waarnemend burgemeester Faber. "Een raadslid zei rustig tegen een wethouder: $u$ bent geen knip voor de neus waard, u weet niet waar $u$ het over heeft, $u$ moet maar vertrekken. Dat gebeurde in korte tijd bij twee wethouders. Men kon elkaar ineens een hak willen zetten en de meest vreselijke dingen zeggen. Wat mij opviel is dat niemand dat corrigeerde, dat lieten ze gewoon lopen. Ik ben dat wel gaan corrigeren, want ik vind dat je dat niet onweersproken kunt laten. Dit soort zaken komt via de media naar buiten en dan denken de inwoners toch weer: zie je wel, ze deugen daar niet."

Wat ook tot de mores leek te behoren was het 'afrekenen' van collegeleden op sommige zaken. "Er werd heel snel gezegd bij zaken die niet goed zijn verlopen: dat had u toch wel anders kunnen doen, waarom heeft u niet zus of zo gedaan? Daarmee verwordt elk debat tot iets defensiefs."

Ook de opvolger van Faber, de in 2009 afgetreden burgemeester Hulman, viel over de ruwe cultuur: "In gedrag, toon en inhoud gaat het er heel scherp aan toe, er wordt scherp geformuleerd. Daarbij geldt dat de hardste schreeuwer heeft gewonnen. Slechts enkele fracties doen daar niet aan mee. Deze grote dynamiek heeft invloed op de collegepartijen, die ook wel eens meedoen aan dat getoeter. Dat levert vervolgens weer onbegrip op bij de collegeleden, die van de harde toon van hun eigen fracties dan weer weinig snappen."

Waarnemend burgemeester Vriesman probeerde, net als Hulman, vanaf het begin van zijn ambtsperiode al te barre vitspraken aan te pakken: "In mijn tweede vergadering werd alweer gesproken over onbehoorlijk bestuur en toen heb ik gezegd dat ik dat niet accepteer. We blijven netjes met elkaar omgaan", aldus Vriesman.

Tops en Van Spijker constateren nog een ander fenomeen dat meespeelt: het ons-kentons principe, dat cliëntelisme in de hand werkt. "Wat we ook vaak hebben gehoord: 'Den Helder is net een dorp'. Dat wordt doorgaans niet als een positief kenmerk gezien. Men associeert het met zaken als: ons kent ons, veel geroddel en geklets (rond de dorpspomp, in het bijzonder een paar cafés); heel veel is op persoonlijke relaties (en conflicten) gebaseerd" (Tops en Van Spijker, 2004: 3). Oud-burgemeester Faber herkent dat beeld: "De stad Den Helder is naar verhouding een kleine wereld. Er bestaan verschillende netwerken, waarin mensen elkaar al jarenlang kennen en onderling ook allerlei lijnen hebben. In Wageningen, waar ik eerder zat, was het de universiteit, hier de club van aannemers binnen de Rotary die bepalen hoe het moet. Er bestaan over en weer allerlei contacten binnen raad, college en organisatie en die komen op verschillende momenten naar boven borrelen. Het gevolg is dat de agenda in de gemeente niet zakelijk beleidsmatig wordt beredeneerd, maar wordt gevuld met wat er aan casuïstiek naar boven komt. Vaak op de gekste manieren, via de krant of ook wel rechtstreeks. Als mensen niet binnenkwamen bij een wethouder of raadslid, ging men rechtstreeks naar de ambtenaar. Allemaal gevolg van hetzelfde." 
Bij het zoeken naar de oorzaak van deze ruwe, negatieve cultuur in de gemeente wordt door sommigen gewezen op de grote invloed van de marine. Oud-burgemeester Staatsen legde in 2006 een rechtstreekse relatie: "Wat meespeelt, is dat de gemeenteraad al decennia wordt gedomineerd door oud-marinemensen. Die gingen vroeger al op 52-jarige leeftijd met pensioen en wilden dus nog wel wat. Velen hadden zich jarenlang geknecht gevoeld en zagen in de gemeentepolitiek een kans om revanche te nemen. Was het op de werf altijd beleefd knikken naar het hoger en trappen naar het lager personeel, nu kwamen ze in een setting waarin ze zelf mochten trappen naar gezagsdragers. In die sfeer zit Den Helder nu gevangen. Het trappen blijkt een aantal raadsleden en een deel van de bevolking enorm te bevredigen. Een raadslid dat tegen een wethouder zegt: "Jij deugt niet", die krijgt waardering. "Eindelijk iemand die tegen die lui met hun mooie kleren en hun hoge salarissen durft te zeggen waar het op staat", denken sommige mensen. In zo'n politieke cultuur speelt het algemeen belang eigenlijk geen rol. Het doel is mensen te beschadigen" (Moerkamp, 13/01/06).

Ook oud-burgemeester Hoekzema schrok soms van wat er in de raad gebeurde. Hij spreekt over een afrekencultuur, die nog altijd aanwezig is in Den Helder. "Als de emoties eenmaal los komen, is het erg moeilijk het tij nog te keren."

Verwachting 8 luidt: In bestuurlijke probleemgemeenten is de bestuurscultuur negatief tot zeer negatief, wat een aanjagende werking heeft op bestuurlijke problemen. De conclusie is dat deze verwachting in alle onderzochte raadsperioden is vitgekomen.

\section{Macrofactor: de invloed van de (pers)media}

De geïnterviewden zijn het erover eens: de rol van de media is niet te veronachtzamen in de beschrijving van de problematiek in Den Helder. Diverse gesprekspartners schrijven hier een grote rol aan toe. Vooral de Helderse Courant wordt in dit verband genoemd. Niet alleen vanwege de artikelen, ook lagen er vele lijnen naar de redactie, waardoor interne stukken ineens bij de journalisten bekend waren. Waarnemend burgemeester Faber heeft enkele keren aangifte gedaan en onderzoek laten doen, maar wie er informatie lekte is nooit duidelijk geworden. De pers speelde overigens nog een derde rol. Het gebeurde in Den Helder nogal eens dat kwesties eerst via de krant werden aangekondigd en dat het gemeentebestuur op de berichtgeving moest reageren. Soms werd de bespreekagenda van het college van B\&W op dinsdagmorgen grotendeels gevuld door de artikelen in de Helderse Courant.

De vraag is of er zonder de invloed van de media geen bestuurscrises waren geweest. Vermoedelijk waren die toch wel ontstaan: partijen blijven zelf verantwoordelijk voor de personen die wethouder worden, wethouders en burgemeesters zijn zelf verantwoordelijk voor hun eigen handelen, college en raad kiezen zelf de wijze waarop zij met elkaar om gaan. Wat wel opvalt aan de Helderse situatie is de vroegtijdige betrokkenheid van de media en de vasthoudendheid: door veelvuldige publicaties, enquêtes over draagvlak en opinies dragen de media wel bij aan het in stand houden van eventuele conflictsituaties. Oud-wethouder Fritzsche noemt hierbij vooral de wat hem betreft stelselmatig negatieve invalshoek van de krant. Hij noemt als voorbeeld de discussie over de nieuwbouw van het gemeentehuis, waar een voorbereidingskrediet van 100.000 euro voor werd gevraagd aan de gemeenteraad: "Gelijk wordt weer geschre- 
ven: wat een geld zeg, weer een college dat er niets van begrijpt. Dat zet toch weer de toon. Er is dan geen enkele nuance, geen enkele trots op wat we met elkaar proberen te bereiken."

Verwachting g luidt: In bestuurlijke probleemgemeenten hebben de (pers)media een grote invloed op het debat, wat een aanjagende werking heeft op bestuurlijke problemen. De conclusie luidt dat ook deze verwachting in alle perioden is vitgekomen.

\subsection{De dynamiek}

Nu alle relevante factoren zijn beschreven in de Helderse context, is het mogelijk aandacht te besteden aan de dynamiek die in de jaren 1998-2010 is ontstaan. Want het is duidelijk dat het juist de dynamiek, wellicht is wrijving een beter woord, tussen de verschillende factoren is die tot het ontstaan van bestuurlijke conflicten en bestuurscrises heeft geleid. Zo ontstond de crisis in 1998-1999 rondom een langslepende kwestie met betrekking tot fraude. Hier kwam nog een onderzoek naar declaratiegedrag van de leden van het college van B\&W bij. De discussies die beide zaken met zich meebrachten fungeerden als het ware als de bestuurlijke 'trigger' voor een dynamisch proces. Hierbij speelden de macrofactoren een rol. Vooral de bestuurlijke cultuur in de gemeenteraad zorgde er voor dat er met priemende vinger werd gewezen naar mogelijke schuldigen. De media berichtten er volop over, waardoor de kwestie ook geen kans kreeg soepel opgelost te worden. De druk op de bestuurders werd groter en groter, het leidde uiteindelijk tot het aftreden van alle wethouders. De burgemeester bleef zitten; een meerderheid van de raad vond dat hij nog met voldoende gezag boven de partijen stond.

Anders was dit in 2005, toen het hele college moest opstappen. Ook hier was weer een dynamische wrijving te zien tussen een kerngebeurtenis (de kwestie rond de Oude Rijkswerf), gemor over individuele handelingen van wethouders, een op confrontatie gerichte bestuurscultuur, een broze coalitie en veel berichtgeving in de media. De burgemeester slaagde er in dit geval niet in boven raad en college te blijven staan. Dat was ook een bewuste keuze: hij vond al in 2003 dat hij mede-verantwoordelijk was voor de keuzes die gemaakt waren. In die zin zijn de gebeurtenissen in 2003 te zien als opmaat naar de crisis in 2005, omdat de gemeenteraad in 2003 al teleurgesteld was in de opstelling van de burgemeester. Ook het feit dat een deel van de bevolking in 2003 vrij openlijk de zijde van het college koos, was sommige partijen heftig in het verkeerde keelgat geschoten. Met de viteindelijke crisis in 2005 tot gevolg.

De kwestie in 2009 laat opnieuw zien dat diverse factoren op elkaar inwerkten en een kerngebeurtenis lieten uitmonden in een bestuurlijk conflict of een bestuurscrisis. In dit geval ging het om de financiële problemen van de burgemeester, die op een nietwettelijke manier zouden moeten worden opgelost. De samenleving reageerde heftig, de raad idem dito. De coalitie bleek hier echter minder broos, waardoor het uiteindelijk vertrek beperkt bleef tot dat van de burgemeester. Kortom: in Den Helder werkten diverse factoren op een dynamische wijze op elkaar in. Is het mogelijk hieruit conclusies te trekken? 


\subsection{Conclusie}

De vraag aan het begin van deze casestudy luidde:

Wat is de verklaring voor het gedwongen vertrek van burgemeesters, wethouders en/of hele colleges in Den Helder in de periode maart 1998 - maart 2010?

Hiervoor zijn de verschillende factoren op verschillende niveaus geanalyseerd. Samenvattend ziet het beeld er als volgt vit:

Tabel 18: De factorenanalyse in Den Helder

\begin{tabular}{|c|l|c|c|c|c|}
\hline & $\begin{array}{l}\text { Verwachting van de invloed van de factor op } \\
\text { de opgetreden bestuurlijke problematiek }\end{array}$ & $\begin{array}{l}\mathbf{1 9 9 8 -} \\
\mathbf{2 0 0 2}\end{array}$ & $\begin{array}{l}\mathbf{2 0 0 2}- \\
\mathbf{2 0 0 6}\end{array}$ & $\begin{array}{l}\mathbf{2 0 0 6}- \\
\mathbf{2 0 1 0}\end{array}$ & $\begin{array}{l}\text { Con- } \\
\text { clusie }\end{array}$ \\
\hline 1 & Burgemeester werkte niet dempend & $+/-$ & + & + & + \\
\hline 2 & Risicofactor wethouders was aanjager & + & + & $+/-$ & + \\
\hline 3 & Optreden college werkte niet dempend & + & $+/-$ & - & $+/-$ \\
\hline 4 & Ontbreken patroon college/ambtenaren was aanjager & + & + & - & + \\
\hline 5 & Zwakke verbinding raad/college was aanjager & + & + & - & + \\
\hline 6 & Zwakke verbinding coalitiepartijen was aanjager & + & + & + & + \\
\hline 7 & Onevenwichtige structuur gemeenteraad was aanjager & + & + & + & + \\
\hline 8 & Negatieve bestuurscultuur was aanjager & + & + & + & + \\
\hline 9 & Invloed van (pers)media op debat was aanjager & & & & \\
\hline Legenda: = verwachting is uitgekomen \\
$\quad+-=$ geen eenduidig beeld op te maken \\
$-=$ verwachting niet vitgekomen
\end{tabular}

De vraag is nu of er, als deze factoren worden gekoppeld aan de opgetreden problemen, een patroon te herkennen is.

\section{Macrofactoren $(7,8,9)$}

Op de eerste plaats is duidelijk dat de macrofactoren in Den Helder een grote rol speelden gedurende de hele onderzoeksperiode en overal een + scoorden. De publieke opinie roerde zich in elke periode danig en ook de media speelden een rol. Ditzelfde geldt voor de cultuur in de gemeenteraad. De manier van omgaan met elkaar door raadsleden was ruw, op sommige momenten ronduit beledigend. Voorstellen van het college werden niet alleen kritisch bejegend, maar soms bijna vijandig. Dit speelde in de periode 19982002, maar ook in latere perioden. Daar kwam vanaf 2002 ook nog een verandering in structuur bij: de raad kreeg te maken met kleinere partijen, afsplitsingen van de PvdA, de Stadspartij of Leefbaar Den Helder. Hierdoor nam het aantal partijen in de raad toe tot tien in 2006 en twaalf in 2010. Een moeilijk werkbare situatie, geven vele geïnterviewden aan. De harde debatcultuur, gecombineerd met de lastige structuur, maakten raadsvergaderingen bij tijd en wijle tot voor bestuurders hachelijke ondernemingen.

De drie onderscheiden macrofactoren waren dus alle drie aanwezig in Den Helder en hadden een aanjagende werking op de bestuurlijke problemen. Dit maakt Den Helder tot een lastig te besturen gemeente. Toch kan geconstateerd worden dat niet in alle perioden een bestuurscrisis is ontstaan. De problemen zijn in de periode 2006-2010 
minder ernstig geweest (burgemeester weg, college bleef zitten) dan in de periode 2002-2006 (college inclusief burgemeester weg) of in de periode 1998-2002 (college weg, burgemeester bleef zitten). Kennelijk spelen de macrofactoren wel een rol, maar wordt de vraag hoe groot een probleem wordt door andere factoren bepaald. De vraag waarom er in de ene periode een college valt en in de andere periode 'slechts' één keer een burgemeester, moet dus worden beantwoord door te kijken naar de micro- en/of mesofactoren.

\section{Microfactoren (1 en 2)}

Ten aanzien van de microfactoren kan geconstateerd worden dat deze in alle perioden wel een rol speelden. Weliswaar op verschillende manieren. In 1999 was het handelen van enkele wethouders onderwerp van onderzoek en viel uiteindelijk het hele college. De burgemeester bleef buiten schot en behield het vertrouwen. In 2005 viel het college door de discussie rondom het functioneren van een wethouder uiteindelijk uit elkaar en bleek ook het krediet van de burgemeester op te zijn. Deze had zich in 2003 nog nadrukkelijk verbonden aan het lot van het college en kon daar nu niet meer los van komen. In 2009 speelde een persoonlijk probleem rondom de op dat moment zittende burgemeester, maar bleef het vertrouwen in de wethouders bestaan. De coalitie bleef intact, het college kon verder functioneren. Ondanks de aanwezigheid van negatieve microfactoren komt het dus niet altijd tot een complete bestuurscrisis. Microfactoren kunnen dus leiden tot problemen voor de burgemeester of wethouders afzonderlijk, maar leiden niet automatisch tot het vertrek van hele colleges. Hiervoor is kennelijk meer nodig.

\section{Mesofactoren $(3,4,5,6)$}

Voor een echte bestuurscrisis, waarbij een heel college valt (soms met burgemeester) waren dus in Den Helder zowel de microfactoren als de macrofactoren niet bepalend. Dan zou het verschil dus moeten worden gemaakt door de mesofactoren, de verbinding tussen de verschillende bestuurlijke componenten. Als dit klopt, is de vraag relevant welke mesofactoren de belangrijkste rol speelden.

Uit de analyse van Den Helder blijkt dat er van veel colleges geen dempende werking uit ging en dat ook de relatie tussen het college en de raad lange tijd een aanjagende werking op bestuurlijke problemen had. Bepalend voor een crisis bleek toch uiteindelijk het gebrek aan vertrouwen van de coalitiepartners in de samenstelling van de coalitie te zijn. Zodra dit vertrouwen begon af te nemen, door problemen in het college en moeizame voortgang van dossiers, namen de problemen toe. Hierdoor kon bijvoorbeeld een ingediende motie van wantrouwen steun krijgen van een coalitiepartij en een raadsmeerderheid halen, zoals in 1999 en 2005. In 2009 hadden de coalitiepartners echter nog vertrouwen in de coalitie (en dus in elkaar) en ontstond er rondom het vertrek van burgemeester Hulman geen bestuurscrisis.

\section{Samengevat:}

Het gedwongen vertrek van gemeentebestuurders in Den Helder in de periode maart 1998 - maart 2010 is toe te schrijven aan drie factoren: (1) het functioneren van de 
burgemeester ( in het bijzonder het wel of niet (kunnen) spelen van de verbindende rol), (2) het persoonlijk functioneren van wethouders en (3) de hechtheid van de coalitie.

De problematiek verminderde op het moment dat deze drie factoren positief waren. Met andere woorden: het bestuur in de gemeente Den Helder kende perioden waarin het besturen risicovoller was dan in andere perioden. Er was sprake van een golfbeweging. Op het moment dat de burgemeester erin slaagde buiten eventuele conflicten te blijven, signalen opving en een verbindende rol speelde, het persoonlijk functioneren van wethouders (misschien tijdelijk) niet ter discussie stond en de coalitie redelijk hecht opereerde, waren de kansen op bestuurlijke crises beduidend kleiner. Weliswaar bleven de andere factoren aanwezig, maar zijn deze meer te beschouwen als constanten, die een bijdrage leverden aan het ontstaan van de bestuurlijke conflicten en bestuurscrises, maar daar niet bepalend in waren.

De volgende casestudies moeten uitwijzen of dit in Den Helder aangetroffen patroon van factoren ook in andere gemeenten aan de orde is geweest. 


\section{Bestuurlijke problematiek in Leiden 1998-2010}

\section{$6.1 \quad$ Inleiding}

Daar waar de bestuurders in Den Helder bepaald niet opkeken van het feit dat hun gemeente hoog scoort voor wat betreft het aantal gedwongen vertrokken bestuurders en colleges, was in Leiden een ander geluid te beluisteren. Een aantal gesprekspartners was aanvankelijk zelfs verbaasd dat de sleutelstad, alles opgeteld, aanwezig is op de lijst van bestuurlijke probleemgemeenten. Na enig nadenken volgde echter instemming: oh ja, die wethouder is ook nog vertrokken, daar viel het hele college, ja, het klopt toch wel. De viteindelijke optelsom: Leiden zag in de afgelopen 12 jaar in totaal negen wethouders voortijdig vertrekken, drie colleges en één burgemeester.

In deze tweede casestudy, waarbij de gemeente Leiden onder het vergrootglas wordt gelegd, zal opnieuw een poging worden gedaan de gebeurtenissen te beschrijven en daarna te analyseren, door in te zoomen op de micro-, meso- en macrofactoren en conclusies te trekken. Ook in Leiden is, net als in Den Helder, tot diep in de laatst bestudeerde bestuursperiode sprake geweest van bestuurlijke problematiek. Het is de vraag of hierbij dezelfde factoren een prominente rol speelden als in de gemeente Den Helder. De te beantwoorden vraag in deze casestudy luidt:

Wat is de verklaring voor het gedwongen vertrek van burgemeesters, wethouders en/of hele colleges in Leiden in de periode maart 1998-maart 2010?

Om dit goed in beeld te kunnen krijgen worden in dit hoofdstuk de verschillende bestuurlijke conflicten en bestuurscrises in Leiden onderzocht. In de laatste paragraaf zal getracht worden conclusies te trekken met betrekking tot de hierboven geformuleerde vraag.

Net als in de andere gemeenten is ook de medewerking in Leiden aan de casestudy uitstekend geweest. De aangezochte leden van het college, gemeenteraad, (oud)burgemeesters of ambtelijke medewerkers bleken bereid terug te kijken en hun oordeel te geven over de gebeurtenissen.

\subsection{Introductie van de gemeente Leiden}

De oude stad Leiden, gelegen in de provincie Zuid-Holland, is bij velen bekend door de aanwezigheid van de universiteit. De Universiteit Leiden is de oudste van Nederland, opgericht in 1575 en destijds geschonken door Willem van Oranje aan Leiden na het Leidens ontzet. Volgens de overlevering (hoewel historici als burgemeester Lenferink dit verhaal naar het rijk der fabelen verwijzen) konden de inwoners na hun verzet tegen de Spanjaarden kiezen uit tien jaar vrijstelling van belastingen of een universiteit. Het werd, zo wil het verhaal, het laatste, waardoor Leiden tot de dag van vandaag bekend 
staat als universiteitsstad. Maar de stad kent op zichzelf ook al een rijke geschiedenis, terug te zien in de oude binnenstad, de grachten en hofjes.

Leiden telt ruim 117.000 inwoners en is daarmee de vijfde stad in Zuid-Holland, na Rotterdam, Den Haag, Zoetermeer en Dordrecht. De stad ontstond als dijkdorp, aan de voet van een kunstmatige heuvel bij de samenvloeiing van de Oude en de Nieuw Rijn. In

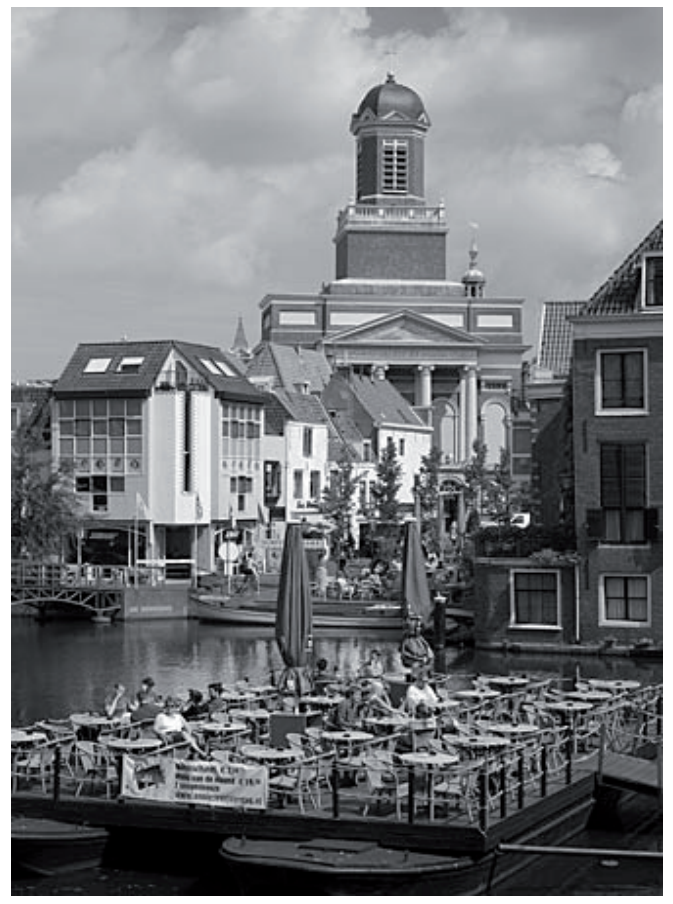

Een karakteristiek beeld van Leiden. Foto: Gemeente Leiden 1266 kreeg de stad officiële bevestiging van al eerder verleende stadsrechten. Nadat de stad de kant van de anti-Spaanse opstand koos, volgde in 1574 een intensieve belegering van de stad. De bevrijding op 3 oktober 1574 wordt nog elk jaar uitbundig gevierd. Leiden kende een grote bloei in de zeventiende eeuw, dankzij de impuls die vluchtelingen uit Vlaanderen gaven aan de textielnijverheid. Begin $18^{\mathrm{e}}$ eeuw had Leiden ruim 70.000 inwoners, waarmee de stad na Amsterdam de grootste van het toenmalige Holland was.

Het huidige Leiden kent in totaal vier stadsdelen, 10 districten en 54 buurten. De stad telt meer dan 3.000 monumenten. Bezienswaardigheden van tegenwoordig zijn onder meer de Pieterskerk, het Rapenburg, de Burcht, de Hooglandse Kerk, twee stadspoorten, maar ook de 35 hofjes en 88 bruggen binnen de singels. Ook het Rijksmuseum van Oudheden, het Museum voor Volkenkunde en de Lakenhal zijn in Leiden gevestigd. Uiteraard mag niet onvermeld blijven dat zowel Rembrandt als Jan Steen in Leiden zijn geboren.

\subsection{2 jaar Leidse politiek}

In de gemeente Leiden heeft de PvdA vrijwel altijd het meeste aantal raadsleden gehad. Dit was al zo voor de onderzoeksperiode en is ook in de bestudeerde jaren te constateren. De enige uitzondering vormden de verkiezingen van 1998, toen de VVD een hele goede vitslag boekte en in zetelaantal eveneens op negen kwam. Verder valt op dat in 2006 de SP enorm groeide (van drie naar zeven zetels) en op slag de tweede partij in Leiden werd.

Afsplitsingen van bestaande partijen zijn er ook geweest in Leiden. De fractiequote (het aantal raadszetels gedeeld door het aantal partijen) komt de gehele onderzoeksperiode 
ruim boven de vier uit. Wel zijn er door de jaren heen steeds partijen geweest met één of twee zetels.

Tabel 19: Samenstelling gemeenteraad Leiden 1998-2010

\begin{tabular}{|c|c|c|c|c|c|c|}
\hline Naam partij & 1998 & $\begin{array}{c}\mathrm{Na} \\
\text { afspl. }\end{array}$ & 2002 & $\begin{array}{c}\mathrm{Na} \\
\text { afspl. }\end{array}$ & 2006 & $\begin{array}{c}\mathrm{Na} \\
\text { afspl. }\end{array}$ \\
\hline 1. $\mathrm{PvdA}$ & 9 & & 8 & & 10 & \\
\hline 2. CDA & 4 & & 5 & & 5 & \\
\hline 3. VVD & 9 & & 7 & & 6 & \\
\hline 4. GroenLinks & 6 & & 6 & & 4 & \\
\hline 5. D66 & 4 & & 5 & & 2 & \\
\hline 6. SP & 5 & 4 & 3 & & 7 & 6 \\
\hline 7. ChristenUnie & 0 & & 1 & & 2 & \\
\hline 8. Leefbaar Leiden & o & 1 & 3 & 2 & 2 & 3 \\
\hline 9. LWG/De Groenen & 1 & & 1 & & 0 & \\
\hline 10. Overig & 1 & & o & & 0 & \\
\hline 11. Stadpartij Leiden Ontzet & 0 & & 0 & & 1 & \\
\hline 12. Fractie Schoonderwoerd* & 0 & & 0 & 1 & & \\
\hline Totaal & 39 & & 39 & & 39 & \\
\hline Aantal fracties & 8 & & 9 & & 9 & \\
\hline Fractiequote & 4,87 & & 4,33 & & 4,33 (gem & $51)$ \\
\hline
\end{tabular}

* Raadslid D. van Schoonderwoerd den Bezemer splitste zich af van Leefbaar Leiden en startte zijn eigen fractie, tot zijn overlijden in 2005. Het nieuwe lid voor de fractie van Leefbaar Leiden splitste zich ook af en vormde ook een eigen fractie.

In Leiden hebben in de onderzoeksperiode twee partijen altijd een plek in de coalitie

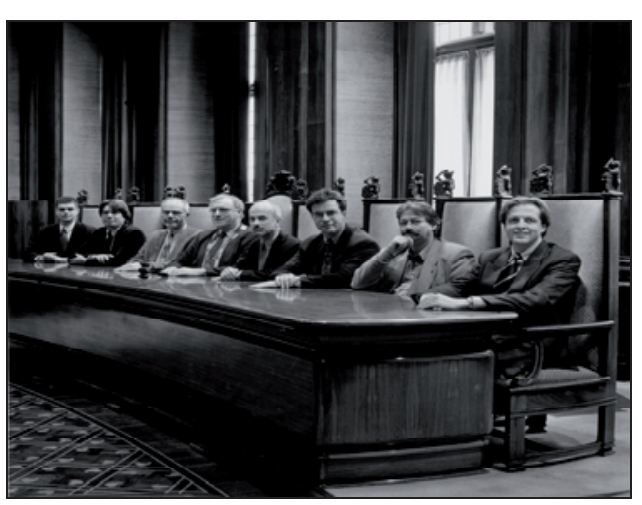

Het college van $B \& W$ van Leiden uit de periode vóór 1998, v.l.n.r. de heren H. Kruijt, H. Baaijens,

Tj. van Rij, burgemeester C. Goekoop, gemeentesecretaris K. de Vries, P. Langenberg, J. Laurier en

A. Pechtold. Foto: M. de Haan gehad, te weten de PvdA en GroenLinks. Deze partijen vormden coalities met afwisselend CDA, D66 of de VVD. Overigens kwam er in januari 2010 een einde aan de samenwerking, omdat GroenLinks uit de coalitie stapte na de parkeergaragecrisis (zie verderop). $\mathrm{Na}$ de verkiezingen in 2006 kwamen ook de SP en de ChristenUnie in het college, maar dat duurde niet lang: beide partijen verdwenen in 2007 uit de coalitie.

De colleges konden bogen op wisselende meerderheden. In 1998 had de coalitie 23 van de 39 raadszetels. De VVD, op dat moment even groot als de PvdA, viel buiten de boot.

$\mathrm{Na}$ het vertrek van de CDA-wethouder kwam de VVD echter toch in het college (met twee wethouders), waardoor het college kon bogen op een meerderheid van 28 van de 39 zetels. Deze coalitie bleef in 2002 in stand, ondanks licht verlies van de PvdA en de VVD. Met 26 van de 39 zetels 
behield het college een ruime meerderheid. Personele wisselingen waren er ook in deze periode volop, maar dat leidde niet tot een andere coalitie.

De verkiezingen van 2006 lieten vervolgens een grote winst van de SP zien, waardoor de partij in het college terecht kwam, ten koste van de VVD. Het college dat aantrad had een linkse signatuur en werd gesteund door de PvdA, SP, GroenLinks en de ChristenUnie, samen goed voor 23 van de 39 raadszetels. Na de overstap van een SPraadslid naar Leefbaar Leiden bleven er daar 22 van over. Een jaar later was de VVD echter weer terug in het stadsbestuur, na de crisis rondom de komst van de Rijn Gouwe Lijn (RGL, zie verderop). Tegelijkertijd stapte de ChristenUnie uit het college, wat de terugkeer (na acht jaar) van het CDA inluidde.

Tabel 20: Samenstelling Colleges van B\&W gemeente Leiden 1998-2010

\begin{tabular}{|c|c|c|c|c|c|c|c|c|c|}
\hline 1998 & Weth. & 1999 & Weth. & 2002 & Weth & 2006 & Weth & 2007 & Weth. \\
\hline PvdA & 2 & PvdA & 2 & PvdA & 2 & PvdA & 2 & PvdA & 2 \\
CDA & 1 & VVD & 2 & VVD & 2 & SP & 2 & VVD & 1 \\
Gr.L. & 1 & Gr.L. & 1 & Gr. L & 1 & Gr.L & 1 & Gr.L & 1 \\
D66 & 1 & D66 & 1 & D66 & 1 & CU & 1 & CDA & 1 \\
\hline
\end{tabular}

Leiden heeft relatief weinig burgemeesterswisselingen gehad. Bijna twintig jaar lang was C.H. Goekoop een markante burgemeester van Leiden. Met grote tegenzin ging hij per 1 januari 1999 met pensioen. Opvolger J.K.T. Postma bleef relatief kort in het ambt: in mei 2002 vertrok hij weer (zie verderop). Na een periode met waarnemend burgemeester W. Lemstra, trad in mei 2003 de Arnhemse wethouder H.J.J. Lenferink aan als burgemeester in Leiden.

Tabel 21: Burgemeesters van Leiden 1980-2010

\begin{tabular}{|l|l|}
\hline Mr. C.H. Goekoop (VVD) & $1980-1999$ \\
\hline Drs. J.K.T. Postma (PvdA) & $1999-$ Mei 2002 \\
\hline Dr. W. Lemstra (CDA, waarnemend) & Juni 2002- Mei 2003 \\
\hline Drs. H.J.J. Lenferink (PvdA) & Mei 2003- Heden \\
\hline
\end{tabular}

\subsection{De problemen op een rij}

Ook de gemeente Leiden kende in de onderzoeksperiode een groot verloop van met name wethouders en colleges. In totaal vertrokken er negen wethouders, één burgemeester en vielen er drie colleges. Net als in de andere casestudies wordt in deze paragraaf op chronologische wijze op een rij gezet wat er in de onderzoeksperiode precies is gebeurd. De beschrijving is gebaseerd op informatie die is verkregen uit gesprekken met betrokkenen en gedrukte informatie uit diverse bronnen. Alle geïnterviewden hebben kennis genomen van de strekking van de hieronder beschreven informatie. Als er letterlijk geciteerd wordt in de beschrijving hebben de betreffende personen met het citaat ingestemd. De getrokken conclusies komen uiteraard geheel voor rekening van de onderzoeker.

\subsubsection{Periode 1998-2002}

De raadsperiode 1998-2002 begint met een bijzondere omstandigheid: de PvdA wordt met negen raadsleden weliswaar de grootste partij, maar moet die positie deze keer 
delen met de VVD. De liberalen komen eveneens op negen zetels. Het leidt niet tot deelname aan het college: na lange onderhandelingen komt een college van PvdA (met de wethouders Tj. van Rij en H. Baaijens), CDA (wethouder H. Kruijt), GroenLinks (wethouder J. Laurier) en D66 (wethouder A. Pechtold) tot stand. Van Rij en Laurier zijn al langer wethouder, Van Rij al vanaf 1990.

De eerste problemen doen zich voor rond wethouder Kruijt, die communicatief volgens zeggen niet uitblinkt en steeds vaker kritiek krijgt op zijn functioneren. Kruijt is afkomstig uit de studentenwereld en volgens sommige informanten achteraf ook wel erg jong 'in het diepe' gegooid. Al snel ontstaat er kritiek op zijn functioneren en het beleid op het gebied van economische zaken. Het leidt tot zijn vertrek en een crisis: het CDA wordt door de andere partijen ingeruild voor de VVD. De kranten staan bol van de verwikkelingen (o.a. Trouw, 210999). Binnen het CDA ontstaat een strijd om de kandidatuur voor het wethouderschap, die zodanig oploopt dat men er uiteindelijk niet uit komt. Het gevolg is dat het CDA tot de oppositie wordt veroordeeld, waar pas acht jaar later verandering in zal komen. De VVD treedt toe tot het college. Om coalitieredenen (de partij is immers even groot als de PvdA) worden er twee VVD-wethouders in plaats van één benoemd, wat leidt tot de komst van de liberale wethouders $B$. Vos en M. Schultz van Haegen in oktober 1999.

Ook de burgemeester is inmiddels een andere: na de pensionering van C. Goekoop treedt in januari $1999 \mathrm{~J}$. Postma aan als burgemeester. Hij is afkomstig van het ministerie van Financiën, waar hij het tot secretaris-generaal heeft gebracht. Postma is een heel ander persoon dan de extraverte Goekoop. Hij bemoeit zich niet met de politieke schermutselingen in college en raad, vanuit de opvatting (te lezen in zijn afscheidsverklaring in mei 2002, zie verderop) dat er van hem als politieke functionaris verwacht wordt dat hij 'buiten en boven' de politiek staat en in raad en college ook zo opereert. Aan de andere kant dient hij wel goed op de hoogte te zijn van diezelfde politieke zaken. Postma worstelt met die rollen, die hij als tegenstrijdig ervaart.

Al snel is het echter alle hens aan dek, want er dreigt opnieuw een crisis. De kosten van de verbouwing van het stadhuis in Leiden blijken enorm uit de hand te lopen. Verantwoordelijk wethouders zijn Van Rij (PvdA, uitvoering, eerder portefeuillehouder voor gemeentelijke huisvesting) en Vos (VVD, financiën, die de portefeuille overnam). De problemen lopen zodanig op dat er inderdaad opnieuw politieke trammelant ontstaat, die uiteindelijk leidt tot het vertrek van beiden. Zuur voor Vos, die in eerste instantie zelf aan de bel had getrokken en uiteindelijk niet langer dan een half jaar wethouder zal zijn. Echt onbekend waren de problemen echter niet: D66 stelde al eerder vragen over de kwestie. Het vertrek van Vos staat volgens enkele gesprekspartners in verband met het vertrek van Van Rij, die informeel ook wel de onderkoning van Leiden wordt genoemd. 'Als er een PvdA-wethouder moet vertrekken, dan ook een wethouder van de VVD', is de gedachte. Tot een coalitiebreuk leidt het niet. De opvolgers komen uit eigen kring van PvdA en VVD: tot wethouders worden R. Hillebrand (PvdA) en R. van der Sande (VVD) benoemd. Later in het jaar vertrekt PvdA-wethouder Baaijens naar de Vereniging Nederlandse Gemeenten (VNG). Hij wordt opgevolgd door H. Buijing. In deze samenstelling lijken college en raad af te koersen op de verkiezingen van maart 2002, maar er komt toch nog een vertrek, op de valreep. Het draait om problemen met 
de sociale werkvoorziening De Zijl Bedrijven (DZB). Al jarenlang een moeizaam draaiend bedrijf, waardoor er in de gemeenteraad regelmatig discussies ontstaan over de financiën. Verantwoordelijk wethouder Laurier lijkt de problemen van zich af te kunnen houden tot de verkiezingen, maar slaagt daar uiteindelijk toch niet in. Vlak voor de Kerst in 2001 stuurt hij een brief naar de raad, waarin hij vraagt om schriftelijk in te stemmen met (opnieuw) een kredietverhoging. Het valt verkeerd bij coalitiepartij VVD: "Wij vonden dat het zo echt niet ging en hebben diverse malen aangegeven dat de wethouder serieus met onze kritiek moest omgaan. Maar die signalen werden naar onze mening niet opgepakt", herinnert VVD-raadslid Van Gruting zich. De kritiek op Laurier leidt uiteindelijk tot een vertrouwensbreuk tussen de gemeenteraad en de wethouder: Laurier vertrekt in februari 2002, is nog betrokken bij de college-onderhandelingen, maar keert niet terug als wethouder. Oud-Tweede Kamerlid M. Rabbae is namens GroenLinks zijn opvolger vanaf mei 2002.

\subsubsection{Periode 2002-2006}

De uitslag van de verkiezingen in 2002 (zie tabel 19) maakt het mogelijk de coalitie ongewijzigd in stand te laten. Opnieuw vormen PvdA, GroenLinks, VVD en D66 het college van sleutelstad Leiden. Tot wethouder worden alle zittende wethouders benoemd, de heren Hillebrand en Buijing (PvdA), Pechtold (D66) en Van der Sande (VVD). Rabbae wordt wethouder namens GroenLinks. Enige vrouw in het gezelschap is M. Schultz van Haegen (VVD).

Het college staat echter niet meer onder voorzitterschap van burgemeester Postma. Hij besluit in mei 2002 zijn ambt neer te leggen. Directe aanleiding is het lekken van gesprekken rondom de evaluatie van zijn eerste drie jaar burgemeesterschap, waar vervolgens publiciteit over ontstaat. Zelf is hij echter ook niet gelukkig in het ambt, zo blijkt uit de verklaring die hij in de raad voorleest.

Verklaring van burgemeester Postma, waarin hij het burgemeesterschap van Leiden neerlegt, mei 2002.

Leden van de Raad,

Graag wil ik u er deelgenoot van maken waar ik vandaag sta na de gebeurtenissen rond mijn persoon in de laatste anderhalve maand, en tot welke conclusies ik ben gekomen. Zoals u weet was er op 15 april een zogenaamd voortgangsgesprek met de Commissaris van de Koningin, dat hij drie jaar na de aanstelling met elke burgemeester voert. In de weken daarvoor had ik een voorbereidend gesprek met een delegatie van de fractievoorzitters. Dit was een goede gelegenheid om voor mijzelf mijn ervaringen als burgemeester van Leiden in de afgelopen drie jaren op een rij te zetten.

Burgemeester van Leiden: een mooie, maar veeleisende baan. Als burgemeester heb ik een aantal rollen te vervullen: voorzitter gemeenteraad, voorzitter college van B\&W, bestuurder, burgervader, ambassadeur. Als bestuurder heb ik de verantwoordelijkheid voor politie, brandweer en ambulancevervoer in de gemeente. En dan is er nog het voorzitterschap van de Stichting Pieterskerk Leiden. Bovendien heb ik een aantal belangrijke 
regionale functies. Zo ben ik voorzitter van het Samenwerkingsorgaan Leidse regio, korpsbeheerder van de politieregio Hollands Midden, voorzitter van de regionale brandweer en van de GHOR (medische hulpverlening bij rampen). Interessante, maar tijdrovende functies. Daarnaast heb ik in de loop van de tijd enkele landelijke functies aanvaard. Daar ben ik selectief in geweest. Ik moet ze met voldoening kunnen vitoefenen, maar ze moeten ook voor de gemeente(n) van belang zijn. Ik ben vorig jaar als vertegenwoordiger van de decentrale overheden lid geworden van het bestuur van het ABP, ben nu lid van de Raad voor de Financiële Verhoudingen en lid van het Bestuur Kenniscentrum Grote Steden Beleid.

Zonder meer staat bij mijn evaluatie voorop, dat Leiden een prachtige stad is, met een mooie oude binnenstad, een rijke historie, een bloeiend verenigingsleven, een zeer bij de stad betrokken bevolking, goede onderwijsvoorzieningen, een klassieke, maar tegelijkertijd moderne universiteit, en vitdagende ontwikkelingsmogelijkheden. Kortom, een prachtige stad om te besturen, met vele plezierige en interessante contacten.

Bij dat besturen is er wel een aantal aandachtspunten om op te letten. Ik moet voortdurend schakelen tussen de vele functies en rollen. Een belangrijk punt is ook, dat door de publieke opinie in de stad aan mij als burgemeester grote invloed op het beleid wordt toegedacht. Als boegbeeld van de stad word ik ook geacht dat vit te stralen, maar in werkelijkheid zijn mijn directe beleidsverantwoordelijkheden binnen de gemeente als benoemde functionaris zeer beperkt.

Min of meer in het verlengde hiervan ligt dat ik als benoemde functionaris geacht word boven en buiten de politiek te staan en in raad en college als zodanig te opereren. In Leiden is deze traditie nogal sterk, een concrete aanduiding daarvan is dat bij crisissituaties wethouders en fractievoorzitters overleggen, zonder de burgemeester. Tegelijkertijd is er wel een sterk verlangen dat de burgemeester op de hoogte is van wat er leeft in fracties en politieke partijen. Uiteraard heb ik ernaar gestreefd aan de verwachtingen te voldoen, maar gelet op de tegenstrijdigheid van de verwachtingen is dat een moeilijke opgave.

Daarbij is ook een factor geweest dat de afgelopen jaren vrij tumultueus zijn verlopen: tussentijdse wisseling van de coalitie, vervanging van vijf wethouders, groot verloop van raadsleden en drie opeenvolgende gemeentesecretarissen. Hoewel ik als burgemeester daar het beste van heb gemaakt, heb ik daar als persoon wel moeite mee gehad.

Raad en college zijn de bakermat van een burgemeester. Maar ook daarbuiten heeft hij tal van functies en rollen te vervullen. Bij mijn evaluatie heb ik terugblikkend onderkend, dat het een belangrijk punt van aandacht moet zijn om intern steeds goed te presenteren met welke zaken buiten raad en college ik bezig ben en welke belangen ik elders voor Leiden behartig.

Daarbij is het ook zaak - gelet op gebleken misverstanden - om de formele posities goed te belichten. Twee zaken verdienen in dat verband nog specifieke aandacht. Het korpsbeheerderschap is een wettelijke functie, waar ik niet in het bijzonder de belangen van Leiden dien te behartigen, maar die van de hele regio. In de SLR ben ik als Leidse burgemeester onafhankelijk voorzitter en vertegenwoordigt de wethouder regiozaken Leiden in het dagelijks bestuur.

Een meer algemeen punt is nog dat het vereiste tijdsbeslag van de vele functies en rollen bij een goede en zorgvuldige taakvervulling zo groot is, dat er voortdurend keuzes moeten worden gemaakt. Mijn politieke en ambtelijke omgeving dringt ook aan op het maken van keuzes en pleit voor het leggen van prioriteit bij die zaken welke het beste bij mijn sterke kanten passen. Maar we weten: bij prioriteiten horen posterioriteiten. En vervol- 
gens is er dan kritiek mogelijk op de gemaakte keuze. Een soortgelijk punt geldt ten aanzien van de voorbereiding van de vele activiteiten. Ook hier moet ik gelet op tijdsbeslag en omvang van ondersteunende en adviserende ambtelijke capaciteit noodgedwongen concessies doen. Ik onderken dat ik gelet op mijn achtergrond en persoon in de afgelopen jaren wel enige moeite heb gehad met de acceptatie van de te grote oppervlakkigheid die daarmee soms noodgedwongen gepaard gaat.

Hoe is nu mijn positie op dit moment tegen de achtergrond van gebeurtenissen en gesprekken in de afgelopen weken? Ik had mij voorgenomen om na het voortgangsgesprek bij de CdK op 15 april op mijn evaluatie van de afgelopen jaren bij de raad terug te komen, de verschillende aandachtspunten ter harte te nemen en daar iets mee te doen. Daarvoor zag ik ook goede mogelijkheden, omdat we raadsbreed hadden afgesproken om ons te gaan bezinnen op de bestuurscultuur onder het nieuwe dualistische bestel, waarbij de rollen van raad, college en burgemeester expliciet aan de orde zouden komen. De hiervoor gesignaleerde punten vergen expliciet aandacht, ook gelet op mijn dubbelfunctie van voorzitter Raad en voorzitter College in het dualistische bestel.

Een verstorende factor in dit verband is geweest dat informatie over de vertrouwelijke gesprekken in de openbaarheid werd gebracht. Dit heeft nadelige consequenties gehad voor mijn positie in Leiden. Hoe de feiten wederzijds ook worden gezien, beeldvorming is voor mijn functioneren als publieke ambtsdrager essentieel.

De afgelopen anderhalve maand is voor mij een zeer ingrijpende periode van evaluatie geweest. Alles op een rij zettend: het geheel van gesprekken, reacties, informatielekken, met andere woorden het geheel van feiten en beeldvorming, heeft voor mij als einduitkomst, dat ik u moet meedelen dat het mij niet mogelijk lijkt nog langer te functioneren als burgemeester van Leiden en dat ik afstand zal doen van de verantwoordelijkheden die aan de functie verbonden zijn.

Scheidend burgemeester Postma wordt opgevolgd door waarnemer W. Lemstra. Een ervaren 'rot in het vak', oud-gemeentesecretaris van Amsterdam, oud-secretaris generaal, oud-burgemeester van Hengelo. Hij wordt gebeld door Commissaris van de Koningin J. Franssen, die hem aangeeft dat het om een waarneming van een maand of drie, vier zal gaan. "Volgens mij wisten wij beiden wel dat het wel eens iets langer zou kunnen zijn, maar we hebben het zo gelaten." Lemstra voelt zich aangetrokken tot Leiden, de stad die hem doet denken aan Amsterdam: "Leiden is natuurlijk kleiner, maar heeft ook een universiteit, een ongeregelde, kritische gemeenteraad en jonge wethouders die er volop tegenaan willen gaan. Ik vond het heerlijk, ik was als een grootvader met jongelui om me heen. Het heeft ook goed gewerkt, ze mochten van mij scoren en eventueel weer komen uithuilen."

Ook Lemstra blijft een vertrek niet bespaard. Het gaat dit keer echter om een vrolijke reden: wethouder $\mathrm{M}$. Schultz van Haegen wordt benoemd tot staatssecretaris van Verkeer en Waterstaat en verdwijnt uit de Leidse politiek. Haar opvolger wordt VVD-er A. Geertsema. 
De procedure om te komen tot een nieuwe burgemeester is inmiddels gestart en nadert de ontknoping. De bedoeling was een burgemeestersreferendum te organiseren, maar nadat de vertrouwenscommissie maar één persoon benoembaar acht, gaat dit niet door. De raad besluit VVD-er H. Groen voor te dragen. Minister van Binnenlandse Zaken Remkes gaat niet akkoord met het in dit stadium van de procedure nog laten vallen van het referendum en het feit dat de oud-wethouder van Amsterdam als enige op de aanbeveling staat. De procedure moet over en er melden zich meer kandidaten.

De raad besluit opnieuw tot een refe-

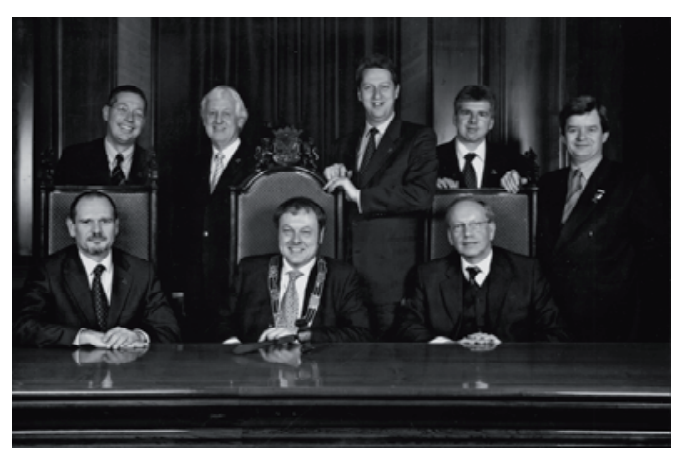
rendum, waarin Groen het moet opnemen tegen de Arnhemse wethouder $H$. Lenferink. Lenferink komt in maart 2003 tot een duidelijke overwinning. Hij wint volgens insiders door een aantal handige keuzes: zo logeert hij bij Leidenaren thuis, daar waar Groen in een hotel verblijft. Ook zijn belangstelling voor de historie van Leiden (Lenferink is opgeleid als historicus) doen het goed bij de trotse

Het college van $B \& W$ van Leiden vit 2003, met boven v.l.n.r. de heren R. Hessing, W. de Boer, $R$. van der Sande, H. Buijing en A. Geertsema. Leidse bevolking. Lenferink wordt op 16 mei 2003 formeel geïnstalleerd als burgemeester. Ook D66 brengt een wisseling in het college aan: wethou$\operatorname{der}$ A. Pechtold wordt benoemd tot burgemeester van Wageningen in oktober 2003 en vertrekt. Zijn opvolger is partijgenoot R. Hessing. Van gedwongen vertrek is in beide gevallen dus geen sprake, maar dat verandert als het in de gemeenteraad opnieuw gaat over ...De Zijl Bedrijven (DZB), het sociale-werkvoorzieningschap, waar eerder al wethouder Laurier over struikelde. Zijn opvolger M. Rabbae, die eerst wegens gezondheidsproblemen al enige tijd was vervangen door partijgenoot $W$. de Boer, neemt verantwoordelijkheid voor de opnieuw ontstane problemen en treedt af. In april 2004 komt De Boer permanent in het college terecht. Hierna blijft de coalitie verdere averij bespaard en blijven alle wethouders op hun post.

\subsubsection{Periode 2006-2010}

De verkiezingen in 2006 laten een behoorlijke verschuiving zien in de Leidse politiek. De PvdA wint twee zetels en komt op tien, D66 keldert van vijf naar twee, maar het meest opvallend: de SP verdubbelt ruim in aantal zetels en gaat van drie naar zeven zetels. Tot enthousiasme van lijsttrekker M. van den Berg van de PvdA, die onmiddellijk aankondigt dat een heus links college nu tot de mogelijkheden behoort en de absolute voorkeur verdient. VVD en D66 worden op die manier vrij snel 'afgeserveerd'. Teleurgesteld laat de VVD weten toch al niets te zoeken te hebben in zo'n links college. Onderhandelaar H. Keereweer van de PvdA, die de zieke Van den Berg later als fractievoorzitter vervangt, kijkt er achteraf met gemengde gevoelens op terug: "Wij vonden dat de winnaar, dus de SP, mee moest doen. Er speelde in die tijd ook op landelijk niveau de 
vraag of de SP zou moeten meebesturen, dus er was grote belangstelling voor onze keuze van landelijke politici. Maar het was wel een grote breuk met het verleden. Achteraf weet ik niet of ik dat nog een keer zo zou doen." De partijen die aan tafel komen zijn dus PvdA, SP en GroenLinks, goed voor 21 van de 39 raadszetels. Om de marge iets groter te maken wordt ook de ChristenUnie uitgenodigd.

Burgemeester Lenferink krijgt van alle partijen het verzoek als informateur de onderhandelingen te leiden. Hij doet het: "De PvdA-fractie was vrijwel geheel nieuw. Dat gold hetzelfde voor de raadsleden van de SP. Die partij kwam in één keer op zeven zetels, met allemaal nieuwe raadsleden. Gold ook voor de ChristenUnie. Er was niemand meer met bestuurlijke ervaring. Er zaten raadsleden met elkaar te praten die van toeten noch blazen wisten. Die wisten helemaal niet waar het over ging. Ik vond dat ik er dan zelf maar beter bij kon gaan zitten." Lenferink realiseert zich dat het lastige onderhandelingen zullen worden: "Het moest lukken, in de wetenschap dat er nauwelijks een alternatief was. Andere partijen waren afgeserveerd, daar kon je niet bij terugkomen. Dus ze moesten eruit komen."

Na lang onderhandelen, waarbij af en toe ook deskundigen van buiten worden ingezet, blijven er uiteindelijk twee grote knelpunten over: de ontwikkeling van het enige nog onbebouwde terrein in de stad (de Oostvlietpolder) tot bedrijventerrein en de aanleg van de Rijn Gouwe Lijn (RGL). Op beide dossiers komen de partijen er niet uit. Bij het eerste dossier wordt besloten de beslissing aan de Raad van State te laten, waar het vraagstuk dan al enige tijd ligt. Als de Raad van State positief is, gaat de ontwikkeling van de Oostvlietpolder door, bij een negatief oordeel stopt de ontwikkeling. Lastiger ligt de besluitvorming rondom de aanleg van de RGL. Deze hoogwaardige openbaar vervoer verbinding is het paradepaardje van de provincie en dient door Leiden heen te lopen. Een tracé door de Breestraat in het centrum van Leiden is daarbij een optie. De $\mathrm{SP}$ is mordicus tegen en eist een referendum. Uiteindelijk komt hier overeenstemming over. Lenferink: "De gedachte was dat het een A-B referendum zou worden, waarbij de kiezers zich zouden kunnen uitspreken over twee tracés. Dat was acceptabel, want zo zou er altijd een oplossing komen." Met deze afspraken gaan de partijen van start.

De PvdA kiest niet meer voor de zittende wethouders, Hillebrand en Buijing. Voor beiden is het een teleurstelling. Met name het vertrek van wethouder Hillebrand (die door zijn stevige opvattingen en stellige manier van doen in de wandelgangen de bijnaam Ron Beton heeft gekregen) is verrassend. Pas op het allerlaatste moment wordt, in ieder geval voor de buitenwereld, duidelijk dat er nieuwe wethouderskandidaten zijn: mw. G. van den Berg en M. Witteman, oud-wethouder in Hillegom en waarnemend burgemeester van Warmond. De SP treedt toe tot het stadsbestuur met de wethouders R. Keur en P. Jonas. Ook GroenLinks komt met een nieuw gezicht: J. Steegh vervangt W. de Boer. De ChristenUnie draagt F. van As voor. Het betekent dat burgemeester Lenferink, zelf ook nog maar drie jaar in functie, al de meest ervaren kracht is.

Het nieuwe college blijkt een kort leven beschoren. Het referendum over de RGL levert een ander beeld op dan tijdens de onderhandelingen werd gedacht. Eén van de twee varianten blijkt veel te duur en valt weg als alternatief, waardoor er nog maar één variant over is. De vraag verschuift dus van een A-B vraagstelling naar een ja/nee vraagstelling. Sommigen zeggen achteraf dat dat bij de start van het college al duidelijk had kunnen 
zijn. Fractievoorzitter Keereweer van de PvdA is echter zeer teleurgesteld en wijst op eerdere ambtelijke notities: "Het ene tracé zou destijds, als ik het me goed herinner, 35 tot 40 miljoen kosten, het andere rond de 70 miljoen. Dat was meer, maar daarmee zouden ook enkele belangrijke ongelijkvloerse kruisingen met de spoorlijn LeidenUtrecht worden aangelegd. Dus die extra investeringen vonden wij verdedigbaar. Maar toen bleek dat de 70 miljoen niet haalbaar was, het moest 170 miljoen worden. Ik vond dat echt ongelofelijk, je moet toch kunnen vertrouwen op ambtelijk advies."

$\mathrm{Na}$ deze verandering neemt de Leidse gemeenteraad afscheid van het te dure tracé, waardoor er maar één alternatief over is en het ja/nee referendum een feit wordt. Lenferink voorziet al snel dat het fout gaat: "lk dacht: dit gaat niet goed. Het zou tot dramatische gevolgen leiden bij een nee. En dat gebeurde ook. Het kwam tot een overtuigend 'nee' tegen de RGL."

De coalitie zit ermee in de maag. Wat zou er met dit nee moeten gebeuren? Er wordt lang gedacht, gewikt en gewogen. Hoogwaardig Openbaar Vervoer (HOV) wordt in een groter verkeer- en vervoersplan opgenomen. Er worden nieuwe varianten bedacht, nieuwe tracés, waar eerst bussen en pas later trams op zouden gaan rijden. De coalitiepartijen lijken zich er wel in te kunnen vinden, maar de provincie Zuid-Holland ziet het anders. Geen gezeur, is het devies, de RGL moet er komen. Het provinciebestuur is bereid haar 'doorzettingsmacht' in te zetten en de lijn zelf aan te leggen. Lenferink betwijfelt achteraf of dat makkelijk haalbaar was geweest, maar wil het ook niet voor de rechter vitvechten. "Ik denk dat ze daar een zware dobber aan hadden gehad, ze hadden zich veel op de hals gehaald, met grote financiële consequenties. Ik denk dat ze het moeilijk hadden gehad. Maar tegen elkaar procederende overheden, dat moet je niet willen."

Achter de schermen wordt druk naar oplossingen gezocht. Een nieuw tracé lijkt toch haalbaar en lijkt in de stad minder weerstand op te leveren. Toch lukt het uiteindelijk niet om de coalitie op één lijn te krijgen. SP en ChristenUnie vinden dat de referendumuitslag duidelijk 'nee' was tegen de RGL en dat andere tracés zo'n uitslag niet respecteren. Beide partijen besluiten uit de coalitie te stappen. Lenferink: "Uiteindelijk zei men: het referendum zei: nee, dus wij vechten nu voor nee. Dat was de positie." Achter de schermen ligt er dan echter wel een overeenkomst met het provinciebestuur over een alternatief tracé, gekoppeld aan de aanleg van de Ringweg Oost. Het overblijvende deel van het college vond dat daarmee een behoorlijke slag kon worden geslagen: het 'hete Leidse hangijzer' van de RGL werd opgelost en er kwam een al langer gewenste Ringweg bij.

De in concept gemaakte afspraken met het provinciebestuur kunnen de goedkeuring van de gemeenteraad echter bepaald niet dragen. In de vergadering na het opstappen van SP en ChristenUnie dringt D66 er op aan op basis hiervan het vertrouwen in het resterende college op te zeggen en dient een motie van wantrouwen in. De SP zou hier vóór zijn, waardoor een ruime meerderheid van de raad ook de rest van de wethouders zou willen ontslaan. Lenferink grijpt in en roept de fractievoorzitters van enkele partijen bij elkaar: "lk heb gezegd, luister, als jullie dit nu doorzetten, dan beschadig je de verhoudingen zodanig, dat het heel moeilijk is om na vanavond nog weer met elkaar om de tafel te gaan zitten om een nieuwe coalitie te vormen. Dus denk even na over de tijd na vanavond." Het pleidooi van de burgemeester leidt ertoe dat de motie van 
wantrouwen wordt gewijzigd in een motie van afkeuring (zie kader), die nog altijd duidelijke taal spreekt, maar de wethouders wel demissionair verder laat functioneren.

De gemeenteraad van Leiden, bijeen op 16 oktober 2007,

Constaterende dat,

de wethouders Keur en Jonas hun ontslag hebben aangeboden;

Tevens constaterende dat,

door de resterende collegeleden een brief aan de provincie is verstuurd met als doel overeenstemming te bereiken over de RijnGouweLijn;

Overwegende dat, het college nog slechts op de steun van een minderheid in de raad kan rekenen; het niet wenselijk is dat belangrijke en controversiële besluiten en voorstellen gedaan worden zonder de steun van een meerderheid van de Leidse gemeenteraad; de RijnGouweLijn als een controversieel onderwerp beschouwd mag worden;

Spreekt als haar mening uit, dat de brief van de resterende collegeleden aan de provincie inzake de RGL als niet verzonden beschouwd moet worden en keurt het verzenden van deze brief af; dat het college gevallen is;

\section{Verzoekt}

de nog zittende wethouders, tot het moment dat een nieuw college is aangetreden, al datgene te doen dat noodzakelijk is voor goede voortgang van de werkzaamheden;

En gaat over tot de orde van de dag.

Paul van Meenen (D66)

Zonder hoofdelijke stemming wordt de motie aanvaard, met dien verstande dat de fracties van PvdA, GL en CU geacht worden tegen de motie gestemd te hebben.

Het demissionaire college kan blijven zitten, er starten nieuwe onderhandelingen. De informatiefase wordt geleid door oud-rector magnificus van de Leidse Universiteit D. Breimer en oud-wethouder en oud-staatssecretaris M. Schultz van Haegen. Zij adviseren de terugkeer van zowel CDA als VVD. De formatiefase die hierop volgt staat onder leiding van twee andere externen: GroenLinkser G. van Hees en D66-er $\mathrm{O}$. Welling, beiden voormalig raadslid en fractievoorzitter. Het is het begin van een moeizaam, twee maanden durend onderhandelingsproces. Er vinden vele gesprekken plaats, volgens insiders wordt er bijzonder veel 'gesteggeld' over woordjes. Er zitten partijen bij elkaar die elkaar niet of nauwelijks vertrouwen, er is veel oud zeer. Woorden die gesproken zijn blijken nog vers in het geheugen te zitten, de gesteunde motie van afkeuring zit lange tijd nog dwars in het keelgat. Bovendien zijn de onderhandelaars onervaren: de fractievoorzitters van GroenLinks en de PvdA worden aan het begin van de onderhandelingen benoemd, de fractievoorzitter van de VVD zit er enkele weken. 
Uiteindelijk lukt het toch een nieuw college te vormen, waarin VVD en CDA terugkeren. De VVD vaardigt de eerder dat jaar in Den Haag opgestapte wethouder P. van Woensel af. Hij krijgt de belangrijke portefeuille Ruimtelijke Ordening: "Toen ik aantrad hoorde ik dat een groot deel van de stad verheugd was dat sinds het vertrek van de Spanjaarden nu eens geen PvdA-er op RO zat", herinnert hij zich. CDA komt met de eveneens jonge fractievoorzitter J. de Haan. De wethouders van PvdA en GroenLinks blijven aan, waardoor er vijf wethouders zijn.

In 2008 en 2009 normaliseren de verhoudingen zich enigszins. De collegeleden spreken zelfs van 'uitstekende verhoudingen' in het college, waarbij wethouders elkaar proberen te helpen en behoeden voor valkuilen, ondanks de soms felle discussies. "Het was een zeer productieve periode, maar te kort", aldus Lenferink. Buitenstaanders karakteriseren het college echter meer als een vechtcollege, waarvoor de verkiezingen in maart 2010 geen moment te vroeg komen. Lenferink spreekt dat tegen en wijst op de goede verhoudingen in het college, in tegenstelling tot die in de coalitie.

Het college zal de verkiezingen echter niet ongeschonden halen. GroenLinkswethouder J. Steegh stapt in januari 2010, twee maanden voor de verkiezingen, op. Het gaat om de komst van een parkeergarage in de wijk Transvaal, waarvan is afgesproken dat deze er komt, maar dat er ook flankerende maatregelen komen. In de raadsvergadering van januari 2010 dient GroenLinks hierover een motie in, naar verluidt zonder deze af te stemmen met de andere partijen. Er staan onhaalbare zaken in, menen de coalitiepartners, die GroenLinks verdenken van een verkiezingsstunt. De partijen komen niet meer tot elkaar en een vertrouwensbreuk is het gevolg, de derde in de onderzochte periode van twaalf jaar. Zonder GroenLinks hobbelt de coalitie van PvdA, CDA en VVD, nog wel goed voor een nipte raadsmeerderheid, naar de verkiezingen toe.

\subsection{De analyse op microniveau}

$\mathrm{Na}$ de beschrijving van de gebeurtenissen, noodzakelijkerwijs een beschrijving op hoofdlijnen, is het mogelijk de verschillende aspecten te analyseren. Dit gebeurt wederom op micro-, meso- en macroniveau.

\section{Microfactor: de burgemeester(s)}

Burgemeester zijn in Leiden is een prachtige baan, die veel vraagt. Daarover zijn de voor dit onderzoek geïnterviewde betrokkenen het eens. Zeker in Leiden is het een zeer publieke functie: "De eerste burger moet zich veel laten zien", zegt oud-waarnemend burgemeester Lemstra. "Zeker in Leiden, waar zoveel ontzettend leuke evenementen zijn dat er zelfs een coördinator voor is. Hoogtepunt is natuurlijk Leidens Ontzet op 3 oktober, dan ben je als burgemeester de hele dag zichtbaar en in touw. Maar er zijn ook veel verenigingen, het barst van de toeristen, de terrassen zitten vol, de burgemeester moet overal bij zijn en zich laten zien."

Op het politieke vlak is het vooral zaak goed te weten hoe het 'spel' loopt, want van het spelen van een politiek spel is vaak sprake in Leiden. Burgemeester Goekoop had daar volgens zeggen geen probleem mee. Hij was bijna 20 jaar burgemeester en kende zijn pappenheimers wel. "In het college wist hij precies op welke momenten hij moest ingrijpen en op welke momenten de discussie nog wel even door kon gaan", zegt de toenmalige loco-secretaris (huidig griffier) Van der Vlist. De opvolger van Goekoop, 
J. Postma, worstelde daar echter mee en vond de rol van burgemeester in Leiden tegenstrijdig. Hij had er ook geen lol in, volgens betrokkenen. "Volgens mij zat hij in de verkeerde film. Het was gewoon niet zijn baan", aldus Van Gruting (VVD), die overigens nog steeds schande spreekt over het in die periode lekken van vertrouwelijke informatie: "Ik heb dat lekken uit vertrouwelijke gesprekken als traumatisch ervaren. Er spreekt vit dat voor sommigen politiek echt oorlog is, waarbij alles is geoorloofd, zelfs het gedrag van een farizeeër. Dat heeft ook weerslag op anderen in de raad."

De opvolger van Postma, waarnemer Lemstra, wist volgens ingewijden het spel beter te spelen. Hij floot volgens zeggen de 'haantjes' in het college regelmatig terug, maar op een manier die werd geaccepteerd. Postma was dit minder gegeven.

Huidig burgemeester Lenferink kon en kan bogen op veel ervaring in de lokale politiek. Hij was jarenlang wethouder in Arnhem en is volgens sommigen nog steeds wethouder, maar dan in Leiden. Hoe het ook zij, als burgemeester kreeg hij zijn vuurdoop al in de eerste collegevergadering. Hij vertelt er smakelijk over: "Op de agenda stond de perspectiefnota van dat jaar. Ik had al gehoord van mijn voorganger dat men daar niet uit kwam en er niet meer met elkaar over wilde praten, maar dat er wel een probleem zat: er was een tekort. Het was de eerste keer dat het op de agenda kwam. Binnen een kwartier was het: 'Boem'. Na een half uur verliet één van de wethouders uit boosheid de kamer. Toen zat ik met iets dat leek uit te draaien op een collegebreuk. Ik dacht: dat is toch ook wat, in mijn eerste vergadering. Toen heb ik als een postiljon d'amour gefungeerd tussen de kamers om de mensen weer aan het praten te krijgen." Wat volgde waren extra vergaderingen, waarin Lenferink het college drie keuzes aanbood: "Ik zei: we kunnen de gemeenteraad een brief sturen, met de mededeling: er komt geen perspectiefnota, want we komen er niet uit en hoe het met het college gaat hoort u nog. Variant twee is: we kennen elkaar zo goed, kennen alle argumenten, als je eruit wilt komen kun je het in vijf minuten regelen met een politiek compromis. De derde variant is: ik doe een voorstel. De derde vonden ze wel grappig, van die nieuwe burgemeester." Op basis van het voorstel van Lenferink kwam de zaak weer in beweging en bleek een compromis mogelijk. "Voor mijn entree was het prettig, maar het geeft aan hoe spannend de dingen waren. Heel regelmatig waren er thema's, die hup weer uit de hand liepen en met politiek overleg gedownsized moesten worden." Burgemeesters die dit spel niet beheersen hebben het in Leiden moeilijk, is uit de praktijk op te tekenen. Als ze het wel beheersen, kan er zeker een conflict-dempende werking van de burgemeester vitgaan.

Verwachting 1 luidt: In bestuurlijke probleemgemeenten legt de burgemeester weinig bindend vermogen aan de dag, waardoor de potentiële dempende werking van de burgemeester afwezig is. De conclusie is dat deze verwachting alleen in de periode 1998-2002 is uitgekomen. In de perioden erna fungeerden er (waarnemend) burgemeesters, waar wel een dempende werking van uit ging.

\section{Microfactor: de wethouder(s)}

Opvallend is dat vrijwel alle betrokkenen in Leiden het erover eens zijn dat persoonlijke risicofactoren van wethouders een belangrijke rol speelden in de sleutelstad, in alle perioden. In Leiden bekleedden in de onderzoeksperiode in totaal 21 personen voor 
korte of langere tijd het wethoudersambt. Van deze 21 dienden er negen voortijdig te vertrekken, kwamen er vijf na de verkiezingen van 2006 niet meer terug in het college en kozen er drie zelf voor een andere baan. De resterende vier wethouders zaten nog op hun post aan het einde van de onderzoeksperiode in maart 2010.

De risicofactoren uitten zich vooral in het persoonlijk optreden van de wethouders. Zeker in de eerste twee perioden van dit onderzoek, 1998-2006, waren er wethouders actief met grote ego's, die soms enigszins regentesk gedrag vertoonden. "Ik weet wel wat goed is voor de stad", was de gedachte. De wethouders lieten zich door niets weerhouden, niet door hun collega's in het college en al zeker niet door het ambtelijk apparaat. "Sommige wethouders hadden bijna minachting voor het ambtelijk apparaat, op het groteske af. Die minachting uitte zich door ze regelmatig te overrulen en ze geen ruimte te geven", aldus oud-burgemeester Lemstra. Oud-wethouder Schultz van Haegen, waarvan door velen gezegd wordt dat ze een conflict-dempende rol speelde in het college, ziet in zo'n houding ook een risico voor de kwaliteit van de ambtelijke voorstellen: "Ambtenaren gaan in zo'n cultuur, waarin ze figuurlijk gesproken worden geslagen in plaats van gesteund, niet excelleren. Als je niet geprezen wordt, ga je niet excelleren. Het gevolg was dat er risicomijdend gedrag werd vertoond: de wethouder kreeg te horen wat hij wilde horen, in plaats van wat hij zou moeten horen."

De werkwijze van sommige wethouders riep weerstand op in het college, maar zeker ook in de raad: "Ik heb wel eens gezegd: jullie krijgen nog eens een koekje van eigen deeg", aldus Lemstra. In de Leidse praktijk is duidelijk geworden dat het vertrek van sommige wethouders in de periode 1998-2006 in de hand werd gewerkt doordat hun 'bestuurlijk krediet' geheel op was. Na 2006 trad een nieuwe generatie wethouders aan, die collegiaal bestuur belangrijker vonden. De grootste crisis in deze laatste raadsperiode ging ook niet om het vertrek van een wethouder, maar om een collegecrisis om een al heel lang spelend hot item in de Leidse politiek: de Rijn Gouwe Lijn. Toch is ook in deze periode een wethouder een aantal keren door het bestuurlijke oog van de naald gegaan, als het om steun van de gemeenteraad ging. Hierbij ging het echter meer om het bestuurlijk optreden van de betreffende wethouder zelf. In het algemeen kan gesteld worden dat wethouders het in de Leidse politiek vrij snel moeilijk kunnen krijgen. "Leiden heeft al heel lang last van een vrij verpolitiekte raad, waarin heel veel dingen snel politiek worden. Het is lastig om daarin te manoeuvreren", zegt huidig burgemeester Lenferink. "Als wethouder moet je sterk zijn, om dat te overleven. Als je als wethouder sterk in het debat bent, heb je een voorsprong. Dan kun je je goed weren in de raad en gaat het ook makkelijker. Als je zwak bent, zwakker, ben je snel aangeschoten wild. Als je het een beetje luchtig weet te houden, op kritiek met een zekere luchtigheid weet te reageren, is het niet moeilijk. Het is een kunstje. Zeg op tijd: dit was niet goed, sorry, en ga daar met enige luchtigheid overheen. En maak het vooral niet te zwaar." Wethouders die dit spel beheersen, redden het wel in Leiden, anderen hebben het zwaarder.

Verwachting 2 lvidt: In bestuurlijke probleemgemeenten hebben de persoonlijke risicofactoren van één of meer wethouder(s) een aanjagende werking op bestuurlijke problemen. De conclusie is dat er ruim voldoende steun is gevonden in Leiden voor deze verwachting, die dus vitkomt. De analyse maakt duidelijk dat de persoonlijke risicofactoren in Leiden op 
verschillende manieren een rol speelden in het verleden. Soms hadden wethouders wel een heel prominente manier van doen, wat het afbreukrisico verhoogde. Hun reflectie was gering of afwezig en ze bleven doen zoals ze deden. Het adaptief vermogen was gering. Soms ook hadden wethouders moeite met de Leidse bestuurscultuur en leidde dat tot groter besturrlijk risico.

\subsection{De analyse op mesoniveau}

Op mesoniveau gaat het om betrekkingen, in het college, tussen college en raad, college en ambtelijke organisatie en tussen de coalitiepartijen.

\section{Mesofactor: het college}

De colleges in Leiden waren in de eerste twee onderzochte perioden echte wethouderscolleges. Dat zijn colleges waarin van collegiaal bestuur weinig sprake is: wethouders hebben hun eigen beleidsagenda, hun eigen zaken die ze willen realiseren. Collega's in het college werden soms gezien als te nemen hindernissen, vindt wethouder Schultz achteraf: "Collegevergaderingen doorstonden in mijn periode de vergelijking met een arena moeiteloos. De belangrijkste vraag voor iedere individuele wethouder was: hoe krijg ik mijn stuk er vandaag door? Hoe komen wij gezamenlijk tot goede oplossingen was een nauwelijks gestelde vraag. Veel zaken werden onmiddellijk geproblematiseerd. 'Zit er nu een mes in mijn rug of niet'?, heb ik wel eens gedacht. Het was een heftige tijd, waarbij de wethouders ook geen helpende hand aan elkaar boden. Als iemand in de problemen kwam, stak er niemand een hand uit."

De colleges waren in de regel niet overbemand en stoelden ook niet op een te ruime meerderheid in de raad, waardoor niemand zich verantwoordelijk zou kunnen voelen voor het college. Maar zowel op het gebied van homogeniteit als verhoudingen slaagden de colleges er niet in uit te groeien tot sterke gehelen. In de volgende perioden kwam hier enige verbetering in en werd de collegialiteit groter. Het leek er ook op dat het nieuwe college, dat na de crisis in 2007 aantrad, de eindstreep zou gaan halen. Door verwikkelingen met betrekking tot de coalitie lukte dit uiteindelijk niet.

Verwachting 3 luidt: In bestuurlijke probleemgemeenten kunnen colleges niet sterk worden, waardoor de potentiële dempende werking van een sterk college afwezig is. Deconclusie is dat deze verwachting vitkomt in de eerste bestudeerde periode in Leiden. De tweede periode geeft een wat diffuser beeld, in de derde periode was de collegialiteit groter en komt de verwachting niet vit.

Mesofactor: de relatie van het college met de ambtelijke organisatie Veel wethouders hadden, zeker in de eerste jaren van de onderzochte periode, niet veel op met de meeste ambtenaren en vonden dat ze de belangrijke stukken eigenlijk nog het beste zelf konden schrijven. Van veel ambtelijk tegengas was geen sprake. Het betekende ook dat stukken pas op de collegetafel kwamen als de betreffende wethouder het er helemaal mee eens was. Bij afwijkende meningen tussen de ambtelijke leiding en de wethouder moest de eerste dus het onderspit delven en het advies of voorstel aanpassen. De laatste paar jaar van de onderzoeksperiode is getracht hier verandering in te brengen, onder leiding van gemeentesecretaris P. van den Wijngaart. "Vroeger had vrijwel elke wethouder een eigen dienst, alles was eigenlijk gefocust op 
de wethouder. De wethouder was de machtsbron, daar kwam het vandaan. Gezond is het niet, het ontkent ook de ambtelijke professionaliteit. Inmiddels hebben wij een trendbreuk geforceerd: als de wethouder en de dienst er niet uit komen, komt een stuk toch op de collegetafel. Dat bevordert ook het collegiaal bestuur."

Ook in een onderzoek naar de aansturing van grote projecten in Leiden, waar tal van problemen mee zijn geweest, staan stevige woorden: "In de relatie tussen ambtelijke organisatie, college en raad is gezaghebbend 'nee' zeggen niet ingeburgerd. Onderlinge relaties zijn open en vriendschappelijk, maar tegelijkertijd is er weinig ruimte om kritiek te uiten (...) Door verkokering komt samenwerking tussen verschillende gemeentelijke disciplines moeilijk tot stand. Door conflictmijding worden heldere belangenafwegingen vermeden en spreekt men elkaar beperkt aan op gedrag en prestatie. (...) Gebrek aan sturing en heldere prioriteitstelling gaan gepaard met hoge werkdruk. Belangrijke beslissingen worden laag in de organisatie genomen" (Commissie van Egdom, 2007: 4).

Het Leids gemeentebestuur probeerde overigens wel tot verbetering van de situatie te komen. Zo werd er tweemaal een bestuurskrachtonderzoek gehouden (2002 en 2005), waarbij er in ogen van het gemeentebestuur wel degelijk vooruitgang werd gerapporteerd (Korsten C.S.,2007: 215), al bleef het voornamelijk gaan om papieren exercities. Burgemeester Lemstra probeerde aan prioriteitstelling te doen, door alle managers te vragen vijf topprioriteiten te benoemen. Dat bleek een lastige keuze: alles had prioriteit. Het blijkt een Leids euvel dat ook in 2007 nog niet verholpen was, zoals blijkt uit het rapport over de aansturing van grote projecten: "Het gemeentebestuur heeft grote ambities en geldingsdrang, die op gespannen voet staan met financiële en organisatorische vitvoerbaarheid. Alles is belangrijk. Financiële ramingen zijn vaak te krap" (Commissie van Egdom, 2007: 4).

Verwachting 4 luidt: In bestuurlijke probleemgemeenten zit weinig patroon in de relatie met het ambtelijk apparaat, wat een aanjagende werking heeft op bestuurlijke problemen. De conclusie is dat deze verwachting voor de eerste twee perioden vit komt. De relatie met de ambtelijke organisatie was vele jaren broos, gebaseerd op macht van wethouders. Pas de laatste periode kwam daar verandering in, al blijft het stellen van prioriteiten een probleem.

\section{Mesofactor: de verbinding tussen college en raad}

De verbinding tussen het college en de gemeenteraad heeft na de invoering van het dualisme behoorlijk onder druk gestaan. De raadsleden gingen vlot op in hun nieuwe rol, maar de wethouders hadden er veel moeite mee, herinnert waarnemend burgemeester Lemstra zich. Samen met griffier Van der Vlist ging hij met het dualisme aan de slag. De wethouders verloren hun vaste plek in de raadzaal en mochten pas aanschuiven als ze werden uitgenodigd: "Sommige wethouders hadden zichtbaar moeite met die rol, het was van hun gezicht af te lezen dat ze soms ongelofelijk de pest in hadden." Toch lijkt de invoering van het dualisme niet te hebben geleid tot extra spanning in de relatie tussen college en gemeenteraad. Cru gezegd: die spanning was er toch al wel, de verbinding stond altijd al onder enige druk.

In de laatste bestuursperiode is getracht meer patroonmatigheid in te bouwen in de contacten, zeker bij moeilijke dossiers (zie de volgende factor). Hier is een aantal keer 
met succes gebruik van gemaakt. Geconstateerd kan worden dat op het moment dat een partij geen gebruik maakte van het vooroverleg en voor een eigen (al snel openbare) aanpak koos, zoals GroenLinks deed bij de parkeergaragecrisis in 2010, dit vrij snel tot een bestuurscrisis leidde.

Verwachting 5 lvidt: In bestuurlijke probleemgemeenten zit geen of weinig patroon in de relatie tussen het college van $B \& W$ en de gemeenteraad, wat een aanjagende werking heeft op bestuurlijke problemen. De conclusie bij deze verwachting is dat er in de eerste periode geen eenduidig beeld is, maar dat deze in de perioden hierna niet is vitgekomen.

\section{Mesofactor: de verbinding tussen de coalitiepartijen}

De verbinding tussen coalitiepartijen geeft een wisselend beeld in Leiden. In de eerste periode (1998-2002) ging het twee keer snel mis. Het CDA stapte in 1999 uit de coalitie, waarna de VVD er weer in kwam. Hier zat nog wel enig oud zeer vanwege de formatie, waarbij de VVD al vrij snel buiten de boot viel. De crisis van het jaar 2000 kostte weer twee wethouders hun baan. De beste periode voor wat betreft verhoudingen tussen coalitiefracties wordt de periode 2002-2006 genoemd. De coalitie kon vrijwel ongewijzigd doorgaan en ook de fracties en fractievoorzitters groeiden naar elkaar toe. Bij problemen wist men elkaar te vinden. Het vertrek van wethouder Rabbae ging eigenlijk vrij geruisloos en zonder crisisdreiging.

In de periode 2006-2010 waren de verhoudingen tussen de fracties en de fractievoorzitters in het begin best goed. Wel waren veel fractieleiders nieuw en moesten ze aan elkaar wennen. Met name de SP, als partij nieuw in het stadsbestuur, had veel behoefte aan informatie. Al snel ging de aandacht naar het referendum over de RGL en naar de vraag wat dat zou moeten betekenen voor de opstelling van de gemeente, met uiteindelijk de val van het college als gevolg.

$\mathrm{Na}$ de val van de coalitie in 2007 kwamen wethouders van VVD en CDA het college versterken. Ook toen begonnen de fractievoorzitters weer vol goede moed. Er werd regelmatig samen gegeten. Over heikele punten was soms zelfs speciaal overleg, het zogeheten 'wof'- overleg: wethouders overleg fractievoorzitters. "Als gezegd wordt: 'We gaan woffen' betekent dat hele grote shit, groter dan vier fractievoorzitters kunnen oplossen", zegt wethouder Van Woensel. "Dat heb ik al een aantal keren mogen meemaken. Soms ook als er nog geen shit is, maar dan om zaken af te stemmen." Fractievoorzitter Keereweer van de PvdA is ook goed te spreken over de samenwerking van na 2007: "Ik weet dat vanuit het college het geluid soms kwam dat de sfeer tussen de fractievoorzitters niet zou deugen, of dat het lag aan de sfeer tussen de fracties, maar dat heb ik helemaal niet zo ervaren. Ik geloof niet dat het aan de onderlinge sfeer lag. We hadden regelmatig contact, er werd steevast met elkaar gebeld als er iets in de fracties gebeurde. Tot december 2009 is dat prima gegaan, er werd open en eerlijk over allerlei zaken gesproken. 'Bij dat punt moet je me maar vreemd laten gaan over links', werd dan gezegd, of er ging weer een andere partij iets met de oppositie doen, de VVD met de SP of zo. Geen probleem, je moet elkaar ook wel iets gunnen, anders wordt het niets. Daar zijn ook problemen mee opgelost." De fractievoorzitters hadden die ruimte soms ook nodig om de eenheid in hun fractie te kunnen bewaren. 
Toch lukte het op de valreep niet de coalitie bij elkaar te houden: in januari 2010 viel de wethouder van GroenLinks over de komst van een parkeergarage in Transvaal. Hierover was afgesproken in het coalitieakkoord dat die garage er zou komen, terwijl tegelijkertijd zogeheten 'flankerende maatregelen' zouden worden genomen om de verkeersproblematiek in de buurt het hoofd te kunnen bieden. Het college kwam eind 2009 met een voorstel, waar ook de GroenLinks-wethouder achter leek te staan. Grote problemen werden in ieder geval niet gemeld, hoorde Keereweer van zijn wethouders. Ook de fractievoorzitters, die regelmatig met elkaar gingen eten, vernamen geen problemen van GroenLinks. In de commissievergadering liep het mis en liep een deel van de raadsleden, waaronder die van GroenLinks, demonstratief weg. GroenLinks bleek veel meer flankerende maatregelen te willen, anders zou de fractie tegen het voorstel stemmen: "Toen was het al eind december, toen dat voor het eerst boven kwam. De wethouders geloofden het zelfs niet", herinnert Keereweer zich. Op de donderdag van de geplande raadsvergadering vernam hij dat er een motie zou komen van GroenLinks. Het verzoek was er verder met niemand over te praten. Andere partijen werden door het verhaal overvallen. Ondanks vele schorsingen en bemiddelingspogingen lukte het niet meer: de partijen kwamen niet tot elkaar. Het was voorbedachte rade, met het oog op de verkiezingen van maart 2010, denkt Keereweer: "Ik heb er een heel slecht gevoel bij. Het verhaal van GroenLinks is dat wij niet de bereidheid hadden in te stemmen met flankerende maatregelen. Die bereidheid was er echter wel, maar wat ze vroegen kon gewoon niet, wettelijk niet. Maar het hielp niet." Keereweer is teleurgesteld: "Als je je toch zo tegen je natuurlijke partner afzet, de partner die je altijd de hand boven het hoofd heeft gehouden, dat gaat ver. We hebben bij de vorming van het college alles op alles moeten zetten om GroenLinks er nog bij te krijgen, dat wilde de VVD eigenlijk niet en het CDA zag het ook niet zitten. Dat wordt na deze geschiedenis een eventuele volgende keer wel heel lastig."

Het bewaren van de eenheid is in Leiden van speciaal belang vanwege de prominente rol van de oppositie. Met name oppositiepartij D66 speelde een kritische rol, waardoor de eenheid van de collegepartijen op de proef werd gesteld.

Verwachting 6 luidt: In bestuurlijke probleemgemeenten bestaat weinig binding tussen coalitiepartijen, wat een aanjagende werking heeft op bestuurlijke problemen. De conclusie met betrekking tot deze verwachting is dat deze vitkomt in de periode 1998-2002 en 2006 - 2010. In deze laatste periode, waarin de verbindingen goed leken te zijn, ontstond door gebrek aan communicatie (bewust gekozen of niet) een coalitiecrisis.

\subsection{De analyse op macroniveau}

Op macroniveau wordt ook in deze casestudy gekeken naar de bestuursstructuur, de bestuurscultuur en de rol van de media.

\section{Macrofactor: bestuursstructuur}

De gemeenteraad van Leiden kende in de onderzoeksperiode een sinds jaren dominante partij: de PvdA. Na de gemeenteraadsverkiezingen in 2010 (waarvan de betekenis buiten dit onderzoek valt) kwam hier overigens een einde aan: D66 groeide van twee 
naar tien zetels en werd de grootste partij, de PvdA viel terug van tien naar zes zetels. Toch is Leiden wel te typeren als een PvdA-stad, aangezien deze partij altijd prominent aanwezig is geweest in het stadsbestuur.

Afsplitsingen zijn er veel minder geweest en hadden ook geen wezenlijke invloed op de toch al kritische cultuur in de raad. Met een gemiddelde fractiegrootte van meer dan vier personen lijkt de versplintering van de raad niet groot. Toch dient hier een kleine nuancering op gemaakt te worden. Door de aanwezigheid van enkele grote fracties, met zeven leden of meer, vertekent het beeld. In de periode 2006-2010 waren er ook vier fracties met één of twee leden. Dit punt speelde echter geen bepalende rol in het ontstaan van bestuurlijke conflicten of bestuurscrises.

Verwachting 7 luidt: In bestuurlijke probleemgemeenten is sprake van versplintering van het politieke landschap, wat een aanjagende werking heeft op bestuurlijke problemen. De conclusie is dat deze verwachting in Leiden in de onderzochte perioden niet is vitgekomen.

\section{Macrofactor: de bestuurscultuur}

Als betrokkenen het ergens over eens zijn, is het wel over het feit dat de gemeenteraad van Leiden een zeer heftige debatcultuur kent. Huidig burgemeester Lenferink gebruikt het woord 'brisant', waarbij hij de raad vergelijkt met de Tweede Kamer: "Men doet hier graag de Tweede Kamer na. Er zitten ook vrij veel jonge mensen in de raad met een academische opleiding. Die vinden het spel leuk, een aantal is er ook goed in. En dat spel ís natuurlijk ook leuk, zolang het uiteindelijk maar om de inhoud gaat en niet om het spel zelf. Dat ontaardt wel eens en dat is lastig." Lenferink trekt de conclusie dat de tijd en sfeer van de polarisatie, in heel Nederland op gang gekomen in de jaren zeventig en tachtig, in Leiden niet is opgehouden. "De persoonlijke verhoudingen zijn niet beroerd, zo moet je het ook niet zien, maar zodra de hamer is gevallen, de vergadering is begonnen, dan zijn het andere lieden. Dan gaan ze ervoor zitten en is de assertiviteit een stuk groter." De commissie-Van Egdom, die onderzoek deed naar de aansturing van grote projecten, is er kritisch over: "De politieke praktijk wordt gedomineerd door pluchepolitiek: het politieke spel is naar binnen gericht en draait om het vestigen en behouden van machtsposities. Politieke inhoud en proces zijn hieraan ondergeschikt" (Commissie-Van Egdom, 2007:4).

Fractievoorzitter H. Keereweer van de PvdA, die in 2006 zijn entree maakte in de Leidse politiek en dus relatief kort meedraait, is absoluut niet te spreken over de cultuur: "Het is hier echt spelletjespolitiek af en toe. Dat stuit me gigantisch tegen de borst. Als het nou goed was voor de stad, als het er mooier van wordt, maar dat is niet zo. Het is slecht voor je stad. Je versjteert de onderlinge verhoudingen er soms ook door. Men heeft in de Leidse raad geen oog voor de mensen achter de bestuurders. Nou weet ik wel dat je er zelf voor kiest om bestuurder te worden, maar dat is niet alles. Ik vind dat je ook, als je zo fors op de persoon speelt, moet kijken dat er achter die mensen ook andere mensen zitten. Partners, gezinnen, medewerkers. Ik heb mensen echt kapot zien gaan, echt over de rooie, van kwaadheid en van verdriet." Voorbeelden van stevig taalgebruik zijn er volop. Een voorbeeld komt uit de vergadering van 16 oktober 2007, waarin de houding van het zittend college (waar de wethouders van SP en CU dan uit zijn gestapt) als volgt wordt getypeerd: "Maar het handelen van het rompcollege en de ondersteunende fracties straalt ook arrogantie uit, of anders geformuleerd: misplaatst 
machtsdenken, of wellicht is het gewoon een vorm van gehechtheid aan het pluche in combinatie met blindheid voor de omgeving."

Verwachting 8 luidt: In bestuurlijke probleemgemeenten is de bestuurscultuur negatief tot zeer negatief, wat een aanjagende werking heeft op bestuurlijke problemen. De conclusie is dat deze verwachting in alle perioden is uitgekomen. De bij tijd en wijle bijna 'destructieve' bestuurscultuur zorgde voor tal van problemen.

\section{Macrofactor: de rol van de media}

Uit de vraaggesprekken en bestudeerde artikelen blijkt dat de verhouding tussen politiek Leiden en de media bij tijd en wijle broos is. Leiden kent twee belangrijke kranten: het Leidsch Dagblad en het Leids Nieuwsblad. Oud-burgemeester Lemstra herinnert zich dat het college enkele jaren geleden besloot voorlopig niet meer te spreken met het Leidsch Dagblad, vanwege een publicatie die finaal in het verkeerde keelgat van de wethouders was geschoten. Ook nog vrij recent (januari 2010) troffen de gemeente en het Leidsch Dagblad elkaar voor de rechtbank. Burgemeester Lenferink eiste rectificatie van een artikel waarin hij van het antidateren van een mandaatbesluit werd beticht en ook wethouder Witteman naar de mening van het college onheus werd bejegend. E.e.a. duidt niet op zeer harmonieuze betrekkingen. Anderzijds overheerst bij veel partijen het besef dat de media onmisbaar zijn als schakel tussen inwoners en politiek. Wethouder Van Woensel: "Hier wordt wel gezegd: als je goede verkiezingen wilt maken en in het college wilt komen heb je het Nieuwsblad nodig, als je erin wilt blijven, het Leidsch Dagblad."

De media berichten uiteraard graag over de schermutselingen in de Leidse politiek. Ook actiegroepen weten de media te vinden, om hun boodschap over het voetlicht te brengen. Dit gold bijvoorbeeld voor de tegenstanders van de komst van de RGL, die veel aandacht kregen.

In Leiden dienen ook de digitale media nog genoemd te worden. Via de website van Sleutelstad.nl, of via de site van de Leidse PvdA-fractie werden en worden regelmatig uitgebreide discussies gevoerd, die niet altijd goed waren en zijn voor de verhoudingen.

Verwachting g luidt: In bestuurlijke probleemgemeenten hebben de (pers)media een grote invloed op het debat, wat een aanjagende werking heeft op bestuurlijke problemen. De conclusie is dat de verwachting is uitgekomen.

\subsection{De dynamiek}

Welk beeld levert de bestudering van Leiden en het analyseren van de factoren op? Is er sprake van een helder beeld? Het lijkt er wel op, aangezien ook de gesprekspartners vrijwel allen in één richting wijzen. In Leiden is sprake van een aantal factoren, die gezamenlijk bepaald niet zorgen voor een rustige politieke omgeving. Op de eerste plaats is daar de sfeer tijdens vergaderingen van de gemeenteraad. Daar waar raadsleden buiten de vergadering nog rustig met elkaar spreken, veranderen zij tijdens de vergaderingen figuurlijk gesproken in botte scheermesjes. De raad is een politieke arena, politieke besluiten komen niet of nauwelijks dan na felle woordenwisselingen en polemiek tot stand. De raad wordt voor een deel ook gevormd door studenten of oud-studenten, 
die soms lijken te genieten van de strijd en het debat. Bovendien zijn de in Leiden opererende media zeer aanwezig. Niet zelden levert een artikel in het Leidsch Dagblad stof op voor raadsvragen of een flink debat. In een dergelijke omgeving kan een wethouder of burgemeester, die wat minder rap van de tongriem gesneden is, minder goed uit de voeten. Als zo'n wethouder dan ook nog een lastig onderwerp bij de kop heeft, is er al snel een flinke voedingsbodem voor een probleem geschapen. En lastige onderwerpen waren (en zijn) er meer dan voldoende in Leiden. Een onderzoekscommissie constateerde nog in 2007 dat de ambities veel te hoog liggen: het college wil alles en het liefst tegelijk, wat leidt tot hoge werkdruk en onvermijdelijk ook tot fouten in de ambtelijke organisatie.

In zo'n omgeving zouden overigens nog geen bestuurlijke problemen hoeven te ontstaan, als de microfactoren (verwachtingen 1 en 2) niet op zouden gaan. Maar dat was in Leiden wel het geval. Burgemeester Postma kon niet lekker gedijen in de turbulente Leidse omgeving en ook enkele wethouders hadden moeite met de heftigheid van sommige kritiek. De media doen uiteraard graag verslag van alle schermutselingen, waardoor er nog meer druk op de ketel komt. Andere wethouders trokken zich er minder van aan, maar die waren uiteindelijk zozeer overtuigd van hun eigen gelijk, dat het zelfs hun eigen fracties begon te irriteren, laat staan de oppositionele fracties.

Daar komt bij dat het onderling vertrouwen van de coalitiepartijen lang niet altijd op hoog niveau stond. Slecht verwerkte coalitievorming speelde een rol. Als er werd gecommuniceerd over problemen met sommige voorstellen, kwam er in de regel wel een oplossing voor. Als dat niet of onvoldoende gebeurde, was soms een klein voorval genoeg om het Leidse kruitvat te laten ontploffen.

\subsection{Conclusie}

De vraag aan het begin van deze casestudy luidde:

Wat is de verklaring voor het gedwongen vertrek van burgemeesters, wethouders en/of hele colleges in Leiden in de periode maart 1998 - maart 2010?

Om deze vraag te beantwoorden is ook hier in beeld gebracht welke problemen er waren en wat de invloed was van de onderscheiden micro-, meso- en macrofactoren.

De factoren zijn per raadsperiode bezien en van de verwachtingen is bekeken of ze wel of niet zijn uitgekomen (zie tabel 22). De vraag is nu of het patroon dat in Den Helder werd aangetroffen, waarin drie factoren een grote rol speelden, ook in Leiden aanwezig is. Concluderend kan worden gesteld dat van de drie factoren die bepalend zijn gebleken bij het optreden van bestuurlijke conflicten en bestuurscrises in Den Helder, er in Leiden eveneens twee van groot belang waren. Bepalend voor bestuurlijke conflicten of bestuurscrises waren ook hier: de persoonlijke risicofactoren van wethouders en de soms slechte communicatie van de coalitiepartijen, kortom de hechtheid van de coalitie. De microfactor burgemeester speelde alleen in de eerste periode een rol, door de rolopvatting van de toenmalige burgemeester. De opvolgers beschikten over meer dempend vermogen. 
Tabel 22: De factorenanalyse in Leiden

\begin{tabular}{|c|l|c|c|c|c|}
\hline & $\begin{array}{l}\text { Verwachting van de invloed van de factor op } \\
\text { de opgetreden bestuurlijke problematiek }\end{array}$ & $\begin{array}{c}\mathbf{1 9 9 8} \\
\mathbf{2 0 0 2}\end{array}$ & $\begin{array}{c}\mathbf{2 0 0 2 -} \\
\mathbf{2 0 0 6}\end{array}$ & $\begin{array}{c}\mathbf{2 0 0 6}- \\
\mathbf{2 0 1 0}\end{array}$ & $\begin{array}{c}\text { Con- } \\
\text { clusie }\end{array}$ \\
\hline 1 & Burgemeester werkte niet dempend & + & - & - & - \\
\hline 2 & Risicofactor wethouders was aanjager & + & + & + & + \\
\hline 3 & Optreden college werkte niet dempend & + & $+/-$ & - & $+/-$ \\
\hline 4 & Ontbreken patroon college/ambtenaren was aanjager & $+/-$ & - & - & - \\
\hline 5 & Zwakke verbinding raad/college was aanjager & + & - & + & + \\
\hline 6 & Zwakke verbinding coalitiepartijen was aanjager & - & - & - & - \\
\hline 7 & Onevenwichtige structuur gemeenteraad was aanjager & + & + & + & + \\
\hline 8 & Negatieve bestuurscultuur was aanjager & + & + & + & + \\
\hline 9 & Invloed van (pers)media op debat was aanjager & & & \\
\hline Legenda: + verwachting is vitgekomen \\
$\quad+-=$ geen eenduidig beeld op te maken \\
$-=$ verwachting niet vitgekomen
\end{tabular}

De macrofactoren 'bestuurscultuur' en '(pers)media' zijn wel nadrukkelijk aanwezig, maar ook in Leiden als een soort 'lastige onderlaag': altijd aanwezig, maar niet in alle perioden bepalend bij problemen.

Het ontbreken van een patroon in de relatie met de ambtelijke organisatie (met name het afwezig zijn van prioriteiten) speelde in Leiden een grote rol, maar dat was ook zo in de periode dat er relatief weinig problemen waren, 2002-2006. Een bepalende factor was het dus niet. Ook in Leiden staat of valt een crisis uiteindelijk met vertrouwen en goede samenwerking tussen en door fracties en fractievoorzitters.

\section{Samengevat:}

Het gedwongen vertrek van gemeentebestuurders in Leiden in de periode maart 1998 maart 2010 is toe te schrijven aan twee factoren: (1) het persoonlijk functioneren van wethouders en (2) de hechtheid van de coalitie. Daarmee is er overeenstemming met het patroon in Den Helder, behalve op het punt van het ontbreken van een bindende burgemeester, dat in Leiden een kleinere rol speelde.

De volgende casestudy moet laten zien of dit patroon ook opgaat in een gemeente waar veel bestuurlijke problemen zijn geweest, maar waar het de laatste jaren 'rustig' was qua gedwongen bestuurlijk vertrek: Delfzijl. 


\section{Bestuurlijke problematiek in Delfzijl 1998-2010}

\subsection{Inleiding}

Sicilië aan de Eems. Zo omschreef ex-burgemeester Appel-de Waart van Delfzijl haar gemeente in een interview met het Dagblad van het Noorden, half februari 2006 (Von Hebel, 170206). Zij is dan net afgetreden vanwege een vertrouwenscrisis tussen haar en het college van B\&W. En Appel-de Waart is niet de enige tussentijds opgestapte Delfzijlster ${ }^{1}$ bestuurder. In de afgelopen twaalf jaar vertrokken er in de Groningse havenplaats twee burgemeesters, tien wethouders (waarvan één persoon twee keer) en vielen er vier colleges. Na de grote crisis in 2006 werd het echter relatief stil in het hoge noorden. Is het tij ten goede gekeerd en zo ja: hoe komt dat?

De gemeente Delfzijl staat bij velen bekend als een gemeente met voor gemeentebestuurders grote risico's. De Groningse gemeente staat op de hoogste plaats in Nederland als het gaat om het aantal gedwongen vertrokken burgemeesters, wethou-

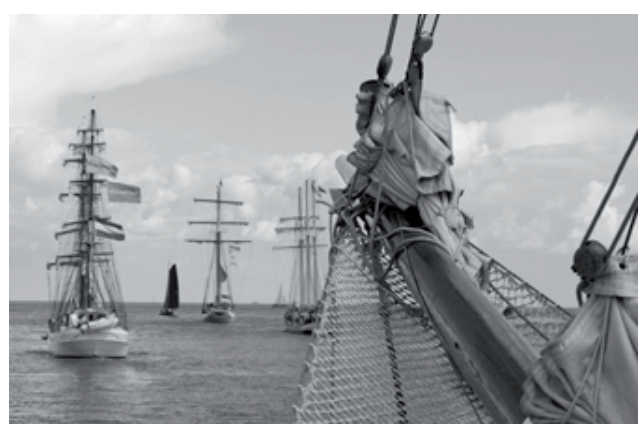

Delfsail in Delfzijl

Foto: Gemeente Delfzijl ders en/of hele colleges in de periode 1998-2010. Er speelden de afgelopen jaren diverse grote en kleinere conflicten, waarbij het vertrek van burgemeester Haaksman in 2003 en de heftige ruzie rondom het vertrek van burgemeester Appel-de Waart in 2006 het meest in het oog sprongen. Hierbij was sprake van grote media-aandacht en heftige vitingen. Appel-de Waart sprak bij haar vertrek van 'guerrillaachtige tegenwerking' en 'amateurisme bij de wethouders, verkrampt gedrag bij incompetente topambtenaren en angst bij de gewone ambtenaren'. Ook in deze casestudy zal een poging worden gedaan de gebeurtenissen te beschrijven en daarna te analyseren, door in te zoomen op de micro-, meso- en macrofactoren en conclusies te trekken. Aan de hand van deze conclusies kan vervolgens worden gekeken of het in Den Helder en Leiden gevonden patroon van relevante factoren ook in Delfzijl aan de orde was. De belangrijkste vraag voor deze casestudy is:

Wat is de verklaring voor het gedwongen vertrek van burgemeesters, wethouders en/of hele colleges in Delfzijl in de periode maart 1998- maart 2010?

Om dit goed in beeld te kunnen krijgen worden in dit hoofdstuk de verschillende bestuurlijke problemen in Delfzijl onderzocht. In de laatste paragraaf zal gepoogd worden conclusies te trekken met betrekking tot de hierboven geformuleerde vraag.

1 In Delfzijl wordt gesproken over Delfzijlster bestuurders, in plaats van Delfzijler bestuurders. 


\subsection{Introductie van de gemeente Delfzijl}

De aan de noordelijke landsgrens gelegen gemeente Delfzijl, provincie Groningen, bestaat uit de havenplaats Delfzijl en in totaal dertien andere dorpen ten noorden en ten zuiden ervan: Bierum, Borgsweer, Farmsum, Meedhuizen, Holwierde, Krewerd, Godlinze, Losdorp, Spijk, Termunterzijl, Termunten, Woldendorp en Wagenborgen. De gemeente telde op 1 januari 2010 in totaal 26.642 inwoners. Hiervan wonen er ruim 16.000 in Delfzijl, gevolgd door Farmsum (bijna 2300) en Wagenborgen (ruim 1800). Het kleinste dorpje van de gemeente Delfzijl is Krewerd, waar op 1 januari 2010 precies 89 mensen woonden.

Delfzijl vormt samen met de Eemshaven de vierde zeehaven van Nederland. Het havenbedrijf (inclusief de uitgifte van industrieterreinen) in Delfzijl wordt uitgevoerd door Groningen Seaports, een gemeenschappelijke regeling van de gemeenten Delfzijl, Eemsmond (Eemshaven) en de provincie Groningen. Daarnaast bevindt zich het tweede (in grootte) chemiepark van Nederland in Delfzijl, waar $17 \%$ van de totale landelijke werkgelegenheid in de chemie aanwezig is. Op het chemiepark bevinden zich o.a. de chemische bedrijven van Akzo Nobel en op het Metalpark is Corus gevestigd, voorheen Aldel aluminiumfabriek.

De gemeente vervult een regionale functie t.b.v. de omliggende gemeenten, vooral door voorzieningen als een ziekenhuis, schouwburg, voortgezet en beroepsonderwijs en een Centrum voor Werk en Inkomen (CWI).

Delfzijl is een herindelinggemeente. In 1990 is het aantal gemeenten in de provincie Groningen gehalveerd naar 25. De toenmalige gemeente Delfzijl (bestaande uit Delfzijl, Farmsum en Meedhuizen met bijna 25.000 inwoners) werd samengevoegd met de plattelandsgemeenten Bierum en Termunten, beiden met ongeveer 4.500 inwoners. Het is een herindeling die niet zonder slag of stoot tot stand kwam. Bierum zou liever samengaan met Hefshuizen en/of Loppersum, Termunten zocht het zuidelijker, richting het Oldambt (zie: Westerink, 2006: 11). Uiteindelijk zijn ten zuiden van Termunten drie gemeenten samengevoegd tot de gemeente Scheemda, ten zuid-oosten ontstond de gemeente Reiderland. De Eemshaven zelf bleef bij de gemeente Eemsmond, voorheen Hefshuizen.

De plaats Delfzijl is voor de kenners ook bekend door de misdaadspeurder Maigret, een figuur van auteur Simenon. Samen met echtgenote Tigy, kokkin Boule en hond Olaf arriveerde deze schrijver in september 1929 met zijn kotter Ostrogoth in Delfzijl. Het oponthoud duurde, vanwege een lek in het schip, langer dan was voorzien. Tijdens zijn verblijf in 'Het Paviljoen' op de dijk in Delfzijl bedacht Simenon de figuur van Maigret. Een half vergane schuit in het Damsterdiep werd zijn werkkamer. Hier schreef hij zijn eerste misdaadroman Maigret en de onbekende wreker. Onmiddellijk daarna volgden er meer, waaronder Maigret in Holland, dat speelt in Delfzijl en waarin diverse plaatsen nog herkenbaar zijn, waaronder het station en het tegenoverliggende hotel. Op het Damsterdiep staat nu een beeld van Maigret. 


\subsection{2 jaar Delfzijlster politiek}

De gemeente Delfzijl telde in de onderzochte periode (1998-2010) eerst 23 en later 21 raadsleden, na de daling van het aantal inwoners onder de 30.000. De samenstelling van de raad was vanaf 1998 als volgt:

Tabel 23: Samenstelling gemeenteraad Delfzijl 1998-2010

\begin{tabular}{|l|cc|cc|cc|}
\hline Naam partij & 1998 & $\begin{array}{c}\text { Na af- } \\
\text { splits. }\end{array}$ & $\mathbf{2 0 0 2}$ & $\begin{array}{c}\text { Na } \\
\text { afsplits. }\end{array}$ & 2006 & $\begin{array}{c}\text { Na af- } \\
\text { splits. }\end{array}$ \\
\hline 1. PvdA & 9 & & 7 & & 9 & 5 \\
\hline 2. CDA & 5 & 4 & 4 & & 3 & \\
\hline 3. VVD & 4 & & 2 & & 2 & \\
\hline 4. Gr. Links (tijdelijk SDE*) & 1 & & 1 & & 0 & \\
\hline 5. D66 & 1 & & 0 & & 0 & \\
\hline 6. SP & 2 & 1 & 0 & & 0 & \\
\hline 7. ChristenUnie (vh. GPV) & 1 & & 1 & & 4 & \\
\hline 8. Gemeentebelangen & 0 & & 6 & 1 & 0 & \\
\hline 9. Delfzijls Belang & 0 & & 0 & 4 & 0 & \\
\hline 10. Lijst Stulp & 0 & 1 & 0 & 1 & 2 & \\
\hline 11. Partij voor het Noorden & 0 & & 0 & & 1 & \\
\hline 12. Fractie 2014 & 0 & & 0 & & 0 & 4 \\
\hline 13. Lijst van der Meij & 0 & 1 & 0 & & 0 & \\
\hline Totaal & 23 & 23 & 21 & 21 & 21 & 21 \\
\hline Aantal fracties & 7 & 9 & 6 & 8 & 6 & 7 \\
\hline Fractiequote & 3,29 & 2,55 & 3,5 & 2,6 & 3,5 & 3 \\
\hline
\end{tabular}

* Het enige raadslid van GroenLinks is in 2005 tijdelijk geroyeerd geweest. Zij ging toen verder onder de naam Sociaal Democratische Eenheid (SDE).

Een aantal zaken is op te tekenen. Op de eerste plaats is duidelijk dat de PvdA altijd de meest dominante partij is geweest in Delfzijl. Na de verkiezingen van 2006 kwam de PvdA uit op negen zetels, net zoveel als in 1998 en twee meer dan in 2002. Door een afsplitsing van vier leden, die doorgingen onder de naam Fractie 2014, bleven er van de negen zetels nog vijf over. Opvallend is tevens de afwezigheid vanaf 2006 van partijen als GroenLinks, D66 en SP. Partijen die er toch in veel gemeenten in slagen zetels in de gemeenteraad te bemachtigen. Zo niet in Delfzijl, waar in 2002 wel veel stemmen en zetels naar de lijst Gemeentebelangen gingen. Vanuit het niets kwam deze partij in 2002 op zes zetels, wat ook deelname in het college betekende. Dit liep niet goed af (zie volgende paragraaf), waarna in 2006 geen enkele zetel meer behaald werd.

De fractiequote (het aantal raadszetels gedeeld door het aantal partijen) zat na de afsplitsingen in 2002 op 2,6, waarna het gemiddeld aantal raadsleden per fractie na de verkiezingen weer omhoog liep naar 3,5 en later 3 .

Delfzijl had in de onderzoeksperiode te maken met in totaal zes colleges. Hiervan vielen er vier voortijdig, te weten de colleges die startten in 1998, 1999, 2002 en 2003 . Onder een 'gevallen' college wordt in deze studie ieder college verstaan waarvan de samenstelling wijzigt doordat één of meerdere partijen niet meer aan de coalitie willen of mogen deelnemen. In de praktijk zullen er hierdoor wethouders verdwijnen en nieuwe 
wethouders aan de collegetafel aanschuiven. Met vier gevallen colleges scoort Delfzijl zeer hoog voor wat betreft het aantal politieke crises.

Tabel 24: Samenstelling Colleges van B\&W gemeente Delfzijl 1998-2010

\begin{tabular}{|l|c|c|c|c|c|c|c|c|c|c|c|}
\hline 1998 & Weth. & 1999 & Weth. & 2001 & Weth & 2002 & Weth. & 2003 & Weth. & 2006 & Weth. \\
\hline PvdA & 2 & Gr.L. & 1 & PvdA & 1 & GB & 1 & PvdA & 1 & PvdA & 2 \\
VVD & 1 & VVD & 1 & VVD & 1 & VVD & $1(0,9)$ & CDA & 1 & CU & 1 \\
CDA & 1 & CDA & 2 & CDA & 2 & CDA & 1 & VVD & 1 & VVD & 1 \\
& & & & & & Gr.L. & $1(0,8)$ & & & & \\
& & & & & & CU & $1(0,45)$ & & & & \\
\hline
\end{tabular}

De colleges in Delfzijl wisselden dus regelmatig van samenstelling. Meer hierover in de volgende paragraaf, waar de verschillende ont- en verwikkelingen worden beschreven. Hier kan worden opgemerkt dat de problematiek een bijzondere invloed had op de verhouding tussen de verkiezingsuitslag en de uiteindelijke samenstelling van het college. Zo is te zien dat in het jaar 2001, als het derde college van de raadsperiode 19982002 aantreedt, de PvdA terugkeert in het college met één wethouder. Het CDA had er al twee en behield die ook. Terwijl de PvdA kon bogen op een totaal van negen zetels in de gemeenteraad en het CDA op vijf. Eenzelfde ietwat scheve verhouding ontstond na de schermutselingen rondom de collegesamenstelling in 2002. Vijf partijen vormden viteindelijk een college, waarbij zowel Gemeentebelangen (zes raadszetels) als GroenLinks en de ChristenUnie (één zetel in de raad) ieder één wethouder mochten leveren.

De verschillende coalities konden bij de start in elke periode rekenen op ruime meerderheden. In 1998 had de coalitie steun van achttien van de 23 raadsleden, in 2002 waren dat er veertien van de 21. De coalitie die in 2006 van start ging en de hele periode bijeen bleef, had een meerderheid van eerst vijftien van de 21 raadsleden en later (na de afsplitsing van vier raadsleden van de PvdA) nog van elf van de 21.

Tabel 25: Burgemeesters van Delfzijl vanaf $1987-2010$

\begin{tabular}{|l|l|}
\hline Dhr. E. Haaksman (VVD) & 1987- Februari 2003 \\
\hline Mw. A. Jorritsma-Lebbink (wnd. VVD) & Februari 2003- Augustus 2003 \\
\hline Dhr. H.A.L. van Hoof (wnd. VVD) & Augustus 2003-April 2004 \\
\hline Mw. M. Appel-de Waart (PvdA) & April 2004-Februari 2006 \\
\hline Dhr. C.J.D. Waal (wnd. PvdA) & Februari 2006-September 2008 \\
\hline Dhr. E.A. Groot (PvdA) & September 2008- Heden \\
\hline
\end{tabular}

Delfzijl had in de onderzochte periode in totaal zes verschillende burgemeesters. Twee hiervan kwamen voortijdig aan het einde van hun ambtsperiode, drie werden benoemd als waarnemend burgemeester. Van deze drie zat C.J.D. Waal behoorlijk lang, een periode van 2,5 jaar. Hier was door Commissaris van de Koningin $\mathrm{H}$. Alders ook bewust voor gekozen: Delfzijl had na het turbulente vertrek van burgemeester Appel behoefte aan rust. Een waarnemer zou beter in staat zijn en over meer gezag beschikken dit tot stand te brengen. Dat vonden kennelijk ook de leden van de raad, want hoewel een wettelijke titel voor het niet open stellen van de vacature ontbrak, nam iedereen genoegen met de situatie. Volgens velen had ook de innemende en tegelijk doortastende 
wijze waarop Waal zijn functie uitoefende hiermee te maken. Hij werd in september 2008 opgevolgd door E.A. Groot als burgemeester van Delfzijl. Als geboren Delfzijlster betekende de benoeming voor hem een terugkeer naar zijn geboorteplaats. Groot was eerder werkzaam als wethouder in Winschoten en burgemeester van buurgemeente Appingedam.

\subsection{De problemen op een rij}

Net als in de vorige casestudies wordt in deze paragraaf op chronologische wijze op een rij gezet wat er in de onderzoeksperiode precies is gebeurd. De beschrijving is gebaseerd op informatie die is verkregen uit gesprekken met betrokkenen en gedrukte informatie uit diverse bronnen. Alle geïnterviewden hebben ingestemd met de strekking van de hieronder beschreven informatie. Ook als er letterlijk geciteerd wordt in de beschrijving hebben de betreffende personen met het citaat ingestemd. De getrokken conclusies komen ook in deze casestudy geheel voor rekening van de onderzoeker.

\subsubsection{Periode 1998-2002}

Ook de beschrijving van de politieke verwikkelingen in de gemeente Delfzijl begint in 1998. Een jaar waarin de PvdA met negen zetels opnieuw de grootste partij in de gemeenteraad wordt en samen met CDA en VVD een college gaat vormen. Wethouders worden J.H. Menninga (PvdA), D.A.J. Doornbos (PvdA), mw. J.F. Snijder-Hazelhoff (VVD) en J. Harms (CDA), waarbij alleen de VVD-wethouder nieuw is. Een redelijk ervaren college dus, dat wordt voorgezeten door de eveneens ervaren burgemeester E. Haaksman. Hij kwam in 1987 naar Delfzijl, na een periode als eerste burger op Terschelling.

Ondanks de ervaring in het college ontstaan er al snel problemen. In de zomer van 1998 wordt duidelijk dat wethouder Menninga twee jaar eerder, toen hij wethouder Economische Zaken was, een grondsubsidie van een half miljoen gulden toezegde aan een bedrijf (Blijdorp) uit Farmsum. De toezegging werd niet voorgelegd aan de gemeenteraad en ook andere collegeleden waren summier op de hoogte. De gemeenteraad neemt de zaak hoog op. Collegepartijen VVD en CDA overwegen sterk een motie van wantrouwen in te dienen, die zou kunnen rekenen op steun van GroenLinks en de SP, gezamenlijk een meerderheid in de raad. Uiteindelijk besluit de gemeenteraad toch eerst een onderzoek in te laten stellen naar de gang van zaken en doet in september 1998 een beroep op oud-Tweede Kamerlid mw. A. Doelman-Pel. De naar haar genoemde commissie gaat aan de slag en komt een maand later met de conclusies. Die zijn duidelijk. Menninga is inderdaad een financiële verplichting aangegaan, waarover de besluitvorming niet helder is vastgelegd: "Het gebruik van het college om in de rondvraag zaken vanuit onderscheiden portefeuilles, die aanzienlijke beleidsinhoudelijke consequenties kunnen hebben, globaal te bespreken en daarvan slechts weinig vast te leggen, leidt op zijn minst tot verschillende percepties van het besprokene en de reikwijdte ervan. Ook de vertrouwelijke verslagen van besloten vergaderingen van de commissie Economische en Sociale Zaken zijn zeer summier, weinig zeggend en kenmerken zich door onduidelijke besluitvorming" (Commissie-Doelman-Pel, 1998: 3). De onderzoekers spreken in het rapport van een 'impliciete cultuur', waarin veel onuitgesproken verwachtingspatronen heersen en een cultuur van informaliteit overheerst. "Daardoor wordt veel handelingsruimte gegeven en genomen, wat in het geval Blijdorp 
heeft geleid tot ver viteenlopende percepties, tot irritaties en tot verstrekkende bestuurlijke implicaties." En: "Wethouder Menninga en de burgemeester hadden een grote handelingsvrijheid. (...) Dat neemt niet weg, dat wethouder Menninga, begaan met het lot van werklozen en handelend vanuit werkgelegenheidsbelang, de grenzen van zijn (in)formele bevoegdheden heeft overschreden."

Het zijn deze woorden waar een meerderheid van de raad genoeg aan heeft. "Niemand heeft de vrijheid om op eigen houtje een half miljoen weg te geven", vindt VVDfractievoorzitter Heijn (Trouw, 171298). Hierop wordt alsnog de motie van wantrouwen, die al eerder was aangekondigd, ingediend en aangenomen: wethouder Menninga moet vertrekken. In januari 1999 wordt hij uit solidariteit gevolgd door zijn partijgenoot Doornbos. De PvdA is daarmee uit het college van B\&W verdwenen. Het college krijgt een nieuwe samenstelling, waarbij GroenLinks in de persoon van wethouder H.B.G. Ketting in het college plaatsneemt. Het CDA levert een tweede wethouder in de persoon van A.J. Huisman. Het college steunt daarbij op een minderheid in de raad. Gedoogsteun komt er van de SP en van de fractie GPV, waardoor er een redelijke meerderheid van 13 tegen 10 stemmen in de raad is.

De situatie zonder PvdA duurt een kleine twee jaar. Dan blijkt dat wethouder Ketting rondrijdt in een auto zonder geldige kentekenplaten. Het leidt tot politieke ophef, vragen en een rel. Het gevolg is dat Ketting zijn ontslag indient en het college wederom van samenstelling verandert. De PvdA keert terug in het bestuur in de persoon van wethouder mw. P.M. Valentien-Smit, nadat blijkt dat terugkeer van de vertrokken wethouder Menninga niet tot de mogelijkheden behoort. De periode 1998-2002 wordt vervolgens met een college met wethouders van PvdA, CDA, VVD afgesloten, na twee collegewisselingen en het gedwongen vertrek van drie wethouders. Een vierde wethouder vertrekt vrijwillig: wethouder Snijder-Hazelhoff wordt in januari 2000 lid van de Tweede Kamer en opgevolgd door partijgenoot $\mathrm{H}$. Houwerzijl.

\subsubsection{Periode 2002-2006}

De verkiezingen van maart 2002 laten een verbluffende uitslag zien. Op de vleugels van de Fortuijn-revolte in Nederland komt ook in Delfzijl het lokale Gemeentebelangen sterk op. Met zes van de 21 raadszetels wordt Gemeentebelangen de tweede partij, na de PvdA. De inzet is om samen met het CDA een drie-partijencollege te gaan vormen. Maar... partijen kunnen het niet eens worden. De gang van zaken leidt tot het opstappen van PvdA-lijsttrekker M. Zijlstra, die in interviews laat weten dat de politiek in Delfzijl 'doodziek' is. In de raadsvergadering van 25 april 2002 wordt het hele proces publiekelijk uit de doeken gedaan. Er vallen harde woorden en verwijten over en weer. Mw. E.M. Koning-Hoevelaken van Gemeentebelangen beschuldigt de PvdA, in het bijzonder lijsttrekker Zijlstra, van 'regentesk' gedrag: "Met de PvdA fractie, onder aansturing van de heer Zijlstra, was in de beleving van onze fractie geen goed garen te spinnen. Twee kapiteins op één schip, de één een redelijke koers, de ander voortdurend langs de klippen stevenend, beiden sjorrend aan het roer. De heer Zijlstra trok te hard en koerste met het schip regelrecht op de klippen. Dat is het juiste beeld van wat zich heeft afgespeeld." PvdA-woordvoerder Scharft ontkent dit: naar haar beleven was het nieuwe college op een haar na rond en was het enige probleem nog dat zittend wethouder Huisman geen aanstelling voor 90\% wilde, maar voor 100\%. "Daar waar de 
situatie schreeuwt om een helder en door allen gedragen plan van aanpak, kiezen bestuurders ervoor om eerst hun eigen persoonlijke positie veilig te stellen, ook al is deze in strijd met het algemeen belang", aldus Scharft, die op scherpe wijze spreekt: "De PvdA heeft naar eer en geweten geprobeerd Delfzijl te verlossen van het halfduistere en schemerige gedoe, waarbij met poppetjes wordt geschoven en persoonlijke belangen worden bevredigd. We zijn gewoon ordinair belazerd."

Ondanks deze harde woorden weten de andere vijf partijen in de raad elkaar te vinden in een 'grote coalitie': een college van Gemeentebelangen, VVD, CDA, GroenLinks en ChristenUnie. En hoewel de zetelverdeling in de raad verschillend is (Gemeentebelangen heeft zes zetels, GroenLinks en de ChristenUnie ieder maar één) leveren alle partijen één wethouder, waarvan er drie parttime gaan werken. Onder dit gesternte, met

een boze PvdA in de oppositie en een college van vijf wethouders, waarvan er twee nieuw zijn (Mw. E.M. Koning-Hoevelaken van Gemeentebelangen en H.J. Lohr van de CU), één eerder als wethouder is weggestuurd (H.B.G. Ketting) en er twee ook in het vorige college zaten (H. Houwerzijl en A.J. Huisman), gaat het college aan het werk. Het wordt een turbulente periode, getekend door een groot aantal conflicten, breed uitgemeten ruzies en veel vertrekkende bestuurders.

De eerste frictie ontstaat al in de zomer van 2002 als raadslid Stulp van Gemeentebelangen zich afscheidt van de fractie en doorgaat als Lijst Stulp. Het blijkt het begin van meer problemen bij de partij, want een half jaar later beginnen vier van de vijf anderen voor zichzelf onder de naam Delfzijls Belang. Zij vinden dat de wethouder teveel haar eigen gang gaat, herinnert toenmalig fractieondersteuner van Delfzijls Belang en later raadslid voor de Partij voor het Noorden G. van Amson zich. Gemeentebelangen bestaat daarmee nog maar uit één persoon. Het duurt niet lang voor ook de wethouder vertrekt. In januari 2003 wordt namelijk bekend dat deze wethouder maandelijks een bedrag betaalt aan raadslid Bruininck van haar partij. Later beschuldigt ze hem ervan haar te hebben aangerand. Het leidt tot enorme publiciteit en het vertrek van de wethouder, die niet wordt opgevolgd. Het college gaat verder met vier wethouders, maar steunt daarbij niet meer op een meerderheid in de gemeenteraad.

Een onwerkbare situatie, die nog wordt verergerd door de problemen rondom het verschijnen van een rapport van de VROM-inspectie over bouw- en woningtoezicht in Delfzijl. Het is een vernietigend rapport, waarin zeer stevige kritiek wordt geuit op de gang van zaken rondom sommige bouwprojecten in Delfzijl. Commissaris van de Koningin Alders neemt het rapport hoog op: "Zwart op wit was aangetoond dat het niet alleen een rommeltje was, maar ook bewust een rommeltje. In sommige gevallen werd op bestuurlijk niveau bewust de andere kant op gekeken." Alders overweegt namens de provincie een bestuurlijke aanwijzing te geven, wat inhoudt dat Delfzijl min of meer onder curatele wordt gesteld. Het is vooral voor burgemeester Haaksman een moeilijk te verteren maatregel, waar hij zich dan ook ernstig tegen verzet. Ook de raad toont zich geschokt, zeker als blijkt dat de inspectie al eerder brieven stuurde over de situatie. Het geheel wordt teveel voor de positie van Haaksman. Tijdens een crisisberaad in het weekeinde op het provinciehuis blijkt dat er te weinig steun is voor hem om aan te blijven en besluit hij op te stappen. Commissaris Alders verleent Haaksman buitengewoon verlof, waarna hij per 1 julizoo3 definitief vertrekt. 
Zijn opvolger meldt zich al een dag later: oud-minister mw. A. Jorritsma-Lebbink wordt geïnstalleerd als waarnemend burgemeester. Alders vraagt bovendien de hoogleraren Elzinga en Dölle zich te buigen over de situatie in Delfzijl en met aanbevelingen te komen om met name het vertrouwen van de bevolking in het gemeentebestuur te herstellen. Zij verzoeken de huidige wethouders niet af te treden, maar hun positie ter beschikking te stellen aan de gemeenteraad. Als het college zou opstappen, zou er binnen 30 dagen een nieuw college moeten zijn. Als dat niet zou lukken, zou waarnemend burgemeester Jorritsma er alleen voor staan. Door als het ware 'demissionair' te zijn, blijft er meer tijd voor formatie van een nieuw college. Het is een primeur in Nederland na invoering van het dualisme. Elzinga noemt de constructie 'een wat wonderlijke figuur, maar in deze situatie heel goed bruikbaar' (Trouw, februari 2003). De wethouders handelen de lopende zaken af in afwachting van een nieuw college. "Door op te stappen bereik je niets. Dan is de stad helemaal stuurloos. We blijven besturen, maar over zware beslissingen overleggen we nog nauwer met de raad", zegt demissionair wethouder Huisman (Trouw, februari 2003). Dölle benadrukte in hetzelfde artikel het belang van 'collegiaal bestuur' en de noodzaak 'schuttersputjes te verlaten en verdrietigheden te vergeten'. "Alleen dan kan Delfzijl de zaak in eigen hand nemen. Het is de laatste kans."

De beide hoogleraren formeren uiteindelijk een nieuw college, waarin in mei 2003 de PvdA terugkeert. Dit gaat ten koste van GroenLinks en de ChristenUnie, die hun plek in het college verliezen. Tot spijt van beiden, maar men legt zich erbij neer. "Het deed pijn, maar we hebben gezegd: het is niet anders. Het was nou eenmaal de realiteit", zegt raadslid Schimmel van de ChristenUnie later.

De nieuwe coalitie legt in het college-akkoord een groot aantal zaken vast. Met name op het gebied van financiën, maar ook op beleidsterreinen als wonen/herstructurering, veiligheid, milieu, sport en welzijn. De nieuwe samenwerking wordt vanaf het begin krachtig onderstreept: "De fracties van PvdA, CDA en VVD in de gemeenteraad van Delfzijl verklaren ten opzichte van elkaar en tegenover de raad en de bevolking van Delfzijl dat zij gezamenlijk verantwoording willen dragen voor de benoeming van wethouders, die samen met de burgemeester het college van Delfzijl vormen. Zij verklaren tevens dat zij aan dit college een program op hoofdpunten ten grondslag wensen te leggen, waaraan deze fracties zich gebonden achten (...) Het beeld van het Delfzijls gemeentebestuur heeft de laatste jaren nogal wat averij opgelopen binnen en buiten de gemeente. De gebeurtenissen die dit veroorzaakten zijn genoegzaam bekend. Het heeft weinig nut om hierbij nu nog stil te staan, noch baat het om schuldigen aan te wijzen of te klagen over dit buiten proportie getrokken negatieve imago. Het beeld moet veranderen, daar gaat het om. Daarvoor zien de drie fracties ook behoorlijke kansen" (Coalitieakkoord 2003-2006: 1).

Met drie wethouders van PvdA, CDA en VVD trekt de karavaan verder. Wethouder voor de PvdA wordt mw. M. Scharft-Beerepoot, die aansluit bij de zittende wethouders Huisman (CDA) en Houwerzijl (VVD). De start is nog met waarnemend burgemeester Jorritsma, maar dat duurt niet lang meer: zij wordt in augustus 2003 benoemd tot burgemeester van Almere. Jorritsma slaagde er volgens velen in zich in korte tijd populair te maken in de havenstad. Zij wordt opgevolgd door oud-staatssecretaris van Defensie 
H. van Hoof. Hij mag zich bezig gaan houden met de organisatie van het burgemeestersreferendum, waartoe de gemeenteraad besluit. De bevolking van Delfzijl zou het laatste woord moeten hebben over de vraag wie de definitieve burgemeester van de havenplaats zou moeten zijn, na het gedwongen vertrek van burgemeester Haaksman. In januari 2004 wordt duidelijk dat de strijd zal gaan tussen twee vrouwelijke kandidaten: de PvdA-burgemeester van de gemeente Bergh, M. Appel-de Waart en VVD-burgemeester J. Hermans-Vloedbeld van de gemeente Ouderkerk. De gemeente Delfzijl stelt een campagnebudget ter beschikking en beide kandidaten krijgen een communicatieadviseur.

Er zijn incidenten tijdens de campagne. Appel-de Waart beschuldigt haar tegenstander ervan haar campagne te dwarsbomen door te 'rommelen' met afspraken. Het team van Hermans-Vloedbeld ontkent de beschuldigingen ten stelligste en eist excuses. De media smullen er weer van. Pas na tussenkomst van burgemeester Van Hoof en Commissaris van de Koningin Alders en enkele stevige gesprekken wordt besloten de campagnes voort te zetten. De uitslag is volgens kenners van het PvdA-gedomineerde Delfzijl

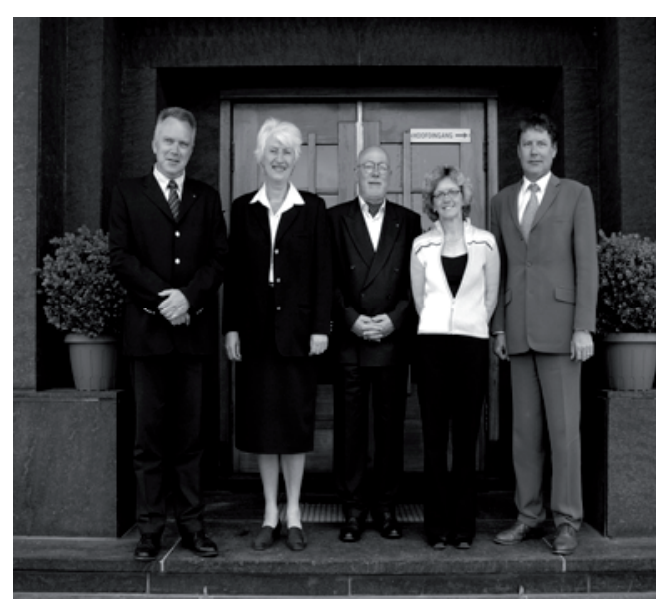

Het college van B\&W van Delfzijl in 2004, met v.l.n.r. A.J. Huisman (CDA), mw. M. Appel-de Waart (burgemeester), H. Houwerzijl (VVD), M.A. Scharft-Beerepoot ( $P v d A)$ en gemeentesecretaris J. Visser.

Foto: gemeente Delfzijl. weinig verrassend: Appel-de Waart blijft haar concurrente ruim voor en wordt op 2 april 2004 officieel benoemd tot nieuwe burgemeester van Delfzijl.

Een volgend bestuurlijk conflict dient zich in augustus 2004 aan, als CDAwethouder Huisman besluit af te treden. Hij voelt zich onvoldoende gesteund door coalitiepartijen PvdA en VVD, na kritiek op de gang van zaken rondom een subsidieverzoek van de openbare bibliotheek. In een brief vraagt deze instelling om subsidie van $€$ 50.000,-. De brief raakt echter zoek, wordt niet doorgestuurd aan de gemeenteraad, terwijl het college wel besluit het verzoek af te wijzen. Huisman besluit na de kritiek hierop op te stappen en wordt opgevolgd door wethouder van buiten B.Westerink, oud-wethouder voor het CDA in

Groningen. In de raad doen zich hierna opnieuw bijzondere situaties voor. Oudwethouder Koning keert terug in de raad, nadat het door haar beschuldigde raadslid Bruininck wegens gezondheidsredenen opstapt. In januari 2005 komt er nog een affaire bij. De fractievoorzitter van Gemeentebelangen wordt door een fractieondersteuner beschuldigd van verkrachting. Nieuws dat de wereld in wordt geholpen door de fractievoorzitter van GroenLinks, mw. M. de Weerd-van der Meij, die als vertrouwenspersoon van het duo-raadslid optreedt. Het leidt tot een crisis tussen De Weerd- van der Meij 
(als eenmansfractie) met haar fractieondersteuning van GroenLinks. Zij gaat tijdelijk als fractie Sociaal Democratische Eenheid (SDE) verder.

Op burgemeester Appel-de Waart, die overigens afzag van het geven van een interview ten behoeve van dit onderzoek, komt intussen enige kritiek los. Ze zou de touwtjes te strak in handen nemen en te weinig ruimte laten aan raadsleden. In de catacomben van het gemeentehuis maakt ze zich bovendien weinig geliefd door een volgens zeggen weinig empatische opstelling. Volgens insiders vallen geanimeerde gesprekken regelmatig stil als de burgemeester binnenkomt. "Het zijn in Delfzijl soms best grappenmakers, maar zodra ze binnenkwam was het over met de grappen", zo wordt gezegd.

In de zomer van 2005 valt Appel enige tijd uit, omdat ze geveld wordt door een hernia. Gemeentesecretaris Visser, die later dat jaar zelf onderwerp van discussie zou worden, meent dat hier een keerpunt in haar opstelling ligt: "We konden ineens weinig tot niets goed meer doen. Ze was van mening dat er informatie werd achtergehouden, dat ze niet alles thuis kreeg, dat er op deze manier voor haar niet te werken viel, enzovoort. Er deugde niets meer van."

De situatie komt tot een climax als Visser voorstelt een tweetal medewerkers met een financiële regeling te laten afvloeien, omdat er geen geschikte functie voor hen kan worden gevonden. De burgemeester ziet de regeling absoluut niet zitten en weigert ermee in te stemmen. De zaak komt in het college aan de orde, waarbij twee wethouders vóór het voorstel zijn en de burgemeester en de derde wethouder tegen. Gezien het feit dat in dergelijke situaties de stem van de burgemeester dubbel telt, is het voorstel van de secretaris van de baan. Hij is er zeer boos over. Hierna verergert de situatie. Bijna alle door Appel-de Waart te ondertekenen brieven worden door haar teruggezonden aan de secretaris, omdat er fouten in zouden staan of de inhoud niet zou kloppen. De medewerkers werden er volgens Visser 'knettergek' van. Visser maakt zich dan ook weinig illusies over zijn functioneringsgesprek van januari van het volgende jaar. Appelde Waart bevestigt wat hij vermoedt: zij is zeer ontevreden over zijn werk. Visser schat in dat de burgemeester voorlopig nog wel in functie zal blijven en geeft aan op zoek te willen gaan naar een andere baan. Er wordt een regeling opgesteld, die in het college wordt gebracht.

Hierna nemen de ontwikkelingen een grote vlucht. Terwijl Appel-de Waart in Amerika verblijft, blijkt dat het college helemaal geen afscheid wil nemen van de secretaris, als blijkt dat de loco-secretaris het niet eens is met de gang van zaken. Het college besluit de burgemeester de portefeuille Personeel \& Organisatie te ontnemen. Vervolgens breekt een waar pandemonium los, waarbij vrijwel de gehele Nederlandse pers zich over de situatie in Delfzijl buigt. Journalisten staan op de luchthaven Schiphol te wachten op de terugkeer van burgemeester Appel-de Waart. Dag na dag wordt er bericht over de voortgang in het conflict. Appel-de Waart stelt na terugkeer in een verklaring dat zij zich zal beraden op haar positie, tenzij de gemeenteraad ingrijpt.

"Vanavond heb ik in een extra vergadering het College van B\&W en vervolgens de fractievoorzitters - via het seniorenconvent - geïformeerd over mijn lezing op de gebeurtenissen van de afgelopen week, die hebben geleid tot een vertrouwensbreuk binnen het college van B\&W. Tijdens deze bijeenkomsten heb ik de gelegenheid gehad om duidelijk te maken dat ik tijdens mijn vakantie met grote verbazing heb kennis genomen van de 
mededeling van de loco-burgemeester, dat de wethouders het onderdeel personeelszaken vit mijn portefeuille hebben gehaald. De reden hiervoor zou zijn het niet (volledig) informeren van de wethouders over zaken die in het algemeen het personeelsbeleid betreffen en meer in het bijzonder de procedure rond het ontslag van de gemeentesecretaris. Ik stel vast dat de wethouders mij daarin op meerdere momenten hun steun hebben betuigd en mij hebben aangemoedigd in het proces, dat heeft geleid tot het vertrek van de gemeentesecretaris. Daarmee acht ik in voldoende mate weerlegd te hebben dat er gedurende dit proces sprake was van solistisch optreden van mijn kant.

Ik spreek bewust in termen als verbazing en verwondering, omdat ik de gang van zaken zoals die door de wethouders is weergegeven, in het geheel niet in overeenstemming acht met de werkelijkheid. In de genoemde bijeenkomsten heb ik vitvoerig en gedetailleerd kunnen weergeven, dat de door de wethouders geschetste onvolledigheid van informatievoorziening van mijn kant ver bezijden de waarheid is. Voor de informatie die daar gewisseld is verwijs ik naar de bijlage bij dit persbericht, met daarin een chronologisch overzicht van de feiten.

Met deze verklaring geef ik gehoor aan de vraag van de fractievoorzitters om geïformeerd te worden door mij als burgemeester. Deze kunnen op deze manier het principe van hoor en wederhoor toepassen. Het is aan hen om een politieke afweging te maken op basis van mijn verklaring en de eerdere verklaring van de wethouders. Op basis van wat daar vitkomt, zal ik zelf een beslissing nemen over het vervullen van het ambt van burgemeester van Delfzijl."

\section{3 februari 2006}

\section{Appel-de Waart, Burgemeester Delfzijl}

De raad steunt echter in meerderheid de stap van de wethouders, wat leidt tot het vertrek van burgemeester Appel-de Waart. Zij neemt ontslag en wordt heel snel opgevolgd door waarnemend burgemeester C.J.D. Waal, eerder wethouder in Leiden en burgemeester van Deventer.

De crisis lijkt achter de rug, maar de beker blijkt nog niet leeg. In de eerste vergadering van het college onder voorzitterschap van de nieuwe burgemeester Waal, voor de gelegenheid voorzien van een maaltijd Chinees voedsel, meldt wethouder Scharft dat er onrust bestaat binnen de PvdA-fractie. Deze fractie, voorgezeten door Menninga, wil terugkomen op de steun, uitgesproken in de raadsbijeenkomst van 9 februari. Men wil het college blijven steunen, maar afstand nemen van het feit dat de portefeuillewisseling tijdens de vakantie van burgemeester Appel-de Waart is doorgevoerd. "Alle nekharen van iedereen die de handel en wandel van Jan Menninga kent, moeten bij een dergelijk bericht in de loodrechtstand schieten. Dat is althans wat er bij mij gebeurt. (....) Bij mij vermengen de ervaring en gevoelens van gisteravond zich met overlevingsinstinct. Ik heb er geen enkele fiducie meer in", schrijft wethouder Westerink in zijn later uitgegeven boek (Westerink, 2006: 71). De wethouders voelen er niets voor als 'kop van jut' in de eerstvolgende raadsvergadering te fungeren, waar zij een motie van wantrouwen verwachten. "Waarom zou ik morgenavond voor vele camera's laten vastleggen hoe ik, onder hoongelach van de dichtbevolkte tribune, overladen met door verkiezingsoverwegingen ingegeven verontwaardiging, door de zijdeur af ga? For the sake of Delfzijl?" (Westerink, 2006: 71). Het college besluit nog dezelfde avond op te stappen. 
Waarnemend burgemeester Waal, net een paar dagen aan de slag, zit er alleen voor en mag Delfzijl door de verkiezingen van maart van dat jaar heen loodsen. Eerst volgt nog de raadsvergadering van 22 februari, waarin de gemeenteraad zich over de dan geheel ontspoorde affaire buigt. De verwijten vliegen over tafel: "Onze fractie wil de coalitie nog feliciteren met de maximale score, behaald in de dartswedstrijd, 180, de maximale score! Geen dartpijlen, maar drie messen in de rug van mevrouw Appel-de Waart. Vals, dodelijk en alle drie effectief", meent S. Roelsma van Delfzijls Belang. "Wij Delfzijlsters zijn zo ongeveer de risee van Nederland. En ik kan mij voorstellen dat velen al niet meer durven zeggen dat ze uit Delfzijl komen", zegt M. de Weerd-van der Meij van GroenLinks. Steunbetuigingen zijn er ook, vooral van CDA en VVD, die de besluiten respecteren, al hebben zij grote vraagtekens bij de timing van het college. Veel vragen zijn er voor PvdA-fractievoorzitter Menninga. Wat voor spel speelt hij, wordt gevraagd. Menninga laat weten slechts de gevoelens van zijn achterban te hebben willen uiten, door aan te kondigen vragen te stellen. Hij was er niet vanuit gegaan dat het college hieruit zou opmaken dat er geen vertrouwen meer zou zijn en op grond hiervan zou vertrekken: "Je hebt het vertrouwen, totdat het tegendeel wordt uitgesproken. Dat is heel helder. Ik vind dus, als wij als fractie enkele kritische noten plaatsen richting college, dat dit niet hoeft te betekenen dat we geen vertrouwen hebben. Zo werkt dat niet in de politiek. Het is hoor en wederhoor, een debat in eerste en tweede termijn en dan maak je de balans op. Dat is onze democratie" (Raadsnotulen Delfzijl 220206: 15).

Het raadsdebat brengt geen verandering in de situatie. Waarnemend burgemeester Waal is aan zet, het college is definitief afgetreden. Hoog tijd voor verkiezingen.

\subsubsection{Periode 2006-2010}

De verkiezingen van 2006 vinden enkele weken na het vertrek van het voltallig college plaats. Het zijn vreemde verkiezingen. Een fors aantal inwoners van Delfzijl brengt een blanco stem uit, uit protest tegen de gang van zaken van eerder dat jaar. Als alle blanco stemmen naar één partij waren gegaan, was die met vijf zetels de tweede partij geworden.

De uitslag betekent vooral voor de ChristenUnie een opsteker. De partij stijgt van één naar vier zetels en wordt de tweede partij in Delfzijl. Na de PvdA, de partij die, ondanks alle perikelen, weer ruimschoots de grootste partij wordt en negen zetels krijgt. Er zijn wel veel nieuwe gezichten: 16 van de 21 raadsleden waren niet eerder lid van de Delfzijlster gemeenteraad. En zij krijgen gelijk hoog bezoek: Minister J.W. Remkes van Binnenlandse Zaken bezoekt een vergadering van de gemeenteraad, uit ongerustheid over de zaken die zich hebben afgespeeld. Het is hoogst uitzonderlijk dat een minister een gemeenteraadsvergadering bijwoont, maar het is wel nodig, zo laat hij weten: "Uit het feit dat het tamelijk uniek is dat ik hier ben, mag u ook de conclusie trekken dat ik mij met name vanuit het perspectief van de burger en het plaatselijke bedrijfsleven zorgen maak. Dat om twee redenen. In de eerste plaats natuurlijk vanuit de invalshoek 'het beeld van het openbaar bestuur', maar ik zeg u er bij dat ik mij ook, dit gebied en deze gemeente wel kennende, in de weken waarin zich dit voltrok, heb zitten te verbijten vanuit juist de wetenschap dat hier in de eerste plaats de komende jaren een geweldige inhoudelijke opgave ligt om de problemen bij de kop aan te pakken. Een inhoudelijke opgave op het terrein van de werkgelegenheid en een inhoudelijke opgave waar het gaat om de stedelijke herstructurering, waar ik mij ook nog enigszins bij 
betrokken voel vanuit mijn verleden als staatssecretaris van VROM. Toen zijn er natuurlijk ook wel gesprekken geweest met het gemeentebestuur. Op het moment dat je dan ziet, dat er in de eerste plaats veel bestuurlijke energie gaat naar onderling gedoe, laat ik het zo maar even formuleren, dan word je daar niet vrolijk van" (Raadsverslag 200306: 3). Remkes verzoekt om een plan van aanpak, maar doet ook de suggestie serieus na te denken over wethouders van buiten de gemeenteraad.

Het is een suggestie die kennelijk aanspreekt. Al vrij spoedig worden drie partijen het eens over een coalitie: PvdA, ChristenUnie (waarvan de verkiezingswinst beloond wordt met een plek in het college) en de VVD. De partijen spreken vervolgens inderdaad af op zoek te gaan naar wethouders van buiten de gemeenteraad, het liefst zelfs van buiten Delfzijl. Het is een bewuste keuze na het advies van de minister. Bovendien blijken er stevige bedreigingen binnen te komen aan het adres van oud-wethouder Menninga, waarbij hij gewaarschuwd wordt vooral geen wethouder te moeten willen worden (Van Wely, 010306). Hij doet aangifte bij de politie.

De keuze valt dus op wethouders van buiten. Voor de PvdA komt R. van der Molen in beeld, die gedurende een periode van 12 jaar wethouder in Stadskanaal was, maar daar zou stoppen. Wel is hij nog als formateur betrokken bij de vorming van een nieuw college in Stadskanaal. Van der Molen krijgt op het provinciehuis van één van de gedeputeerden de vraag of hij zou willen overwegen wethouder in Delfzijl te worden. Als hij wil, wordt zijn naam doorgegeven, waarna de bemoeienis van de gedeputeerden (die in hun netwerk naar kandidaten zouden uitkijken) weer op zou houden. Van der Molen is geïnteresseerd, maar kent ook de Delfzijlster geschiedenis. Toch overheerst positiviteit: hij zegt wel wethouder te willen worden, maar in geen geval te zullen verhuizen.

Op dezelfde manier wordt oud-gedeputeerde J.R.A. Boertjens (VVD) wethouder. Ook hij wordt gepolst en stemt in. De tweede PvdA-wethouder komt na een selectieprocedure naar voren. Het is raadslid mw. Th. van der Veen uit Hoogezand-Sappemeer. De enige Delfzijlster in het gezelschap is de CU-wethouder, politie-inspecteur M. Joostens. Hij was echter nooit eerder actief in de Delfzijlster politiek. Het is een college zonder verleden, klaar om er fris tegenaan te gaan.

In het voorjaar van 2006 presenteert het college het nieuwe collegeprogramma. Opvallend is de grote nadruk op het woord 'samen': "Raad, college en ambtelijke organisatie staan samen voor een nieuwe frisse start en gaan voor een goede, onderlinge samenwerking. Het eerste woord van dit collegeprogramma is SAMEN. Het college wil benadrukken dat zij hiermee doelt op alle betrokken partijen. Burgers, dorpen, bedrijven, instellingen, raadsleden en ambtenaren. Laten we met $z^{\prime} n$ allen de komende jaren de schouders eronder zetten en van de gemeente Delfzijl iets moois maken waar we trots op kunnen zijn" (Collegeprogramma 2006-2010: 3).

Het nieuwe college wordt, voorgezeten door waarnemend burgemeester Waal, volgens zeggen vrij snel een team. "We voelden het zelf als een speciale opdracht, we moesten er echt iets van maken", aldus Van der Molen. De wethouders voelen zich vrij om iets 'vrijer en losser' te opereren dan als zij rechtstreeks uit de fracties voortgekomen waren. Problemen doen zich dan ook niet voor in het college. Maar wel in de gemeenteraad. De negenkoppige PvdA-fractie is vanaf het begin geen eenheid. Vijf van de negen leden zijn met voorkeurstemmen in de raad gekomen en komen van lagere plekken op de 
kandidatenlijst van de partij. Daarmee zit er vanaf het begin al enige onevenwichtigheid in de fractie. Tot fractievoorzitter wordt de relatieve nieuwkomer A.A. Zoethout gekozen. Als oud-vakbondsman en partijbestuurder weet hij van wanten, terwijl hij niet betrokken was bij de problemen uit het recente verleden. Zoethout schat in dat het lastig zal zijn van de fractie een geheel te maken, gezien het feit dat er ook nog eens drie oud-wethouders in zitten. Toch ziet hij geen alternatief voor zichzelf en zegt hij 'ja' op de vraag de fractie te gaan leiden. Vanaf het begin is er sprake van twee kampen, zoals hij dat vitdrukt. Het ene kamp concentreert zich rond oud-wethouder Menninga, het andere kamp bestaat uit mensen die deels wat korter in de politiek in Delfzijl meelopen, deels ook minder op hebben met de oude manier van politiek bedrijven. Vanaf het begin levert deze situatie problemen op. Gezamenlijke sessies op de hei, vele vergaderingen, eenheid komt er niet. De fractie opereert voor buitenstaanders vrij onnavolgbaar, het is nooit duidelijk welk standpunt ingenomen gaat worden. De wethouders, die toch al het gevoel hebben door een deel van de fractie niet geaccepteerd te worden, vragen zich na afloop van fractievergaderingen soms vertwijfeld af uit hoeveel delen de negenkoppige PvdA-fractie eigenlijk bestaat. Het leidt tot wisselend stemgedrag en langzaam oplopende irritaties, zowel binnen de partij als bij de coalitiepartners.

De emmer blijkt vol als de fractieleden Menninga en Schumer een interview geven in de lokale krant en kritiek leveren op hun collega-fractieleden. Zij zouden zich teveel op het college richten en te weinig op de inwoners van Delfzijl. Voor Zoethout is de maat vol: hij eist excuses, anders kunnen beide leden vertrekken. De excuses komen er niet. Het leidt tot fors gedoe in de partij en een emotionele ledenvergadering, waarin Zoethout aangeeft wat hem en een meerderheid van de fractie de voorbije periode dwars heeft gezeten. Genoemd worden onder meer het weglopen voor de kennismaking met de PvdA-wethouders, zich niet houden aan afspraken over perscontacten, regelmatig aangeven de fractie te zullen verlaten, inbreng in het raadsdebat niet vooraf delen met de fractie en in het algemeen geen bereidheid 'op te schuiven' bij verschillen van inzicht. Zoethout laat aan zijn achterban weten dat er een onwerkbare situatie is ontstaan. Het resultaat is dat uiteindelijk vier leden van de fractie besluiten uit de PvdA te stappen. Zij beginnen de Fractie 2014, volgens sommigen genoemd naar het jaar waarin Menninga 40 jaar in de politiek zal zitten.

De breuk in de PvdA-fractie leidt wel tot een andere verhouding in de coalitie. Die houdt een kleine meerderheid van 11 tegen 10 stemmen over. Bovendien laat een lid van de VVD-fractie weten op sommige onderdelen van het beleid, met name op economisch terrein, niet mee te zullen stemmen met de coalitiepartijen. Het lijkt een lastige situatie, maar levert in de praktijk geen grote problemen op. Er blijkt goed samengewerkt te kunnen worden met het CDA, dat volgens insiders bezig is zich voor te bereiden op een terugkeer in het Delfzijlster college na 2010. Al met al is de periode 2006-2010 de rustigste sinds 1998. 


\subsection{De analyse op microniveau}

$\mathrm{Na}$ de beschrijving van de gebeurtenissen, noodzakelijkerwijs een beschrijving op hoofdlijnen, is het mogelijk de verschillende aspecten te analyseren. Dit gebeurt opnieuw op micro-, meso- en macroniveau aan de hand van de geformuleerde verwachtingen.

\section{Microfactor: de burgemeester(s)}

Delfzijl heeft in de onderzoeksperiode te maken gehad met zes burgemeesters (zie tabel 25). Van deze zes waren er drie waarnemend en drie regulier benoemd. De twee burgemeesters die gedwongen werden om te vertrekken, belandden allebei in het middelpunt van de discussie. Zij waren niet meer in staat boven de partijen te staan, maar werden onderdeel van het conflict. Oud-CdK H. Alders omschrijft het zo in het geval van het vertrek van burgemeester Haaksman: "Als je onderdeel bent van het conflict, kun je geen onderdeel zijn van de oplossing." Aan Haaksman ging, volgens betrokkenen, steeds meer kritiek kleven. Hij bleek niet in staat een einde te maken aan de voortdurende grote en kleinere rellen rondom raadsleden of leden van het college van $B \& W$.

Haaksman slaagde er op het laatst niet meer in objectief te blijven en boven de partijen te blijven staan. Hij koos positie, ging bijvoorbeeld de verbale strijd met Menninga aan. Maar er bleek meer aan de hand. Diverse gesprekspartners geven aan dat steeds vaker getwijfeld werd of de burgemeester nog wel grip had op de situaties die zich voordeden, of hij nog wel voldoende 'in control' was. Had hij wel voldoende gedaan aan de situatie rond wethouder Ketting, die met valse kentekenplaten rondreed? Meerdere mensen wisten dat er iets met de auto van de wethouder niet deugde. Had de burgemeester de wethouder niet bij zich moeten roepen en verordonneren de boel goed te regelen? Hierna kwamen er meer twijfels over het optreden van Haaksman in de verschillende andere kwesties. Er leken mogelijkheden om het tij te keren, met de start van het nieuwe college in 2002. Maar al vrij snel ging het fout rond wethouder Koning, gevolgd door het kritische rapport van de VROM-inspectie. Het werd het Waterloo voor de burgemeester. Toenmalig CdK Alders zette hard en kritisch in. In een beraad in het weekeind bij de provincie bleek dat de fractievoorzitters het niet meer zagen zitten met Haaksman. Na de problemen van de afgelopen jaren had hij geen positie meer. Na rijp beraad diende hij zelf zijn ontslag in, waarna eervol ontslag volgde.

Gelijk de volgende maandag stond de nieuwe waarnemend burgemeester op de stoep van het gemeentehuis: oud-minister Jorritsma. Zij heeft het volgens insiders redelijk makkelijk gehad. Raad en college waren geschrokken van de situatie en probeerden zich te 'herpakken'. Een proces waar het aanstekelijk enthousiasme van Jorritsma zeer goed bij te pas kwam. Zij promootte Delfzijl volop, wees op alle mooie dingen en probeerde de haven beter op de bestuurlijke kaart van Nederland te zetten. Toen een medewerkster om het leven kwam na huiselijk geweld ging zij uitstekend om met de golf van emotie die door het gemeentehuis vloeide. De raadzaal was beschikbaar voor koffie, kaarsen en gesprekken, Jorritsma ontpopte zich als warme burgermoeder. $\mathrm{Na}$ haar vertrek naar Almere volgde oud-defensieman H.A.L. van Hoof. Formeler dan zijn voorgangster, maar ook goed ontvangen in Delfzijl. 
Hierna kwam, na een referendum over het burgemeestersambt, burgemeester Appelde Waart ten tonele. Over het verloop van haar burgemeesterschap in Delfzijl en het einde ervan is al veel gezegd en geschreven. Appel-de Waart zegt zelf gevloerd te zijn door tegenstanders van haar pogingen de cultuur te veranderen. In een geruchtmakend interview na haar vertrek (Von Hebel, 2006) geeft zij aan structureel tegengewerkt te zijn: "Wat ik bedoel is dit: je spreekt iets af en later kom je er achter dat het anders is gegaan. Als je dan vroeg 'hoezo' kwam er een vitvlucht en zat ik weer met een niet nagekomen afspraak. Dit soort praktijken nam hand over hand toe. Des te meer ik aangaf dat dingen volgens regels en procedures moeten, des te meer er een soort guerrilla-achtige tegenwerking ontstond. Kortom, mijn opdracht om meer kwaliteit in de organisatie te krijgen en om wethouders hun portefeuilles strakker aan te laten sturen voor een beter presterend Delfzijl, des te meer kritiek ik kreeg. Ik was opeens formeel, niet benaderbaar, niet communicatief, etcetera. Waarover beter gecommuniceerd moest worden, kreeg ik nimmer te horen. Formeel is het laatste wat ik ben en ik sta altijd open voor een ieder. Alleen niet voor mensen die gewend waren hun belangen via achterkamertjes of directe privé-lijntjes met wethouders te behartigen. Daarvoor is een commissie bezwaarschriften en niet een burgemeester. Maar dat is niet de bedoeling en dus merkte ik gaandeweg de macht en kracht van belangen op de achtergrond. Daarnaast is er een duidelijk belangenverbond tussen ambtenaren en sommige wethouders. Hoe de bestuurs- en politieke macht al tientallen jaren in Delfzijl is verdeeld, werd mij steeds duidelijker." Dan komt zij met de inmiddels beroemde uitspraak over Sicilië: "Waar ik te laat achter kwam - men kan mij op dit punt naïviteit verwijten - is dat er in wezen sprake is van 'Sicilië aan De Eems'. Heel goed voor een kleine kring belanghebbenden, maar een belediging en een blijk van minachting voor de eigen bevolking. Maar ik ben ook democraat in hart en nieren en accepteer dus dat een meerderheid van de raad heeft ingestemd met het voorstel van de wethouders. Tegelijkertijd was ik graag doorgegaan om Delfzijl weer in positieve zin op de kaart te zetten. De bevolking verdient het."

Het interview viel slecht in het gemeentehuis: wethouders en ambtenaren voelden zich in hun eer aangetast. Enkele voor dit onderzoek geïnterviewde betrokkenen geven aan dat het streven van de burgemeester juist wèl positief werd beoordeeld. Appel-de Waart wilde formalisering van een groot aantal zaken en meer heldere afspraken, kortom: professionalisering van het bestuur. De informele cultuur, de 'moet kunnen'- cultuur, die al in 1998 tot politieke problemen had geleid, was weliswaar behoorlijk teruggedrongen, helemaal weg was hij nog zeker niet. De voortvarende burgemeester verslikte zich volgens zeggen echter in de loop van de tijd in haar voornemen. De bezem ging er weliswaar door, maar de 'menselijk maat' werd uit het oog verloren. De onderlinge verhoudingen, zeker in het college, verslechterden op den duur. En wel zodanig, dat herstel viteindelijk niet meer tot de mogelijkheden behoorde.

Als nieuwe burgemeester is in september 2008 de geboren Delfzijlster E.A. Groot benoemd. Hij was burgemeester in buurgemeente Appingedam en wist dus duidelijk waar hij aan begon. Zijn voornemen: authentiek en eerlijk blijven: "Als er iets niet goed zit dan moet dat op tafel, wat mij betreft de deuren en de ramen open. Ik wil daar graag recht in zitten, open en direct. Wel gedoseerd en gefaseerd en rustig kijkend. Ik heb geen haast, maar ga er gestaag mee aan de slag als zich de mogelijkheden voordoen. 
Daarbij wil ik graag authentiek blijven en me niet voortdurend afvragen of mijn herbenoeming in gevaar komt."

De inzet van Groot is om de positief gestemden, de raadsleden die geen zin meer hebben in de ruwe omgangsvormen en het vele gedoe, meer ruimte te geven: "Die zijn nu een beetje murw, investeren niet meer. Het moet net de andere kant op, de positieven moeten zich meer bemoeien met de gang van zaken."

Verwachting 1 luidt: In bestuurlijke probleemgemeenten legt de burgemeester weinig bindend vermogen aan de dag, waardoor de potentiële dempende werking van de burgemeester afwezig is. De conclusie met betrekking tot deze verwachting is dat deze factor in twee van de drie bestudeerde perioden wel degelijk van invloed was op het ontstaan van bestuurlijke problemen en dus is uitgekomen. De laatste periode kwam de verwachting niet uit, aangezien er toen wel een dempende werking van de (eerst waarnemend, later reguliere) burgemeester vit ging.

\section{Microfactor: de wethouder(s)}

Wethouders zijn er behoorlijk wat geweest in Delfzijl in de onderzoeksperiode. In totaal mogen zestien personen zich tussen 1998 en 2010 korte of langere tijd wethouder in de havenplaats noemen. Slechts enkelen doen dat langer dan één periode. Een vitzondering is CDA-wethouder Harms, die twee volle perioden in functie blijft (1994-2002). Verder vertrekt er een wethouder vrijwillig tussentijds (Snijder-Hazelhoff, lid van de $2^{\text {e }}$ Kamer) en eindigt voor vijf wethouders (waaronder in de periode 2006-2010 het hele college van vier wethouders) hun termijn normaal bij de verkiezingen. De overblijvende negen wethouders dienden allen voortijdig te vertrekken. De omstandigheden waaronder dit gebeurde zijn in het feitenoverzicht al beschreven. Uit deze opsomming blijkt duidelijk dat Delfzijl bepaald geen traditie van sterke wethouders heeft, die gedurende vele jaren het beleid in de stad sterk beïnvloeden of zelfs bepalen. Wethouders bleken vooral in de periode 1998-2002 een korte zittingsperiode te hebben, van in sommige gevallen iets meer dan een jaar. De omstandigheden van vertrek hadden ook in sterke mate te maken met het handelen van de wethouders zelf. De affaire met de kentekenplaten, de betalingen die door een wethouder aan een raadslid zouden zijn gedaan, het zijn door persoonlijk handelen ontstane bestuurlijke conflicten, gebaseerd op een gebrek aan professionaliteit.

In 2006 trad een college aan dat geheel bestond uit wethouders van buiten, op één na zelfs van buiten Delfzijl. Onder leiding van waarnemend burgemeester Waal slaagden deze wethouders erin wel een team te worden. De onderlinge verhoudingen waren goed, het college wist zich op hoofdlijnen ook gesteund door de gemeenteraad.

Verwachting 2 luidt: In bestuurlijke probleemgemeenten hebben de persoonlijke risicofactoren van één of meer wethouder(s) een aanjagende werking op bestuurlijke problemen. De conclusie is dat deze verwachting in de eerste twee perioden is vitgekomen in Den Helder. De persoonlijke risicofactor was van invloed, maar dan vooral op het ontstaan van bestuurlijke problemen op individueel niveau. 


\subsection{De analyse op mesoniveau}

Op mesoniveau gaat het vooral om betrekkingen. Getoetst worden de verwachtingen 3 , 4 en 5 .

\section{Mesofactor: het college}

De verschillende colleges in Delfzijl startten zowel in 1998 als in 2002 niet bepaald goed. In 1998 werd wethouder Menninga weggestuurd, gevolgd door wethouder Doornbos. Ook de wethouders die daarna aan traden hadden het moeilijk. In de toenmalige sfeer (zie macrofactoren) kreeg het college niet de kans om heel sterk te worden. Dat gold nog minder voor het college dat in 2002 aantrad en waar vrijwel continu problemen optraden. Ook hier was geen sprake van een team, chemie ontbrak, een visie was er niet, evenmin als een verbindend leider. Duidelijk was dat in beide gevallen een college niet alleen geen kans kreeg uit te groeien tot een sterk geheel (vgl. Korsten en Schoenmaker, 2008: 227 e.v.), maar dat ook het omgekeerde niet op ging: het college wist vanwege de omstandigheden het tij ook niet te keren.

Het college dat in 2006 aan de start verscheen had betere mogelijkheden. Niet alleen traden er wethouders van buiten aan, ook een verbindend leider was aanwezig in de vorm van waarnemend burgemeester Waal. Ook aan de andere voorwaarden voor het zijn van een sterk college werd voldaan. De wethouders konden goed met elkaar opschieten en hadden ook iets voor elkaar over.

Verwachting 3 lvidt: In bestuurlijke probleemgemeenten kunnen colleges niet sterk worden, waardoor de potentiële dempende werking van een sterk college afwezig is. De conclusie is dat deze verwachting uit komt in Delfzijl in de eerste twee onderzochte perioden. Het college dat in 2006 aantrad wist door haar optreden de kans op bestuurlijke problemen te verkleinen, in tegenstelling tot eerdere en zwakkere colleges, die de problemen juist groter maakten.

\section{Mesofactor: verbinding van college met ambtelijke organisatie}

De ambtelijke organisatie is in Delfzijl volgens velen een constante factor geweest, die ervoor heeft gezorgd dat 'de winkel gewoon open bleef'. Tegelijkertijd kan worden geconstateerd dat het lang heeft geduurd voor de kwaliteit van de organisatie zich kon spiegelen aan de moderne vereisten. Zo trof de latere gemeentesecretaris Visser bij zijn aantreden in 1997 als hoofd van de sociale dienst een organisatie aan, die nog voortkwam uit een periode die voorbij was. "Er lagen overal dossiers, het was feitelijk een rommeltje. Ik heb ook letterlijk een dag de zaak dicht gehouden en een opruimactie gedaan." Het was ook in die periode dat bijvoorbeeld wethouder Menninga regelmatig de afdeling op liep om zaken te regelen voor mensen die hem hadden aangesproken. Visser sprak hem daar ook op aan, waarna ook Menninga inzag dat dat eigenlijk niet kon. In ieder geval had politiek Delfzijl in die jaren weinig over voor de organisatie, het mocht eigenlijk weinig tot niets kosten. Visser werd de geestelijk vader van een nieuwe organisatie en kon daar enige tijd later ook zelf sturing aan geven als gemeentesecretaris. Langzamerhand werd de relatie tussen het college, de gemeenteraad en de ambtelijke organisatie meer patroonmatig van aard, gebaseerd op vaste afspraken. 
De relatie met het college en de individuele wethouders was overigens in het algemeen goed. Het kwam dan ook hard aan dat burgemeester Appel-de Waart in het Siciliëinterview zo stevig uithaalde naar het ambtelijk apparaat. Onder leiding van burgemeester Waal werd hier later herstelwerk verricht: zowel de ambtenaren als de in opspraak geraakte gemeentesecretaris ontvingen een excuusbrief. Visser bleef uiteindelijk nog tot mei 2006, waarna hij aan de slag ging als gemeentesecretaris in de Noord-Hollandse gemeente Wijdemeren.

Huidig secretaris Havinga is best te spreken over de kwaliteit van de ambtelijke organisatie. Hij kwam van Stadskanaal, waar hij zeven jaar secretaris was. De afspraak is om zeker tot 2012 in Delfzijl te blijven en te werken aan een aantal grote opdrachten: verbetering van de samenwerking in de regio, het terughalen van de Ontwikkelings Maatschappij Delfzijl (OMD) onder de vleugels van de gemeente en de verdere verbetering van de kwaliteit van de gemeentelijke organisatie.

Verwachting 4 lvidt: In bestuurlijke probleemgemeenten zit weinig patroon in de relatie van het college van B\&W met het ambtelijk apparaat, wat een aanjagende werking heeft op bestuurlijke problemen. De conclusie luidt dat deze verwachting alleen in de eerste periode op gaat in Delfzijl. Hierna werd de relatie professioneler en patroonmatiger.

\section{Mesofactor: de verbinding tussen raad en college}

Het dualisme is ook in Delfzijl in 2002 ingevoerd, maar al snel waren gemeenteraad en college in die periode drukker met andere zaken. Griffier $\mathrm{O}$. Rijkens probeerde de rollen van raad en college duidelijker te maken, maar dat bleek een proces van lange adem te zijn.

Hulp kwam in maart 2003 van de geestelijke vader van het dualisme, hoogleraar Elzinga. Samen met hoogleraar Dölle formeerde hij een nieuw college, waarbij in het collegeprogramma een balans moest worden gevonden tussen strakke afspraken (die nodig waren om zoveel mogelijk afwijkingen en discussies uit te sluiten) en nog enigszins gescheiden verantwoordelijkheden. "Dit program bevat slechts een aantal ijkpunten, opdat er ruimte voldoende overblijft voor de raad om in meer dualistische verhoudingen te beraadslagen en besluiten over zaken van openbaar bestuur" (Coalitieakkoord 2003-2006: 1). Kortom: de duale verhoudingen waren vanaf maart 2003 op zich helder. Toch bleef het ook in Delfzijl zoeken naar de juiste verhouding. Waarnemend burgemeester Waal constateerde na zijn komst in 2006 dat het voor enkele raadsleden nog lastig was om niet op de stoel van de wethouder te gaan zitten.

Vanaf 2006 is er in de nieuwe coalitie een opgaande lijn te ontdekken als het gaat om dualisme. De raad koos er zelfs voor in 2009 nog met een andere manier van werken te experimenteren, waarbij de raadsbijeenkomsten (waarin raadsvergaderingen technisch werden voorbereid) zijn afgeschaft en zogenaamde Ronde tafelgesprekken (model Voorst) werden ingevoerd. Met de opgedane ervaringen zouden na de verkiezingen van 2010 weer nieuwe stappen kunnen worden gezet.

Verwachting 5 lvidt: In bestuurlijke probleemgemeenten zit geen of weinig patroon in de relatie tussen het college van $B \& W$ en de gemeenteraad, wat een aanjagende werking heeft op bestuurlijke problemen. De conclusie is dat deze verwachting voor de eerste duale 
periode, 2002-2006, op gaat. Weliswaar was er aandacht voor, maar goed ingebed was het dualisme zeker nog niet en ook de rolopvattingen liepen door elkaar. Hierna gaf het ontbreken van een patroonmatige relatie minder aanleiding tot problemen.

\section{Mesofactor: de verbinding tussen de fracties}

In zowel de raadsperiode 1998-2002 als de periode 2002-2006 kan worden geconstateerd dat de coalitie niet hecht functioneerde. In de eerstgenoemde periode was er al snel een wisseling van partijen, na het vertrek van de PvdA. Een nieuwe coalitie kon alleen met gedoogsteun van enkele niet-collegepartijen functioneren. De periode 20022006 kenmerkte zich al helemaal door een groot aantal problemen. Eerst met Gemeentebelangen, dan met burgemeester Haaksman, de terugkeer van de PvdA in het college en het vertrek van burgemeester Appel-de Waart. Een periode waarin coalitieoverleg nauwelijks werd gevoerd. ledere raadsvergadering leek een avontuur, partijen wisten vaak niet wat ze aan elkaar zouden hebben, noch wat er zou gaan gebeuren met de voorstellen. De val van het college in februari 2006 was zelfs geheel te wijten aan slechte verbinding, slechte communicatie ook, tussen coalitiepartijen.

De coalitie die in 2006 van start ging, zat beter in elkaar. Wel was er de eerste jaren soms onduidelijkheid over de vraag wat de PvdA zou gaan doen met sommige voorstellen. $\mathrm{Na}$ de breuk in de fractie is daarover meer duidelijkheid ontstaan. In die zin beschrijven sommigen de breuk als een op zich betreurenswaardige, maar tegelijk noodzakelijke stap, die duidelijkheid heeft gebracht. Er was hierna sprake van enig coalitieoverleg, zegt CU-fractielid H.J. Schimmel: "Soms moet je gewoon even overleggen. Dat is geen achterkamertjespolitiek, want dan zouden wij het stiekem doen en we zijn er eerlijk over dat het gebeurt. Gebeurt dat voldoende? We hebben het af en toe, maar dat hoeft niet al te vaak. Het gaat erom: bel elkaar eens op. Zorg dat je open en eerlijk bent. Ik heb een voorstel, kun je dat steunen, ja of nee. Als het goed is, moet je het omarmen. Vind je het minder goed, kijk je waar je het moet aanpassen. De vraag is: wat is goed voor Delfzijl?"

Ook andere partijen werden soms gezocht bij het formuleren van voorstellen. De raad koos er zelfs voor om nog in 2009 met een andere manier van vergaderen te beginnen, om ervaring op te doen voor de nieuwe periode. Een periode die, als het aan burgemeester Groot ligt, een succes gaat worden. Met goede afspraken in een goed coalitieakkoord, dat strak uitgevoerd gaat worden: "Er ligt zoveel werk, daar moeten we alles voor aan de kant zetten."

Verwachting 6 luidt: In bestuurlijke probleemgemeenten bestaat weinig binding tussen coalitiefracties, wat een aanjagende werking heeft op bestuurlijke problemen. De conclusie is dat deze verwachting zeker vit komt in de eerste twee onderzochte perioden. Als er geen of weinig sprake is van coalitiemanagement en de fractievoorzitters (te) weinig communiceren, neemt de kans op een conflict of crisis fors toe.

\subsection{De analyse op macroniveau}

Op macroniveau gaat het om factoren die betrekking hebben op de politieke structuur en cultuur in een gemeente en de rol van de media, inclusief actiegroepen. 
Macrofactor: de bestuursstructuur

In de onderzoeksperiode was er sprake van één dominante partij: de PvdA. Een partij die vanaf de herindeling van 1990 al in het college was vertegenwoordigd. Na het (gedwongen) vertrek van de PvdA uit het college in 1998 ontstonden problemen. Tegelijkertijd kreeg de gemeenteraad een aantal keer te maken met afsplitsingen: dit was het geval bij Gemeentebelangen in 2002, maar ook bij de PvdA in 2008. De afsplitsingen hebben bijgedragen aan het debat in de raad, en niet altijd positief. Afgesplitste raadsleden hebben de neiging zich af te blijven zetten tegen hun oude fractie, en omgekeerd geldt dat net zo. Dat betekende in Delfzijl vaak dat als de PvdA ergens 'ja' tegen zei, de Fractie 2014 met enige felheid het 'nee'-standpunt verdedigde, of viceversa. Toch leidde deze structuur op zich niet tot bestuurlijke conflicten of bestuurscrises, maar de spanning werd er wel door verhoogd.

Verwachting z luidt: In bestuurlijke probleemgemeenten is sprake van versplintering van het politieke landschap, wat een aanjagende werking heeft op bestuurlijke problemen. De conclusie is dat deze verwachting vit komt. De structuur van de raad heeft invloed op de debatcultuur in de raad, maar lijkt niet bepalend te zijn geweest bij het ontstaan van bestuurlijke problematiek.

\section{Macrofactor: de bestuurscultuur}

De negatieve cultuur in de raad speelde een belangrijke rol in de afgelopen jaren. "Wat je in Delfzijl zag, sloeg alles. We praten hier over persoonlijke vetes die gedurende 25 jaar zijn opgebouwd en via de politiek worden uitgevochten", aldus oud-CdK Alders. Er is ook al eerder onderzoek naar de bestuurscultuur in Delfzijl gedaan. Bovens, Noordegraaf e.a. gaan in het vierde jaarbericht van de Vernieuwingsimpuls Dualisme en lokale democratie in op de bestuurscultuur in Delfzijl. Zij concluderen dat Delfzijl een traditie heeft van impliciet en informeel besturen, waarbij de aandacht vooral naar binnen is gericht. Ook eigenzinnigheid hoort bij die cultuur (Vernieuwingsimpuls, 2006: 96-98). De vraag is hoe die bestuurscultuur tot stand is gekomen. Hangt het op personen? Dat wordt door sommigen wel gezegd. Gewezen wordt dan op de aanwezigheid van J.H. Menninga (die overigens niet inging op een uitnodiging mee te werken aan dit onderzoek) in de lokale politiek. Hij wordt verantwoordelijk gehouden voor menig crisis. Een enkeling neemt het voor hem op, door erop te wijzen dat er soms wel heel snel 'Komt door Menninga' wordt geroepen als er iets mis gaat. Door meerderen wordt hij geprezen voor de manier waarop hij, als de burgemeester afwezig is, de gemeenteraad voorzit als waarnemend raadsvoorzitter. Maar het algemeen gevoelen is toch dat Menninga, na zijn gedwongen vertrek vit het college in 1998, de Delfzijlster politiek in de wurggreep houdt. Zijn naam wordt vooral genoemd als persoon die het vertrek van het hele college in 2006 in de hand werkte, door onduidelijk te zijn over de steun van de PvdA-fractie voor het college. Menninga was bovendien betrokken bij de breuk in de PvdA-fractie in 2008, waarbij hij samen met drie andere leden een eigen lijst begon.

Buiten de persoonlijke invloeden zijn er andere mogelijke oorzaken voor het feit dat de leden van de gemeenteraad van Delfzijl zulke ruwe omgangsvormen hebben. De 'vechthouding' van veel raadsleden kan zijn oorzaak vinden in de ontstaansgeschiedenis van Delfzijl als gemeente. De herindeling van 1990 kwam niet makkelijk tot stand. 
De gemeenteraden in Bierum en Termunten hadden eigenlijk andere gedachten, maar hun gemeenten werden uiteindelijk bij Delfzijl gevoegd. De nieuwe gemeenteraad kreeg daardoor te maken met vertegenwoordigers uit de gemeenten Bierum en Termunten. Het CDA zette de Bierummer ex-wethouder K. Stulp op de lijst, de PvdA vaardigde ex-wethouder vit Termunten J.H. Menninga af. Menninga speelt zoals beschreven nog steeds een rol in de politiek, Stulp is afgezwaaid, maar opgevolgd door zijn zoon met de lijst Stulp. Oud-waarnemend burgemeester Waal ziet in de herindeling in ieder geval twee oorzaken voor de kritische, bij tijd en wijle agressieve, cultuur van de gemeenteraad: "De gemeente heeft jarenlang geen goed antwoord gegeven op de vraag: wat voor gemeente wil je zijn: een gemeente met werkgelegenheid en industrie of een plattelandsgemeente. Delfzijl heeft allebei, maar het heeft lang ontbroken aan een gedegen toekomstvisie op het geheel. Dat leverde spanningen op."

Een tweede punt is het 'dorpisme' in de gemeenteraad: "Bijna alle raadsleden uit de dorpen hebben daar een kwart van de kiesdeler gehaald, veel stemmen dus. Dat betekent dat ze bij voorstellen wat meer letten op de vraag: wat betekent iets voor mijn dorp en minder oog hebben voor het geheel."

Bovendien wordt gekeken naar de economische situatie. Het verhaal van Delfzijl is namelijk ook een beetje het verhaal van de niet waargemaakte verwachtingen, de 'Boulevard of broken dreams'. Het zou immers prachtig worden in Delfzijl. De stad zou groeien, de werkgelegenheid zou aantrekken, er dienden vele huizen gebouwd te worden. De werkelijkheid bleek anders. De werkgelegenheid groeide lang niet zo snel als was voorspeld. Er kwamen wel nieuwe bedrijven, maar die hadden veel minder personeel nodig dan was ingeschat. De investeringen vonden meer plaats in de kapitaalintensieve sfeer dan in de arbeidsintensieve sfeer. Huizen waren er al wel gebouwd, maar kopers of huurders dienden zich niet aan. Politiek Delfzijl heeft, zo menen vele geïnterviewden, nooit echt gedurfd de keuze voor krimp te maken. Er is weliswaar begonnen met sanering, maar tot voor kort is er niet echt doorgezet. Bovendien hadden vele raadsleden een moeizame relatie met de speciaal opgerichte Ontwikkelings Maatschappij Delfzijl, waar de woningcorporatie en de gemeente ieder $49 \%$ van de aandelen in bezitten en de provincie de resterende $2 \%$. Deze maatschappij kwam tot stand vanwege de turbulente politieke verhoudingen in Delfzijl: andere overheden wilden zeker weten dat er op een goede manier gewerkt zou gaan worden. Toenmalig staatssecretaris Remkes van VROM (die later als Minister van BZK ook met Delfzijl te maken zou krijgen) wilde de rijksinvesteringen absoluut niet zonder meer overmaken naar de gemeente. Er diende een maatschappij tussen te komen, die de zaken in handen zou nemen. Het negatieve imago van Delfzijl speelde hier dus nadrukkelijk een rol. Het had wel tot gevolg dat gemeenteraad en (soms) het college zich behoorlijk afzetten tegen de ontwikkelingsmaatschappij. Oud-CdK H. Alders: "Het was de bedoeling dat de gemeente de ontwikkelingsmaatschappij als haar eigen vehikel zou zien, maar velen konden dat niet opbrengen."

Het gevolg is dat er in de hele onderzoeksperiode voortdurend spanningen rondom de raad en de raadsdebatten te voelen waren. De cultuur is daarbij vooral gericht op 'afrekenen'. Burgemeester Groot: "Ik heb in mijn Appingedammer tijd wel eens tegen commissaris Alders gezegd, over een tijdelijke benoeming: men is niet erg gevoelig 
voor positie en statuur. Ik ben bang dat zo iets niet veel indruk maakt." Belangrijk is ook dat er in elke raadsperiode oud-wethouders in de raadsbankjes plaats nemen, die de toon in bepaalde debatten behoorlijk kunnen zetten. Enig opportunisme is de meeste raadsleden daarbij niet vreemd. Groot: "Als er wordt ingesproken, omdat een subsidie is geweigerd bijvoorbeeld, dan is de kans groot dat wanneer één partij zegt dat de subsidie toch maar moet worden verstrekt, de rest gemakkelijk meegaat. Soms in strijd met de eigen subsidieverordening. Van dit soort dingen moeten we echt af. Dan is het heel lastig voor het college om een rechte koers vast te houden."

Veel conflicten vonden plaats in de periode 2002-2006. In deze periode deed een nieuwkomer haar intrede in de Delfzijlster gemeenteraad: Gemeentebelangen, met later de afsplitsingen van lijst Stulp en Delfzijls Belang. Een partij die op de golven van het Fortuynisme met zes zetels in de raad kwam, maar onderling weinig verband kende en geen gezamenlijke ideologie onderschreef. Een oorzaak voor veel weinig voorspelbaar stemgedrag en, zoals bleek, een grote hoeveelheid incidenten.

Verwachting 8: In bestuurlijke probleemgemeenten is de bestuurscultuur negatief tot zeer negatief, wat een aanjagende werking heeft op bestuurlijke problemen. De conclusie luidt dat de cultuur in de Delfzijlster raad op sommige momenten in alle onderzochte perioden inderdaad zeer negatief was: de verwachting komt vit.

\section{Macrofactor: de invloed van de media}

Voor Delfzijl kan geconstateerd worden dat de media inderdaad een belangrijke rol speelden in de onderzochte periode. Met name het Dagblad van het Noorden en de regionale omroep RTV-Noord bleken alom aanwezig. Oud-wethouder Westerink schrijft er in zijn boek over de bestuurscrisis in 2006 bladzijden over vol. Hij vindt de berichtgeving bij tijd en wijle tendentieus. "De wijze waarop de media verslag doen, voegt negativisme toe. De berichtgeving over gebeurtenissen in Groningens' havenstad dragen nadrukkelijk bij aan het al bestaande negatieve imago. Gewoon door aspecten weg te laten en andere te benadrukken." (Westerink, 2006: 89). Ook in vergaderingen van de gemeenteraad is een dergelijk geluid te horen. CDA-fractievoorzitter Smid wees er tijdens het einddebat over de kwestie Appel-de Waart op: "Gelukkig zeggen nog veel inwoners dat ze met plezier in Delfzijl wonen. En het wrange is, dat dit plezier mede komt door goede maatregelen die een vorig of huidig gemeentebestuur ooit heeft genomen en die voorbereid en uitgevoerd zijn door onze ambtenaren. Wat betreft de herstructurering, de sociale dienst, de voorzieningen op het gebied van onderwijs, cultuur en sport, de Vrom-achterstanden en nog veel meer punten, zijn er de afgelopen jaren belangrijke stappen vooruit gezet. Als we daarover praten, dan zien we de pers hier niet" (Raadsnotulen Delfzijl, 220206).

Bijzonder in Delfzijl is dat er volgens betrokkenen regelmatig stukken worden gelekt naar de journalisten. Hierdoor staan beleidsintenties van het college al heel snel in de media, waarna standpunten van partijen via diezelfde media worden uitgewisseld. De debatten in de gemeenteraad krijgen daarmee vanaf het begin al een wat kribbig karakter.

Toch geven betrokkenen aan dat het niet zo is dat de media verantwoordelijk zijn te houden voor de crisis. Net als in andere gemeenten helpt de berichtgeving echter niet 
om zaken soepel op te lossen. Maar ja, zullen de journalisten zeggen, moeten we dan maar niet opschrijven wat er gebeurt?

Niet onvermeld mag blijven de oproep om maar niet te gaan stemmen in 2006 (de witte zakdoekjes-actie). Een heftige uiting van ongenoegen met de plaatselijke politiek, waar uiteraard veel publiciteit over was.

Verwachting g luidt: In bestuurlijke probleemgemeenten hebben de (pers)media een grote invloed op het debat, wat een aanjagende werking heeft op bestuurlijke problemen. De conclusie is dat deze verwachting uit komt in Delfzijl.

\subsection{De dynamiek}

Nu alle factoren in beeld zijn gebracht, is het mogelijk iets te zeggen over de dynamiek die op sommige momenten in Delfzijl ontstond. Onder dynamiek verstaan we hier de manier waarop verschillende factoren op elkaar inwerken en er een ontplofbaar mengsel van bestuurlijke risicofactoren ontstaat. De aandacht gaat hierbij vooral uit naar de dynamiek bij de twee grote bestuurscrises, waarbij het hele college uit elkaar viel. Zo kwamen bij de eerste grote bestuurscrisis in 2003 verschillende factoren samen. De burgemeester werd steeds minder gezien als oplosser van problemen, maar veeleer als onderdeel van het probleem. Hij zou te weinig in staat zijn zaken op te lossen, wethouders uit problemen te houden. Dit had geen punt hoeven worden bij wethouders die uit zichzelf ook niet zo snel in de problemen zouden komen, maar dat bleek in de jaren 2002-2003 een illusie in Delfzijl. Verschillende wethouders liepen al snel tegen grote moeilijkheden op. Als daar bovenop dan een zeer kritisch rapport komt van de VROMinspectie, waar een zeer kritische reactie van de provincie op volgt, is er een probleem geboren. Bij een sterke coalitie, met partijen die elkaar vast zouden willen houden, was dit vermoedelijk nog oplosbaar geweest. Maar in die jaren was de coalitie niet sterk: zij was ontstaan met de bedoeling de PvdA eens uit het college te houden. Het college bestond uit een regenboog aan partijpolitieke kleuren, waar geen eenheid van gesmeed was. Het gevolg is bekend: na het vertrek van wethouder Koning en burgemeester Haaksman viel de coalitie geheel uit elkaar.

Het nieuwe college beschikte vervolgens over een ruime meerderheid in de raad. Dit kon niet voorkomen dat er opnieuw een wethouder vertrok in 2004, na kritiek vanuit diezelfde gemeenteraad.

De grote crisis in 2006 was ook een product van ongekend negatief dynamische werking tussen factoren. Burgemeester Appel-de Waart, toch al niet bij iedereen populair door haar soms als steil ervaren optreden, werd middelpunt van een crisis. Zij stond daardoor in ieder geval niet meer boven de partijen. De wethouders opereerden op zich een stuk meer als collectief dan een paar jaar eerder, maar slaagden er viteindelijk niet in de crisis rondom de burgemeester te overleven. De PvdA-fractie bleek moeite te hebben met de manier waarop de burgemeester haar portefeuille $\mathrm{P} \& \mathrm{O}$ werd ontnomen en wilde daar kritiek op uiten. Het college vroeg zich af of het nog gesteund wordt en besloot het antwoord niet af te wachten: de wethouders traden af. De kritische toon van de gemeenteraad speelde hier een rol, maar vooral het gebrek aan coalitiemana- 
gement. Daar waar een goed voorbereid gezamenlijk overleg wellicht schade had kunnen voorkomen, werden zaken te veel op zijn beloop gelaten. Dit kwam ook door de PvdA-fractievoorzitter, die aangaf dat het niet mogelijk was zijn bijdrage in de gemeenteraad van tevoren te laten lezen. Hierdoor ontstonden onduidelijkheid en twijfel over de noodzakelijke steun, die de val van het hele college inluidden.

\subsection{Conclusie}

De vraag aan het begin van deze casestudy was:

Wat is de verklaring voor het gedwongen vertrek van burgemeesters, wethouders en/of hele colleges in Delfzijl in de periode maart 1998-maart 2010?

Het totaal aan aangetroffen invloed is in onderstaande tabel opgenomen:

Tabel 26: De factorenanalyse in Delfzijl

\begin{tabular}{|c|c|c|c|c|c|}
\hline & $\begin{array}{l}\text { Verwachting van de invloed van de factor op de } \\
\text { opgetreden bestuurlijke problematiek }\end{array}$ & $\begin{array}{c}1998- \\
2002\end{array}$ & $\begin{array}{l}2002- \\
2006\end{array}$ & \begin{tabular}{|c|}
$2006-$ \\
2010
\end{tabular} & $\begin{array}{l}\text { Con- } \\
\text { clusie }\end{array}$ \\
\hline 1 & Burgemeester werkte niet dempend & + & + & - & + \\
\hline 2 & Risicofactor wethouders was aanjager & + & + & - & + \\
\hline 3 & Optreden college werkte niet dempend & + & + & - & + \\
\hline 4 & Ontbreken patroon college/ambtenaren was aanjager & + & - & - & - \\
\hline 5 & Zwakke verbinding raad/college was aanjager & - & + & - & - \\
\hline 6 & Zwakke verbinding coalitiepartijen was aanjager & + & + & - & + \\
\hline 7 & Onevenwichtige structuur gemeenteraad was aanjager & + & + & + & + \\
\hline 8 & Negatieve bestuurscultuur was aanjager & + & + & + & + \\
\hline 9 & Invloed van (pers)media op debat was aanjager & + & + & + & + \\
\hline \multicolumn{6}{|c|}{ Legenda: } \\
\hline
\end{tabular}

De conclusie is dat het oorspronkelijk in Den Helder gevonden patroon van factoren, dat bepalend is gebleken bij het optreden van bestuurlijke conflicten en bestuurscrises, ook in Delfzijl opgaat. De microfactor burgemeester, die in Leiden geen grote rol speelde, was in Delfzijl nadrukkelijk wel als factor aanwezig. Bepalend waren opnieuw het niet oppikken van signalen, het niet adaptief zijn en onvoldoende spelen van de verbindende rol door de burgemeester, de persoonlijke risicofactoren van wethouders en de slechte communicatie van de coalitiepartijen, kortom de hechtheid van de coalitie. De colleges werkten de eerste jaren ook niet dempend, maar dat bleek niet bepalend voor de problematiek. De problemen verminderden namelijk op het moment dat aan de drie factoren werd gewerkt. De waarnemend burgemeesters vormden in hun periode geen risicofactor en waren niet betrokken bij een conflict. Hetzelfde geldt voor de huidige burgemeester. Het persoonlijk functioneren van de wethouders stond de afgelopen jaren in veel gevallen ter discussie, maar vanaf 2006 veel minder. 
Het ontstaan van bestuurlijke conflicten werd dus in Delfzijl in grote mate bepaald door het handelen van personen zelf. Er waren ook enkele constante negatieve factoren, zoals dat ook in Den Helder en Leiden het geval was. In Delfzijl gaat het dan vooral om de cultuur in de gemeenteraad, die op zijn zachtst gezegd erg kritisch was, maar ook beide andere macrofactoren speelden een rol.

Bij het ontstaan van bestuurscrises bleek vooral de hechtheid van coalities van belang te zijn. Dat was zeker het geval bij de crisis in 2006, die pas ontstond na twijfel over de hechtheid van de coalitie, doordat de PvdA kritische vragen zou gaan stellen. Als dat niet was gebeurd, was de crisis vermoedelijk beperkt gebleven tot het vertrek van de burgemeester. Zodra er sprake was van duidelijk coalitiemanagement en heldere afspraken tussen partijen, kortom: goede communicatie, nam het bestuurlijk risico fors af.

In de laatste casestudy zal worden bekeken of dit patroon eveneens is te herleiden in Zundert. 


\section{Bestuurlijke problematiek in Zundert 1998-2010}

\section{$8.1 \quad$ Inleiding}

Ook in deze laatste casestudy zal een poging worden gedaan de gebeurtenissen te beschrijven en te analyseren, door in te zoomen op de micro-, meso- en macrofactoren en conclusies te trekken. Tegelijkertijd is dit de laatste toetsing van het patroon, dat uit de voorgaande casestudies naar voren is gekomen. De vraagstelling luidt:

Wat is de verklaring voor het gedwongen vertrek van burgemeesters, wethouders en/of hele colleges in Zundert in de periode maart 1998 - maart 2010?

Om dit goed in beeld te kunnen krijgen worden in dit hoofdstuk op dezelfde wijze als in de andere casestudies de verschillende bestuurlijke conflicten en bestuurlijke crises onderzocht. In de laatste paragraaf zal getracht worden conclusies te trekken met betrekking tot de hierboven geformuleerde vraag. Bezien wordt of inderdaad de factoren die van belang bleken bij het ontstaan van een bestuurlijk conflict of bestuurscrisis in de andere onderzochte gemeenten, nu ook opgeld doen.

De casestudy in Zundert kent een bijzonderheid. Anders dan in de andere gemeenten, waren er in Zundert geen verkiezingen in 1998, maar in 1999. Dit had te maken met het ontstaan van de gemeente per 1 januari 1997, na samenvoeging met de gemeente Rijsbergen. Een herindeling die de gemoederen nog lang heeft bezig gehouden, maar daarover in de casestudy meer. Het oorspronkelijk bij de Tweede Kamer ingediende wetsvoorstel voorzag voor de per 1 januari 1997 aangetreden nieuwe gemeenteraden in Noord-Brabant in een zittingsduur van vijf jaar en vier maanden (tot de reguliere gemeenteraadsverkiezingen in 2002). De Tweede Kamer vond deze zittingsduur echter te lang. Bij amendement van het lid Verhagen werd daarom een tussentijdse verkiezing toegevoegd, samenvallend met de provinciale statenverkiezing van 3 maart 1999. Hierdoor wijkt de gemeente voor wat betreft de eerste onderzoeksperiode af van de andere onderzochte gemeenten. Het zittende college, dat op dat moment net twee jaar functioneerde, veranderde na de verkiezingen van 1999 wel van samenstelling.

\subsection{Introductie van de gemeente Zundert}

De gemeente Zundert ligt op de grens van Nederland en België, in West-Brabant. De gemeente bestaat uit vijf dorpen: Zundert, Klein-Zundert, Rijsbergen, Wernhout en Achtmaal. Dorpen die al erg oud zijn. De oudste vermeldingen van plaatsen die nu deel uitmaken van de gemeente Zundert gaan terug naar het midden van de twaalfde eeuw. Om precies te zijn naar 1157, wanneer de bisschop van Luik de schenking door Arnulfus of Arnoud II van Brabant aan de abdij van Tongerlo van tienden en het patronaatsrecht (het recht om de pastoor te benoemen) van de kerk te Sunderda (Zundert) bevestigt. De naam Rijsbergen komt voor het eerst aan de orde in documenten vit 1159. In afzonderlijke akten bevestigen de bisschop van Luik en Arnoud I, hertog van 
Brabant, dat Werner van Rijsbergen, een zoon van de hertog en broer van Arnoud II, zijn eigendom te Esschen aan de abdij van Tongerlo geschonken heeft en keuren dit goed. In hetzelfde jaar wordt nog een derde zoon van Arnoud I in documenten genoemd: Otto van Rijsbergen. Als men zich naar een plaats vernoemt of ernaar vernoemd wordt, mag aangenomen worden dat deze van enige omvang is en dat er zich omstreeks dat moment een kerk en misschien wel een parochie bevinden, meldt de Zundertse website.

\section{Zundert-Hertog}

Uit de schepenbank Zundert-Hertog is een tweede enclave ontstaan, de schepenbank Wernhout met de hoge jurisdictie (het recht om doodvonnissen uit te spreken en uit te voeren). Met de oprichting in 1815 van het Koninkrijk der Nederlanden werd de bestuurlijke organisatie gewijzigd. De Zundertse heerlijkheden werden samengevoegd tot de gemeente Zundert en Wernhout. Tegen het einde van de negentiende eeuw werd de gemeentenaam vereenvoudigd tot Zundert.

De nieuwe gemeente Zundert

Begin jaren negentig van de twintigste eeuw kwam een proces van per regio geplande herindeling in de provincie Noord-

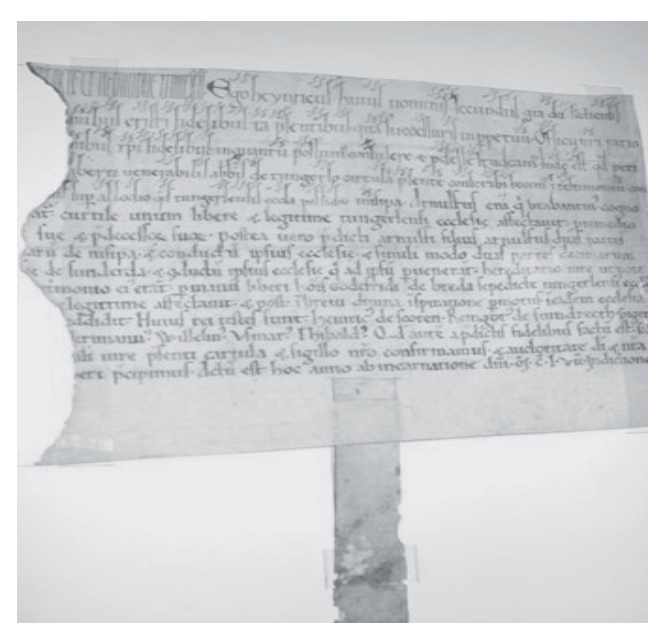

De historische acte van Zundert.

Foto: Gemeente Zundert Brabant op gang. Deze ontwikkeling ging uiteindelijk ook aan de voormalige gemeenten Zundert en Rijsbergen niet voorbij. Per 1 januari 1997 vormen zij samen de nieuwe gemeente Zundert, een gemeente met per 1 januari 2010 ongeveer 21.000 inwoners. De gemeente heeft een forse oppervlakte van 120 vierkante kilometer en veel bedrijvigheid in het kader van boomen aardbeienteelt.

De bekendste oud-inwoner van Zundert is ongetwijfeld schilder Vincent van Gogh, die in 1853 aan de Markt in Zundert werd geboren. Zijn vader Theo was predikant in Zundert. Het geboortehuis is afgebroken, maar op de plaats waar het heeft gestaan is heden ten dage het Van Goghhuis gevestigd. Zundert staat ook bekend om het traditionele bloemencorso, dat jaarlijks plaatsvindt op de eerste zondag van september. Dit corso is het grootste van Europa en komt tot stand dankzij de inzet van vele honderden vrijwilligers.

\subsection{2 jaar Zundertse politiek}

De Zundertse gemeenteraad telt negentien raadsleden na de herindeling in 1997. De eerste verkiezingen in de onderzoeksperiode waren die van 1999. Het totaalbeeld is als volgt: 
Tabel 27: Samenstelling gemeenteraad Zundert 1999-2010

\begin{tabular}{|l|c|cc|c|}
\hline Naam partij & 1999 & 2002 & Na afspl. & 2006 \\
\hline 1. CDA & 5 & 4 & 4 & 4 \\
\hline 2. VVD & 4 & 4 & 3 \\
\hline 3. NZ\&W & - & 5 & 4 & - \\
\hline 4. Werknemersbelang Zundert & 2 & - & 2 & 2 \\
\hline 5. PvdA & 1 & 2 & 2 \\
\hline 6. Dorpsbelangen & 1 & 2 & - \\
\hline 7. Agrarisch Belang & 2 & 2 & - \\
\hline 8. Nieuw Zundert & 2 & - & - \\
\hline 9. Welzijn '97 & 1 & - & - \\
\hline 10. Fractie Jacobs & 1 & - & 2 \\
\hline 11. Lijst De Rooij & - & - & 19 \\
\hline 12. 3D Partij & - & - & 7 & 7 \\
\hline Totaal & 19 & 19 & 2,71 (gem. $=2,66$ ) \\
\hline Aantal fracties & 9 & 6 & & - \\
\hline Fractiequote & 2,11 & 3,16 & & 2 \\
\hline
\end{tabular}

In Zundert leverden de verkiezingen in 1999 vijf zetels op voor het CDA, dat daarmee de grootste partij werd. Met uitzondering van de VVD, die vier zetels haalde, kwamen maar liefst zeven partijen op één of twee zetels vit. Dit leverde het totaal van negen partijen op in de gemeenteraad, met een gemiddelde bezetting (fractiequote) van 2,1 , wat erg laag is. Bij de verkiezingen in 2002 bundelden Nieuw Zundert en Werknemersbelangen Zundert hun krachten en ontstond de partij NZ\&W. De partij behaalde vijf zetels en werd de grootste in Zundert, groter dan het CDA, dat een zetel verloor. Het leverde toch een coalitie op zonder NZ\&W (zie casestudy). Door de samenvoeging verdwenen er enkele kleinere partijen, al vond in deze periode wel de enige afsplitsing plaats: fractielid De Rooij van NZ\&W stapte uit de partij en begon zijn eigen Lijst De Rooij. De verkiezingen van 2006 tenslotte gaven weinig verschuiving te zien, al kwam er nog wel een nieuwkomer bij: 3D, de politieke partij voor democratie, duidelijkheid en daadkracht. 3D behaalde twee zetels bij de verkiezingen in 2006.

Van dominantie van partijen is nauwelijks sprake geweest. Wel behaalden met name CDA en Agrarisch Belang (AB) vrij vaste uitslagen van respectievelijk vier of vijf zetels en twee zetels. Er is een behoorlijk aantal lokale lijsten, maar dat komt in provincies als Limburg en Noord-Brabant vaker voor (zie paragraaf 3.5).

Tabel 28: Samenstelling Colleges van B\&W gemeente Zundert 1997-2010

\begin{tabular}{|c|c|c|c|c|c|c|c|c|c|c|c|}
\hline 1997 & Weth & $\mathbf{1 9 9 9}$ & Weth & $\mathbf{2 0 0 2}$ & Weth & $\mathbf{2 0 0 4}$ & Weth & $\mathbf{2 0 0 5}$ & Weth & $\mathbf{2 0 0 8}$ & Weth \\
\hline CDA & 1 & CDA & 1 & CDA & $1 * *$ & CDA & 1 & Za- & 1 & CDA & $1 * * *$ \\
Wnb-Z & 1 & VVD & 1 & VVD & $1 * *$ & VVD & 1 & ken- & 1 & VVD & $1 * * *$ \\
$*$ & & AB & 1 & AB. & $1 * *$ & AB & 1 & colle- & 1 & NZ\&W & $1 * * *$ \\
& & & & PvdA & $1 * *$ & & & ge & & & \\
\end{tabular}

* Wnb-Z = Werknemersbelangen Zundert

** $90 \%$ (PvdA: 50\%)

$* * * 70 \%$ 
De verschillende colleges in Zundert konden bogen op wisselende meerderheden. Het college dat startte in 1999 bestond uit drie partijen, die samen goed waren voor elf van de negentien zetels. In 2002 was de situatie nog rianter. De PvdA voegde zich bij de collegepartijen, waardoor er een meerderheid was van twaalf van de negentien raadszetels. Een bijzondere situatie ontstond na de verkiezingen van 2006, toen besloten werd het zakencollege dat was gevormd te laten zitten en ook geen coalitie of oppositie te vormen. Alle partijen, op 3D na, onderschreven het opgestelde raadsprogramma in de vorm van een 'elf-punten plan' (zie casestudy). Pas in 2008 was er weer sprake van een min of meer regulier college, waar CDA, VVD en NZ\&W voor tekenden, een meerderheid van elf van de negentien zetels. Dit college, waar als vierde wethouder nog één externe kandidaat was blijven zitten, haalde de eindstreep net niet, door het vertrek van de wethouder van NZ\&W in februari 2010.

Tabel 29: Burgemeesters van Zundert vanaf 1997 - 2010

\begin{tabular}{|l|l|}
\hline Mr.P. Neeb (VVD) & $1997-2002$ \\
\hline Mr. H.G. Vos (CDA) & $2003^{-2005}$ \\
\hline I.J.P. Keijzer (VVD, wnd.) & $2004^{-2007^{*}}$ \\
\hline Mw. L.C. Poppe de Looff (CDA) & Maart 2007-Heden \\
\hline
\end{tabular}

*Vanaf 2004 waarnemend wegens ziekte van bgm. Vos

Zundert kende in de onderzoeksperiode vier burgemeesters. De gemeente startte met burgemeester P. Neeb, die het ambt zes jaar vervulde en op 1 januari 2003 met vervroegd pensioen ging. Hij werd na enige schermutselingen (zie casestudy) opgevolgd door H.G. Vos, die zich een jaar later ziek meldde en niet meer zou terugkeren in Zundert. Vos werd later benoemd tot waarnemend burgemeester in Nederweert en 'vaste' burgemeester in het Limburgse Nuth. Zundert kreeg na het vertrek van Vos te maken met waarnemend burgemeester I.J.P. Keijzer, die een behoorlijke tijd bleef: vanaf de zomer van 2004 tot maart 2007. Vanaf maart 2007 is mw. L.C. Poppe-de Looff burgemeester van Zundert, na een periode van zestien jaar als wethouder in Vlissingen.

\subsection{De problemen op een rij}

De gemeente Zundert staat bekend om haar turbulente bestuurlijk klimaat. In de onderzoeksperiode zijn drie colleges gevallen of tussentijds van samenstelling veranderd, is één burgemeester na ziekte voortijdig gestopt en verloren vijf wethouders voortijdig hun baan. Bovendien zat er gedurende lange tijd, circa 2,5 jaar, een 'zakencollege' met wethouders van buiten. Vanwege de onmogelijkheid een nieuw, eigen, college te formeren zijn deze wethouders na de verkiezingen in 2006 blijven zitten, om begin 2008 plaats te maken voor een nieuw Zunderts college. Zonder slag of stoot ging dit niet: pas na tussenkomst van een externe formateur kon een nieuw college aan de slag. Verwikkelingen genoeg dus.

\subsubsection{Periode 1997-2002}

De nieuwe gemeente Zundert ontstaat per 1 januari 1997. De herindeling, die eraan voorafgaat, verloopt bepaald niet vlekkeloos. Zowel de gemeente Zundert als de gemeente Rijsbergen willen helemaal niet fuseren. Sterker nog: tot zeer kort voor de herindeling staan beide partijen voor de rechtbank in Breda, om uit te vechten of er nu 
wel of niet oneigenlijke vitgaven zijn gedaan vlak vóór de herindeling. Rijsbergse bestuurders vinden het 'grote' Zundert te dominant in de aanloop naar de herindeling en zetten de hakken in het zand. Het feit dat de nieuwe gemeente weer Zundert zal heten helpt daarbij ook niet. De Rijsbergse wethouders in de stuurgroep, die de herindeling moet voorbereiden, lopen daar op de valreep zelfs boos vit weg. Het merendeel van de ambtenaren krijgt pas vlak voor de kerstdagen te horen welke baan men in de nieuwe gemeente zal krijgen. Kortom: absoluut geen ideale omstandigheden, maar de samenvoeging is opgelegd en gaat door: "Het is natuurlijk overdreven, maar ik zeg wel eens dat het de grootste ramp is die na de oorlog is gebeurd", zegt oud-CDAwethouder en raadslid A.M.M. van der Kloot. Hij kan het weten, want hij treedt na de fusie op 1 januari 1997 aan als wethouder in de nieuwe gemeente.

Ook daarvoor was Van der Kloot overigens al wethouder in Zundert, van 1990 tot 1995. Hij struikelde toen over een motie van wantrouwen, nadat zijn partij een brief had geschreven, waarin werd opgeroepen voortgang te maken met de fusie. Dat viel bij een meerderheid van de gemeenteraad niet goed, waardoor hij diende af te treden. Van der Kloot behaalt bij de verkiezingen, eind 1996, echter ruim 1.700 voorkeurstemmen en komt terug in het college.

De tweede wethouder is J. Jacobs van Werknemersbelangen Zundert. Een minderheidscollege, dat echter de steun krijgt van

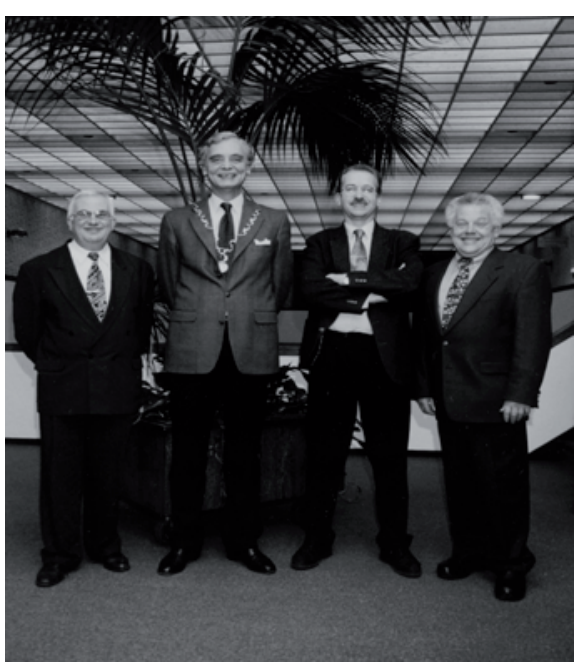

Het college van B\&W dat in 1997 aantrad, met v.l.n.r. wethouder A. van der Kloot, burgemeester $P$. Neeb, gemeentesecretaris

B. Hartman en wethouder J. Jacobs.

Foto: Ton Schluter, Zundert Bron: Regionaal Archief West-Brabant Dorpsbelangen en $\mathrm{AB}$. Tot nieuwe burgemeester wordt $P$. Neeb benoemd, oudburgemeester van Oudenbosch. Hij is één van de vele Brabantse burgemeesters, die na de herindelingsoperatie een nieuwe gemeente krijgt. Neeb staat niet als eerste op de voordracht, maar krijgt de voorkeur van commissaris Houben en ook van de Minister van Binnenlandse Zaken, die in hem de man zien om enige rust te brengen in de woelige Zundertse gelederen na de herindeling. "Dat ik niet op de eerste plaats stond heb ik nog wel enige tijd moeten horen", herinnert Neeb zich. Hij gaat desalniettemin opgetogen aan de slag, in een lastige situatie. Eigenlijk is er nog vrijwel niets op orde: de financiële huishouding, de vergunningenadministratie, alles moet worden opgebouwd. Bovendien zijn er spanningen rondom de nieuwe secretaris. $\mathrm{Hij}$ is afkomstig uit Zundert en daardoor bij voorbaat verdacht bij veel ambtenaren en bestuurders met een Rijsbergse achtergrond. Pas twee maanden na de start van de gemeente is er groen licht en kan hij aan de slag (Kloeg, 2004). Al snel komt er vanuit de nieuwe raad echter kritiek, die vrij hard op de persoon wordt gespeeld. Het dreigt uit de hand te lopen, personen lopen beschadigingen op. Burgemeester Neeb besluit tot een biechtstoelprocedure, waarin hij alle 
raadsleden stuk voor stuk op zijn werkkamer vitnodigt om over de situatie te praten. Het geeft enige lucht, de raadsleden geven aan de situatie te willen accepteren. Maar het leed blijkt al te zeer geleden te zijn. De secretaris komt in de ziektewet terecht en zal hierna een andere baan zoeken.

Het nieuwe college draait best redelijk, gezien de omstandigheden. "De verwachtingen waren zo slecht, dat het alleen maar mee kon vallen", herinnert Van der Kloot zich. Van consistent beleid was echter weinig sprake, aldus oud-burgemeester Neeb. "De sfeer was zo: er was een besluit genomen, maar na enige tijd werd dan gezegd: zullen we het toch maar anders doen? Dan was men in het dorp, of het café, weer een belangengroep tegen gekomen, die het ergens niet mee eens was. We spraken wel af dat een besluit ook echt een besluit was, maar dat bleef moeilijk."

De landelijke gemeenteraadsverkiezingen van 1998 gaan aan de neus van Zundert voorbij, maar in 1999 zijn er weer wel verkiezingen. Opnieuw behalen CDA en Werknemersbelangen Zundert een goede uitslag. Het CDA wil nu echter een bredere basis voor het college en ziet mogelijkheden om AB, waar al eerder mee was samengewerkt, weer in de coalitie te betrekken. Dit stuit op problemen bij Werknemersbelangen Zundert, waar vooral persoonlijke tegenstellingen achter zitten. Wethouder Jacobs keert op grond hiervan niet meer terug in het college. Onder leiding van burgemeester Neeb gaat uiteindelijk een coalitie van CDA, VVD en AB van start. Wethouders worden opnieuw A. van der Kloot (CDA), tezamen met C.F.J. Verheijen (VVD) en B. Poppelaers $(A B)$. Dit college draait op zich wel goed, al zorgen twee zaken steeds voor spanning. Op de eerste plaats is dat de herindeling, die voor grote problemen in de organisatie heeft gezorgd. De samenvoeging van de twee ambtelijke organisaties verloopt bepaald niet soepel, na de gemeentesecretaris raken ook andere personen op sleutelposities beschadigd. Bovendien blijkt dat de begroting met steeds meer moeite sluitend gemaakt kan worden. Toch blijven het college grote bestuurlijke problemen bespaard, al is het wel zo dat er nog een personele wisseling is. Wethouder Verheijen wordt gemeentesecretaris in Rucphen en wordt opgevolgd door VVD-partijgenoot P. Utens. De tijd is echter redelijk kort, want in maart 2002 staan er opnieuw verkiezingen voor de deur.

\subsubsection{Periode 2002-2006}

De raadsperiode 2002-2006 zal een zeer turbulente periode blijken te zijn in de Brabantse gemeente. De gemeenteraadsverkiezingen tonen een bescheiden winst van een aantal partijen. Zowel Dorpsbelangen als de PvdA winnen een zetel en komen op twee, net zo groot als Agrarisch Belang. Ook een nieuwe partij doet zijn intrede: Nieuw Zundert \&Werknemersbelang (NZ\&W), een fusie van de partijen Nieuw Zundert en Werknemersbelangen Zundert. De partij wint de verkiezingen en komt met vijf zetels in de gemeenteraad. De VVD blijft stabiel op vier zetels, het CDA verliest een zetel en komt eveneens op vier zetels.

Er volgt een lastige formatieperiode. NZ\&W neemt, als grootste partij, het voortouw. Lijsttrekker Marijnissen ligt echter niet zo heel goed bij zijn gesprekspartners. Terwijl wel van hem gezegd wordt dat hij het goed heeft gedaan als wethouder in de voormalige gemeente Zundert. "Volgens mij zat er bij enkelen ook wel enige afgunst bij, waarbij het ook typisch Zunderts is om zo iemand dan extra kritisch te benaderen, onder het motto: hij moet niet denken dat hij hier de dienst kan uitmaken", zegt oud-burgemeester Keijzer. 
Belangrijk bespreekpunt is in ieder geval de toekomst van recreatiepark Patersven. Een gebied met van oorsprong stacaravans en kleinere dagverblijven, dat in de periode 1997-2000 langzaam is verdeeld in ongeveer 500 kavels, met evenzoveel (kleine) woningen erop. Bij deze operatie is in het bestemmingsplan vastgelegd dat er niet permanent in de woningen gewoond zou mogen worden, een afspraak die later met de eigenaren ook privaatrechtelijk is vastgelegd. De woningen werden vaak bewoond door de, veelal uit Polen afkomstige, aardbeienplukkers van bedrijven uit de omgeving, maar... viteindelijk toch ook steeds meer door permanente bewoners. De vraag of hier niet eens ingegrepen zou moeten worden houdt de Zundertse politiek al enige tijd bezig. Zeker nadat er meldingen binnen komen, dat er zaken zouden gebeuren die het daglicht niet zouden kunnen verdragen. Dienen nu echt de teugels aangetrokken te worden en de op zich verboden permanente bewoning aangepakt te worden? De partijen wachten op instructies uit Den Haag, waar op het Ministerie van VROM ook wordt nagedacht over dit type vraagstukken. Er komen verschillende brieven over het onderwerp, die voor zowel voorstanders als tegenstanders van handhaving aanknopingspunten bieden. Als echte duidelijkheid uitblijft, wordt de knoop doorgehakt: de gemeente Zundert zal gaan handhaven en permanente bewoning tegengaan.

Het is een afspraak waar NZ\&W zich niet in kan vinden. De partij doet niet mee aan de vorming van het college, dat wordt gevormd door het CDA, PvdA, VVD en Agrarisch Belang. Samen goed voor een ruime meerderheid van twaalf van de negentien raadszetels. Voor het CDA wordt M.J.C.M. van Tilburg wethouder en loco-burgemeester. Deze nieuwkomer is afkomstig uit ondernemerskring en gevraagd om de politiek in te komen. Voor de PvdA komt wethouder J. Damen in het college, de VVD komt met wethouder A.J.H.C. Jacobs, dezelfde persoon als in de periode 1997-1999. Hij stapt over van Werknemersbelangen Zundert naar de VVD en wordt nu opnieuw wethouder. AB tenslotte vaardigt H.J.M. Poppelaers af, die ook al eerder wethouder was en de meest ervaren man in het college. Op burgemeester Neeb na dan, maar dat duurt niet lang: hij geeft in mei 2002 te kennen dat hij wil gaan stoppen per 1 januari 2003. "De zes jaar van mijn benoeming waren voorbij, ik vond het mooi geweest."

De raad begint met goede moed aan de opvolgingsprocedure. Een profielschets wordt opgesteld, de selectie van nieuwe kandidaten begint. De raadsleden zijn het na alle gesprekken eens over de kandidaat: de uit het Limburgse Meijel afkomstige burgemeester H.G. Vos moet benoemd worden tot burgemeester van Zundert. Het voordragen van een tweede kandidaat vindt de raad niet nodig, wat tegen de op dat moment geldende eisen is. ledere gemeenteraad dient twee kandidaten openbaar bekend te maken. Minister J. Remkes van Binnenlandse Zaken tilt er zwaar aan, wijst de voordracht af en zet de gemeenteraad opnieuw aan het werk. Dat duurt even: de raad is eigenlijk niet van plan zich de les te laten lezen door de minister. In plaats daarvan wordt de schuld neergelegd bij het provinciebestuur van Noord-Brabant, dat volgens de raadsleden eerder had moeten waarschuwen, waarna het provinciebestuur aangeeft dat wel degelijk gedaan te hebben. In ieder geval betekent het oponthoud dat locoburgemeester Van Tilburg een half jaar lang de burgemeesterlijke teugels overneemt. En de tijd lijkt in dit geval in het voordeel van Zundert te werken: de verplichte tweede, openbare, voordracht wordt op enig moment ingetrokken: één openbare kandidaat mag dan ook. De gemeenteraad komt opnieuw met burgemeester Vos, die uiteindelijk 
op 1 juli 2003 wordt benoemd. Hij wordt feestelijk ingehaald en geeft aan met veel plezier en elan te willen beginnen als burgemeester.

\section{Ziekte en vertrek burgemeester}

Echt lekker loopt het echter niet met de nieuwe eerste burger, ondanks het feit dat Zundert twee keer koos voor Vos. Aan diens inzet ligt het niet: die wordt door alle gesprekspartners geroemd. Vos heeft hart voor Zundert en is bereid er alles aan te doen om er iets van te maken. Maar de omstandigheden werken bepaald niet mee. Al vrij vlot krijgt Vos te maken met verhalen over onterechte declaraties (verhuiskosten) van zowel de gemeentesecretaris als oud-burgemeester Neeb. Onderzoek wijst uit dat er inderdaad enkele zaken niet kloppen. Het wordt rechtgezet, maar het gezag van de secretaris lijdt eronder. Een jaar later zal hij vertrekken. Bovendien functioneert het college, ook door alle schermutselingen bij de formatie, bepaald niet als vriendenteam. In de gemeenteraad zelf is de sfeer er, met de verongelijkte NZ\&W in de oppositie, ook al niet beter op geworden. In die sfeer blijkt vervolgens ook de huisvesting van Vos zelf een probleem te worden. De gemeenteraad geeft aan niet van plan te zijn de burgemeester te helpen met de huisvesting. De ambtswoning, ten tijde van zijn functioneren bewoond door voorganger Neeb, staat weliswaar leeg, maar de raad wil niet investeren in dit gemeentelijke pand. Het huis kan mogelijk een rol spelen in de huisvesting van de gemeentelijke organisatie. Een voorstel van Vos om het desnoods tijdelijk te huren, in afwachting van een andere woning, vindt geen genade. Een meerderheid van de gemeenteraad vindt bovendien de investering in het pand, om het op te knappen, te groot. De Zundertse raad laat weten al bij de sollicitatiegesprekken te hebben aangegeven dat Vos zelf in zijn huisvesting moet voorzien en niet van plan te zijn daar van af te stappen. Oud-wethouder Van Tilburg verklaart deze opstelling uit de volksaard: "In een dorp als Zundert ligt de huisvesting van de burgemeester lastig. Eigenlijk wordt gevonden dat het een gewone man tussen de mensen moet zijn, die moet je niet teveel privileges geven. Ik vond zelf wel dat er iets moest gebeuren, dat wij toch moesten investeren in de ambtswoning. Maar daar was op dat moment geen meerderheid voor te halen. Misschien had Vos het ook iets meer tijd moeten geven. Hij ging er gelijk met de fractievoorzitters over in gesprek, misschien was dat wat kort door de bocht en had hij het via de collegeleden moeten laten lopen." Hoe dan ook: zolang het huis in de vorige gemeente niet verkocht is, blijft het gezin van de burgemeester daar wonen en rijdt de burgemeester zelf heen en weer tussen Meijel en Zundert, een ritje van op en neer ruim 220 kilometer. Als het uitkomt, overnacht Vos in een vakantiewoning of bij een bevriend echtpaar. Geen ideale situatie.

Al snel komt de onduidelijkheid over de gekozen burgemeester er bij. Bij de verkiezingen van maart 2006 zouden volgens plan van het kabinet alle Nederlandse burgemeesters ontslagen worden, waarna er in elke gemeente burgemeestersverkiezingen zouden worden georganiseerd. Zouden, want dit kabinetsvoorstel sneuvelt uiteindelijk na de behandeling en stemming in de Eerste Kamer. Voorafgaand hieraan betekent het wel dat nieuw benoemde burgemeesters ontheffing kunnen krijgen van hun verhuisplicht. Het zet Vos aan het denken, laat hij weten: "Ik ben mijn huis aan het verkopen. De woningmarkt is al geen hosanna. En voor drie jaar een duur huis kopen in Zundert? Dat maakt het er allemaal niet makkelijker op. Als men wil dat de burgemeester en zijn 
gezin zo snel mogelijk integreren in de gemeente, dan is er misschien wel enige actie van de gemeenteraad en het college gewenst" (Kloeg, 2003).

Er komt echter geen actie. Vos vindt uiteindelijk een woning in Rijsbergen, maar besluit dan toch iets anders. Hij kiest ervoor in Meijel te blijven en verzoekt de raad hem ontheffing te verlenen van het woonplaatsvereiste, blijkt uit het verslag van de raadsvergadering van 3 mei 2004: "De voorzitter geeft aan dat zijn vrouw en kinderen hebbenbesloten niet naar Zundert te verhuizen in verband met de onzekerheid die is ontstaan rondom de gekozen burgemeester. In maart 2006 krijgen alle burgemeesters gezamenlijk ontslag. Hij vraagt begrip voor de maatschappelijke situatie waarin hij terecht is gekomen en hij vraagt de raad een standpunt in te nemen omtrent de ontheffingsmogelijkheid. Indien de raad geen ontheffing wenst te verlenen, zal hij zelf woonruimte zoeken in de gemeente Zundert. Over enige tijd moet hier duidelijkheid over komen. In dit stadium wordt er niet met de pers over gecommuniceerd." De raadsleden besluiten korte tijd later dat de ontheffing verleend kan worden. Tegen die tijd heeft Vos zich echter ziek gemeld en zal hij, zo blijkt later, ook niet meer terugkeren. De ziekte heeft te maken met de werksituatie, geeft hij aan in een interview in 2004: "Hoe de werksituatie is in Zundert in de gemeenteraad, in het college en in het management is iedereen bekend. In ieder geval matchten Vos en Zundert niet zo goed. Ik heb kwaliteiten en vaardigheden en die kwamen niet volledig tot zijn recht in Zundert. Ik heb er heel veel energie in gestopt. Het werd steeds duidelijker dat Zundert een pittige gemeente is. Je wilt er toch iets van maken. Gaat steeds harder werken, zeventig, tachtig uur per week. Je bent regelmatig van huis. De toekomst is onzeker vanwege de gekozen burgemeester. En toen? Toen had ik een burn-out" (Kloeg, 2004).

De politiek in Zundert krijgt na de ziekmelding van Vos een schrobbering van Commissaris van de Koningin (CdK) J.R.H. Maij-Weggen. "De spanning in deze gemeenteraad is burgemeester Vos te veel geworden", aldus commissaris Maij-Weggen in september 2004 (Kloeg, 2004). Achteraf zegt ze daar geen spijt van te hebben: "Er zijn stevige woorden gesproken en dat was ook nodig." Mede omdat zij geïnformeerd wordt over ernstige ordeverstoringen door Marokkaanse jongeren in de wijk De Berk gaat Maij-Weggen op zoek naar een waarnemend burgemeester. Het moet iemand zijn die gepokt en gemazeld is in het vak. Ze neemt contact op met de in Brabant bekende oudburgemeester I.J.P. Keijzer. Deze begon zijn loopbaan als burgemeester in 1965 in de gemeenten Benthuizen en Moerkapelle, waarna hij achtereenvolgens burgemeester was in Waalre (1978), Veghel (1985) en opnieuw Veghel na de herindeling (1994). Na zijn pensionering werd Keijzer al direct waarnemer in Vught (1999), na het vertrek van burgemeester F. de Graaf naar Apeldoorn. Rond de eeuwwisseling (van december 1999 tot half april 2000) functioneerde hij in de gemeente Aalburg ter vervanging van een zieke collega. Later in het jaar 2000 werd Keijzer vervolgens waarnemer in Ravenstein, dat toen nog zelfstandig was, maar per 1 januari 2003 (mede door zijn adviezen) fuseerde met Oss. De omslachtige procedure maakte dat hij daar bijna 2,5 jaar functioneerde. Kortom: een ervaren man, ingevoerd in het Brabantse politieke metier. Keijzer meldt zich op het provinciehuis en ontmoet de fractievoorzitters, waarvan enkelen overigens, in een eerder gevoerd gesprek met de $\mathrm{CdK}$, hadden aangeven een waarnemer niet nodig te vinden. De commissaris denkt daar anders over. Een nieuw gesprek werkt kennelijk verhelderend, want unaniem stemt men in met de komst van Keijzer als 
waarnemer. Hij gaat in juli 2004 aan de slag. Hij spreekt af te blijven tot de terugkeer van Vos. De onduidelijkheid daarover, gekoppeld aan de situatie in Zundert, maken dat de waarneming uiteindelijk bijna drie jaar duurt.

Keijzer treft een ambtelijke organisatie aan die leidt onder de bestuurlijke problematiek en naar zijn oordeel niet goed geleid wordt. Bovendien zijn er regelmatig inhuurkrachten aanwezig, om de vaak voorkomende vacatures in te vullen. Dat heeft tot gevolg dat de echte binding met de gemeente ontbreekt. Ook de gevolgen van de herindeling blijken nog lang niet verwerkt te zijn. Keijzer nodigt alle raadsleden vit voor een gesprek, maar ook meerdere personen uit de lokale samenleving, om zo een helder beeld te krijgen van de situatie. Hij constateert kritiek en diep onderling wantrouwen. Van constructief besturen is geen sprake. Er moet iets gebeuren, vindt hij, om de zaak op te schudden. Hij besluit, met instemming van college en fractievoorzitters, hulp te vragen in Breda. In november doet Keijzer het verzoek aan de burgemeester van Breda een team uit diens ambtelijke organisatie een onderzoek te laten instellen naar het samenspel tussen de gemeenteraad, het college van B\&W en de ambtelijke organisatie in Zundert. Het team komt onder leiding te staan van de Bredase gemeentesecretaris Bernard Ouwerkerk en zal in januari 2005 al een rapport opleveren, dat er niet om liegt.

\section{Vertrek wethouder}

Keijzer krijgt overigens te maken met een college van drie in plaats van vier personen. Wethouder J. Damen van de PvdA is dan inmiddels vertrokken. Hij kondigt zijn ontslag aan in april 2004, na kritiek van zijn eigen PvdA-fractie. In de gemeenteraadsvergadering van 29 april 2004 geeft hij tekst en uitleg, blijkt uit het verslag: "Wethouder Damen zegt dat zijn besluit om op te stappen is ingegeven door het feit dat hij is geconfronteerd met standpunten waarmee hij niet verder kon. Niet alleen omdat ze inhoudelijk niet strookten met zijn opvattingen, maar vooral omdat deze in strijd waren met de afspraken die met elkaar waren gemaakt. Hierdoor is het voor hem een vertrouwenskwestie geworden. Als het onderlinge vertrouwen wordt aangetast, ontbreekt de basis om samen te werken en te functioneren, ook binnen een duaal stelsel" (Raadsnotulen gemeente Zundert, 290404). Een opvolger komt er niet, waardoor de coalitie nog kan bogen op een meerderheid van tien van de negentien zetels. Het leidt vóór de komst van Keijzer wel tot een discussie over de verdeling van de portefeuille van Damen. Ook burgemeester Vos zou hier een deel van moeten overnemen, maar hij kiest ervoor geen politiek-inhoudelijke dossiers tot zich te nemen. De fractievoorzitters hadden het voornemen hier nog een keer met hem over te praten, maar door de ziekte van Vos komt dat er niet meer van.

\section{Crisis rond Patersven}

Intussen gaat het werk verder. Wethouder Van Tilburg, die waardering had geoogst voor zijn optreden als loco-burgemeester na het vertrek van Neeb en de verlate komst van Vos, is voortvarend aan de slag gegaan met de afgesproken handhaving op het park Patersven. Op de eerste plaats vraagt en krijgt hij een budget van $€ 300.000,-$ van de gemeenteraad om ambtelijke expertise in te huren en andere zaken te regelen. Om een start te maken wordt een selectie gemaakt van woningen waarvan sterke vermoedens zijn dat er permanent gewoond wordt. De gemeente zoomt met de handhavings- 
bril op de eerste veertig percelen in, maar het blijkt lastig en tijdrovend om ze allemaal aan te pakken. In tien van de veertig gevallen wordt echter geconstateerd dat er vrijwel zeker sprake is van permanente bewoning. Een aantal van deze bewoners wordt aangeschreven, waarna een juridische strijd volgt. In november 2004 zijn de eerste twee van de tien zaken gewonnen: de rechter bepaalt dat er niet permanent in de betreffende woningen gewoond mag worden. Dan echter blijkt het beschikbare budget op te zijn en dient het college van B\&W, in de persoon van wethouder Van Tilburg, zich opnieuw met een kredietaanvraag bij de gemeenteraad te melden. "Dat ontaardde in een enorme discussie", zegt Van Tilburg. "Een aantal partijen draaide het om en wilde onderzoeken of men kon legaliseren, want men vond het al met al toch wel een kostbare aangelegenheid worden." Met name oppositiepartij NZ\&W, wijzend op haar al eerder ingenomen standpunt, wakkert het vuurtje aan en de VVD blijkt er gevoelig voor te zijn. De partij neemt een ander standpunt in, keert zich nu tegen handhaving en kiest voor legalisering. "Het handhavingsbeleid heeft tot op heden tot niets geleid. Het kost een enorme inzet aan ambtelijke capaciteit, terwijl er zoveel andere voor de burger belangrijke zaken te doen zijn", aldus fractievoorzitter Vreijsen (Handelingen gemeenteraad, november 2004). Een meerderheid van de Zundertse raad is daarmee tegen het verder aflopen van het handhavingspad en vraagt het college middels een amendement te onderzoeken of legalisering niet toch een optie is. Wethouder Van Tilburg kan er niet mee uit de voeten: "Ik heb hierna gezegd: dat gaat mij een brug te ver. Voor mij had dat ook te maken met de periode van de bouwstop, die Zundert kreeg opgelegd. Heel veel jonge Zundertenaren moesten toen noodgedwongen elders gaan wonen. Toen kwam de discussie rond Patersven en kwamen er veel telefoontjes bij de gemeente, met de vraag: mogen we daar wonen? Er is toen steeds gezegd: doe dat niet, dat mag niet. Dus een groot aantal is verhuisd naar buiten Zundert. Maar de mensen die de regels aan de laars lapten, zijn er gaan wonen. Het betekende wel dat op grote schaal willens en wetens de wet overtreden werd, terwijl er zowel bestuursrechtelijke als privaatrechtelijke afspraken lagen en ook de rechter al twee keer had gesproken. Dus toen het geld er niet kwam en de raad zei: onderzoek of je het kunt legaliseren, heb ik gezegd: die opdracht leg ik naast me neer. Ik vond dat ik niet anders kon." Waarnemend burgemeester Keijzer probeert de wethouder nog tot andere gedachten te bewegen: "Ik vond dat hij het iets slimmer had kunnen spelen, dan had hij het wellicht nog in zijn richting kunnen ombuigen. In wezen kwam alles wat zich had afgespeeld rond de coalitievorming in 2002 hier weer om de hoek kijken." Maar Van Tilburg is vastbesloten. Ook wethouder Poppelaers, die het met Van Tilburg eens is, stapt op. De enige wethouder die blijft zitten is VVD-wethouder Jacobs, maar ook hij wordt korte tijd later gedwongen te vertrekken. Het gevolg: waarnemend burgemeester Keijzer zit vanaf eind 2004 met een uiteengevallen college, vanaf begin 2005 zonder wethouders en is nog de enige bestuurder in de gemeente.

\section{Rapport-Ouwerkerk}

Begin januari 2005 komt het aangekondigde rapport van de commissie-Ouwerkerk naar buiten. Het laat aan duidelijkheid niets te wensen over. In een kleine 25 pagina's worden buitengewoon harde noten gekraakt over de Zundertse bestuurscultuur, de manier van (niet) samenwerken, het onderlinge wantrouwen, het functioneren van personen, kortom: over alles. Enkele citaten zeggen genoeg. Zo wordt er in Zundert 
bestuurd 'op basis van de macht en angst: de macht van de een en de angst van de ander. Een slechtere basis voor collegiaal bestuur is niet denkbaar' (CommissieOuwerkerk, 2005: 9). Over de cultuur: "Het algemeen beeld van de manier van omgaan met elkaar is er één gekenmerkt door wantrouwen, minachting, gebrek aan openheid en aan initiatief en twijfel aan integriteit, waarbij informele verhoudingen en relaties bepalender zijn dan de formele" (Commissie-Ouwerkerk, 2005: 10). Ook visie is er niet: "De goede bedoelingen van individuele raadsleden om tot enige visieontwikkeling te komen stranden vaak in de boventoon van het eigen belang en de belangen van individuele burgers" (Commissie-Ouwerkerk, 2005: 16). En dit is nog maar een bloemlezing uit de vaak vernietigende analyses en conclusies. De commissie komt tot 25 aanbevelingen, op elk niveau. Zo zou er ruimte moeten komen voor nieuwe raadsleden, dient de griffier ondersteund te worden, moet er een meerjarenvisie komen met een reëel werkprogramma en dienen bevoegdheden tussen gemeenteraad, college en management helder onderscheiden te worden. Bovendien zouden wethouders van buiten goede diensten kunnen bewijzen.

\section{Zakencollege}

De Zundertse partijen buigen zich vervolgens over de vraag wat er zou moeten gebeuren. Het onderling vertrouwen is ver te zoeken, de verschillende partijen zien eigenlijk geen mogelijkheden het eens te worden over een coalitie of (als een coalitie tòch gevormd kan worden) over de personen van de wethouders. Kortom: het geheel ligt volledig in duigen. Commissaris Maij-Weggen vraagt de fractievoorzitters opnieuw naar Den Bosch te komen, alwaar zij laat weten te eisen dat er snel een oplossing komt voor de problemen. "Er zijn opnieuw harde woorden gesproken. Ik vond dat ze in Zundert alleen met zichzelf bezig waren. Het openbaar bestuur kwam daar opnieuw in opspraak door grote ego's en lange tenen. Dus toen hebben wij ze echt stevig de wacht aangezegd. Het moest afgelopen zijn." Gesproken wordt over de mogelijkheid waarnemend burgemeester Keijzer te vragen een nieuw college te formeren, maar die ziet dat niet zitten: "Ik had al laten weten daar geen trek in te hebben. Ik kon het met negentien raadsleden goed vinden. Als ik een college zou vormen, zouden er winnaars en verliezers zijn. Ook al zou iedereen alle goeds beloven, ik deed het toch liever niet." In plaats van Keijzer komt hierna oud-kamerlid D.W. de Cloe in beeld, een bekende van Keijzer. Aan hem wordt gevraagd zich over de zaak te buigen. De Cloe komt na gesprekken met het voorstel (in navolging van het rapport-Ouwerkerk) een college van 'buiten' te formeren. Er wordt door de raad mee ingestemd, al gaat het opnieuw niet van harte. VVD en NZ\&W laten weten een dergelijke constructie niet nodig te vinden. Een meerderheid van de gemeenteraad is echter vóór en steunt de benoeming van wethouders van buiten Zundert. De zoektocht leidt naar oud-wethouder S.M.T.P. Vermeulen uit Bergen op Zoom, A.L. van den Wollenberg uit Cuijk en P.R.M. van de Wiel uit Waalwijk. Bovendien komt er een interim-secretaris, gezien het in het rapport-Ouwerkerk geconstateerde gebrek aan vertrouwen in de zittende secretaris.

Dit nieuwe college gaat aan de slag, gereed om Zundert door de beschreven 'woelige wateren' te loodsen. 


\subsubsection{Periode 2006-2010}

De verkiezingen in 2006 leveren kleine verschuivingen op. De VVD en NZ\&W verliezen allebei een zetel, nieuwkomer $3 \mathrm{D}$ komt op twee zetels. Besloten wordt het college van buiten in tact te laten. Er is wel tevredenheid over de situatie. Wel houdt de uit Cuijk afkomstige wethouder Van den Wollenberg ermee op. Privéomstandigheden en de reistijd maken dat hij aangeeft niet nog een termijn verder te willen in Zundert. Besloten wordt opnieuw op zoek te gaan naar een onbesproken wethouder van buiten, die niet te ver af moet wonen. In een straal van 50 kilometer rondom Zundert stuiten de zoekende gemeentebestuurders op GroenLinkser C. Meulman uit Geertruidenberg.

Door het verlies van een zetel aan de SP komt GroenLinks in de persoon van Meulman niet in het Geertruidenbergse college en is hij beschikbaar. Zijn profiel past: "Ik ben er min of meer ingerold", aldus Meulman achteraf. Het college gaat dus weer van start met drie bestuurders, onder leiding van waarnemend burgemeester Keijzer. De procedure rondom het uiteindelijke vertrek van voorganger Vos loopt namelijk niet zo vlot. Bovendien wil commissaris Maij-Weggen enige rust in Zundert houden en zal de vacature pas later opengesteld worden.

In het raadsprogramma 2006-2010 worden de intenties nog eens duidelijk gemaakt: "Voor de komende raadsperiode hebben alle raadsfracties in goed overleg unaniem gekozen voor een college met wethouders van buiten Zundert, ervaren bestuurders, die elders hun sporen hebben verdiend. Wel willen we dat het politieke klimaat aan het eind van de raadsperiode zich zo ontwikkelt, dat voor de volgende raadsperiode meerdere opties voor collegevorming mogelijk zijn" (Raadsprogramma 2006-2010:3). Het raadsprogramma wordt door alle partijen gesteund, op één na: de 3D-partij besluit om oppositie te gaan voeren. In het programma staan elf inhoudelijke punten, waarvan het college geacht wordt die in de komende periode verder te brengen.

\section{Nieuwe burgemeester}

In de loop van 2006, als definitief vaststaat dat burgemeester Vos niet terugkeert, wordt geoordeeld dat Zundert klaar is voor een nieuwe, vaste, burgemeester. De raad installeert opnieuw een vertrouwenscommissie en, tot verbazing van velen, loopt de procedure uitstekend. "Daar hebben ze het nu nog over, dat dat zo goed liep", zegt oud-wethouder Van Tilburg. "Eigenlijk was iedereen daar verbaasd over. In de raad was het kat en hond, maar dit ging goed. De manier van samenwerken, de snelheid, de vertrouwelijkheid, perfect. Dus het kón wel."

Onder de sollicitanten zit mw. L. Poppe-de Looff, die zestien jaar wethouder was in Vlissingen en daar in 2006 is gestopt. "Ik wilde toch wel eens wat anders en werd gewezen op Zundert. Mooie plaats, vlakbij de Belgische grens en mijn man en ik hebben wel wat met België." Poppe-de Looff kent de reputatie van Zundert, maar laat zich niet afschrikken. Ze ziet zelfs wel uit naar enige confrontaties: "Ik zou mezelf geen straatvechter willen noemen, maar ik ben wel recht voor zijn raap. Ik had het idee dat dat hier wel zou kunnen werken. Bovendien was Vlissingen ook niet makkelijk."

Poppe-De Looff wordt viteindelijk per 1 maart 2007 benoemd. Zij start met investeren in de relatie met de gemeenteraad en het college. De raadsleden komen allemaal apart langs: "lk weet ook wel dat ze dan niet gelijk het achterste van hun tong laten zien, maar dan weet je toch wat beter hoe mensen in elkaar zitten. Met het college ben ik 
snel op de hei gaan zitten en heb ik kenbaar gemaakt wat ik voor ogen heb en hoe ik het aan wilde pakken, met collegiaal bestuur."

Poppe-de Looff start ook de zoektocht naar een nieuwe secretaris, die zij vindt in een

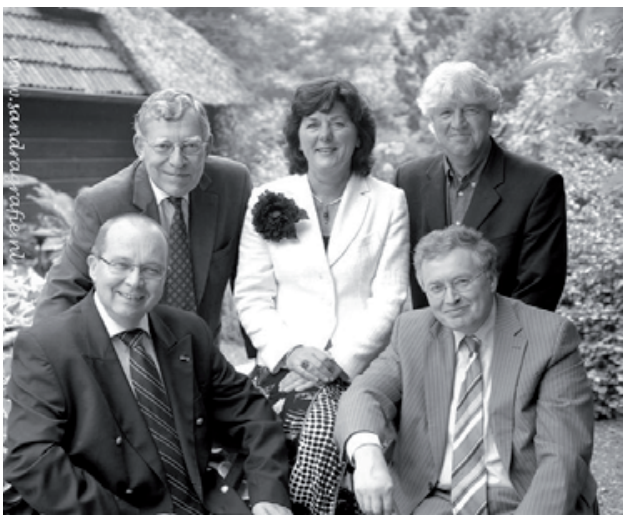

Het 'zakencollege' na de komst van de nieuwe

burgemeester. Staand v.l.n.r. wethouder

Vermeulen, burgemeester Poppe-de Looff en wethouder Meulman. Zittend: gemeentesecretaris Thomassen en wethouder Van der Wiel. (foto: Sandra Mutsters Fotografie) oud-directeur van de gemeente Vlissingen. Intern wordt hard gewerkt aan versteviging van de griffie en verbetering van de informatievoorziening aan de gemeenteraad: "Ik hoorde alleen maar klachten over de informatievoorziening, dus dat traject is ook in gang gezet."

In het college loopt het echter niet soepel. Poppe-de Looff is niet erg overtuigd van de constructie en ook niet van het draagvlak van sommige wethouders: "Ik had het gevoel dat sommige leden van de gemeenteraad continu met een motie van wantrouwen in de tas zaten". Twee externe wethouders zien het anders en besluiten op grond hiervan in september dat zij ermee op zullen houden. Zundert moet het weer zelf doen. Het besluit leidt tot verbaasde, soms zelfs boze reacties bij de gemeenteraadsfracties. Er was toch besloten dat de interim-periode tot $2010 \mathrm{zou}$ duren? René de Bruijn, fractievoorzitter van Dorpsbelangen, laat in BN/De Stem weten te vinden dat de interim-periode wel wat langer had mogen duren. "We zijn tenslotte altijd voorstander geweest van een periode van vier jaar. En of de tijd rijp is voor eigen wethouders kan ik niet zeggen, want dan moet eerst duidelijk zijn wat we daar met elkaar precies onder verstaan. Daarover hebben we nog niet gesproken" (Bökkerink, 2007).

Het blijken voorspellende woorden, want de opvolging wordt opnieuw een drama. Na lang overleggen en soebatten lijkt een college met wethouders van VVD, PvdA en NZ\&W mogelijk te zijn. Een minderheid, maar op basis van het vrijwel raadsbreed gesteunde coalitieprogramma uit 2006 zou het mogelijk moeten zijn. Maar... het gaat mis op de invulling van de wethoudersposten. De kandidaat van NZ\&W blijkt grote weerstand op te roepen. De plaatselijke ondernemers kopen zelfs een pagina in de krant om hun ongenoegen te viten:

\section{Ingezonden brief ondernemers (in BN/De Stem, 04 december 2007)}

Het twee jaar geleden gepresenteerde rapport 'Nu zaaien, straks oogsten' van Bernard Ouwerkerk lijkt nooit geschreven te zijn. Als het rapport toch ooit bij de betrokkenen terecht is gekomen, dan hebben deze er hooguit kennis van genomen en het weggemoffeld in de spreekwoordelijke lade. Zij realiseren zich blijkbaar niet dat het rapport in Den Bosch nog altijd binnen handbereik ligt. 
De door de Zundertse samenleving en dus ook het Zundertse bedrijfsleven zo gewenste vernieuwing in de Zundertse politiek bleef na de laatste verkiezingen helaas uit. Dit was op zich natuurlijk een grote gemiste kans. Echter het externe college gaf nog enig perspectief en hoop aan de Zundertse samenleving, waar wij als bedrijfsleven nadrukkelijk deel van uitmaken.

De Zundertse politiek laat zien weinig tot niets te hebben geleerd van het verleden. Het gaat wederom om de poppetjes, het enorme misplaatste ego van partijen en mensen met de hang naar het pluche. Dat hierbij het algemeen belang wederom achteloos terzijde wordt geschoven, dringt blijkbaar niet tot de betrokkenen door.

De twee aftredende wethouders stelden dat Zundert weer klaar is voor een bestuur van eigen mensen. Hoewel wat vroeg, was er hoop. Goede profielschetsen, met daaraan gekoppeld geschikte, onafhankelijke Zundertse personen, leek het Zundertse bedrijfsleven een uitgelezen kans. Een kans om de gemeente Zundert nog een toekomst te gunnen en deze met opgeheven hoofd tegemoet te treden.

Helaas!! Het draaide uit op een truc uit de hoge hoed. Alle belangen en het gezond verstand van de inwoners van Zundert schofferend. Zundert, een gemeente met zoveel kwaliteit, enthousiasme en dadendrang. Een gemeente welke het verdient om een goed bestuur te hebben, geschoond van oud zeer en met een objectieve, onafhankelijke kijk op het heden en de toekomst. Een bestuur, dat bereid is tot samenwerking en overleg, en een bestuur dat de welbekende Zundertse kwaliteiten tot volle wasdom kan laten komen.

Wij zien dit als een gemiste kans, maar wellicht is er nog een sprankje hoop voor onze mooie gemeente. Als Zunderts bedrijfsleven willen we alle betrokkenen nadrukkelijk verzoeken de ontstane situatie in overweging te nemen. Neem de situatie ernstig in ogenschouw en zorg ervoor dat Zundert alsnog een college krijgt wat zij verdient. Zodat wij als Zunderts bedrijfsleven en Zundertse samenleving met gevoelens van trots en vertrouwen de toekomst tegemoet kunnen zien.

Ingezonden brief, geschreven door: Ondernemersvereniging Zundert Centrum, Bedrijvenkring Gemeente Zundert, Rijsbergse ondernemersvereniging, ZLTO afdeling Zundert en Rijsbergen, Koninklijke Horeca Nederland afdeling Zundert en Rijsbergen.

De brief leidt tot veel commotie, waardoor er opnieuw personen beschadigd raken. Burgemeester Poppe-de Looff, die zich eigenlijk had voorgenomen de zaak door de Zundertse partijen zelf te laten regelen, besluit in te grijpen en benadert een externe formateur: de oud-burgemeester van Noord-Beveland, C. van Liere. Hij gaat als een wervelwind door de Zundertse porseleinkast en komt na enige weken met groen licht: een coalitie van CDA, VVD en NZ\&W behoort tot de mogelijkheden. Wethouders worden raadslid mw. W. van Hees (VVD) en de in Zundert woonachtige niet raadsleden J.A.A.M. Roelands (CDA) en H.J.M. Bonenkamp (NZ\&W). Voor de continuïteit wordt bovendien zittend wethouder $C$. Meulman toegevoegd, die daarmee met zijn twee Zundertse jaren gelijk de meest ervaren bestuurder is.

Dit college gaat de rest van de periode voortvarend aan de slag en lijkt erin te slagen zaken zonder kleerscheuren verder te brengen. Lijkt, want op de valreep blijkt dat wethouder Bonenkamp toch niet kan rekenen op onverdeelde steun van de raad en zijn eigen partij. In februari 2010 stuit hij op een zeer kritische raad, die een rapport over kassenbouw in Rijsbergen en de communicatie daarover afkeurt. 


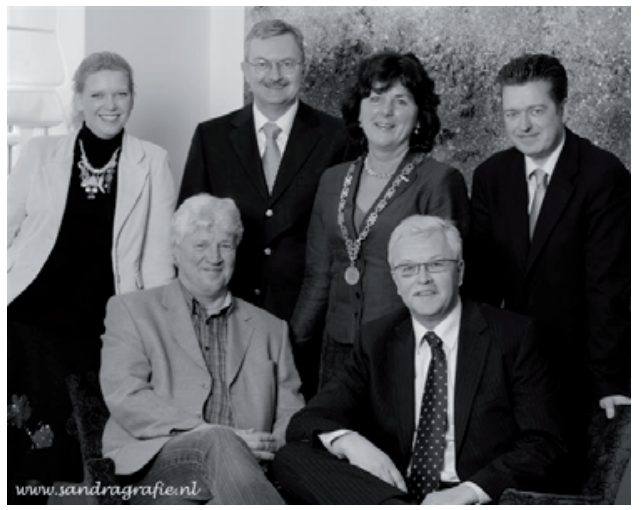

Het nieuwe college uit 2008, met v.l.n.r. wethouder Van Hees, wethouder Meulman, gemeentesecretaris Priem, burgemeester

Poppe de Looff, wethouder Roelands en wethouder Bonenkamp (foto: Sandra Mutsters Fotografie)

Het stuk was ter kennisname voorgelegd, maar er volgt een zeer kritische bespreking. Ook woordvoerder en partijgenoot J.C.M. van den Bemd van NZ\&W gaat er fors in: "Voor mij is voor de zoveelste keer pijnlijk duidelijk geworden dat de communicatie tussen raad en college voor de zoveelste keer weer zeer slecht is geweest. Werkafspraken worden niet of slecht nagekomen, dit komt de sfeer tussen raad en college niet ten goede. Het tijdstraject is weer niet voldoende gebleken, omdat afspraken gewoon niet nagekomen worden. Het college is collectief aansprakelijk voor het traject zoals dat zou moeten zijn verlopen. Als raad hebben wij recht op duidelijkheid en op gegevens die op waarheid berusten" (Raadsnotulen Zundert, 250210). Duidelijk wordt dat meerdere partijen niet met wethouder Bonenkamp verder willen. Hij besluit de eer aan zichzelf te houden en treedt af. De motieven staan in een persverklaring:

\section{Persverklaring wethouder H.J.M. Bonenkamp, 26 februari 2010}

"In de raadsvergadering van afgelopen donderdag is het rapport inzake de kassenbouw behandeld. De onderzoeker heeft gekozen om geen hoor en wederhoor toe te passen, hetgeen ik betreur. Bij de behandeling bleek al snel dat de politieke verhoudingen op scherp gesteld werden. Nog geen week voor de verkiezingen is dat een slechte zaak. Immers, de partijen moeten na 3 maart gezamenlijk een stevig fundament leggen voor de komende vier jaar. Daarom heb ik besloten om mijn portefeuille in te leveren. Ik ben wethouder geworden om Zundert te dienen en nu kon ik Zundert het beste dienen door op te stappen en de angel ervit te halen. Wij zijn de verkiezingen ingegaan met voorvit kijken. Door mijn vertrek is daar nu met alle partijen gelegenheid toe."

Het blijkt de laatste schermutseling in Zundert in de onderzoeksperiode. De raadsverkiezingen van 2010 staan voor de deur.

\subsection{De analyse op microniveau}

$\mathrm{Na}$ de beschrijving van de gebeurtenissen, noodzakelijkerwijs een beschrijving op hoofdlijnen, is het mogelijk ook in deze gemeente de verschillende aspecten te analy seren.

Microfactor: de burgemeester(s)

Het ambt van burgemeester in Zundert vergt een dikke huid, zoveel werd uit het feitenonderzoek wel duidelijk. Burgemeesters moeten tegen een stootje kunnen en ook 
niet schromen 'terug te botsen'. Burgemeester Poppe-de Looff zegt wel eens demonstratief te zijn weggelopen bij een commissievergadering, waar zij op de tribune zat omdat het ging om haar huisvesting. "Toen was er een raadslid, dat toch weer op hoge toon meende te moeten zeggen dat het altijd hetzelfde is met die burgemeesters, dat het altijd te duur wordt. Toen dacht ik: dit pik ik niet, ik vertrek." Na een gesprek met het betreffende raadslid, de volgende dag, is de relatie weer hersteld. Maar het geeft wel aan dat het in Zundert kennelijk nodig is als burgemeester af en toe eens van je te laten horen als het te ver gaat. Daarbij is het lastig om in te schatten wat de gemeenteraad, toch een belangrijk referentiepunt voor de burgemeester, nu wel en niet verwacht. "Als je in Zundert te ver voor de muziek uit loopt, dus teveel dingen onderneemt, zegt men al snel: ho, ho, het kan wel iets minder. Maar als je wat meer pas op de plaats maakt en de dingen ook eens laat lopen, zegt men: nou, die doet ook niet veel. Het is erg zoeken naar de balans", zegt oud-burgemeester Neeb.

Zundert had in de onderzoeksperiode te maken met vier burgemeesters. Burgemeester Vos zat relatief het kortst: na een klein jaar meldde hij zich ziek, om niet meer terug te keren in Zundert. Hierbij speelde de discussie over zijn huisvesting een belangrijke rol. De gemeenteraad wilde niet investeren in de ambtswoning, terwijl de verkoop van het huis in de vorige gemeente niet vlot verliep. Het gevolg was dat de burgemeester veel heen en weer moest reizen en zich niet lekker kon settelen in Zundert. Buiten dit had Vos moeite met de manier waarop zaken werden besproken in de Zundertse raad. Oudwethouder Van Tilburg: "Zijn inzet en betrokkenheid waren perfect. Maar er zitten in de raad ook enkele zure azijnvreters, daar doe je het nooit goed bij. Je moet leren daarmee om te gaan. Het hoeven er maar één of twee in een vergadering te zijn en die verpesten het dan voor de rest. Als je inzet groot is en je krijgt toch bakken kritiek over je heen, daar kon hij slecht mee uit de voeten."

Vos geeft desgevraagd aan dat dit zeker meespeelde, maar dat hij vooral een ankerpunt miste: "lk had geen punt waar ik me aan kon optrekken. De ambtelijke organisatie functioneerde nog niet goed, er waren heel veel interimmers actief. Als dat wel goed was geweest, hadden we daarmee de boel rustig kunnen opbouwen. De secretaris was beschadigd en de griffier voelde zich naar mijn gevoel meer betrokken bij de raad dan bij de burgemeester. Als het college dan ook niet goed functioneert en er veel oud zeer in de gemeenteraad zit, dan heb je nergens houvast meer. Ik kon dat niet keren. Ik heb geleerd dat ik in zo'n omgeving niet goed kan functioneren."

De gepokt en gemazelde opvolger Keijzer kon er beter tegen, maar maakte ook gebruik van het feit dat hij als waarnemer werd aangesteld en de raad de (niet op prijs gestelde) boze blikken van de CdK in de rug voelde. Na de komst van burgemeester Poppe-de Looff besloot de gemeenteraad overigens, wellicht door schade en schande wijs geworden, wèl de benodigde investeringen in de ambtswoning aan te gaan. Ook de werkkamer, in een krantenartikel al eens vergeleken met het rommelhok van Malle Pietje (Jense, 2005) kreeg een opknapbeurt. Het is echt een omslag, wellicht geïnspireerd door de problemen uit het verleden. Want ook waarnemer Keijzer, die in OudBeijerland bleef wonen en heen en weer reed, kreeg in zijn tijd te maken met een raad met de hand op de knip. Hij herinnert zich het verhaal over de ambtsketen: "Er was geen ambtsketen, die was ten tijde van Neeb gestolen. Men vond dat volstaan kon worden met de keten van de voormalige gemeente Rijsbergen. Ik zei: dat is onwaardig, 
een gemeente als Zundert moet toch een eigen keten hebben? Maar dat was te duur. Er was zelfs niet nagegaan of de diefstal aan de verzekeringsmaatschappij was gemeld. Daarop heb ik het op eigen initiatief geregeld. Bovendien vond ik dat er vanuit het lokale bestuur richting de actieve gemeenschap te weinig blijken van waardering werden gevit, ik achtte het gewenst dat gelijktijdig goed te regelen. Dat was best een gedoe, maar viteindelijk kwam Zundert zonder kosten weer in het bezit van een eigen ambtsketen en kreeg tegelijkertijd de beschikking over een aantal erepenningen, conform een inmiddels door de raad vastgestelde verordening."

Keijzer kon bogen op langdurige ervaring en had die nodig ook: "Als je hier niet met de nodige ervaring binnen komt, kun je gemakkelijk sneuvelen. Toen ik kwam heb ik met alle raadsleden gesproken en ze hebben allemaal gezegd: het is hier heel slecht, het is compleet onbestuurbaar. Maar dat lag altijd aan de anderen, het ging nooit over henzelf of hun groepering."

Keijzer is van oordeel dat, naast alle inzet voor het bestuurlijk functioneren, vooral ook veel aandacht moet worden geschonken aan de activiteiten van en in de samenleving. De burgers hebben weinig waardering voor alles wat er in hun gemeentehuis gebeurt. Juist die contacten acht hij van groot belang voor de toekomst van Zundert.

Het feit dat de burgemeestersfunctie in ruim vijf jaar in vijf verschillende handen was (naast de vier benoemde burgemeesters ook nog in die van wethouder en locoburgemeester Van Tilburg) hielp niet bij het managen van de verschillende problemen. De verbindende kwaliteiten kwamen hierdoor moeilijk uit de verf. Toch wijzen de verschillende gesprekspartners en analyses niet in de richting van de competenties van de burgemeesters als probleem in conflicten of crises. Ook het vertrek van burgemeester Vos zat vooral in de weerbarstige cultuur in de raad, waar hij moeilijk mee uit de voeten kon.

Verwachting 1 luidt: In bestuurlijke probleemgemeenten legt de burgemeester weinig bindend vermogen aan de dag, waardoor de potentiële dempende werking van de burgemeester afwezig is. De conclusie is dat deze verwachting is vitgekomen in de tweede periode, door de mismatch tussen persoon en gemeente. In de andere perioden kwam deze verwachting niet vit.

\section{Microfactor: de wethouder(s)}

Wethouder word je niet zomaar in Zundert, zo is wel gebleken uit sommige voorvallen. Wethouder blijf je trouwens ook niet zomaar. Om wethouder te worden moet je goed liggen binnen je partij, om het te blijven moet die steun ook gedurende de periode aanwezig zijn. Bovendien moeten andere partijen met de kandidatuur in kunnen stemmen, wat in Zundert ook niet altijd een uitgemaakte zaak is. Zo vertrok in 1999 wethouder Jacobs vanwege problemen rond zijn persoon bij de andere collegepartijen, die overigens wederzijds waren. Het vertrek van wethouder Damen in 2004 hield verband met door hem gevoeld verminderd vertrouwen van de eigen fractie. De crisis in 2004/2005 rond Patersven hing volgens de meeste zegslieden en verslagen minder samen met personen, maar kwam voort uit het wegvallen van het vertrouwen tussen coalitiepartners. De laatste periode kende zowel wethouders van buiten als eigen wethouders, zodat het beeld lastiger is te bepalen. Wel hield wethouder Bonenkamp de eer 
aan zichzelf in februari 2010, na opnieuw harde kritiek uit de raad op het college en de manier waarop de zaken in de portefeuille van de wethouder waren aangepakt. Kortom: het welslagen als wethouder hangt af van vele zaken in Zundert. Als er persoonlijke risicofactoren zijn, blijkend uit herhaalde discussies over het functioneren van een wethouder, is dat in de Zundertse setting risicovol en leidt dat vrij snel tot problemen.

Verwachting 2 luidt: In bestuurlijke probleemgemeenten hebben de persoonlijke risicofactoren van één of meer wethouder(s) een aanjagende werking op bestuurlijke problemen. De conclusie luidt dat deze verwachting uit komt in Zundert, behalve in de laatste periode, waar het beeld moeilijker te bepalen is. De grootste reden voor het vertrek van wethouders ligt echter bij een andere factor: het gebrekkige coalitiemanagement.

\subsection{De analyse op mesoniveau}

Op mesoniveau gaat het vooral om de betrekkingen, in het college, tussen college en raad, college en ambtelijke organisatie, etcetera.

\section{Mesofactor: het college}

Uit de analyse blijkt dat van sterke colleges in brede zin in Zundert weinig sprake is geweest. Dat lag niet aan het feit dat er teveel wethouders of ondersteunende partijen waren; colleges hadden in de regel drie personen, soms vier. Wel ontbrak het in menig college aan een verbindend leider in de persoon van een reguliere burgemeester (zie microfactor 1 ). Een uitzondering is wellicht het eerste college vit de onderzoeksperiode, dat in 1999 aantrad en tot 2002 zou blijven. Dit college startte in moeilijke omstandigheden, aangezien de wonden van de fusie nog niet geheeld waren. Desalniettemin ging men voortvarend aan de slag, vooral met de opbouw van de nieuwe organisatie. Bestuurlijke conflicten of bestuurscrises deden zich in die jaren niet voor.

Vanaf 2002 was het echter vooral een kwestie van overleven voor de zittende wethouders en de burgemeester. De start van het college was al lastig, de formatie bleek een ingewikkelde klus. Een homogeen gezelschap was het college niet, een verbindend leider ontbrak opnieuw. Na de crisis van begin 2005 kwam er meer stabiliteit met het aantreden van het interim-college van buiten, maar dat was dan ook een vrij unieke situatie voor bestuurlijk Nederland. Zeker toen dit college op verzoek van de gemeenteraad na de verkiezingen in 2006 bleef zitten, wellicht geïnspireerd door het feit dat er in de samenleving waarderend over de achterliggende periode werd gesproken. De situatie was bovendien nog zo onstabiel dat een regulier college niet tot de mogelijkheden behoorde. Dit trad pas aan in het voorjaar van 2008, na opnieuw een zeer moeilijke formatie. In die omstandigheden is uitgroeien tot sterk college een utopie.

Verwachting 3 lvidt: In bestuurlijke probleemgemeenten kunnen colleges niet sterk worden, waardoor de potentiële dempende werking van een sterk college afwezig is. De conclusie is dat deze verwachting uit komt in de laatste twee perioden, niet in de eerste.

Mesofactor: verbinding van college met ambtelijke organisatie

In Zundert bleek de verhouding in algemene zin tussen 'de politiek' en 'de ambtenaren' nogal broos. Dit werd in de hand gewerkt door het ontbreken van een formeel patroon 
van betrekkingen. Raadsleden hadden de gewoonte rechtstreeks te bellen naar ambtenaren om informatie te krijgen. De lijnen vanuit de gemeenschap en de gemeenteraad liepen dwars door de gemeentelijke gebouwen, rechtstreeks naar de ambtenaren. Wethouders werden op die manier in vergaderingen van commissies geconfronteerd met informatie die ze niet kenden, waarbij de vragenstellers meldden één en ander 'van ambtenaren gehoord te hebben.' Maar er was meer aan de hand, constateerde locosecretaris B. Rijsbergen toen hij in 2008 kwam werken in Zundert: "Er zat totaal geen sturing op de bestuurlijke processen. Tussentijds hadden ambtenaren contact over al door het college vastgestelde stukken, die als het nodig was gewijzigd werden voordat ze naar de gemeenteraad werden gestuurd. Wethouders zaten dan met andere stukken voor de neus dan de raad."

Inmiddels is er een vast punt in de week waarop de vergaderstukken voor commissie en raad naar de griffie gaan. Rijsbergen: "Voor die tijd werd de hele stapel over de schutting gegooid. Er was geen kritische kijk, ook niet met betrekking tot de vraag wat je wel en niet bijvoegt als bijlagen. De vraag of de raad er eigenlijk wel over gaat werd ook nooit gesteld. Dat is wel veranderd." Toch blijft het, ook anno 2010, nog opboksen tegen wantrouwen bij de raadsleden. Wantrouwen dat wordt gevoed doordat soms toch blijkt dat stukken niet op orde zijn, of dat er een tussentijds raadsvoorstel moet komen, omdat het budget niet op orde is. Rijsbergen: "Telkens geef je dan weer voeding aan de raad, die dan zegt: zie je wel, we moeten er toch bovenop zitten. Daar ligt wel een opgave voor de toekomst. Raadsvergaderingen waren en zijn soms niet stimulerend om als ambtenaar bij te zitten, door het gebrek aan vertrouwen dat uit de bijdragen blijkt. ledereen die hier binnen komt moet daar heel erg aan wennen, aan het feit dat als je bij het college hoort je per definitie niet vertrouwd wordt, tot het moment dat je bewezen hebt dat je toch wel te vertrouwen bent."

Moeilijk punt is ook de personele formatie, die behoorlijk onder de norm ligt van vergelijkbare gemeenten. "Er wordt al drie jaar geprobeerd er formatie bij te krijgen, maar dat stuit telkens weer op bezwaren. Het is nooit goed onderbouwd, de cijfers deugen niet, kan het niet met efficiency, er is altijd iets waardoor het niet klopt, met een ondertoon van: ze kunnen wel wat harder werken. De OR heeft zelfs besloten een brief te schrijven aan de raad, dat men teleurgesteld was. De reactie? Kennelijk is het management er niet in geslaagd ons besluit uit te leggen. Dus er is nog weinig zelfreflectie."

Verwachting 4 luidt: In bestuurlijke probleemgemeenten zit weinig patroon in de relatie van het college met het ambtelijk apparaat, wat een aanjagende werking heeft op bestuurlijke problemen. De conclusie kan luiden dat deze verwachting in de eerste twee bestudeerde perioden uit komt in Zundert. Bepalend lijkt de factor niet, het is meer een factor die voeding geeft aan processen van ongenoegen, die meewegen in de rol die andere factoren spelen.

\section{Mesofactor: de verbinding tussen raad en college}

Bij de analyse van de verbinding tussen raad en college kan het dualisme, dat in 2002 werd ingevoerd, worden betrokken. In Zundert heeft dit geleid tot forse problemen. In 2003 werd een griffier aangesteld, maar raad en college bleken grote moeite te hebben met het vinden van hun eigen rol en verantwoordelijkheden. "De term duellisme was 
hier meer van toepassing", zegt griffier A. van der Veen, die vanaf 2003 werd aangesteld. Ondanks notities over dualisme en vele gesprekken met raadsleden, lukte het niet een wezenlijk andere situatie te creëren. Van der Veen zelf wordt in het rapport van de commissie-Ouwerkerk zelfs het $20^{\mathrm{e}}$ raadslid genoemd, omdat hij nogal wat tijd in oppositiepartij NZ\&W stak. "De grootste partij was een oppositiepartij. Om de werkverhoudingen tussen deze partij en de gemeenteraad te optimaliseren, heb ik extra tijd in die partij geïnvesteerd. Sommigen vonden dat ik te veel bij die ene partij betrokken was. Ik heb na die kritiek ook aan de raad gevraagd of men vond dat ik het probleem was, dan zou ik onmiddellijk vertrekken. Maar dat was niet het geval."

Van der Veen vindt dat pas vanaf 2008 het dualisme, met het verhogen van de formatie van de griffie, beter is geimplementeerd in Zundert. Ook de nieuwe locosecretaris Rijsbergen constateerde bij zijn aantreden in 2008 nog volop onduidelijkheden: "Het waren eigenlijk nog monistische verhoudingen. Van beide kanten werd de grens overschreden, zo er al een grens gezien werd. De raad was gewend alle details te vragen, het college was gewend alle details te geven. Als je daarin blijft steken, kom je er nooit vit. Men was gewend voortdurend op elkaars stoel te gaan zitten."

Wethouder Damen wijt er zelfs zijn vertrek aan, blijkt uit het verslag van de vergadering van de Zundertse raad van 29 april 2004: "Inmiddels zijn er meer dan 80 wethouders afgetreden en dat is met name het gevolg van de invoering van het dualisme. Dualisme is verworden tot een begrip waar eindeloos veel kan worden ondergebracht. In de lokale politiek is het wellicht ook het meest misbruikte woord geworden en een kapstok om ongewoon en ongewenst politiek gedrag aan op te hangen. Klaarblijkelijk is het voor de raad ook de legitimatie om te pas en te onpas in wisselende meerderheden standpunten in te nemen, is het ook de legitimatie om afspraken binnen eigen achterban en coalities op ieder moment in te ruilen voor nieuwe inzichten en is het ook de legitimatie om in achterkamertjes afspraken te maken waarover blijkbaar vooral niet gecommuniceerd behoeft te worden."

Inmiddels is de griffie beter opgetuigd en komen er steeds meer spelregels om het dualisme ook in de praktijk in betere banen te geleiden. De verbinding tussen raad en college is in Zundert echter de hele onderzoeksperiode problematisch geweest.

Verwachting 5 lvidt: In bestuurlijke probleemgemeenten zit geen of weinig patroon in de relatie tussen het college van $B \& W$ en de gemeenteraad, wat een aanjagende werking heeft op bestuurlijke problemen. De conclusie met betrekking tot deze verwachting is dat deze is uitgekomen. Juist door het ontbreken van goede verbindingen tussen college en gemeenteraad konden problemen ontstaan.

\section{Mesofactor: de verbinding tussen de coalitiepartijen}

De analyse van de verbinding tussen coalitiepartijen geeft een wisselend beeld in Zundert. Er functioneerde langere tijd een college van buiten, waarbij de raad een vrijwel raadsbreed gesteund programma van uitgangspunten hanteerde. Het onderscheid tussen coalitie en oppositie viel hierdoor vrijwel geheel weg. Wat oud-wethouder Meulman betreft overigens een prima situatie, ook al betekende het in de praktijk dat het college in veel gevallen pas tijdens de raadsvergaderingen vernam of een voorstel het zou halen of niet. "Ik heb ook wel eens colleges meegemaakt, waarbij de voorstellen door de coalitie allemaal vooraf waren dichtgetimmerd. De meest slechte voor- 
stellen kwamen er gewoon door en vijf jaar later zei men: hadden wij toch maar naar de oppositie geluisterd. De voorstellen waar wij mee kwamen moesten we wel goed doordenken en beargumenteren, we moesten goed in de commissie luisteren en horen wat je nog zou moeten doen om toch een meerderheid te halen in de raad. Af en toe werd je door de nood gedwongen om ergens beter naar te kijken."

De grote crisis rond Patersven in 2004 was wel een gevolg van een crisis in de coalitie. De moeizaam bereikte overeenstemming om te gaan handhaven tegen permanente bewoning, werd viteindelijk door de VVD-fractie opgezegd. De liberalen vonden de resultaten te mager en wilden onderzoeken of legaliseren niet toch mogelijk zou zijn. Onoverkomelijk, constateerden CDA en Agrarisch Belang en de crisis was een feit.

Geconcludeerd kan worden dat pas de laatste paar jaar in de onderzochte periode, vanaf 2008, er enige sprake is van overleg. Al stelde dat nu ook weer niet zo heel veel voor, aldus oud-wethouder Meulman: "Bij sommige zaken was er wel eens overleg tussen fractievoorzitters en wethouders, maar dat liep ook niet echt lekker. We wilden wel allemaal hetzelfde, maar dan werden ineens de tegenstellingen weer opgezocht. Het ging meer over toezeggingen en verwachtingen. Het is belangrijk om toezeggingen na te komen, maar soms vond men al wel heel snel dat er een toezegging was gedaan. Zelfs het simpel knikken met je hoofd bleek een toezegging."

Verwachting 6 luidt: In bestuurlijke probleemgemeenten bestaat weinig binding tussen coalitiefracties, wat een aanjagende werking heeft op bestuurlijke problemen. De conclusie is dat over de eerste periode te weinig materiaal aanwezig is om een conclusie te trekken. De verwachting is in de laatste twee perioden zeker vit gekomen; de factor speelde volgens betrokkenen een bepalende rol bij de crisis in 2004, die een rechtstreeks gevolg was van het ontbreken van goede verbindingen tussen de fracties.

\subsection{De analyse op macroniveau}

Op macroniveau worden drie factoren onderzocht: de bestuursstructuur, de bestuurscultuur en de rol van de media (inclusief berichtgeving over opvattingen van actiegroepen).

\section{Macrofactor: de bestuursstructuur}

Zundert kende een vrij gefragmenteerde bestuursstructuur in de onderzochte periode. Vanaf 1999 zaten er negen partijen in de raad, in 2002 en 2006 kwam het aantal fracties uit op zeven. Dit maakt dat de gemiddelde fractiequote onder de drie uit komt $(2,68)$, wat erg laag is. Afsplitsingen zijn er weinig geweest, alleen in de periode 2002-2006. Grootste partijen waren afwisselend het CDA en NZ\&W. De partijen blijken vaak erg lokaal georiënteerd, waardoor er veel meningen door de raadszaal klinken. Al met al maakt de aanwezigheid van veel partijen in de gemeenteraad de bestuurbaarheid lastig: er zijn moeilijk coalities te maken en het aantal partijen dat luidkeels een mening verkondigt is erg groot.

Verwachting z luidt: In bestuurlijke probleemgemeenten is sprake van versplintering van het politieke landschap, wat een aanjagende werking heeft op bestuurlijke problemen. De 
conclusie is dat deze verwachting is uitgekomen in Zundert. Het grote aantal partijen maakte het moeilijker tot stabiele verhoudingen te komen.

\section{Macrofactor: de bestuurscultuur}

De bestuurscultuur wordt door velen in Zundert omschreven als vrijwel onwerkbaar. De commissie-Ouwerkerk schrijft erover in stevige bewoordingen: "Het algemeen beeld van de manier van omgaan met elkaar is er een gekenmerkt door wantrouwen, minachting, gebrek aan openheid en aan initiatief en twijfel aan integriteit, waarbij informele verhoudingen en relaties bepalender zijn dan de formele. Een cultuur ook, waarin 'oud zeer' in hoge mate bepalend is voor de onderlinge verhoudingen" (CommissieOuwerkerk, 2005: 10). De commissie somt vervolgens een aantal zaken op:

\section{Opmerkingen over de bestuurscultuur in Zundert uit het rapport van de commis- sie- Ouwerkerk, januari 2005:}

- De manier van besturen berust op machtsdenken, is autoritair, directief en allesbehalve integraal

- Verborgen agenda's en informele lijntjes bepalen de besluitvorming

- Afspraak is hier geen afspraak

- Er is geen ruimte voor ontplooiingskansen, men gunt elkaar het licht in de ogen niet

- In Zundert is alles twee: hoor je niet bij de een, dan hoor je bij de ander

- Zundert is Zundert, de rest van de wereld is niet zo van belang

- Het gaat hier nooit om de inhoud, maar om de 'poppetjes'

- Er wordt over je, niet met je gesproken; er wordt op de man gespeeld

- 'Achterkamertjespolitiek': er wordt geritseld, achter gesloten deuren worden zaken beklonken

- 'Indekcultuur': er wordt defensief samengewerkt; men is bang op 'het lijstje van Jacobs' te komen

- 'Afrekencultuur': openheid en eerlijkheid worden afgestraft; fouten worden 'in de muur gekerfd'

Het zijn stevige woorden. De cultuur in de Zundertse politiek was zonder meer destructief. Ook wethouder Damen sprak erover in zijn afscheidswoorden: "De gemeente Zundert heeft een vergadercultuur die een ieder ontzettend bezig houdt en die ontzettend veel tijd kost. Misschien nog wel meer dan in de tijd voor de invoering van het dualisme. Kaderstellen en controle is nog steeds niet anders dan meedenken, meepraten en meedenken op gedetailleerd niveau. Het handgereedschap van de raad is een doos kleurpotloden om zelf plannen te bedenken en een waterpas en een meetlint om bouwpercelen te controleren. De werkwijze van de raad is eindeloos discussiëren. Als dit dan niet voldoende oplevert, schroomt men niet om het gemeentebestuur op een andere manier aan te pakken. Dit alles mag wat kosten en soms maakt de gemeente Zundert zich daar ook belachelijk mee" (raadsnotulen 290404).

Oud-wethouder Van Tilburg vond alle aspecten van zijn werk leuk, maar de raad kwam op hem over als een tribunaal, waarbij je maar moest wachten wat eruit kwam. Hij vond 
het niet prettig, maar kan het achteraf ook relativeren. "Het ligt ook aan jezelf. Als wethouder ben je intensief betrokken bij projecten, daar ga je voor, voor 300\%. En op het moment dat een raadsvergadering begint, dan zit je eigenlijk al veel te ver op het puntje van je stoel, dan kun je niet meer normaal discussiëren. In feite is het heel simpel, je zegt: luister, raad, we hebben een voorstel, we hebben het goed bekeken, maar het is aan $\mathrm{u}$. En als $\mathrm{u}$ het niet wilt, ok, dan niet. Op het moment dat je daar te diep in betrokken bent, te enthousiast in bent, dan wil je koste wat kost zo'n project door laten gaan. En als dat dan niet gaat, is de teleurstelling groot."

Desalniettemin was de cultuur in de onderzochte periode gebaseerd op gebrek aan onderling vertrouwen. De commissie-Ouwerkerk komt met een drietal redenen voor dit gebrek. De eerste reden is de gemeentelijke herindeling. "De discussies en spanningen die zijn samengegaan met de gemeentelijke herindeling van 1997 komen nog steeds tot uiting in de raad (...). In de raad komt de spanning terug in de samenstelling en afkomst van sommige fracties. Daarnaast wordt een en ander zichtbaar in de wijze van communiceren tussen de raadsleden tijdens debatten. Mensen worden soms aangesproken als representant van een gemeenschap ("hij daar uit Achtmaal..")" (CommissieOuwerkerk, 2005: 4). Op de tweede plaats waren er in Zundert ten tijde van het onderzoek door de commissie-Ouwerkerk relatief veel raadsleden actief geweest als raadslid en/of wethouder binnen meerdere partijen. "Het overstappen naar een andere partij laat altijd zijn sporen na in de samenwerking tussen de desbetreffende partijen. Wanneer dit incidenteel gebeurt, dan zal dit binnen het natuurlijke krachtenspel op redelijke termijn tot een werkbare situatie leiden. Wij hebben geconstateerd dat dit laatste in Zundert niet het geval is en dat het zelfs de al aanwezige spanning bevestigt" (Commissie-Ouwerkerk, 2005: 5). Een laatste punt is de samenstelling van de gemeenteraad: "Bij het beoordelen van de samenstelling van de gemeenteraad valt ons een aantal zaken op. Zo bestaat de gemeenteraad voor een belangrijk deel uit raadsleden, die met hun derde of daaropvolgende raadsperiode(n) bezig zijn. Zij brengen niet alleen ervaring, maar ook 'pijn uit het verleden' mee en dat is merkbaar. Daarbij komt dat het hier vaak gaat om oud-wethouders en/of mensen die van partij zijn veranderd. Het is in Zundert heel gebruikelijk dat een voormalig collegelid terugkomt in de gemeenteraad, kennelijk in de verwachting dat de ene rol makkelijk is in te wisselen voor de andere" (CommissieOuwerkerk, 2005: 5).

Wellicht is de Zundertse cultuur terug te voeren op de geschiedenis. Zundert ligt pal aan de grens met België. In het verleden werd er veel gesmokkeld. De grensovergang bij Wernhout was (voor de komst van de grensovergang bij Breda) destijds de grootste van Nederland. Het hele gebied was een smokkelgebied. "Smokkelaars zijn individualisten", zegt oud-burgemeester Keijzer. "Jan wist dat Piet het was, Piet wist dat Jan het was, dat zijn zwager het was, of de buurman, hoeveel boter iedereen had. Daar werd uiteraard niet over gesproken en men gunde het elkaar eigenlijk ook niet. Maar: tegenover de buitenstaander was het één geheel. Men had een solistische mentaliteit aangekweekt, maar vormde tegelijk tegenover buitenstaanders een gesloten front. Kenmerken van die historische structuur zie je terug in het huidige politieke landschap in Zundert en ook wel in andere gemeenten, zoals St. Willibrord, Rucphen. Hechte historische 
structuren." Keijzer karakteriseert de inwoners van Zundert kernachtig: "Het waren smokkelaars, het zijn smokkelaars en het zullen smokkelaars blijven."

Het onafhankelijke uit zich in de gemeenteraad en in sommige standpunten die worden ingenomen. Zundert dopt graag de eigen boontjes, inmenging wordt niet op prijs gesteld. Zundert is er na de herindeling maar heel moeilijk in geslaagd een eigen identiteit te ontwikkelen. Het bloemencorso verbroedert, maar is vooral iets van het dorp Zundert zelf, zoals Rijsbergen al decennia lang op de eerste zaterdag van augustus 'zijn' boerendag organiseert. De plaats Rijsbergen, hemelsbreed op vijf kilometer afstand, lijkt soms lichtjaren ver weg te liggen. De spanning tussen de preciezen (Rijsbergen) en de rekkelijken (Zundert) van destijds is in de raad nog wel terug te vinden. Tegelijkertijd klinken er bij alle gesprekspartners bewonderende woorden over de enorme inzet van veel inwoners voor het eigen dorp. De inzet voor evenementen, het bloemencorso voorop, is hartverwarmend. "De mensen in de gemeenschap heb ik ervaren als solidair, actief, aanpakkers. Wat dat betreft is het jammer dat Zundert ook die andere geschiedenis heeft", zegt oud-burgemeester Neeb.

Verwachting 8 lvidt: In bestuurlijke probleemgemeenten is de bestuurscultuur negatief tot zeer negatief, wat een aanjagende werking heeft op bestuurlijke problemen. De conclusie is dat deze verwachting is uitgekomen. De raadscultuur in Zundert was soms zodanig negatief, dat de spanning iedere vergadering weer voelbaar was.

\section{Macrofactor: de invloed van de media}

Zundert mag zich verheugen in een redelijk grote belangstelling van dagblad BN/De Stem. Soms leidt dat overigens tot kruisbestuiving: VVD-wethouder W. van Hees werkte als freelancer voor deze krant. Niet iedereen is echter enthousiast over de kwaliteit van de berichtgeving: "Ik vind de berichtgeving weinig inhoudelijk en als het inhoudelijk is, is het de helft van het verhaal", is het oordeel van oud-wethouder Van Tilburg. Toch kan niet gezegd worden dat er eigenlijk niets was om over te schrijven, maar dat de media de zaak hebben opgeklopt. De berichtgeving gaf soms nieuwe dynamiek aan de discussie, maar discussies waren er al. Actiegroeperingen lieten zich ook via de media horen. De oproep van lokale ondernemers aan de formateurs van een nieuw college spreekt wat dat betreft boekdelen, maar vertolkt wel het gevoelen van de samenleving.

Verwachting g luidt: In bestuurlijke probleemgemeenten hebben de (pers)media een grote invloed op het debat, wat een aanjagende werking heeft op bestuurlijke problemen. De conclusie luidt dat deze factor wel is uitgekomen, maar niet bepalend was in een bestuurlijk conflict of bestuurscrisis in Zundert.

\subsection{De dynamiek}

Ook in Zundert was sprake van het op elkaar in werken van factoren in de onderzoeksperiode. Om te beginnen waren er enkele basisvoorwaarden voor een problematische situatie aanwezig: de gemeenteraad was buitengewoon kritisch, zowel in de richting van het college als onderling in de richting van de respectievelijke fracties. Er heerste binnen de raad een breed wantrouwen: het gevoel dat wat door college en ambtelijke organisatie werd aangeleverd per definitie als onjuist en onvolledig diende te worden 
beschouwd (Commissie-Ouwerkerk, 2005: 5). De raadsleden dachten het zelf beter te weten en etaleerden dat ook. Een houding die wellicht voortkomt uit de onafhankelijke volksaard van de Zundertenaren, die zich toch al weinig laten vertellen door anderen. Frequente berichtgeving over de op die manier opdoemende problemen in de media maakte de situatie er niet makkelijker op.

Het wantrouwen zette zich bovendien onderling voort. Fracties vertrouwden elkaar niet of nauwelijks en hadden ook weinig op met eventuele wethouderskandidaten van andere partijen. Coalities kwamen op die manier moeizaam tot stand. De grote hoeveelheid partijen hielp hier niet bij: met een gemiddelde fractiebezetting van iets meer dan twee leden per fractie was de fractiequote erg laag. Als er dan wethouders zijn met gebrekkige communicatievaardigheden of een andere persoonlijke risicofactor, kan het zó mislopen. Zeker als op enig moment, voor de komst van de waarnemer, een vaste burgemeester ontbreekt, zoals in Zundert het geval is geweest. Deze combinatie van factoren maakte Zundert de afgelopen periode zeker tot een bestuurlijke probleemgemeente.

\subsection{Conclusie}

De vraag aan het begin van deze casestudy luidde:

Wat is de verklaring voor het gedwongen vertrek van burgemeesters, wethouders en/of hele colleges in Zundert in de periode maart 1998-maart 2010?

In eerdere casestudies zijn de verschillende factoren onderzocht en bleek een bepaald patroon aanwezig. Ook hier zijn de factoren per raadsperiode bezien en kan, gekoppeld aan de opgetreden bestuurlijke conflicten en bestuurscrises, beoordeeld worden welke factoren in Zundert bepalend waren.

Tabel 30: De factorenanalyse in Zundert

\begin{tabular}{|c|c|c|c|c|c|}
\hline & $\begin{array}{l}\text { Verwachting van de invloed van de factor op de } \\
\text { opgetreden bestuurlijke problematiek }\end{array}$ & $\begin{array}{c}1998- \\
2002\end{array}$ & \begin{tabular}{c|}
$2002-$ \\
2006
\end{tabular} & \begin{tabular}{c|}
$2006-$ \\
2010
\end{tabular} & $\begin{array}{l}\text { Con- } \\
\text { clusie }\end{array}$ \\
\hline 1 & Burgemeester werkte niet dempend & - & + & - & - \\
\hline 2 & Risicofactor wethouders was aanjager & + & + & $+/-$ & + \\
\hline 3 & Optreden college werkte niet dempend & - & + & + & + \\
\hline 4 & Ontbreken patroon college/ambtenaren was aanjager & + & + & - & + \\
\hline 5 & Zwakke verbinding raad/college was aanjager & + & + & + & + \\
\hline 6 & Zwakke verbinding coalitiepartijen was aanjager & $+/-$ & + & + & + \\
\hline 7 & Onevenwichtige structuur gemeenteraad was aanjager & + & + & + & + \\
\hline 8 & Negatieve bestuurscultuur was aanjager & + & + & + & + \\
\hline & Invloed van (pers)media op debat was aanjager & + & + & + & + \\
\hline \multicolumn{6}{|c|}{ Legenda: } \\
\hline
\end{tabular}

De conclusie is dat het eerder gevonden patroon ook lijkt te passen in Zundert. Bij de burgemeesters ligt de nadruk meer op het relatief grote aantal wisselingen in korte tijd, 
waardoor de dempende mogelijkheden van 'het instituut burgemeester' minder vit de verf kwamen. De microfactoren rondom de wethouders gaven wel de doorslag bij conflicten, gecombineerd met de verbindingen tussen de coalitiepartijen.

$\mathrm{Er}$ is nog een tweede kanttekening te maken: de bestuurlijke cultuur in Zundert is zó problematisch geweest, dat die bijna op zichzelf garant stond voor problemen. Zelfs wethouders zonder persoonlijke risicofactor voelden zich soms 'met een blinddoek in een auto' als het ging om de behandeling van voorstellen in de gemeenteraad. In die zin verdient het model nog enige aanscherping: de bestuurlijke cultuur geeft op zichzelf niet de doorslag, maar kan wel zorgen voor situaties die politiek 'explosief' kunnen worden.

In het volgende hoofdstuk wordt de eindconclusie getrokken en de centrale onderzoeksvraag beantwoord. 


\section{Hoofdstuk 9}

\section{Conclusies}

\section{$9.1 \quad$ Inleiding}

Dit onderzoek is gericht op Nederlandse gemeenten waar relatief veel bestuurlijke conflicten en bestuurscrises voorkomen. Zelfs zoveel, dat deze gemeenten er om bekend zijn komen te staan dat het bestuurlijk leven er ongewis is. Ze worden in de wandelgang wel 'moeilijke gemeenten' genoemd, of 'bestuurlijk risicovolle gemeenten'. In deze studie zijn ze betiteld als 'bestuurlijke probleemgemeenten.' De te beantwoorden onderzoeksvraag met betrekking tot deze gemeenten luidde:

Wat is de verklaring voor de aanhoudende crisissituaties en daarmee het gedwongen vertrek van burgemeesters, wethouders en/of hele colleges van $B$ \& $W$ in bestuurlijke probleemgemeenten in Nederland in de periode maart 1998 - maart 2010?

Om deze vraag te kunnen beantwoorden is op de eerste plaats literatuuronderzoek gedaan. Op basis hiervan is een negental verwachtingen geformuleerd, dat wil zeggen verwachte uitkomsten van de analyse. In vier casestudies is vervolgens in beeld gebracht wat er in de betreffende gemeenten aan de hand is geweest. Dit verschilde per gemeente en per onderzochte raadsperiode. In de ene periode kon het gaan om het vertrek van één of twee wethouders, in de volgende periode was er een complete bestuurscrisis, waarbij alle wethouders en de burgemeester dienden te vertrekken. $\mathrm{Er}$ was dus verschil per periode per gemeente. De exercitie om de verschillende bestuurlijke conflicten en bestuurscrises te begrijpen, leidt tot de bevinding dat er een patroon van conflictactiverende en aanjagende invloedsfactoren valt waar te nemen. Dit patroon wordt nogmaals samengevat en enigszins uitgewerkt in paragraaf 9.2, door alle negen verwachtingen de revue te laten passeren. De beantwoording van de centrale onderzoeksvraag vindt vervolgens plaats in paragraaf 9.3.

\subsection{Verwachte verklaringen}

In de vier casestudies zijn negen relevante verklaringen - in de vorm van verwachte uitkomsten - voor het ontstaan en voortduren van bestuurlijke conflicten of bestuurscrises in bestuurlijke probleemgemeenten tegen het licht gehouden. Bezien is of een relevant patroon van factoren te ontdekken is, dus een clustering is waar te nemen. Om dit te onderzoeken werden in vier bestuurlijke probleemgemeenten drie achtereenvolgende raadsperioden onderzocht. Bij de selectie van de cases is er rekening mee gehouden dat zich in elke periode een bestuurlijk probleem heeft voorgedaan. Op die manier was het mogelijk conflicten en crises in totaal twaalf perioden te onderzoeken en te bekijken welke van de negen factoren frequent aanwezig waren en welke samenloop van factoren er was. De resultaten zijn per casestudy weergegeven. Hierbij zijn de volgende verwachtingen geformuleerd: 
Tabel 31: Verwachte uitkomsten per factor

\begin{tabular}{|l|l|}
\hline Verwachting 1 & $\begin{array}{l}\text { In bestuurlijke probleemgemeenten legt de burgemeester weinig bindend } \\
\text { vermogen aan de dag, waardoor de potentiële dempende werking van de } \\
\text { burgemeester afwezig is. }\end{array}$ \\
\hline Verwachting 2 & $\begin{array}{l}\text { In bestuurlijke probleemgemeenten hebben de persoonlijke risicofactoren } \\
\text { van één of meer wethouder(s) een aanjagende werking op bestuurlijke } \\
\text { problemen. }\end{array}$ \\
\hline Verwachting 3 & $\begin{array}{l}\text { In bestuurlijke probleemgemeenten kunnen colleges niet sterk worden, } \\
\text { waardoor de potentiële dempende werking van een sterk college afwezig is. }\end{array}$ \\
\hline Verwachting 4 & $\begin{array}{l}\text { In bestuurlijke probleemgemeenten zit weinig patroon in de relatie van het } \\
\text { college van B\&W met het ambtelijk apparaat, wat een aanjagende werking } \\
\text { heeft op bestuurlijke problemen. }\end{array}$ \\
\hline Verwachting 5 & $\begin{array}{l}\text { In bestuurlijke probleemgemeenten zit geen of weinig patroon in de relatie } \\
\text { tussen het college van B\&W en de gemeenteraad, wat een aanjagende } \\
\text { werking heeft op bestuurlijke problemen. }\end{array}$ \\
\hline Verwachting 6 & $\begin{array}{l}\text { In bestuurlijke probleemgemeenten bestaat weinig binding tussen coalitie- } \\
\text { fracties, wat een aanjagende werking heeft op bestuurlijke problemen. }\end{array}$ \\
\hline Verwachting 7 & $\begin{array}{l}\text { In bestuurlijke probleemgemeenten is sprake van versplintering van het } \\
\text { politieke landschap, wat een aanjagende werking heeft op bestuurlijke } \\
\text { problemen. }\end{array}$ \\
\hline Verwachting 8 & $\begin{array}{l}\text { In bestuurlijke probleemgemeenten is de bestuurscultuur negatief tot zeer } \\
\text { negatief, wat een aanjagende werking heeft op bestuurlijke problemen. }\end{array}$ \\
\hline Verwachting 9 & $\begin{array}{l}\text { In bestuurlijke probleemgemeenten hebben de (pers)media een grote in- } \\
\text { vloed op het debat, wat een aanjagende werking heeft op bestuurlijke } \\
\text { problemen. }\end{array}$ \\
\hline
\end{tabular}

\section{Waargenomen verklaringen}

Samengevat ziet de analyse per verwachte uitkomst er per case als volgt uit:

Tabel 32: De factorenanalyse voor de vier onderzochte gemeenten over de periode van 12 jaar

\begin{tabular}{|c|l|c|c|c|c|}
\hline & Verwachting & $\begin{array}{c}\text { Den } \\
\text { Helder }\end{array}$ & $\begin{array}{c}\text { Leiden } \\
\text { Delf- } \\
\text { Zijl }\end{array}$ & Zundert \\
\hline 1 & Burgemeester werkte niet dempend & + & - & + & - \\
\hline 2 & Risicofactor wethouders was aanjager & + & + & + & + \\
\hline 3 & Optreden college werkte niet dempend & + & $+/-$ & + & + \\
\hline 4 & $\begin{array}{l}\text { Ontbreken patroon college/ambtenaren } \\
\text { was aanjager }\end{array}$ & $+/-$ & + & - & + \\
\hline 5 & Zwakke verbinding raad/college was anjager & + & - & - & + \\
\hline 6 & Zwakke verbinding coalitiefracties was aanjager & + & + & + & + \\
\hline 7 & $\begin{array}{l}\text { Onevenwichtige structuur gemeenteraad } \\
\text { was aanjager }\end{array}$ & + & - & + & + \\
\hline 8 & Negatieve bestuurscultuur was aanjager & + & + & + & + \\
\hline 9 & Invloed van (pers)media op debat was aanjager & + & + & + & + \\
\hline & $\begin{array}{l}\text { Legenda: }+=\text { verwachting is uitgekomen; } \\
+/-=\text { geen eenduidig beeld over de verwachting op te maken; } \\
-=\text { verwachting niet vitgekomen }\end{array}$ & & & \\
\hline
\end{tabular}


Een leesvoorbeeld kan tabel 32 verduidelijken. Verwachting 6 in tabel 32 toont dat in alle vier de cases de coalitiefracties een zwakke verbinding vertoonden - viermaal plus wat een aanjagende werking had op het ontstaan en voortbestaan van conflicten. Verwachting 1 luidde: 'In bestuurlijke probleemgemeenten legt de burgemeester weinig bindend vermogen aan de dag, waardoor de potentiële dempende werking van de burgemeester (op het ontstaan van conflicten in de gemeente) afwezig is'. Deze verwachte vitkomst is in alle gemeenten wel in minimaal één periode waargenomen. De 'optelsom' voor de drie onderzochte perioden laat echter zien dat deze vitkomst vooral in Den Helder en Delfzijl vaak opgaat. Vandaar het plusteken bij deze gemeenten in tabel 32.

Uit tabel 32 blijkt tevens dat van de negen relevante factoren, die invloed hebben op het ontstaan of voortduren van een bestuurlijk conflict of bestuurscrisis, er vier in elke periode in elke bestuurlijke probleemgemeente optraden: de risicofactoren van wethouders; de zwakke verbinding tussen coalitiefracties; de negatieve bestuurscultuur en de invloed van de persmedia. Twee factoren kwamen drie keer voor: het optreden van een niet sterk college en de onevenwichtigheid in de structuur van de gemeenteraad, bijvoorbeeld in de vorm van een versnippering in fractieomvang (veel kleine fracties). Drie factoren kwamen twee keer voor. Dat houdt in dat alle invloedsfactoren ergens in een probleemgemeente 'werking' hebben op het ontstaan en voortbestaan van conflicten en dus relevant zijn gebleken voor het begrijpen van de bestuurlijke probleemgemeente. Hierbij past de aantekening dat tabel 32 een beperking heeft. In tabel 32 is de optelsom weergegeven van de analyse van de werking van invloedsfactoren zoals geformuleerd in de verwachtingen (tabel 31) per probleemgemeente. Tabel 32 is dus de optelsom van plussen en minnen voor elke periode, waarbij twee minnen en een plus tot min leiden. Uit een minteken mag dus niet begrepen worden dat deze verwachte uitkomst in geen enkele periode waargenomen is. Voor het verfijndere beeld voor elke periode wordt terugverwezen naar de rapportages over elke gemeente in eerdere hoofdstukken.

Uit tabel 32 blijkt dat de gemeenten Den Helder en Zundert op het eerste gezicht over de drie perioden heen het meest problematische 'cumulatieve' beeld laten zien: acht plusscores, dat wil zeggen dat acht van de negen verwachte factoren optraden. In de gemeente Delfzijl gaat het om zeven factoren, terwijl Leiden op basis van de overallanalyse een iets ander beeld geeft met vijf uitgekomen verwachtingen. Mogen Den Helder en Zundert dan gezien worden als meer problematische bestuurlijke probleemgemeenten dan Leiden? Hierbij past nogmaals de kanttekening dat het in tabel 32 gaat om een optelsom. De werking van elke factor op zich kan, gegeven een plusteken, toch tussen cases verschillen. Dat kan inhouden dat als een factor werkzaam is, de werking daarvan enorm kan zijn in de ene gemeente en qua 'impact' sterk kan verschillen van een plus in een andere case. Tabel 32 brengt dat niet in beeld. Plus- en mintekens drukken geen verschil in sterkte van een invloedsfactor op een schaal van o tot 10 of van o tot 100 uit. Dat betekent dat vastgehouden wordt aan de vaststelling dat alle vier de cases bestuurlijke probleemgemeenten zijn. Op basis van tabel 32 kan dus niet gesteld worden dat de ene gemeente een grotere probleemgemeente is dan de andere. 
Maar is toch een patroon van verklaringen zichtbaar, zodanig dat door clustering van factoren misschien typen probleemgemeenten waarneembaar zijn? De analyse van vier gemeenten was niet primair gericht op onderscheid, maar op overeenkomst. Het aantal onderzochte cases is te gering om op zoek te kunnen gaan naar typen binnen de verzamelcategorie van probleemgemeenten. De afzonderlijke casestudies brachten echter wel aan het licht dat de gemeente Leiden enigszins afwijkend is ten opzichte van andere cases. Het is evenals de andere een vulkaan, maar een wat afwijkende 'bestuurlijke vulkaan'. Dat blijkt ook uit tabel 32.

\section{Verwachtingen nader bezien}

Uit de casestudies is op te maken welke factoren direct gekoppeld kunnen worden aan het ontstaan van een bepaald bestuurlijk conflict of bestuurscrisis en welke factoren weliswaar (in negatieve zin) aanwezig waren, maar niet direct leidden tot problematiek. Dit beeld is als volgt.

Verwachting 1: In bestuurlijke probleemgemeenten legt de burgemeester weinig bindend vermogen aan de dag, waardoor de potentiële dempende werking van de burgemeester afwezig is.

Het belang van de rol van de burgemeester in het gemeentebestuur is in de literatuur uitvoerig belicht. De burgemeester is niet alleen naar buiten toe het eerste gezicht van het gemeentebestuur en daardoor vaak gekend, maar in formeel opzicht ook voorzitter van het college en de raad en meestal ook van het raadspresidium. Hij of zij heeft soms een eigen portefeuille met taken en verantwoordelijkheden en daar bovenop in elk geval een eigenstandige verantwoordelijkheid op het gebied van orde en veiligheid. De burgemeester voert doorgaans meerdere driehoeksoverleggen, waaronder met de secretaris en griffier. De burgemeester schuift populair gesteld 'voortdurend aan' en de burgemeestersfunctie is dus bij uitstek een schakel- en verbindingsfunctie (ook uitgedrukt in woorden als een intermediair, een trait d'union). De verwachting is dan ook dat de burgemeester er in bestuurlijke probleemgemeenten in deze zin toe deed en doet: wie verbindt, remt het ontstaan en voortduren van conflicten en crises; wie niet verbindt, remt niet en jaagt misschien zelfs aan. Deze verwachting is bezien over de hele periode van twaalf jaar. In twee van de vier gemeenten is deze verwachting gedurende langere tijd uitgekomen en in de twee andere incidenteel (wat in tabel 32, die de optelsom voor drie geanalyseerde perioden per gemeente geeft, niet goed tot uitdrukking komt). Dat betekent dat de burgemeesters er in de bestuurlijke probleemgemeenten niet voldoende, of niet steeds voldoende, in slaagden om te binden en verbinden in het college, tussen college en raad en tussen college en ambtelijke top, zo dat bestuurlijke conflicten of bestuurscrises uitbleven. Door communicatie of andere interventies of juist bewuste non-interventies bleken ze niet (steeds) in staat om bijvoorbeeld plooien glad te strijken of spanning van processen te halen. Beperkingen in gedrag en houding, conflicten waarin ze zelf partij waren of betrokkene en wegvallend vertrouwen leidden er hier en daar toe dat enkele burgemeesters zelfs van het gemeentelijk bestuurstoneel verdwenen.

Wat ging hier achter schuil? Het niet of niet tijdig oppikken door de (niet-dempende) burgemeesters van signalen ten aanzien van verwachtingen over het eigen gedrag en 
de beeldvorming bij anderen daarover, de reflectie daarop en het eventueel aanpassen van het gedrag. Als gevolg hiervan viel ook het vermogen om te binden weg. Sommigen zien zelfs maanden na hun vertrek deze zwakte niet en persisteren in een verongelijkt gevoel dat hen onrecht is aangedaan. Ze zouden zo opnieuw hun gedrag herhaald hebben.

Sommige burgemeesters in dezelfde bestuurlijke probleemgemeente slaagden wel in de ontwikkeling van een verbindende rol, al was dat meestal door een andere positie, namelijk die van waarnemer. Ze hadden echter een voordeel; ze waren al gewaarschuwd voor problemen in de probleemgemeente en de overgebleven acteurs in de probleemgemeente waren zich (iets) bewust(er) van de situatie. Ze hadden ook nog een ander voordeel. Waarnemend burgemeesters, zoals die zijn aangesteld in Delfzijl, Den Helder, Leiden en Zundert, kunnen makkelijker bestuurlijk opereren op een manier die aan verwachtingen van relevante actoren beantwoordt, omdat ze in een andere verhouding staan ten opzichte van de gemeenteraad. De kans dat fracties of gemeenteraden als geheel het vertrouwen opzeggen in een waarnemend burgemeester is relatief klein, omdat de betrokken functionaris per definitie na enige tijd weer zal vertrekken

Tegelijkertijd kan vastgesteld worden dat in de vier gemeenten ook reguliere burgemeesters zijn benoemd, die niet tegen een politiek-bestuurlijke problematiek opliepen. Zo lijken de burgemeesters die bij het afsluiten van dit onderzoek in de onderzochte gemeenten actief zijn er (vooralsnog) wel in te slagen hun ambt te vervullen door de verbindende rol te kiezen en aan adequaat verwachtingenmanagement te doen. Wat hierbij helpt, zo is gebleken, is een goede relatie met de griffier en met de secretaris. Als het met de griffier niet lekker loopt (Zundert) kan dat tot spanning leiden in de relatie met de gemeenteraad, die van nature geneigd is de 'eigen' griffier te steunen. Als het in de tandem burgemeester-secretaris niet goed loopt, kan dit al snel leiden tot spanning in het college (Delfzijl). Andersom kunnen burgemeesters ook steun hebben aan griffiers met een goede rolinvulling (Leiden). Toch gaat het hier om hulpstructuren. Uiteindelijk moeten burgemeesters zelf een manier vinden om zich te handhaven in gemeenten als de onderzochte gemeenten, waar de bestuurlijke cultuur soms ronduit grof en op de persoon gericht is. Daar moet je mee om kunnen gaan. Herinnerd kan worden aan de woorden van burgemeester Lenferink van Leiden, die er ook elementen van een spel in ziet, dat op een bepaalde manier gespeeld moet worden.

Het kan overigens ook zo zijn dat juist de persoonlijke situatie van een burgemeester problemen veroorzaakt (cf Korsten en Aardema, 2006; Korsten en Schoenmaker, 2008). De huisvesting kan een probleem zijn, zoals in Zundert (2004) en Den Helder (2009) bleek. Op zo'n moment kraken de gelederen, juist vanwege de (individuele) problemen rondom een burgemeester. Toch hoeft dat niet gelijk te leiden tot een bestuurscrisis, waarbij ook het wethouderscollectief opstapt. In beide gemeenten vertrok uiteindelijk de burgemeester zelf, in Zundert na een periode van ziekte, zonder dat er op dat moment ook wethouders vertrokken of een college viel. Kennelijk is er meer nodig om een brede bestuurscrisis te veroorzaken. 
Deze belangrijke factor 'conflict dempen door een burgemeester' doet er overigens niet altijd en overal in dezelfde mate toe. Burgemeesters sneuvelen ook niet overal in elke periode, maar als ze niet sneuvelen, wil dat nog niet zeggen dat ze dan wel voldoende bindend en conflictoplossend optraden. Voor een genuanceerd beeld per case per periode moet terugverwezen worden naar eerdere hoofdstukken.

Conclusie: De manier waarop de burgemeester (niet) opereert (en beeldvorming daarover) kan leiden tot een bestuurlijk conflict en het voortduren daarvan, maar hoeft niet te leiden tot een bestuurscrisis. Het feit dat de dempende mogelijkheden van de burgemeester weg vielen, leidde in enkele onderzochte gemeenten- vitgaande van de grove optelsommethode achter tabel 32- op een bepaald moment tot het escaleren van de problematiek.

Verwachting 2: In bestuurlijke probleemgemeenten hebben de persoonlijke risicofactoren van één of meer wethouder(s) een aanjagende werking op bestuurlijke problemen.

Deze verwachting is in alle vier gemeenten uitgekomen. In alle onderzochte gemeenten zijn bestuurlijke problemen ontstaan door persoonlijke factoren van of rond de wethouder. Dat kan een probleem met de achterban zijn, maar het kan ook gaan om andere omstandigheden, waarbij bedacht moet worden dat het wethouderschap stoelt op vertrouwen van de gemeenteraad in de wethouder. Vertrouwen genieten is essentieel. In Leiden steeg de persoonlijke risicofactor van enkele wethouders door hun solistisch optreden, waardoor er irritaties ontstonden bij sommige raadsfracties. In Delfzijl waren er zaken aan de orde die niet zozeer met het wethoudersvak te maken hadden (kentekens, aangiftes bij politie), maar wel zorgden voor grote spanningen rondom de betreffende wethouder. Hetzelfde gold voor Den Helder, waar ook wethouders zijn vertrokken vanwege (vrijwel) onhoudbaar persoonlijk gedrag. Zundert heeft ook wethouders gekend die persoonlijke risicofactoren meedroegen, maar in deze gemeente was het veel meer de onvoorspelbaarheid van de gemeenteraad die voor problematiek zorgde. Overigens is het ook voorgekomen dat wethouders zijn blijven zitten en hun termijn konden vitdienen, terwijl ze zowel in de media als in de gemeenteraad omstreden waren en onder vuur lagen (Leiden, in mindere mate Den Helder). Kennelijk hoeft een persoonlijke risicofactor niet te leiden tot problemen, als een andere factor (krachtig) dempend werkt, in dit geval de hechtheid van de coalitie en daarmee de geregelde communicatie tussen coalitiepartners.

Om te overleven is het voor wethouders niet alleen nodig dat ze over signalerend en reflectief vermogen op persoonlijk gedrag in samenleving, gemeentebestuur en gemeentelijke organisatie beschikken, maar in het algemeen ook de 'politieke landkaart' van de eigen gemeente (met metaforisch gesproken zijn pieken, dalen, waterpartijen en kronkelwegen) goed kunnen lezen.

Conclusie: verwachting 2 is uitgekomen. Het wel of niet optreden van wethouders en de risicograad van wethouders in het bijzonder, is een verklaring voor bestuurlijke conflicten in probleemgemeenten. Persoonlijke risicofactoren zorgen niet per definitie voor bestuurlijke conflicten of bestuurscrises. Soms kan een andere factor, vooral de hechtheid van de coalitie, een dempende of remmende invloed hebben. 
Verwachting 3: In bestuurlijke probleemgemeenten kunnen colleges niet sterk worden, waardoor de potentiële dempende werking van een sterk college afwezig is.

Colleges van B\&W hebben het in principe moeilijk in de gemeenten die in dit onderzoek centraal staan, namelijk de bestuurlijke probleemgemeenten (vgl. Korsten en Schoenmaker, 2008). In de twaalf perioden die zijn onderzocht (drie perioden van vier jaar in de vier gemeenten) was in theorie sprake van twaalf colleges. Immers: na elke gemeenteraadsverkiezing verschijnt weer een nieuw bestuurscollege aan de start, dat is samengesteld door politieke partijen die samen een coalitie vormen en een meerderheid van stemmen in de gemeenteraad hebben. In totaal zijn er in de vier gemeenten twaalf colleges gevallen. In Delfzijl gebeurde dit vier keer, in Leiden en Zundert drie keer, in Den Helder twee keer. In de casestudies is aangetoond dat bij het ontstaan van deze bestuurscrises de potentiële dempende rol van het college niet opging, behalve in situaties waarin er colleges van buiten waren aangesteld. Voorbeelden zijn te vinden in de gemeenten Delfzijl en Zundert, waar een waarnemend burgemeester werd aangesteld en vrijwel alle wethouders echt 'van buiten' kwamen. Het optreden van de reguliere colleges werkte echter in algemene zin niet conflictdempend. Het bleken geen super-teams met enorme vakmatige bekwaamheid, die erin slaagden de conflicten door overtuigingskracht in debatten 'weg te spelen' of ineen te laten schrompelen. Toch is in de onderzochte gemeenten niet aangetroffen dat deze factor bij het ontstaan van problemen een belangrijke rol speelde. Andere factoren bleken een meer bepalende rol te spelen.

Conclusie: de verwachting dat de colleges in bestuurlijke gemeenten in het algemeen niet sterk zijn en er daardoor geen dempende werking van vit gaat, is vitgekomen. Er traden geen colleges op die zodanig sterk waren, dat ze als het ware de bestuurlijke problematiek van zich af hielden of virtuoos van de kaart veegden. Andere factoren waren echter meer bepalend voor bestuurlijke conflicten of bestuurscrises dan deze 'kracht van college'factor.

Verwachting 4: In bestuurlijke probleemgemeenten zit weinig patroon in de relatie van het college van B\&W met het ambtelijk apparaat, wat een aanjagende werking heeft op bestuurlijke problemen.

De relatie tussen het dagelijks bestuur en de ambtelijke organisatie blijkt in alle onderzochte probleemgemeenten van evident belang te zijn geweest. In twee gemeenten (Delfzijl en Zundert) was sprake van een - over het algemeen - niet goed presterende organisatie, die de slag van het oude secretariemodel naar de moderne tijd nog onvoldoende had gemaakt en mede daardoor onvoldoende kwaliteit kon leveren. In beide gemeenten is met veel inspanning gewerkt aan verbetering van de prestaties (zie Abma en Korsten, 2007). Leiden en Zundert laten in de onderzoeksperiode een gebrek aan patroonmatigheid zien, in Den Helder is dat minder duidelijk, voor Delfzijl geldt dit over de hele periode genomen niet. Het beeld is niet eenduidig of de bestuurlijke problematiek door deze factor werd aangejaagd. Het is niet zo dat de bestuurlijke problemen in de ambtelijke organisatie begonnen, al ging het op enig moment soms wel wringen 'rondom de gemeentesecretaris' als hoogste ambtenaar en schakelpunt. Soms is al van veraf zichtbaar dat de gemeentesecretaris gaat sneuvelen, zoals voor Delfzijl is waar- 
genomen (zie ook Westerink, 2006). Dit bleek ook al uit specifiek onderzoek naar de val van burgemeesters (Korsten en Aardema, 2006).

Conclusie: Een weinig patroonmatige verhouding tussen het college en de ambtelijke organisatie (in relatie tot gebreken in het prestatievermogen van de ambtelijke organisatie) houdt verband met het ontstaan en voortduren van bestuurlijke problemen. Toch is niet eenduidig aangetoond dat dergelijke problemen ook echt aangejaagd worden door deze factor. De voedingsbodem voor het zijn van een bestuurlijke probleemgemeente ligt niet primair hier.

Verwachting 5: In bestuurlijke probleemgemeenten zit geen of weinig patroon in de relatie tussen het college van $B \& W$ en de gemeenteraad, wat een aanjagende werking heeft op bestuurlijke problemen.

Bij deze factor gaat het om een patroonmatige relatie, goed debat, het voorop staan van de gezamenlijkheid in plaats van het bestaan van (enigszins) antagonistische wij-zij verhoudingen. Gebleken is dat deze relatie in geen van de vier gemeenten een sterk punt is geweest. In Den Helder en Zundert was het ook een aanjager van bestuurlijke problemen. In drie van de vier gemeenten pakte ook het dualisme hierdoor een tijd lang problematisch uit. In plaats van het scheppen van een nieuwe orde, gingen zowel in Den Helder, Delfzijl als Zundert gemeenteraad en college vooral op zoek naar hun eigen rol en werden de nieuwe dualistische verhoudingen - die bijdroegen aan meer afstandelijkheid dan in de monistische tijd - nogal strikt toegepast. Waar de afstand tussen college en raad toeneemt door de markering van de eigen rol en instrumentering daarvan in de Gemeentewet, moeten er wel bruggen worden geslagen (eventueel door de erkenning dat de raad stuurt op hoofdlijnen en het college op details; door kaderstelling van de raad of ontlokking van kaderstelling door het college; overleg in de driehoek van burgemeester, griffier en gemeentesecretaris; of informeel overleg tussen fractieleiders en wethouders) en dat gebeurde te weinig. Er bestond al snel rolonduidelijkheid. Zo gingen bijvoorbeeld raadsleden graag zitten op de stoel van het college, en collegeleden gingen met veel overbodige informatie naar de gemeenteraad. Deze onduidelijkheid leidde tot spanningen tussen raad en college, maar in alle gemeenten is duidelijk geworden dat die spanningen er vóór de invoering van het dualisme ook al waren. Alleen in Leiden ging de invoering van de dualisering in 2002 soepeler; hier heeft vermoedelijk de schaal en de omvang van de gemeentelijke organisatie mee van doen, alsmede de invoeringsstrategie.

Vanaf 2006 is er een kentering te zien. Zowel in Den Helder als in Zundert en Delfzijl werd steeds serieuzer aandacht besteed aan het dualisme. Delfzijl experimenteerde met een nieuwe vergaderstructuur, Zundert zette structureel meer formatie in, Den Helder kwam met tal van initiatieven om de gemeenteraad bekender te maken bij de inwoners.

De mogelijkheid om wethouders van buiten aan te stellen vanaf 2002 is in alle gemeenten benut. In de gemeente Zundert wordt deze mogelijkheid zelfs als redding gezien: anders was het na de Patersven-crisis in 2005 praktisch onmogelijk geweest een eigen college met voldoende steun in de gemeenteraad te installeren. Het Zundertse college 'van buiten' bleef ook na de verkiezingen van 2006 aan, om pas halverwege 2007 aan te 
kondigen te vertrekken. Ook in Leiden is gebruik gemaakt van de mogelijkheid om wethouders van buiten aan te trekken.

Conclusie: De conclusie met betrekking tot verwachting 5 is dat het beeld weliswaar niet eenduidig is, maar dat de verhoudingen tussen raad en college in alle onderzochte bestuurlijke probleemgemeenten gespannen waren. Het dualisme zorgde vanaf begin 2002 tijdelijk voor extra druk op de relatie tussen de gemeenteraad en het college van $B \& W$, in ieder geval in drie van de vier gemeenten. De dualisering temperde niet. Vanaf 2002 werd het mogelijk wethouders van buiten te benoemen, wat weer voor nieuwe (positieve) impulsen zorgde. Gelet op de in alle gemeenten al aanwezige spanningen is echter niet aangetoond dat het dualisme deze spanningen nog vergrootte en voor een verhoogd risico zorgde. Dat gemeenten een bestuurlijke probleemgemeente werden, is niet op het conto van de dualisering te schrijven. Een gemeente wordt geen probleemgemeente door een wetswijziging, maar eerder door de kwaliteit van gedrag of non-gedrag van mensen en de kwaliteit van de interactie en non-interactie tussen en binnen instituties (raad en college, fracties onderling) en tussen individuele actoren.

Verwachting 6: In bestuurlijke probleemgemeenten bestaat weinig binding tussen de coalitiefracties, wat een aanjagende werking heeft op bestuurlijke problemen.

Deze verwachting is in alle gemeenten uit gekomen. In Den Helder hing de coalitie in 2005 (voornamelijk veroorzaakt door problemen rondom wethouders) als los zand aan elkaar. Echt gesproken werd er eigenlijk niet met elkaar, waardoor er ook geen goede onderlinge afspraken konden worden gemaakt. Dit werd anders vanaf 2006, toen de fractievoorzitters elkaar wel konden vinden en ook vertrouwden. Deze vertrouwensbasis zorgde ervoor, dat na de crisis rond burgemeester Hulman het college kon blijven zitten, daar waar het anders ongetwijfeld ook had moeten opstappen. En hoewel sommigen in Den Helder vinden dat dit eigenlijk ook had moéten gebeuren, toont het wel aan dat goed coalitieoverleg een bestuurscrisis kan voorkomen of de kans erop aanzienlijk kan verminderen. De coalitie heeft immers de meerderheid in de raad. Het bewijs voor deze verwachting werd ook gevonden in Delfzijl, waar vanaf 2006 veel intensiever werd samengewerkt en gecommuniceerd dan voor die tijd. Gebrek aan vertrouwen gaf in februari 2006, nog net in de oude periode, zelfs het laatste zetje aan het college, dat na het vertrek van burgemeester Appel-de Waart zelf ook vertrok.

In Zundert was vanaf 2008 weer sprake van enig coalitieoverleg. Daar bleek het woord vertrouwen nog broos te zijn: in februari 2010 vertrok toch weer een wethouder in het Brabantse dorp. In Leiden, tenslotte, zorgde coalitieoverleg ervoor dat het college, dat na de crisis in 2007 aantrad, de rit kon uitzitten. Bij gebrek aan alternatieven hield men elkaar ook bij de slechtste voorstellen stevig vast, aldus critici. Met goed overleg hebben we alle klippen omzeild, zeggen voorstanders. Hoe het ook zij: ondanks heftige kritiek bleven de aangetreden wethouders op hun post, tot januari 2010. Toen koos GroenLinks voor een eigen koers en was er van goede onderlinge communicatie plotseling geen sprake meer. Het resultaat in Leiden: toch nog een wethouder weg.

Geconstateerd kan overigens worden dat de politieke fracties na een crisis in eerste instantie, begrijpelijkerwijze, dichter naar elkaar toe kruipen en zich voornemen vanaf dat moment echt geen 'gedoe' meer te zullen hebben. Er worden in het algemeen strakke afspraken gemaakt: men laat elkaar niet vallen. Ondanks het feit dat er in de 
raad nog steeds bij tijd en wijle een slechte sfeer hangt en er harde woorden worden gesproken, worden voorstellen van het college in de regel wel aangenomen. De coalitie-afspraken doen hun werk, bestuurders worden niet meer geconfronteerd met meerderheden in de gemeenteraad tegen hun voorstel. En als er al moties van wantrouwen komen, krijgen die in principe geen meerderheid. Een nadeel van een dergelijke benadering is dat er een nieuwe vorm van wij-zij denken wordt geïntroduceerd. Daar waar het in het verleden ging om de wij-zij relatie tussen het college en de gemeenteraad, is dat dan verschoven naar de wij-zij relatie tussen coalitie en oppositie. Hier schuilt op termijn ook een risico in, namelijk dat de cultuur in de gemeenteraad zich nog meer verhardt.

Conclusie: verwachting 6 is uitgekomen op basis van beoordeling in de vier onderzochte gemeenten. Gebrek aan communicatie en vertrouwen zijn tussen coalitiefracties veel voorkomende en dus gewichtige oorzaken voor het ontstaan en voortduren van bestuurscrises.

Verwachting 7: In bestuurlijke probleemgemeenten is sprake van versplintering van het politieke landschap, wat een aanjagende werking heeft op bestuurlijke problemen.

Te veronderstellen is dat in bestuurlijke probleemgemeenten vrijwel altijd sprake is van een gefragmenteerde en dus versplinterde raad, waarin de gemiddelde fractiegrootte beperkt is, vrij veel kleinere fracties opereren en grotere fracties ontbreken. In een dergelijke constellatie ontstaan makkelijk coalities van meerdere partijen en niet van een heel beperkt aantal en doet zich het verschijnsel van wisselende meerderheden bij besluitvorming in de gemeenteraad wat makkelijker voor. In een dergelijke arena kan naar voren komen dat fracties antagonistisch(er) worden. Waar de grote politiekideologische verhalen vanuit fracties geen verwoording vinden en/of fracties met afsplitsingen geconfronteerd worden die kwaad bloed zetten, wordt de kans groter dat raadsleden of fracties figuurlijk gesproken naar elkaar gaan slaan. Veel apen op een kleine apenrots gaan ook naar elkaar bijten, zoals wel is vastgesteld in gemeenten als Echt en Brunssum (zie ook Korsten en Aardema, 2006). Het is ook voorgekomen dat een raad anderszins eenzijdig is, namelijk doordat een grote partij nagenoeg de meerderheid in de gemeenteraad heeft. Dat kan ook onaangenaamheden tot gevolg hebben, waarover vitvoerig is bericht door de journalist Gerard van Westerloo (over Arnhem, Van Westerloo, 2003) en ex-burgemeester Loekie Van Maaren-Van Balen (over Leeuwarden, Van Maaren-van Balen, 2003).

Wat bleek in de onderzochte bestuurlijke probleemgemeenten: de gevolgen van versplintering of van dominantie? Dat de fragmentatie er wel was, maar minder scherp dan hier gesteld en verwacht. Vaak kwamen er na verkiezingen in de vier onderzochte gemeenten veel partijen in de gemeenteraad, waar dan in de loop van de periode ook nog afsplitsingen bij kwamen. Zo liep de fractiequote in Den Helder, Zundert en Delfzijl over de gemeten periode fors terug (op of onder de drie fractieleden). De gemiddelde bezetting per fractie was in Leiden hoger, maar dit kwam door aanwezigheid van een aantal grotere partijen. Ook Leiden telde en telt enkele kleine fracties in de gemeenteraad. Een dominante partij is eveneens aangetroffen in Leiden en Delfzijl.

Het gevolg van beide waarnemingen is dat de structuur van de gemeenteraad onevenwichtig is, dat er weinig balans in het geheel zit. Op zichzelf hoeft dat geen onoverko- 
melijk probleem te zijn, maar wel als dat gecombineerd wordt met een 'lastige' (negatieve) bestuurscultuur. In een versnipperde raad is het per definitie moeilijk om een 'werkbare meerderheid' te verkrijgen, laat staan als er een negatieve bestuurscultuur van gekissebis, andere antagonismen en/of mogelijk ook cliëntelisme heerst. Dan viert politiek opportunisme hoogtij en is van een vaste strategische koers op korte en langere termijn niet of niet makkelijk sprake (zie ook bij verwachting 8 ).

Uit de casestudies blijkt ook dat als nieuwe partijen in de raad hun entree maken of plotseling heel groot worden en doorstoten naar het college, er sprake is van bestuurlijke risico's. Er is dan immers geen sprake geweest van het ontwikkelen van vakbekwaamheid, van het opdoen van veel ervaring in samenwerking en functioneren en van het ontwikkelen van patronen in de betrekkingen tussen fracties en tussen fractie en college. Dan is het een kwestie van wennen. Dit fenomeen geldt niet slechts voor lokale lijsten, maar voor (bijna) alle partijen die nieuw zijn en doorstoten. Overigens is bekend dat, als een raad heel veel kleine partijen kent (ook lokale lijsten) er makkelijk wisselende meerderheden optreden. Dit fenomeen kan samen met een bepaalde bestuurlijke cultuur het ontstaan van een gebrekkig strategisch beleid en veel bestuurlijke wispelturigheid en dus van conflicten en crises aanjagen. In Zundert, om een voorbeeld te noemen, kwam in de periode van onderzoek op dit vlak (en dat van de drie cruciale variabelen) heel veel samen.

Conclusie: De conclusie met betrekking tot verwachting 7 is dat die is uitgekomen. De onevenwichtigheid van de raadssamenstelling speelde een zekere rol, maar was niet bepalend. Om het metaforisch te zeggen: een raad met veel fracties of een dominante fractie kan wel een bedding zijn voor de (bestuurlijke) rivier, maar geeft nog geen voorspelbare uitkomst (op basis van dit ene gegeven) over hoeveel kolkend water (lees: conflicten en crises) er door de rivier gaat.

Verwachting 8: In bestuurlijke probleemgemeenten is de bestuurscultuur negatief tot zeer negatief, wat een aanjagende werking heeft op bestuurlijke problemen.

Dit blijkt een buitengewoon belangrijke factor te zijn in elke gemeente. De vaak destructieve bestuurlijke cultuur in Den Helder, Leiden, Delfzijl en Zundert zorgde in deze gemeenten voor een grote hoeveelheid bestuurlijke spanning. Woorden als 'politieke arena', 'slangenkuil', 'slagveld', en 'intriges' vallen gemakkelijk. Het zijn woorden die duidelijk maken dat het bedrijven van politiek in dergelijke raden gelijk stond aan het op alle manieren bestrijden van elkaar. Dit bestrijden omvatte bij tijd en wijle niet alleen min of meer gezonde spelelementen, maar ging verder. Het optreden van bestuurlijke conflicten en bestuurscrises werd vaak gevoed door een geschiedenis van jaren. In de onderzochte gemeenten zaten ook oud-wethouders in de raden, die in sommige gevallen nog wrok koesterden jegens hun opvolgers en vaak zeer kritische inbreng leverden. Van het voeren van betrouwbaar strategisch beleid was geen sprake, opportunisme vierde hoogtij. De leden van het college van B\&W wisten door de cultuur in de raad vaak absoluut niet waar ze aan toe waren bij de behandeling van een onderwerp. De zeer negatief op elkaar in werkende personen maakten hierbij niet alleen de wethouder of het college het bestuurlijk leven moeilijk, de besluitvorming werd er ook grillig en onvoorspelbaar door. 
Tegelijkertijd moet geconstateerd worden dat niet kan worden gesteld dat de factor bepalend is geweest bij het ontstaan van bestuurlijke conflicten of bestuurscrises. Cultuur is niet iets van een jaar. Het is vaak ingebakken in het doen en laten van de raad en wordt in de onderzochte gemeenten in stand gehouden en gereproduceerd door persoonlijke vetes en animositeit (Delfzijl, Zundert, Den Helder) of raadsleden die graag 'Tweede Kamertje' spelen (Leiden, ook Zundert).

Opvallend is dat in alle gemeenten de rol van de bestuurscultuur door de politiekbestuurlijke acteurs gezien en erkend wordt en vaak in rapporten verwoording vindt. $\mathrm{Er}$ zijn ook pogingen gedaan na een bestuurscrisis veranderingen in de cultuur op gang te brengen. Kennelijk was er een bepaalde 'schok' nodig om in ieder geval te proberen een veranderingsproces op gang te brengen. Dit is te vergelijken met de verandering in beleidsprocessen, die ook vaak pas na een onverwachte gebeurtenis tot stand komt (vgl. De Ridder \& Kempkers, 2002). Tegelijkertijd geldt ook hier de wet van de bestuurlijke traagheid (vgl. Lulofs e.a., 2005), die inhoudt dat elke verandering van richting of tempo meer energie vergt dan het in stand houden ervan. Bovendien: door de schok een cultuurschok te noemen, hoeft geen van de acteurs zich het probleem van de bestuurlijke probleemgemeente persoonlijk aan te trekken.

Conclusie: verwachting 8 is vitgekomen en heel belangrijk gebleken als factor bij de bestuurlijke problematiek. Maar het is een factor die altijd aanwezig is, terwijl bewezen is in enkele onderzochte gemeenten dat niet in alle perioden bestuurlijke problemen zijn ontstaan. Dus de factor is niet bepalend geweest in de vier gemeenten.

Verwachting 9: In bestuurlijke probleemgemeenten hebben de (pers)media een grote invloed op het debat, wat een aanjagende werking heeft op bestuurlijke problemen.

De (pers)media blijken in alle gemeenten een zekere rol te spelen. Nergens waren de persmedia permanent afwezig. In Den Helder ging de invloed van de pers ver, want de inhoud van de Helderse Courant bepaalde soms de agenda van het college van B\&W. Toch gebeurde dat in een tijd dat er géén conflicten of crises meer aan de orde waren.

Een krachtige (bepalende) verklaring voor het ontstaan en voortduren van een bestuurscrisis zijn de media in de vier gemeenten niet. Tegelijkertijd kan niet ontkend worden, dat de media in de vier onderzochte gemeenten wel degelijk een rol speelden in sommige bestuurlijke conflicten of bestuurscrises, en wel op twee manieren. Op de eerste plaats kwamen er soms kwesties op de bestuurstafel, doordat mensen of instanties de publiciteit zochten. Boze bewoners die met foto en al het beleid van het gemeentebestuur hekelden, probeerden met publiciteit het debat in de raad te beïnvloeden en andere besluitvorming af te dwingen. In Zundert zochten de gezamenlijke ondernemers in 2007 de publiciteit, om te voorkomen dat een hun onwelgevallig college zou worden geïnstalleerd. Het lukte, waardoor er pas na een formatie-missie door een persoon van buiten de Zundertse politiek een nieuw bestuurscollege kon worden gevormd. Artikelen in de kranten of items op radio of televisie hebben in die zin een agenderend effect in de bestuurlijke arena gehad.

Op de tweede plaats had de voortdurende media-aandacht een 'aanwakkerend' effect. Door voortdurende publiciteit rondom bijvoorbeeld problemen rond het functioneren 
van een wethouder kreeg zo'n kwestie niet meer de gelegenheid over te waaien of vanzelf te doven (vgl. Korsten/Aardema, 2006).

De constatering moet echter evenzeer zijn dat in de onderhavige gemeenten de bestuurders zelf genoeg stof gaven om over te publiceren. Een vuurtje mag dan wel niet doven door de media-aandacht, het ontstaan ervan is toch in handen van lokale bestuurders. Wel is het zo dat de onderzochte gemeenten bij tijd en wijle een zeer brandbare omgeving boden, waar een klein vonkje al genoeg was voor een heidebrand.

Conclusie: verwachting 9 is uitgekomen. Bepalend was deze factor niet, gezien het feit dat er ook perioden zijn geweest waarin de media-aandacht aanzienlijk was, maar er geen bestuurlijke conflicten of bestuurscrises zijn voorgekomen in de verschillende gemeenten.

Samengevat blijkt uit de casestudies het volgende.

- Een burgemeester kan in de problemen komen, als hij of zij niet signaleert dat er veranderingen zijn opgetreden in de situatie in de gemeente en niet in staat is zijn of haar gedrag daar op aan te passen. Een burgemeester kan echter ook een dempende rol spelen bij het ontstaan of voortduren van conflicten.

- Wethouders kunnen door hun persoonlijk optreden voor risico's zorgen en in de politieke problemen komen. In de onderzochte gemeenten is gebleken dat andere factoren soms een dempende rol spelen, waarbij vooral de hechtheid van de coalitie belangrijk is. Als de coalitiepartijen elkaar 'vast houden' neemt de kans op een bestuurlijke conflict of bestuurscrisis af.

- Het optreden van colleges van B\&W werkte in het algemeen niet dempend op het ontstaan of voortbestaan van bestuurlijke problemen. Weliswaar waren er in sommige perioden in sommige gemeenten vitzonderingen, maar over het geheel genomen speelden de colleges geen krachtige of sterke rol.

- Het ontbreken van een patroonmatige relatie tussen het college van B\&W en de ambtelijke organisatie speelde in sommige gemeenten een rol, maar niet is aangetoond dat hier de problematiek door werd aangejaagd.

- Het ontbreken van een patroon in de relatie tussen het college van B\&W en de gemeenteraad speelde in twee van de vier gemeenten een rol, maar niet is aangetoond dat er direct politieke problemen door ontstonden.

- Het ontbreken van hechtheid tussen de coalitiefracties, blijkend uit een gebrek aan communicatie en vertrouwen, bleek in alle vier onderzochte gemeenten een belangrijke rol te spelen bij het ontstaan en voortduren van bestuurlijke conflicten en bestuurscrises. Tegelijkertijd kan deze factor ook een dempende werking hebben, zo bleek in Den Helder en Delfzijl.

- De versplintering van het politieke landschap was in drie van de vier gemeenten aanwezig, wat een onrustig beeld gaf. De bestuurlijke problematiek ontstond er niet door, maar werd er wel door aangejaagd.

- De negatieve bestuurscultuur was in alle onderzochte gemeenten in alle perioden aanwezig. Toch ontstond niet altijd een bestuurlijk conflict of bestuurscrisis.

- De persmedia hadden een aanjagende werking op het ontstaan of voortduren van bestuurlijke conflicten of bestuurscrises in alle perioden. Tegelijkertijd ontstonden niet in alle perioden problemen en speelde de factor, zo blijkt in de casestudies, een minder belangrijke rol dan de aanwezige bestuurscultuur. 
Kortom:

In de onderzochte gemeenten is gebleken dat microfactoren rond de burgemeester en/of de wethouders en de hechtheid van de coalitie rechtstreeks kunnen leiden tot bestuurlijke problemen. Eerst de microfactoren. Bekend is dat wie als bestuurder wil blijven voortleven aan verwachtingenmanagement moet doen. Ga na hoe anderen je zien, welke beeldvorming je als juist of onjuist ziet en corrigeer zo nodig je eigen gedrag en houding. Dat getuigt van reflexiviteit, voortschrijdend inzicht en adaptiviteit. Daarmee wordt men nog geen kameleon of draaitol. In bestuurlijke probleemgemeenten bleken die kwaliteiten bij bepaalde spelers afwezig of slecht ontwikkeld gebleken. Wie als bestuurder in de gevarenzone belandt of de voorfase daarvan, kan door een gebrek aan oog voor eigen zwakheden en bezinning daarop en het niet in staat zijn om het eigen gedrag aan te passen, het veld moeten ruimen.

Maar dat is niet het hele verhaal. Tegelijkertijd speelden in alle bestuurlijke probleemgemeenten meerdere (soms wisselende) factoren een rol, waarbij met name de voortdurende aanwezigheid van enkele zeer aanjagende macrofactoren - zoals de bestuurscultuur en in mindere mate de rol van de persmedia - in het oog springen. De bestuurscultuur zorgde in de onderzochte gemeenten voor veel spanningen tussen tal van actoren, waardoor lastige dossiers gemakkelijk konden ontsporen. Veel media-aandacht maakte het geheel tot een explosief mengsel, een woelige onderlaag, waarin conflicten en crises op de loer liggen. Of er een bestuurlijk probleem optrad, hing echter vooral af van de omschreven microfactoren en de hechtheid van de coalitie. Coalitiepartners die langs elkaar heen leefden en niet of slecht communiceerden, functioneerden niet als dempende actoren. Het waren in feite slechte partners van elkaar, die 'de boel de boel lieten', dus die zaken op hun beloop lieten.

\section{Bestuurlijk risico}

De conclusie kan nader worden onderbouwd door in termen van 'bestuurlijk risico' te spreken. Hierbij wordt aangesloten bij eerder onderzoek naar risico's: "Alle pogingen risico te definiëren zijn gebaseerd op de algemene notie dat iets ons overkomt, omdat er een gevaar is waaraan we worden blootgesteld en wat dan tot schade kan leiden. Dat het lijden van schade niet vaststaat, is daarbij essentieel" (Ale, 2009). Dit onderzoek sluit aan bij de gebruikelijke definitie van risico: de kans dat een bepaalde gebeurtenis optreedt vermenigvuldigd met het gevolg van die gebeurtenis. In de termen van dit onderzoek gaat het dus om de kans dat zich een bestuurlijk conflict of bestuurscrisis voordoet, vermenigvuldigd met het gevolg van een dergelijk conflict of dergelijke crisis. De kans is in dit onderzoek gedefinieerd in een aantal factoren, die het ontstaan van bestuurlijke conflicten en bestuurscrises aanjagen. Hoe meer factoren er in een bepaalde gemeente een rol spelen en een kant op wijzen, hoe groter de kans dat er bestuurlijke conflicten of bestuurscrises ontstaan. Het gevolg is vervolgens het vertrek van één of meerdere wet-houders, de burgemeester of het hele wethouderscollectief, of het college. Hoe meer bestuurders er opstappen, hoe groter de gevolgen zijn.

De twee microfactoren en de factor 'hechtheid van de coalitie 'vormen als ze optreden, een regelrecht risico. Dat wil zeggen dat bij deze factoren de gevolgen groot zijn: een bestuurlijk conflict of een bestuurscrisis. Met deze factoren kan de gemeente in de gevarenzone, de risicozone, belanden. Als dat bij één factor gebeurt, hoéft dat nog geen probleem te zijn. Er zijn genoeg voorbeelden bekend van wethouders die door 
hun functioneren risico met zich mee brachten, maar door individuele bezinning en gedragsaanpassing (training, hulp), goede collegiale steun of een hechte coalitie niet in de bestuurlijke problemen kwamen. 'Wethouders kunnen om hun collega heen gaan staan', wordt bijvoorbeeld wel gezegd. Dat drukt uit dat ze het voor de wethouder die in het nauw is gaan opnemen.

Als echter ook de burgemeester in de problemen komt, en daarmee zijn 'verbindend werk' - een taak die in heel veel profielschetsen van gevraagde burgemeesters voorkomt- niet kan doen, nemen de risico's fors toe. Bij werking van alle drie de genoemde factoren is het risicoprofiel compleet. Dan zijn metaforisch gezien de centrifugale krachten aan het werk. Er hoeft maar iets te gebeuren of de bestuurlijke poppen zijn aan het dansen. Zijn er andere genoemde factoren, zoals een negatieve bestuurscultuur, dan hebben die een cumulerend effect naar het risicogebied toe. Als ze allemaal optreden maakt een gemeente een bijna 100 procent kans op bestuurlijke problemen, maar als de belangrijkste drie factoren afwezig zijn hoeven er geen bestuurlijke gevolgen in termen van conflict en crisis te zijn. Dan mag het nog zo zijn dat de raad versplinterd is, de cultuur in de raad en de pers kritisch is en de verbindingen niet goed zijn, als:

(1) de burgemeester goed functioneert, boven de partijen staat, erin slaagt geen onderdeel te worden van een conflict en zijn dempende rol kan spelen

(2) de wethouders op zich naar mening van een meerderheid in de raad (in ieder geval de coalitie) goed functioneren

(3) de coalitie zelf goed functioneert

is er geen reden te veronderstellen dat er bestuurlijke problemen gaan ontstaan. Dan is het ontploffingsgevaar slechts latent. Het rommelt in het binnenste van 'de vulkaan', maar dat die op vitbarsten staat is niet aannemelijk, maar ook niet uitgesloten. Anders wordt dat als één van de drie andere factoren verandert. Als de burgemeester wel onderdeel wordt van een bepaald probleem, neemt de risicograad toe. Dit gebeurt ook als de wethouders naar mening van de raad minder gaan functioneren, of het college als geheel aan kracht verliest. Risicovol is eveneens als de coalitie zelf minder goed gaat functioneren, doordat partijen elkaar niet opzoeken, maar langs elkaar heen werken. Vaak treden dergelijke processen in samenhang op, maar ook bij een negatieve score op slechts één van de drie factoren neemt het risicoprofiel van een gemeente toe.

Op grond hiervan is te zien dat de boog niet altijd gespannen staat in een bestuurlijke probleemgemeente. De casestudies tonen aan dat er in de onderzochte periode jaren geweest zijn zonder bestuurlijke problemen of de dreiging daarvan, terwijl de bestuurscultuur problematisch was en ook de persmedia druk uitoefenden op het politiek proces.

Uit de analyse van Den Helder, Leiden, Delfzijl en Zundert is op te maken dat de bestuurlijke problematiek fluctueerde. De gemeenten hadden wel in alle drie onderzochte perioden te maken met bestuurlijk vertrek, al vond het vertrek van het voltallig college en de burgemeester in Delfzijl vlak vóór de verkiezingen van 2006 plaats. Puur formeel gesproken vonden er dus in de periode 2006-2010 geen vertrekken plaats, 
maar de effecten van de crisis waren zodanig (waarnemend burgemeester, college met wethouders van buiten, raadsperiode begint met bezoek van de minister van Binnenlandse Zaken en koninkrijksrelaties) dat Delfzijl toch is onderzocht.

De periode 2006-2010 is hierna wel de rustigste in twaalf jaar tijd geworden, het college diende de rit uit. De oorzaken hiervan zijn al in de casestudy aan de orde geweest en kunnen worden samengevat door te stellen dat in Delfzijl de in deze studie benoemde kritische factoren nu temperend gingen werken. De waarnemend burgemeester (later ook de regulier benoemde opvolger) was alert en kon een bindende rol spelen. De wethouders kwamen 'van buiten' de gemeente, betrekkelijk onthecht ten opzichte van raadsleden en partijgeschiedenissen en ze waren berekend op hun taak. In het verlengde hiervan functioneerde het college meer als eenheid. De coalitiepartijen zochten elkaar op bij problemen en communiceerden goed. Dit alles gebeurde ondanks het feit dat de macrofactoren niet veranderden: de cultuur in de gemeenteraad was bij tijd en wijle nog steeds negatief, er vond nog een splitsing plaats in de grootste partij, de fractie van de PvdA (bestuursstructuur) en de invloed van de media veranderde ook niet wezenlijk. Desondanks kregen (anders dan in andere perioden) de temperende factoren de overhand, waardoor problemen uitbleven.

Ook in Den Helder was er een periode dat de bestuurlijke risicozone leek te zijn verlaten, de periode na de crisis in 2005 (zie casestudy). Ook hier speelde een waarnemend burgemeester en een college van buiten een belangrijke rol. In 2006 kwamen er weer 'eigen' wethouders, maar besloten de fractievoorzitters een hechte coalitie te maken. Problemen zouden worden besproken, in principe zou het nieuwe college voor de verandering 'de rit eens uit moeten gaan zitten'. Dit was ook bijna gelukt, ware het niet dat een microfactor (de burgemeester) de gemeente weer deed opschuiven naar de risicozone. De macrofactoren in Den Helder zorgden er voor dat dit opnieuw richting bestuurlijk conflict ging, bijna richting een crisis. Dat het niet zover kwam en uiteindelijk alleen zittend burgemeester Hulman vertrok, had te maken met de hechte coalitie, vastbesloten zich niet uit te laten spelen en de kwestie te laten ontaarden in iets anders.

Leiden laat op het vlak van het lopen van bestuurlijke risico's een wisselend beeld zien. Er zijn relatief rustige perioden geweest, maar ook perioden met extreme politieke problemen. Ook hier in een setting waarin de macrofactoren conflictbevorderend werkten. Soms echter bleken de drie in dit onderzoek gevonden dominante factoren hiertegen bestand, zodat bestuurlijke problemen uitbleven, soms ook niet. Op het moment dat de coalitie problemen liet zien (crisis 2007, zie casestudy) was het hek al vrij snel van de Leidse dam.

In Zundert tenslotte bleek ook het ontbreken van vertrouwen in de coalitie de basis voor het vallen ervan (2004). Een lang zittende wethoudersploeg van buiten had hier minder last van, waardoor de gemeente hierna niet meer in de bestuurlijke risicozone zat. Problemen rond de microfactor wethouder, zorgden (in de Zundertse bestuurscultuur) echter toch op de valreep nog voor het vertrek van een wethouder. 


\subsection{Beantwoording van de centrale onderzoeksvraag}

In dit onderzoek is op systematische wijze getracht inzicht te verschaffen in de complexe problematiek van bestuurlijke probleemgemeenten, in de wandelgangen ook wel 'moeilijke gemeenten' genoemd. Deze probleemgemeenten zijn gemeenten die bekend staan om de grote doorloopsnelheid van individuele gemeentebestuurders, het uiteenvallen van wethoudersploegen en zelfs hele colleges, dus inclusief de burgemeester. De vraag was: wat is er aan de hand in die gemeenten?

Om deze vraag te kunnen beantwoorden is een analysekader opgesteld, op basis van literatuuronderzoek. Vervolgens is in heel Nederland onderzocht om welke gemeenten het eigenlijk ging en gaat. Hier kwam een lijst van negen gemeenten uit, die op basis van een aantal criteria te kenschetsen zijn als evidente bestuurlijke probleemgemeenten. In vier van deze gemeenten is een casestudy gedaan. Op basis van de resultaten is antwoord te geven op de centrale vraagstelling van het onderzoek, die luidt:

Wat is de verklaring voor de aanhoudende crisissituaties en daarmee het gedwongen vertrek van burgemeesters, wethouders en/of hele colleges in bestuurlijke probleemgemeenten in Nederland in de periode maart 1998 - maart 2010?

Het antwoord luidt als volgt: Het ontstaan en voortbestaan van crisissituaties in probleemgemeenten kan niet monocausaal worden begrepen of verklaard. Er moeten veel gebeurtenissen en omstandigheden in een tijd- en plaatsafhankelijke situatie samenkomen voor er problemen ontstaan. In bestuurlijke probleemgemeenten kómen die factoren regelmatig samen, is gebleken.

Uit literatuuronderzoek is gebleken dat er negen factoren zijn die een rol spelen of kunnen spelen bij het gedwongen vertrek van gemeentebestuurders. Nadere analyse van de problematiek in vier onderzochte bestuurlijke probleemgemeenten leert dat er vervolgens een onderscheid is te maken.

1. Sommige factoren zijn continu negatief aanwezig, maar spelen een rol op de achtergrond. Hierbij gaat het vooral om de bestuurscultuur $(4 \mathrm{x})$, de persmedia $(4 \mathrm{x})$ en de bestuursstructuur (3x).

2. Drie factoren kunnen leiden tot bestuurlijke problematiek. Hierbij zijn twee microfactoren aan de orde (de burgemeester en de wethouder) en een mesofactor: de hechtheid van de coalitie.

Microfactoren

Bij de microfactoren gaat het om een burgemeester of wethouder(s) die persoonlijke risicofactoren met zich meedragen. Ze zijn niet goed opgewassen tegen de functie, komen zelf in opspraak of hebben een moeizame relatie met hun achterban (wat alleen voor wethouders geldt) en lopen hierdoor grote kans gedwongen naar een andere baan te moeten uitkijken. Hun vakbekwaamheid, hun politiek-bestuurlijk gevoel, hun vermogen tot spiegelen en zich anderszins te bezinnen op hun gedrag en beeldvorming over gedrag of non-gedrag en zich aanpassen is onvoldoende aan de orde, niet (voldoende) gericht op de goede dingen of komt te laat op gang. Ze laten zich niet vaak 
waarschuwen en als ze gewaarschuwd worden, doen ze er niets of te weinig mee. Ze bagatelliseren, of ze houden vast aan 'wie ze zijn' of ze hebben nog andere uitvluchten om niet te doen wat nodig is om te overleven. Op collectief niveau, bijvoorbeeld op collegeniveau of in de interactie met raadsfracties, lukt het ook niet om te temperen, bijvoorbeeld door om een wethouder of burgemeester te gaan staan of anderszins het college door 'woelige baren' te loodsen. Ook het dempend vermogen van het 'instituut' burgemeester zelf valt hierdoor weg.

De kwaliteit van bestuurders of het gemis ervan doen er dus toe. Dat zijn nooit aanwezige of ontbrekende kwaliteiten op zich, want wethouders en burgemeesters functioneren voortdurend in groepen en in interacties met andere entiteiten. Voor een burgemeester gaat het om een rol als voorzitter van het college en wellicht als portefeuillehouder, het voorzitterschap van de raad, veelal ook het voorzitterschap van het raadspresidium en een rol in de driehoek van burgemeester, gemeentesecretaris en raadsgriffier. Hoe opereert een burgemeester hierin? Is dat: proactief, deskundig, warm of bot, communicatief of niet communicatief, attent of niet attent, hartelijk, open, coachend, verbindend, geloofwaardig, authentiek, conflictmijdend, oplossend of conflicten veroorzakend, productief, ideeën lancerend, beleidsinhoudelijk gericht, etcetera. Daarnaast onderhoudt een burgemeester tal van contacten met delen van de samenleving en is hij bestuurlijk of anderszins actief in gremia buiten de gemeente in strikte zin, zoals in intergemeentelijke samenwerkingsverbanden. Is hij op goede momenten op de juiste plaats? Is de burgemeester vaak afwezig? Weet men of de afwezigheid het gemeentelijk belang dient of niet? Het gedrag wordt door velen waargenomen en beoordeeld. Voor wethouders geldt iets vergelijkbaars, waarbij ook nog fractie en kiezers in beeld komen. Zowel burgemeesters als wethouders moeten oog hebben voor hoe ze daarin functioneren. Men mag zichzelf blijven, maar moet niet blind zijn voor kritiek en negatieve beeldvorming, anders nemen de persoonlijke risicofactoren teveel toe.

Opmerkelijk is dat bijna alle burgemeesters of wethouders bepaalde kwaliteiten hadden. Burgemeesters die sneuvelen waren immers vaak al burgemeester geweest in andere gemeenten. Ook wethouders zijn op enig moment komen 'bovendrijven' in een groep. Maar waar het op aankomt, is dat ze bepaalde kwaliteiten die verlangd worden, niet hadden of ontwikkelden en daar amper of niet bij stilstonden.

\section{Mesofactor: coalitie}

De derde factor die kan leiden tot bestuurlijke problemen is de hechtheid van de coalitie: fracties die een stevige verbinding met elkaar zijn aangegaan, met fractievoorzitters die elkaar wel mogen en vertrouwen en overleggen. Hier kan een sterk dempende werking van uitgaan op het ontstaan of escaleren van bestuurlijke conflicten en bestuurscrises in probleemgemeenten. Als de coalitiepartijen geen 'gedoe' willen, om wat voor reden dan ook, kan zelfs een niet functionerende wethouder blijven zitten. Dan blijkt dat wethouders, of een burgemeester, die tegen problemen aanlopen niet zonder meer in een bestuurlijk conflict hoeven te komen, of dat een bestuurlijk conflict niet automatisch vitloopt op een heuse crisis. Daarmee is de hechtheid van de coalitie dus de factor die bepalend of van groot gewicht is in de vraag of er in gemeenten een bestuurscrisis ontstaat of niet. Als om wat voor reden dan ook de coalitie onder druk 
komt te staan, blijkt de positie van bestuurders of hele colleges in dergelijke gemeenten broos te zijn. Als het onderling vertrouwen tussen de fracties of hun voorzitters weg is, is ook de laatste rem van de kar en is het wachten op de helling naar beneden.

Voor burgemeesters speelt die hechtheid van de coalitie een minder belangrijke rol. De vraag of een burgemeester wel of niet moet vertrekken bij problemen strekt zich uit tot de hele raad (niet alleen de coalitie) en hangt ook erg samen met het (opgebouwde) 'bestuurlijk krediet' van de betreffende functionaris en blijvend vertrouwen. Of een burgemeester samen met de rest van een college moet verdwijnen, is een combinatie hiervan. Als de burgemeester in micro-opzicht goed functioneert, maar de wethouders niet, kan het zijn dat bij het uiteenvallen van een coalitie de burgemeester gewoon blijft zitten. Als de burgemeester zich echter nadrukkelijk verbindt aan het collegebeleid en zich nauwelijks als voorzitter van de gemeenteraad manifesteert, wordt dat lastiger en neemt de kans dat hij of zij bij een crisis ook wordt weggestuurd, aanzienlijk toe. Dan kan het voorkomen dat een raadslid stelt: 'Hij is niet van ons'.

\section{Geen leidende rol}

Op basis van de resultaten is ook aan te geven dat sommige factoren weliswaar aanwezig waren, maar op zichzelf niet leidden tot bestuurlijke conflicten of het escaleren tot bestuurscrises in een bestuurlijke probleemgemeente. Om te beginnen is het niet zo dat de oorzaak voor de 'talrijke' bestuurlijke conflicten en crises in bestuurlijke probleemgemeenten alleen of voornamelijk gezocht moet worden in de rol van de persmedia of het actiever worden van persberichtgeving. De factor 'pers' kwam overal voor, maar kan gerelativeerd worden.

In het verlengde hiervan ligt de constatering dat de oorzaak voor het ontstaan van een probleemgemeente niet ligt in het handelen van grote meerderheden of minderheden uit de gemeentelijke samenleving. Burgers kijken er naar en verbazen zich. Natuurlijk zijn er wel conflicten waarin burgers positie kiezen (denk aan de Rijn-Gouwe lijn in Leiden) maar het zijn niet de burgers die een gemeente rechtstreeks doen vitgroeien tot een bestuurlijke probleemgemeente. Het is niet zo dat een gemeente een bestuurlijke probleemgemeente wordt als gevolg van alleen het ontstaan en opereren van actiegroepen, of van specifiek en herhaald massaal of groot protest van burgers tegen de beleidsinhoud van genomen besluiten door college of gemeenteraad.

Van een groot of politiek overheersend beleidsvraagstuk als enige oorzaak van crises met een bestuurlijk probleemgemeente-etiket tot gevolg gedurende langere tijd is slechts incidenteel sprake. Dat is begrijpelijk vanuit het perspectief dat de lokale politiek, zoals eerder aangegeven, in sterke mate uitvoering in medebewind is van rijksbeleid.

Er kan nog meer worden afgestreept. Het is ook niet zo dat een gemeente een bestuurlijke probleemgemeente is en blijft, omdat alleen een voordracht voor en aanstelling van een bepaalde burgemeester naderhand als een vergissing moet worden betiteld. De burgemeester is weliswaar een belangrijke spelverdeler en verbinder op het politiekbestuurlijk speelveld, maar de status van bestuurlijke probleemgemeente valt niet te 
herleiden tot slechts één acteur. In het onderzoek is evenmin naar voren gekomen dat als je nu maar een sterk college hebt van sterke wethouders (vakbekwaam, visionair, charismatisch, interactief, communicatief, elkaar ondersteunend, etc.) dat het dan allemaal vanzelf goed gaat en de bedreiging om bestuurlijke probleemgemeente te worden volkomen afwezig is of de kans op een dergelijke status gering.

Het is evenmin zo dat een disfunctionerende ambtelijke top van een gemeente een gemeente tot een bestuurlijke probleemgemeente maakt. Begrijpelijk. Het is niet de ploeg van het veldonderhoud en de administratieve staf die de voetbalwedstrijd op het veld verliest.

Een veel gehoorde andere mening in bestuurlijke kringen is geweest dat de dualisering sinds begin 2002 veel bestuurlijke problemen heeft gegeven. De dualisering hield in dat de verstrengeling tussen college en raad ongedaan werd gemaakt. Wethouders waren niet langer meer lid van de gemeenteraad en geen voorzitter van commissies meer. $\mathrm{Er}$ ontstond meer afstand. De raad bleef hoogste bestuursorgaan en kreeg ook meer instrumenten, zoals een versterkte controlemogelijkheid, bij voorbeeld via het recht op enquête en de instelling van lokale of regionale rekenkamers. De analyse van vier bestuurlijke probleemgemeenten bevestigt dit beeld van verhoogde animositeit, uitlopend op een etiket van 'bestuurlijke probleemgemeente', niet. Bestuurlijke probleemgemeenten waren in feite al probleemgemeenten voor de dualisering werd ingezet. Dualisering heeft echter ook niet geholpen de situatie ten goede te laten keren. De dualisering heeft geen rust gebracht in probleemgemeenten, maar dat was ook geen doel achter de dualisering. De dualisering heeft de onderzochte probleemgemeenten niet conflict- en crisesvrij gemaakt.

In het volgende hoofdstuk wordt gereflecteerd op het onderzoeksresultaat, door dat resultaat nog eens van enige afstand te beschouwen. De vraag is: zijn er op basis van het onderzoek suggesties te doen om het 'bestuurlijk probleemgehalte' in Nederland te laten dalen? 


\section{Reflectie op bevindingen}

\subsection{Inleiding}

Het doel van dit onderzoek was om te bezien wat er aan de hand is in Nederlandse gemeenten waar relatief veel gemeentebestuurders voortijdig moesten vertrekken in de periode maart 1998-maart 2010: de bestuurlijke probleemgemeenten. Hiervoor is enige lijn aangebracht in de hoeveelheid cijfers over vertrekkende gemeentebestuurders en bezien hoeveel gemeenten er nu werkelijk aan te merken zijn als bestuurlijke probleemgemeente. Aan de hand van onderzoek in vier van deze gemeenten is gepoogd te begrijpen waarom gemeenten bestuurlijke probleemgemeenten zijn en wat daarop van invloed is. In hoofdstuk 9 zijn de conclusies van het onderzoek gepresenteerd. Dit laatste hoofdstuk is geschreven als reflectie op de vitkomsten. Bezien wordt wat er uit het onderzoek is geconcludeerd en hoe daarover gedacht kan worden. In dat verband wordt gezocht naar suggesties met betrekking tot de vraag hoe om te gaan met bestuurlijke probleemgemeenten, of wellicht zelfs bestuurlijke probleemgemeenten te 'normaliseren'.

Op de eerste plaats dient in deze reflectie echter gewezen te worden op het feit dat dit onderzoek zich richtte op het aantal gedwongen vertrokken gemeentebestuurders per Nederlandse gemeente en dat op die manier een aantal bestuurlijke probleemgemeenten kon worden geselecteerd. Er zijn in Nederland echter ook gemeenten, waar geen sprake is van het meer dan gemiddeld naar huis sturen van wethouders of burgemeesters, maar die toch als bestuurlijk zeer zorgelijk of problematisch worden ervaren (zie ook hoofdstuk 4). Dit blijkt bijvoorbeeld uit cultuuranalyses van deze gemeenten. Analyses die vaak gemaakt worden in opdracht van of in nauwe samenspraak met de Commissaris van de Koningin, in de regel vanwege een (dus niet zeer veel voorkomende) actuele crisis in zo'n gemeente. Voorbeelden zijn er volop. Dergelijke analyses zijn bijvoorbeeld gemaakt van de gemeente Zeewolde, Alblasserdam, Boxmeer, en recentelijk ook van Maasdriel (Diepeveen, Van Hout, Riezebos, 2010). Vaak leveren zulke rapporten een zeer kritische analyse op van de situatie in zo'n gemeente. In het rapport over Maasdriel valt bijvoorbeeld te lezen dat 'vrijwel alle mogelijke middelen zijn geoorloofd om politieke doelen te bereiken. Ingegeven door het persoonlijke karakter van de bestuurscultuur van Maasdriel is politiek verengd tot een spel, waarin het draait om macht en de poppetjes en niet om de inhoud. Persoonlijke twisten blokkeren inhoudelijke samenwerking. In de bestuurscultuur van Maasdriel voelen velen zich niet veilig' (Diepeveen C.S., 2010: 4).

Dit leidt tot de conclusie dat er kennelijk verschillende bestuurlijke probleemgemeenten zijn. Probleemgemeenten waar de zaak zichtbaar is ontspoord en die in dit onderzoek centraal staan, maar ook gemeenten waar de problematiek doorgaans wel zichtbaar is, maar niet leidt tot aanhoudende conflicten of bestuurscrises in de vorm van veel aftredende bestuurders. In dit verband kan gewezen worden op het onderscheid dat Korsten (2011) maakt tussen manifeste probleemgemeenten en latente probleemgemeenten (zie ook in hoofdstuk 9). Een manifeste probleemgemeente is een 
gemeente die 'evident en zichtbaar problemen in politiek en bestuur kent door het aftreden van meer dan één burgemeester en/of wethouders, waarbij ook botsingen in de gemeenteraad plaatsvinden die doorgaans niet slechts van zakelijke aard zijn' (Korsten, 2011: 12). De negen gemeenten die in dit onderzoek zijn onderscheiden, zijn te beschouwen als manifeste bestuurlijke probleemgemeenten. Het zijn de 'sterk actieve vulkanen'.

Een latente bestuurlijke probleemgemeente is een probleemgemeente, met crisisdreiging en bestuurlijke problematiek, maar waar geen cumulatie optreedt van aftredende burgemeester(s) of wethouder(s) of de val van een college optreedt (Korsten, 2011: 13). Er is evident iets aan de hand, blijkt ook vaak uit onderzoek zoals uitgevoerd in Maasdriel, maar tot veel bestuurlijk conflicten komt het niet of nauwelijks. Korsten trekt in dit verband de vergelijking met vulkanen door. Latente bestuurlijke probleemgemeenten kunnen ofwel worden beschouwd als een 'vulkaan in ruste', waar het ooit heel onrustig was, maar waar de situatie weer tot rust lijkt te zijn gekomen. Zeker weten doe je het echter niet in deze gemeenten. Het kan ook zijn dat er sprake is van een licht actieve vulkaan, waar eigenlijk voortdurend een verhoogde politieke spanning waarneembaar is. Blijkbaar zijn in deze gemeenten factoren werkzaam die een remmend effect hebben op het ontstaan van veel bestuurlijke problematiek. Dat kan een verbindende burgemeester zijn, dan wel een hechte coalitie in een bepaalde periode. De suggesties ter verbetering van de situatie, die in deze reflectie worden gedaan, kunnen voor alle typen bestuurlijke probleemgemeenten van nut zijn.

\section{Nuances}

Over het geven van suggesties kan overigens genuanceerd worden gedacht. Na het bestuderen van de praktijk in de in dit onderzoek betrokken gemeenten dringt de vraag zich namelijk op of het doen van aanbevelingen, of het geven van aanwijzingen, mogelijk en zinvol is. Een eerste reden voor enige terughoudendheid op dit terrein is dat er in het onderzoek niet minder, maar ook niet meer dan vier gemeenten uit een bestand van negen nader zijn beschouwd in de casestudies. De problematiek in meer gemeenten beschrijven was niet aan de orde: elk onderzoek kent zijn beperkingen in tijd en mogelijkheden. De analyses hebben een eerste beeld opgeleverd van wat een gemeente tot probleemgemeente maakt, maar tegelijk is dat beeld beperkt. Bovendien kent het werken met casestudies nadelen: resultaten zijn niet te veralgemeniseren, dus 'aanbevelingen' ook niet. Er is nog een derde reden om terughoudend te zijn met aanbevelingen. De praktijk is namelijk niet zo simpel, dat met het opvolgen van een paar aanbevelingen het bestuur gegarandeerd verbetert. De lokale bestuurlijke processen, die zich in de onderzochte gemeenten hebben voltrokken, lenen zich slecht voor enkelvoudige beschouwingen. Natuurlijk helpt het als wethouders beter worden toegerust op hun werk, om maar een mogelijke suggestie te noemen. Maar daarmee is nog niets gezegd over tal van andere factoren, die inwerken op de bestuurlijke risicovolheid van een gemeente. Factoren die in wisselwerking staan met elkaar, waardoor een bepaalde dynamiek ontstaat. Soms een positieve dynamiek, maar in de onderzochte gemeenten vaak een negatieve. De wisselwerking zorgde als het ware voor een negatieve spiraal in betrokken gemeenten. Voor die wisselwerking zijn veel minder makkelijk aanbevelingen in de vorm van 'vitwegen' te geven. Sterker nog: die wisselwerking is zo specifiek gebonden aan een gemeente, dat algemene aanbevelingen vermoedelijk lang 
niet altijd op gaan. Aanbevelingen zijn vaak instrumenteel van karakter en kunnen, als het erop aankomt, stuk voor stuk wegspoelen in de bestuurlijke dynamiek rond een bestuurscrisis in een gemeente.

Toch is er gezocht naar handreikingen, mede omdat er binnen het departement van BZK, het parlement en op provinciaal niveau bij Commissarissen van de Koningin behoefte hieraan bestaat. Er is ook discussie over deze thematiek binnen het kader van de Vereniging van Nederlandse Gemeenten en het Nederlands Genootschap van Burgemeesters. Begrijpelijk, in bestuurlijke probleemgemeenten komen mensen immers 'tussen de wielen', worden bestuurlijke en ambtelijke reputaties geknakt; dan is vanzelfsprekend de vraag naar preventie of andere interventie aan de orde. Delen van de bevolking accepteren het ook niet dat het gemeentebestuur zo conflict- en crisisrijk is. Een gemeentebestuur dat in ernstige mate bestuurlijk instabiel is, tast het vertrouwen van veel burgers in het gemeentebestuur en de politieke fracties en partijen aan. Dat kan ernstige vormen aannemen. In Delfzijl stemde 25 procent van de inwoners bij de raadsverkiezingen in 2006 uit protest blanco, wat goed zou zijn geweest voor vijf raadszetels.

In deze reflectie zal daarom in alle beperktheid toch een poging worden gedaan tot enige ordening van suggesties. Hierbij worden enkele separate perspectieven uitgewerkt, die verderop op elkaar worden betrokken. Hierbij worden de denklijnen van Korsten (2011: 7) gevolgd. Korsten noemt op basis van literatuurstudie (o.a. werk van Fleurke, 2008 en Broeksteeg, 2009), eigen onderzoek naar de val van burgemeesters (Korsten en Aardema, 2006; Korsten, e.a. 2008; Korsten, 2010) en besprekingen met enkele topambtenaren van het ministerie van BZK en met Commissarissen van de Koningin drie perspectieven:

1 Het autonomieperspectief: een gemeente is zelf bestuurlijk verantwoordelijk in gevolge de Grondwet en moet dus zelfreinigend optreden (paragraaf 10.2).

2 Het perspectief van de systeemverantwoordelijke rijksoverheid: de 'hogere' overheid moet handelen (paragraaf 10.3).

3 Het ecologisch perspectief: niets doen, het herstel moet langs natuurlijke weg optreden (paragraaf 10.4).

In paragraaf 10.5 volgt een slotoverdenking met enige relativering.

\subsection{Het autonomieperspectief}

Gemeenten zijn wettelijk gezien autonoom en dienen, volgens de code voor goed bestuur (zie paragraaf 3.3) te beschikken over zelfreinigend vermogen. Het kabinetBalkenende IV heeft dit nog eens belicht. Lokale bestuurders moeten dus op de eerste plaats zich zelf bezinnen op de vraag wat goed en fout bestuur is en wat beter moet, en hoe. De 'oplossingen' voor bestuurlijke problemen ('if any') moeten in dit perspectief op gemeentelijk niveau zelf gezocht worden. Een gemeentebestuur moet zichzelf de maat nemen, in de spiegel kijken en besluiten tot correctie, indien nodig. Zijn gemeentebesturen en hun organisaties tot zelfreiniging in staat en wat dient zich dan aan? Hier 
gaat het erom waartoe bestuurlijke probleemgemeenten in staat zijn. Direct is vast te stellen dat ze in zelfreiniging niet uitblinken, want anders was het niet zo ver gekomen dat ze bestuurlijke probleemgemeente werden en bleven. Maar wat is gepoogd en hoe ver reikten de pogingen?

Vooraf moet gezegd worden dat de opdracht om tot lokale zelfreiniging over te gaan iets heeft van baron von Münchhausen, die zichzelf uit het moeras, waarin hij verzonken is, moet zien te redden. Een onmogelijkheid, of toch niet? Wie op zelfreiniging uit is, is in ieder geval betrekkelijk onthand. Er is ook nog geen 'best practice' of handleiding ten aanzien van zelfreinigende kwaliteiten beschikbaar, als die er al ooit komt. Maar tips zijn er vele (bij voorbeeld Korsten en Aardema, 2006; Korsten en Schoenmaker, 2008).

Daarbij moet worden aangetekend dat het in veel gemeenten qua conflict- en crisisgraad 'goed' gaat, dus blijkbaar functioneert het gemeentelijk bestel impliciet wel zodanig dat bestuurlijke probleemgemeenten een minderheid vormen en dus de uitzondering zijn. In de meeste gemeenten is blijkbaar sprake van een zekere conflictregulering, doordat aanjagende factoren ook weer gedempt worden door 'remmers', of het zijn (beheer)gemeenten waarin niet veel conflictstof op de plank ligt. Zo gezien, bestaat er wel degelijk ervaringskennis op het vlak van zelfreiniging.

Als het gaat om de vraag welke acties door gemeentebesturen (en ondersteuners) zelf kunnen worden genomen om uit de bestuurlijke risicozone te komen, of te voorkomen dat deze zone wordt bereikt, kan het makkelijkst worden bezien wat er bij de in dit onderzoek betrokken gemeenten is gebeurd. Welke problemen traden op en welke op herstel of normalisatie gerichte mechanismen zijn waargenomen in de beschreven gemeenten?

Op basis van de autonomie van gemeenten wordt in deze paragraaf beschreven wat er is gebeurd in de onderzochte gemeenten om de situatie te verbeteren en wat dat heeft opgeleverd. Vervolgens wordt gekeken of de bevindingen rond de verschillende factoren nog suggesties opleveren.

\subsubsection{Wat is er gedaan in bestuurlijke probleemgemeenten?}

Geen remedie zonder diagnose. Diagnose is wel het minste wat nodig is. Als gekeken wordt naar de onderzochte bestuurlijke probleemgemeenten, dan blijkt dat in alle probleemgemeenten tussentijds rapporten zijn verschenen over de bestuurlijke problematiek, die een analyse bevatten ('wat is er aan de hand?', 'hoe kon het zo ver komen?','wat te doen?') en als katalysator voor verbetering zouden kunnen functioneren. In Delfzijl verscheen zo'n analyse in 1998 (commissie-Doelman-Pel), een rapport dat vervolgens een bestuurscrisis inluidde. Maar ook in Den Helder (rapport-Tops en Van Spijker, gefinancierd door de provincie Noord-Holland), Leiden (commissie-Van Egdom, onderzoek naar grote projecten) en Zundert (commissie-Ouwerkerk) zijn onderzoeken gedaan naar de bestuurlijke problematiek en aanbevelingen geformuleerd. Hebben ze gewerkt? 
In ieder geval gaven ze in alle gemeenten een schok van herkenning en werden er pogingen ondernomen om aan de hand van de aanbevelingen de situatie te verbeteren. Op korte termijn leverde dat nergens groot succes op. Sterker nog: in Den Helder en Zundert viel uiteindelijk het zittend college alsnog, ook de wethouder in Delfzijl diende na het verschijnen van het rapport te vertrekken. Een rapport werd aangegrepen voor 'afrekening'. Wel droegen de rapporten bij aan een bepaalde 'sense of urgency' in een gemeente, waardoor er na deze crises wèl aan veranderingen kon worden gewerkt. lets dergelijks is ook waargenomen in andere gemeenten die in bestuurlijke problemen kwamen, zoals in Vlissingen.

Ergo, in het algemeen kunnen rapporten van externe commissies over problemen in een bestuurlijke probleemgemeente zin hebben en functioneel zijn. Een dergelijk rapport is dan een voertuig, een opstap om met elkaar binnen een gemeente in gesprek te komen. Het rapport effent wellicht het pad naar bezinning, maar een rapport roept niet als vanzelf een verbeterplan op. Er moet ook rekening gehouden worden met de kans op een paradox: een rapport dient (soms) niet alleen om te begrijpen en opnieuw te beginnen, maar kan ook verergerend werken en een 'Barbertje moet hangen'- proces van afrekening op gang brengen. Echter, aannemende dat een rapport een opstap is om te 'spiegelen' en te verbeteren: naar welke oplossing dan?

\section{Wethouder of wethoudersploeg van buiten}

Veel van wat conflicten kan voorkomen, begraven of neutraliseren lijkt, gezien dit onderzoek, de moeite van het overdenken waard. Eén van de aangetroffen verbeteracties haakt hierop aan: het aanstellen van een college met een wethoudersploeg die geheel uit buitenstaanders bestaat, vaak zelfs uit mensen van buiten de gemeente. In zowel Den Helder als in Delfzijl en Zundert werkte dit concept goed. In kringen van commissarissen van de koningin ( $\left(\mathrm{dK}^{\prime} \mathrm{s}\right)$ erkent men dit, zo zeggen informanten die spraken met CdK's (Korsten en Aardema, 2006).

In Delfzijl en Zundert startten in 2006 colleges die volledig van buiten kwamen, waarbij het Delfzijlster college de rit afmaakte tot 2010. In Zundert kwamen er begin 2008 weer meer 'eigen' wethouders. In Leiden is ook een wethouder van buiten gekomen, in 2007. In deze gemeenten is gebleken dat zo'n college een temperende werking heeft op conflicten. In Delfzijl duurde de periode vier jaar (2006-2010), waarna er weer 'eigen' wethouders werden gekozen. In die vier jaar is de rust bewaard gebleven. De hoofdreden is volgens betrokkenen dat dit college al snel een team werd, zeker ook door het optreden van de waarnemend burgemeester. Dit straalt af op de gemeenteraad, die wel kritisch blijtt, maar toch minder op 'destructie' lijkt te zijn gericht. Een risico zit er ook in: raadsleden met wethoudersambities vanuit de eigen fractie kunnen zich gepasseerd voelen door de buitenstaanders. Vroegtijdige communicatie kan voorkomen dat verwachtingen hierbij te hoog oplopen.

\section{Verbindingen}

Tenslotte is in drie van de vier gemeenten bewust gewerkt aan de verbindingen tussen college en raad en tussen fracties onderling, door het inzetten van speciale trajecten met betrekking tot duale verhoudingen. Alleen in Leiden was geen sprake van extra inzet op dit terrein. Het beste resultaat leverde dit op in Delfzijl, waar vanaf de crisis in 2006 geen problemen meer zijn geweest. 
Het werken aan de hechtheid van de coalitie was een relevante factor in dit onderzoek en daarom lijkt het hieraan sleutelen door geactiveerd of verbeterd coalitieoverleg een zinnige remedie.

Is het maken van rapporten, het aanstellen van wethouders van buiten en verbeterd coalitieoverleg genoeg gebleken? Het heeft wel geholpen. Vooral de colleges van buiten brachten rust en konden, vaak in combinatie met een waarnemend burgemeester, werken aan de zaken die er toe doen in een gemeente: goede verbindingen en verhoudingen tussen alle betrokkenen. Tegelijkertijd blijkt dat zich voor het inzetten van een dergelijke oplossing twee omslagmomenten voordoen: de periode na de bestuurscrisis zelf, dan wel de verkiezingen. In het eerste geval speelt ook een psychologische dimensie mee. Alle betrokkenen in een gemeente moeten een zodanige hekel aan de voortdurende twisten hebben gekregen, dat men als het ware collectief zegt: nu moet het echt anders. Dan is de voedingsbodem voor een college met wethouders van buiten productief. Een CdK kan in zo'n afweging ook een (soms informele) adviesrol vervullen. En niet te vergeten het op gang brengen van coalitieoverleg.

\section{In het algemeen: openingsmomenten benutten}

Opvallend is dat uit de cases niet blijkt dat bestuurlijke probleemgemeenten een groot vermogen hebben in het organiseren van bevordering van patroonmatigheid in het 'politieke verkeer', ondanks dat aan dualisering is gewerkt. Het bleek niet dat er regelmatig na de verkiezingen een door alle politieke partijen aangestelde informateur aan de slag mag gaan, die ordentelijkheid brengt in het overleg over wie met wie een coalitie gaat vormen en hoe een collegeprogramma er uit kan zien. Politici en bestuurders uit bestuurlijke probleemgemeenten zijn blijkbaar - ondanks dat ze besluiten tot het starten van een onderzoek naar 'hoe het zover heeft kunnen komen' - niet goed in staat om 'het andere te denken', om zich los te maken van gegroeide praktijken en om juist vanwege de dreigende conflictgraad uit het verleden naar verbetering te zoeken die temperend werkt. Terwijl toch al in de jaren negentig informateurs voorkwamen in gemeenten als Heerlen en 's-Hertogenbosch, die veel politieke fracties kenden en waarbij coalitievorming niet eenvoudig was (Korsten, 1998). Hier is tegenin te brengen dat niet aangetoond is dat de conflicten en crises die in probleemgemeenten optreden hun primaire oorzaak hebben in de coalitievorming. Maar de repliek kan dan toch zijn, dat de periode direct na gemeenteraadsverkiezingen wel een goed moment is en een opening, een 'policy window' biedt om vragen te stellen die later niet aan bod komen, zoals of de opstelling van een profielschets van wethouders mogelijk en nodig is, en of wethouders van buiten aangetrokken moeten of kunnen worden.

\section{Drukregulering}

Wat eveneens niet erg aanwezig is in probleemgemeenten, is de inzet van middelen om de druk van de politiek-bestuurlijke ketel te halen of druk niet te laten ontstaan. In kringen van burgemeesters wordt bijvoorbeeld wel gezegd: biedt tijdens elke vergadering van het raadspresidium de mogelijkheid om terug te kijken op de laatste raadsvergadering. Daardoor is er een kans voor presidiumleden, vaak zijn dat ook fractieleiders, om het 'ventiel open te zetten' en lucht uit de band te laten ontsnappen. Anders gesteld, zo haal je druk van de ketel. Bestuurlijke probleemgemeenten lijken niet alle 
kansen te benutten om druk van de ketel te halen. Dat laat zich hieruit verklaren dat de meeste bestuurlijke actoren ook een rol of meerdere rollen vervullen, geen overzicht over en inzicht hebben in alle belangrijkste processen en geen professionele waarnemers zijn van crisis(achtige) processen. Hier is tegenin te brengen: de echte conflicten en crises bouwen zich op en dan helpen eenmalige kleine suggesties als een ventiel organiseren niet genoeg. Dit levert desalniettemin de suggestie op: haal waar dat kan (politieke druk) druk van de ketel. Opnieuw geldt hier in aansluiting op dit onderzoek: benut conflicttemperingsmogelijkheden en vermijdt aanjagende processen.

\subsubsection{Suggesties en aanbevelingen op basis van het patroon van factoren}

In dit onderzoek is gebleken dat vooral de microfactoren rond de burgemeester en de wethouder(s) en de verbinding tussen de coalitiepartijen (hechtheid van de coalitie) kunnen leiden naar het ontstaan van bestuurlijke conflicten en bestuurscrises. Als dit de belangrijkste factoren zijn, zou een poging tot verbetering van de situatie ook bij deze factoren het meest aan moeten slaan.

\section{Burgemeester}

Bij de eerste factor, de burgemeester, kan een aantal zaken aangeduid worden als belangrijk om problemen te voorkomen. Zo is in de praktijk van bestuurlijke probleemgemeenten gebleken dat het soms mis gaat wegens een mismatch tussen de gemeente en de persoon van de burgemeester (zie o.a. Van Maaren-van Balen, 2003; Warbroek, 2007). Op grond hiervan is te onderbouwen dat gemeenteraden goed dienen na te denken over de profielschets en de vraag welke burgemeester hun gemeente nodig heeft. Daarbij moeten zij rekening houden met wat eerder werd aangeduid als de psychologisering van het ambt van burgemeester (Korsten en Aardema, 2006; Korsten, 2010c). Een burgemeester staat tegenwoordig zo in het blikpunt van aandacht en verschijnt vaak in kritische fora en in persmedia, dat in feite zijn totale persoon als op een röntgenfoto zichtbaar wordt. Gezag wordt niet vanzelfsprekend met ontzag tegemoet getreden. Er wordt meer en meer gelet op hoe een bestuurder in elkaar steekt, op (on)waarachtigheid, op beloften die niet gestand worden gedaan, op (on)handigheden of versprekingen, op een briljante of verkeerde toonzetting, op het vermogen om fouten te erkennen en recht te zetten. Bestuurders moeten daar rekening mee houden en zich zo nodig aanpassen of hulp inroepen.

De selectie gebeurt tegenwoordig in gemeenten ook steeds serieuzer, met training en ondersteuning en dat is nodig. Met name dienen raden kritisch en eerlijk stil te staan bij de vraag wat voor type burgemeester er bij de cultuur in hun gemeente past. Natuurlijk dient deze altijd verbindende kwaliteiten te hebben en, zoals uit dit onderzoek weer blijkt, over reflexieve vermogens te beschikken (Korsten, 2009 en 2010). Profielschetsen waarin aan de nieuwe man of vrouw geen verbindende kwaliteit wordt gevraagd, zijn zeldzaam: verbinden is een soort minimumpositie voor burgemeesters. Tegelijkertijd is puur vriendelijk verbinden niet in alle gemeenten voldoende om er te slagen. Soms zijn er ook andere kernkwaliteiten nodig. De casestudy in Zundert maakt dat duidelijk: burgemeester Vos was niet de persoon om de soms sterk negatieve bestuurscultuur in het Brabantse kerkdorp het hoofd te bieden. Hij werd als burge- 
meester door allerlei acteurs gewaardeerd, maar hij werd zelf ziek van de bestuurscultuur en het opereren van de soms wispelturige raad.

Van burgemeesters wordt ook enige mate van signalerend vermogen verwacht, en het vermogen om na die signaleringen ook zichzelf te corrigeren of anderszins aan te passen. Hierbij hoort de aantekening dat ook profielschetsen een houdbaarheidsdatum hebben. Als de tijd verstrijkt, kan het zijn dat de politiek-bestuurlijke situatie in een gemeente vraagt om een andere aanpak. Een sensitieve burgemeester dient dat te signaleren en ernaar te handelen. Net als bij de wethouders is een vorm van intervisie hierbij nuttig. Al is het geen reddingsvest (Korsten en Aardema, 2006), het helpt soms als relatieve buitenstaanders, met een onbevangen blik, advies geven en zelfs confronterend optreden naar acteurs die werkelijkheid en beeldvorming niet willen zien.

\section{Wethouders}

Wat hier voor burgemeesters is opgemerkt, zoals de psychologisering van het functioneren, geldt in belangrijke mate ook voor wethouders, want dat zijn ook dagelijks bestuurders. Uit de praktijk in de vier probleemgemeenten valt af te leiden dat in sommige gevallen wethouders niet (helemaal) op hun taak berekend waren en eenzijdigheden kenden. Bezinning lijkt dus geen overbodigheid. Welke opties dienen zich dan aan? Politieke partijen zouden voor wethouders een profielschets kunnen opstellen. Dat blijkt incidenteel al wel voor te komen (Korsten en Schoenmaker, 2008).

Politieke partijen zouden bovendien veel langer van tevoren duidelijk moeten maken wie hun wethouderskandidaat is. Ook de wethoudersvereniging pleit hiervoor: "Nu gebeurt het nog te vaak dat iemand op het laatste moment wethouder wordt en dus in het diepe wordt gegooid. Als je lang van tevoren duidelijk maakt wie wethouderskandidaat is, voorkom je dat je in een 'God-zegene-de-greep'-situatie terecht komt. Zo'n kandidaat kan zich dan ook voorbereiden op het wethouderschap", aldus oud-voorzitter P. Depla (Bouwmans, 230109). Informateurs en coalitiepartijen zouden ook moeten nastreven, dat de leden van een bestuurscollege daadwerkelijk een team kunnen vormen.

Zou scholing gericht op professionalisering een oplossing kunnen bieden? (vergelijk Hartman en Tops, 1994). Het probleem is dat de selectie van wethouderskandidaten in het algemeen een lastige zaak is. Er is immers geen school voor wethouders, waarvan een einddiploma een garantie op succes geeft. Vaak blijkt pas in de praktijk of iemand een goede wethouder is, de portefeuille beheerst, de politieke kant van de zaak in de vingers heeft (zicht heeft op verhoudingen en gevoeligheden) en over voldoende signalerend, reflexief en adaptief vermogen beschikt.

Vooral is van belang dat een wethouder de beeldvorming over zichzelf kent. Wethouders moeten leren naar zichzelf te kijken, zij het niet in een autistische reflex, maar om eigen kwaliteiten, beperkingen en onhebbelijkheden te zien en die zo nodig te corrigeren of er verstandig mee om te gaan, bijvoorbeeld door zich - als dat nodig is- met ambtelijke steun beter te prepareren op een raadsdebat. Dat is niet eenvoudig, want retorisch talent is niet eenvoudig te 'bouwen'.

Wethouders kunnen evenals burgemeesters aan intervisie doen of (tijdelijk) een coach nemen. De betekenis van de negatieve effecten van het eventueel bekend worden 
daarvan moet overigens worden ingeschat, zeker in het licht van de wetenschap dat 'al het persoonlijke politiek is'. Een gemeentebestuurder die publiekelijk laat weten het ook niet allemaal te weten, staat al snel als niet sterk te boek.

Het ontlopen van bezinning is zinloos. Wethouders en burgemeesters worden geacht vanaf dag één hun werk goed te doen. Ruimte voor vragen of twijfel is er eigenlijk niet. Toch is het niet vreemd dat wethouders of burgemeesters met vragen rondlopen. Zowel de wethoudersvereniging als het Nederlands Genootschap van Burgemeesters (NGB) proberen hierin te voorzien, door intervisie te organiseren: mogelijkheden om met collega's in gelijke omstandigheden te praten over de dilemma's, die voorkomen in het vak. Het is zeker aan te raden hier gebruik van te maken. Tegelijkertijd dient zich vaak dichterbij hulp aan. In normale omstandigheden kunnen ook de secretaris of de griffier goede diensten bewijzen, door mee te denken en meer persoonlijke adviezen te geven (bijvoorbeeld casus Leiden).

\section{Hechtheid van de coalitie}

In de praktijk van bestuurlijke probleemgemeenten is duidelijk geworden dat de hechtheid van de coalitiepartijen de derde veel voorkomende factor is in de verklaring van bestuurlijke conflicten en bestuurscrises in bestuurlijke probleemgemeenten. Een niet hechte coalitie valt sneller uit elkaar en dan is een bestuurscrisis vlug een feit. De vraag is hoe een hechte coalitie kan ontstaan. In het boek 'Sterke colleges' doen Korsten en Schoenmaker (2008) hier aanbevelingen voor. Zo moeten er niet teveel partijen in een college zitten, anders voelt niemand zich meer verantwoordelijk voor de coalitie.

Daarnaast zijn er andere manieren om een hecht geheel te smeden. Uit de casestudies blijkt dat het helpt als de lijsttrekkers (die later vaak wethouder of fractievoorzitter worden) elkaar al tijdens de verkiezingen eens opzoeken, om een beetje aan elkaar te wennen. Tijdens de formatie, eigenlijk tijdens de hele raadsperiode, kan hier voordeel vit gehaald worden. Overigens gaat het hier om een 'aanbeveling' in 'ideale' omstandigheden. Uiteraard komt het vaak voor dat de lokale bestuurders elkaar al lang kennen en de sympathieën en antipathieën volop bekend zijn. Om politieke stabiliteit te bereiken is het ook dan nodig om te investeren in de onderlinge relatie.

Tegelijkertijd is een waarschuwing op zijn plaats in gevallen waarin de coalitiepartijen, vaak na een bestuurlijk conflict of bestuurscrisis, erg naar elkaar toe kruipen. Hierdoor kan het gebeuren dat iedere inbreng van de oppositie, hoe interessant ook, per definitie wordt weggestemd. Vaak ontstaat hier een 'wij-zij' relatie uit, die op termijn ongezond is voor een goed functionerende lokale democratie. Een goede coalitie verdient een goede oppositie.

Het aangeven van de betekenis van coalitiehechtheid impliceert geen pleidooi om terug te keren naar de voordualistische periode. De zegeningen van goede onderlinge communicatie en elkaar verstaan, ook - indien nodig- tussen wethouders en fractie, moeten, uitgaande van de ervaringen in de bestuurlijke probleemgemeenten, echter niet onderschat worden. 


\section{Nieuwe coalitie}

Het vormen van een nieuwe coalitie (en dus een nieuw college) kan, zo blijkt uit de casestudies, een bron van onrust vormen als het niet goed gaat. Grofweg kan het misgaan op twee manieren: in de manier waarop het college wordt samengesteld en in de samenstelling van het college zelf.

Om met het eerste te beginnen: de manier waarop een college wordt gevormd, luistert nauw. Zo kan het niet goed betrekken van alle partijen bij de vorming van een coalitie gedurende de hele volgende periode onrust geven. Een voorbeeld is de gemeente Delfzijl, waar de PvdA-fractie buiten de coalitie werd gehouden in 2002 en daar heel lang boos over is geweest. Nu is niet te vermijden dat er teleurstellingen zijn, maar het kan wel helpen het proces van coalitievorming duidelijk te maken. Dit zou al voor de verkiezingen kunnen beginnen, door afspraken tussen de lijsttrekkers van de partijen te maken over het proces na de verkiezingsavond. Hoe transparant wordt dat? Neemt de grootste partij de leiding? Speelt de burgemeester een rol? Wanneer dient er een coalitie te zijn? Komt er een informateur? Het kan erg helpen als in de relatieve rust van voor de verkiezingen dit soort afspraken wordt gemaakt en bezegeld.

De tweede mogelijke bron van onrust is de samenstelling van het college zelf. Wethouders en burgemeester dienen als team te functioneren en dan helpt het als de 'samenstelling' van het team klopt. In voetbaltermen: niet alleen maar spitsen, ook een stugge verdediger erbij. Dit lijkt een open deur, maar de vorming van een college en vooral de personele samenstelling is buitengewoon ondoorzichtig, zelfs voor mensen die redelijk dicht op het proces zitten. Dit komt door twee zaken (zie: Korsten en Schoenmaker, 2008). Op de eerste plaats is het op lokaal niveau zeer ongebruikelijk om als potentiële wethouderskandidaat te bevestigen dat je potentiële wethouderskandidaat bent. Sterker nog: de persoon die aangeeft wethouder te willen zijn, wordt dat meestal niet. Om (soms onnodige) onrust binnen een partij te voorkomen, helpt het (het is eerder aangegeven) als er binnen een politieke partij snel duidelijkheid komt over de vraag welke persoon een partij naar voren zal schuiven voor een plek op het wethouders-pluche.

Op de tweede plaats geldt het fenomeen dat, als een partij eenmaal bekend heeft gemaakt wie de kandidaat is, er nauwelijks wordt gelet op de kandidaten van de andere coalitiepartijen. Dit is misschien in sommige situaties ook wel veel gevraagd, maar het betekent dat het toeval is als de verzameling individuen ook een goed team vormt. Dat hoeft niet, als partijen eerder beginnen en zonder personen te beschadigen kijken welke bestuurlijke stijlen er in het college vertegenwoordigd zijn of zullen zijn, en hoe die bij elkaar passen. In de praktijk is er tot nu toe echter nauwelijks ruimte om elkaars kandidaten te 'wegen' en te bespreken.

\subsubsection{Doen alle factoren er toe?}

Buiten de drie krachtige factoren, zijn ook zes andere factoren van betekenis gebleken. Zijn deze factoren belangrijk als het gaat om verbeteringen vanuit een autonomieperspectief, waarin zelfreiniging centraal staat? Zeker. De bestuurscultuur is hier een belangrijk voorbeeld van. Op de man spelen, cliëntelisme bedrijven, afscheidingen met veel persoonlijk geruzie, het zijn zaken die de sfeer in de raad enorm beïnvloeden. Hier valt aan te werken, maar het is een proces van jaren en vaak door personen beïnvloed. 
Desalniettemin een belangrijke suggestie: probeer er iets aan te doen. Dit kan op verschillende manieren, zowel formeel als informeel. Een informele manier is het regelmatig organiseren van raadsuitstapjes, om de leden van de raad aan elkaar te laten wennen. Het kan ook wat formeler, door gezamenlijke cultuurtrajecten te doorlopen, waar diverse adviesbureaus bij kunnen assisteren. Maar hierbij past de kanttekening dat er gemeenten zijn waar zelfs het organiseren van uitstapjes tot de onmogelijkheden behoort. Voor cultuurtrajecten geldt in het algemeen dat lang niet zeker is dat ze volgehouden worden, terwijl uit de literatuur bekend is dat ze juist eerst bij langdurigheid zoden aan de dijk kunnen zetten. Daarom wordt ook wel voorgesteld om al werkende weg werkwijzen te verbeteren en niet langer gewenste gewoonten te doorbreken. Daarop sluit aan dat de burgemeester in de dagelijkse praktijk de 'normen en waarden' in de raadzaal bewaakt. Lelijke woorden, op de man spelen of onheuse bejegening van collega-raadsleden kan en moet worden aangepakt. De voorbeeldfunctie van gemeentebestuurders dient geaccentueerd te worden.

\section{Wat niet?}

Weten we nu ook welke remedies van duidelijk minder betekenis zijn om een bestuurlijke probleemgemeente vanuit een zelfreinigingsperspectief te 'normaliseren'? Ja, er zijn secundair belangrijke factoren die men kan willen temperen, maar die niet erg cruciaal leken te zijn voor de voortdurende val van wethoudersploeg of individuele bestuurders. Een voorbeeld. In het algemeen is het wel van belang om een goede gemeentesecretaris aan te stellen, maar in geen van de vier onderzochte gemeenten was de kwaliteit van de gemeentesecretaris de primaire bron van alle bestuurlijke ellende. Wel is gebleken dat als er meerdere malen bestuurders onder vuur komen te liggen of een hele wethoudersploeg verdwijnt, eerder of later ook een gemeentesecretaris onder vuur komt te liggen en vervangen wordt. Zie o.a. Delfzijl. Er ligt dus in sommige gemeenten wel degelijk een relatie tussen de secretaris of de ambtelijke organisatie en eventuele bestuurlijke problematiek, maar het is geen oorzakelijke factor gebleken. Kortom: het is in het algemeen nuttig om de kwaliteit van de ambtelijke organisatie in het oog te houden of te verbeteren, maar dat voorkomt niet dat er bestuurlijke problematiek kan ontstaan.

\subsection{Het perspectief van de systeemverantwoordelijke overheid}

In de vorige paragraaf stond het perspectief voorop dat gemeentebesturen zelf verantwoordelijk zijn voor hun kwaliteit en over zelfreinigend vermogen moeten beschikken. De praktijk van probleemgemeenten is geweest dat de rijksoverheid betrekkelijk op afstand is gebleven (nergens is een regeringscommissaris geplaatst) maar er heeft wel overleg plaatsgevonden tussen de CdK en de minister van BZK over enkele probleemgemeenten. Minister Remkes heeft in zijn ambtsperiode een bestuurlijke probleemgemeente opgezocht. Deze opstelling van terughoudendheid, is die vanuit de wijsheid van de casestudies en het perspectief op de toekomst gericht, vol te houden?

Een hint is direct te geven. Gebleken is namelijk dat het zelfreinigend vermogen van probleemgemeenten niet vanzelf op gang komt, vaak (te) laat plaatsvindt en niet voldoende adequaat is. Het perspectief om alle kaarten te zetten op de autonome 
(probleem)gemeente die zelf wel tot zelfreiniging komt, heeft naast voordelen (verbeteren moet ook gewild worden en verinnerlijken) ook beperkingen. De langjarige worsteling in Den Helder, Delfzijl en Zundert is illustratief. CdK's kunnen dus niet lijdzaam toezien en deden dit ook niet, maar waren ook niet sterk pro-actief. Ze hebben onderzoek bevordert en het komen tot verbeteracties (bijvoorbeeld Delfzijl en Den Helder). Hier en daar is een CdK in gesprek gegaan met fracties (Zundert, Delfzijl), bijvoorbeeld om het pad te effenen naar normalisatie en te bevorderen dat een nieuwe burgemeester een kans krijgt zich te ontplooien. Recent tonen enkele CdK's zich vroeger actief, onder meer in het bevorderen van onderzoek (bijvoorbeeld in Steenbergen en Maasdriel). Ze laten de gang van zaken al wat minder dan pakweg vóór 2005 op hun beloop en gaan (nog) eerder in gesprek.

Het is nu tijd voor verbreding van de reflectie. Expliciet kan de aandacht worden gericht op de systeemverantwoordelijke hogere overheid, met als startpunt een beschouwing van Korsten (2011). Welke middelen heeft de hogere overheid richting een probleemgemeente en welke betekenis hadden of hebben die? En is het denkbaar om vanuit de caseanalyse nog additionele suggesties te doen?

\section{Toezicht en bijstand}

De Minister van Binnenlandse Zaken en Gedeputeerde Staten van de provincie, in het bijzonder de CdK - die ook nog een eigenstandige (rijks)ambtrol vervult -, hebben een rol bij het oplossen van (bestuurlijke) problemen in gemeenten. Beide 'hogere' overheden houden toezicht en beschikken over mogelijkheden in te grijpen in situaties waarin het 'verkeerd' gaat of dreigt te gaan (Broeksteeg, 2009). Naar aanleiding van concrete situaties, vooral de problematiek in Delfzijl, onderzocht Fred Fleurke in opdracht van het ministerie van BZK welke mogelijkheden tot eventueel ingrijpen het Rijk ter beschikking staan en of er nog zaken aan dit repertoire toegevoegd zouden moeten worden.

Fleurke wijst op het feit dat hogere bestuurslichamen de plicht hebben het lokaal bestuur bij te staan, de zogenaamde organische bijstandsplicht (Fleurke, 2008: 16), die uit twee vormen bestaat: ondersteuning en overdracht. Bij ondersteuning moet gedacht worden aan extra financiële hulp, een wetswijziging, grenswijziging of bestuurlijke hulp. Bij overdracht gaat het om tijdelijke regionalisatie of centralisatie van taken, of zelfs van 'in plaats treding', waarbij de hogere overheid taken naar zich toe trekt. Op de eerste plaats heeft de wet de hogere overheid in dit kader de bevoegdheid gegeven om een besluit van een gemeente te schorsen en te vernietigen, als deze in strijd is met het recht of het algemeen belang, in casu in strijd is met het belang van het Rijk respectievelijk het provinciebestuur. Dit instrument werd in de periode 1993-2005 in totaal 27 keer toegepast. "Dit instrument is echter bedoeld om 'verkeerde besluiten' af te weren en niet om taakontwijking of taakverwaarlozing op een positieve wijze te beïnvloeden. Dit neemt niet weg dat het weren van een besluit soms een gunstig effect kan hebben op gemeenten in crisissituaties", aldus Fleurke (2008: 25).

De tweede vorm van generiek toezicht is de regeling voor taakverwaarlozing ex artikel 132 Grondwet. Deze regeling is bedoeld om een gemeente, die niet op eigen kracht, noch via het verlenen van bijstand van buitenaf, in staat is het bestuur en regeling van 
haar huishouden op orde te krijgen tot een andere gedragslijn te bewegen (Fleurke, 2008: 25). In de bestuurlijke historie is het vijf keer voorgekomen dat deze regeling is ingezet, te weten in Opsterland en Weststellingwerf (1895, weigering aanpassing van de gemeentelijke begroting), Beerta (1933, de meerderheid van de raad werd onbekwaam geacht de belangen van de gemeente naar behoren te behartigen), opnieuw Opsterland (1946, onvoldoende blijk geven van erkenning voor de geldende gezagsverhoudingen) en de laatste keer in 1951 in Finsterwolde, toen het ging om angst voor bestuurlijke ongehoorzaamheid, ondermijning van het algemeen belang en handelen in strijd met de wet (Fleurke, 2008: 25).

\section{Rijkscommissaris?}

In de praktijk van de vier voor dit onderzoek onderzochte gemeenten leidde alleen in Delfzijl de bestuurlijke problematiek (en de publiciteit daarover) tot een interventie van de minister: toenmalig minister Remkes bezocht de gemeenteraad, adviseerde tot wethouders van buiten en stelde ook ambtelijke capaciteit beschikbaar om aan verbetering te werken. "Men maakte er echt een bende van", verklaart Remkes zijn betrokkenheid achteraf. "Ik heb toen ook zeer serieus overwogen om een ingreep te doen en een soort Rijkscommissaris aan te stellen. In nauw overleg met de toenmalige CdK Alders hebben we besloten een zware waarnemer aan te stellen en dat eerst maar eens te proberen. We vonden het uit oogpunt van geloofwaardigheid van de lokale democratie niet meer geloofwaardig wat daar gebeurde. In dat kader heb ik later ook besloten om er heen te gaan." Remkes koos er niet voor het taakverwaarlozingsartikel van stal te halen. Broeksteeg, die de mogelijkheden tot ingrijpen analyseerde, heeft daar begrip voor: "De Grondwet laat voorzieningen slechts toe in geval van grove taakverwaarlozing. Daarvan is in Delfzijl-achtige situaties geen sprake" (Broeksteeg, 2009: 156). Toch wordt wel geopperd dat er gezocht moet worden naar mogelijkheden om 'steviger ingrijpen van hogerhand' mogelijk te maken, zonder ogenblikkelijk in grove taakverwaarlozing te vervallen. Gesproken wordt dan over een bestuurlijke variant van de artikel 12-regeling, voor gemeenten die in financiële problemen zitten. Bij deze financiële artikel 12-regeling wordt verwezen naar artikel 12 van de Financiële Verhoudings Wet (FVW), op grond waarvan gemeenten extra financiën krijgen, maar onder 'financiële curatele' staan (Broeksteeg, 2009: 147). De vraag is of het nodig is ook bestuurlijke probleemgemeenten onder een dergelijk regime van toezicht te plaatsen, maar dan onder 'bestuurlijke curatele'. Broeksteeg (2009) deed een poging te beschrijven hoe een dergelijke regeling er uit zou moeten zien, waarbij hij uitging van een regeling voor lichte verwaarlozing van autonome taken, daar er voor medebewindstaken en grove verwaarlozing al regelingen bestaan. Uit de analyse van Broeksteeg blijkt echter dat een dergelijke regeling vele vragen oproept. Hoe is vast te stellen dat een gemeente structurele bestuurlijke problemen kent? Wie constateert dat dan? Bovendien: een gemeente is autonoom. Een bestuurlijke artikel-12 regeling grijpt hier diepgaand op in. Broeksteeg gelooft niet in dergelijke regelingen en vertrouwt op de bestaande mogelijkheden.

Hij sluit hierbij in feite aan bij Fleurke (2008), die pleit voor de eerder omschreven organische bijstand: Rijk en provincie staan gemeenten met structurele bestuurlijke problematiek bij, soms gelijktijdig, door het ter beschikking stellen van denkkracht en personeel. De casus Delfzijl laat zien dat dergelijke hulp zeer effectief kan zijn. 
De casus Den Helder laat niet zien dat de rijksoverheid hier te hulp wilde schieten. Dat voert opnieuw naar de rol van de CdK als intermediair tussen minister en gemeentebestuur.

\section{$C d K$}

Het is nuttig apart stil te staan bij de rol van de CdK. Deze rol is op twee manieren op te vatten. Op de eerste plaats is er een grote informele betrokkenheid van CdK's bij gemeentebesturen, specifiek bij burgemeesters. CdK's leggen immers traditioneel werkbezoeken af en spreken elk gemeentebestuur met regelmaat. Een CdK kan proactief zijn naar gemeenten, maar ook een belangrijke rol spelen op de achtergrond. Gemeentebestuurders kunnen op hun beurt bij de CdK te rade gaan als er problemen zijn. Met burgemeesters hebben de meeste CdK's periodieke gesprekken, maar ook in tijden van crisis kan een CdK potentieel een vraagbaak en mogelijke facilitator zijn. Zo kwam de (mislukte) mediation tussen het college van B\&W en burgemeester Hulman van Den Helder (2009) op initiatief van de toenmalige CdK Borghouts tot stand. Ook de eindoplossing, waarbij het gemeentebestuur de woning van Hulman zou kopen teneinde een spoedig einde aan de zaak te bewerkstelligen, ontstond na suggestie van Borghouts. Toenmalig CdK Nijpels in Friesland was nauw betrokken bij de problemen, die de viteindelijk vertrokken burgemeester van Leeuwarden, L. van Maaren-van Balen, ondervond. Hij adviseerde haar regelmatig. In 'Hoezo burgemeester?' schrijft Van Maaren-van Balen over zijn reactie op een omstreden interview dat ze gaf: "Loek, doorgaan. Geen reactie meer. Laat zitten, wel of geen coaching. Ga niet meer in discussie. Met niemand. Het is nu over en uit. ledereen heeft je interview van 1 januari kunnen horen. De Partij van de Arbeid moet nu eens ophouden en je maar nemen zoals je bent. Ze hebben je gewild en moeten je die zes jaar gunnen. Ik zal ze dat nog eens zeggen" (Van Maaren-van Balen, 2003: 215). Later meldde de burgemeester zich ook bij de minister.

Overigens wordt de betrokkenheid van de CdK lang niet altijd positief gewaardeerd. Oud-burgemeester Staatsen van Den Helder was zeer ontevreden over de manier waarop het rapport van Tops en Van Spijker naar buiten was gebracht door het provinciebestuur, in casu de CdK (Moerkamp, 270106). In Delfzijl riep het optreden van Alders tijdens een vergadering over de ontstane situatie irritatie op: "Het is een genante vertoning. Als er een moment is waarop ik spijt ervaar dat ik aan deze missie ben begonnen, dan is het dit" (Westerink, 2006: 69).

\section{Waarnemers}

Als het, ondanks de al of niet positief beoordeelde inmenging van de CdK, toch mis gaat in bestuurlijke probleemgemeenten en ook de burgemeester is vertrokken, heeft de CdK nog een krachtige mogelijkheid: de inzet van een waarnemend burgemeester. In alle vier onderzochte gemeenten is op enig moment een waarnemend burgemeester aangesteld. In Den Helder (in het geval van waarnemend burgemeester Faber), Delfzijl en Zundert was dat bewust voor een langere periode. De waarnemers kwamen hier aan het roer na een bestuurscrisis, waarna de CdK's bewust langere tijd hebben gewacht met het open stellen van de burgemeestersvacature. In Leiden bleef waarnemend 
burgemeester Lemstra korter, maar daar was (na het vertrek van burgemeester Postma) ook geen bestuurscrisis aan de orde geweest.

Het inzetten van de waarnemers bleek in alle gevallen een heilzaam effect te sorteren. De waarnemend burgemeesters slaagden erin enige rust te bewaren en de verbindingen tussen de raad en het college te normaliseren. "Een waarnemer is verlost van eigen belangen en kan alle tijd en zorg aan de zaken zelf geven", zegt de ervaren waarnemer les Keijzer. Als belangrijk punt noemt deze het optreden naar buiten, waar in crisissituaties vaak weinig tijd voor is: "De gemeenschap verwacht van bestuurders aandacht en belangstelling. Juist in situaties waarin spanningsvelden overheersen, is daar veel behoefte aan. Bovendien kun je je als waarnemer buiten die spanningen plaatsen en zo kom je ook van raadsleden alles te weten." Waarnemend burgemeesters stellen zich in de praktijk vaak op als boven de partijen staande burgervader of burgermoeder, een rol waar behoefte aan blijkt te bestaan.

Belangrijk bij waarnemers is, met andere woorden, dat zij de 'negatieve spiraal', die in bestuurlijke probleemgemeenten optreedt, proberen te doorbreken. Dat doen zij vooral door ordentelijkheid in de verhoudingen en benaderingswijze te propageren. Waarnemend burgemeester Faber trad in Den Helder hard op in de gemeenteraad als er teveel op de man werd gespeeld. Ook werd gepoogd het lekken naar de pers van vertrouwelijke gemeentelijke stukken aan banden te leggen.

Het nut van op normalisatie gerichte waarnemers is ook gebleken in andere gemeenten dan de hier genoemde probleemgemeenten, zoals gemeenten waar een burgemeester onder druk vertrok, of een heel college plaats maakte (bijvoorbeeld in Vlissingen).

\section{Het ambt: meer mogelijkheden voor de CdK?}

Moeten CdK's over ruimere bevoegdheden beschikken in relatie tot een bestuurlijke probleemgemeente? In kringen van CdK's heeft enkele jaren terug een bezinning plaatsgevonden op de toekomst van hun ambt. De minister van BZK had de Raad voor het openbaar bestuur (Rob) om een advies hierover gevraagd. Zowel het advies als de bezinning hebben er niet toe geleid dat de mogelijkheden voor de CdK's om zich in te laten met bestuurlijke probleemgemeenten zijn gewijzigd. De CdK's hebben zich hierop in een speciale vergadering wel bezonnen, maar zijn niet met voorstellen richting minister gekomen. Daarvoor bestonden diverse argumenten. Het eerste argument was dat gemeentebesturen autonoom zijn in het besturen van hun gemeente en over zelfreinigend vermogen moeten beschikken. Ze moeten de problemen die ze veroorzaken ook zelf oplossen. Dit argument zou ook gelden voor een bestuurlijke probleemprovincie, omdat ook die autonoom is.

Het tweede argument behelsde, dat de ene bestuurlijke probleemgemeente de andere niet is. Elke CdK zal altijd te maken hebben met bepaalde bestuurders en met omstandigheden van tijd en plaats.

Een derde argument was dat CdK's een zekere speelruimte hebben in hun contacten met gemeentebesturen. Laat die speelruimte bestaan en ga die niet inengen, zo vonden enkele $\mathrm{CdK}^{\prime}$ 's, aldus informant Arno Korsten die deze vergadering als externe voorzitter leidde en als lid van de Rob betrokken was bij het eerder verschenen Rob-advies. Aan een speciale wettelijke bepaling om een recht op onderzoek te krijgen hadden de CdK's toen geen behoefte. 
Inmiddels is die behoefte er wel. Een diagnostisch onderzoek is zowel vit een oogpunt van zelfreiniging gewenst als een middel voor CdK en minister om zo nodig in gesprek te komen met bestuurlijke probleemgemeenten. Dit kunnen gemeenten zijn waarin de problematiek zo manifest is dat er daadwerkelijk gemeentebestuurders gedwongen moeten vertrekken, maar dit kunnen ook meer 'latente' probleemgemeenten zijn (zie De Cloe en Korsten, 2011). Dit zijn gemeenten waar het al langere tijd 'rommelt', maar waar (nog) geen bestuurlijke problemen zijn ontstaan. Het kunnen ook gemeenten zijn die al wel manifeste problemen lieten zien, maar waar het nu wat rustiger is. CdK's bevorderen anno 2011 dan ook actief dergelijk onderzoek, bijvoorbeeld in Steenbergen en in Maasdriel.

CdK J. Remkes van Noord-Holland vindt desgevraagd (begin 2011) wel dat er duidelijker vastgelegd kan worden dat een CdK ook mág handelen als de situatie in een gemeente daarom vraagt. Niet in een wettelijke regeling, maar in de ambtsinstructie van een CdK. "In zijn rol als Rijksorgaan heeft de CdK een grote verantwoordelijkheid. In de ambtsinstructie moet wat mij betreft komen te staan dat de CdK een rol dient te spelen in het kader van het bewaken van de integriteit en kwaliteit van het openbaar bestuur in zijn provincie. Hij zou hier op verzoek van of in samenspraak met de minister invulling aan kunnen geven." Burgemeesters dienen in ieder geval bij problemen snel de CdK te informeren, vindt Remkes: "Je moet nog wel kunnen acteren, nog wel iets kunnen doen. Het is belangrijk vroegtijdig aan de bel te trekken."

CdK C.G.A. Cornielje van Gelderland geeft desgevraagd (juni 2011) aan het noodzakelijk te vinden dat er meer mogelijkheden komen voor een CdK of de minister om te handelen: "In Maasdriel heb ik een waarnemend burgemeester benoemd en aangegeven dat als er geen verbetering zou komen bij de gemeenteraad er, in samenspraak met de minister, bevoegdheden van de raad zouden over gaan naar de waarnemer, die dan een regeringscommissaris zou zijn. Het is nog niet nodig gebleken, maar we zitten er bovenop." De regeringscommissaris (Rijkscommissaris) vloeit voort vit artikel 132 lid 5 van de Grondwet, waarin gesproken wordt over 'grove taakverwaarlozing'. Het is de vraag, zoals aangegeven door Broeksteeg (Broeksteeg, 2009) of er in dergelijke gemeenten zonder meer sprake is van grove taakverwaarlozing. In dat verband verdient het aanbeveling dat het Ministerie van BZK de regeling voor de inzet van een regerings- of Rijkscommissaris nader gaat omschrijven. Niet op de laatste plaats omdat Cornielje voorspelt in elk geval dat er op termijn meer bestuurlijke probleemgemeenten gaan ontstaan en denkt dat de mogelijkheid van een regeringscommissaris steeds vaker een serieuze optie gaat of zou moeten worden. "Alleen al de mogelijkheid zou kunnen helpen om gemeenten tot betere bestuurlijke prestaties aan te zetten."

Valt verder te denken aan wetswijzigingen? Drie voorstellen passeren de revue: het tegengaan van afsplitsingen van raadsfracties, wijziging van de zittingsduur van bestuurders en het mogelijk maken van raadsontbinding.

\section{Wettelijke vernieuwing: tegengaan van afsplitsing}

Vanuit de praktijk van dit onderzoek kan ten aanzien van de bestuursstructuur de suggestie worden gedaan nog eens na te denken over het fenomeen van de 'afscheidingen van raadsleden', die versplintering in de hand werken. Het gaat dan om 
raadsleden die voor partij $A$ in de gemeenteraad zijn gekozen, maar na een interne ruzie zich aansluiten bij partij $B$ of zelf beginnen met partij $C$. Dit leidt niet zelden tot een bron van irritatie binnen de 'verlaten' fractie en mogelijk de gehele raad. Gezocht kan worden naar een mogelijkheid dit wettelijk onmogelijk te maken, in alle gevallen dat de betreffende raadsleden de kiesdeler niet op eigen kracht hebben gehaald. Als dat inderdaad het geval is, dan zouden deze bij een niet oplosbaar verschil van mening, dat zou leiden tot een afsplitsing binnen de partij, wettelijk gedwongen moeten worden hun zetel op te geven. Toegegeven: het heeft haken en ogen. De Kieswet spreekt immers over 'gekozene' en rept niet over partijen. Een zetel valt op deze grond niet toe aan een partij bij afsplitsingen, maar 'is' van een gekozene (Fransman, 2005). Toch zorgt deze praktijk voor aanzienlijke onrust in sommige raden, zo bleek in Den Helder en Delfzijl. Het verdient daarom aanbeveling te onderzoeken wat er moet gebeuren om het wettelijk mogelijk te maken zetels echt aan fracties van politieke partijen te binden. Dit zou meer recht doen aan de verkiezingsstrijd zelf, die immers ook door partijen wordt gevoerd op basis van opgestelde programma's. Inwoners stemmen weliswaar op een persoon, maar wel op een persoon die op de lijst van een partij staat. Het zou eerlijk zijn als die persoon, als hij de lijn van de fractie van die partij niet meer kan of wil volgen, zijn zetel beschikbaar moet stellen aan de volgende kandidaat op de lijst. In plaats van, zonder enig mandaat, een eigen lijst te beginnen en daarmee de versplintering te vergroten.

\section{Wettelijke vernieuwingen: andere zittingsduur en raadsontbinding?}

Fleurke pleit als aanvulling op het bestaande arsenaal voor twee wettelijke vernieuwingen met betrekking tot de regeling en het bestuur van de gemeente. De eerste is de zittingsduur van gekozen en benoemde bestuurders. De onbeperkte zittingsduur van gekozen en benoemde bestuurders kan bij het ontstaan en aanhouden van politiekbestuurlijke crisissituaties in gemeenten een belangrijke rol spelen, aldus Fleurke (2008: 30). Hij pleit voor een zittingsduur voor raadsleden, wethouders en burgemeesters van maximaal acht jaar. Bovendien pleit Fleurke voor de mogelijkheid tot raadsontbinding en het uitschrijven van nieuwe verkiezingen, als blijkt dat het college van $\mathrm{B} \& \mathrm{~W}$ niet meer het vertrouwen geniet van de raad. Huberts (2009) zet hier echter enkele vraagtekens bij. "Voor die voorstellen is veel te zeggen, maar de grote vraag is waarom ze een effectief middel zouden zijn tegen bestuurlijk falen. Of raadsontbinding Delfzijl had geholpen, is per definitie niet te schatten. Anders ligt dat voor de zittingsduur. Raakte Delfzijl in de problemen door aan het pluche gehechte burgemeesters, wethouders en raadsleden? Ik zie dat in de empirie niet overtuigend terug" (Huberts, 2009: 102). Het bestuur van de Vereniging van Nederlandse Gemeenten (VNG) liet bij de presentatie van het rapport van Fleurke bij monde van voorzitter A. Jorritsma-Lebbink weten in te zetten op het zelfreinigend vermogen van gemeenten. Het pleidooi voor een maximale zittingsduur en het kunnen uitschrijven van nieuwe verkiezingen werd niet overgenomen.

Ook uit dit onderzoek komen wisselende aanwijzingen met betrekking tot deze voorstellen. Het ontbinden van de raad en (mogen) uitschrijven van tussentijdse verkiezingen kan helpen, doordat afsplitsingen wellicht verdwijnen of 'notoire dwarsliggers' niet meer in de raad terugkeren. Maar het hoéft niet, de uitslag van verkiezingen is (in navolging van Huberts) per definitie niet te voorspellen. Bovendien gaan dan in Neder- 
land gaandeweg verkiezingen zich spreiden over de periode, wat een versplinterd beeld kan opleveren.

Ook de maximale zittingsduur kan van twee zijden worden benaderd. Ook hier zouden personen die veel discussie oproepen kunnen verdwijnen, maar dat geldt ook voor ervaren raadsleden die potentieel dempende werking kunnen hebben. De maximale zittingsduur staat ook op gespannen voet met het passieve kiesrecht. Het ministerie van BZK heeft de suggesties van Fleurke niet verder uitgewerkt.

\subsection{Het ecologisch perspectief}

Na het perspectief van de autonomie en het perspectief van de systeemverantwoordelijke hogere overheid is er nog een derde perspectief: het ecologisch perspectief (Korsten, 2011). Wat betekent dit in relatie tot probleemgemeenten? Deze kijk op normalisatie van bestuur en een ontwikkeling naar goed bestuur is in de interventiehiërarchie als een startmoment te zien (geen actie; 'laat maar gebeuren') maar ook als een ultimum remedium, een laatste redmiddel als andere middelen zijn uitgewerkt. Het ecologisch perspectief is een perspectief dat uitgaat van geringe maakbaarheid, van een somberder beeld omtrent het kunnen 'verbeteren' van bestuurlijke probleemgemeenten.

Dit perspectief is geïnspireerd op processen in de natuur. Kenmerk: niemand doet iets! Want: waarom zou je perse iets aan een complexe bestuurlijke problematiek moeten doen (zie ook Van Dam, 2010), als je de vele acteurs niet aan een touwtje hebt? Het besturen van een gemeente brengt risico's met zich mee, die nooit helemaal uit te sluiten zijn en bovendien soms ongrijpbaar zijn, zo wordt in dit perspectief verondersteld. Bestuurlijke problemen komen soms gewoon voor in een gemeente en zullen daar op enig moment ook wel weer verminderen of verdwijnen. Gemeenten hebben hun eigen regulerende mechanismen en conflicten horen nu eenmaal bij politiek. Gemeenteraadsverkiezingen brengen nieuwe personen in de arena, waardoor er een nieuw evenwicht kan ontstaan en de gemeente zich uit de problematiek kan worstelen. Deze meer ecologische kijk, die stoelt op de gedachte dat net als in de natuur ook in de lokale politiek op 'natuurlijke wijze' weer een nieuwe orde ontstaat, lijkt voor bestuurders die willen handelen en wellicht opgejaagd worden door berichtgeving en vragen van volksvertegenwoordigers, een wat wezensvreemde benadering. Maar waarom zou er niet gewacht worden op 'natuurlijk' herstel van een bestuurlijke probleemgemeente? Als er droogte ontstaat, sterven bepaalde planten en bloemen af, maar na zekere tijd past de natuur zich aan en komen er nieuwe planten en bloemen, die in nieuwe klimatologische omstandigheden juist wel gedijen. Zo zou het ook in de lokale politiek kunnen gaan. Als een burgemeester vertrekt, een wethoudersploeg van samenstelling verandert en de raadsleden plaatsmaken voor nieuwe, kan een nieuwe harmonie ontstaan, waarin de kenmerken van een probleemgemeente verminderen of ineens verdwenen zijn. Nieuwe mensen kunnen nieuwe chemie geven, ze kunnen nieuwe relaties aangaan in nieuwe verhoudingen, waarin geen plaats meer blijkt te zijn voor het voortdurend wegsturen van bestuurders, van verderfelijke strijd in een politieke cultuur van op de man spelen en rauw communiceren, van wispelturigheid in besluitvorming en gebrek aan strategisch beleid. Volgens de ecologische benadering moet de tijd gewoon zijn 
werk doen, zonder sturende ingrepen. De ecologische benadering kan men aanhangen als men wat sceptischer is over de mogelijkheden verandering aan te brengen, niet (meer) gelooft in de instrumentele aanpak, of als laatste vangnet zien als men geprobeerd heeft de gemeentelijke hoofdrolspelers op het 'rechte pad' te houden via intervisie of het aanstellen van coaches, cultuurtrajecten en wat dies meer zij. Ook voor wie een systeemverantwoordelijk perspectief als verkapt centralisme geldt, kan een wat 'anarchistisch' perspectief als muziek in de oren klinken.

\subsection{Slotwoord}

Wat is nu de hoofdlijn van de reflectie op deze studie, gecombineerd met de inzichten uit de literatuur? Vooral dat de problematiek in bestuurlijke probleemgemeenten vanuit drie perspectieven bezien moet worden. Er zijn voorbeelden waar de ecologie haar werk moet doen en ook doet. Verkiezingen brengen nieuwe spelers in de arena, de problematiek vermindert. In de onderzochte gemeenten blijkt dat het zelfreinigende vermogen echter niet groot was. Er werden wel pogingen ondernomen, bijvoorbeeld door het maken van rapporten, maar de problematiek bleef. Veranderingen kwamen (met uitzondering van Leiden) uiteindelijk onder (soms zware) druk van de CdK tot stand. Hieruit blijkt dat 'checks and balances' een zekere nut hebben en een samenspel van 'meedenken, hulp en druk' uiteindelijk tot (enig) resultaat kan leiden. Belangrijk hierin is vooral de mogelijkheid tot ingrijpen, die zich voordoet als er een waarnemend burgemeester moet worden benoemd door de CdK. In alle onderzochte gemeenten leverde de waarnemer een evidente bijdrage aan het remmen of temperen van de problemen. Eventueel zou een CdK kunnen besluiten een waarnemend burgemeester bewust langer te laten zitten, om te pogen de gemeente naar bestuurlijk rustiger vaarwater te loodsen, zoals in sommige gemeenten gebeurde.

Of er over enige tijd toch een zodanige probleemcumulatie in een bestuurlijke probleemgemeente optreedt, dat sprake is van een bijna permanent actieve 'bestuurlijke vulkaan' en het fenomeen van de regeringscommissaris van stal moet worden gehaald, moet worden afgewacht.

\section{Bliksem}

Op de voorkant van dit boek is een bliksemflits afgebeeld. Het bijzondere aan bliksem is dat die op verschillende manieren voorkomt. Soms bij noodweer, als het al langere tijd donker bewolkt is en alle voortekenen van naderend onheil er zijn. De parallel met bestuurlijke probleemgemeenten is bij deze bliksemvariant dat dergelijke gemeenten regelmatig in zo'n situatie zitten, vanwege de macrofactoren in zo'n gemeente. Deze studie laat zien hoe zo'n situatie herkend kan worden en waar eventuele bliksemgeleiders (parallel aan de drie veel voorkomende factoren) het beste geplaatst kunnen worden.

Soms echter komt het voor dat bliksem op klaarlichte dag inslaat, tot verrassing van velen, zelfs in gemeenten met op zich voldoende dempende mechanismen. Garanties dat het bestuurlijk altijd goed gaat in een gemeente, zijn er dus niet. 'Die Politik is keine exakte Wissenschaft', zei Otto von Bismarck in 1863, erop wijzend dat in de politiek sentimenten een rol spelen. Soms gaat het gewoon mis in een gemeentebestuur en komt er pas na enige tijd weer 'rust in de tent'. Bovendien zijn er wel adviezen te geven, 
maar een ideaal pakket aan maatregelen is er niet. Soms helpen wethouders van buiten, soms een waarnemer, soms een combinatie met andere op tempering gerichte ingrepen. En soms... moet de ecologie maar zijn werk doen. Dan moet de tijd het doen, vanuit de gedachte dat er na de bestuurlijke schroei ook wel weer bloei zal komen.

Als uit de verschillende casestudies één ding duidelijk is geworden, is het wel dit: alle suggesties ten spijt, gaat het uiteindelijk om vertrouwen. Vertrouwen in vele actoren: de burgemeester, vertrouwen in de wethouders, vertrouwen van fractievoorzitters, in de coalitie, in de raad als geheel en in elkaar, in de gemeentesecretaris en griffier en anderen. Dat laat zich, als het erop aankomt, niet afdwingen door regels, noch door afspraken of veelvuldig overleg. Vertrouwen is er, of het is er niet. En vertrouwen komt te voet... maar gaat te paard. Politiek blijft uiteindelijk mensenwerk, waarbij elkaar verstaan veel 'grote' zaken en strijd tot kleinere proporties kan terugbrengen. 


\section{Literatuur}

Aardema, H., Verbindend leiderschap, InAxis, Den Haag, 2005.

Aardema, H., W. Derksen, M. Herweijer en P. de Jong (red.), Meerwaarde van de bestuurskunde. Liber amicorum voor prof. dr. Arno F.A. Korsten, Boom Lemma, Den Haag, 2010.

Abma, K. en A.F.A. Korsten, Normenkaders bij bestuurskrachtmetingen - Een beeld van de ideale gemeente?, in: Bestuurswetenschappen, jrg. 62, 2008, nr. 6, pp. 42-68.

Abma, K. en A.F.A. Korsten, Gemeenten in rapportcijfers, Eburon, Delft, 2009.

Abma, T. en R. in 't Veld (red), Handboek Beleidswetenschap, Boom, Amsterdam, 2001.

Addink, G.H., G. Anthony a.o. (eds.), Human Rights and Good Governance, Universiteit Utrecht, Utrecht, 2010.

Addink, G.H., Goed bestuur, Kluwer, Alphen aan den Rijn, 2010.

Addink, G.H., Borgen van publieke waarden: behoorlijk of goed bestuur?, in: Bestuurskunde, jrg. 20, 2011, nr. 2, pp. 12-23.

Ale, B., Risicoanalyse, in: Muller, E.R., U. Rosenthal, I. Helsloot en E.R.G. van Dijkman, Crisis. Studies over crisis en crisisbeheersing, Kluwer, Deventer, 2009, pp. 327-354.

Baas, J.H., Bestuurskunde in hoofdlijnen, Wolters-Noordhoff, Groningen, 1995.

Bakker, E. de, T. Brandsen en M. Oude Vrielink, Grenzen aan governance, in: Bestuurskunde, jrg. 16, 2007, nr. 4, pp. 63-75.

Becking, K. en G. Rensen (red.), Meesterlijk besturen - De burgemeester als leider, ROI, Sdu, Den Haag, 2006.

Bekkers, H. en B. Warbroek, Een enkele crisis in oases van rust, in: Binnenlands Bestuur, 31 oktober 2008, pp. 28-33.

Bellinga, W.F. en J.H.W. Mulder, Rapportage en advies van de informateurs inzake de vorming van een college, Den Helder, oktober 2003.

Berg, J. Th.J. van den, Verantwoorden of vertrekken. Een essay over politieke verantwoordelijkheid, VNG Uitgeverij, Den Haag, 1999.

Binnenlands Bestuur, Doorstart college Den Helder, 14 november 2003.

Binnenlands Bestuur, Burgemeester neemt alle telefoontjes aan, 9 april 2004.

Binnenlands Bestuur, Gemeente Den Helder besmet met verzuringsvirus, 18 juni 2004.

Binnenlands Bestuur, Staatsen daagt Den Helder,8 juni 2006.

Binnenlands Bestuur, SP-wethouders stappen vit college Leiden, 12 oktober 2007.

Binnenlands Bestuur, College Leiden struikelt over light-rail, 17 oktober 2007.

Binnenlands Bestuur, Duiven op excursie voor betere sfeer, 16 mei 2008, pg. 5

Binnenlands Bestuur, Spraakmaker: Reg van Loo, 30 mei 2008.pg. 4

BN/De Stem, 'Bekwaam bestuurder' Vos uitgeluid, 1 april 2005.

BN/De Stem, Crisis in Bredase gemeenteraad, 14 maart 2008.

Bobbio, L., Italy: After the storm, in: Denters, B. en L.E. Rose (eds.), Comparing Local Governance. Trends and developments, Palgrave Macmillan, Hampshire, 2005, pp. 2946.

Boers, E., Het duale raadslid actief, Instituut voor Publiek en Politiek, Amsterdam, 2002. Bogumil, J. u.a., Perspektiven kommunaler Verwaltungsmodernisierung, Sigma, Berlijn, 2007.

Bogumil, J., S. Grohs, S. Kuhlmann en A. Ohm (Hrsg.), Zehn Jahre Neues Steverungsmodell, Edition Sigma, Berlin, 2008. 
Bökkerink, N., Vertrek wethouders verrast raadsleden, in: BN/De Stem, 7 september 2007.

Boogers, M.J.G.J.A. en R. Keizers, Een verdeelde eenheid. Lokale politiek in Sittard tussen 1900 en 1991, Margraten Magazine v.o.f., Sint Geertruid, 1991.

Boogers, M.J.G.J.A., Lokale politiek in Nederland. De logica en dynamiek van plaatselijke politiek, Lemma, Den Haag, 2007.

Boogers, M.J.G.J.A., S.A.H. Denters en G.H. Reussing, Bestuur in beweging: veranderingen in het lokale politiek-bestuurlijke landschap, in: Bestuurswetenschappen, $64^{\mathrm{e}}$ jaargang, juni 2010, nr. 3, pp. 6-28.

Bordewijk, P., Het nut van wethouders, Samsom, Alphen aan den Rijn, 1991.

Borraz, O. en P. le Galès, France: the intermunicipal revolution, in: Denters, B. en L.E. Rose (eds.), Comparing Local Governance. Trends and developments, Palgrave Macmillan, Hampshire, 2005, pp. 12-28.

Borrie, G., F.M. Wibaut - Mens en magistraat, Staatsdrukkerij, Den Haag, 1968.

Boskma, A.F. en M. Herweijer, Beleidseffectiviteit en casestudies: een vergelijking van verschillende onderzoeksontwerpen, in: Beleidswetenschap, 1988/1, pp. 52-69.

Boskma, A.F., M. Herweijer en J.A. van Selm, Veilig verkeer tussen Rijk en gemeente, Kluwer, Deventer, 1990.

Bossert, J., Public Governance, Nyenrode, Breukelen, 2003.

Bouwmans, H., Burgemeester laat lot afhangen van raad, in: Binnenlands Bestuur, 19 september 2003.

Bouwmans, H., 145 gevallen, in: Binnenlands Bestuur, 7 januari 2005.

Bouwmans, H., 90 gevallen, in: Binnenlands Bestuur, 6 januari 2006.

Bouwmans, H., Meer wethouders weg in 2006, in: Binnenlands Bestuur, 7 januari 2007.

Bouwmans, H., Deze wethouders gingen in 2007 van hun zetel, in: Binnenlands Bestuur, 4 januari 2008.

Bouwmans, H., Vallende wethouders, in: Binnenlands Bestuur, 9 januari 2009, pp. 27-31. Bouwmans, $H$., 'Lang van tevoren duidelijk maken wie wethouderskandidaat is', in: Binnenlands bestuur, 23 januari 2009, pp. 26.

Bouwmans, H., Voor wethouders was 2009 slecht jaar, in: Binnenlands Bestuur, 7 januari 2010.

Bouwmans, H., Financiën zijn politiek mijnenveld, in: Binnenlands Bestuur, 8 januari 2010.

Bouwmans, H., Geen vrije val. Gebrek aan vertrouwen speelt coalities parten, in: Binnenlands Bestuur, 7 januari 2011, pp. 25-35.

Bovaird, T. en E. Löffler, Moving from excellence models of local service delivery to benchmarking of 'good local governance', in: International Review of Administrative Sciences, 2002, 68 (1), pp. 9-24.

Bovens, M.A.P., Wie het profiel past, FED, Arnhem,1983.

Bovens, M.A.P., Op elkaar aangewezen. Een verkenning van kwetsbaarheden in de professionele verantwoordelijkheden van topambtenaren. Eindrapportage in opdracht van het college van Burgemeester en Wethouders van gemeente Amsterdam, Utrecht, 2004. Bovens, M.A.P., G.J. Brandsma, D. Thesingh en T. Wever, Aan het pluche gekleefd? Aard en achtergrond van het aftreden van individuele bewindslieden, in: Beleid en Maatschappij, 2010, nr.4. 
Bovens, Th., P. van Geest en J. Prij (red.), Amsterdam is Ameland niet, in: Christen Democratische Verkenningen, Boom, Amsterdam, 2010.

Boverhof, M. en M. Krijnsen, Dossier Dinkelland. Hoe een bestuurscrisis een straatgevecht werd. Uitgeverij Kroost, Hengelo, 2010.

Brandsen, T., G.J.M. van den Brink, F. Hendriks, P.M. Kruyen, E.D. van den Munckhof, M.J. Oude Vrielink en S.B. Soeparman, Scanning Good Governance: Een handreiking, in: Goed bestuur, 2006-4, pp. 23-29.

Broeksteeg, J.L.W., Een bestuurlijke artikel 12-regeling. Ingrijpen in gemeenten in geval van voortdurende bestuurlijke problemen, in: De Gemeentestem, jrg. 159, 21 maart 2009, nr. 7314, pp. 147-157.

Brouwer, Ph., Afrekenen in Heythuysen, in: Binnenlands Bestuur, 25 oktober 2002, pp. 28-33.

Brouwer, Ph., Burgemeester kritiseert provincie, in: Binnenlands Bestuur, 9 juli 2004.

Cachet, A., H. Daemen, A. Ringeling en L. Schaap, Bestuurscultuur in Volendam, in: Openbaar Bestuur, jrg. 11, sept. 2001, pp. 2-7.

Cachet, L. en L. Schaap, Burgemeesters, over veranderingen en stilstand, in: Becking, K. en G. Rensen (red.), Meesterlijk besturen - De burgemeester als leider, ROI, Sdu, Den Haag, 2006. pp. 19-29.

Caminada, I.W.L.A., R. Ellermeijer en P.P. Kohnstamm, Samenwerken in vertrouwen. Rapport onderzoek in opdracht van burgemeester Bronckers, Sittard-Geleen, 2006.

Capgemini Nederland, Bestuurskracht gemeente Bussum, Capgemini Nederland, Utrecht, 2005.

Carabain, W., Beperkt houdbaar. Bouwstenen voor verdere professionalisering van het wethouderschap, SDU Uitgevers, Den Haag, 2009.

Carnevale, D.G., Thrustworthy Government, Jossey-Bass, San Francisco, 1995.

Castenmiller, P., De burgemeester in historisch perspectief, in: Becking, K. en G. Rensen (red.), Meesterlijk besturen - De burgemeester als leider, ROI, Sdu, Den Haag, 2006, pp. 13-19.

Castenmiller, P., M. Meesters en H. Pluut, Terugtredende wethouders, Ministerie van BZK, Den Haag, 2006.

Castenmiller, P. en M.J.E.M. van Dam, Wethouder van buiten is 'gewoon' geworden, in: VNG Magazine, 22 februari 2008, pp. 14-15.

Castenmiller, P., M.J.E.M. van Dam, N. Damen en D. Emans, Terugtredende wethouders. Trendanalyse en redenen voor het verlaten van het ambt. Ministerie van BZK, Den Haag, 2010.

Cloe, D. de en A.F.A. Korsten, Maasdriel: van bestuurlijke noodtoestand naar bestuurlijke deugdelijkheid, Maasdriel, maart 2011.

Commissie doorlichting interbestuurlijke toezichtarrangementen (commissie-Oosting), Van specifiek naar generiek - Doorlichting en beoordeling van interbestuurlijke toezichtarrangementen, Den Haag, 2007.

Commissie Dualisme en Lokale Democratie, De gemeente vernieuwt, Samsom, Alphen aan den Rijn, 2000.

Commissie-Daamen, Cultural governance- Kwaliteit van bestuur en toezicht in de culturele sector: een pleidooi voor zelfregulering, Eindrapport, 2000.

Commissie-van Egdom, Leiden, stad van ambities. Raadsonderzoek naar overschrijdingen van grote projecten, Leiden, 2007. 
Commissie-Glasz, De raad van toezicht in het hbo, HBO-Raad, Den Haag, 2000.

Commissie-Glasz, Naar professioneel toezicht - Advies van de Commissie Intern Toezicht woningcorporaties, Aedes, Almere, 2000.

Commissie Health Care Governance (commissie-Meurs), Health Care Governance, Soesterberg, 1999.

Commissie-Doelman-Pel (Commissie van Onderzoek in de zaak-Menninga),

Eindrapport, Delfzijl, 24 oktober 1998.

Commissie-Ouwerkerk, Nu zaaien, straks oogsten. Rapport van de Commissie-Ouwerkerk naar aanleiding van het onderzoek naar het samenspel tussen gemeenteraad, college van burgemeester en wethouders en ambtelijke organisatie in de gemeente Zundert, Zundert, januari 2005.

Commissie-Tabaksblat, De Nederlandse corporate governance code- Beginselen van deugdelijk ondernemingsbestuur en best practice bepalingen, 2003.

Cools, K., Controle is goed, vertrouwen nog beter - Over bestuurders en corporate governance, Van Gorcum, Assen, 2005.

Corporaal, D., Rapportage aan de Commissaris van de Koningin in Zuid-Holland, de heer J. Franssen, met betrekking tot de bestuurlijke en ambtelijke problematiek in de gemeente Alblasserdam. Den Haag, 2007.

Cox, J.C.M., De Heeren van Alkmaer. Regeerders en Regenten, Vroedschap en Raad, 1264-2005, Gemeente Alkmaar, 2005.

Crul, I., De methode Bandell: 'Kijk naar de mensen achter de dossiers', in: VNG Magazine, 21 februari 2010.

Dam, M.J.E.M. van, Als ze vallen, in: Openbaar Bestuur, Kluwer, augustus 2010.

Denters, B. en L.E. Rose, Comparing Local Governance. Trends and Developments,

Palgrave Macmillan, Hampshire, 2005.

Denters, B., O. Gabriel en L.E.Rose, Citizen's Views about Good Local Governance, in:

Rosema, M., B. Denters en K. Aarts (eds.), How Democracy Works, Pallas Publications, Amsterdam University Press, Amsterdam, 2010, pp. 137-159.

Depla, P., Lokaal besturen is nu veel moeilijker, in: De Volkskrant, 1 maart 2010.

Derksen, W., De burgemeesterscarrière in Nederland: binnengemeentelijk en tussengemeentelijk, in: Acta Politica, jrg. 12, 1977, nr. 4, pp. 475-499.

Derksen, W., Tussen loopbaan en carrière, Vuga, Den Haag, 1980.

Derksen, W. e.a., De gekozen burgemeester benoemd, Kluwer, Deventer, 1983. Derksen, W. en M. van der Sande (red.), De burgemeester, van magistraat tot modern bestuurder, Kluwer, Deventer, 1984.

Derksen, W. en A.F.A. Korsten (red.), Lokaal bestuur in Nederland, Samsom, Alphen aan den Rijn, 1985 en 1989.

Derksen, W., J. van der Drift e.a., De bestuurskracht van kleine gemeenten - Beleidsrapport, Leiden, april 1987.

Derksen, W., Institutionele normen in het lokaal bestuur, Leiden,1990.

Derksen, W. en K. Kas, Vallende wethouders, in: Tops, P.W., A.F.A. Korsten en C.A.T. Schalken (red.), De wethouder. Positie en functioneren in een veranderend bestuur, Vuga, Den Haag, 1994, pp. 109-117.

Derksen, W., R. Kreeft en S. Tijsterman, Ten val gekomen, in: Binnenlands Bestuur, 16 mei 1997, nr. 20, pp. 26-33.

Derksen, W. en L. Schaap, Lokaal bestuur, Convoy Uitgevers, Dordrecht, 2010. 
Diepeveen, J., E. van Hout en C. Riezebos, Onderzoeksrapportage bestuurscultuur Maasdriel, BMC, december 2010.

Dijkstra, G. en S. van de Walle, Good governance en ontwikkelingsbeleid: spijkerhard of boterzacht?, in: Bestuurskunde, jrg. 20, 2011, nr. 2, pp. 23-33.

Dohmen, J., De vriendenrepubliek, SUN, Nijmegen, 1996.

Eenhoorn, H.B. en P.F. Rozenberg, Samenwerkend naar zelfstandigheid? - Een onderzoek naar randvoorwaarden voor zelfstandigheid van gemeenten in de Randstad, Wassenaar/Voorburg, 2006.

Ernst en Young, De uitdaging van het dualisme, Amsterdam, 2002.

Euser, B., Lokale leiders- De opkomst van de geuzendemocratie, Augustus, Amsterdam, 2009.

Faber, S., Burgemeester en democratie, Samsom, Alphen aan den Rijn, 1974.

Fleurke, F., Organische bijstand. Analyse van het interventierepertoire voor gemeenten in aanhoudende bestuurscrisis, Ministerie van BZK, Den Haag, 2008.

Fransman, J.S.T., Crisisverschijnselen in de lokale politiek. Een onderzoek naar politieke versnippering van gemeenteraden, CLB, 2005.

Gabriel, O.W. en S. Eisenmann, Germany: a new type of local government?, in: Denters, B. en L.E. Rose (eds.), Comparing Local Governance. Trends and developments, Palgrave Macmillan, Hampshire, 2005, pp. 119-138.

Garrard, J. en J.L. Newell, Scandals in past and contemporary politics, Manchester University Press, 2006.

Gemeente Delfzijl, Coalitieakkoord voor de periode 2003-2006, Delfzijl, 2003.

Gemeente Delfzijl, Verslagen van de vergaderingen van de gemeenteraad, diverse jaren. In het bijzonder: 22 februari 2006 en 20 maart 2006.

Gemeente Delfzijl, Samen werken aan Delfzijl. Collegeprogramma 2006-2010. Delfzijl, 2010.

Gemeente Den Helder, Verslagen van de vergaderingen van de gemeenteraad, diverse jaren.

Gemeente Den Helder, Coalitieprogramma 2004-2006, VVD, CDA, Leefbaar Den Helder en D66, gemeente Den Helder, 5 november 2003.

Gemeente Den Helder, Strategische visie 2020, Den Helder, mei 2007.

Gemeente Den Helder, Raadsinformatiebrief betreffende woonlasten burgemeester, 16 januari 2009.

Gemeente Den Helder, Brief van burgemeester aan gemeenteraad, 16 januari 2009.

Gemeente Den Helder, Gezamenlijke slotverklaring van het mediationtraject, 19 februari 2009 .

Gemeente Leiden, Handelingen vergadering gemeenteraad, diverse jaren. In het bijzonder: 25 september 2007 en 16 oktober 2007.

Gemeente Zundert, Verslagen van de openbare raadsvergaderingen, diverse jaren. In het bijzonder: 29 april 2004 en 25 februari 2010.

Gemeente Zundert, Raadsprogramma 2006-2010.

Graaf, G., V. van Doeveren, A.Reynaers en Z. van der Wal, Goed bestuur als management van spanningen tussen verschillende publieke waarden, in: Bestuurskunde, jrg. 20, 2011, nr. 2, pp. 5-12.

Graaf, P., Vakantiepark kost Zundert wethouders, in: De Volkskrant, 9 december 2004. 
Hartman, C. en P.W. Tops, Professionalisering van de wethouder, in: Korsten, A.F.A. e.a. (red.), De wethouder, Vuga, Den Haag, 1994, pp. 313-321.

Haverland, M. en D. Yanow, Hoe overleef ik discussies over bestuurskundig onderzoek?, in: Bestuurskunde, jaargang 19, nr. 4, Reed Business, Amsterdam, 2010, pp. 87-95.

Hebel, F. von en M. van Wely, Stevige kritiek PvdA op wethouders Delfzijl, in: Dagblad van het Noorden, 22 februari 2006.

Hebel, F. von en M. van Wely, Nieuwkomers moeten de politieke kar trekken, in: Dagblad van het Noorden, 23 februari 2006.

Hebel, F. von en M. van Wely, Wethouder Scharft: Het was een slag in mijn gezicht, in: Dagblad van het Noorden, 23 februari 2006.

Hebel, F. von, 'Hier is sprake van Sicilië aan de Eems', in: Dagblad van het Noorden, 17 februari 2006.

Heijningen, B. van, Op werkbezoek: Robert Waltmann, in: Binnenlands Bestuur, 28 juni 2002.

Hendriks, F. en G. Drosterij, Goed bestuur in de stad: wat staat op het spel?, in: Bestuurskunde, jrg. 19, 2010, nr. 4, pp. 6-17.

Hertogh, M. en E. Westerveld, Playing with complexity. Management and organisation of large infrastructure projects, Thieme, Amsterdam, 2009.

Hiemstra, J., Het besturen van grote gemeenten, Samsom, Alphen aan den Rijn, 1999.

Hiemstra, J., Presterende gemeenten. Hoe gemeenten beter kunnen presteren, Kluwer, Alphen aan den Rijn, 2003.

Hijum, E. van en J. Hiemstra, Bestuurskwaliteit en presterende gemeente, in: Openbaar Bestuur, 2002, nr. 12, pp. 11-14.

Hoogerwerf, A., Wegwijzers voor politici. Van Hammoerabi tot heden, Damon, Budel, 2004 .

Hopman, N., Bestuurscompetenties voor burgemeesters, vergeleken met competentiekaders voor topfunctionarissen op nationaal en Europees bestuursniveau, in: Becking, K. en G. Rensen (red.), Meesterlijk besturen - De burgemeester als leider, ROI, Sdu, Den Haag, 2006, pp. 107-117.

Horst, M. van der, Bestuurlijke spaghetti. Lenthe Publishers, Amsterdam, 2006.

Huberts, L.W.J.C. en E. van Hout, Goed bestuur: kiezen of delen?, in: Bestuurskunde, jrg. 20, 2011, nr. 2, pp. 53-63.

Huberts, L.W.J.C., C.L. Jurkiewicz en J.B. Maesschalck (eds.), Ethics and Integrity of Governance. Perspectives across Frontiers. Cheltenham UK en Northampton, MA, USA: Edward Elgar, 2008.

Huberts, L.W.J.C., Fleurke's organische bijstand aan gemeenten in crisis: de weg naar goed besturen?, in: De Ridder, J., P.L. Polhuis en L.W.J.C. Huberts (red.), Eigenzinnig bestuur. Liber Amicorum Fred Fleurke. Wolf Legal Publishers, Nijmegen, 2009.

Huijser, P., Afspraken en Zundert gaan niet goed samen, in: BN/De Stem, 8 december 2004.

Hulst, M.J. van, Bestuurscultuur in de Nederlandse gemeente, Centre for local democracy, Faculty of Social Sciences, Erasmus University Rotterdam, 2001.

Hulst, M.J. van, Town Hall Tales. Culture as storytelling in local government, Eburon, Delft, 2008. 
Instituut voor Arbeidsvraagstukken (IVA), Een beter loopbaanperspectief voor politieke ambtsdragers. Het bestaat echt!, P\&O Services Groep, Hedel, 2008.

Intégis, Rapportage voor College van Burgemeester en Wethouders van de gemeente Vlissingen inzake feiten en omstandigheden project Dokkershaven, 7 februari 2008.

Jann, W, u.a. (Hrsg.), Public Management- Grundlagen, Wirkungen, Kritiek, Edition Sigma, Berlin, 2006.

Janssen, J.I.H. en A.F.A. Korsten (red.), Gemeenteraden kiezen, Eburon, Delft, 1995.

Janssen, J.I.H. en A.F.A. Korsten, De wederopstanding van lokale lijsten. Paper politicologenetmaal Noordwijkerhout, Maastricht, 2002.

Jense, L., les Keijzer is klaar met puinruimen, in: Brabants Dagblad, 5 maart 2005.

John, P., Local Governance in Western Europe, Sage Publications, London, 2001.

Judge, D., G. Stoker en H. Wolman (eds.), Theories of Urban Politics, Sage, Londen, 1995 .

Kaiser, H., De deugdelijke gemeente. Over het samenspel tussen politiek, bestuur en organisatie in de nieuwe gemeente, Rijnconsult, Utrecht, 2004.

Kemenade, J. (red), Behoorlijk bestuur, Elsevier, Amsterdam, 2001.

Kerley, R., Managing in Local Government, MacMillan, Londen, 1994.

Klijn, E.H., Netwerken als perspectief op beleid en vitvoering van beleid, in: Beleidswetenschap, jrg. 19, 2005, nr. 4, pp. 32-55.

Klinkers, L. e.a., Burgemeesters wegen hun ambt, Utrecht, 1982.

Kloeg, R., Verhuizen is een probleem voor burgemeester Vos, in: BN/De Stem, 3 oktober 2003.

Kloeg, R., Zundert bestuurlijk op zijn gat, in: BN/De Stem, 7 december 2004 .

Kloeg, R., 'Vos en Zundert matchen niet goed', in: BN/De Stem, 1 april 2005.

Kok, A. de, W. Carabain en T. Lont, Nieuwe wethouders op weg, Wethoudersvereniging en Kluwer, 2010.

Korsten, A.F.A. en Th.A.J. Toonen, Bestuurskunde - Hoofdfiguren en kernthema's, Stenfert Kroese, Leiden, 1988.

Korsten, A.F.A. en W. Kuiper (red.), Limburg kiest, Kerckebosch, Zeist, 1991.

Korsten, A.F.A. en P.W. Tops (red.), Lokaal bestuur in Nederland, Samsom, Alphen aan den Rijn, 1998.

Korsten, A.F.A., De lokale formateur bij bestuurlijke coalitievorming, in: W. Derksen (red.), Politiek voor bestuurders, VNG Uitgeverij, Den Haag, 1998, pp. 87-101.

Korsten, A.F.A., De staat van de dualisering in Eindhoven, Eindhoven, 2004.

Korsten, A.F.A., Visiteren van gemeenten, Maastricht/Heerlen, 2004.

Korsten, A.F.A. en J.W. Notten, Van rambo naar mambo - Dualisering van Heerlen of naar meer samenspel vanuit een eigen rol, Heerlen, 2005.

Korsten, A.F.A. en G. Leers, Inspirerend leiderschap in de risicomaatschappij, Lemma, Utrecht, 2005.

Korsten, A.F.A. en H. Aardema, Vallende burgemeesters, Ministerie van BZK, Den Haag, 2006.

Korsten, A.F.A. en J.M. van de Laar, De kus en de oorvijg. Het gedwongen vertrek van burgemeester Lidewij Digici. PricewaterhouseCoopers, 2007.

Korsten, A.F.A., K. Abma en J.M.L.R. Schutgens, Bestuurskracht van gemeenten. Meten, vergelijken en beoordelen, Eburon, Delft, 2007. 
Korsten, A.F.A., K. Abma, M. Schoenmaker en J. Schutgens, Doen wij het goed? Gemeentelijke bestuurskrachtmetingen onder het vergrootglas, in: Bestuurskunde, jrg. 16, 2007, nr. 2, pp. 24-34.

Korsten, A.F.A. en M. Schoenmaker, Sterke colleges, Reed Elsevier, Den Haag, 2008.

Korsten, A.F.A., De wind ging liggen - Dualisering in gemeentebestuur in de periode maart 2002-juni 2008, met bijzondere aandacht voor de betrekkingen in gemeenten tussen college, raad, presidium en bevolking, in: Ministerie van BZK, Congresuitgave Staat van de dualisering, Den Haag, 2008, pp. 43-59.

Korsten, A.F.A., H. Aardema en A.P. Resoort, Gebroken ketens van macht - Gedwongen vertrek van burgemeesters vanaf begin 2000, in: Bestuurswetenschappen, jrg. 62, 2008, nr. 6, pp. 9-42.

Korsten, A.F.A., In politiek vaarwater - Verkenning van dilemma's in de praktijk van raadsgriffiers, Open Universiteit Nederland/Parkstad Limburg, Heerlen, 2009.

Korsten, A.F.A., A. Resoort e.a., De burgemeester op de divan, GITP, Nijmegen, $2010 a$.

Korsten, A.F.A., Gedwongen vertrek van burgemeesters, in: Justitiële verkenningen, jrg. 36, nr. 3, juni 2010b, pp. 10-30.

Korsten, A.F.A., Deugdelijk bestuur, afscheidsrede, Open Universiteit, Heerlen, 2010c.

Korsten, A.F.A., 'Gezond bestuur' en de ziekte die 'probleemgemeente' heet - Over (on)deugdelijk bestuur en wat te doen, essay, 2011.

Korsten, A.F.A. en M. Schoenmaker, Gezond bestuur en bestuurlijke probleemgemeenten. Tijd voor de bestuursschout?, in: Bestuurswetenschappen, jrg. 65, 2011, nr. 3, pp. 28-49.

Leemans, A.F., De eenheid in het bestuur der grote stad, Vuga, Den Haag, 1968.

Lendering, J., Polderdenken - De wortels van de Nederlandse overlegcultuur, Athenaeum - Polak en Van Gennep, Amsterdam, 2005.

Lijphart, A., Verzuiling, pacificatie en kentering in de Nederlandse politiek, J.H. De Bussy, Amsterdam, 1984 .

Logtenberg, H. en M. Wiegman, Job Cohen - Burgemeester van Nederland, Nieuw Amsterdam, Amsterdam, 2010.

Lonkhuyzen, P. van, Opstelten: "Er bestaan misvattingen over leiderschap", in:

Management Team, 28 november 2007.

Louter, J., Het functioneren van een burgemeester in een kleine gemeente, Den Haag, 1988.

Lulofs, K. e.a., Schokgolven in het openbaar bestuur na 'Enschede', Lemma, Utrecht, 2005 .

Luyken, C., Bedrijfsleven Zundert vreest crisis, in: BN/De Stem, 4 december 2007.

Maaren-Van Balen, L. van, Hoezo burgemeester- Ervaringen van de burgemeester van Leeuwarden 1999-2001, Uitgeverij BZZToH, Den Haag, 2003.

Meurs, P. en T. van der Grinten (red.), Gemengd besturen - Besturingsvragen en trends in de gezondheidszorg, Academic Service/Sdu, Den Haag, 2005.

Ministerie van BZK, Krachtige gemeenten - Beleidsnotitie gemeentelijke herindeling, Den Haag, 1998.

Ministerie van BZK, Bestuurscompetenties burgemeesters, Den Haag, mei 2001.

Ministerie van BZK, Dualisme en lokale democratie, Gemeentewet vanaf 7 maart 2002.

Ministerie van BZK, Staat van het bestuur 2006, Den Haag, 2006.

Ministerie van BZK, Staat van het bestuur 2008, Den Haag, 2008. 
Ministerie van BZK, Nederlandse code voor goed openbaar bestuur. Beginselen van deugdelijk overheidsbestuur, Den Haag, juni 2009.

Ministerie van BZK, Staat van het bestuur 2010, Den Haag, 2010.

Moerkamp, J., Stuurloos Den Helder, in: Binnenlands Bestuur, 13 januari 2006.

Moerkamp, J., Ik voel mij beschadigd, in: Binnenlands Bestuur, 27 januari 2006.

Moerkamp, J., Staatsen winnaar en verliezer kort geding, in: Binnenlands Bestuur, 8 juni 2007.

Montfort, C. van, Ruimte voor goed bestuur - Tussen prestatie, proces en principe, WRR, Den Haag, 2004.

Montfort, C. van, Besturen van het onbekende - Goed bestuur bij publiek-private samenwerking, Tilburg, 2008.

Mudde, L., In Ganzedijk vond wethouder zijn Waterloo, in: VNG Magazine, 21 maart 2008, pp. 18-20.

Mudde, L., 'Populisme kan nooit het antwoord zijn', Interview met de Commissaris van de Koningin in Zuid-Holland, in: VNG Magazine, nr. 2/2009, 23 januari 2009, pp. 17-19.

Muller, E.R., U. Rosenthal, I. Helsloot en E.R.G. van Dijkman e.a. (red.), Crisis. Studies over crisis en crisisbeheersing, Kluwer, Deventer, 2009.

Nelissen, N., H. Goverde en N. van Gestel (red.), Bestuurlijk vermogen. Analyse en beoordeling van nieuwe vormen van besturen, Coutinho, Bussum, 2000.

Nelissen, N., P. de Goede en M. van Twist, Oog voor openbaar bestuur, Een beknopte geschiedenis van de bestuurskunde, Elsevier, 's-Gravenhage, 2004.

Noordegraaf, M., Professioneel bestuur, Utrecht, 2008.

NRC Handelsblad, Aldus uit de Eerste Kamer, 14 oktober 2009.

Nutt, P.C., Why decisions fail. Avoiding the blunders and traps that lead to debacles. Berrett-Koehler Publishers, Inc., San Francisco, 2002.

Ohlenforst, M.H.M., Democratie en Dorpspolitiek. Lokale politiek in Echt tussen 1946 en 1990, Custers drukwerk, Sint Geertruid, 1992.

Onafhankelijke Commissie Governance Code BVE (commissie-Meijerink), Goed bestuur in het mbo, jan. 2008.

Osborne, D. en T. Gaebler, Reinventing government, Reading, Addison-Wesley Publ. co, 1992.

Osch, H. van, Bram Peper-Man van contrasten, Boom, Amsterdam, 2010.

Oud, P.J. e.a., Gedenkboek Gemeentewet 1851 - 1951, Vereniging van Nederlandse Gemeenten, Den Haag, 1951.

Pennarts, H.F.T., Beginselen van behoorlijk bestuur, Maklu, Antwerpen, 2008.

Peters, K., Verdeelde macht. Een onderzoek naar invloed op rijksbeslvitvorming in Nederland, Boom, Amsterdam, 2002.

Peters, K., Het opgeblazen bestuur. Een kritische kijk op de provincie, Boom, Amsterdam, 2007.

Plees, Y., Belgium: the changing world of Belgian municipalities, in: Denters, B. en L.E. Rose (eds.), Comparing Local Governance. Trends and developments, Palgrave Macmillan, Hampshire, 2005, pp. 47-64.

Poelje, G.A. van, Hedendaagsch gemeenterecht, Nijhoff, Den Haag, 1914.

Poelje, G.A. van, Met ledige handen. Enkele algemene opmerkingen in het jaar van het eeuwfeest der gemeentewet, in: Vereniging van Nederlandse Gemeenten, Gedenkboek Gemeentewet 1851-1951. Den Haag, 1951, pp. 82-133. 
Polak, J.M. en C.J.N. Versteden, De cafébrand in Volendam - Een ramp om van te leren, Haarlem, 26 maart 2001.

Princen, C. , (bew. C. Kortmann), De burgemeester, Samsom, Alphen aan den Rijn, 1969. Pröpper, I. en $\mathrm{H}$. Kessens, Tussen pluche en publiek - Lokale politiek in de praktijk, Coutinho, Bussum, 2005.

Raad voor het Openbaar Bestuur (ROB), Democratie vereist partijdigheid. Politieke partijen en formaties in beweging, ROB, Den Haag, 2009.

Reynaert, H. en K. Steyvers (red.), De kerktorenpolitiek voorbij? - Lokale politiek in Vlaanderen, VandenBroele, Brugge, 2010.

Rhodes, R.A.W., Understanding Governance- Policy Networks, Governance, Reflexivity and Accountability, Open University Press, Buckingham, 1997.

Ridder, K. de en R. Kempkers, Inertie en aanpassing, in: Beleidswetenschap, 16(3), 2002, pp. 236-258.

Rihoux, B., en C.C. Ragin, Configurational Comparative Methods. Qualitative Comparative Analysis (OCA) and Related Techniques. SAGE Publications, 2009.

Rokx, C.J.M.C., Governance and Malnutrition, Maastricht, 2006.

Rosenthal, U. en M. Zannoni, Bestuurders in crisistijd, in: Becking, K. en G. Rensen (red.), Meesterlijk besturen - De burgemeester als leider, ROI, Sdu, Den Haag, 2006, pp. 19-37.

Rutgers, M.R., Het Gulden Boekje uit de Nederlandse Bestuurskunde, Eburon, Delft, 2005.

Schenk, W., Wethouder Den Helder sjoemelde nog meer, in: De Volkskrant, 8 september 1999 .

Schipper, A., Vlissingen: de fles gebarsten. Een onderzoek naar de val van het college van $B \& W$ van Vlissingen. Eindscriptie t.b.v. Open Universiteit, Vlissingen, 2010.

Schouw, A.G., Bestuursstijlen van wethouders, VNG Uitgeverij, Den Haag, 1995.

Schouw, A.G. en P.W. Tops, Stijlen van besturen, Atlas, Amsterdam, 1998.

Sitalsing, K., Delfzijl gaat er eens goed voor zitten, in: De Volkskrant, 23 februari 2006.

Smit, G., M. Dijk en M. de Vries, Lokale politici zijn vooral met elkaar bezig, Radboud Universiteit Nijmegen, 2006.

Smith, B.C., Good Governance and Development, Palgrave, Londen, 2007.

Stamsnijder, P., Goed nieuws in kwade tijden - Crisiscommunicatie in de praktijk, Academic Service, Schoonhoven, 2002.

Steur, B.F., Het duel om dualisme, in: Openbaar Bestuur, 2006, nr. 3, pp. 31-36.

Stipdonk, V. van en R. Leeuwenburg, Politiek en emotie: Over de rol van emoties in de lokale politiek, SGBO, Den Haag, 2007.

Streefkerk, J., Burgemeesters in de branding, over rollen en rolopvattingen, in: Becking, K. en G. Rensen (red.), Meesterlijk besturen - De burgemeester als leider, ROI, Sdu, Den Haag, 2006, pp. 37-47.

Stuurgroep Evaluatie Dualisering Gemeentebestuur, Aangelegd om in vrijheid te werken - Dualisering, bijsturing geboden, Den Haag, 2004.

Thijn, E. van, F. Alink, P. van Dijk e.a., De sorry-democratie. Recente politieke affaires en de ministeriële verantwoordelijkheid, Van Gennep, Amsterdam, 1998.

Thijn, E. van, De formatie, Uitgeverij Augustus, Amsterdam, 2010.

Tijdelijke commissie van onderzoek naar de ambtelijke organisatie, Samen werken aan de menselijke maat, Gemeente Veghel, 2008. 
Tilburg, M. van, Lokaal of nationaal? Het lokale karakter van de gemeenteraadsverkiezingen in Nederlandse gemeenten (1974-1990), VNG-uitgeverij, Den Haag, 1993.

Toonen, Th.A.J., M.J.E.M. van Dam, M. Glim en G. Wallagh, Gemeenten in ontwikkeling - Herindeling en kwaliteit, Van Gorcum, Assen, 1998.

Tops, P.W., Afspiegeling en afspraak, Vuga, Den Haag, 1990.

Tops, P.W., A.F.A. Korsten en C.A.T. Schalken (red.), De wethouder, Vuga, Den Haag,1994.

Tops, P.W. en S. Zouridis, Affaires en conflicten in het lokaal bestuur, in: Korsten, A.F.A. en P.W. Tops (red.), Lokaal bestuur in Nederland, Samsom, Alphen aan den Rijn, 1998, pp. 416-427.

Tops, P.W. en S. Zouridis, De binnenkant van politiek, Atlas, Amsterdam, 2002. Tops, P.W. e.a., Het burgemeestersreferendum in Vlaardingen, Vlaardingen, augustus 2002.

Tops, P.W. en W. van Spijker, Den Helder, Doe normaal - Verbeterprogramma voor de gemeente Den Helder, Den Helder, 2004.

Tops, P.W., Regimeverandering in Rotterdam - Hoe een stadsbestuur zichzelf opnieuw uitvond, Atlas, Amsterdam, 2007.

Trouw, Wethouders stappen op, 11 maart 1999.

Trouw, Crisis in CDA-fractie leidt tot crisis in Leids college, 21 september 1999.

Trouw, College staat op springen vanwege 'wollige' wethouder, 17 december 1998.

Trouw, Status van bruggenbouwer kon Postma niet waarmaken, 16 mei 2002.

Trouw, Wethouders Delfzijl zijn nu demissionair, februari 2003.

Twist, M. van en E. Romein (red.), Kleine verhalen vit de grote steden - Bureaucratie en bestuur van binnenuit beschouwd, NSOB, Den Haag, 2008.

Veldheer, V., Kantelend bestuur - Onderzoek naar de ontwikkeling van taken van het lokale bestuur in de periode 1851-1985, SCP, Rijswijk, 1994.

Verbeek, M., 'Tijd voor goed bestuur', in: VNG-magazine, nr. 23/24, 29 september 2006. Vereniging van Gemeentesecretarissen (VGS) en Vereniging voor Bestuurskunde (VB), Over bestuurskracht en maatschappelijke veerkracht. Pleidooi voor het organiseren van veerkracht in lokale gemeenschappen, VGS en VB, Den Haag, 2007.

Vereniging van Nederlandse Gemeenten, Commissie Gemeentewet en Grondwet, De eerste overheid, VNG, Den Haag, 2007.

Vereniging van Nederlandse Gemeenten, Bestuurlijke Stabiliteit. Een bloemlezing over het versterken van stabiel bestuur, Excelsior, Den Haag, 2010.

Verheul, W.J., Een overzicht van de literatuur over publiek leiderschap en burgemeesters, in: Becking, K. en G. Rensen (red.), Meesterlijk besturen - De burgemeester als leider, ROI, Sdu, Den Haag, 2006, pp. 89-107.

Verhoeff, C. en R. Wever, Sterke koppels, sterk bestuur, BMC, Leusden, 2007.

Vernieuwingsimpuls Dualisme en lokale democratie, De positie van de wethouder: de toekomst van het verleden, VNG Uitgeverij, Den Haag, 2004.

Vernieuwingsimpuls Dualisme en lokale democratie, Culturen rond besturen. Bestuurskracht en bestuurscultuur in gedualiseerde gemeenten, Ministerie van BZK en VNG, 2006. Verschuren, P. en H. Doorewaard, Het ontwerpen van een onderzoek, Lemma, Utrecht, 1995.

Volkskrant, De, PvdA-wethouder Den Helder weg wegens fraude, 10 maart 1999.

Vossen, G.J. van der, Goed toezichthouderschap, Sdu, Den Haag, 2007. 
Vries, G. de, Boomkwekers versus forensen, in: NRC Handelsblad, 9 december 2004. Vries, M. de, P.S. Reddy en M.S. Haque (eds.), Improving Local Government, Palgrave MacMillan, Londen, 2008.

Vulperhorst, L., Praktische dromers - Over het vak van wethouders. Van Gennep, Amsterdam, 2010.

Waal, C.J.D., De rol van waarnemend burgemeesters in het openbaar bestuur. Delfzijl, 2008.

Wallage, J., De strijd om het publieke vertrouwen, in: Jaarboek Vereniging van Griffiers 2008, SDU Uitgevers, Den Haag, 2008, pp. 11-22.

Warbroek, B., De val van een burgemeester, De Fontein, Baarn, 2007.

Weegen, E. van, Cultuurontwikkeling in Stadskanaal: van eendenbewustzijn naar zwanentrots, in: Openbaar Bestuur, jrg. 11, november 2001, nr. 11, pp. 29-34.

Wely, M. van, CDA: Delfzijl moet verder met landdrost, in: Dagblad van het Noorden, 20 februari 2006.

Wely, M. van, Menninga: Ik ben zeker zes keer bedreigd, in: Dagblad van het Noorden, 1 maart 2006.

Wely, M. van en M. de Bruin, Jan Menninga hoort nooit de gong van de laatste ronde, in: Dagblad van het Noorden, 4 maart 2006.

Werkgroep 2duizend, Uit liefde voor de stad. In gesprek met twaalf ervaren wethouders, Werkgroep 2duizend/Laagland'advies, Amersfoort, 2002.

Wesseling, H. e.a., Bestuurskracht en democratie, in: Openbaar Bestuur, februari 2004a, pp. 20-24.

Wesseling, H. e.a., Werken aan het vertrouwen van burgers, in: Openbaar Bestuur, maart 2004b, pp. 8-12.

Wesseling, H. e.a., Bestuurskracht en werken in ketens, in: Openbaar Bestuur, april 2004C, pp. 10-14.

Wesseling, H. e.a., Richten op bestuurskracht, in: Openbaar Bestuur, mei 2004d, pp. 16-20.

Wesseling, H. en M.J.W. van Twist, Innoveren en besturen, in: Openbaar Bestuur, april 2006, nr. 4, pp.2-7.

Westerink, B., Delfzijl aan de Eems. Een orkaan in een vingerhoed, Delfzijl, 2006.

Westerloo, G. van, Niet spreken met de bestuurder, De Bezige Bij, Amsterdam, 2003.

Wijmen, F.C.B. van, Beste stuurlui- Een actueel perspectief op bestuur en toezicht in zorginstellingen, Maastricht, 2010 (paper).

Willemse, R., Het bestaansrecht van de Nederlandse gemeente, Eburon, Delft, 2001.

Wolthekker, D. (red.), Een keten van macht- Amsterdam en zijn burgemeesters vanaf 1850, vitgeverij Balans, Amsterdam, 2006.

Yin, R.K., Case study research: Design and methods, Beverly Hills, 1984.

Zannoni, M., Onrust aan de top: bestuurlijke crises verkend, in: Muller, E.R., U. Rosenthal, I. Helsloot en E.R.G. van Dijkman e.a. (red.), Crisis. Studies over crisis en crisisbeheersing, Kluwer, Deventer, 2009, pp. 223-246. 


\section{Bijlage 1 De gegevens van alle gemeenten}

In deze bijlage zijn de bestuurlijke conflicten en bestuurscrises in Nederlandse gemeenten opgenomen in de periode maart 1998 - maart 2010, zoals die in dit onderzoek zijn gebruikt. Aangegeven is hoeveel wethouders er per conflict of crisis zijn vertrokken, of het college als gevolg van de problematiek is gevallen en of de burgemeester er bij betrokken was of niet. In de kolom Totaal is het totaal aantal vertrokken bestuurders en colleges in de verschillende gemeenten aangegeven. De positie op de ranglijst geeft aan hoe de relatieve positie ten opzichte van andere gemeenten is, waarbij de positie hoger is naarmate er meer bestuurlijke conflicten en bestuurscrises zijn voorgekomen.

De gegevens zijn afkomstig van de gemeenten zelf en aangevuld met informatie uit andere, openbare, bronnen. Meer over de criteria in hoofdstuk 4. De auteur houdt zich van harte aanbevolen voor verbeteringen en aanvullingen.

Bestuurlijke conflicten en bestuurscrises in Nederlandse gemeenten, maart 1998 - maart 2010

\begin{tabular}{|c|c|c|c|c|c|}
\hline Gemeente & $\begin{array}{l}\text { Aantal } \\
\text { Inw. op } \\
\text { 1-1-2010 }\end{array}$ & Provincie & $\begin{array}{l}\text { Bestuurlijke conflicten en crises } \\
\text { (weth. = wethouder) } \\
\text { (weths. = wethouders) }\end{array}$ & $\begin{array}{l}\text { To- } \\
\text { taal }\end{array}$ & $\begin{array}{l}\text { Positie } \\
\text { op } \\
\text { ranglijst }\end{array}$ \\
\hline Aa en Hunze & 25.593 & Drenthe & geen bijzonderheden gemeld & 0 & 279 \\
\hline Aalburg & 12.630 & N-Brabant & geen bijzonderheden gemeld & 0 & 280 \\
\hline Aalsmeer & 29.182 & N-Holland & 2004: weth. conflict partij & 1 & 210 \\
\hline Aalten & 27.516 & Gelderland & 2006: collegecrisis, 3 weths. & 4 & 68 \\
\hline Abcoude & 8.789 & Utrecht & $\begin{array}{l}\text { 2000: weth., andere coalitie } \\
\text { 2001: weth., andere coalitie } \\
\text { 2008: weth. breuk fractie, crisis }\end{array}$ & 6 & 33 \\
\hline Achtkarspelen & 28.091 & Friesland & geen bijzonderheden gemeld & 0 & 281 \\
\hline Alblasserdam & 19.006 & Z-Holland & 2007: burgemeester na rapport & 1 & 211 \\
\hline Albrandswaard & 24.081 & Z-Holland & $\begin{array}{l}\text { 2000: weth., crisis } \\
\text { 2008: crisis, } 3 \text { weths. }\end{array}$ & 6 & 34 \\
\hline Alkmaar & 93.912 & N-Holland & $\begin{array}{l}\text { 2006:2x weth., crisis } \\
\text { 2006: weth. na negatieve SMS } \\
\text { 2008: weth., VVD uit coalitie }\end{array}$ & 6 & 35 \\
\hline Almelo & 72.621 & Overijssel & geen bijzonderheden gemeld & 0 & 282 \\
\hline Almere & 188.209 & Flevoland & $\begin{array}{l}\text { 1999: weth. na conflict met raad } \\
\text { 2001: weth. na confl coll., crisis } \\
\text { 2004: weth., breuk coalitie } \\
\text { 2004: weth. na kritiek op aankoop won. }\end{array}$ & 6 & 36 \\
\hline $\begin{array}{l}\text { Alphen aan den } \\
\text { Rijn }\end{array}$ & 72.577 & Z-Holland & $\begin{array}{l}\text { 1998: weth. na conflict met raad } \\
\text { 2000: weth. na conflict met raad } \\
\text { 2001: weth. na conflict met raad } \\
\text { 2004: weth. na conf. over bezuinigingen }\end{array}$ & 4 & 69 \\
\hline Alphen-Chaam & 9.445 & N-Brabant & $\begin{array}{l}\text { 1998: weth. } \\
\text { 2001: weth. }\end{array}$ & 2 & 145 \\
\hline Ameland & 3.503 & Friesland & 2001: weth. na extern onderzoek & 1 & 212 \\
\hline Amersfoort & 144.879 & Utrecht & $\begin{array}{l}\text { 2003: weth. - crisis } \\
\text { 2004: weth. }\end{array}$ & 3 & 97 \\
\hline Amstelveen & 80.722 & N-Holland & 2008: weth. & 1 & 213 \\
\hline Amsterdam & 767.849 & N-Holland & $\begin{array}{l}\text { 2001: } 2 \text { X weth., coalitiebreuk } \\
\text { 2000, 2004, 2005, 2008: weths. }\end{array}$ & 7 & 18 \\
\hline Andijk & 6.488 & N-Holland & $\begin{array}{l}\text { 2001: weth. na motie, coal. wissel } \\
\text { 2005: weth. }\end{array}$ & 3 & 98 \\
\hline
\end{tabular}




\begin{tabular}{|c|c|c|c|c|c|}
\hline Anna-Paulowna & 14.255 & $\mathrm{~N}-\mathrm{Holland}$ & geen bijzonderheden gemeld & 0 & 283 \\
\hline Apeldoorn & 155.775 & Gelderland & 2006: 4 weths., crisis (affaire Reesink) & 5 & 51 \\
\hline Appingedam & 12.046 & Groningen & $\begin{array}{l}\text { 2004: weth. } \\
\text { 2005: weth., crisis }\end{array}$ & 3 & 99 \\
\hline Arnhem & 147.244 & Gelderland & $\begin{array}{l}\text { 2008: weth. } \\
\text { 2009: weth. }\end{array}$ & 2 & 146 \\
\hline Assen & 66.874 & Drenthe & 2001: $2 \times$ weth., coalitiebreuk & 3 & 100 \\
\hline Asten & 16.342 & N-Brabant & $\begin{array}{l}\text { 2003: weth. op eigen initiatief } \\
\text { 2004: } 2 \text { x weth. }+ \text { collegecrisis }\end{array}$ & 3 & 101 \\
\hline Baarle-Nassau & 6.701 & N-Brabant & geen bijzonderheden gemeld & 0 & 284 \\
\hline Baarn & 24.364 & Utrecht & $\begin{array}{l}\text { 2004: weth. } \\
\text { 2008: weth. }\end{array}$ & 2 & 147 \\
\hline Barendrecht & 46.525 & Z-Holland & geen bijzonderheden gemeld & 0 & 285 \\
\hline Barneveld & 52.472 & Gelderland & 2004 en 2005 : weth. & 2 & 148 \\
\hline Bedum & 10.444 & Groningen & 2009: weth. na opspraak & 1 & 214 \\
\hline Beek & 16.586 & Limburg & 2005: weth., coalitiebreuk & 2 & 149 \\
\hline Beemster & 8.592 & $\mathrm{~N}-\mathrm{Holland}$ & geen bijzonderheden gemeld & 0 & 286 \\
\hline Beesel & 13.912 & Limburg & geen bijzonderheden gemeld & 0 & 287 \\
\hline Bellingwedde & 9.275 & Groningen & geen bijzonderheden gemeld & 0 & 288 \\
\hline Bergambacht & 9.733 & Z-Holland & geen bijzonderheden gemeld & 0 & 289 \\
\hline Bergeijk & 18.064 & N-Brabant & geen bijzonderheden gemeld & 0 & 290 \\
\hline Bergen & 30.989 & N-Holland & $\begin{array}{l}\text { 2004: crisis, college weg } \\
\text { 2009: weth. }\end{array}$ & 6 & 37 \\
\hline Bergen & 13.384 & Limburg & 2006: weth., coalitiebreuk & 2 & 150 \\
\hline Bergen op Zoom & 65.908 & N-Brabant & $\begin{array}{l}\text { 1998: weth. na conflict raad } \\
\text { 2003: weth. } \\
\text { 2009: weth. na afgestemde motie }\end{array}$ & 3 & 102 \\
\hline Berkelland & 44.968 & Gelderland & $\begin{array}{l}\text { 2006: weth. na vertr. partij uit coalitie } \\
\text { 2008: weth. na afgestemde motie }\end{array}$ & 3 & 103 \\
\hline Bernheze & 29.663 & N-Brabant & geen bijzonderheden gemeld & o & 291 \\
\hline Bernisse & 12.454 & Z-Holland & $\begin{array}{l}\text { 2005: } 2 \text { weths., collegecrisis } \\
\text { 2008: weth., CDA uit coalitie }\end{array}$ & 5 & 52 \\
\hline Best & 28.943 & N-Brabant & geen bijzonderheden gemeld & 0 & 292 \\
\hline Beuningen & 25.475 & Gelderland & geen officiële bijzonderheden gemeld & o & 293 \\
\hline Beverwijk & 38.850 & N-Holland & $\begin{array}{l}\text { 2000: } 2 \times \text { weth. } \\
\text { 2004: college valt, nieuwe coalitie } \\
\text { 2006: weth., nieuwe coalitie } \\
\text { 2008: weth. }\end{array}$ & 10 & 6 \\
\hline 't Bildt & 10.908 & Friesland & geen bijzonderheden gemeld & o & 294 \\
\hline Binnenmaas & 28.960 & Z-Holland & $\begin{array}{l}\text { 2007: weth., partij uit coalitie } \\
\text { 2008: weth. }\end{array}$ & 3 & 104 \\
\hline Bladel & 19.173 & N-Brabant & 2006: weth. na verlies vertrouwen raad & 1 & 215 \\
\hline Blaricum & 8.962 & N-Holland & $\begin{array}{l}\text { 2003: weth. } \\
\text { 2006: weth. }\end{array}$ & 2 & 151 \\
\hline Bloemendaal & 22.045 & N-Holland & $\begin{array}{l}\text { 1999: weth. conf. raad, coal.wis. } \\
\text { 2005: weth. na conflict, geen opvolging }\end{array}$ & 4 & 70 \\
\hline Boarnsterhim & 19.359 & Friesland & $\begin{array}{l}\text { 2001: weth. na motie } \\
\text { 2009: grote crisis, } 3 \text { weth. en bgm. weg }\end{array}$ & 6 & 38 \\
\hline Bodegraven & 19.434 & Z-Holland & 2008: collegecrisis, 2 weths. & 3 & 105 \\
\hline Boekel & 9.780 & N-Brabant & geen bijzonderheden gemeld & 0 & 295 \\
\hline Bolsward & 9.916 & Friesland & geen bijzonderheden gemeld & 0 & 296 \\
\hline Borger-Odoorn & 26.075 & Drenthe & geen bijzonderheden gemeld & 0 & 297 \\
\hline Borne & 21.332 & Overijssel & geen bijzonderheden gemeld & 0 & 298 \\
\hline
\end{tabular}




\begin{tabular}{|c|c|c|c|c|c|}
\hline Borsele & 22.643 & Zeeland & 2006: weth. & 1 & 216 \\
\hline Boskoop & 15.091 & Z-Holland & geen bijzonderheden gemeld & o & 299 \\
\hline Boxmeer & 28.575 & N-Brabant & 2008: weth., geen opvolger & 2 & 152 \\
\hline Boxtel & 30.300 & N-Brabant & geen bijzonderheden gemeld & 0 & 300 \\
\hline Breda & 173.445 & N-Brabant & $\begin{array}{l}\text { 2000: weth. na verlies vert. raad } \\
\text { 2009: weth. na verlies vert. fractie }\end{array}$ & 2 & 153 \\
\hline Breukelen & 14.610 & Utrecht & $\begin{array}{l}\text { 2002: collegecrisis, weth. } \\
\text { 2009: weth., crisis }\end{array}$ & 4 & 71 \\
\hline Brielle & $15 \cdot 752$ & Z-Holland & 2006: weth, probl. fractie, partij uit coal. & 2 & 154 \\
\hline Bronckhorst & 37.737 & Gelderland & 2008: weth. & 1 & 217 \\
\hline Brummen & 21.156 & Gelderland & 2005: weth., crisis & 2 & 155 \\
\hline Brunssum & 29.463 & Limburg & $\begin{array}{l}\text { Telefonisch: 1998: weth. } \\
\text { 2004: weth. na wisseling partij, partij uit } \\
\text { coalitie }\end{array}$ & 3 & 106 \\
\hline Bunnik & 14.473 & Utrecht & $\begin{array}{l}\text { 2003: weth. } \\
\text { 2004: weth. na conf. over bezuinigingen }\end{array}$ & 2 & 156 \\
\hline Bunschoten & 20.000 & Utrecht & $\begin{array}{l}\text { 2007: weth. na rapport } \\
\text { 2009: weth., crisis }\end{array}$ & 3 & 107 \\
\hline Buren & 25.880 & Gelderland & $\begin{array}{l}\text { 2004: weth. na verlies vertr. partij } \\
\text { 2007: weth. te weinig steun fractie } \\
\text { 2007: weth. na conflict met fractie }\end{array}$ & 3 & 108 \\
\hline Bussum & 32.128 & N-Holland & 2004: weth. vertrekt vrijwillig & 0 & 301 \\
\hline \begin{tabular}{|l} 
Capelle aan den \\
IJssel \\
\end{tabular} & 65.406 & Z-Holland & $\begin{array}{l}\text { 2005: weth. } \\
\text { 2008: weth., coalitiebreuk }\end{array}$ & 3 & 109 \\
\hline Castricum & 34.629 & N-Holland & $\begin{array}{l}\text { 2005: weth. } \\
\text { 2009: weth., crisis }\end{array}$ & 3 & 110 \\
\hline Coevorden & 36.146 & Drenthe & 2010: weth. na rapport & 1 & 218 \\
\hline Cranendonck & 20.344 & N-Brabant & $\begin{array}{l}\text { 2000: weth. na conflict met raad } \\
\text { 2003: weth. na conflict in college } \\
\text { 2004: weth., breuk in coalitie } \\
\text { 2008: coalitiebreuk, } 2 \text { weths. }\end{array}$ & 7 & 19 \\
\hline Cromstrijen & 12.835 & Z-Holland & 2003: weth. na coalitiebreuk & 2 & 157 \\
\hline Cuijk & 24.447 & N-Brabant & 2009: weth. & 1 & 219 \\
\hline Culemborg & 27.493 & Gelderland & 2004: grote crisis, 3 weths. en bgm. weg & 5 & 53 \\
\hline Dalfsen & 27.261 & Overijssel & geen bijzonderheden gemeld & 0 & 302 \\
\hline Dantumadeel & 19.289 & Friesland & geen bijzonderheden gemeld & o & 303 \\
\hline De Bilt & 42.072 & Utrecht & $\begin{array}{l}\text { 2002: weth. na conflict fractie } \\
\text { 2004: crisis, } 4 \text { weths. }\end{array}$ & 6 & 39 \\
\hline De Marne & 10.519 & Groningen & geen bijzonderheden gemeld & 0 & 304 \\
\hline De Ronde Venen & 34.411 & Utrecht & 2004: weth. na eigen keuze & 0 & 305 \\
\hline De Wolden & 23.549 & Drenthe & 2004: weth. conflict raad & 1 & 220 \\
\hline Delft & 96.691 & Z-Holland & 2005: weth. na kritiek & 1 & 221 \\
\hline Delfzijl & 26.642 & Groningen & $\begin{array}{l}\text { 1998: weth. na motie (coalitiewissel) } \\
\text { 1999: 2e ontslag uit solidariteit } \\
\text { 2000: weth. na vals kenteken (crisis) } \\
\text { 2003: weth. na beschuld. (coal. wissel) } \\
\text { 2003: bgm. na rapport, grote crisis } \\
\text { 2004: wethouder } \\
\text { 2006: grote crisis, bgm. en college weg }\end{array}$ & 16 & 1 \\
\hline Den Haag & 489.375 & Z-Holland & 2004: weth. na verlies vert. fractie & 1 & 222 \\
\hline Den Helder & 57.454 & N-Holland & $\begin{array}{l}\text { 1999: } 2 \times \text { weth., crisis } \\
\text { 2005: grote crisis, bgm en college } \\
\text { 2009: bgm na huisvestingprobleem }\end{array}$ & 10 & 7 \\
\hline
\end{tabular}




\begin{tabular}{|c|c|c|c|c|c|}
\hline Deurne & 31.536 & N-Brabant & geen bijzonderheden gemeld & 0 & 306 \\
\hline Deventer & 98.660 & Overijssel & 2009: $2 \times$ crisis, viteind. 2 weths. & 4 & 72 \\
\hline Diemen & 24.630 & N-Holland & $\begin{array}{l}\text { 2000: weth. na conflict met fractie } \\
\text { 2003: weth. na motie } \\
\text { 2004: weth. na motie, collegecrisis }\end{array}$ & 7 & 20 \\
\hline Dinkelland & 26.051 & Overijssel & $\begin{array}{l}\text { 2007: crisis rond burgemeester } \\
\text { 2008: weth. }\end{array}$ & 2 & 158 \\
\hline Dirksland & 8.439 & Z-Holland & geen bijzonderheden gemeld & 0 & 307 \\
\hline Doesburg & 11.606 & Gelderland & geen bijzonderheden gemeld & o & 308 \\
\hline Doetinchem & 56.111 & Gelderland & $\begin{array}{l}\text { 2004: weth. na vertr. breuk college } \\
\text { 2006: collegecrisis } \\
\text { 2010: weth. }\end{array}$ & 7 & 21 \\
\hline Dongen & 25.068 & N-Brabant & 2005: bgm weg na privé-kritiek & 1 & 223 \\
\hline Dongeradeel & 24.317 & Friesland & 2008: weth. & 1 & 224 \\
\hline Dordrecht & 118.607 & Z-Holland & 2007: weth. conflict raad & 1 & 225 \\
\hline Drechterland & 19.282 & N-Holland & $\begin{array}{l}\text { Fusiegemeente, geen bijzonderheden } \\
\text { gemeld }\end{array}$ & 0 & 309 \\
\hline Drimmelen & 26.570 & N-Brabant & $\begin{array}{l}\text { 2004: burgemeester na motie } \\
\text { 2004: weth. uit coal. na anon. beschuld. } \\
\text { 2006: weth. } \\
\text { 2007: weth. } \\
\text { 2008: crisis, } 2 \text { weths. }\end{array}$ & 8 & 13 \\
\hline Dronten & 39.825 & Flevoland & $\begin{array}{l}\text { 2004: coalitiecrisis } \\
\text { 2007: weth. }\end{array}$ & 4 & 73 \\
\hline Druten & 18.106 & Gelderland & $\begin{array}{l}\text { 2008: weth. + coalitiebreuk } \\
\text { 2009: weth., zelfde crisis }\end{array}$ & 3 & 111 \\
\hline Duiven & 25.624 & Gelderland & geen bijzonderheden gemeld & 0 & 310 \\
\hline Echt en Susteren & 32.321 & Limburg & $\begin{array}{l}\text { 2005: weth. } \\
\text { 2009: } 2 \text { x weth. na Sinterklaasaffaire }\end{array}$ & 3 & 112 \\
\hline Edam-Volendam & 28.520 & N-Holland & $\begin{array}{l}\text { 2000: } 2 \times \text { wet, coalitiecrisis } \\
\text { 2001: bgm. en weth. na cafebrand } \\
\text { 2007: } 2 \times \text { weth. }+ \text { crisis }\end{array}$ & 8 & 14 \\
\hline Ede & 107.832 & Gelderland & geen bijzonderheden gemeld & 0 & 311 \\
\hline Eemnes & 8.843 & Utrecht & 2009: crisis, twee weths. & 3 & 113 \\
\hline Eemsmond & 16.419 & Groningen & geen bijzonderheden gemeld & 0 & 312 \\
\hline Eersel & 18.166 & N-Brabant & 2001: weth. na conflict & 1 & 226 \\
\hline Eijsden & 11.439 & Limburg & 2004: college na motie van wantr. & 3 & 114 \\
\hline Eindhoven & 214.036 & N-Brabant & $\begin{array}{l}\text { 2004: weth. } \\
\text { 2005: } 3 \text { weths. + coalitiewissel }\end{array}$ & 5 & 54 \\
\hline Elburg & 22.193 & Gelderland & geen bijzonderheden gemeld & o & 313 \\
\hline Emmen & $109 \cdot 510$ & Drenthe & $\begin{array}{l}\text { 1999: weth. na conflict raad } \\
\text { 2003: weth. na conflict raad }\end{array}$ & 2 & 159 \\
\hline Enkhuizen & 18.186 & N-Holland & $\begin{array}{l}\text { 2000, 2003: weth. } \\
\text { 2004: weth. + crisis } \\
\text { 2007: weth. + crisis }\end{array}$ & 6 & 40 \\
\hline Enschede & 157.321 & Overijssel & 2000: 2 weths. na vuurwerkramp & 2 & 160 \\
\hline Epe & 32.892 & Gelderland & $\begin{array}{l}\text { 2001: weth. na twijfel over steun fractie } \\
\text { 2008: weth. weg als partij uit coal. stapt }\end{array}$ & 3 & 115 \\
\hline Ermelo & 26.261 & Gelderland & $\begin{array}{l}\text { 2009: weth. na ontvallen steun fractie, } \\
\text { geen opvolger }\end{array}$ & 2 & 161 \\
\hline Etten-Leur & 41.550 & N-Brabant & 2000: weth. na motie van wantrouwen & 1 & 227 \\
\hline Ferwerderadiel & 8.841 & Friesland & $\begin{array}{l}\text { Telefonisch: geen bijzonderheden } \\
\text { gemeld }\end{array}$ & 0 & 314 \\
\hline Franekeradeel & 20.621 & Friesland & geen bijzonderheden gemeld & 0 & 315 \\
\hline
\end{tabular}




\begin{tabular}{|c|c|c|c|c|c|}
\hline Gaasterlan-Sleat & 10.304 & Friesland & 2007: burgem. na probleem met raad & 1 & 228 \\
\hline Geertruidenberg & 21.104 & N-Brabant & 2005: weth. na conflict raad & 1 & 229 \\
\hline Geldermalsen & 26.261 & Gelderland & 2009: weth., geen opvolger & 2 & 162 \\
\hline Geldrop-Mierlo & 38.111 & N-Brabant & 2007: weth. na interne perikelen & 1 & 230 \\
\hline Gemert-Bakel & 28.751 & N-Brabant & geen bijzonderheden gemeld & o & 316 \\
\hline Gennep & 17.140 & Limburg & 2004: weth. na begrotingsperikelen & 1 & 231 \\
\hline Giessenlanden & 14.439 & Z-Holland & 2005: 2 weths. na coalitie/collegeconflict & 3 & 116 \\
\hline Gilze en Rijen & 25.973 & N-Brabant & geen bijzonderheden gemeld & 0 & 317 \\
\hline Goedereede & 11.426 & Z-Holland & $\begin{array}{l}\text { 2003: weth. na motie + coalitiewissel } \\
\text { 2004: burgemeester na conflict } \\
\text { 2005: weth. houdt eer aan zichzelf }\end{array}$ & 4 & 74 \\
\hline Goes & 36.643 & Zeeland & $\begin{array}{l}\text { wel enig gedoe rond collegevorming } \\
2006\end{array}$ & 0 & 318 \\
\hline Goirle & 22.804 & N-Brabant & $\begin{array}{l}\text { 2004: grote crisis, } 4 \text { weths. weg, } \\
\text { zakencollege gevormd }\end{array}$ & 5 & 55 \\
\hline Gorinchem & 34.621 & Z-Holland & 2000: $4 \times$ weth. na bestuurscrisis & 5 & 56 \\
\hline Gouda & 71.167 & Z-Holland & $\begin{array}{l}\text { 2001: weth. na conflict partij } \\
\text { 2005: weth. na verlies vertrouwen partij, } \\
\text { geen opvolger. }\end{array}$ & 3 & 117 \\
\hline Graafstroom & 9.814 & Z-Holland & geen bijzonderheden gemeld & 0 & 319 \\
\hline Graft De Rijp & 6.499 & N-Holland & $\begin{array}{l}\text { 2000: crisis om bouw gemeentehuis } \\
\text { 2004: weth. na conflict, coalitiewissel }\end{array}$ & 4 & 75 \\
\hline Grave & 12.900 & N-Brabant & 2008: weth., geen opvolger & 2 & 163 \\
\hline Groesbeek & 18.947 & Gelderland & 2004: grote crisis, 3 weths. weg & 4 & 76 \\
\hline Groningen & 187.622 & Groningen & 2004: conflict met eigen fractie & 1 & 232 \\
\hline Grootegast & 12.129 & Groningen & 2005: weth. na conflict met raad & 2 & 164 \\
\hline Gulpen-Wittem & 14.597 & Limburg & $\begin{array}{l}\text { 2000: weth. } \\
\text { 2005: weth. } \\
\text { 2009: } 2 \times \text { weth. en crisis }\end{array}$ & 5 & 57 \\
\hline Haaksbergen & 24.482 & Overijssel & geen bijzonderheden gemeld & 0 & 320 \\
\hline Haaren & 13.639 & N-Brabant & $\begin{array}{l}\text { 2009: weth. na moties tegen beleid, } \\
\text { crisis }\end{array}$ & 2 & 165 \\
\hline Haarlem & $149 \cdot 516$ & N-Holland & $\begin{array}{l}\text { 2000: weth. na conflict raad } \\
\text { 2001: weth. na conflict fractie }\end{array}$ & 2 & 166 \\
\hline $\begin{array}{l}\text { Haarlemmerl.- } \\
\text { Spaarnw. }\end{array}$ & 5.404 & N-Holland & geen bijzonderheden gemeld & 0 & 321 \\
\hline Haarlemmermeer & 142.882 & N-Holland & $\begin{array}{l}\text { 1998, 2003, } 2005 \text { ( } 2 x \text {, partij uit coalitie) } \\
\text { 2006: weth., later bgm. na Schiphol- } \\
\text { brand }\end{array}$ & 7 & 22 \\
\hline Halderberge & 29.300 & N-Brabant & $\begin{array}{l}\text { 2007: weth. weg, coalitiecrisis } \\
\text { 2008: weth. }\end{array}$ & 3 & 118 \\
\hline Hardenberg & 59.016 & Overijssel & $\begin{array}{l}\text { 2002: weth. voorvitlopend op conflict } \\
\text { 2004: weth. na conf. met raad, coal.br. }\end{array}$ & 3 & 119 \\
\hline Harderwijk & 44.052 & Gelderland & 2009: weth. na onvold. vertr. raad & 1 & 233 \\
\hline \begin{tabular}{|l} 
Hardinxveld- \\
Giessendam
\end{tabular} & 17.500 & Z-Holland & $\begin{array}{l}\text { 2003: weth., collegewissel } \\
\text { 2004: 2x weth., } 2 \text { collegewissels }\end{array}$ & 6 & 41 \\
\hline Haren & 18.535 & Groningen & 2009: coalitiebreuk, 1 weth. & 2 & 167 \\
\hline Harenkarspel & 16.076 & N-Holland & $\begin{array}{l}\text { 2004: conflict met raad } \\
\text { 2008: collegecrisis, } 3 \text { weths. weg }\end{array}$ & 5 & 58 \\
\hline Harlingen & 15.800 & Friesland & 2007: weth. boos weg na rapport & 1 & 234 \\
\hline Hattem & 11.797 & Gelderland & Tel: geen bijzonderheden gemeld & 0 & 322 \\
\hline Heemskerk & 38.892 & N-Holland & geen bijzonderheden gemeld & 0 & 323 \\
\hline Heemstede & 26.060 & N-Holland & 2007: weth. na gebrek steun raad & 1 & 235 \\
\hline
\end{tabular}




\begin{tabular}{|c|c|c|c|c|c|}
\hline Heerde & 18.329 & Gelderland & 2005: weth. vertrekt, maar komt terug & 0 & 324 \\
\hline Heerenveen & 43.391 & Friesland & geen bijzonderheden gemeld & 0 & 325 \\
\hline Heerhugowaard & 51.253 & N-Holland & $\begin{array}{l}\text { 2002: weth. na motie } \\
\text { 2003: motiedreiging } \\
\text { 2009: weth., geen opvolger }\end{array}$ & 4 & 77 \\
\hline Heerlen & 89.267 & Limburg & $\begin{array}{l}\text { 2004: } 2 \times \text { weth., coal. wissel } \\
\text { 2005: weth., coal. wissel } \\
\text { 2007: weth. }\end{array}$ & 6 & 42 \\
\hline Heeze-Leende & 15.277 & N-Brabant & $\begin{array}{l}\text { Geen eigen reactie. Uit media: } \\
\text { 1999: weth. na motie } \\
\text { 2004: } 3 \text { weths. en bgm. weg, } 2 \text { x crisis }\end{array}$ & 7 & 23 \\
\hline Heiloo & 22.459 & N-Holland & geen bijzonderheden gemeld & 0 & 326 \\
\hline Hellendoorn & 35.784 & Overijssel & geen bijzonderheden gemeld & o & 327 \\
\hline Hellevoetsluis & 39.799 & Z-Holland & 2008: weth. na conflict met raad & 1 & 236 \\
\hline Helmond & 88.338 & N-Brabant & 2000: weth. & 1 & 237 \\
\hline $\begin{array}{l}\text { Hendrik-Ido- } \\
\text { Ambacht }\end{array}$ & 26.864 & Z-Holland & geen bijzonderheden gemeld & o & 328 \\
\hline Hengelo & 80.809 & Overijssel & geen bijzonderheden gemeld & 0 & 329 \\
\hline 's-Hertogenbosch & 139.754 & N-Brabant & $\begin{array}{l}\text { 1998: collegecrisis, } 3 \text { weths. } \\
2000+2001 \text { (+ coal. wissel): weth. }\end{array}$ & 7 & 24 \\
\hline Heumen & 16.646 & Gelderland & $\begin{array}{l}\text { 2001, 2003: weth. en coal. wissel } \\
\text { 2007: weth. na conflict }\end{array}$ & 5 & 59 \\
\hline Heusden & 42.981 & N-Brabant & 2001: geen vertrouwen binnen college & 2 & 168 \\
\hline Hillegom & 20.489 & Z-Holland & 2008: weth., coalitiewissel & 2 & 169 \\
\hline Hilvarenbeek & 14.984 & N-Brabant & 2007: weth., coalitiecrisis & 2 & 170 \\
\hline Hilversum & 84.573 & N-Holland & $\begin{array}{l}\text { 1998: collegecrisis ( } 3 \text { weths.) } \\
\text { 2000: weth. conflict met raad } \\
\text { 2001: collegecrisis (3 weths.) } \\
\text { 2004: weth. } \\
\text { 2007: privé, maar na forse kritiek }\end{array}$ & 10 & 8 \\
\hline Hof van Twente & 35.464 & Overijssel & geen bijzonderheden gemeld & 0 & 330 \\
\hline Hoogeveen & 54.787 & Drenthe & $\begin{array}{l}\text { 2002: weth. na fouten } \\
\text { 2007: weth. na publicaties }\end{array}$ & 2 & 171 \\
\hline Hoogezand-Sap. & 34.787 & Groningen & 2001: weth. na verlies vertrouwen & 1 & 238 \\
\hline Hoorn & 70.206 & N-Holland & $\begin{array}{l}\text { 1999: weth. persoonlijk } \\
\text { 2008: weth., coalitiebreuk }\end{array}$ & 2 & 172 \\
\hline $\begin{array}{l}\text { Horst aan de } \\
\text { Maas }\end{array}$ & 41.436 & Limburg & geen bijzonderheden gemeld & 0 & 331 \\
\hline Houten & 47.682 & Utrecht & 2001: collegecrisis, 2 weths. & 3 & 120 \\
\hline Huizen & 41.940 & N-Holland & $\begin{array}{l}\text { 2000: weth. weg } \\
\text { 2010: burgemeester weg }\end{array}$ & 2 & 173 \\
\hline Hulst & 27.855 & Zeeland & geen bijzonderheden gemeld & 0 & 332 \\
\hline IJsselstein & 34.246 & Utrecht & 2004: 3 weths. Weg, crisis & 4 & 78 \\
\hline Kaag en Braasem & 25.662 & Z-Holland & nog geen gegevens, nieuwe gemeente & 0 & 333 \\
\hline Kampen & 50.073 & Overijssel & $\begin{array}{l}\text { 2003: weth. na druk partij } \\
\text { 2007: weth. na motie, partij uit coalitie } \\
\text { 2008: coalitiecrisis, } 2 \text { weths. weg }\end{array}$ & 6 & 43 \\
\hline Kapelle & 12.423 & Zeeland & $\begin{array}{l}\text { 2004: weth.+ coll wisseling } \\
\text { 2006: weth. }\end{array}$ & 3 & 121 \\
\hline Katwijk & 61.831 & Z-Holland & 2005: weth. na conflict & 1 & 239 \\
\hline Kerkrade & 47.681 & Limburg & geen bijzonderheden gemeld & 0 & 334 \\
\hline Koggenland & 21.985 & $\mathrm{~N}-\mathrm{Holland}$ & Fusiegemeente, geen bijz. gemeld & 0 & 335 \\
\hline Kollumerland c.a. & 13.002 & Friesland & geen bijzonderheden gemeld & 0 & 336 \\
\hline
\end{tabular}




\begin{tabular}{|c|c|c|c|c|c|}
\hline Korendijk & 10.887 & Z-Holland & 2009: weth. onvold. steun fractie & 1 & 240 \\
\hline \begin{tabular}{|l|} 
Krimpen aan den \\
IJssel
\end{tabular} & 28.832 & Z-Holland & $\begin{array}{l}\text { geen bijzonderheden gemeld. Wel weth. } \\
\text { weg om dualisme }\end{array}$ & 0 & 337 \\
\hline Laarbeek & 21.599 & N-Brabant & 1999: weth. na motie & 1 & 241 \\
\hline Landerd & 14.894 & N-Brabant & $\begin{array}{l}\text { 2007: weth. na vertrouwensbreuk } \\
\text { college }\end{array}$ & 2 & 174 \\
\hline Landgraaf & 38.452 & Limburg & $\begin{array}{l}\text { 1999: weth. } \\
\text { 2004: crisis, partij uit coalitie }\end{array}$ & 3 & 122 \\
\hline Landsmeer & 10.240 & $\mathrm{~N}-\mathrm{Holland}$ & 2003: crisis, 3 weths. & 4 & 79 \\
\hline Langedijk & 26.993 & $\mathrm{~N}$-Holland & geen bijzonderheden gemeld & 0 & 338 \\
\hline Lansingerland & 52.535 & Z-Holland & geen bijzonderheden gemeld & 0 & 339 \\
\hline Laren & 11.342 & $\mathrm{~N}-\mathrm{Holland}$ & geen bijzonderheden gemeld & 0 & 340 \\
\hline Leek & 19.365 & Groningen & geen bijzonderheden gemeld & 0 & 341 \\
\hline Leerdam & 20.758 & Z-Holland & $\begin{array}{l}\text { 1998: val college ( } 2 \text { weths.) } \\
\text { 2000: val college ( } 2 \text { weths.) } \\
\text { 2003: weth. probleem coll., coal.wissel } \\
\text { 2007: weth., probleem fractie }\end{array}$ & 9 & 10 \\
\hline Leeuwarden & 94.131 & Friesland & $\begin{array}{l}\text { 2001: burgemeester } \\
\text { 2002: weth. }\end{array}$ & 2 & 175 \\
\hline Leeuwarderadiel & 10.431 & Friesland & 2002: weth. & 1 & 242 \\
\hline Leiden & $117 \cdot 342$ & Z-Holland & $\begin{array}{l}\text { 1999: weth. + coalitiewissel } \\
\text { 2000: } 2 \text { x wethouder } \\
\text { 2002: wethouder + (separaat) bgm } \\
\text { 2004: wethouder } \\
\text { 2007: coalitiecrisis } \\
\text { 2010: weth., coalitiebreuk }\end{array}$ & 13 & 2 \\
\hline Leiderdorp & 26.420 & Z-Holland & $\begin{array}{l}\text { 2004: weth. na motie } \\
\text { 2005: idem } \\
\text { 2008: weth., coalitiecrisis }\end{array}$ & 4 & 80 \\
\hline \begin{tabular}{|l} 
Leidschendam- \\
Voorburg
\end{tabular} & 72.226 & Z-Holland & 2009: weth. na problemen met fractie & 1 & 243 \\
\hline Lelystad & 74.682 & Flevoland & 2009: weth., VVD uit coalitie & 2 & 176 \\
\hline Lemsterland & 13.615 & Friesland & geen bijzonderheden gemeld & 0 & 342 \\
\hline Leudal & 36.795 & Limburg & $\begin{array}{l}\text { fusiegemeente, geen problemen ge- } \\
\text { meld }\end{array}$ & 0 & 343 \\
\hline Leusden & 28.829 & Utrecht & geen bijzonderheden gemeld & 0 & 344 \\
\hline Liesveld & 9.745 & Z-Holland & geen bijzonderheden gemeld & 0 & 345 \\
\hline Lingewaal & 10.900 & Gelderland & geen bijzonderheden gemeld & 0 & 346 \\
\hline Lingewaard & 45.453 & Gelderland & 2001: crisis na start gemeente, 2 weths. & 3 & 123 \\
\hline Lisse & 22.321 & Z-Holland & $\begin{array}{l}\text { 2005: } 2 \times \text { weth. } \\
\text { 2006: weth. }\end{array}$ & 3 & 124 \\
\hline Lith & 6.656 & N-Brabant & 2005: weths. na moties & 3 & 125 \\
\hline Littenseradiel & 10.921 & Friesland & geen bijzonderheden gemeld & 0 & 347 \\
\hline Lochem & 33.437 & Gelderland & 2006: conflict college-raad, 3 weths. & 4 & 81 \\
\hline Loenen & 8.475 & Utrecht & $\begin{array}{l}\text { 2005: coalitiebreuk, } 2 \times \text { weth. } \\
\text { 2008: weth. }\end{array}$ & 4 & 82 \\
\hline Loon op Zand & 23.027 & N-Brabant & geen bijzonderheden gemeld & 0 & 348 \\
\hline Lopik & 14.181 & Utrecht & geen bijzonderheden gemeld & 0 & 349 \\
\hline Loppersum & 10.439 & Groningen & tel: weinig tijd (art. 12), geen meldingen & 0 & 350 \\
\hline Losser & 22.640 & Overijssel & $\begin{array}{l}\text { 2004: crisis om Landesgartenschau } \\
\text { 2008: weth. } \\
\text { 2009: } 3 \text { weths., crisis, hierna } \\
\text { college van buiten }\end{array}$ & 11 & 3 \\
\hline
\end{tabular}




\begin{tabular}{|c|c|c|c|c|c|}
\hline Maarssen & 39.707 & Utrecht & 2001: weth. weg na pol. tegenstellingen & 2 & 177 \\
\hline Maasdonk & 11.219 & N-Brabant & $\begin{array}{l}\text { 1999: weth. weg, best.crisis } \\
\text { 2007: weth. weg, partij vit coalitie } \\
\text { 2007: burgemeester weg }\end{array}$ & 5 & 60 \\
\hline Maasdriel & 23.770 & Gelderland & 2006: weth. & 1 & 244 \\
\hline Maasgouw & 24.318 & Limburg & Herindeling in 2001, verder geen bijz. & 0 & 351 \\
\hline Maassluis & 31.625 & Z-Holland & 2005: weth. na conflict met partij & 1 & 245 \\
\hline Maastricht & 118.597 & Limburg & $\begin{array}{l}\text { 2004: } 2 \times \text { weth. na confl. raad en fractie } \\
\text { 2010: bgm. na dreigende motie }\end{array}$ & 3 & 126 \\
\hline Margraten & 13.400 & Limburg & geen bijzonderheden gemeld & 0 & 352 \\
\hline Marum & 10.461 & Groningen & 2008: weth. na vertr. breuk fractie & 1 & 246 \\
\hline Medemblik & 27.366 & $\mathrm{~N}-\mathrm{Holland}$ & Herindeling, geen bijzonderh. gemeld & 0 & 353 \\
\hline Meerssen & 19.567 & Limburg & 2008: weth., nieuwe coalitie & 2 & 178 \\
\hline Menaldumadeel & 13.756 & Friesland & geen bijzonderheden gemeld & 0 & 354 \\
\hline Menterwolde & 12.486 & Groningen & $\begin{array}{l}\text { 2005: burgemeester } \\
\text { 2006: weth. en coalitiebreuk }\end{array}$ & 3 & 127 \\
\hline Meppel & 32.399 & Drenthe & geen bijzonderheden gemeld & 0 & 355 \\
\hline Middelburg & 48.019 & Zeeland & $\begin{array}{l}\text { 2000: bgm na conflict raad, } 2 \times \text { weth. } \\
\text { conflict fractie } \\
\text { 2001: wnd bgm confl raadsfractie } \\
\text { 2005: } 2 \text { x weth. na coalitiebreuk } \\
\end{array}$ & 7 & 25 \\
\hline Middelharnis & 17.966 & Z-Holland & geen bijzonderheden gemeld & 0 & 356 \\
\hline Midden-Delfland & 17.905 & Z-Holland & $\begin{array}{l}\text { 2008: coalitiebreuk, weth. door voor } \\
\text { andere partij }\end{array}$ & 1 & 247 \\
\hline Midden-Drenthe & 33.586 & Drenthe & geen bijzonderheden gemeld & 0 & 357 \\
\hline Mill en St. Hubert & 11.036 & N-Brabant & geen bijzonderheden gemeld & 0 & 358 \\
\hline $\begin{array}{l}\text { Millingen aan de } \\
\text { Rijn }\end{array}$ & 5.919 & Gelderland & $\begin{array}{l}\text { 2000: weth. } \\
\text { 2004: burgemeester } \\
\text { 2005: weth. na motie, coal. wissel } \\
\text { 2007: weth. }\end{array}$ & 5 & 61 \\
\hline Moerdijk & 36.556 & N-Brabant & geen bijzonderheden gemeld & 0 & 359 \\
\hline Montferland & 35.183 & Gelderland & oud-weth. werd burgemeester & 0 & 360 \\
\hline Montfoort & 13.494 & Utrecht & geen bijzonderheden gemeld & 0 & 361 \\
\hline \begin{tabular}{|l|} 
Mook en \\
Middelaar \\
\end{tabular} & 8.069 & Limburg & 2002: weth. na conflict fractie & 1 & 248 \\
\hline Muiden & 6.510 & $\mathrm{~N}-\mathrm{Holland}$ & $\begin{array}{l}\text { 1999: weth. } \\
\text { 2000: crisis, } 1 \text { weth. } \\
\text { 2004: crisis, } 3 \text { weths. }\end{array}$ & 7 & 26 \\
\hline Naarden & 17.038 & $\mathrm{~N}-\mathrm{Holland}$ & 2009: coalitiebreuk, 1 weth. & 2 & 179 \\
\hline Neder-Betuwe & 22.555 & Gelderland & 2008: weth. na conflict met fractie & 1 & 249 \\
\hline Nederlek & 14.109 & Z-Holland & 2004: weth. na motie van wantrouwen & 1 & 250 \\
\hline Nederweert & 16.619 & Limburg & 2008: weth., coalitiebreuk & 2 & 180 \\
\hline Neerijnen & 11.873 & Gelderland & 2004: weth, coalitie blijft intact & 1 & 251 \\
\hline Niedorp & 12.135 & $\mathrm{~N}-\mathrm{Holland}$ & $\begin{array}{l}\text { 2004: weth. na motie } \\
\text { 2009: weth. }\end{array}$ & 2 & 181 \\
\hline Nieuwegein & 60.846 & Utrecht & $\begin{array}{l}\text { 2003: weth. en partij na motie } \\
\text { 2009: weth. na conflict partij }\end{array}$ & 3 & 128 \\
\hline Nieuwkoop & 26.939 & Z-Holland & $\begin{array}{l}\text { Fusiegemeente } \\
\text { 2009: weth. na scheuring partij }\end{array}$ & 2 & 182 \\
\hline \begin{tabular}{|l|} 
Nieuw- \\
Lekkerland
\end{tabular} & 9.535 & Z-Holland & bgm. na dreiging geen herbenoeming & 1 & 252 \\
\hline Nijefurd & 10.957 & Friesland & geen bijzonderheden gemeld & 0 & 362 \\
\hline
\end{tabular}




\begin{tabular}{|c|c|c|c|c|c|}
\hline Nijkerk & 39.544 & Gelderland & geen bijzonderheden gemeld & 0 & 363 \\
\hline Nijmegen & 162.932 & Gelderland & $\begin{array}{l}\text { 1998: } 2 \text { weths. na conflict college } \\
\text { 2001: weth. na conflict met raad } \\
\text { 2009: weth. na problemen. Later grote } \\
\text { crisis (totaal } 6 \text { weth. demissionair) } \\
\end{array}$ & 11 & 4 \\
\hline Noord-Beveland & 7.408 & Zeeland & 2001: weth. & 1 & 253 \\
\hline Noordenveld & 30.804 & Drenthe & 2003: weth. & 1 & 254 \\
\hline Noordoostpolder & 46.102 & Flevoland & $\begin{array}{l}\text { 2004: weth. } \\
\text { 2007: collegecrisis, weth. }\end{array}$ & 3 & 129 \\
\hline Noordwijk & 25.424 & Z-Holland & $\begin{array}{l}\text { 2000: weth. } \\
\text { 2004: crisis, } 2 \text { weths. }\end{array}$ & 4 & 83 \\
\hline Noordwijkerhout & 15.541 & Z-Holland & 2008: weth. na onvold. vertrouwen & 1 & 255 \\
\hline Nuenen ca & 22.227 & N-Brabant & $\begin{array}{l}\text { 1998: 2x weth. } \\
\text { 1999, 2000, 2006: weth. } \\
\text { 2007: weth. na vertrouwensbr. fractie }\end{array}$ & 6 & 44 \\
\hline Nunspeet & 26.670 & Gelderland & 2004: weth. & 1 & 256 \\
\hline Nuth & 15.681 & Limburg & 2008: crisis, viteindelijk 3 weths. & 4 & 84 \\
\hline Oegstgeest & 22.622 & Z-Holland & $\begin{array}{l}\text { 1999: weth. gebrek draagvlak } \\
\text { 2000: weth. conflict fractie } \\
\text { 2005: weth. na motie van wantrouwen }\end{array}$ & 3 & 130 \\
\hline Oirschot & 17.749 & N-Brabant & 2009: crisis, 3 weths. Weg & 4 & 85 \\
\hline Oisterwijk & 25.845 & N-Brabant & 2008: geen herbenoeming bgm. & 1 & 257 \\
\hline Oldambt & 39.428 & Groningen & Fusiegemeente, nog geen gegevens & 0 & 364 \\
\hline Oldebroek & 22.765 & Gelderland & 2001: weth. na verlies vertrouwen & 1 & 258 \\
\hline Oldenzaal & 31.976 & Overijssel & geen bijzonderheden gemeld & 0 & 365 \\
\hline Olst-Wijhe & 17.536 & Overijssel & geen bijzonderheden gemeld & o & 366 \\
\hline Ommen & 17.402 & Overijssel & 2007: weth. na coalitiebreuk & 2 & 183 \\
\hline Onderbanken & 8.082 & Limburg & geen bijzonderheden gemeld & 0 & 367 \\
\hline Oost Gelre & 30.028 & Gelderland & 2007: weth. na aankondiging motie & 1 & 259 \\
\hline Oosterhout & 54.164 & N-Brabant & $\begin{array}{l}\text { 1999: grote crisis, } 2 \text { weths. weg } \\
\text { 2000: burgemeester na rapport }\end{array}$ & 4 & 86 \\
\hline Oostflakkee & 10.384 & Z-Holland & geen bijzonderheden gemeld & 0 & 368 \\
\hline Ooststellingwerf & 26.209 & Friesland & 2000: weth. na verlies vertr. partij & 1 & 260 \\
\hline Oostzaan & 9.152 & N-Holland & $\begin{array}{l}\text { 2003: college om Irak, crisis } \\
\text { 2004: weth. na motie, crisis }\end{array}$ & 4 & 87 \\
\hline Opmeer & 11.382 & $\mathrm{~N}-\mathrm{Holland}$ & 2003: weth. na verlies vertrouwen & 1 & 261 \\
\hline Opsterland & 30.048 & Friesland & 2010: weth. na motie, geen opv. & 2 & 184 \\
\hline Oss & 77.405 & N-Brabant & 2000: collegecrisis, 4 weths. & 5 & 62 \\
\hline Oud-Beijerland & 23.564 & Z-Holland & $\begin{array}{l}\text { 2002: weth. na dreigende motie } \\
\text { 2004: coalitiecrisis, } 3 \text { weths. } \\
\text { 2009: weth. na conflict raad }\end{array}$ & 7 & 27 \\
\hline Oude IJsselstreek & 39.895 & Gelderland & geen bijzonderheden gemeld & 0 & 369 \\
\hline Ouder-Amstel & 13.094 & N-Holland & geen bijzonderheden gemeld & 0 & 370 \\
\hline Ouderkerk & 8.145 & Z-Holland & $\begin{array}{l}\text { 2002: weth. week voor verkiezingen } \\
\text { 2004: weth. na conf. fractie, coal. breuk }\end{array}$ & 3 & 131 \\
\hline Oudewater & 9.853 & Utrecht & geen bijzonderheden gemeld & 0 & 371 \\
\hline Overbetuwe & 45.546 & Gelderland & geen bijzonderheden gemeld & 0 & 372 \\
\hline Papendrecht & 31.838 & Z-Holland & 2003: weth. 2005: weth. & 2 & 185 \\
\hline Peel en Maas & 43.020 & Limburg & Fusiegemeente, nog geen gegevens & 0 & 373 \\
\hline Pekela & 13.038 & Groningen & geen bijzonderheden gemeld & 0 & 374 \\
\hline $\begin{array}{l}\text { Pijnacker- } \\
\text { Nootdorp }\end{array}$ & 47.891 & Z-Holland & $\begin{array}{l}\text { 2009: weth. en coalitiebreuk over } \\
\text { IJslands geld }\end{array}$ & 2 & 186 \\
\hline
\end{tabular}




\begin{tabular}{|c|c|c|c|c|c|}
\hline Purmerend & 79.035 & $\mathrm{~N}$-Holland & 2005: weth., coalitiebreuk & 2 & 187 \\
\hline Putten & 23.610 & Gelderland & $\begin{array}{l}\text { 2000: weth. } \\
\text { 2007: weth., coalitiebreuk }\end{array}$ & 3 & 132 \\
\hline Raalte & 36.791 & Overijssel & $\begin{array}{l}\text { 2004: weth. }+ \text { crisis } \\
\text { 2007: burgemeester }\end{array}$ & 3 & 133 \\
\hline Reeuwijk & 13.055 & Z-Holland & geen bijzonderheden gemeld & 0 & 375 \\
\hline Reimerswaal & 21.450 & Zeeland & geen bijzonderheden gemeld & 0 & 376 \\
\hline Renkum & 31.684 & Gelderland & 2004: collegecrisis, 3 weths. & 4 & 88 \\
\hline Renswoude & 4.612 & Utrecht & geen bijzonderheden gemeld & 0 & 377 \\
\hline \begin{tabular}{|l} 
Reusel- \\
De Mierden
\end{tabular} & 12.564 & N-Brabant & $\begin{array}{l}\text { 2004: collegecrisis, } 2 \text { weths. } \\
\text { 2008: weth., geen opvolger }\end{array}$ & 5 & 63 \\
\hline Rheden & 43.718 & Gelderland & $\begin{array}{l}\text { 2004: weth. na conflict met raad } \\
\text { 2005: weth. na coalitiebreuk } \\
\text { 2006-2007: crisis, andere coalitie } \\
\text { 2008: weth. }\end{array}$ & 7 & 28 \\
\hline Rhenen & 18.849 & Utrecht & 2003: weth. na spanning in coalitie & 2 & 188 \\
\hline Ridderkerk & 44.826 & Z-Holland & geen bijzonderheden gemeld & 0 & 378 \\
\hline Rijnwaarden & 11.064 & Gelderland & geen bijzonderheden gemeld & 0 & 379 \\
\hline Rijnwoude & 18.564 & Z-Holland & geen bijzonderheden gemeld & 0 & 380 \\
\hline Rijssen-Holten & 37.082 & Overijssel & 2007: weth. na integriteitonderzoek & 1 & 262 \\
\hline Rijswijk & 46.752 & Z-Holland & 2003: weth. & 1 & 263 \\
\hline Roerdalen & 21.298 & Limburg & Fusiegemeente. 2008: coalitiecrisis & 3 & 134 \\
\hline Roermond & 55.176 & Limburg & $\begin{array}{l}\text { 2003: weth. verliest vertr partij } \\
\text { 2004: weth. en partij uit coalitie }\end{array}$ & 3 & 135 \\
\hline Roosendaal & 77.571 & N-Brabant & $\begin{array}{l}\text { 2001: weth. conflict raad } \\
\text { 2008: } 2 \text { weths., crisis }\end{array}$ & 4 & 89 \\
\hline Rotterdam & 590.131 & Z-Holland & $\begin{array}{l}\text { 2004: weth. na verlies vertrouwen fractie } \\
\text { 2005: weth. na motie } \\
\text { 2008: weth. } \\
\text { 2009: } 2 \text { x weth. na coalitiebreuk }\end{array}$ & 6 & 45 \\
\hline Rozenburg & 12.489 & Z-Holland & $\begin{array}{l}\text { 2000: weth., coalitiebreuk } \\
\text { 2008: weth., coalitiebreuk }\end{array}$ & 4 & 90 \\
\hline Rozendaal & 1.499 & Gelderland & geen bijzonderheden gemeld & 0 & 381 \\
\hline Rucphen & 22.489 & N-Brabant & $\begin{array}{l}\text { 2004: weth. na vert. breuk coalitie } \\
\text { 2008: weth. breuk fractie }\end{array}$ & 3 & 136 \\
\hline Schagen & 18.722 & N-Holland & geen bijzonderheden gemeld. & 0 & 382 \\
\hline Schermer & 5.361 & N-Holland & geen bijzonderheden gemeld & 0 & 383 \\
\hline Scherpenzeel & 9.320 & Gelderland & 2008: collegecrisis, weth. & 2 & 189 \\
\hline Schiedam & 75.792 & Z-Holland & $\begin{array}{l}\text { 2004: bijna crisis } \\
\text { 2005: weth. }\end{array}$ & 1 & 264 \\
\hline Schiermonnikoog & 941 & Friesland & geen bijzonderheden gemeld & 0 & 384 \\
\hline Schijndel & 22.994 & N-Brabant & 1999: weth. na motie, coal. breuk & 2 & 190 \\
\hline Schinnen & 13.504 & Limburg & $\begin{array}{l}\text { 2007: weth., coalitiebreuk } \\
\text { 2008: weth. vlg. afspraak (niet geteld) }\end{array}$ & 2 & 191 \\
\hline Schoonhoven & 11.986 & Z-Holland & $\begin{array}{l}\text { 2003: weth. } \\
\text { 2008: weth. weg, coalitiebreuk }\end{array}$ & 3 & 137 \\
\hline $\begin{array}{l}\text { Schouwen- } \\
\text { Duiveland }\end{array}$ & 34.131 & Zeeland & $\begin{array}{l}\text { 2001: weth na vertr. breuk in college } \\
\text { 2003: weth. na conflict partij } \\
\text { 2004: college valt, } 4 \text { weths. }\end{array}$ & 7 & 29 \\
\hline Simpelveld & 10.995 & Limburg & geen bijzonderheden gemeld & 0 & 385 \\
\hline Sint Anthonis & 11.846 & N-Brabant & geen bijzonderheden gemeld & 0 & 386 \\
\hline \begin{tabular}{|l|} 
Sint- \\
Michielsgestel
\end{tabular} & 28.128 & N-Brabant & 2005: weth. na motie van ongenoegen & 1 & 265 \\
\hline
\end{tabular}




\begin{tabular}{|c|c|c|c|c|c|}
\hline Sint-Oedenrode & 17.687 & N-Brabant & geen bijzonderheden gemeld & 0 & 387 \\
\hline Sittard-Geleen & 95.213 & Limburg & $\begin{array}{l}\text { 2002: weth. na discussie raad } \\
\text { 2003: crisis ( } 6 \text { weths.) } \\
\text { 2005: weth. en burgemeester }\end{array}$ & 11 & 5 \\
\hline Skarsterlan & 27.295 & Friesland & weth. zelf opgestapt & 0 & 388 \\
\hline Sliedrecht & 24.061 & Z-Holland & weth. zelf opgestapt & 0 & 389 \\
\hline Slochteren & 15.577 & Groningen & geen bijzonderheden gemeld & 0 & 390 \\
\hline Sluis & 24.093 & Zeeland & $\begin{array}{l}\text { 2006: coalitiecrisis, } 4 \text { weths. } \\
\text { 2007: weth. na vertr. fractie } \\
\text { 2009: weth. na collegebesluit }\end{array}$ & 7 & 30 \\
\hline Smallingerland & 55.294 & Friesland & 1998: weth. na diverse problemen & 1 & 266 \\
\hline Sneek & 33.427 & Friesland & geen bijzonderheden gemeld & 0 & 391 \\
\hline Soest & 45.732 & Utrecht & $\begin{array}{l}\text { telefonisch: geen bijzonderheden } \\
\text { gemeld }\end{array}$ & 0 & 392 \\
\hline Someren & 18.249 & N-Brabant & geen bijzonderheden gemeld & 0 & 393 \\
\hline Son en Breugel & 15.538 & N-Brabant & geen bijzonderheden gemeld & 0 & 394 \\
\hline Spijkenisse & 72.442 & Z-Holland & geen bijzonderheden gemeld & 0 & 395 \\
\hline Stadskanaal & 33.451 & Groningen & geen bijzonderheden gemeld & 0 & 396 \\
\hline Staphorst & 16.154 & Overijssel & geen bijzonderheden gemeld & 0 & 397 \\
\hline Stede Broec & 21.268 & N-Holland & 2003: 3 weths. na confl raad & 4 & 91 \\
\hline Steenbergen & 23.219 & N-Brabant & $\begin{array}{l}\text { 2001: weth. na conf. raad, coalitiewissel } \\
\text { 2005: } 2 \text { weths. na conf. raad, coal.wissel } \\
\text { 2008: collegecrisis, } 2 \text { x weth. } \\
\end{array}$ & 8 & 15 \\
\hline Steenwijkerland & 43.195 & Overijssel & 2008: wet na vertrouwensbreuk fractie & 1 & 267 \\
\hline Stein & 25.660 & Limburg & $\begin{array}{l}\text { 2002: breuk in coalitie, } 2 \text { weths. } \\
\text { 2008: weth, na dreiging motie, crisis } \\
\text { 2009: ook tweede weth. stapt op }\end{array}$ & 6 & 46 \\
\hline Strijen & 8.926 & Z-Holland & geen bijzonderheden gemeld & 0 & 398 \\
\hline Ten Boer & 7.431 & Groningen & geen bijzonderheden gemeld & 0 & 399 \\
\hline Terneuzen & 54.892 & Zeeland & geen bijzonderheden gemeld & 0 & 400 \\
\hline Terschelling & 4.724 & Friesland & geen bijzonderheden gemeld & 0 & 401 \\
\hline Texel & 13.783 & N-Holland & geen bijzonderheden gemeld & 0 & 402 \\
\hline Teylingen & 35.761 & Z-Holland & fusiegemeente, geen probl. gemeld & 0 & 403 \\
\hline Tholen & 25.410 & Zeeland & twee incidenten, niet gedwongen & 0 & 404 \\
\hline Tiel & 41.240 & Gelderland & 2004: weth. & 1 & 268 \\
\hline Tilburg & 204.924 & N-Brabant & $\begin{array}{l}\text { 2002: } 2 \text { weths., crisis } \\
\text { 2008: crisis, } 2 \text { weths. } \\
\text { 2009: zelfde crisis, weth. en bgm weg }\end{array}$ & 8 & 16 \\
\hline Tubbergen & 21.152 & Overijssel & geen bijzonderheden gemeld & 0 & 405 \\
\hline Twenterand & 33.568 & Overijssel & 2004: weth. na kritiek & 1 & 269 \\
\hline Tynaarlo & 32.364 & Drenthe & wel gedoe rondom herbenoeming & 0 & 406 \\
\hline Tytsjerksteradiel & 32.260 & Friesland & 2005: persoonlijk, vanwege dualisme & 0 & 407 \\
\hline Ubbergen & 9.338 & Gelderland & geen bijzonderheden gemeld & 0 & 408 \\
\hline Uden & 40.553 & N-Brabant & $\begin{array}{l}\text { 2004: collegecrisis, weth. } \\
\text { 2007: weth. } \\
\end{array}$ & 3 & 138 \\
\hline Uitgeest & 12.673 & N-Holland & 2008: crisis, nieuwe coalitie, 2 weths. & 3 & 139 \\
\hline Uithoorn & 28.088 & N-Holland & geen bijzonderheden gemeld & 0 & 409 \\
\hline Urk & 18.318 & Flevoland & $\begin{array}{l}\text { 2005: collegecrisis, weth. weg } \\
\text { 2005: burgemeester }\end{array}$ & 3 & 140 \\
\hline Utrecht & 306.731 & Utrecht & $\begin{array}{l}\text { 2003: weth. } \\
\text { 2005: weth. } \\
\text { 2009: crisis, } 3 \text { weths. }\end{array}$ & 6 & 47 \\
\hline
\end{tabular}




\begin{tabular}{|c|c|c|c|c|c|}
\hline $\begin{array}{l}\text { Utrechtse } \\
\text { Heuvelrug }\end{array}$ & 48.792 & Utrecht & $\begin{array}{l}\text { Fusiegem. } \\
\text { 2007: weth. na verworpen motie } \\
\text { 2009: weth. }\end{array}$ & 2 & 192 \\
\hline Vaals & 9.874 & Limburg & 2009: weth. & 2 & 193 \\
\hline $\begin{array}{l}\text { Valkenburg a/d } \\
\text { Geul }\end{array}$ & 17.097 & Limburg & 2007: Partij stapt uit coalitie, weth. & 2 & 194 \\
\hline Valkenswaard & 30.734 & N-Brabant & $\begin{array}{l}\text { 2000: weth. } \\
\text { 2002: college (3 weths.) } \\
\text { 2005: weth. na just. onderzoek } \\
\text { 2008: } 3 \text { weths. na collegecrisis }\end{array}$ & 10 & 9 \\
\hline Veendam & 28.015 & Groningen & geen bijzonderheden gemeld & 0 & 410 \\
\hline Veenendaal & 62.072 & Utrecht & $\begin{array}{l}\text { 2000: crisis, } 4 \text { weths. } \\
\text { 2005: weth., coalitiewissel }\end{array}$ & 7 & 31 \\
\hline Veere & 21.932 & Zeeland & geen bijzonderheden gemeld & 0 & 411 \\
\hline Veghel & 37.301 & N-Brabant & $\begin{array}{l}\text { 2005: weth. na coalitiebreuk } \\
\text { 2008: grote crisis, } 5 \text { weths. en bgm. }\end{array}$ & 9 & 11 \\
\hline Veldhoven & 43.256 & N-Brabant & 2007: weth. na conflict fractie & 1 & 270 \\
\hline Velsen & 67.371 & N-Holland & $2003,2004,2005$ en 2009: weths. & 4 & 92 \\
\hline Venlo & 100.328 & Limburg & geen bijzonderheden gemeld & 0 & 412 \\
\hline Venray & 42.785 & Limburg & $2000+2008:$ weths. & 2 & 195 \\
\hline Vianen & 19.663 & Utrecht & $\begin{array}{l}\text { 2003: weth. na conflict raad } \\
\text { 2005: weth na motie van wantrouwen }\end{array}$ & 2 & 196 \\
\hline Vlaardingen & 70.540 & Z-Holland & $\begin{array}{l}\text { 2007: weth. na conflict raad } \\
\text { 2007: weth. na conflict fractie }\end{array}$ & 2 & 197 \\
\hline Vlagtwedde & 16.264 & Groningen & 2002: $2 \times$ weth. weg & 2 & 198 \\
\hline Vlieland & 1.157 & Friesland & geen bijzonderheden gemeld & 0 & 413 \\
\hline Vlissingen & 44.608 & Zeeland & $\begin{array}{l}\text { 2007: weth. na motie } \\
\text { 2007: grote crisis, } 4 \text { weths. + bgm. }\end{array}$ & 7 & 32 \\
\hline Vlist & 9.760 & Z-Holland & geen bijzonderheden gemeld & 0 & 414 \\
\hline Voerendaal & 12.711 & Limburg & 2009: weth. na vertrek partij uit coalitie & 2 & 199 \\
\hline Voorschoten & 23.479 & Z-Holland & 2009: weth.na overschrijding budget & 1 & 271 \\
\hline Voorst & 23.781 & Gelderland & 2006: 4 weths. weg na dreigende motie & 5 & 64 \\
\hline Vught & 25.449 & N-Brabant & $\begin{array}{l}\text { 2004: crisis, } 4 \text { weths. weg } \\
\text { 2006: bgm. na conflict met raad }\end{array}$ & 6 & 48 \\
\hline Waalre & 16.538 & N-Brabant & 2004: conflict & 1 & 272 \\
\hline Waalwijk & 45.756 & N-Brabant & $\begin{array}{l}\text { 2004: } 2 \text { weths. na conf. raad } \\
\text { 2008: crisis, } 2 \text { weths. }\end{array}$ & 5 & 65 \\
\hline Waddinxveen & 25.415 & Z-Holland & 2003: college demiss., 1 weth. weg & 2 & 200 \\
\hline Wageningen & 37.332 & Gelderland & $\begin{array}{l}\text { Tel: 2007: weth. } \\
\text { 2009: weth, tijdelijke crisis }\end{array}$ & 3 & 141 \\
\hline Wassenaar & 25.839 & Z-Holland & $\begin{array}{l}\text { 2005: burgemeester } \\
\text { 2008: crisis, } 1 \text { weth. }\end{array}$ & 3 & 142 \\
\hline Waterland & 17.058 & N-Holland & $\begin{array}{l}\text { 2003: crisis, } 3 \text { weths. } \\
\text { 2008: weth., breuk coalitie }\end{array}$ & 6 & 49 \\
\hline Weert & 48.405 & Limburg & \begin{tabular}{|l|} 
2004: weth. \\
2004: burgemeester
\end{tabular} & 2 & 201 \\
\hline Weesp & 17.623 & N-Holland & $\begin{array}{l}\text { 2003: weth. } \\
\text { 2008: crisis, } 3 \times \text { weth. }\end{array}$ & 5 & 66 \\
\hline Werkendam & 26.382 & N-Brabant & 2001: conflict binnen fractie & 1 & 273 \\
\hline Wervershoof & 8.794 & N-Holland & $\begin{array}{l}\text { 2007: weth. na conf eigen partij, } \\
\text { breuk in coalitie }\end{array}$ & 2 & 202 \\
\hline $\begin{array}{l}\text { West Maas en } \\
\text { Waal }\end{array}$ & 18.409 & Gelderland & geen bijzonderheden gemeld & 0 & 415 \\
\hline
\end{tabular}




\begin{tabular}{|c|c|c|c|c|c|}
\hline Westerveld & 19.332 & Drenthe & 2007: grote crisis, bgm. en 2 weths. & 4 & 93 \\
\hline Westervoort & 15.242 & Gelderland & geen bijzonderheden gemeld & 0 & 416 \\
\hline Westland & 99.744 & Z-Holland & Fusiegemeente. 2009: weth. & 1 & 274 \\
\hline Weststellingwerf & 25.841 & Friesland & geen bijzonderheden gemeld & 0 & 417 \\
\hline Westvoorne & 14.072 & Z-Holland & $\begin{array}{l}\text { 2005: crisis, } 2 \text { weths. } \\
\text { 2009: weth. na motie }\end{array}$ & 4 & 94 \\
\hline Wierden & 23.430 & Overijssel & geen bijzonderheden gemeld & 0 & 418 \\
\hline Wieringen & 8.639 & N-Holland & $\begin{array}{l}\text { 2005: weth. } \\
\text { 2005: burgemeester } \\
\text { 2009: weth. en crisis }\end{array}$ & 4 & 95 \\
\hline Wieringermeer & 12.584 & N-Holland & $\begin{array}{l}\text { 2004: weth. } \\
\text { 2008: weth. }\end{array}$ & 2 & 203 \\
\hline Wijchen & 40.158 & Gelderland & $\begin{array}{l}\text { 1999: weth. na conflict } \\
\text { 2009: weth. andere partij }\end{array}$ & 2 & 204 \\
\hline Wijdemeren & 23.403 & N-Holland & $\begin{array}{l}\text { 2004: weth. } \\
\text { 2008: } 2 \text { x weth. }\end{array}$ & 3 & 143 \\
\hline \begin{tabular}{|l|} 
Wijk bij \\
Duurstede
\end{tabular} & 23.183 & Utrecht & geen bijzonderheden gemeld & 0 & 419 \\
\hline Winsum & 14.078 & Groningen & 2008: crisis, 3 weths. & 4 & 96 \\
\hline Winterswijk & 29.026 & Gelderland & 2001: weth. & 1 & 275 \\
\hline Woensdrecht & 21.662 & N-Brabant & 2005: weth. & 1 & 276 \\
\hline Woerden & $49 \cdot 342$ & Utrecht & $\begin{array}{l}\text { 2007: weth. } \\
\text { 2008: weth., coalitiebreuk }\end{array}$ & 3 & 144 \\
\hline Wormerland & 15.873 & $\mathrm{~N}-\mathrm{Holland}$ & 2002: weth., coalitiebreuk & 2 & 205 \\
\hline Woudenberg & 11.910 & Utrecht & geen bijzonderheden gemeld & 0 & 420 \\
\hline Woudrichem & 14.441 & N-Brabant & 2004: weth. & 1 & 277 \\
\hline Wunseradiel & 11.833 & Friesland & geen bijzonderheden gemeld & 0 & 421 \\
\hline Wymbritseradiel & 16.151 & Friesland & geen bijzonderheden gemeld & 0 & 422 \\
\hline Zaanstad & 145.282 & N-Holland & $\begin{array}{l}\text { 2005: bgm. na conflict college } \\
\text { 2002: weth. na onderzoek } \\
\text { 2002: } 2 \text { x na uiteenvallen fractie }\end{array}$ & 5 & 67 \\
\hline Zaltbommel & 26.431 & Gelderland & geen bijzonderheden gemeld & 0 & 423 \\
\hline Zandvoort & 16.639 & $\mathrm{~N}-\mathrm{Holland}$ & 2005: weth., coalitiebreuk & 2 & 206 \\
\hline Zederik & 13.386 & Z-Holland & 2008: weth. na conf. raad, coal. breuk & 2 & 207 \\
\hline Zeevang & 6.306 & N-Holland & 2005: weth. na 2 moties afkeuring & 1 & 278 \\
\hline Zeewolde & 20.927 & Flevoland & $\begin{array}{l}\text { 2004: weth. na motie, coal. wissel } \\
\text { 2007: weth. trekt conclusies } \\
\text { 2008: } 2 \text { weths. + crisis }\end{array}$ & 6 & 50 \\
\hline Zeist & 60.272 & Utrecht & geen bijzonderheden gemeld & 0 & 424 \\
\hline Zevenaar & 31.890 & Gelderland & geen bijzonderheden gemeld & 0 & 425 \\
\hline Zijpe & 11.598 & $\mathrm{~N}-\mathrm{Holland}$ & geen bijzonderheden gemeld & 0 & 426 \\
\hline Zoetermeer & 121.580 & Z-Holland & $\begin{array}{l}\text { 2002: weth. na raadsenquête } \\
\text { 2010: weth., hele college wordt } \\
\text { demissionair. }\end{array}$ & 8 & 17 \\
\hline Zoeterwoude & 8.116 & Z-Holland & geen bijzonderheden gemeld & 0 & 427 \\
\hline Zuidhorn & 18.563 & Groningen & geen bijzonderheden gemeld & 0 & 428 \\
\hline Zuidplas & 40.387 & Z-Holland & Fusiegemeente & 0 & 429 \\
\hline Zundert & 21.098 & N-Brabant & $\begin{array}{l}\text { 2004: weth. weg, coalitiebreuk } \\
\text { 2004: burgemeester vertrekt } \\
\text { 2004: } 2 \text { weths. stappen op } \\
\text { 2005: laatste weth. weg, crisis } \\
\text { 2010: weth. weg, coalitiebreuk }\end{array}$ & 9 & 12 \\
\hline
\end{tabular}




\section{Bijlage 2 Gebruikte tabellen en figuren}

Tabel 1: Inwoneraantal gemeenten in 1900 resp. 2010

Tabel 2: Percentage weths. van buiten de raad, gespecificeerd naar gemeentegrootte

Tabel 3: Afgetreden wethouders per bestuursperiode

Tabel 4:

De kwaliteitsmatrix voor beoordeling van gemeentelijke bestuurskracht

Tabel 5:

Perspectieven op onderzoek van bestuurlijke probleemgemeenten

Tabel 6:

Overzicht van aspecten en indicaties per analyseniveau

Tabel 8: Totaalbeeld aantal conflicten en crises in Nederland, maart 1998 - maart 2010

Tabel 9: Gemeenten met het hoogste aantal gedwongen vertr. bestuurders, 1998-2010

Tabel 10:

Aantal collegecrises in Nederland 1998-2010

Tabel 11:

Reden voor vertrek van gemeentebestuurder(s)

Tabel 12:

Gemeenten met de meeste bestuurlijke problemen, inged. naar inwoneraantal

Tabel 13:

Vertrokken bestuurders en colleges in de 26 grootste Nederlandse gemeenten,

Tabel 14:

Bestuurlijke probleemgemeenten in Nederland, 1998-2010

Tabel 15:

Samenstelling gemeenteraad Den Helder 1998-2010

Tabel 16:

Samenstelling Colleges van B\&W gemeente Den Helder 1998-2010

Tabel 17:

Burgemeesters van Den Helder vanaf 1985

Tabel 18

De factorenanalyse in Den Helder

Samenstelling gemeenteraad Leiden 1998-2010

Tabel 20: Samenstelling Colleges van B\&W gemeente Leiden 1998-2010

Tabel 21: Burgemeesters van Leiden 1980-2010 122

Tabel 22: De factorenanalyse in Leiden 141

Tabel 23: Samenstelling gemeenteraad Delfzijl 1998-2010 $\quad 145$

Tabel 24: Samenstelling Colleges van B\&W gemeente Delfzijl 1998-2010 146

Tabel 25: Burgemeesters van Delfzijl vanaf 1987-2010 146

$\begin{array}{ll}\text { Tabel 26: } & \text { De factorenanalyse in Delfzijl } \\ & 167\end{array}$

Tabel 27: Samenstelling gemeenteraad Zundert 1999-2010 171

Tabel 28: Samenstelling Colleges van B\&W gemeente Zundert 1997-2010 171

Tabel 29: $\quad$ Burgemeesters van Zundert vanaf 1997-2010 172

Tabel 30: De factorenanalyse in Zundert $\quad 194$

$\begin{array}{ll}\text { Tabel 31: Verwachte vitkomsten per factor } & 198\end{array}$

Tabel 32: De factorenanalyse voor de vier onderzochte gemeenten over de periode van 12 jaar

\section{Figuren}

Figuur 1: Aantal gedwongen vertrokken gemeentebestuurders in Nederland, 1998-2010 


\section{Bijlage 3 Gesprekspartners en meedenkers (alf. volgorde)}

\author{
Algemeen \\ Dhr. prof. dr. H. Aardema \\ Dhr drs. G.H.F. Boekhoff \\ Dhr. dr. M. J.G.J.A. Boogers \\ Dhr. J. Buijs \\ Dhr. prof. dr. Th.W.A. Camps \\ Dhr. dr. P. Castenmiller \\ Dhr. dr. M.J. Cohen \\ Dhr. C.G.A. Cornielje \\ Dhr. dr. J.C.M. Cox \\ Dhr. dr. M.J.E.M. van Dam \\ Dhr. prof. dr. S.A.H. Denters \\ Dhr. prof. dr. W. Derksen \\ Dhr. prof. dr. J.L.A. Geurts \\ Dhr. dr. J.J.P.M. Gilissen \\ Dhr. dr. M. Herweijer \\ Dhr. prof. dr. A.F.A. Korsten \\ Dhr. prof. dr. E.R. Muller \\ Dhr. A. Noordergraaf \\ Mw. dr. K. Peters \\ Dhr. J.W. Remkes
}

Dhr. mr. L.A. Wieringa

\section{Gesprekspartners Den Helder: \\ Dhr. W.F. Bellinga \\ Dhr. mr. H.C.J.L. Borghouts \\ Dhr. J. de Bruin}

Mw. mr. G.H. Faber

Dhr. B. Fritzsche

Dhr. drs. W. Hoekzema

Dhr. mr. drs. M. Huisman

Dhr. drs. S. Hulman

Dhr. F.C. Klut

Mw. H. Raasing

Dhr. T. Rijnten

Dhr. drs. J.M. Staatsen

Dhr. M.K.M. Stegers

Dhr. ir. C.J. Vriesman bijzonder hoogleraar Open Universiteit

wethouder in Bussum

hoofddocent Universiteit Tilburg

oud-gemeentesecretaris gemeente Bussum

hoogleraar TIAS Universiteit Tilburg

lector aan Fontys Bestuursacademie

oud-burgemeester van Amsterdam

Commissaris van de Koningin in Gelderland gemeentesecretaris van Alkmaar

bestuurskundige en adviseur

hoogleraar Universiteit Twente

hoogleraar Erasmus Universiteit Rotterdam

hoogleraar TIAS Universiteit Tilburg

burgemeester van Venray

voormalig hoogleraar Universiteit Groningen

emeritus hoogleraar Open Universiteit/

bijzonder hoogleraar Universiteit Maastricht

hoogleraar Universiteit Leiden en adviseur veiligheid (COT) burgemeester van Soest

bestuurskundige en adviseur

oud-minister van Binnenlandse Zaken en Koninkrijkrelaties, Commissaris van de Koningin in Noord-Holland (vanaf 2010) griffier in Bussum

\section{Betrokkenheid bij Den Helder}

Raadslid VVD (1998-2010)

Commissaris van de Koningin in Noord-Holland (2002-2009)

Gemeentesecretaris (1993-2001),

raadslid CDA (2006-2010, vanaf sept. 2009

fractievoorzitter)

Wnd. burgemeester (2005-2007)

Wethouder VVD (2006-2010)

Burgemeester (1995-2001)

Griffier (2006 - heden)

Burgemeester (2007-2009)

Raadslid D66 (1990 - heden)

Gemeentesecretaris (2007-heden)

Fractievoorzitter PvdA (2006-heden)

Burgemeester (2001-2005)

Wethouder CDA (1994-2001)

Wnd. Burgemeester (2009) 


\author{
Gesprekspartners Leiden: \\ Dhr. J. Franssen \\ Mw. G. van Gruting \\ Dhr. mr. H.H. Keereweer \\ Dhr. prof. dr. W. Lemstra \\ Dhr. drs. H.J.J. Lenferink \\ Dhr. drs. J. K.T. Postma* \\ Mw. drs. M.H. Schultz-van Haegen \\ Mw. E.H.T. van der Vlist \\ Dhr. drs. O.F.J. Welling \\ Dhr. P.I.M. van den Wijngaart \\ Dhr. mr. P.T. van Woensel \\ *reactie op concept
}

\section{Gesprekspartners Delfzijl: \\ Dhr. J.G.M. Alders \\ Dhr. G.A. van Amson \\ Dhr. E.A. Groot \\ Dhr. K.J. Havinga \\ Dhr. R. van der Molen \\ Dhr. O. Rijkens \\ Dhr. H.J. Schimmel \\ Dhr. drs. J. Visser \\ Dhr. mr. C.J.D. Waal \\ Dhr. A.A. Zoethout}

\section{Gesprekspartners Zundert:}

Dhr. D.W. de Cloe

Dhr. I.J.P. Keijzer

Dhr. A.M.M. van der Kloot

Mw. J.R.H. Maij-Weggen

Dhr. C. Meulman

Dhr. P. Neeb

Mw. L.C. Poppe-De Looff

Dhr. drs. B.A.M. Rijsbergen

Dhr. R. van Tilburg

Dhr. A. van der Veen

Dhr. mr. H.G. Vos

\section{Betrokkenheid bij Leiden}

Commissaris van de Koningin in Zuid-Holland (2000 - heden)

Raadslid VVD (1994 - heden)

Fractievoorzitter en raadslid PvdA( 2006 - heden)

Wnd. burgemeester (2002 - 2003)

Burgemeester (2003-heden)

Burgemeester (1999-2002)

Wethouder VVD (1999-2003), informateur (2007)

Loco-secretaris en griffier (vanaf 2002)

Raadslid D66 (1994-2003), formateur college (2007)

Gemeentesecretaris (2001-2010)

Wethouder VVD (2007- heden)

\section{Betrokkenheid bij Delfzijl}

Commissaris van de Koningin in Groningen (1996-2007)

Fractieondersteuner Delfzijls Belang (2002-2006)

Raadslid Partij voor het Noorden (2006-2010)

Burgemeester (2008-heden)

Gemeentesecretaris (2006-heden)

Wethouder PvdA (2006-2010)

Griffier (2002-heden)

Raadslid ChristenUnie (2002-2010)

Gemeentesecretaris (1997-2003)

Wnd. burgemeester (2006-2008)

Fractievoorzitter PvdA (2006-heden)

\section{Betrokkenheid bij Zundert}

Formateur extern college (2005)

Wnd. burgemeester (2004-2007)

Wethouder CDA (1990-1995 en 1997-2002)

Raadslid (2002-2008)

Commissaris van de Koningin in Noord-Brabant (2003-2009)

Wethouder (2006-2010)

Burgemeester (1997-2002)

Burgemeester (2007-heden)

Loco-secretaris (2008-heden)

Wethouder CDA (2002-2004), raadslid (2006-2010)

Griffier (2002-heden)

Burgemeester (2003-2004) 


\section{Samenvatting}

In het lokaal bestuur in Nederland vertrekken regelmatig burgemeesters, wethouders of hele colleges voordat de periode waarvoor zij benoemd of gekozen zijn, is verstreken. Door een bestuurlijk conflict of bestuurscrisis (of de dreiging daarvan) in de gemeente wordt (of voelt) de betrokken bestuurder (zich) gedwongen zijn of haar positie op te geven. In sommige gemeenten gebeurt dat zelden, in andere gemeenten vaak. Zelfs zo vaak dat deze gemeenten bekend zijn komen te staan om de bestuurlijke problemen die zich er voordoen of hebben voorgedaan. Dit onderzoek richt zich op deze categorie gemeenten: bestuurlijke probleemgemeenten.

Uit de literatuur blijkt dat $30 \%$ van de gemeentebestuurders tussentijds vertrekt, waarbij conflicten een belangrijke rol spelen. Er zijn echter nog vele vragen onbeantwoord. Niet duidelijk is bijvoorbeeld hoeveel en welke gemeenten nu daadwerkelijk opvallen als het gaat om het aantal gedwongen vertrokken gemeentebestuurders, en welke problematiek er in deze gemeenten speelt of speelde. Er zijn schattingen, er circuleren aantallen en er worden namen van gemeenten genoemd, maar een totaaloverzicht ontbreekt. Doel van dit onderzoek is om daarin te voorzien, de bestaande kennis en inzichten met betrekking tot conflicten en crises in bestuurlijke probleemgemeenten vit te bouwen en enige lessen te trekken.

\section{Begrippen}

Onder een bestuurlijk conflict wordt in deze studie verstaan: een zodanig groot meningsverschil tussen een gemeentebestuurder en de eigen fractie, het college of de gemeenteraad, dat de betreffende bestuurder zich gedwongen voelt of gedwongen wordt zijn functie neer te leggen. Het gaat daarbij om één persoon, waarbij de rest van het college blijft zitten en de functie kan blijven uitoefenen. Anders is dit bij een bestuurscrisis ofwel collegecrisis, waarbij het hele college (soms inclusief de burgemeester) valt. Gemeenten waar bestuurlijke conflicten en bestuurscrises veelvuldig voor komen of zijn voor gekomen, worden in dit onderzoek bestuurlijke probleemgemeenten genoemd. Het vinden van een antwoord op de vragen wat veelvuldig is, om hoeveel gemeenten in Nederland het gaat en wat er in deze gemeenten aan de hand is (geweest) vormt de kern van dit onderzoek. Uitgangspunt is dat bij bestuurlijke probleemgemeenten in ieder geval in twee aaneengesloten raadsperioden bestuurlijke conflicten of bestuurlijke crises zijn opgetreden, waarvan minimaal één keer een ernstige crisis, waarbij alle wethouders (wellicht ook de burgemeester) definitief dienden te vertrekken.

Bij gedwongen vertrek wordt een onderscheid gemaakt tussen direct en indirect gedwongen vertrek. Onder direct gedwongen vertrek van gemeentebestuurders worden in deze studie alle situaties opgevat, waarin de gemeenteraad middels een motie het vertrouwen in de samenwerking met de wethouder of het hele college heeft opgezegd, dan wel een aanbeveling tot ontslag van de burgemeester heeft gedaan. Van indirect gedwongen is sprake als een gemeentebestuurder een motie van wantrouwen niet afwacht en zelf 'gedwongen vrijwillig' vertrekt, of als de fractie geen steun meer wil geven aan de coalitie en de wethouder terugtrekt. 


\section{Centrale vraagstelling en onderzoeksperiode}

De vraag die centraal staat in dit onderzoek naar bestuurlijke probleemgemeenten in Nederland luidt:

Wat is de verklaring voor de aanhoudende crisissituaties en daarmee het gedwongen vertrek van burgemeesters, wethouders en/of hele colleges in bestuurlijke probleemgemeenten in Nederland in de periode maart 1998 - maart 2010?

In de onderzochte tijdsperiode, maart 1998 tot en met maart 2010, vallen drie bestuursperioden: 1998-2002, 2002-2006 en 2006-2010.

De centrale vraagstelling is opgedeeld in drie deelvragen. Deze deelvragen geven richting aan het onderzoek en gaan in op de gebruikte woorden 'verklaring' en de veronderstelde aanwezigheid van 'bestuurlijke probleemgemeenten' in Nederland.

De deelvragen luiden:

1. Wat zegt de bestaande literatuur over mogelijke verklaringen voor de aanhoudende bestuurlijke problematiek in bestuurlijke probleemgemeenten?

2. Welke gemeenten in Nederland zijn aan te duiden als bestuurlijke probleemgemeente in de periode maart 1998- maart 2010?

3. Welke verklaringen komen naar voren na analyse van de praktijk in besturlijke probleemgemeenten?

\section{Deelvraag 1: Vier invalshoeken}

Voor de beantwoording van deelvraag 1 is bureauonderzoek gedaan naar de al beschikbare kennis over bestuurlijke probleemgemeenten en de mogelijkheden deze te onderzoeken. Hierbij zijn vier theoretische vertrekpunten overwogen. Op de eerste plaats is gekeken naar beoordeling op basis van bestuurskracht, waarbij de onderzoeker nagaat of een gemeentebestuur in staat is de eigen ambities en opgaven en de wettelijke opgaven op een voldoende niveau te realiseren, dus uit te voeren. De veronderstelling met betrekking tot dit perspectief luidt dat de bestuurskracht van bestuurlijke probleemgemeenten in een aantal opzichten op dit beoordelingskader lager scoort dan van gemeentebesturen, die niet als bestuurlijke probleemgemeente zijn te beschouwen. Het probleem is echter dat via deze invalshoek het bestuurlijk functioneren van een gemeente niet of nauwelijks in beeld komt, omdat de beschikbare metingen niet in gaan op factoren als de bestuurscultuur of de fragmentatie van de raad, die zeker een rol spelen in bestuurlijke probleemgemeenten.

De tweede mogelijke invalshoek is die van 'good governance', waarbij kan worden nagegaan of bestuurlijke probleemgemeenten absoluut en/of relatief zwakker scoren op criteria die aan dit principe zijn verbonden. Het gaat dan om termen als effectiviteit en responsiviteit. Ook hier is de veronderstelling dat bestuurlijke probleemgemeenten lager scoren op deze karakteristieken van goed bestuur. Deze benadering zegt echter weinig over het verloop in de tijd en is wat statisch van karakter. 
In dit onderzoek is gekozen voor een combinatie van twee andere invalshoeken. Op de eerste plaats is gewerkt met de factorenanalyse, geïntroduceerd door Korsten en Aardema (2006) in hun onderzoek naar het gedwongen vertrek van Nederlandse burgemeesters. Zij onderscheiden in gemeenten een drietal niveaus, te weten het microniveau, het mesoniveau en het macroniveau. Lag het vertrek aan individuele factoren (micro-niveau), dat wil zeggen aan de persoonlijke kwaliteiten van één of meer wethouders of een burgemeester, in casu aan bij voorbeeld hun vakbekwaamheid, hun communicatieve en relationele kwaliteiten en 'humeuren', hun gebrekkige reflectie daarop en hun onvoldoende ontwikkeld adaptief vermogen? Of moeten de beïnvloedende factoren, wellicht zelfs oorzaken, gezocht worden op mesoniveau, in de sfeer van de verbindingen binnen een college of raad, tussen college en ambtelijke organisatie, tussen college en gemeenteraad of tussen de raadsfracties in de coalitie? Of ging het om de derde laag, de macrofactoren, waarbij gedacht moet worden aan de bestuursstructuur of de bestuurscultuur in een gemeente, of onrust in de samenleving? Korsten en Aardema kwamen tot het besef dat het gedwongen vertrek van burgemeesters in bestuurlijke probleemgemeenten niet aan één factor ligt, maar dat er meerdere factoren tegelijkertijd invloedrijk zijn.

Deze invalshoek van factoren is gecombineerd met een vierde entree: de studie naar sterke en zwakke bestuurscolleges van Korsten en Schoenmaker (2008). Zij stelden op grond van uitgebreide literatuurstudie en eigen onderzoek een checklist vast, waarin 37 adviezen staan om tot een 'sterk college' te komen. Hoewel deze aanpak op zichzelf iets te beperkt is om over te nemen in dit onderzoek, gezien de focus op louter het dagelijks bestuur, is de checklist een uitstekend hulpmiddel om de eerder genoemde factoren te voorzien van indicatoren.

In dit onderzoek naar bestuurlijke probleemgemeenten zijn in totaal negen factoren van indicatoren voorzien en geanalyseerd. Op microniveau zijn dat aspecten van de burgemeester (1) en de wethouder(s) (2). Op mesoniveau gaat het om verbindingen, respectievelijk binnen het college (3), tussen het college en de ambtelijke organisatie (4), tussen college en raad (5) en tussen de coalitiepartijen (6). Op macroniveau is er aandacht voor de bestuursstructuur (7), de bestuurscultuur (8) en de rol van de media (9).

De factoren zijn op elk niveau in een viertal casestudies beschouwd en geanalyseerd, waarbij een verwachting is geformuleerd (zie tabel). De vraag is: is er een patroon van veel voorkomende factoren te ontdekken in deze gemeenten?

Tabel A: Verwachte uitkomsten voor het begrijpen van bestuurlijke probleemgemeenten: afzonderlijke invloedsfactoren

\begin{tabular}{|l|l|}
\hline Verwachting 1 & $\begin{array}{l}\text { In bestuurlijke probleemgemeenten legt de burgemeester weinig bindend } \\
\text { vermogen aan de dag, waardoor de potentiële dempende werking van de } \\
\text { burgemeester afwezig is. }\end{array}$ \\
\hline Verwachting 2 & $\begin{array}{l}\text { In bestuurlijke probleemgemeenten hebben de persoonlijke risicofactoren } \\
\text { van één of meer wethouder(s) een aanjagende werking op bestuurlijke } \\
\text { problemen. }\end{array}$ \\
\hline
\end{tabular}




\begin{tabular}{|l|l|}
\hline Verwachting 3 & $\begin{array}{l}\text { In bestuurlijke probleemgemeenten kunnen colleges niet sterk worden, } \\
\text { waardoor de potentiële dempende werking van een sterk college afwezig is. }\end{array}$ \\
\hline Verwachting 4 & $\begin{array}{l}\text { In bestuurlijke probleemgemeenten zit weinig patroon in de relatie van het } \\
\text { college van B\&W met het ambtelijk apparaat, wat een aanjagende werking } \\
\text { heeft op bestuurlijke problemen. }\end{array}$ \\
\hline Verwachting 5 & $\begin{array}{l}\text { In bestuurlijke probleemgemeenten zit geen of weinig patroon in de relatie } \\
\text { tussen het college van B\&W en de gemeenteraad, wat een aanjagende } \\
\text { werking heeft op bestuurlijke problemen. }\end{array}$ \\
\hline Verwachting 6 & $\begin{array}{l}\text { In bestuurlijke probleemgemeenten bestaat weinig binding tussen coalitie- } \\
\text { fracties, wat een aanjagende werking heeft op bestuurlijke problemen. }\end{array}$ \\
\hline Verwachting 7 & $\begin{array}{l}\text { In bestuurlijke probleemgemeenten is sprake van versplintering van het } \\
\text { politieke landschap, wat een aanjagende werking heeft op bestuurlijke } \\
\text { problemen. }\end{array}$ \\
\hline Verwachting 8 & $\begin{array}{l}\text { In bestuurlijke probleemgemeenten is de bestuurscultuur negatief tot zeer } \\
\text { negatief, wat een aanjagende werking heeft op bestuurlijke problemen. }\end{array}$ \\
\hline Verwachting 9 & $\begin{array}{l}\text { In bestuurlijke probleemgemeenten hebben de (pers)media een grote in- } \\
\text { vloed op het debat, wat een aanjagende werking heeft op bestuurlijke } \\
\text { problemen. }\end{array}$ \\
\hline
\end{tabular}

\section{Deelvraag 2: Identificeren van bestuurlijke probleemgemeenten}

Om te kunnen bepalen welke Nederlandse gemeenten aangeduid kunnen worden als bestuurlijke probleemgemeente, is kwantitatief onderzoek gedaan in heel Nederland. Allereerst is onderzocht hoeveel wethouders, burgemeesters en/of colleges gedwongen zijn vertrokken in alle Nederlandse gemeenten, in de periode 1998-2010. Als peildatum fungeerde 1 januari 2010, toen er in Nederland 431 gemeenten waren. Vervolgens is, op basis van de resultaten uit de eerste stap, opgemaakt welke gemeenten uit de analyse als bestuurlijke probleemgemeente naar voren komen.

Het totaalbeeld is als volgt:

Tabel B: Aantal conflicten en crises in Nederland, periode maart 1998 - maart 2010

\begin{tabular}{|l|c|c|}
\hline Aantal conflicten en crises & Aantal gemeenten & In procenten \\
\hline 0 & 153 & $35,5 \%$ \\
\hline 1 of 2 & 134 & $31,1 \%$ \\
\hline $3 \mathrm{t} / \mathrm{m} 5$ & 94 & $21,8 \%$ \\
\hline $6 \mathrm{t} / \mathrm{m} 8$ & 38 & $8,8 \%$ \\
\hline$>9$ & 12 & $2,8 \%$ \\
\hline Totaal & 431 & $100 \%$ \\
\hline
\end{tabular}

Uit het kwantitatieve onderzoek blijkt dat 278 van de 431 gemeenten in Nederland $(64,5 \%)$ te maken hebben gehad met het gedwongen vertrek van gemeentebestuurders in de periode 1998-2010. In 153 van de 431 gemeenten was géén sprake van gedwongen vertrek van gemeentebestuurders. In deze gemeenten (35,5\%) was de afgelopen twaalf jaar alleen sprake van wisselingen in het college na verkiezingen, of na eigen keuzes van de betrokken bestuurders. Van de 278 gemeenten waar wel problemen waren meldden 134 gemeenten, een substantieel deel, één of twee vertrokken gemeentebestuurders of colleges, wat neerkomt op 31,1\%. Het aantal gemeenten met drie tot vijf vertrokken bestuurders of colleges komt op 93 (21,6\%), terwijl nog eens 39 
gemeenten met zes, zeven of acht bestuurlijke conflicten of bestuurscrises te maken hadden ( $9,0 \%)$. In 12 gemeenten (2,8\%) werden negen of meer gedwongen vertrekken gemeld.

\section{Typen gemeenten}

Uit het onderzoek naar bestuurlijke conflicten en bestuurscrises in Nederlandse gemeenten van 1998 t/m 2010 blijkt dat er verschillende typen gemeenten te onderscheiden zijn. Het gaat in totaal om vijf verschillende soorten gemeenten.

\section{Gemeenten zonder gedwongen vertrek}

In ruim 35\% van de Nederlandse gemeenten komt gedwongen vertrek niet voor. Dit wil overigens helemaal niet zeggen dat er geen spanningen zijn gerapporteerd, want die waren er wel degelijk. Het leidde echter niet tot het gedwongen vertrek van gemeentebestuurders.

\section{Gemeenten met een gemiddeld vertrek}

Tot de tweede categorie behoren gemeenten die het gedwongen vertrek van één of twee gemeentebestuurders konden melden in de onderzoeksperiode, wat gemiddeld te noemen is. Het gaat hier om 134 gemeenten, ruim 30\% van het totaal. Het betreft hier dus losse, eenmalige incidenten, waarbij ook een duidelijk aanwijsbare reden is aan te geven. In deze gemeenten bleef het vervolgens bij het vertrek van deze ene bestuurder. Hooguit kwam er een beperkte collegewisseling, waarbij de ene partij de andere verving.

\section{Gemeenten met een 'onrustig jaar'}

Een derde categorie is de groep gemeenten waar één onrustige periode te melden viel, waardoor er meerdere wethouders en/of een burgemeester gedwongen moesten vertrekken en een heel college van samenstelling veranderde. In deze gemeenten was het jaren bestuurlijk rustig en ontstond plotseling een heftige crisis.

\section{Gemeenten met zo nu en dan een incident}

Er zijn ook gemeenten waar door de jaren heen zo nu en dan een incident voorkwam. Meestal ging het dan om een individuele wethouder, soms veranderde daardoor het college van samenstelling. Een echte crisis werd het echter zelden. De wethouders kwamen vaak door persoonlijk gedrag in de problemen. Er zaten ook behoorlijke tijdsperiodes tussen de verschillende conflicten of crises, waardoor ze eigenlijk allemaal als incidenten zijn te beschouwen. Het zijn er echter meer dan één of twee, zonder dat er een bestuurlijk rampjaar tussen zit. De term 'structureel incidentalisme' lijkt hier van toepassing.

\section{De bestuurlijke probleemgemeente}

Bestuurlijke probleemgemeenten zijn gemeenten die bij voortduring worden geconfronteerd met bestuurlijke conflicten en bestuurscrises: individuele wethouders vertrekken, partijen stappen uit de coalitie, een wethoudersploeg of een heel college moet vertrekken, burgemeesters liggen onder vuur. De bestuurlijke conflicten en bestuurscrises zijn ook niet in een bepaald jaar te plaatsen, maar komen gedurende de hele 
looptijd voor, al kan het zijn dat een bepaald jaar er met een complete collegecrisis vit springt.

Op grond van analyse van de resultaten kunnen negen gemeenten in Nederland tot de categorie bestuurlijke probleemgemeenten worden gerekend. Deze gemeenten hebben het hoogste aantal bestuurlijke problemen gekend in heel Nederland, met minimaal twee gevallen colleges, waarvan zeker één keer een ernstige crisis en bestuurlijke problemen in twee opeenvolgende perioden. Het gaat dan om Delfzijl, Leiden, Losser, Beverwijk, Den Helder, Hilversum, Valkenswaard, Leerdam en Zundert.

\section{Deelvraag 3: Het uitvoeren van casestudies}

De derde deelvraag is beantwoord door het uitvoeren van een viertal casestudies. Hiervoor is gekozen omdat casestudies, binnen de beperkingen die voor elk onderzoek gelden, uitstekend passen bij het explorerend karakter van dit onderzoek. Om te bepalen welke gemeenten geselecteerd moeten worden voor het doen van diepteonderzoek, is een drietal criteria ontwikkeld:

(1) In elke raadsperiode moet minimaal één bestuurlijk conflict of bestuurscrisis zijn geweest

(2) De te selecteren gemeenten bevinden zich bij voorkeur in verschillende provincies

(3) De te selecteren gemeenten zijn bij voorkeur verschillend van grootte

Op grond hiervan zijn de bestuurlijke probleemgemeenten Delfzijl, Leiden, Den Helder en Zundert geselecteerd. Zundert is afkomstig uit de categorie gemeenten met minder dan 25.000 inwoners, Delfzijl uit de groep 25.000 - 50.000 inwoners, Den Helder vit de groep van 50.000 - 100.000 inwoners en Leiden vit de gemeenten met meer dan 100.000 inwoners.

\section{Beantwoording onderzoeksvraag}

$\mathrm{Na}$ het beantwoorden van de deelvragen 1 en 2 en het uitvoeren van de vier casestudies (deelvraag 3) kan de onderzoeksvraag worden beantwoord. Het antwoord luidt als volgt: het ontstaan en voortbestaan van crisissituaties in probleemgemeenten kan niet monocausaal worden begrepen of verklaard. Er moeten veel gebeurtenissen en omstandigheden in een tijd- en plaatsafhankelijke situatie samenkomen voor er problemen ontstaan. In bestuurlijke probleemgemeenten kómen die factoren regelmatig samen, is gebleken. Nadere analyse van de problematiek in vier onderzochte bestuurlijke probleemgemeenten leert dat er vervolgens een onderscheid is te maken.

1. Sommige factoren zijn continu negatief aanwezig, maar spelen een rol op de achtergrond. Hierbij gaat het vooral om de bestuurscultuur (4x), de persmedia (4x) en de bestuursstructuur (3x).

2. Drie factoren kunnen vervolgens leiden tot bestuurlijke problematiek. Hierbij zijn twee microfactoren aan de orde (de burgemeester en de wethouder) en een mesofactor: de hechtheid van de coalitie. 


\section{Microfactoren}

Bij de microfactoren gaat het om een burgemeester of wethouder(s) die persoonlijke risicofactoren met zich meedragen. Ze zijn niet goed opgewassen tegen de functie, komen zelf in opspraak of hebben een moeizame relatie met hun achterban (wat alleen voor wethouders geldt) en lopen hierdoor grote kans gedwongen naar een andere baan te moeten uitkijken. Hun vakbekwaamheid, hun politiek-bestuurlijk gevoel, hun vermogen tot spiegelen en zich anderszins te bezinnen op hun gedrag, beeldvorming over gedrag of non-gedrag en zich aanpassen is onvoldoende aan de orde, niet (voldoende) gericht op de goede dingen of komt te laat op gang. Ze laten zich niet vaak waarschuwen en als ze gewaarschuwd worden, doen ze er niets of te weinig mee. Ze bagatelliseren, houden vast aan 'wie ze zijn' of ze hebben nog andere uitvluchten om niet te doen wat nodig is om te overleven. Op collectief niveau, bijvoorbeeld op collegeniveau of in de interactie met raadsfracties, lukt het ook niet om te temperen, bijvoorbeeld door om een wethouder of burgemeester te gaan staan of anderszins het college door 'woelige baren' te loodsen. Ook het dempend vermogen van het 'instituut' burgemeester zelf valt hierdoor weg.

\section{Mesofactor: hechtheid coalitie}

De derde factor die kan leiden tot bestuurlijke problemen is de hechtheid van de coalitie: fracties die een stevige verbinding met elkaar zijn aangegaan, met fractievoorzitters die elkaar wel mogen en vertrouwen en overleggen. Hier kan een sterk dempende werking van uitgaan op het ontstaan of escaleren van bestuurlijke conflicten en bestuurscrises in probleemgemeenten. Als de coalitiepartijen geen 'gedoe' willen, om wat voor reden dan ook, kan zelfs een niet functionerende wethouder blijven zitten. Dan blijkt dat wethouders, of een burgemeester, die tegen problemen aanlopen niet zonder meer in een bestuurlijk conflict hoeven te komen, of dat een bestuurlijk conflict niet automatisch vitloopt op een heuse crisis. Daarmee is de hechtheid van de coalitie dus de factor die van groot gewicht is in de vraag of er in gemeenten een bestuurscrisis ontstaat of niet. Als om wat voor reden dan ook de coalitie onder druk komt te staan, blijkt de positie van bestuurders of hele colleges in dergelijke gemeenten broos te zijn. Als het onderling vertrouwen tussen de fracties of hun voorzitters weg is, is ook de laatste rem van de kar en is het wachten op de helling naar beneden.

\section{Geen leidende rol}

Op basis van de resultaten is aan te geven dat sommige factoren weliswaar aanwezig waren, maar op zichzelf niet leidden tot bestuurlijke conflicten of het escaleren tot bestuurscrisis ervan in een bestuurlijke probleemgemeente. Om te beginnen is het niet zo dat de oorzaak voor de talrijke bestuurlijke conflicten en crises in probleemgemeenten alleen of voornamelijk gezocht moet worden in de rol van de persmedia of het actiever worden van persberichtgeving. De factor 'pers' kwam overal voor, maar kan gerelativeerd worden.

In het verlengde hiervan ligt de constatering dat de oorzaak voor het ontstaan van een probleemgemeente niet ligt in het handelen van grote meerderheden of minderheden uit de gemeentelijke samenleving. Burgers kijken er naar en verbazen zich. Natuurlijk zijn er wel conflicten waarin burgers positie kiezen (denk aan de Rijn-Gouwe lijn in 
Leiden) maar het zijn niet de burgers die een gemeente rechtstreeks doen uitgroeien tot een bestuurlijke probleemgemeente.

Van een groot of politiek overheersend beleidsvraagstuk als enige oorzaak van crises met een probleemgemeente-etiket tot gevolg gedurende langere tijd is slechts incidenteel sprake. Dat is begrijpelijk vanuit het perspectief dat de lokale politiek in sterke mate uitvoering in medebewind is van rijksbeleid.

Het is ook niet zo dat een gemeente een bestuurlijke probleemgemeente is en blijft, omdat alleen een voordracht voor en aanstelling van een bepaalde burgemeester naderhand als een vergissing moet worden betiteld. De status van bestuurlijke probleemgemeente valt niet te herleiden tot slechts één acteur. In het onderzoek is evenmin naar voren gekomen dat, als je nu maar een sterk college hebt van sterke wethouders (vakbekwaam, visionair, charismatisch, interactief, communicatief, elkaar ondersteunend, etc.) dat het dan allemaal vanzelf goed gaat en de bedreiging om probleemgemeente te worden volkomen afwezig is, of de kans op een dergelijke status gering.

Het is evenmin zo dat een disfunctionerende ambtelijke top van een gemeente een gemeente tot een bestuurlijke probleemgemeente maakt. Het is niet de ploeg van het veldonderhoud en de administratieve staf die de voetbalwedstrijd op het veld verliest.

Een veel gehoorde andere mening in bestuurlijke kringen is geweest dat de dualisering sinds begin 2002 veel bestuurlijke problemen heeft gegeven. De dualisering hield in dat de verstrengeling tussen college en raad ongedaan werd gemaakt. Wethouders waren niet langer meer lid van de gemeenteraad en geen voorzitter van commissies meer. Er ontstond meer afstand. De raad bleef hoogste bestuursorgaan en kreeg ook meer instrumenten, zoals een versterkte controlemogelijkheid, bijvoorbeeld via het recht op enquête en de instelling van lokale of regionale rekenkamers. De analyse van vier probleemgemeenten bevestigt dit beeld van verhoogde animositeit, uitlopend op een etiket van 'bestuurlijke probleemgemeente', niet. Bestuurlijke probleemgemeenten waren in feite al probleemgemeenten voor de dualisering werd ingezet. Dualisering heeft echter ook niet geholpen de situatie ten goede te laten keren. De dualisering heeft geen rust gebracht in probleemgemeenten, maar dat was ook geen doel achter de dualisering. De dualisering heeft de onderzochte probleemgemeenten niet conflicten crisesvrij gemaakt.

\section{Reflectie op bevindingen}

Het doel van dit onderzoek was om te bezien wat er aan de hand is in Nederlandse gemeenten, waar relatief veel gemeentebestuurders voortijdig moesten vertrekken in de periode maart 1998-maart 2010, in dit onderzoek aangeduid als bestuurlijke probleemgemeenten. Hiervoor is enige lijn aangebracht in de hoeveelheid cijfers over vertrekkende gemeentebestuurders en bezien hoeveel gemeenten er nu werkelijk aan te merken zijn als bestuurlijke probleemgemeente. Aan de hand van onderzoek in vier van deze gemeenten is gepoogd te begrijpen waarom gemeenten bestuurlijke probleemgemeenten zijn en wat daarop van invloed is. 
In de reflectie op het onderzoek is een poging gedaan te komen tot enige ordening van suggesties om het probleemgehalte van gemeenten te verminderen. Hierbij worden, in navolging van Korsten, drie perspectieven uitgewerkt: het autonomieperspectief (een gemeente is zelf bestuurlijk verantwoordelijk in gevolge de Grondwet en moet dus zelfreinigend optreden), het perspectief van de systeemverantwoordelijke rijksoverheid (de 'hogere' overheid moet handelen) en het ecologisch perspectief (niets doen, het herstel moet langs natuurlijke weg optreden).

Wat leert ons nu het inzicht uit deze studie en de reflectie erop, gecombineerd met de inzichten uit de literatuur? Vooral dat de problematiek in bestuurlijke probleemgemeenten niet alleen vanuit drie perspectieven bezien kán worden, maar ook móet worden. Zo zijn er voorbeelden waar de ecologie haar werk moet doen en ook doet. Verkiezingen brengen nieuwe spelers in de arena, de problematiek vermindert. In de onderzochte gemeenten blijkt echter dat het zelfreinigende vermogen niet groot was. Er werden wel pogingen ondernomen, bijvoorbeeld door het maken van rapporten, maar de problematiek bleef. Veranderingen kwamen (met vitzondering van Leiden) uiteindelijk onder (soms zware) druk van de Commissaris van de Koningin (CdK) tot stand. Hieruit blijkt dat 'checks and balances' een zeker nut hebben en een samenspel van 'meedenken, hulp en druk' uiteindelijk tot (enig) resultaat kan leiden. Belangrijk hierin is vooral de mogelijkheid tot ingrijpen, die zich voordoet als er een waarnemend burgemeester moet worden benoemd door de CdK. In alle onderzochte gemeenten leverde de waarnemer een evidente bijdrage aan het remmen of temperen van de problemen. Eventueel zou een CdK kunnen besluiten een waarnemend burgemeester bewust langer te laten zitten, om te pogen de gemeente naar bestuurlijk rustiger vaarwater te loodsen, zoals in sommige gemeenten gebeurde.

Of er over enige tijd toch een zodanige probleemcumulatie in een probleemgemeente optreedt, dat sprake is van een bijna permanent actieve 'bestuurlijke vulkaan' en het fenomeen van de regeringscommissaris van stal moet worden gehaald, moet worden afgewacht.

Garanties dat het bestuurlijk altijd goed gaat in een gemeente, zijn niet te geven. 'Die Politik is keine exakte Wissenschaft', zei Otto von Bismarck in 1863, erop wijzend dat in de politiek sentimenten een rol spelen. Soms gaat het gewoon mis in een gemeentebestuur en komt er pas na enige tijd weer 'rust in de tent'. Bovendien zijn er wel adviezen te geven, maar een ideaal pakket aan maatregelen is er niet. Soms helpen wethouders van buiten, soms een waarnemer, soms een combinatie met andere op tempering gerichte ingrepen. En soms... moet de ecologie maar zijn werk doen. Dan moet de tijd het doen, vanuit de gedachte dat er na de bestuurlijke schroei ook wel weer bloei zal komen.

Als uit de verschillende casestudies één ding duidelijk is geworden, is het wel dit: alle suggesties ten spijt, gaat het uiteindelijk om vertrouwen. Vertrouwen in vele actoren: de burgemeester, vertrouwen in de wethouders, vertrouwen van fractievoorzitters, in de coalitie, in de raad als geheel en in elkaar, in de gemeentesecretaris en griffier en anderen. Dat laat zich, als het erop aankomt, niet afdwingen door regels, noch door 
afspraken of veelvuldig overleg. Vertrouwen is er, of het is er niet. En vertrouwen komt te voet... maar gaat te paard. Politiek blijft uiteindelijk mensenwerk, waarbij elkaar verstaan veel 'grote' zaken en strijd tot kleinere proporties kan terugbrengen. 


\section{Summary}

In local authorities in The Netherlands mayors and aldermen often resign from their posts before the end of their term. They are forced to resign (or perceive such a force), because of a governmental conflict or governmental crisis (or the idea that such a conflict or crisis is imminent) within the municipal council. While in some councils (local governments) this is rare, in others it happens frequently. In some municipalities this is so common that they become known for their governmental problems. Such municipal councils are the focus of this research: governmental problem-councils.

The literature shows that premature resignations at the local level have increased to about 30\% of all mayors and aldermen and conflicts have been an important cause of that increase. Many questions, however, remain unanswered. It remains unclear, for instance, which municipalities attract attention through their resignations, and which problems characterised their municipal councils. Although educated guesses, estimates, and names of municipalities are mentioned, a complete overview remains lacking. The aim of this research is to provide that overview, to expand existing knowledge about conflicts and crises in governmental problem-councils, and consider which lessons can be learned from insights gained.

\section{Concepts}

In this study a (local) governmental conflict is understood as a conflict between a mayor and council executive and his or her own political party, the municipal executive board $\left({ }^{\prime}\right.$ college $\left.{ }^{\prime 2}\right)$, or the council, leading to a forced resignation. A governmental conflict concerns the resignation of a single individual, while other members of the municipal executive keep their posts. A governmental crisis or 'college' crisis, in contrast, is a situation where the whole executive board (sometimes including the mayor) resigns. In this study municipal councils where governmental conflicts and governmental crises happen frequently are called 'governmental problem-councils'. Finding out what should be considered 'frequent', how many municipal councils in The Netherlands are involved, and which relevant issues play a role in those councils is the core of this research. For a municipal council to be considered a governmental problem-council this study takes the following as starting-point: the occurrence of governmental conflicts or governmental crises in at least two consecutive terms of office of the council, with at least one serious crisis, as result of which the council executive board members definitely were forced to resign prematurely.

With forced resignations a distinction can be made between directly and indirectly forced resignations. In this study directly forced resignations of municipal executive board members are regarded as all those cases where the council has withdrawn its

2 In The Netherlands the executive governmental board of municipal councils, or executive board, consisting of a mayor ('burgemeester') and 'aldermen' ('wethouders'), is called 'college van burgemeester en wethouders', or simply 'college'. The executive board is distinguished from the directly elected municipal council ('gemeenteraadsleden'). As in a division of executive and legislative powers members of the executive board, neither mayor nor 'wethouders' are elected councillors. 
confidence in an individual alderman or the whole executive board ('college') through a motion of no-confidence, or has initiated a request for resignation of the mayor. Indirectly forced resignations are those resignations where an alderman resigns before a formal motion is given, expecting a withdrawal of confidence, or those resignations where an alderman resigns after losing the support from his or her own political party in the council.

\section{Main research question and research time frame}

The main research question which this study into governmental problem-councils in The Netherlands aims to answer is:

What is the explanation for persistent crisis situations and related forced resignations of mayors, aldermen, or complete municipal executive boards in governmental problemcouncils in The Netherlands between March 1998 and March 2010?

This research time frame of March 1998 until March 2010 includes three municipal council terms of office: 1998-2002, 2002-2006 and 2006-2010. March is the month in which every four year local elections take place in the Netherlands.

The main research question can be divided into three sub-questions. Those subresearch questions guide and inform the research and deal with the terms 'explanation' and the assumption of the existence of 'governmental problem-councils' in The Netherlands.

The sub-questions are:

1. What does the existing literature tell us about possible explanations for persistent governmental problems in governmental problem-councils?

2. Which municipal councils in The Netherlands can be considered governmental problem-councils in the period March 1998-March 2010?

3. Which explanations follow from the analysis of the situation in practice in governmental problem-councils?

\section{Sub-question 1: Four perspectives}

To answer sub-question 1 a research of the literature was done into existing knowledge on governmental problem-councils and the possibilities to do research into them. Four theoretical perspectives were considered. First, evaluation on the basis of governmental power, where the researcher assesses whether a municipal executive is capable of fulfilling its own ambitions, responsibilities and legal obligations to a satisfactory level. This perspective is based on the assumption that the governmental power of problemcouncils does not score as high in this evaluative framework as governments of councils that cannot be regarded as problem-councils. However, the limitation of this approach is that it lacks a focus on governmental performance of a council, because the available indicators do not take the administrative culture or fragmentation within the council into account, factors that certainly play a role in governmental problem-councils. 
The second potential perspective is that of 'good governance', which would serve to ascertain whether governmental problem-councils have low scores, in absolute or relative sense, on 'good governance' indicators. These could include concepts like effectiveness and responsiveness. Also in this respect it is assumed that governmental problem-councils have relatively low scores on these characteristics of good governance. However, this approach does not take changes over time into account, and provides a rather static perspective.

This research has adopted a combination of two other perspectives. First, the method of analysis introduced by Korsten and Aardema (2006) in their research into forced resignations of mayors has been used. They distinguish three levels of analysis in municipal councils - a micro level, meso level and macro level. They ascertain whether a resignation was due to individual aspects (micro level), in other words the individual abilities of one or more aldermen or a mayor, for instance their professional expertise, their communicative and social skills and 'temper', their ability for self-reflection, or their adaptability. Or, alternatively, whether a main influence or even direct cause can be found at meso level, such as the relationships within the municipal executive or the council, between the council and civil service, between the municipal executive board and the council, or between different political parties in the council's governing coalition. A third option was the location of key factors at the macro level, such as the municipal authority's governance structure or administrative culture, or unrest within society more broadly. Korsten and Aardema concluded that forced resignations of mayors in governmental problem-councils are not due to a single factor, but that a variety of factors has an influence at the same time.

This perspective of different factors is combined with a fourth angle: Korsten and Schoenmaker's (2008) study into weak municipal council governments ('colleges'). They designed a checklist on the basis of literature research and their own empirical work, with 37 points of advice to achieve a 'strong municipal executive'. Although this approach is in this form too restricted to adopt in this study because of its singular focus on everyday governance, the checklist used still provides an excellent tool to match indicators with the earlier mentioned factors.

In this research into governmental problem-councils a total of nine factors has been matched with indicators and analysed. At the micro level of analysis those are aspects of the mayor (1) and the aldermen ('wethouders') (2). The meso level of analysis is concerned with connections, within the municipal executive board ('college') (3), between the municipal executive board and civil service (4), between the municipal executive board and the city council (5) and between government coalition political parties (6). At the macro level attention is paid to the governance structure (7), administrative culture (8) and the role played by the media (9).

These factors are considered and analysed at each level in the case studies, where for each an expectation was made (see table A). The key question is whether a pattern of particularly influential factors can be discovered in those municipal councils. 
Table A: Expected findings on governmental problem-councils: separate factors of influence.

\begin{tabular}{|c|c|}
\hline Expectation 1 & $\begin{array}{l}\text { In governmental problem-councils the mayor is insufficiently capable to } \\
\text { draw different factions together, which means the absence of the mode- } \\
\text { rating potential of the mayor. }\end{array}$ \\
\hline Expectation 2 & $\begin{array}{l}\text { In governmental problem-councils the personal risk factors of one or more } \\
\text { aldermen (wethouders) can have an escalating effect on problems of } \\
\text { governance. }\end{array}$ \\
\hline Expectation 3 & $\begin{array}{l}\text { In governmental problem-councils municipal executive boards can not get } \\
\text { stronger, which means the absence of the moderating potential of a strong } \\
\text { municipal executive board. }\end{array}$ \\
\hline Expectation 4 & $\begin{array}{l}\text { In governmental problem-councils no clear pattern can be found in the } \\
\text { relationship between the municipal executive board and the civil service, } \\
\text { which has an escalating effect on problems of governance. }\end{array}$ \\
\hline Expectation 5 & $\begin{array}{l}\text { In governmental problem-councils no clear pattern can be found in the } \\
\text { relationship between the municipal executive board and the elected coun- } \\
\text { cil, which has an escalating effect on problems of governance. }\end{array}$ \\
\hline Expectation 6 & $\begin{array}{l}\text { In governmental problem-councils there is little connection between } \\
\text { government coalition parties, which has an escalating effect on problems of } \\
\text { governance. }\end{array}$ \\
\hline Expectation 7 & $\begin{array}{l}\text { In governmental problem-councils there is political fragmentation, which } \\
\text { has an escalating effect on problems of governance. }\end{array}$ \\
\hline Expectation 8 & $\begin{array}{l}\text { In governmental problem-councils the administrative culture is negative or } \\
\text { very negative, which has an escalating effect on problems of governance. }\end{array}$ \\
\hline Expectation 9 & $\begin{array}{l}\text { In governmental problem-councils the media have considerable influence } \\
\text { on the political debate, which has an escalating effect on problems of } \\
\text { governance. }\end{array}$ \\
\hline
\end{tabular}

\section{Sub-question 2: The identification of governmental problem-councils}

To establish which Dutch municipal councils can be considered governmental problemcouncils quantitative research covering the whole country was carried out. In the first place quantitative research focused on the number of resignations of mayors, aldermen and/or executive boards in all Dutch municipal councils between 1998 and 2010.

The 1th of January 2010 was chosen as review date, when The Netherlands counted 431 municipalities. Subsequently the findings of the first stage were used to establish which municipal councils appeared as governmental problem-councils from the analysis.

The quantitative research demonstrated that 278 out of 431 municipal councils in The Netherlands (64.5\%) have been involved in forced resignations of council executives between 1998 and 2010. That means that 153 out of 431 councils did not face forced resignations of their executives. In those councils (35.5\%) executive boards only changed after elections or after resignations out of own free choice. A substantial 134 of the 278 councils that did encounter problems reported one or two forced resignations from executive board members or complete executive boards, which comes down to $31.1 \%$. There were 93 councils with between three and five resigned executives or boards (21.6\%), while another 39 councils counted six, seven or eight governmental conflicts or crises (9.0\%). In twelve councils (2.8\%) there were more than eight forced resignations. 
This produces the following overview:

Table B:Number of conflicts and crises in The Netherlands, March 1998- March 2010

\begin{tabular}{|l|c|c|}
\hline Number of conflicts and crises & Number of municipal councils & In percentages \\
\hline o & 153 & $35.5 \%$ \\
\hline 1 or 2 & 134 & $31.1 \%$ \\
\hline $3-5$ & 94 & $21.8 \%$ \\
\hline $6-8$ & 38 & $8.8 \%$ \\
\hline$>9$ & 12 & $2.8 \%$ \\
\hline Total & 431 & $100 \%$ \\
\hline
\end{tabular}

\section{Council types}

Research into Dutch municipal councils from 1998 to 2010 shows that, related to governmental problems, different types of councils can be distinguished. There are five types of councils in total.

\section{Councils without forced resignations}

In 35\% of councils in The Netherlands there are no forced resignations. That does not necessarily mean there were no tensions reported, because such tensions were found. They just did not result in forced resignation of municipal executives.

\section{Councils with an average amount of resignations}

The second category includes those councils that noted the forced resignation of one or two municipal executives within the time frame of this research, which can be considered typical of the average council. This applies to 134 councils, more than $30 \%$. Those were mostly separate, isolated incidents, with a clear and apparent cause. In those councils the resignation of that single executive did not lead to more resignations. There was at most a small change of personnel within the executive board, with one party replacing another.

\section{Councils with a 'troubled year'}

A third category is the group of councils where there was a particular troublesome period, with several aldermen and/or the mayor forced to resign, and a complete change of the makeup of the executive board. In those councils years of governmental calm were suddenly followed by a serious crisis.

\section{Councils with regular incidents}

There are also councils where throughout the years incidents occur now and then. Those mostly involved a single alderman, with sometimes changes within the executive board. Those events did, however, not develop into real crises. Individual aldermen got into trouble because of personal behaviour. There were also considerable periods of time between the different conflicts or crises, which all could be considered as separate incidents. There were, though, more than one or two of those incidents, without a truly administratively terrible year. The term 'structurally incidental' seems to apply to those councils. 


\section{The governmental problem-councils}

Governmental problem-councils are municipal councils that are continuously faced with governmental conflicts and crises: individual aldermen resign, political parties leave governing coalitions, a group of aldermen or a complete executive board has to resign, and mayors are under attack. The conflicts and crises are not specific to a particular year, but occur during the whole time period, although it may be that a single year has seen an especially serious crisis. On the basis of the analysis of research findings nine councils in The Netherlands can be put in the governmental problem-council category. Those councils have seen the highest number of governmental problems in The Netherlands, with at least two resignations of complete executive boards, of which at least one serious crisis, and problems in two following council terms of office. Those councils are: the local governments of Delfzijl, Leiden, Losser, Beverwijk, Den Helder, Hilversum, Valkenswaard, Leerdam and Zundert.

\section{Sub-question 3: The case studies}

The third sub-question is answered through four casestudies. This approach was chosen because case studies, taking their limitations into account, fit the exploratory character of this research particularly well. Three criteria were used to determine which municipal councils to select for further in-depth research:

(1) In each council term of office there has been at least one governmental conflict or crisis.

(2) Selected councils are preferably located in different provinces.

(3) Selected councils are preferably of different sizes.

On this basis the governmental problem-councils of Delfzijl, Leiden, Den Helder and Zundert were selected. Zundert is a municipality with less than 25,000 inhabitants, Delfzijl belongs in the $25,000-50,000$ inhabitant category, Den Helder in the 50,000 100,000 inhabitant category, while Leiden has more than 100,000 inhabitants.

\section{Research findings}

After finding answers to sub-questions 1 and 2, and completing the four casestudies (sub-question 3) the main research question can be answered. The findings are as follows: There is no single causal explanation or understanding of the emergence and persistence of crisis situations in problem-councils. It is only a plurality of coinciding situated events and circumstances that lead to these problems. The research shows that in governmental problem-councils those factors coincide frequently. Further analysis of the issues in four governmental problem-council casestudies demonstrates that distinctions can be made.

1. Certain factors are continuously present with a negative influence, but play a role in the background. Those are in the first place the administrative culture $(4 x)$, the media (4X) and the governance structure (3x). 
2. Three factors can cause governmental problems. Those include two micro factors (the mayor and the aldermen) and one meso factor: the coherence of the governing coalition.

\section{Micro factors}

Micro factors are those where a mayor or alderman carries personal risk factors. They are ill-prepared for their role, become controversial figures, or have a difficult relationship with their grassroots supporters (in the case of aldermen), which increases the chance they would have to leave the council. Their professional skills, their political instinct, their ability for self-reflection and self-criticism regarding their behaviour and public image, and their adaptability are insufficient, not enough focused on what does work well, or are developed too late. They are unavailable for warnings, and are unresponsive when warnings are given. They belittle critique, stick to 'who they are' or have other evasive reactions to avoid doing what is required to survive. Collectively, for instance at executive board level or in interaction with councillors, there is a failure to moderate, for instance by protecting an alderman or by managing to weather the storm together otherwise. In this way the moderating influence of the position of the mayor is lost.

\section{Meso factors: coalition coherence}

The third factor that can result in governmental problems is the coherence of the governing coalition: political parties within the council that build a strong connection with each other, with leaders that get along well, trust each other, and consult each other regularly. This can have an important moderating effect on escalating governmental conflicts and crises in governmental problem-councils. If the parties represented in the coalition want to avoid 'trouble', for whatever reason, even a failing alderman can stay on. In those situations it emerges that aldermen or a mayor in trouble do not necessarily need to end up involved in a governmental conflict, or that a governmental conflict does not necessarily need to lead to a full-blown crisis. In that respect the coherence of the coalition can be the key factor, or at least of high importance, in determining whether or not a council is faced with a governmental crisis. If mutual trust between different coalition partners or their political leaders is absent there is no further instrument to avoid escalation.

\section{Lacking leadership}

The research findings show that some factors did play a role, but on their own did not cause a governmental conflict, or the escalation of such a conflict into a governmental crisis in a problem-council. First, it is not the case that the cause of frequent governmental conflicts and crises can be found in the role played by the media, or in an increasing intensity of reporting of issues in the press. As a causal factor 'the media' did play a role, but that role should be put in perspective.

In addition, it appeared that behaviour of large majorities, or minorities, within municipal society at large are not the cause of the emergence of a council as governmental problem-council. Municipal citizens look on and wonder. Of course there are conflicts where citizens choose sides (see for instance the Rijn-Gouwe light rail project in Leiden) 
but it is not the citizens who turn a council directly into a governmental problemcouncil.

A large or politically dominant policy issue as only cause of crises with a long term problem-council status as result is relatively rare. That is understandable given the fact that local government has to a large degree the role of implementing national government policy.

It is not necessarily the case either that a municipal council is stuck with its status as governmental problem-council, just because of a mistaken appointment of a particular mayor. Being a governmental problem-council cannot be traced back to the influence of a single actor. The research also did not show that as long as there is a strong executive board with strong aldermen (with professional expertise, vision, charisma, social and communicative skills, mutually supportive, etc.), things will work out well automatically without any risk of the council becoming a problem-council.

Neither is it the case that underperforming civil servants turn the council into a governmental problem-council. This is understandable; it is after all not the field maintenance team and administrative staff that make a football team lose a game.

In governmental circles the opinion that the separation of the executive and elected representative bodies of municipal councils in 2002 led to trouble from the start is often voiced. That separation of powers caused the close interconnections between executive boards and elected councillors to become undone. Aldermen were no longer elected councillors, and no longer leaders of subject committees. The executive and representative entities became more separate from each other. The elected council remained the most important governmental body of the municipal council, and received tools enhancing its influence, such as stronger powers of control, for instance through the right to initiate investigations or the establishment of local or regional audit offices. The analysis of four problem-councils does not confirm the existence of increased animosity leading to the labelling of councils as 'governmental problemcouncils'. In fact, governmental problem-councils already had that status before the municipal separation of executives and elected representatives was introduced. However, that separation did not help the situation improve. It did not calm problemcouncils down, although that never was the aim of the separation. Separation of executives and elected representatives did not solve the conflicts and crises in problemcouncils studied in this research.

\section{Discussion of research findings}

The aim of this study was to evaluate what went wrong in Dutch municipal councils that saw relatively large numbers of council executives resign between March 1998 and March 2010. Those councils have been termed governmental problem-councils in this research. To carry out the research data on council executive resignations was analysed, to consider how many councils can be really regarded as governmental problemcouncils. Research into four of those councils aimed to improve our understanding of 
what causes councils to become such problem-councils, and which influential causal factors there are.

Reflecting on these findings, it has been the goal to formulate a structured set of suggestions which could help tackle the problems of municipal councils. In this respect, following Korsten, three perspectives are elaborated upon: the autonomy perspective (a municipal council is according to the Constitution responsible for its own governmental policy, and should therefore take responsibility for its own problems); the perspective of the responsibility of the national government for the whole national governance system (the 'higher' level government should intervene); and the ecological perspective (no action, recovery should occur 'naturally').

What can we learn from the insights produced in this study and reflection on those insights, in combination with insights from the literature? Principally that using three different perspectives to evaluate issues in governmental problem-councils is not just a possibility, but a necessity. There are examples of cases where the ecological approach is used, and works well. Elections bring in new actors, with a reduction of problems as a result. It appeared, however, that in the councils analysed in this study the ability of the council to solve its own problems is not very advanced. Attempts to come to a solution were made, such as investigative reports, but the problems stayed. With the exception of Leiden, changes were eventually only made after pressure, sometimes severe, from the provincial governor ('Commissaris van de Koningin'). This means that 'checks and balances' can be useful, and a combination of 'team-play, support and pressure' can be successful in the end. In this respect the opportunity to intervene is important; an opportunity arising when the provincial governor has to appoint an acting mayor. In all councils studied in this research that temporary mayor provided a clear contribution to the moderation or tackling of the problems. Potentially a provincial governor could decide to let an acting mayor stay on longer for that purpose, in an attempt to stabilise the situation in the council, as happened in some of the councils.

Whether eventually a stockpiling of problems will still happen in problem-councils, in such a way that the council becomes permanently 'explosive', and a national government special envoy has to be called in, remains to be seen.

There are no guarantees that governance will always run smoothly in a municipal council. 'Die Politic is keine exakte Wissenschaft', did Otto von Bismarck say in 1863, pointing to the fact that in politics emotions do play a role. Sometimes things simply go wrong in a council, and it takes a little while for things to calm down. In addition, it may be possible to give advice, but there is no ideal combination of solutions. Sometimes aldermen from outside the council give a hand, sometimes a temporary mayor steps in, and sometimes a combination of other interventions aimed to ease tensions is used. And sometimes... ecology needs to do its job. In those cases it simply takes time for things to improve, with the idea that every cloud has a silver lining.

If there is one thing the different case studies demonstrated, it is the following: despite various suggestions, in the end trust is paramount. Trust in many actors: trust in the mayor, trust in aldermen, trust of political leaders, trust within the governing coalition, 
in the council as a whole, and mutually within the council, in top civil servants and clerks, and in others. Such trust cannot, in the end, be enforced by rules, by agreements or regular consultation. Trust cannot be established artificially, and trust takes time to develop and can be easily lost. Ultimately politicians are only human, while empathy and mutual understanding can help put many 'big' issues and clashes in perspective. 
CV

Milo Schoenmaker (Alkmaar, 1967) is politicoloog, hoofdvak bestuurskunde. Hij studeerde aan de Universiteit van Amsterdam en behaalde zijn doctoraalexamen in 1991.

$\mathrm{Na}$ een periode in het bedrijfsleven werd hij in 1994 actief in de lokale politiek, als lid van de gemeenteraad van Haarlemmermeer. In 1998 werd hij in dezelfde gemeente wethouder. Schoenmaker werd in 2003 benoemd tot burgemeester van Bussum. Vanaf die tijd werkt hij regelmatig mee aan publicaties over politiek-bestuurlijke onderwerpen.

In 2008 publiceerde Schoenmaker met prof. dr. A.F.A. Korsten het boek 'Sterke colleges' (Reed Elsevier), waarin nader wordt ingegaan op de kracht (of zwakte) van colleges van $B \& W$.

Schoenmaker geeft regelmatig lezingen over het lokaal bestuur en is gecertificeerd mediator. 